\author{
UNIVERSIDADE DE SÃO PAULO \\ FACULDADE DE FILOSOFIA, LETRAS E CIÊNCIAS HUMANAS \\ DEPARTAMENTO DE LINGÜÍSTICA \\ PROGRAMA DE PÓS-GRADUAÇÃO EM LINGÜÍSTICA
}

Contribuições para o Atlas Toponímico do Estado de Mato Grosso Mesorregião Sudeste Mato-Grossense

Maria Aparecida de Carvalho

São Paulo

2010 


\author{
UNIVERSIDADE DE SÃO PAULO \\ FACULDADE DE FILOSOFIA, LETRAS E CIÊNCIAS HUMANAS \\ DEPARTAMENTO DE LINGÜÍSTICA \\ PROGRAMA DE PÓS-GRADUAÇÃO EM LINGÜÍSTICA
}

\title{
Contribuições para o Atlas Toponímico do Estado de Mato Grosso - Mesorregião Sudeste Mato-Grossense
}

Maria Aparecida de Carvalho

Tese apresentada ao Programa de PósGraduação em Lingüística, do Departamento de Lingüística, da Faculdade de Filosofia, Letras e Ciências Humanas da USP - Universidade de São Paulo, para obtenção do título de Doutora em Letras.

Orientadora: Profa Dra Maria Vicentina de Paula do Amaral Dick

São Paulo 


\section{FOLHA DE APROVAÇÃO}

Maria Aparecida de Carvalho

Contribuições para o Atlas Toponímico do Estado de Mato Grosso - Mesorregião Sudeste Mato-grossense

Tese apresentada à Faculdade de Filosofia, Letras e Ciências Humanas da Universidade de São Paulo para obtenção do título de Doutora.

Área de Concentração: Semiótica e Lingüística Geral

Aprovada em:

\section{Banca Examinadora}

Profa Dra Maria Vicentina de Paula do Amaral Dick

Instituição: Universidade de São Paulo Assinatura:

$\operatorname{Prof}^{\mathrm{a}} \mathrm{Dr}^{\mathrm{a}}$

Instituição:

Assinatura:

$\operatorname{Prof}^{\mathrm{a}} \mathrm{Dr}$

Instituição:

Assinatura:

Profa $D r^{a}$

Instituição:

Assinatura:

Profa ${ }^{a}{ }^{a}$

Instituição:

Assinatura: 
Eternos agradecimentos

À minha mãe Sebastiana Rodrigues Carvalho (in memorian) 


\section{AGRADECIMENTOS}

$\mathcal{N}$ esta oportunidade agradeço com alegria e gratidão a todas as pessoas que direta ou indiretamente contribuíram para o desenvolvimento e a conclusão deste trabalho e sou especialmente grata:

A Deus, Inteligência Suprema que rege o Universo;

A Jesus, Condutor Seguro das minhas jornadas evolutivas;

Aos meus pais (in memoriam), que se sacrificaram para nos proporcionar oportunidades de estudo e vida digna;

Aos meus irmãos, minhas irmãs e meus familiares, sobretudo, minha irmã Ana Laura pelos apoios, tolerâncias e colaborações durante todo esse tempo e pelas disponibilidades para atender meus pedidos;

Aos meus amigos e amigas pelos incentivos e compreensão das minhas ausências;

Aos amigos e companheiros de Ideal Espírita pelas preces e estímulos;

A Secretaria de Estado de Planejamento e Coordenação Geral do Estado de Mato Grosso

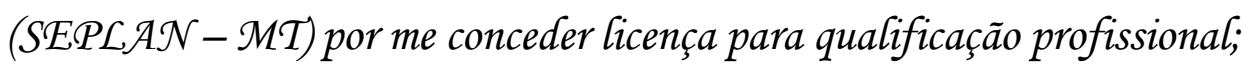

À minha orientadora Profa $\mathfrak{D r}^{a}$ Maria Vicentina de Paula do Amaral Dickpelas orientações no mestrado e no doutorado;

À Profa Dra Maria Aparecida Barbosa e à Profa Dr $^{a}$ Maria Margarida Andrade pelas contribuições no Exame de Qualificação e colaborações posteriores;

Às professoras e amigas Odila Watzele Térèse Jeanne Margotti pelas versões do resumo;

À professora e amiga Maria de Jesus Patatas pelas colaborações; 
A Rogério Teodoro pela elaboração do programa que possibilitou a confecção das fichas lexicográfico-toponímicas;

Ao amigo e colega de trabalho João B. M. Figueiredo pelas colaborações e revisões;

Às amigas Zita Marimon pelas leituras do meu trabalho e Alexandra Oliveira pelas colaborações;

À amiga Letícia Thomen, ao colega de trabalho Adriano Garcez e a Silvia Maria Pigueira pelas contribuições na formatação da tese;

Ao colega de trabalho Juraci Ozeda por atender às minhas solicitações de esclarecimentos sobre as cartas topográficas;

Aos colegas da SEPLAN - MTT e mais particularmente aos colegas da SEI que me ajudaram;

À senhora Profa Áurea e aos senhores Antônio João, Diller Anderson, Eduardo R. Ribeiro, Manoel R. dos Santos e Paulo Sérgio Delgado pelas colaborações nas classificações taxionimicas;

Aos senhores Félix, Pe Gonçalo Ochoa Camargo, José Guilherme, Mário Bordignon Enawureu (Mestre Mário), Raimundo Itugoga que contribuíram com informaçôes sobre topônimos indígenas e minimizaram minhas dificuldades. 


\section{RESUMO}

Este trabalho é o resultado da pesquisa lexicográfico-toponímica dos topônimos de cabeceiras, córregos, morros, ribeirões, rios, serras, vazantes, etc. registrados nos mapas e cartas topográficas dos 22 (vinte e dois) municípios que compõem a mesorregião Sudeste Mato-grossense. Os topônimos individualizam os acidentes físicos ou antrópicos, possibilitam uma localização específica dentro de um espaço geográfico amplo, concorrem para delimitar ou unir áreas em um determinado contexto territorial, seja ele, rural ou urbano e demonstram pela amplitude e variedade, extenso campo de estudo para a pesquisa lexicológica. $O$ ato de denominar contribui para diferenciar e, até mesmo, para especificar algo ou alguém que de certo modo apresentava-se igual aos da mesma espécie. O estudo dos nomes próprios de lugares denomina-se Toponímia que é uma das subdivisões da Onomástica. O nome de lugar ou topônimo constitui-se, portanto, o principal objeto de estudo em uma pesquisa lexicográfico-toponímica e, muitas vezes, traz em seu bojo expressiva riqueza histórico-cultural. A conclusão desta pesquisa representa também a elaboração de mais uma etapa do Atlas Toponímico do Estado de Mato Grosso (ATEMT), vinculado ao Projeto ATB - Atlas Toponímico do Brasil. As taxionomias de natureza física destacam-se dentre os topônimos pesquisados e constata-se expressivo registro de topônimos de etimologia bororo e tupi.

Palavras-chave: Acidentes Antrópicos. Acidentes Físicos. Lexicográfico. Pesquisa. Sudeste. Toponímico. 


\begin{abstract}
This study is a result fo a lexicographic-toponymic research of the headwaters, small tributary streams, hills, large streams, rivers, mountain ridges, low waters, etc. registered in the maps and topographic letters of the 22 (twenty-two) municipalities that are part of the Mato-grossense Southeastern mesoregion. The toponyms individualize the physical or human-caused accidents, make possible a specific localization within a wide geographic space, allow the delimitation or joining of areas in a certain territorial context, be it, rural or urban and show through wideness and variety, a vast study field for the lexicological research. The act of naming contributes to differentiate and, even, specify something or someone that in a certain way presented itself similar to those of the same species. The study of the proper names of places is called Toponymy which is one of the subdivisions of the Onomastics. The name of a place or toponymy is, therefore, the main object of study in a lexicographic-toponymic research and, many times, brings impressive historicalcultural wealth. The conclusion of this research also represents the elaboration of one more phase of the Toponymic Atlas of the State of Mato Grosso (ATEMT), linked to the ATB - Project Toponymic Atlas of Brazil. The taxonomies of a physical nature stand out among the researched toponyms and an expressive record of toponyms of bororo and tupi etymology is acknowledge.
\end{abstract}

Key-words: Natural Accidents. Human-made Accidents. Lexicographic. Research. Southeast. Toponymic. 


\section{RESUMÉ}

Cet ouvrage est le résultat d'une recherche lexicographique-toponymique des toponymes de sources des cours d'eau, torrents, colines, ruisseaux, rivières, chaines de montagnes, marécages, etc. registrés sur les cartes et cartes topographiques des 22 (vingt-deux) communes qui composent la meso-région Sudest de Mato-Grosso. Les toponymes individualisent les accidents physiques ou anthropiques, rendent possible une localisation déterminée dans un ample espace géographique, servent à délimiter ou unir des aires dans un contexte territorial déterminé, qu'il soit rural ou urbain et démontrent par leur amplitude et variété un grand champ d'étude pour la recherche lexicologique. L'acte de dénommer contribue pour différencier et, même pour spécifier quelque chose ou quelqu'un que d'une certaine façon se présente semblable à ceux de la même espèce. L'étude des noms propres de lieux se dénomine Toponymie, qui est l'une des subdivisions de l'Onomasiologie. Donc le nom de lieu ou toponyme constitue l'objet principal d'une recherche lexicographique-toponymique et, très souvent renferme une expressive richesse historico-culturelle. La conclusion de cette recherche représente aussi l'élaboration d'une nouvelle étape de l'Atlas Toponymique de l'Etat de Mato Grosso (ATEMT), rattaché au Projet ATB - Atlas Toponymique du Brésil. On remarque les taxionomies de nature physique parmi les toponymes étudiés et l'on constate un registre expressif des toponymes d'étimologie bororo et tupi.

Mots-clé: Accidents Antropiques. Accidents Physiques. Lexicographique. Recherche. Sud-est. Toponymique. 


\section{LISTA DE GRÁFICOS}

GRÁFICO 1 - Total dos hidrotopônimos da microrregião Alto Araguaia........... 118

GRÁFICO 2 - Total dos zootopônimos da microrregião Alto Araguaia............ 125

GRÁFICO 3 - $\quad$ Total dos fitotopônimos da microrregião Alto Araguaia.............. 131

GRÁFICO 4 - Total dos litotopônimos da microrregião Alto Araguaia.............. 137

GRÁFICO 5 - Total dos geomorfotopônimos da microrregião Alto Araguaia... 140

GRÁFICO 6 - $\quad$ Total dos cromotopônimos da microrregião Alto Araguaia........ 143

GRÁFICO 7 - Total dos dimensiotopônimos da microrregião Alto Araguaia.... 145

GRÁFICO 8 - $\quad$ Total dos cardinotopônimos da microrregião Alto Araguaia...... 147

GRÁFICO 9 - $\quad$ Total dos ergotopônimos da microrregião Alto Araguaia........... 151

GRÁFICO 10 - Total dos sociotopônimos da microrregião Alto Araguaia.......... 155

GRÁFICO 11 - Total dos antropotopônimos da microrregião Alto Araguaia...... 157

GRÁFICO 12 - Total dos animotopônimos da microrregião Alto Araguaia........ 160

GRÁFICO 13 - Total dos hodotopônimos da microrregião Alto Araguaia.......... 162

GRÁFICO 14 - Total dos ecotopônimos da microrregião Alto Araguaia............ 164

GRÁFICO 15 - Total dos hierotopônimos da microrregião Alto Araguaia.......... 165

GRÁFICO 16 - Total dos hagiotopônimos da microrregião Alto Araguaia......... 167

GRÁFICO 17 - Total dos topônimos de natureza física da microrregião Alto

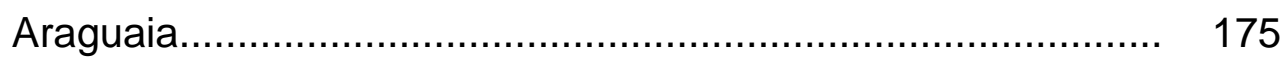

GRÁFICO 18 - Total dos topônimos de natureza antrópica da microrregião Alto Araguaia ............................................................... 176

GRÁFICO 19 - Total dos topônimos por grupos lingüísticos da microrregião

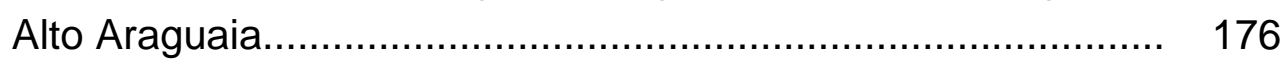

GRÁFICO 20 - Total geral dos topônimos da microrregião Alto Araguaia......... 177

GRÁFICO 21 - Total dos fitotopônimos da microrregião Primavera do

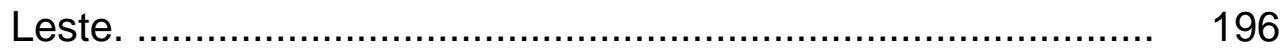

GRÁFICO 22 - Total dos zootopônimos da microrregião Primavera do

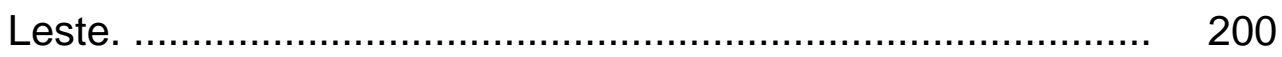

GRÁFICO 23 - Total dos hidrotopônimos da microrregião Primavera do

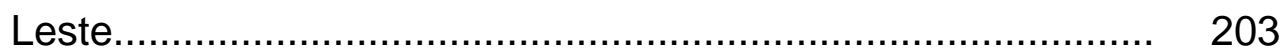

GRÁFICO 24 - Total dos litotopônimos da microrregião Primavera do

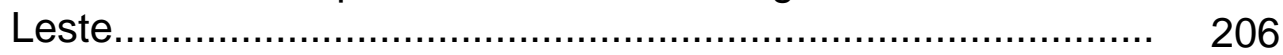

GRÁFICO 25 - Total dos geomorfotopônimos da microrregião Primavera do

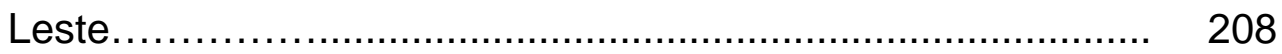

GRÁFICO 26 - Total dos ergotopônimos da microrregião Primavera do Leste. 212 
GRÁFICO 27 - Total dos sociotopônimos da microrregião Primavera do Leste 214 GRÁFICO 28 - Total dos animotopônimos da microrregião Primavera do Leste.

GRÁFICO 29 - Total dos topônimos de natureza física da microrregião

Primavera do Leste.

GRÁFICO 30 - Total dos topônimos de natureza antrópica da microrregião Primavera do Leste.

GRÁFICO 31 - Total dos topônimos por grupos lingüísticos da microrregião Primavera do Leste

GRÁFICO 32 - Total geral dos topônimos da microrregião Primavera do Leste.

GRÁFICO 33 - Total dos zootopônimos da microrregião Rondonópolis.

GRÁFICO 34 - Total dos fitotopônimos da microrregião Rondonópolis...... 288

GRÁFICO 35 - Total dos hidrotopônimos da microrregião Rondonópolis. 295

GRÁFICO 36- Total dos litotopônimos da microrregião Rondonópolis.. 302

GRÁFICO 37 - Total dos geomorfotopônimos da microrregião Rondonópolis... 306

GRÁFICO 38 - Total dos dimensiotopônimos da microrregião Rondonópolis... 309

GRÁFICO 39 - Total dos cromotopônimos da microrregião Rondonópolis........ 311

GRÁFICO 40 - Total dos ergotopônimos da microrregião Rondonópolis 316

GRÁFICO 41 - Total dos sociotopônimos da microrregião Rondonópolis......... 320

GRÁFICO 42 - Total dos antropotopônimos da microrregião Rondonópolis...... 324

GRÁFICO 43 - Total dos animotopônimos da microrregião Rondonópolis........ 327

GRÁFICO 44 - Total dos hagiotopônimos da microrregião Rondonópolis......... 329

GRÁFICO 45 - Total dos hodotopônimos da microrregião Rondonópolis.......... 332

GRÁFICO 46 - Total dos etnotopônimos da microrregião Rondonópolis............ 334

GRÁFICO 47 - Total dos somatotopônimos da microrregião Rondonópolis...... 336

GRÁFICO 48 - Total dos numerotopônimos da microrregião Rondonópolis...... 338

GRÁFICO 49 - Total dos hierotopônimos da microrregião Rondonópolis. 340

GRÁFICO 50 - Total dos topônimos de natureza física da microrregião Rondonópolis.

GRÁFICO 51 - Total dos topônimos de natureza antrópica da microrregião Rondonópolis.

GRÁFICO 52 - Total dos topônimos por grupos lingüísticos da microrregião Rondonópolis

GRÁFICO 53 - Total geral dos topônimos da microrregião Rondonópolis. 351

GRÁFICO 54 - Total dos zootopônimos da microrregião Tesouro 
GRÁFICO 55 - Total dos fitotopônimos da microrregião Tesouro...................... 433

GRÁFICO 56 - Total dos hidrotopônimos da microrregião Tesouro................... 442

GRÁFICO 57 - Total dos litotopônimos da microrregião Tesouro...................... 451

GRÁFICO 58 - Total dos geomorfotopônimos da microrregião Tesouro........... 457

GRÁFICO 59 - Total dos dimensiotopônimos da microrregião Tesouro............. 463

GRÁFICO 60 - Total dos cardinotopônimos da microrregião Tesouro............... 465

GRÁFICO 61 - Total dos sociotopônimos da microrregião Tesouro................... 471

GRÁFICO 62 - Total dos ergotopônimos da microrregião Tesouro................... 475

GRÁFICO 63 - Total dos antropotopônimos da microrregião Tesouro.............. 479

GRÁFICO 64 - Total dos animotopônimos da microrregião Tesouro................. 482

GRÁFICO 65 - Total dos hagiotopônimos da microrregião Tesouro.................. 485

GRÁFICO 66 - Total dos hodotopônimos da microrregião Tesouro................... 487

GRÁFICO 67 - Total dos numerotopônimos da microrregião Tesouro.............. 489

GRÁFICO 68 - Total dos hierotopônimos da microrregião Tesouro................... 491

GRÁFICO 69 - Total dos etnotopônimos da microrregião Tesouro..................... 493

GRÁFICO 70 - Total dos somatotopônimos da microrregião Tesouro............... 495

GRÁFICO 71 - Total dos dirrematotopônimos da microrregião Tesouro........... 497

GRÁFICO 72 - Total dos topônimos de natureza física da microrregião

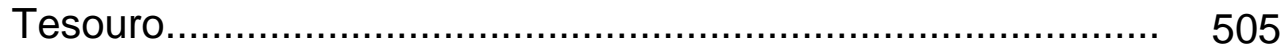

GRÁFICO 73 - Total dos topônimos de natureza antrópica da microrregião

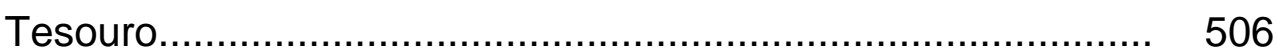

GRÁFICO 74 - Total dos topônimos por grupos lingüísticos da microrregião

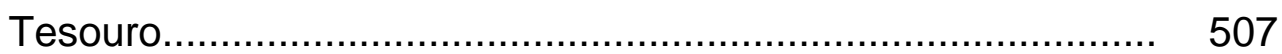

GRÁFICO 75 - Total geral dos topônimos da microrregião Tesouro.................. 508

ANEXO A - $\quad$ Mapa de Mato Grosso por microrregiões................................... 539 


\section{LISTA DE QUADROS}

4.3.2.1 Relação dos acidentes físicos do município de Alto Araguaia, de seus topônimos e taxionomias...............................................

4.3.2.2 Relação dos acidentes humanos do município de Alto Araguaia, de seus topônimos e taxionomias.

4.3.3.1 Relação dos acidentes físicos do município de Alto Garças, de seus topônimos e taxionomias.

4.3.3.2 Relação dos acidentes humanos do município de Alto Garças, de seus topônimos e taxionomias.

4.3.4.1 Relação dos acidentes físicos do município de Alto Taquari, de seus topônimos e taxionomias.

4.3.4.2 Relação do acidente humano do município de Alto Taquari, de seu topônimo e taxionomia.

4.4.2.1 Relação dos acidentes físicos do município de Campo Verde, de seus topônimos e taxionomias.

Relação dos acidentes humanos do município de Campo Verde, de seus topônimos e taxionomias.

4.4.3.1 Relação dos acidentes físicos do município de Primavera do Leste, de seus topônimos e taxionomias...

4.4.3.2 Relação dos acidentes humanos do município de Primavera do Leste, de seus topônimos e taxionomias...

4.5.2.1 Relação dos acidentes físicos do município de Dom Aquino, de seus topônimos e taxionomias...

4.5.2.2 Relação dos acidentes humanos do município de Dom Aquino, de seus topônimos e taxionomias.

4.5.3.1 Relação dos acidentes físicos do município de Itiquira, de seus topônimos e taxionomias.

4.5.3.2 Relação do acidente humano do município de Itiquira, de seu topônimo e taxionomia.

4.5.4.1 Relação dos acidentes físicos do município de Jaciara, de seus topônimos taxionomias.

4.5.4.2 Relação dos acidentes humanos do município de Jaciara, de seus topônimos e taxionomias.

4.5.5.1 Relação dos acidentes físicos do município de Juscimeira, de seus topônimos e taxionomias.

4.5.5.2 Relação dos acidentes humanos do município de Juscimeira, de 
seus topônimos e taxionomias

4.5.6.1 Relação dos acidentes físicos do município de Pedra Preta, de seus topônimos e taxionomias.

4.5.6.2 Relação dos acidentes humanos do município de Pedra Preta, de seus topônimos e taxionomias.

4.5.7.1 Relação dos acidentes físicos do município de Rondonópolis, de seus topônimos e taxionomias

4.5.7.2 Relação dos acidentes humanos do município de Rondonópolis, de seus topônimos e taxionomias.

4.5.8.1 Relação dos acidentes físicos do município de São José do Povo, de seus topônimos e taxionomias.

Relação dos acidentes humanos do município de São José do Povo, de seus topônimos e taxionomias.

4.5.9.1 Relação dos acidentes físicos do município de São Pedro da Cipa, de seus topônimos e taxionomias.

4.5.9.2 Relação dos acidentes humanos do município de São Pedro da Cipa, de seus topônimos e taxionomias.

4.6.2.1 Relação dos acidentes físicos do município de Araguainha, de seus topônimos e taxionomias.

4.6.2.2 Relação dos acidentes humanos do município de Araguainha, de seus topônimos e taxionomias.

4.6.3.1 Relação dos acidentes físicos do município de General Carneiro, de seus topônimos e taxionomias.

4.6.3.2 Relação dos acidentes humanos do município de General Carneiro, de seus topônimos e taxionomias.

4.6.4.1 Relação dos acidentes físicos do município de Guiratinga, de seus topônimos e taxionomias

4.6.4.2 Relação dos acidentes humanos do município de Guiratinga, de seus topônimos e taxionomias.

4.6.5.1 Relação dos acidentes físicos do município de Pontal do Araguaia, de seus topônimos e taxionomias.

4.6.5.2 Relação dos acidentes humanos do município de Pontal do Araguaia, de seus topônimos e taxionomias.

4.6.6.1 Relação dos acidentes físicos do município de Ponte Branca, de seus topônimos e taxionomias.

4.6.6.2 Relação dos acidentes humanos do município de Ponte Branca, de seus topônimos e taxionomias.

4.6.7.1 Relação dos acidentes físicos do município de Poxoréu, de seus 
topônimos e taxionomias

4.6.7.2 Relação dos acidentes humanos do município de Poxoréu, de seus topônimos e taxionomias.

4.6.8.1 Relação dos acidentes físicos do município de Ribeirãozinho, de seus topônimos e taxionomias.

4.6.8.2 Relação do acidente humano do município de Ribeirãozinho, de seu topônimo e taxionomia.

4.6.9.1 Relação dos acidentes físicos do município de Tesouro, de seus topônimos e taxionomias.

4.6.9.2 Relação dos acidentes humanos do município de Tesouro, de seus topônimos e taxionomias.

4.6.10.1 Relação dos acidentes físicos do município de Torixoréu, de seus topônimos e taxionomias.

4.6.10.2 Relação dos acidentes humanos do município de Torixoréu, de seus topônimos e taxionomias.

Apêndice B Composição da mesorregião Sudeste Mato-grossense. 534

Anexo B Ficha Lexicográfico-toponímica do Projeto ATESP 


\section{LISTA DE TABELAS}

1 - Topônimos da microrregião Alto Araguaia por municípios e 116 Taxionomia...

2 - Topônimos da microrregião Primavera do Leste por municípios e taxionomias.

3 - Topônimos da microrregião Rondonópolis por municípios e taxionomias.

4 - Topônimos da microrregião Tesouro por municípios e taxionomias.

5 - Topônimos da mesorregião Sudeste Mato-grossense, por grupos lingüísticos, microrregiões e municípios. 


\section{LISTA DE ABREVIATURAS E SIGLAS}
ATB -
Atlas Toponímico do Brasil
ATEMT -
Atlas Toponímico do Estado de Mato Grosso
ATESP -
Atlas Toponímico do Estado de São Paulo
DSG -
Diretoria de Serviço Geográfico
córr. -
Córrego
FCR -
Fundação de Pesquisas Cândido Rondon
IBGE -
Instituto Brasileiro de Geografia e Estatística
rib. -
Ribeirão
SEPLAN
Secretaria de Estado de Planejamento e Coordenação Geral do Estado de Mato Grosso 
1 INTRODUÇÃO

1.1 Tema

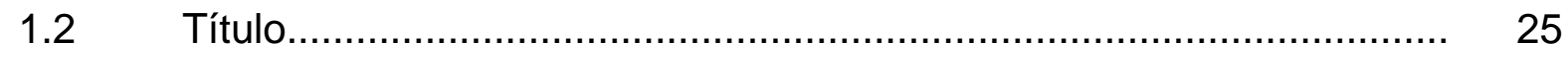

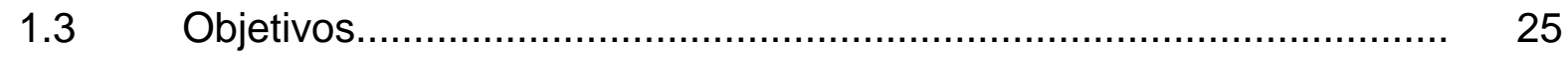

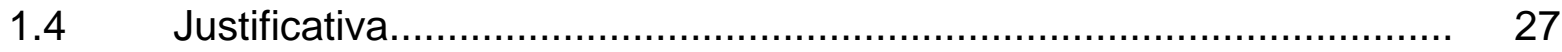

2 FUNDAMENTAÇÃO TEÓRICA .................................................... 30

$2.1 \quad$ Princípios da Toponímia.......................................................... 30

2.1.1 O signo toponímico............................................................. 32

2.1.2 A estrutura do signo toponímico.................................................. 33

2.1.3 Taxionomias toponímicas....................................................... 35

2.1.3.1 Taxionomias de natureza física.................................................. 35

2.1.3.2 Taxionomias de natureza antrópica.............................................. 38

3 METODOLOGIA, ORGANIZAÇÃO E ESTABELECIMENTO

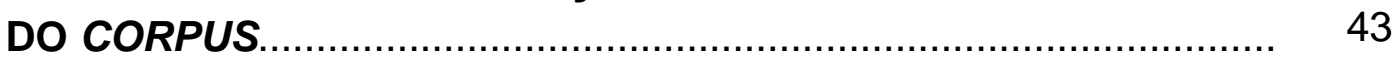

3.1 Etapas da pesquisa...................................................................... 43

3.2 Estabelecimento do corpus............................................................ 45

3.3 Levantamento e organização dos dados.......................................... 47

3.4 Fichas lexicográfico-toponímicas..................................................... 50

3.4.1 Ficha lexicográfico-toponímica de município......................................... 55

3.4.1.1 Ficha lexicográfico-toponímica de município....................................... 56

3.4.2 Ficha lexicográfico-toponímica de acidente físico................................ 60

3.4.2.1 Ficha lexicográfico-toponímica de acidente físico................................ 61

3.4.3 Ficha lexicográfico-toponímica de acidente humano............................ 62

3.4.3.1 Ficha lexicográfico-toponímica de acidente humano........................... 63

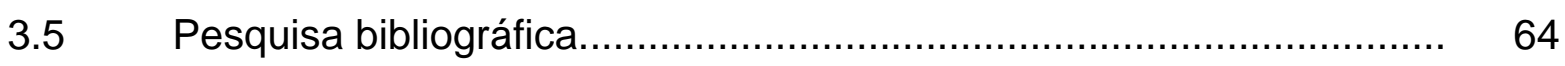

3.6 Análise e tratamento dos dados........................................................ 64

$4 \quad$ CARACTERÍSTICAS GERAIS E ANÁLISE TOPONÍMICA................ 67

4.1 Características gerais do estado de Mato Grosso................................ 67

4.1.1 Algumas características históricas dos primeiros povoamentos.......... 67

4.1.2 Algumas características atuais do estado de Mato Grosso.................. 72

4.2 Mesorregião Sudeste Mato-grossense.............................................. 80

4.2.1 Características gerais da mesorregião Sudeste Mato-grossense.......... 80 
4.3 Microrregião Alto Araguaia......................................................... 83

4.3.1 Características gerais da microrregião Alto Araguaia........................... 83

4.3.2 Características gerais do município de Alto Araguaia........................... 86

4.3.3 Características gerais do município de Alto Garças............................. 99

4.3.4 Características gerais do município de Alto Taquari............................ 109

4.3.5 Análise toponímica da microrregião Alto Araguaia............................... 113

4.4 Microrregião Primavera do Leste.................................................... 179

4.4.1 Características gerais da microrregião Primavera do Leste.................. 179

4.4.2 Características gerais do município de Campo Verde.......................... 181

4.4.3 Características gerais do município de Primavera do Leste................... 187

4.4.4 Análise toponímica da microrregião Primavera do Leste....................... 191

4.5 Microrregião Rondonópolis.......................................................... 230

4.5.1 Características gerais da microrregião Rondonópolis........................... 230

4.5.2 Características gerais do município de Dom Aquino........................... 232

4.5.3 Características gerais do município de Itiquira.................................... 237

4.5.4 Características gerais do município de Jaciara.................................. 245

4.5.5 Características gerais do município de Juscimeira............................... 249

4.5.6 Características gerais do município de Pedra Preta............................ 254

4.5.7 Características gerais do município de Rondonópolis........................... 260

4.5.8 Características gerais do município de São José do Povo..................... 267

4.5.9 Características gerais do município de São Pedro da Cipa................... 271

4.5.10 Análise toponímica da microrregião Rondonópolis............................... 275

4.6 Microrregião Tesouro............................................................. 352

4.6.1 Características gerais da microrregião Tesouro................................ 352

4.6.2 Características gerais do município de Araguainha............................. 354

4.6.3 Características gerais do município de General Carneiro.................... 359

4.6.4 Características gerais do município de Guiratinga.............................. 365

4.6.5 Características gerais do município de Pontal do Araguaia................... 378

4.6.6 Características gerais do município de Ponte Branca........................... 384

4.6.7 Características gerais do município de Poxoréu................................. 389

4.6.8 Características gerais do município de Ribeirãozinho........................... 398

4.6.9 Características gerais do município de Tesouro.................................. 402

4.6.10 Características gerais do município de Torixoréu................................ 409

4.6.11 Análise toponímica da microrregião Tesouro....................................... 417

CONSIDERAÇÕES FINAIS ....................................................... 509 


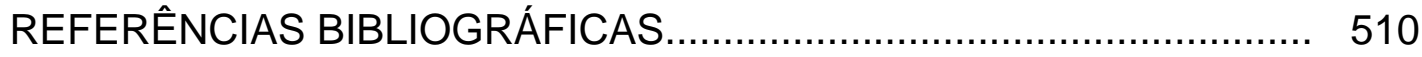

MAPAS MUNICIPAIS ..................................................... 517

CARTAS TOPOGRÁFICAS........................................... 519

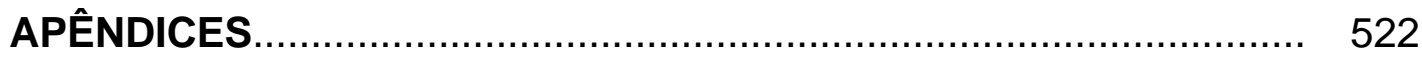

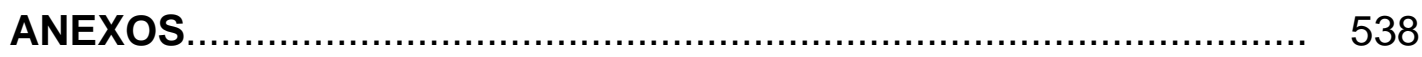




\section{INTRODUÇÃO}

Esta tese apresenta os resultados da pesquisa toponímica realizada nos mapas e nas cartas topográficas dos 22 (vinte e dois) municípios que compõem a mesorregião Sudeste Mato-grossense no estado de Mato Grosso. O objetivo desta pesquisa é elaborar o Atlas Toponímico da Mesorregião Sudeste Mato-grossense que será parte integrante do Atlas Toponímico de Mato Grosso (ATEMT) relativo, de modo mais sistemático, ao método do Atlas Toponímico Brasileiro (ATB), Dick (1994).

Mato Grosso é um estado de riquezas expressivas nas áreas sócioeconômico-culturais que se refletem também em sua toponímia. Na mesorregião Sudeste Mato-grossense não se constata a variada gama de acidentes físicos que compõem a mesorregião Centro-Sul Mato-grossense que foi pesquisada para a dissertação de mestrado. No geral, a mesorregião Sudeste Mato-grossense apresenta quantidades significativas de acidentes físicos com características comuns aos demais acidentes físicos brasileiros: cabeceira, córrego, lagoa, morro, ribeirão, rio, serra.

Alguns fatores motivaram a continuidade do desenvolvimento da pesquisa toponímica em uma segunda mesorregião mato-grossense. O primeiro já foi mencionado no parágrafo anterior. O segundo foi o desafio de realizar nova pesquisa que, de antemão, sabia-se que não abrangeria área tão vasta quanto a primeira mesorregião pesquisada, mas que possibilitaria, por meio de estudo lexicográfico-toponímico, inventariar os topônimos da mesorregião Sudeste Matogrossense, classificá-los taxionomicamente, desenvolver a análise toponímica correspondente e, conseqüentemente, montar um banco de dados toponímicos que permitirá o desenvolvvimento de posteriores estudos.

O estudo sistematizado possibilita o desenvolvimento de uma pesquisa acadêmica que demonstra aspectos antrópicos, lingüísticos, etnolingüísticos, históricos, etc. característicos dos povos de uma determinada região. Às vezes, investigações desenvolvidas para analisar lingüisticamente alguns topônimos podem 
conduzir a resultados inesperados e, até mesmo, surpreendentes. Essas investigações toponímicas podem constituir-se em um desafio para o pesquisador devido à existência de outros fatores, como, por exemplo: o isolamento da região, o desconhecimento do denominador, a opacidade dos topônimos.

A ação de nomear ou denominar lugares estabelece relações que denotam aspectos variados das atividades humanas: sociais, políticos, religiosos, culturais, regionais, econômicos, entre outros. Esses aspectos podem apresentar-se com características regionais, mais específicas ou gerais. É certo também que algumas delas são mais produtivas em acidentes físicos que em acidentes antrópicos, mas em geral, isso não constitui regra; podem apresentar-se, diferentemente, em um ou em outro nível, e pode-se até mesmo, observar que são variáveis de acordo com as especificidades das regiões.

Genericamente, os topônimos dos acidentes físicos são mais estáveis e mais espontâneos do que os antrópicos e representam mais o aspecto de anonimato do denominador. Esses fatores, às vezes, apresentam-se como obstáculos às classificações taxionômicas, porque de certa forma contribuem para a opacidade dos topônimos, ou seja, dificultam a recuperação do significado dos topônimos.

O terceiro fator aponta para um aspecto mais acadêmico: elaborar o Atlas Toponímico da Mesorregião Sudeste Mato-grossense, a fim de que venha a ser parte integrante do Atlas Toponímico do Estado de Mato Grosso. O acervo toponímico de Mato Grosso é muito amplo e rico, por isso tem-se a convicção de que seja possível desenvolver uma pesquisa acadêmica ampla e de bom nível. Estes estudos somar-se-ão aos estudos já elaborados ou em fase de elaboração, coordenados pela pesquisadora Dick, nos estados de São Paulo, Mato Grosso do Sul, Tocantins, etc.

O Atlas Toponímico requer, para sua elaboração, um somatório de esforços. Sabe-se, também, que desenvolver um estudo sincrônico e composto, em maioria quase absoluta, por topônimos de acidentes físicos e buscar suas motivações, não constitui tarefa fácil, devido principalmente, aos fatores anteriormente citados. 
O estado de Mato Grosso é o limite ocidental do Brasil e foi conquistado, ou melhor, constituído pelo "deslocamento" da linha imaginária do Tratado de Tordesilhas (acordo firmado entre Portugal e Espanha) para além do rio Paraguai. Essa expansão territorial só foi possível pelo destemor, ousadia, espírito de aventura, busca de riquezas por centenas e centenas de seres humanos, em sua maioria, anônimos, porque poucos nomes são mencionados, nas páginas da História.

Mencionam-se esses fatos para reforçar a tese da dificuldade de contextualizar todos os topônimos. Isso ocorre porque muitos deles já existiam antes mesmo da chegada dos "mamelucos paulistas" e que depois foram seguidos por outros aventureiros. No caso específico da mesorregião Sudeste Mato-grossense pode-se supor que foram os garimpeiros, sobretudo os de diamante que, provavelmente, denominaram grande quantidade de acidentes. Esses topônimos constituem um acervo antropológico-histórico-geográfico, sintetizando, cultural, não só da conquista destas terras, mas também da sua manutenção e posse, bem como, do processo de reconquista de parte delas como território mato-grossense.

O estado de Mato Grosso apresenta aspectos singulares e particulares na unidade nacional do Brasil. Talvez seja oportuno inserir aqui a observação feita por um estudioso da Geografia, da História e da Cultura mato-grossense. Para esse Historiador, há um aspecto geral no estado de Mato Grosso que destaca-se mais que a sua riqueza vegetal: é a sua riqueza hidronímica. Na opinião dele, o topônimo que hoje particulariza o estado de Mato Grosso e o classifica taxionomicamente, como um fitotopônimo não demonstra a sua principal característica:

Mais do que as plantas, cuja marca se gravou, embora impropriamente, no próprio título da Capitania, quando criada, os rios desempenham papel preponderante no devassamento e ocupação do território mato-grossense. Corrêa Filho (1962, p.42)

A principal característica de Mato Grosso, mencionada acima pelo pesquisador, está demonstrada pela gama variada e quantitativa de acidentes hídricos que existem em todo estado de Mato Grosso. As relações dos topônimos antecedidos pelos respectivos acidentes físicos, de cada um dos municípios que 
integra o corpus desta pesquisa, evidenciam esta inestimável riqueza. O potencial hídrico de Mato Grosso é resultante do somatório dos pequenos caudais que se juntam formando grandes rios que fazem parte de três bacias hidrográficas do nosso país.

A mesorregião já pesquisada e a que compõe esta pesquisa trazem em si, por meio de seus municípios, afinidades e contrastes que apresentam-se de tal modo inter-relacionados como se formassem um todo. Há municípios que diferem, um do outro, principalmente quanto ao aspecto geomorfológico, de modo bem nítido. Por outro lado, entretanto, apresentam características comuns que os unem como, por exemplo, seus cursos d'água pertencem a uma das três bacias hidrográficas: Amazônica, Araguaia-Tocantina ou Pratina.

Este estudo apresenta o levantamento dos topônimos dos municípios que formam a mesorregião Sudeste Mato-grossense, classifica-os taxionomicamente e desenvolve um estudo lingüístico dos topônimos sudeste-mato-grossenses, registrados nos mapas e nas cartas topográficas que compõem o corpus desta pesquisa. 


\subsection{Tema}

Toponímia Sudeste Mato-grossense

\subsection{Título}

Contribuições para o Atlas Toponímico do Estado de Mato Grosso Mesorregião Sudeste Mato-grossense

\subsection{Objetivos}

Esta tese tem por objetivo principal apresentar o resultado do estudo toponímico em 22 (vinte e dois) municípios mato-grossenses que integram a mesorregião Sudeste Mato-grossense. Todos os topônimos estudados nesta pesquisa estão registrados em mapas elaborados nas três últimas décadas do século XX, pela Fundação de Pesquisas Cândido Rondon (FCR) e Secretaria de Estado de Planejamento e Coordenação Geral do Estado de Mato Grosso (SEPLAN - MT) e em cartas topográficas elaboradas pelo Instituto Brasileiro de Geografia e Estatística (IBGE) e pela Diretoria de Serviço Geográfico (DSG) do Ministério do Exército. As cartas topográficas usadas para coleta dos topônimos foram publicadas em 1976.

Todos os mapas e as cartas topográficas estão editados em escala de 1:100.000. Esta escala é considerada de bom padrão para pesquisas desta natureza, com bom nível de abrangência das características geomorfológicas da região, e conseqüentemente, de registros dos acidentes físicos e acidentes antrópicos com seus respectivos topônimos. Atende também, a uma das condições para integrar o Atlas Toponímico do Brasil. Dick (1994). 
O estado de Mato Grosso está composto por 05 (cinco) mesorregiões que subdividem-se em 22 (vinte e duas) microrregiões. Essas microrregiões estão formadas por 141 (cento e quarenta e um) municípios. Nesta segunda etapa, optouse por eleger, para elaboração preliminar do Atlas Toponímico, o estudo dos topônimos dos municípios que encontram-se na mesorregião Sudeste Matogrossense que está formada por 04 (quatro) microrregiões, as quais agregam 22 (vinte e dois) municípios.

Para realizar esta pesquisa toponímica, foram tomados como base os pressupostos teóricos contidos em Dick (1980, 1990 e 1994), para investigar a natureza semântica e as estruturas dos topônimos de acordo com as categorias taxionômicas propostas pela Autora, e também, desenvolver um estudo lingüístico dos topônimos registrados nos mapas e nas cartas topográficas.

Assim, foram estabelecidos os seguintes objetivos que norteiam esta pesquisa:

- levantar nos mapas e nas cartas topográficas os acidentes toponimizados;

- classificá-los taxionomicamente;

- analisar a representatividade dos topônimos indígenas no geral e dos tupis e bororos em particular, tanto no que se refere à quantificação quanto à acepção específica, por municípios e por microrregiões.

Para desenvolver a pesquisa toponímica da mesorregião Sudeste Matogrossense e alcançar os objetivos acima propostos, fez-se necessário estabelecer os seguintes recortes, devido principalmente, ao volume de topônimos a ser estudado:

a. estudar apenas os topônimos que se referem a:

a.1. acidentes físicos: baías, córregos, morros, ribeirões, rios, serras, etc.;

a.2. acidentes antrópicos: colônias, distritos, localidades, povoados, municípios, terras indígenas e vilas; 
b. não incluir nesta pesquisa os topônimos referentes aos demais acidentes humanos, tais como: escolas, estradas, fazendas, pontes, retiros, ruas, sítios, etc.;

c. o resultado da pesquisa deve ser apresentado por municípios, por meio de relações de topônimos e, em seguida, a análise dos mesmos agrupados por microrregiões, no contexto geral da mesorregião.

Com base no levantamento inicial, chegou-se à conclusão de que, apesar do grande volume de topônimos encontrados, seria possível desenvolver uma pesquisa profunda e que abrangesse, totalmente, a área de cada um dos municípios pesquisados. A pesquisa ficaria bastante ampla, porém, passível de ser realizada e, certamente, proporcionaria resultados satisfatórios.

\subsection{Justificativa}

O estudo dos topônimos de uma determinada região pode constituir, ao mesmo tempo, um registro científico, um resgate e, até mesmo, a preservação da cultura e da memória dos povos que habitaram e ainda habitam determinado lugar. No Brasil, existe hoje um progressivo aumento nas pesquisas toponímicas e esses estudos demonstram a importância da disciplina no contexto acadêmico.

Acredita-se que as pesquisas pioneiras, realizadas por vários pesquisadores no exterior e em vários estados brasileiros, artigos publicados nesta área por Dauzat, Rostaing, Backheuser, Drumond e Dick, no que concerne às análises dos topônimos, dão os suportes necessários ao trabalho. As pesquisas e os artigos publicados por Dick, iniciados com sua tese de doutoramento em 1980 e que tiveram prosseguimento nos anos subseqüentes, estabeleceram no Brasil, um marco firme e divisor nesta área. Pode-se considerar que são trabalhos que serviram e servem de base para estudos e pesquisas realizadas em vários estados. 
Esta tese apresenta o estudo dos topônimos registrados em apenas uma das mesorregiões do estado de Mato Grosso, mas eles proporcionam um rico cabedal toponímico que deve ser lingüisticamente pesquisado e classificado taxionomicamente.

O objetivo de desenvolver uma pesquisa nesta área e a decisão por trabalhar nesta tese, apenas com os topônimos dos acidentes físicos e dos aglomerados humanos, mencionados no subitem anterior, limitou o corpus em 2.348 (dois mil trezentos e quarenta e oito) topônimos. A inclusão dos demais acidentes humanos propiciaria um estudo mais amplo da toponímia da mesorregião Sudeste Matogrossense, porém, proporcionaria um aumento bem considerável no total dos topônimos a ser analisado. Alguns motivos se destacam na opção por esses recortes na pesquisa toponímica:

- Mato Grosso, desde os seus primórdios, sempre teve uma posição geopolítica de grande importância para o país e, atualmente, tem também destacado valor na economia nacional;

- Mato Grosso é pólo aglutinador de pessoas oriundas de todos os estados do Brasil, assim como, de muitos países estrangeiros e isso, de certa forma, reflete-se na toponímia da região;

- Mato Grosso está constituído por 22 (vinte e duas) microrregiões que são ricas em acidentes físicos, algumas com características especificamente regionais;

- Com o acentuado desenvolvimento social e econômico ocorrido, principalmente, a partir da segunda metade do século passado, o estado de Mato Grosso (apesar da divisão territorial de 1977, com a cessão de parte de sua área para criar o estado de Mato Grosso do Sul) tem apresentado um ritmo constante e crescente de desenvolvimento econômico, social, demográfico, cultural. Esses fatores provocam um acréscimo proporcional na toponímia antrópica.

Esta pesquisa pretende ser exaustiva, de acordo com a metodologia indicada e a área recortada. O método adotado foi o indutivo-dedutivo, seguindo o percurso onomasiológico de investigação. 
Assim, este trabalho se justifica como uma pesquisa lingüística que visa elaborar um inventário toponímico de 04 (quatro) microrregiões mato-grossenses e que por meio da análise toponímica, dá sua cota de contribuição para consolidar e, até mesmo, se possível, resgatar parte da cultura regional e, conseqüentemente, conter as condições acadêmicas necessárias para compor parte do Atlas Toponímico do Estado de Mato Grosso. 


\section{FUNDAMENTAÇÃO TEÓRICA}

\subsection{Princípios da Toponímia}

A Toponímia ou o estudo dos nomes de lugares é um dos segmentos da Onomástica, dentro da Ciência Lingüística. Outro segmento da Onomástica é a Antroponímia ou o estudo dos nomes próprios individuais. O termo toponímia é a aglutinação de dois radicais gregos topos + onoma, topos significa lugar e onoma nome. Desse modo ambos estão contidos no sistema onomástico - Toponímia e Antroponímia - e este no sistema lingüístico.

Uma definição mais abrangente do termo toponímia pode variar dependendo do aspecto, ou melhor, da ênfase que se queira dar ao estudo que vai ser realizado. Como este termo é considerado semanticamente rico, insere-se aqui uma breve pesquisa lexicográfica do termo toponímia, registrado na macroestrutura de três dicionários brasileiros, e também no dicionário de lingüística, muito embora se reconheça que as acepções aqui registradas possam não abranger todos os aspectos desta ciência. O dicionário Aurélio o registra assim: "Toponímia S. f. Estudo lingüístico ou histórico da origem dos topônimos." Aurélio (1975, p. 1388).

toponímia s.f. (1899 cf. CF) 1 LEX parte da onomástica que estuda os nomes próprios de lugares 2 lista, relação de topônimos 3 estudo etimológico e/ou histórico sobre os topônimos [Compreende diversas subdivisões, como corônimos, limnônimos, eremônimos, potamônimos, talassônimos, etc.] 4 p.met. livro (ou outro suporte) que contém tal relação ou estudo. Houaiss (2001, p. 2735).

toponímia Nf [Abstrato de estado] 1 estudo da origem dos topônimos: a toponímia, todavia, é muito rica em termos designativos para os cursos de água menores (GEO) [Concreto] 2 conjunto de nomes de lugar: as planícies de inundação, conhecidas como várzeas na toponímia popular do Brasil, constituem a forma mais comum de sedimentação fluvial. (GEO) Borba (2002, p. 1551).

toponímia é a parte da lingüística que se ocupa da origem dos nomes de lugares, de suas relações com a língua do país, com as línguas de outros países ou com as línguas desaparecidas. A matéria é geralmente dividida segundo a geografia (há especialistas de nomes 
de rios, de nomes de montanhas; há especialistas também para esta ou aquela região determinada).

A mais importante verificação da toponímia, num plano geral, é que existem poucas relações entre os nomes de lugares de um país e a língua do povo que o habita. Explica-se isto pela forte resistência dos substratos neste domínio.

É assim que grande parte dos nomes dos estados, de cidades e de acidentes geográficos da América do Norte, Central e do Sul são de origem indígena. Dubois et al.(1973, p. 590).

Portanto, este estudo tem caráter interdisciplinar e se inter-relaciona com a Geografia, História, Lexicologia, Lexicografia, Antropologia, Cartografia, etc.

[...] a Toponímia é, antes de tudo, um imenso complexo lingüísticocultural, em que os dados das demais ciências se interseccionam necessariamente e, não, exclusivamente. Dick (1980, p.8)

Vale ressaltar que a Toponímia é reconhecida como disciplina autônoma desde a segunda metade do século XIX. Os primeiros estudos e pesquisas foram realizados no continente europeu, e logo, destacaram-se e começaram a conquistar interesse e dedicação de pesquisadores em vários países e em várias áreas do conhecimento humano acima descritas. Esses estudiosos se predispuseram a seguir os passos dos primeiros investigadores e pesquisadores, já citados. Logo depois, porém, expandiram e aprofundaram esses conhecimentos, de acordo com as circunstâncias e características próprias das regiões ou países estudados.

$\mathrm{O}$ ato de nomear sempre fez parte do cotidiano de todo e qualquer grupo humano. Dar nomes a lugares e a pessoas permite a individualização e a identificação de pessoas e de lugares. $O$ ato de denominar permite maior interação entre os seres humanos e uma maior interação das pessoas com o meio em que vivem. Esses aspectos são assim evidenciados:

A nomenclatura geográfica de uma região encerra, na tipicidade de suas designações, amplas possibilidades de estudo. A tessitura toponímica, com efeito, longe está de ser monótona no significado que recobre ou destituída de interesse prático ou científico. Através das camadas onomásticas, revelam-se, numa perspectiva globalizante, as feições características do local, sejam as de ordem física quanto sócio-culturais. De tal modo esses aspectos se corporificam nos topônimos que se pode, mesmo, muitas vezes, 
estabelecer a correlação entre o "nome" dos acidentes e o "ambiente" em que ele se acha inscrito. Dick (1992, p.35)

Na mesorregião Sudeste Mato-grossense há topônimos que em muitos casos demonstram características específicas nos acidentes físicos existentes, como: Vermelha (serra), Azul (morro), Verde (córr.), etc. (evidenciando o seu aspecto cromático). Às vezes, ocorre a substantivação do adjetivo e, assim, os topônimos passam a destacar os aspectos descritivos, tais como: Bonito (rib.), Feio (córrego), Tortinho (córr), etc. ou, até mesmo, a transformação de acidentes físicos em topônimos: Cachoeira (córr.), Cachoeirinha (córr.), Ribeirãozinho (córr.), etc. Essas denominações serão mais amplamente estudadas no capítulo que contém as características gerais dos municípios, as relações dos topônimos e as análises dos topônimos das microrregiões Alto Araguaia, Primavera do Leste, Rondonópolis e Tesouro.

\title{
2.1.1 O signo toponímico
}

O topônimo é, em princípio, uma unidade lexical como outra qualquer da língua na qual está inserido. Neste trabalho, usam-se as designações unidade lexical, lexia, vocábulo e termo como parassinônimos, indistintamente. O toponimista francês transcreve a seguinte citação de Muret (1930) que reitera esse conceito:

\begin{abstract}
Un nom de lieux (cést évident, mais on n'y prend pas garde) est une forme de langue, un mot formé, comme tous les autres, de voyelles et de consonnes, de phonèmes articulés par les organes de la parole et transmis par l'oreille au cerveau. II ne saurait donc être étudié autrement qu'un autre mot quelconque, en dehors de la langue dont il fait partie et dont il porte l'empreinte. "Ces lignes de M. Ernest Muret situent exactement le problème. Le toponyme est un mot comme les autres, soumis aux lois de la phonétique. Rostaing $(1969, \text { p.9 })^{1}$.
\end{abstract}

\footnotetext{
${ }^{1}$ Um nome de lugar (isso é evidente, mas não se leva em conta) é uma forma de língua, uma palavra formada, como todas as demais, de vogais e de consoantes, de fonemas articulados pelos órgãos da fala e transmitidos pelos ouvidos ao cérebro. Logo, ela não poderia ser estudada diferentemente de outra palavra qualquer, fora da língua a qual pertença e da qual ela leva marca". Essas linhas de Sr. Ernest Muret situam, exatamente, o problema. O topônimo é uma palavra como as outras, submetido às leis da fonética.
} 
Nesta pesquisa toponímica a unidade lexical que exerce a função de topônimo é analisada quanto ao seu valor semântico (aquele que estiver, de modo específico, relacionado ao significado) para que possa ser classificada taxionomicamente. Para esse procedimento são feitas pesquisas em dicionários de língua geral, principalmente Houaiss e, quando necessário, em dicionários de línguas indígenas, porque, em geral, as unidades lexicais se mostram polissêmicas. Devido a esse fato (as várias acepções) e, também, pela estrutura da ficha lexicográfico-toponímica, pode $(\mathrm{m})$ ocorrer recorte(s) na microestrutura da unidade lexical. Em sua maioria, os topônimos são formados por substantivos comuns que se transformam em substantivos próprios, modificados, ou não, por um adjetivo, ou até mesmo, por um conectivo.

A unidade lexical usada na denominação do acidente, e que não estiver dicionarizada, será pesquisada em outras obras, quais sejam: enciclopédias, dissertações, livros, revistas, teses, internet e, até mesmo, se necessário, em pesquisa de campo, para que sejam reduzidos, ao mínimo possível, os topônimos sem classificações taxionômicas.

As justificativas mostram-se necessárias porque a pesquisa toponímica é realizada por meio de levantamentos cartográficos e, nem sempre, é possível inferir a motivação do denominador. O pesquisador francês faz referência a esse fato.

Tout nom de lieu a une signification mais cette signification a pu, pour diverses raisons, n'être plus perceptible pour les habitants. Parfois le mot s'est cristallisé et on ne l'a plus compris.... Parfois par une partie de ses éléments il se rapprochait d'un mot don't le sens était connu et consciemment (si l'on avait le sentiment d'une mauvaise prononciation ou d'une "faute") ou inconsciemment, on a corrigé le mot et on l'a inséré dans une série où il n'avait que faire: l'étymologie populaire ou attraction paronymique a alors agi. ... Rostaing (1969, p.13) $)^{2}$

\subsubsection{A estrutura do signo toponímico}

\footnotetext{
2 Todo nome de lugar tem um significado, mas esse significado pode, por diversas razões, não ser mais perceptível por seus habitantes. As vezes a palavra se cristalizou e não é mais possível compreendê-la..." As vezes por uma parte de seus elementos formadores ela se aproximava de uma palavra cujo sentido era conhecido e conscientemente (se havia a impressão de uma má pronúncia ou de um "erro") ou inconscientemente, a palavra foi corrigida e inserida em uma série da qual não fazia parte: a etimologia popular ou atração paronímica então agiu...
} 
Nos mapas e nas cartas topográficas o topônimo é registrado acompanhado por um termo antecedente, com o qual forma um sintagma toponímico:

\begin{abstract}
Ao designar, tradicionalmente, o nome próprio de lugar, o topônimo, em sua formalização na nomenclatura onomástica, liga-se ao acidente geográfico que identifica, com ele constituindo um conjunto ou uma relação binômica, que se pode seccionar para melhor se distinguir os seus termos formadores.

Dessa simbiose, depreende-se dois dados básicos, um que se convencionou denominar termo ou elemento genérico, relativo à entidade geográfica que irá receber a denominação, e o outro, o elemento ou termo específico, ou topônimo propriamente dito, que particularizará a noção espacial, identificando-a e singularizando-a dentre outras semelhantes. Dick (1992, p.10)
\end{abstract}

Assim, o sintagma toponímico é formado por um termo genérico que é o acidente físico ou o acidente humano propriamente dito, seguido do termo específico que é o topônimo do acidente. O termo genérico pode apresentar-se preposicionado ou não, como por exemplo: vila, vila da, rio, rio do, serra, serra das, lagoa, lagoa dos, etc. Vale ressaltar que, neste trabalho, os termos genéricos, per si, não são objeto de pesquisa. Casos há, no entanto, em que o conectivo (preposição + artigo definido) do termo genérico interfere diretamente no(s) valor(es) semântico(s) do(s) topônimo(s), isto é, interfere na classificação taxionômica. São os topônimos ou termos específicos que constituem o corpus desta pesquisa. Deve-se, ainda registrar, que nesta pesquisa, as unidades lexicais antropo-cultural, antrópico e humano possuem o mesmo valor semântico.

Quanto a suas estruturas, podem os topônimos ser classificados em: simples, compostos e híbridos. Os critérios utilizados para a classificação dos topônimos nestas três estruturas foram desenvolvidos pela pesquisadora. Vale registrar, todavia, que os topônimos usados como exemplos, neste caso específico, fazem parte do corpus desta pesquisa.

Entramos, assim, paulatinamente, na composição morfológica dos toponomásticos, ou melhor dizendo, nos elementos que os distribuem em específicos simples, compostos ou híbridos.

(...)

elemento específico simples é aquele que se faz definir por um só formante (seja substantivo ou adjetivo, de preferência), podendo, contudo, se apresentar, também, acompanhado de sufixações 
(diminutivos, aumentativos ou outros de procedência lingüística): Bonito (córr.), Divisa (córr.), Barreirinho (córr.), Estrela (serra), Cervo (córr.), Onça (córr.), Olaria (córr.), Cutia (córr.), Mata (córr.), Pedras (córr.);

topônimo composto ou elemento específico composto é aquele que se apresenta com mais de um elemento formador, de origens diversas entre si, do ponto de vista do conteúdo, gerando, por isso, às vezes, formações inusitadas que, talvez, apenas a história local poderá elucidar, convenientemente: Vista Alegre (córr.), Retiro das Éguas (córr.), Quebra Pigarro (córr.), Campo Bonito (córr.), Quebracabeça (córr.), Água Amarela (córr.), Gato Preto (rib.), São Francisco (córr.), Campestre Grande (córr.), Morro Vermelho (serra);

topônimo híbrido ou elemento específico híbrido, como o entendemos, é aquele designativo que recebe em sua configuração elementos lingüísticos de diferentes procedências; a formação que se generalizou no país é a portuguesa + indígena ou a indígena + portuguesa: Buriti Alto (córr.), Buritizinho (córr.), Macaúbas (córr.), Pindaibão (córr.), Capão Redondo (córr.), Alto Taquari (município), Cabeceira da Macaúba (córr.) Dick (1992, p. 13-14).

\subsubsection{Taxionomias toponímicas}

A classificação dos topônimos, no que se refere ao conteúdo léxicosemântico, é feita com base nas taxionomias toponímicas elaboradas por Dick, mas os topônimos utilizados para exemplificação em cada uma das taxionomias estão contidos no corpus deste trabalho.

Após a conclusão dessa etapa: a classificação dos topônimos da mesorregião Sudeste Mato-grossense, constatou-se que há 01 (um) topônimo que não foi classificado porque não se conseguiu (ainda) recuperar o valor semântico que lhe é correspondente.

As taxionomias subdividem-se em taxionomias de natureza física e em taxionomias de natureza antropo-cultural:

\subsubsection{Taxionomias de natureza física}


1) Astrotopônimos: topônimos relativos aos corpos celestes em geral: serra da Estrela (Alto Garças), córrego Saturno (Guiratinga), Jaciara (município).

2) Cardinotopônimos: topônimos relativos às posições geográficas em geral: córrego do Meio (Alto Araguaia), córrego da Divisa (Alto Garças), Alto Taquari (município), Alto Coité (distrito).

3) Cromotopônimos: topônimos relativos à escala cromática: morro Azul (Alto Araguaia), córrego Vermelho (Alto Araguaia), serra Preta (Alto Taquari), cabeceira Escura (Primavera do Leste), ribeirão Claro (Campo Verde), córrego Verde (Dom Aquino).

4) Dimensiotopônimos: topônimos relativos às características dimensionais dos acidentes geográficos, como extensão, comprimento, largura, grossura, espessura, altura, profundidade: córrego Comprido (Alto Garças), córrego Fundo (Alto Araguaia), córrego Grande (Alto Araguaia), córrego Pequeno (Torixoréu).

5) Fitotopônimos: topônimos de índole vegetal, espontânea, em sua individualidade: córrego Bacuri (Alto Araguaia), córrego do Cipó (Alto Araguaia), córrego Jatobá (Alto Garças), córrego Aricá (Campo Verde), córrego do Sapé (Primavera do Leste), córrego Babaçu (Rondonópolis), córrego Cambará (Juscimeira), córrego Mangabeira (Pontal do Araguaia), córrego Mumbeca (Guiratinga);

- em conjuntos da mesma espécie: córrego Laranjal (Alto Araguaia), córrego do Pinhal (Alto Garças), córrego Curitiba (Alto Garças), córrego do Buritizal (Campo Verde), córrego Indaial (Itiquira), córrego Cocal (Ribeirãozinho), córrego Goiabal (Torixoréu), córrego Bananal (Rondonópolis);

- ou de espécie diferente: córrego do Mato (Alto Araguaia), córrego das Flores (Alto Garças), córrego da Capoeira (Itiquira), córrego Cerradinho (Juscimeira), córrego Capão Redondo (Torixoréu), córrego Pindaibão (Pontal do Araguaia).

- além de formações não espontâneas individuais: córrego da Melancia (Alto Araguaia), córrego Cafezinho (Alto Garças), córrego Cacau (Alto Garças), córrego do Maxixe (Alto Araguaia), córrego da Mamona (Rondonópolis), serra da Pimenta 
(Dom Aquino), rio Coité (Poxoréu), córrego Laranjeira (Pontal do Araguaia), córrego Manjerona (Tesouro).

6) Geomorfotopônimos: topônimos relativos às formas topográficas: elevações de terrenos: córrego Chapada (Alto Araguaia), córrego da Vertente Comprida (Pedra Preta), serra do Espigão Mestre (Itiquira), córrego da Serra (Pedra Preta), córrego da Ilha (Itiquira), Torixoréu (município), córrego Monte Negro (Pontal do Araguaia), córrego Morro Alto (Ponte Branca);

- depressões de terrenos: córrego Baixadão (Alto Araguaia), córrego Várzea (Campo Verde), córrego Grota (Rondonópolis), córrego Esbarrancado (Ponte Branca), distrito Vale Rico (Guiratinga).

7) Hidrotopônimos: topônimos resultantes de acidentes hidrológicos em geral. Ex.: córrego Água Branca (Alto Araguaia), córrego Água Limpa (Alto Garças); córrego da Cachoeira (Alto Araguaia), córrego Cabeceira do Pontal (Pedra Preta), córrego Corgão (Juscimeira), Itiquira (município), ribeirão Parnaíba (Dom Aquino), vazante Riozinho (Itiquira), córrego Lagoa (Ponte Branca), rio Poxoréo (Poxoréu).

8) Igneotopônimos: topônimos relativos ao fogo, abrangendo todos os produtos resultantes de sua ação direta: morro do Fogo (Alto Araguaia), córrego da Faísca (Itiquira), cachoeira da Fumaça (Jaciara), córrego Queimadinha (Torixoréu).

9) Litotopônimos: topônimos de índole mineral, relativos também à constituição do solo, representados por indivíduos: córrego Barro Preto (Alto Garças), córrego Lajeadinho (Alto Araguaia), córrego da Areia (Alto Garças), córrego Cupim (Campo Verde), morro do Chibiu (Dom Aquino), córrego do Ouro (Pedra Preta), córrego Prata (Itiquira), córrego Barreiro (Araguainha), córrego da Lama (General Carneiro), córrego do Sal (Torixoréu);

- conjunto da mesma espécie: córrego das Pedras (Alto Araguaia), ribeirão Pedreiras (Alto Garças), córrego Pedregulho (Guiratinga), córrego Lajes (Campo Verde).

10) Meteorotopônimos: topônimos relativos a fenômenos atmosféricos: morro da Neblina (Alto Araguaia), córrego do Trovão (Alto Araguaia), Primavera do 
Leste (município), cabeceira da Chuva (Itiquira), córrego Votuporanga (Rondonópolis), córrego Corisco (General Carneiro).

11) Morfotopônimos: topônimos que refletem o sentido de forma geométrica: córrego Atravessado (Alto Garças), córrego Tortinho (Alto Araguaia), morro Chato (Guiratinga), morro Redondo (Tesouro), córrego da Volta (Tesouro).

12) Zootopônimos: topônimos de índole animal, representados por indivíduos domésticos: córrego do Cavalo (Alto Garças), córrego dos Bois (Alto Araguaia), córrego do Burro (Alto Araguaia), córrego dos Porcos (Dom Aquino), córrego da Vaca (Pedra Preta), córrego da Bezerra (Torixoréu), córrego Cadela (Tesouro), córrego da Égua (Pontal do Araguaia);

- não domésticos: córrego da Anta (Alto Araguaia), córrego Cateto (Alto Araguaia), córrego do Lobo (Alto Taquari), córrego da Cobra (Guiratinga), córrego Jia (Pontal do Araguaia), córrego Beija-flor (General Carneiro), córrego Caxixe (Torixoréu);

- da mesma espécie em grupos: rio das Garças (Alto Araguaia), lagoa dos Patos (Alto Garças), córrego dos Veados (Alto Araguaia), córrego das Galinhas (Pontal do Araguaia), córrego dos Macacos (Poxoréu), córrego das Pacas (Torixoréu).

\subsubsection{Taxionomias de natureza antrópica}

1) Animotopônimos: topônimos relativos à vida psíquica, à cultura espiritual, abrangendo todos os produtos do psiquismo humano, cuja matéria prima fundamental, e em seu aspecto mais importante como fato cultural, não pertence à cultura física: córrego Boa Esperança (Alto Garças), córrego Encantado (Alto Araguaia), córrego Maravilha (Alto Garças), córrego Feio (Pontal do Araguaia), serra da Saudade (Tesouro), córrego Inveja (Poxoréu), córrego Sossego (Pontal do Araguaia), córrego Vitória (Poxoréu), córrego Triunfo (Itiquira). 
2) Antropotopônimos: topônimos relativos aos nomes próprios individuais:

- prenome: córrego do Felipe (Alto Garças), córrego do Inácio (Alto Garças), córrego do Rafael (Alto Garças), córrego do Leandro (Guiratinga), córrego do Jorge (Tesouro), córrego do Bento (Campo Verde), cabeceira do Marlo (Primavera do Leste), distrito Selma (Jaciara), córrego do Camilo (Itiquira);

- hipocorístico: córrego do Elpidão (Alto Garças), córrego do Lazinho (Alto Araguaia), cabeceira Ladinha (Campo Verde), cabeceira do Joca (Pontal do Araguaia), córrego Juca (Araguainha), córrego Luizão (General Carneiro), serra do Tonhá (Guiratinga);

- prenome + hipocorístico: córrego Júlio do Manezinho (Alto Garças), córrego João Irara (Pedra Preta);

- hipocorísitico + prenome: córrego Zé Abílio (Alto Araguaia);

- apelido de família: córrego do Amorim (Alto Garças), ribeirão do Correia (Alto Araguaia), córrego Pitaluga (Rondonópolis), córrego Gorgulho (Torixoréu), córrego Magalhães (General Carneiro), córrego Vilela (Guiratinga);

- prenome + apelido de família: córrego José Dutra (Alto Taquari), córrego Bento Ribeiro (Jaciara), córrego João Gomes (Araguainha);

- hipocorístico + nome de família: córrego Chico Nunes (Dom Aquino), córrego Chiquinha Maciel (Jaciara), córrego Chico França (Guiratinga);

- hipocorístico + hipocorístico: córrego Candinho Mineiro (Rondonópolis), córrego Chico Preto (São Pedro da Cipa);

- prenome + prenome: córrego Paulo Afonso (Tesouro), córrego João Euzébio (Torixoréu);

- apelido de família + apelido família: córrego Correia Dantas (Araguainha).

3) Axiotopônimos: topônimos relativos aos títulos e dignidades de que se fazem acompanhar os nomes próprios individuais: General Carneiro (município), 
córrego Capitão Agostim (Campo Verde), distrito Coronel Ponce (Campo Verde), ribeirão Tenente Amaral (Jaciara).

4) Corotopônimos: topônimos relativos aos nomes de cidades, países, estados, regiões e continentes: córrego da África (Alto Araguaia), córrego Babilônia (Pontal do Araguaia), córrego Bahia (Campo Verde).

5) Cronotopônimos: topônimos que encerram indicadores cronológicos representados, em Toponímia, pelos adjetivos novo/nova, velho/velha: ribeirão das Velhas (Alto Garças), córrego Novo (Pontal do Araguaia), povoado Nova Catanduva (São José do Povo).

6) Dirrematotopônimos: topônimos constituídos por frases ou enunciados lingüísticos: córrego Quebra-cabeça (Alto Araguaia), córrego Quebra Pigarro (Alto Garças), córrego Vista Alegre (Alto Araguaia), córrego Passa Três (Campo Verde), córrego Mata Cavalo (Dom Aquino), córrego Rola Burro (Guiratinga).

7) Ecotopônimos: topônimos relativos às habitações de um modo geral: córrego do Rancho (Alto Araguaia), córrego Tapera (Alto Araguaia), córrego do Castelo (Itiquira).

8) Ergotopônimos: topônimos relativos aos elementos da cultura material: córrego do Arame (Alto Taquari), córrego do Cocho (Alto Araguaia), córrego da Espora (Alto Araguaia), córrego Balão (Araguainha), córrego Bateia (Guiratinga), córrego da Clarineta (Poxoréu), córrego Monjolo (Tesouro).

9) Etnotopônimos: topônimos referentes aos elementos étnicos, isolados ou não (povos, tribos, castas): córrego dos Baianos (Alto Araguaia), córrego dos Bugres (Poxoréu), córrego Bororo (Poxoréu), serra dos Índios (Pontal do Araguaia), córrego Alagoano (São José do Povo), córrego do Goiano (Pedra Preta), córrego Xavante (Primavera do Leste).

10) Hierotopônimos: topônimos relativos aos nomes sagrados de diferentes crenças: cristã, hebraica, maometana, etc.; às efemérides religiosas; às associações religiosas; aos locais de culto: morro da Cruz (Alto Araguaia), córrego do Paraíso 
(Alto Araguaia), ribeirão das Almas (Poxoréu), córrego Salvação (São José do Povo), córrego Igrejinha (Ribeirãozinho), morro Natal (Poxoréu).

10.a. Hagiotopônimos: topônimos relativos aos santos e santas do hagiológio romano: córrego São Francisco (Alto Araguaia), córrego São José (Alto Araguaia), córrego São Paulo (Alto Araguaia), córrego São Carlos (Poxoréu), córrego São Miguel (Guiratinga), córrego São Bento (Juscimeira), córrego São Domingos (Dom Aquino).

10.b. Mitotopônimos: topônimos relativos às entidades mitológicas: córrego Inferninho (Tesouro).

11) Historiotopônimos: topônimos relativos aos movimentos de cunho histórico-social e aos seus membros, assim como às datas correspondentes: córrego Bandeira (Alto Garças), córrego Bandeirantes (Juscimeira).

12) Hodotopônimos: topônimos relativos às vias de comunicação rural ou urbana: córrego da Pinguela (Alto Araguaia), córrego da Ponte (Alto Araguaia), córrego Ponte de Terra (Alto Araguaia), córrego do Atalho (Itiquira), córrego da Vereda Grande (Rondonópolis), córrego Ponte Falsa (Campo Verde), córrego do Desvio (Poxoréu).

13) Numerotopônimos: topônimos relativos aos adjetivos numerais: córrego Dois Irmãos (Alto Garças), córrego Três Barras (Alto Garças), córrego Sete Voltas (Araguainha), morro Três Coqueiros (Rondonópolis), córrego Quarta Cabeceira (Campo Verde), córrego Sete (Poxoréu), serra Quatro Passagens (Ponte Branca).

14) Poliotopônimos: topônimos constituídos pelos vocábulos vila, aldeia, cidade, povoado, arraial: córrego da Aldeia (Alto Araguaia), córrego da Corrutela (Alto Garças), distrito Vila Operária (Rondonópolis).

15) Sociotopônimos: topônimos relativos às atividades profissionais, aos locais de trabalho e aos pontos de encontro dos membros de uma comunidade (largo, pátio, praça): córrego Boiadeiro (Alto Araguaia), córrego do Garimpo (Alto Araguaia), córrego da Roça (Alto Araguaia), córrego da Revolta (Alto Garças), 
córrego da Fazenda (Pedra Preta), córrego do Piquenique (Itiquira), cabeceira da Zorra (Rondonópolis), córrego do Trabalho (Poxoréu).

16) Somatotopônimos: topônimos empregados em relação metafórica a partes do corpo humano ou do animal: córrego Bracinho (Alto Araguaia), córrego do Guampo (Alto Araguaia), córrego do Cobreiro (Alto Araguaia), córrego das Guelas (Torixoréu), córrego Gordura (Itiquira) córrego Suspiro (Primavera do Leste). 


\title{
3 METODOLOGIA, ORGANIZAÇÃO E ESTABELECIMENTO DO CORPUS
}

\subsection{Etapas da pesquisa}

A pesquisa toponímica pode ser realizada por meio de fontes documentais, ou seja, mapas, cartas topográficas, documentos oficiais ou até mesmo em pesquisa de campo, quando o próprio pesquisador faz o levantamento da nomenclatura. O corpus desta pesquisa foi estabelecido por meio de cartas topográficas e mapas; assim, considera-se que seja pertinente inserir a acepção correspondente a cada um destes termos:

\begin{abstract}
Mapa é a representação no plano, normalmente em escala pequena, dos aspectos geográficos, naturais, culturais e artificiais de uma área tomada na superfície de uma figura planetária, delimitada por elementos físicos, político-administrativos, destinada aos mais variados usos, temáticos, culturais e ilustrativos (IBGE, 2000, p. 30).

Carta é a representação no plano, em escala média ou grande, dos aspectos artificiais e naturais de uma área tomada de uma superfície planetária, subdividida em folhas delimitadas por linhas convencionais - paralelos e meridianos - com a finalidade de possibilitar a avaliação de pormenores, com grau de precisão compatível com a escala (IBGE, 2000, p. 30).
\end{abstract}

Ao optar pela pesquisa em fontes documentais, como mapas e cartas topográficas, faz-se necessário que alguns critérios sejam observados, e um dos que mais se destaca, no caso específico de pesquisa, é a escala, que varia de acordo com o nível de abrangência que se queira atingir. Já a época da confecção dos documentos pode ou não ter aspectos relevantes, dependendo do objetivo a ser atingido pela pesquisa.

As cartas topográficas e os mapas, no geral, são elaborados para atender a um determinado objetivo e, para que estejam completos, devem registrar todos os acidentes físicos contidos na área de abrangência como córregos, ribeirões, morros, serras, etc. e também os acidentes humanos ou antrópicos, ou seja, os acidentes construídos pelos seres humanos como: lagoas artificiais, hidrelétricas, estradas, 
pontes, etc. Para que esses registros sejam possíveis, faz-se necessário compatibilizar a representação do acidente com o espaço pretendido. A esse fator dá-se o nome de escala:

É utilizada aqui a microestrutura da unidade lexical escala tal como encontrase registrada na macroestrutura do Dicionário de Geografia do Brasil:

\begin{abstract}
ESCALA
Relação entre as dimensões reais de uma superfície e a representação dessas dimensões no mapa. Ex: um mapa desenhado na escala 1 para 1.000 .000 (1:1.000.000) significa que $1 \mathrm{~cm}$ no mapa equivale a $1.000 .000 \mathrm{~cm}$ ou $10 \mathrm{~km}$ no terreno. Magalhães $(1973, \mathrm{p}$. 162).
\end{abstract}

As cartas topográficas ou os mapas elaborados na escala 1:100.000, escala considerada compatível para um boa pesquisa toponímica, de acordo com a metodologia do Atlas Toponímico do Brasil (ATB) e do Atlas Toponímico de São Paulo (ATESP). Registram características mais amplas da área cartografada e, portanto, maior quantidade de acidentes físicos e antrópicos que mapas ou cartas topográficas em escalas maiores. Com base na definição dada, um mapa elaborado na escala de 1 para 100.000 significa que $1 \mathrm{~cm}$ no mapa corresponde a $100.000 \mathrm{~cm}$ ou $1 \mathrm{~km}$ no terreno ou 1.000 metros.

Deve-se registrar que a escolha da escala foi a segunda decisão tomada com relação à pesquisa, antecedida apenas pela escolha da área a ser pesquisada. A adoção das escalas de 1:50.000 ou de 1:100.000 é norma tanto do ATB como do ATESP. Desse modo, com a localização das cartas e dos mapas em uma das escalas pretendidas: escala de 1:100.000, foram seguidas as seguintes etapas na realização da pesquisa:

- delimitação da área a ser pesquisada;

- obtenção de cópias dos mapas municipais;

- pesquisas nas cartas topográficas e nos mapas;

- levantamento dos topônimos por município;

- elaboração das relações de topônimos por município; 
- classificação dos topônimos nas taxionomias;

- elaboração e preenchimento das fichas lexicográfico-toponímicas;

- análise e tratamento dos dados.

\subsection{Estabelecimento do corpus}

Para proceder a delimitação do corpus da pesquisa foram estabelecidas várias etapas. A primeira etapa foi a seleção dos municípios, inseridos no corpus desta pesquisa, dentre os municípios mato-grossenses e, conseqüentemente, as microrregiões e a mesorregião que são formadas por eles. Estes dois termos fazem parte da nomenclatura:

O modelo atual, ao nível teórico-conceitual, parte de terminações mais amplas da totalidade nacional. As Unidades da Federação foram tomadas como universo de análise. Posteriormente, por divisões sucessivas, através do processo analítico, identificaram-se as escalas regionais subseqüentes, isto é, as mesorregiões e, finalmente, as microrregiões.

Entende-se por mesorregião uma área individualizada, em uma Unidade da Federação, que apresenta formas de organização do espaço geográfico definidas pelas seguintes dimensões: o processo social, como determinante, o quadro natural, como condicionante e, a rede de comunicação e de lugares, como elemento de articulação espacial. Estas três dimensões possibilitam que o espaço delimitado como mesorregião tenha uma identidade regional. Esta identidade é uma realidade construída ao longo do tempo pela sociedade que aí se formou. O conhecimento da realidade espacial brasileira evidencia que o Agreste, a Mata e o Sertão Nordestinos; o Sul de Minas Gerais; o Triângulo Mineiro; a Campanha Gaúcha; as áreas coloniais Antiga e Nova do Rio Grande do Sul; o Vale do Itajaí; o Norte do Paraná; o Pantanal Mato-grossense; a Bragantina, são unidades espaciais identificadas como mesorregiões.

As microrregiões foram definidas como parte das mesorregiões que apresentam especificidades, quanto à organização do espaço. Essas especificidades não significam uniformidade de atributos, nem conferem às microrregiões auto-suficiência e tampouco o caráter de serem únicas, devido a sua articulação a espaços maiores, quer à mesorregião, à Unidade da Federação, quer à totalidade nacional. Essas especificidades referem-se à estrutura de produção, agropecuária, industrial, extrativismo mineral, ou pesca. Essas 
estruturas diferenciadas podem resultar da presença de elementos do quadro natural ou de relações sociais e econômicas particulares, a exemplo, respectivamente, das serras úmidas nas áreas sertanejas, ou à presença dominante da mão-de-obra não remunerada numa área de estrutura social capitalista.

A organização do espaço microrregional foi identificada, também, pela vida de relações ao nível local, isto é, pela interação entre as áreas de produção e locais de beneficiamento e pela possibilidade de atender as populações, através do comércio de varejo ou atacado ou dos setores sociais básicos. Assim, estrutura da produção para identificação das microrregiões é considerada em sentido totalizante, constituindo-se pela produção propriamente dita, distribuição, troca e consumo, incluindo atividades urbanas e rurais. Dessa forma ela expressa a organização do espaço a nível micro ou local (IBGE 1990, p. 8).

A segunda etapa foi a opção pela escala em que deveriam estar elaborados todos os mapas municipais e todas as cartas topográficas. Esta segunda delimitação foi tomada com o objetivo de que a pesquisa apresente as condições para integrar o Atlas Toponímico do Brasil (ATB), projeto coordenado pela pesquisadora Dick (1989).

Em seguida, foram efetuados os procedimentos necessários para que fosse possível obter as cópias dos mapas. Neste momento, dificuldades começaram a apresentar-se. Foram obtidas cópias de mapas de 21 (vinte e um) municípios, porém, em escalas diferentes. Não havia mapa do município de São José do Povo. Eram 21 (vinte e um) mapas nas seguintes escalas:

- 17 (dezessete) mapas em escala de 1:100.000;

- 04 (quatro) mapas em escala de 1:250.000;

A padronização da escala foi considerada, para esta pesquisa, de grande importância, portanto, fez-se necessário buscar outras fontes. Era necessário manter um padrão de uniformidade no corpus da pesquisa porque isso contribui sobremaneira no volume de topônimos e na análise toponímica.

Decidiu-se, desse modo, a trabalhar com as cartas topográficas nos 04 (quatro) municípios cujos mapas estão em escala 1:250.000 e no município que não tinha mapa. As cartas abrangeram as áreas dos 05 (cinco) municípios restantes: Guiratinga, Itiquira, Pedra Preta, Poxoréu e São José do Povo. Nessas cartas estão 
marcados manualmente os limites atuais de cada um dos municípios e para isso fazse necessário estar com cópias atualizadas das leis de divisão territorial.

Depois foram efetuadas novas verificações dos limites municipais já traçados nessas cartas topográficas. Conferiu-se também, os topônimos registrados nos mapas dos outros municípios com os topônimos registrados nas respectivas cartas topográficas.

O corpus deste trabalho foi constituído por:

- 14 (quatorze) mapas elaborados pela Fundação de Pesquisas Cândido Rondon (FCR), órgão estadual já extinto, referentes aos municípios de: Alto Araguaia, Alto Garças, Alto Taquari, Araguainha, Campo Verde, Dom Aquino, General Carneiro, Juscimeira, Pontal do Araguaia, Ponte Branca, Primavera do Leste, Ribeirãozinho, Rondonópolis e São Pedro da Cipa;

- 03 (três) mapas elaborados pela Secretaria de Estado de Planejamento e Coordenação Geral do Estado de Mato Grosso (SEPLAN - MT), referentes aos municípios de Jaciara, Tesouro e Torixoréu;

- 14 (quatorze) cartas topográficas elaboradas pelo Instituto Brasileiro de Geografia e Estatística (IBGE);

- 28 (vinte e oito) cartas topográficas elaboradas pela Diretoria de Serviço Geográfico (DSG), do Ministério do Exército.

Todos estão elaborados em escala de 1:100.000. Assim, de posse de $100 \%$ do corpus da pesquisa, iniciou-se o trabalho de padronização das relações de topônimos, o levantamento dos topônimos, e depois, as conferências necessárias. O montante de topônimos a ser analisados neste presente estudo é de 2.269 (dois mil, duzentos e sessenta e nove) topônimos de acidentes físicos e 79 (setenta e nove) topônimos de acidentes antrópicos, perfazendo um total de 2.348 (dois mil, trezentos e quarenta e oito) topônimos.

\subsection{Levantamento e organização dos dados}


O levantamento dos topônimos foi realizado, em um primeiro momento, nos mapas municipais com escala de 1:100.000, e depois, cada relação de topônimos foi conferida nas cartas topográficas correspondentes a cada município. Assim, foram trabalhados, primeiramente, 17 (dezessete) municípios.

Numa segunda etapa, os topônimos dos outros 05 (cinco) municípios, registrados nas cartas topográficas, foram coletados. Também nas cartas topográficas foram necessárias verificações, só que, desta vez, confrontavam-se as cartas topográficas com os mapas dos municípios, muito embora os mapas estivessem em escala maior à das cartas topográficas. Este último procedimento visava re-conferir os limites municipais e marcar, quando necessário, os acidentes antrópicos de cada município nas cartas topográficas.

Antes de iniciar o levantamento dos sintagmas toponímicos (termo genérico + topônimo), propriamente ditos, os mapas foram divididos em quadrículas e estas quadrículas foram marcadas na horizontal por números (de 1.... n) e na vertical pelas letras do alfabeto (sem as letras k, w, y). Em alguns mapas houve repetição de letras do alfabeto, devido ao tamanho maior desses mapas. Tomou-se essas precauções para que tanto o acidente quanto o topônimo possam ser, mais facilmente, localizados nos respectivos mapas. No que se refere às cartas topográficas, respeitou-se as quadrículas existentes que foram marcadas da forma acima descrita. Cabe ainda registrar que foi designado um número a cada carta topográfica e esse número, em conjunto com as letras e os números das quadrículas, possibilitam pronta identificação dos topônimos.

É preciso também destacar que, com o levantamento nas cartas topográficas, é possível saber quantos e quais topônimos existem por carta topográfica em cada município. Isso foi feito porque, para trabalhar com a área total do município é necessário reunir duas ou mais cartas para cobrir toda sua extensão territorial. A esse processo dá-se o nome de articulação de cartas topográficas. O número de cartas varia de acordo com a extensão territorial do município.

Como já mencionado, essas cartas topográficas não trazem os limites municipais demarcados e, além disso, devido aos muitos desmembramentos de áreas municipais para criação de novos municípios, faz-se necessário atualizar os 
limites dos municípios que fizeram cessão de áreas, portanto, houve necessidade de articulá-las, pois algumas cartas contêm áreas de mais de um município. Nesses casos, os limites já estão traçados a mão, os topônimos são coletados dentro das áreas limítrofes de cada unidade administrativa municipal e não ocorre a inserção de topônimos de um município em outro.

Após o levantamento dos topônimos, para cada município, foi elaborada uma relação para os acidentes físicos e outra para os antrópicos. A relação contém quatro colunas:

- na primeira coluna consta a numeração (que permite, facilmente, verificar quantos topônimos há em cada município);

- na segunda coluna estão os termos genéricos ou acidentes físicos I antrópicos (organizados por ordem alfabética);

- na terceira coluna estão os topônimos (organizados por ordem alfabética, dentro de cada grupo de acidente físico / antrópico);

- na quarta coluna estão as taxionomias correspondentes aos topônimos.

Vale ainda ressaltar, como já mencionado, que buscou-se possibilitar a localização precisa de cada topônimo, seja nos mapas ou nas cartas topográficas e, por isso, foram inseridas notas entre parênteses, na terceira coluna da relação de topônimos, logo após cada topônimo. Essas notas adicionais são letra(s) e número(s) de quadrícula(s), quando registrados nos mapas e quando coletados nas cartas topográficas, as notas adicionais são número da carta topográfica, letra(s) e número(s) da(s) quadrícula(s).

Acredita-se que, com este sistema, seja possível alcançar um importante objetivo, que é estabelecer uma visão toponímica global de cada município, por meio das relações de topônimos. Também é possível saber quais os tipos de acidentes e quantos existem; a quantidade de topônimos por município e, se necessário, saber quantos e quais topônimos por tipo de acidente, quais as taxionomias existentes, quais as taxionomias predominantes por município, por microrregião e por mesorregião. 
A etapa final da busca e organização dos dados foi o preenchimento da ficha lexicográfico-toponímica para cada topônimo encontrado. Foram elaborados três tipos de fichas: um para os municípios, um para os acidentes físicos e um terceiro tipo de ficha para os demais acidentes antrópicos. Pode-se, ainda, destacar que quando ocorre dupla denominação, ou seja, um mesmo acidente recebe dois nomes é elaborada uma ficha lexicográfico-toponímica para cada topônimo do acidente. Cada uma delas com a classificação taxionômica correspondente que é devidamente computada no total de topônimos do município.

\subsection{Fichas lexicográfico-toponímicas}

Antes de iniciar a análise dos dados, optou-se por adotar o procedimento metodológico de preencher as fichas lexicográfico-toponímicas referentes a cada município, porque elas contêm os elementos necessários para o estudo mais aprofundado dos topônimos. Desse modo e a partir desse ponto, é possível fazer a análise dos topônimos por município, também por microrregião e, conseqüentemente, por mesorregião.

Optou-se por manter os modelos de fichas lexicográfico-toponímicas que foram utilizadas na pesquisa do mestrado, visto que elas contêm às características necessárias para subsidiar esta pesquisa toponímica.

Com o objetivo de criar um banco de dados e também de estabelecer critérios coerentes para a análise dos topônimos, registrados nas cartas topográficas elaboradas pela Diretoria de Serviço Geográfico (DSG) do Ministério do Exército, pelo Instituto Brasileiro e Geografia e Estatística (IBGE), e também, nos mapas elaborados pela Secretaria de Estado de Planejamento e Coordenação Geral do Estado de Mato Grosso (SEPLAN - MT) e pela Fundação de Pesquisa Cândido Rondon (FCR), manteve-se os 03 (três) modelos de fichas lexicográfico-toponímicas. Foram 17 (dezessete) municípios da mesorregião Centro-Sul Mato-grossenses, quando da dissertação de mestrado e 22 (vinte e dois) municípios da mesorregião Sudeste Mato-grossense, que compõem o corpus desta tese de doutorado. 
- ficha lexicográfico-toponímica de município para registrar informações relativas a municípios / cidades;

- ficha lexicográfico-toponímica de acidente humano para registrar informações relativas a distritos, localidades, povoados, terras indígenas, etc. Esses acidentes humanos são considerados, quer tenham sido criados por lei ou não, desde que constem nos mapas ou nas cartas topográficas que compõem os corpus desta pesquisa.

- ficha lexicográfico-toponímica de acidente físico para registrar as informações pertinentes aos acidentes físicos existentes em cada um dos municípios já referidos.

A ficha lexicográfico-toponímica de acidente humano (distritos, vilas, povoados, etc.), é bastante semelhante à ficha lexicográfico-toponímica do município. Não possui apenas o campo 19 (limites) e tem, portanto, vinte e cinco campos.

A ficha lexicográfico-toponímica de acidente físico (baía, córrego, morro, etc.), é praticamente igual à ficha lexicográfico-toponímica de acidente humano. Tem vinte e cinco campos, e também, não possui o campo 19 (limites). A única diferença entre elas é que o campo 06 em uma constam os vocábulos: acidente humano e na outra constam os vocábulos: acidente físico.

Faz-se necessário estabelecer, ou melhor, especificar os campos das fichas lexicográfico-toponímicas: 


\section{Campos da ficha lexicográfico-toponímica de município}

Os campos que compõem a ficha lexicográfico-toponímica de município são os seguintes:

. Campo 01 - deste campo consta o número seqüencial do topônimo.

. Campo 02 - UNIDADE DA FEDERAÇÃO - neste campo registra-se a sigla da Unidade Federativa onde encontra-se o município pesquisado.

. Campo 03 - MESORREGIÃO - este campo contém o nome da mesorregião na qual o município está inserido.

. Campo 04 - MICRORREGIÃO - deste campo consta o nome de uma das microrregiões que compõe a mesorregião e na qual está localizado o município.

. Campo 05 - MUNICÍPIO - deste campo consta o nome atual do município.

. Campo 06 - ACIDENTE HUMANO - deste campo consta o termo genérico do sintagma toponímico (município / cidade), porque ambos estão intrínsecos, não sendo possível desmembrá-los.

. Campo 07 - TOPÔNIMO - deste campo consta a denominação atual do acidente humano, e neste caso, será obrigatoriamente a mesma do campo 05.

. Campo 08 - VARIANTE GRÁFICA - deste campo consta (se houver) a forma variante do vocábulo que dá nome ao acidente humano.

- Campo 09 - TAXIONOMIA - neste campo registra-se a qual campo semântico pertence o topônimo.

. Campo 10 - ESTRUTURA DO TOPÔNIMO - deste campo consta qual é a estrutura (simples, híbrida ou composta) do topônimo. 
. Campo 11 - ESTRUTURA MORFOLÓGICA - deste campo consta a qual classe de palavras pertence o topônimo e, se apresentar estrutura composta ou derivação, especifica-se como está formado.

. Campo 12 - ETIMOLOGIA TUPI / BORORO / AFRICANA - registra(m)-se neste campo a(s) acepção(ões) selecionada(s) da unidade lexical que dá nome ao acidente humano e a especificação a qual grupo lingüístico ela pertence.

- Campo 13 - FONTE - deste campo consta a fonte da(s) acepção(ões) selecionada(s).

- Campo 14 - ENTRADA LEXICAL - registra(m)-se neste campo a(s) acepção(ões) que mais se adequar(em) à definição do topônimo, quando retirada(s) de dicionário de língua geral.

. Campo 15 - FONTE - deste campo consta a fonte (nome do dicionário) da(s) acepção(ões) selecionada(s).

- Campo 16 - INFORMAÇÕES ENCICLOPÉDICAS - registra(m)-se, neste campo, a(s) acepção(ões) da unidade lexical, quando essa(s) acepção(ões) não constar(em) em dicionários de língua geral, dicionários tupis, enciclopédia bororo ou vocabulário(s) de língua(s) indígena(s).

. Campo 17 - FONTE - deste campo consta a fonte pesquisada (dicionário de nomes, enciclopédias, etc.). Para esta pesquisa, no caso de nomes de pessoas, deu-se preferência as definições encontradas no dicionário de M. GÜÉRIOS. Registra-se, para nomes de entidades cristãs ou pagãs, informação contida em livro e/ou enciclopédia.

. Campo 18 - CONTEXTO - neste campo registra-se a acepção do topônimo, quando esta não constar em uma das fontes já citadas e tiver sido pesquisada na internet ou colhida em pesquisa de campo.

. Campo 19 - LIMITES - deste campo constam os nomes dos municípios limítrofes. 
- Campo 20 - OBSERVAÇÕES GERAIS - neste campo relacionam-se informações consideradas relevantes para situar a localização da cidade.

. Campo 21 - ÓRGÂO EXPEDIDOR - deste campo consta o nome do órgão que elaborou o mapa ou a carta topográfica.

- Campo 22 - DATA DO MAPA OU DA CARTA TOPOGRÁFICA - deste campo consta o ano em que o mapa ou a carta topográfica foi elaborado(a).

. Campo 23 - ESCALA DO MAPA OU DA CARTA TOPOGRÁFICA - deste campo consta a escala em que o mapa ou a carta topográfica foi elaborado(a).

- Campo 24 - PESQUISADORA - deste campo consta o nome da pesquisadora que elaborou e preencheu a ficha.

. Campo 25 - REVISORA - deste campo consta o nome da pesquisadora que revisou a ficha.

. Campo 26 - DATA E LOCAL DA COLETA - neste campo registra-se a cidade e a data (mês e ano) do preenchimento da ficha. 


\subsubsection{Ficha lexicográfico-toponímica de município}

\begin{tabular}{|l|l|l|l|l|}
\hline$N^{0}$ & Unidade da Federação: & Mesorregião: & Microrregião: & Município: \\
\hline
\end{tabular}

\begin{tabular}{|l|l|l|l|}
\hline Acidente humano: & Topônimo: & Variante gráfica: & Taxionomia: \\
\hline
\end{tabular}

\begin{tabular}{|l|l|}
\hline Estrutura do topônimo: & Estrutura morfológica: \\
\hline
\end{tabular}

\begin{tabular}{|l|l|}
\hline Etimologia indígena ou africana: & Fonte: \\
\hline
\end{tabular}

\begin{tabular}{|l|l|}
\hline Entrada lexical: & Fonte: \\
\hline Informações enciclopédicas: & Fonte: \\
\hline
\end{tabular}

\section{Contexto}

Limites:

Observações gerais:

\begin{tabular}{|l|l|l|}
\hline Órgão expedidor: & Data do mapa: Escala do mapa
\end{tabular}

\begin{tabular}{|l|l|}
\hline Pesquisadora: & Revisora: \\
\hline
\end{tabular}

Local e data da coleta: 


\subsubsection{Ficha lexicográfico-toponímica do município de Alto Taquari}

\begin{tabular}{|l|l|l|l|l|}
\hline $\begin{array}{l}\text { No } \\
36\end{array}$ & $\begin{array}{l}\text { Unidade da Federação: } \\
\text { Mato Grosso - MT }\end{array}$ & $\begin{array}{l}\text { Mesorregião: } \\
\text { Sudeste Mato- } \\
\text { grossense }\end{array}$ & $\begin{array}{l}\text { Microrregião: } \\
\text { Alto Araguaia }\end{array}$ & $\begin{array}{l}\text { Município: } \\
\text { Alto Taquari }\end{array}$ \\
\hline $\begin{array}{l}\text { Acidente humano: } \\
\text { cidade / município }\end{array}$ & $\begin{array}{l}\text { Topônimo: } \\
\text { Alto Taquari (J8) }\end{array}$ & $\begin{array}{l}\text { Variante Gráfica: } \\
\varnothing\end{array}$ & $\begin{array}{l}\text { Taxionomia: } \\
\text { cardinotopônimo }\end{array}$ \\
\hline
\end{tabular}

\begin{tabular}{|l|l|}
\hline $\begin{array}{l}\text { Estrutura do topônimo: } \\
\text { híbrida }\end{array}$ & $\begin{array}{l}\text { Estrutura morfológica: } \\
\text { adjetivo + substantivo comum }\end{array}$ \\
\hline
\end{tabular}

Etimologia tupi:
taquari s.m. (1873 cf. DHPT) B 2 angios planta de até $12 \mathrm{~m}$
(Merostachys burchellii), da fam. das gramíneas, nativa do Brasil
(SP, PR), de colmo fistuloso, ramos verticilados e folhas com a
margem áspera; taquara, taquara-fina, taquara-lisa, taquara-mansa
3 angios planta de até $18 \mathrm{~m}$ (Merostachys clausseni), da mesma
fam., de lâminas ovadolanceoladas e espigas subfalciformes;
taquara-do-mato, taquarapoca, taquara-verdadeira, taquaricé,
taquaruçu

\begin{tabular}{l|l}
\hline Entrada lexical: & Fonte:
\end{tabular}

${ }^{1}$ alto adj. (sXIII cf. IVPM) 16 situado em ponto próximo à nascente Houaiss (diz-se de trecho e circunvizinhanças de rio) 17 mais para o Norte (diz-se de região)

Fonte:

Houaiss

Informações enciclopédicas:

Fonte:

$\varnothing$

\section{Contexto \\ $\varnothing$}

\section{Limites:}

O município de Alto Araguaia e os estados de Goiás e Mato Grosso do Sul.

Observações gerais:

A cidade de Alto Taquari localiza-se entre as cabeceiras do rio Taquari e dos córregos Dutra e Esteio.

\begin{tabular}{|l|l|l|}
\hline Órgão Expedidor: & Data do mapa: & Escala do mapa \\
Fundação de Pesquisas Cândido Rondon (FCR) & 1988 & $1: 100.000$ \\
\hline
\end{tabular}

\begin{tabular}{|l|l|}
\hline Pesquisadora: & Revisora: \\
Maria Aparecida de Carvalho & DICK \\
\hline
\end{tabular}

Local e data da coleta:

Cuiabá, janeiro / 2008 
Campos das fichas lexicográfico-toponímicas de acidente físico e de acidente humano

Os campos que compõem as fichas lexicográfico-toponímicas de acidente físico e de acidente humano são os seguintes:

. Campo 01 - deste campo consta o número seqüencial do topônimo.

. Campo 02 - UNIDADE DA FEDERAÇÃO - neste campo registra-se a sigla da Unidade Federativa onde encontra-se o topônimo pesquisado.

. Campo 03 - MESORREGIÃO - este campo contém o nome da mesorregião na qual o acidente está inserido.

. Campo 04 - MICRORREGIÃO - deste campo consta o nome de uma das microrregiões que compõe a mesorregião e na qual registra-se o topônimo.

. Campo 05 - MUNICÍPIO - deste campo consta o nome do município onde localiza-se o topônimo.

. Campo 06 - ACIDENTE FÍSICO OU ACIDENTE HUMANO- deste campo consta o termo genérico (baía, córrego, distrito, vila, etc.) do sintagma toponímico.

. Campo 07 - TOPÔNIMO - deste campo consta a denominação do acidente físico ou do acidente humano.

. Campo 08 - VARIANTE GRÁFICA - deste campo consta (se houver) a forma variante do vocábulo que dá nome ao acidente físico ou acidente humano.

- Campo 09 - TAXIONOMIA - neste campo registra-se a qual campo semântico pertence o topônimo.

. Campo 10 - ESTRUTURA DO TOPÔNIMO - deste campo consta qual é a estrutura (simples, híbrida ou composta) do topônimo. 
. Campo 11 - ESTRUTURA MORFOLÓGICA - deste campo consta a qual classe de palavras pertence o topônimo e, se apresentar estrutura composta ou derivação, especifica-se como está formado.

. Campo 12 - ETIMOLOGIA TUPI / BORORO / AFRICANA - registra(m)-se neste campo a(s) acepção(ões) selecionada(s) da unidade lexical que dá nome ao acidente físico ou ao acidente humano e a especificação a qual grupo lingüístico ela pertence.

. Campo 13 - FONTE - deste campo consta(m) a fonte da(s) acepção(ões) selecionada(s).

- Campo 14 - ENTRADA LEXICAL - registra(m)-se neste campo a(s) acepção(ões) que mais se adequar(em) à definição do topônimo, quando retirada(s) de dicionário de língua geral.

. Campo 15 - FONTE - deste campo consta a fonte (nome do dicionário) da(s) acepção(ões) selecionada(s).

. Campo 16 - INFORMAÇÕES ENCICLOPÉDICAS - neste campo registra(m)se a(s) acepção(ões) da unidade lexical, quando essa(s) acepção(ões) não constar(em) em dicionário(s) de língua geral, dicionário(s) tupi(s), enciclopédia bororo ou vocabulário(s) de língua(s) indígena(s).

. Campo 17 - FONTE - deste campo consta a fonte pesquisada (dicionário de nomes, enciclopédias, etc.). Para esta pesquisa, no caso de nomes de pessoas, deu-se preferência as definições encontradas no dicionário de M. GÜÉRIOS. Registra-se, para nomes de entidades cristãs ou pagãs, informação contida em livro e/ou enciclopédia.

. Campo 18 - CONTEXTO - neste campo registra-se a acepção do topônimo, quando esta não constar em uma das fontes já citadas e tiver sido pesquisada na internet ou colhida em pesquisa de campo.

- Campo 19 - OBSERVAÇÕES GERAIS - neste campo relacionam-se informações consideradas relevantes para situar o acidente físico ou o humano. 
. Campo 20 - ÓRGÂO EXPEDIDOR - deste campo consta o nome do órgão que elaborou o mapa ou a carta topográfica.

- Campo 21 - DATA DO MAPA OU DA CARTA TOPOGRÁFICA - deste campo consta o ano em que o mapa ou a carta topográfica foi elaborado(a).

. Campo 22 - ESCALA DO MAPA OU DA CARTA TOPOGRÁFICA - deste campo consta a escala em que o mapa ou a carta topográfica foi elaborado(a).

- Campo 23 - PESQUISADORA - deste campo consta o nome da pesquisadora que elaborou e preencheu a ficha.

. Campo 24 - REVISORA - deste campo consta o nome da pesquisadora que revisou a ficha.

. Campo 25 - DATA E LOCAL DA COLETA - neste campo registra-se a cidade e a data (mês e ano) do preenchimento da ficha. 


\subsubsection{Ficha lexicográfico-toponímica de acidente físico}

\begin{tabular}{|l|l|l|l|l|}
\hline NNo & Unidade da Federação: & Mesorregião: & Microrregião: & Município: \\
\hline Acidente físico: & Topônimo: & Variante gráfica: & Taxionomia: \\
\hline
\end{tabular}

Estrutura do topônimo: Estrutura morfológica:

Etimologia indígena ou africana:

Fonte:

Entrada lexical:

Fonte:

Informações enciclopédicas:

Fonte:

Contexto:

Observações gerais:

Órgão expedidor: Data do mapa: Escala do mapa:

Pesquisadora:

Revisora:

Local e data da coleta: 


\subsubsection{Ficha lexicográfico-toponímica de acidente físico}

\begin{tabular}{|l|l|l|l|l|}
\hline $\begin{array}{l}N^{0} \\
1\end{array}$ & $\begin{array}{l}\text { Unidade da Federação: } \\
\text { Mato Grosso - MT }\end{array}$ & $\begin{array}{l}\text { Mesorregião: } \\
\text { Sudeste Mato- } \\
\text { grossense }\end{array}$ & $\begin{array}{l}\text { Microrregião: } \\
\text { Tesouro }\end{array}$ & $\begin{array}{l}\text { Município: } \\
\text { Guiratinga }\end{array}$ \\
\hline
\end{tabular}

\begin{tabular}{|l|l|l|l|}
\hline $\begin{array}{l}\text { Acidente físico: } \\
\text { córrego do }\end{array}$ & Topônimo: & Variante Gráfica: & Taxionomia: \\
etnotopue (M11, M12) & $\varnothing$ & $\varnothing$ etnimo \\
\hline
\end{tabular}

\begin{tabular}{|l|l|}
\hline $\begin{array}{l}\text { Estrutura do topônimo: } \\
\text { simples }\end{array}$ & $\begin{array}{l}\text { Estrutura gramatical: } \\
\text { substantivo comum }\end{array}$ \\
\hline
\end{tabular}

\begin{tabular}{l|l|}
\hline Etimologia africana: & Fonte: \\
moleque s.m. (a1716 cf. RB) 1 menino novo, de raça negra ou mista & Houaiss \\
2 B garoto de pouca idade 3 B menino criado à solta; menino de rua & \\
$\begin{array}{ll}4 \text { B garoto travesso } & \end{array}$ \\
\hline
\end{tabular}

\begin{tabular}{|l|l|}
\hline Entrada lexical: & Fonte: \\
$\varnothing$ & $\varnothing$ \\
\hline & \\
\hline Informações enciclopédicas: & $\begin{array}{l}\text { Fonte: } \\
\varnothing\end{array}$ \\
\hline
\end{tabular}

\begin{tabular}{l|l|} 
Contexto \\
$\varnothing$
\end{tabular}

Observações gerais:

Deságua no córrego Barreiro.

\begin{tabular}{|l|l|l|}
\hline Órgão Expedidor: & Data do mapa: & Escala do mapa: \\
Fundação de Pesquisas Cândido Rondon (FCR) & 1990 & $1: 100.000$ \\
\hline
\end{tabular}

\begin{tabular}{|l|l|}
\hline Pesquisadora: & Revisora: \\
Maria Aparecida de Carvalho & DICK \\
\hline
\end{tabular}

Local e data da coleta:

Cuiabá, novembro / 2008 


\subsubsection{Ficha lexicográfico-toponímica de acidente humano}

\begin{tabular}{|l|l|l|l|l|}
\hline$N^{0}$ & Unidade da Federação: & Mesorregião: & Microrregião: & Município: \\
\hline
\end{tabular}

\begin{tabular}{|l|l|l|l|}
\hline Acidente humano: & Topônimo: & Variante gráfica: & Taxionomia: \\
\hline
\end{tabular}

\begin{tabular}{|l|l}
\hline Estrutura do topônimo: & Estrutura gramatical:
\end{tabular}

Etimologia indígena ou africana:

Fonte:

Entrada lexical:

Fonte:

Informações enciclopédicas:

Fonte:

Contexto

Observações gerais:

Órgão expedidor:

Data do mapa: Escala do mapa:

Pesquisadora:

Revisora:

Local e data da coleta: 


\subsubsection{Ficha lexicográfico-toponímica de acidente humano}

\begin{tabular}{|l|l|l|l|l|}
\hline $\begin{array}{l}N^{0} \\
1\end{array}$ & $\begin{array}{l}\text { Unidade da Federação: } \\
\text { Mato Grosso - MT }\end{array}$ & $\begin{array}{l}\text { Mesorregião: } \\
\text { Sudeste Mato- } \\
\text { grossense }\end{array}$ & $\begin{array}{l}\text { Microrregião: } \\
\text { Alto Araguaia }\end{array}$ & $\begin{array}{l}\text { Município: } \\
\text { Alto Araguaia }\end{array}$ \\
\hline $\begin{array}{l}\text { Acidente humano: } \\
\text { distrito }\end{array}$ & $\begin{array}{l}\text { Topônimo: } \\
\text { Buriti (AI11) }\end{array}$ & $\begin{array}{l}\text { Variante Gráfica: } \\
\varnothing\end{array}$ & $\begin{array}{l}\text { Taxionomia: } \\
\text { fitotopônimo }\end{array}$ \\
\hline
\end{tabular}

\begin{tabular}{|l|l|}
\hline $\begin{array}{l}\text { Estrutura do topônimo: } \\
\text { simples }\end{array}$ & $\begin{array}{l}\text { Estrutura gramatical: } \\
\text { substantivo comum }\end{array}$ \\
\hline
\end{tabular}

Etimologia tupi:
buriti s.m. (c1631 cf. AGC) angios B 1 design. comum a plantas dos
gên. Mauritia, Mauritiella, Trithrinax e Astrocaryum, da fam. das
palmas, de folhas ger. penatífidas e flabeliformes, coletadas para
coberturas de casas rústicas e esp. para extração de fibras, us. em
inúmeras obras trançadas; buritizeiro, muritizeiro, murutizeiro 1.1
palmeira muito alta (Mauritia flexuosa), nativa de Trinidad e Tobago
e do Norte da América do Sul, com estipe ger. flexuoso, drupas de 3
a $5 \mathrm{~cm}$, revestidas de escamas triangulares castanho-avermelhadas,
e polpa amarela, doce e, como a semente, muito oleaginosa;
[Fornece palmito saboroso, fécula e madeira; dos frutos extrai-se
óleo comestível, tb. us. para amaciar e envernizar couro, e do estipe
e das inflorescências imaturas faz-se refresco e, após fermentação,
o vinho de buriti.]

\begin{tabular}{l|l}
\hline Entrada lexical: & Fonte: \\
$\varnothing$ & $\varnothing$
\end{tabular}

\begin{tabular}{l|l} 
Informações enciclopédicas: & Fonte: \\
$\varnothing$ & $\varnothing$
\end{tabular}

\section{Contexto}

$\varnothing$

Observações gerais:

A sede do distrito localiza-se às margens do córrego Buriti

\begin{tabular}{|l|l|l|}
\hline Órgão Expedidor: & Data do mapa: & Escala do mapa: \\
Fundação de Pesquisas Cândido Rondon (FCR) & 1990 & $1: 100.000$ \\
\hline
\end{tabular}

Pesquisadora:

Maria Aparecida de Carvalho

Revisora:

DICK

Fonte:

Houaiss

Local e data da coleta:

Cuiabá, janeiro / 2008 


\subsection{Pesquisa bibliográfica}

Para a fundamentação teórica deste trabalho realizou-se a pesquisa bibliográfica com leituras e análises de textos em lexicologia, lexicografia e, sobretudo, em toponímia, já referidos, a fim de obter o embasamento necessário para efetuar a análise dos topônimos.

Foram efetuadas pesquisas em dicionários: de língua geral, principalmente Houaiss, em dicionário de nomes e sobrenomes, dicionários de línguas indígenas, principalmente tupi e na enciclopédia bororo. A estas fontes foram acrescidas pesquisas em enciclopédias, obras religiosas, livros, internet (os endereços eletrônicos estão nas fichas lexicográfico-toponímicas) e quando necessário, realizou-se pesquisas de campo, neste caso específico, solicitação de informações. O objetivo principal é contextualizar cada topônimo, isto é, buscar a acepção adequada, e após, classificá-lo por campo semântico, ou seja, por taxionomia.

Leituras de obras históricas e geográficas também fizeram-se necessárias e contribuíram para a elaboração do trabalho, porque são ciências que se entrecruzam com a Toponímia, e conseqüentemente, os estudos toponímicos dão e recebem suas parcelas de colaboração(ões) para com as outras ciências.

\subsection{Análise e tratamento dos dados}

O levantamento dos dados foi desenvolvido nos mapas ou nas cartas topográficas. É necessário ressaltar que foram respeitados os limites municipais atuais e tomou-se o cuidado de cobrir $100 \%$ da área de cada município estudado.

Após o término do primeiro levantamento total dos topônimos registrados nos mapas e/ou nas cartas topográficas, reiterou-se a convicção de que se fazia necessário manter o recorte no corpus da pesquisa, devido ao grande número de 
topônimos encontrados. Definiu-se, portanto, que esta pesquisa ficaria delimitada aos topônimos dos acidentes físicos e a de alguns acidentes humanos. Optou-se por não trabalhar, de forma conjunta, com os topônimos dos acidentes físicos e com todos os topônimos dos acidentes humanos porque isso elevaria muito o total de topônimos a ser estudado. O número total atingiria mais que o dobro dos topônimos já pesquisados e conseqüentemente o prazo disponível para elaborar a tese de doutorado não seria suficiente para desenvolver uma pesquisa de tal porte, pois o volume do trabalho seria muito grande.

Para a elaboração do Atlas Toponímico do Estado de Mato Grosso Mesorregião Sudeste Mato-grossense, realizou-se o levantamento de todos os topônimos dos acidentes físicos registrados: baía, cabeceiras, chapada, córregos, lagoas, morros, morrinho, porto, riachos, ribeirãozinho, ribeirões, rios, serras, vazantes. E dos aglomerados humanos: colônias, distritos, localidades, municípios / cidades, povoados e vilas, registrados nos mapas e nas cartas topográficas, a fim de relacioná-los e classificá-los quanto à estrutura e aos respectivos campos semânticos.

Não se inserem nesta pesquisa, portanto, os topônimos relativos a: aeroporto, agropecuárias, avenidas, bairros, balneários, centros educacionais, chácaras, colônias penitenciárias, empórios, escolas, estâncias, fazendas, granjas, igrejas, loteamentos, marcos, mineradoras, penitenciárias agrícolas, pontes, postos de gasolina, retiros, ruas, sítios, terminais turísticos, usinas, usinas hidrelétricas, etc. devido aos motivos já mencionados.

A escolha dos acidentes físicos baseou-se em dois critérios: o primeiro foi a uniformização dos acidentes físicos, tanto em cartas topográficas quanto em mapas que são utilizados, em geral, em fontes documentais desse teor; o segundo critério é que todos os acidentes físicos deveriam estar toponimizados. A seleção dos acidentes antrópicos referiu-se, principalmente, a aglomerados humanos e a áreas de proteção ambiental, neste caso, terras indígenas registradas no corpus da pesquisa.

Assim, desenvolveu-se o levantamento dos topônimos dos acidentes físicos e humanos nos mapas dos municípios: Alto Araguaia, Alto Garças, Alto Taquari, 
Araguainha, Campo Verde, Dom Aquino, General Carneiro, Jaciara, Juscimeira, Pontal do Araguaia, Ponte Branca, Primavera do Leste, Ribeirãozinho, Rondonópolis, São Pedro da Cipa, Tesouro e Torixoréu e, posteriormente, estes levantamentos foram confrontados com as cartas topográficas correspondentes a cada município. Nos municípios de Guiratinga, Itiquira, Pedra Preta, Poxoréu e São José do Povo realizou-se o levantamento dos topônimos diretamente nas cartas topográficas. Elaborou-se, em seguida, as relações de topônimos por município.

Manteve-se a grafia do topônimo tal como ela encontra-se nos mapa e na carta topográfica. 


\section{CARACTERÍSTICAS GERAIS E ANÁLISE TOPONÍMICA}

\subsection{Características gerais do estado de Mato Grosso}

A história de Mato Grosso desde seu início sempre foi muito rica e apresentála demandaria uma pesquisa muito ampla. Pretende-se, por isso, destacar duas nuanças retiradas dos relevantes acontecimentos que compõem a história e as características gerais do estado de Mato Grosso:

- Algumas características históricas dos primeiros povoamentos;

- Algumas características atuais do estado de Mato Grosso

\subsubsection{Algumas características históricas dos primeiros povoamentos}

O estado de Mato Grosso começou a ser delineado quando "mamelucos paulistas", os bandeirantes, iniciaram a penetração pelo interior, em direção ao rio Paraná. Eles navegaram pelo rio Tietê, chegaram ao rio Paraná e ao atingirem a margem oposta daquele rio começaram a adentrar no "sertão" em um primeiro momento, em busca de índios para escravizar. Eles também acalentavam o sonho de descobrir, nas novas paragens, cobiçados metais como ouro, diamantes e esmeraldas.

Inicialmente, as terras da região onde hoje localiza-se o estado de Mato Grosso do Sul não Ihes despertaram grandes interesses, talvez por não terem observado em suas formações sinais que mostrassem a presença desses raros e ambicionados metais preciosos. Elas caracterizavam, em princípio, apenas grandes distâncias a serem vencidas na busca pela concretização de suas esperanças.

Parte das terras que formam os estados de Mato Grosso e Mato Grosso do Sul já havia sido palmilhada por aventureiros espanhóis e, ao que tudo indica, antes 
deles apenas os habitantes autóctones conheciam a região. Não se pode esquecer que pelo Tratado de Tordesilhas, oficialmente, toda essa área pertencia à Espanha. No transcorrer do tempo, o destemor dos bandeirantes pelo desconhecido e as suas ambições formaram a alavanca que ao ser impulsionada por suas ações mudou o rumo da história desta região, de sua gente e, acima de tudo, do Brasil.

No início, um ou outro bandeirante acompanhado de seus homens e de índios já "domesticados", que sabiam caminhar pelas matas e falar o idioma dos povos autóctones da região, embrenharam-se por essas terras, enfrentando todos os tipos de desconforto: fome, doenças, feras, silvícolas chamados de hostis, mas que na realidade lutavam para defender seus territórios, manter a hegemonia do grupo, etc. Apesar de tudo, eles prosseguiram nos seus intentos. Infelizmente, são poucos os registros, pode-se até mesmo dizer que são quase inexistentes os registros escritos da epopéia da conquista dessas áreas.

\begin{abstract}
Sabe-se vagamente que varou, pelo vale do Miranda, até alcançar o domínio dos incas, o misterioso Aleixo Garcia, que não deixou sequer o roteiro de suas audazes peregrinações, efetuadas no primeiro quartel do século XVI. E mais, que Antônio Raposo Tavares Ihe ultrapassou as pegadas, para ir surpreender os moradores do Baixo Amazonas, por onde rodou, depois de marinhar por escarpas andinas, ao completar o périplo sobre-humano.

Os seus feitos, porém, e dos que Ihe seguiram o exemplo, quando muito contribuíram para apontar as linhas de acesso aos remotos sertões, onde se multiplicavam os viveiros de nativos suscetíveis de escravização.

O exame das peculiaridades locais somente começaria depois da fixação dos andejos bandeirantes em Cuiabá, atraídos pelo ouro de suas lavras. Corrêa Filho (1969, p. 25)
\end{abstract}

Assim, as incursões bandeirantes penetravam cada vez mais as terras matogrossenses. No início do século XVIII, o sorocabano Pascoal Moreira Cabral, após receber informações de outro bandeirante, Antônio Pires, sobre uma região propícia para prear índios, adentrou pela região do rio Cuiabá. Antônio Pires e seus homens, um pouco antes, haviam logrado êxito na luta contra os índios coxiponés e estavam de retorno a São Paulo.

De posse dessas informações, Pascoal Moreira dirigiu-se com sua bandeira para o local indicado, com o intuito de efetuar aprisionamento de índios e, de posse 
de suas conquistas, também retornar a São Paulo, mas a sua pretensão haveria de sofrer uma grande reviravolta. O grande achado do Bandeirante Paulista não seria integrantes de uma tribo indígena para escravizar, mas sim o ouro, ouro farto a "brotar" das areias que margeiam o rio Coxipó.

Esses fatos determinaram o marco inicial do nascimento da futura província que com o decorrer dos decênios iria transformar-se no estado de Mato Grosso. Foi como se os acontecimentos ocorressem em cascata: descoberto o ouro era necessário que houvesse o estabelecimento de pessoas para que a posse da área fosse efetivada. Para que houvesse a efetivação da posse fazia-se necessário manter intercâmbio e receber apoio do povoado, neste caso específico, de São Paulo, pois toda a região fazia parte daquela capitania. Para que o intercâmbio ocorresse era necessário estabelecer uma rota de viagem que as pessoas pudessem utilizar. Pode-se ter uma idéia da distância e das dificuldades a serem vencidas:

Como conseqüência imediata da descoberta do ouro cuiabano operou-se a transformação da principal rota sertanista, já quase sesqui-secular da penetração ocidental, para a devassa das terras e preia do índio em via comercial e militar.

Criava-se o episódio das monções, inserto com o maior relevo nos anais do bandeirantismo.

Assumiria ímpar originalidade não só em nossos fastos nacionais como nos do Universo.

É, com efeito: em parte alguma do globo as condições geográficas, demográficas, comerciais, coexistiram e associaram-se, tão originais quanto as que caracterizaram esta via anfíbia de milhares de quilômetros de imensos percursos fluviais e pequena jornada terrestre: a estrada das monções entre Araraitaguaba e Cuiabá, separados por três mil e quinhentos quilômetros da mais áspera navegação com mínima solução de continuidade constituída por alguns quilômetros do varadouro de Camapoã e os do vencimento, pela varação dos saltos e cachoeiras. Taunay (195_, p. 113)

A notícia da descoberta do ouro, a facilidade que tinham em retirá-lo do solo e a abundância com que ele apresentava-se, obteve transmissão veloz e, rápidamente, chegou a São Paulo. A partir desse momento, começou o desvario pelo ouro. As grandes viagens eram organizadas e todos os tipos de pessoas lançavam-se nessas aventuras. Muitos jamais chegaram a concluí-las, há registro desse fato: 
Divulgada a noticia pellos povoados foi tal o movimento que cauzou nos ânimos que das minas gerais Rio de Janeiro e de toda a Capitania de Sam Paulo se aballaraõ muitas gentes deixando cazas, fazendas, mulheres e filhos botando-se para estes Sertoens como se fora de promissam ou o Parahyso incoberto em que Deus pos nossos primeiros Paes.

"Anno de mil setecentos e vinte partirão dos povoados bastantes gentes para essas conquistas divididas em diversos comboyos de canoas imbarcando na Aritagoaba descendo o rio Tietê e o grande sobindo o Anhandohy asima da barra do rio pardo atravesando a vacaria descendo pelo Mateteu e desse pello Paragoay asima padecerão grandes destrosos perdiçoens de canoas nas coxoeiras por falta de pilotos praticos que ainda os não havia mortandade de gente por falta de sustento doenças comidos de onsas e outras misérias. Barbosa de Sá (1975, p. 4-5).

Durante três longas décadas todas as decisões administrativas ou políticas, eram repassadas para o Além Paraná e depois, via rio Tietê, chegavam até a São Paulo, seguindo esses duros e longos percursos.

As espantosas jornadas fluviais do Paredão de Araraitaguaba a Cuiabá não encontram similares em outra região do globo".

(...)

Nada mais evocativo do que o modo pelo qual os primeiros moradores de Cuiabá designavam o Tietê e S. Paulo: rio do Povoado e Povoado.

Retirar-se para o Povoado, no dizer singelo dos documentos setecentistas era expressão sinônima de partir para S. Paulo. Taunay (195_, p. 114)

Essas viagens epopéicas continuaram, mas a partir de 1728 já começava a se evidenciar um declínio na extração do ouro em Cuiabá. A ambição pelo ouro somada à ganância do fisco da coroa portuguesa deram palcos a perseguições cruéis e, muitas vezes, injustas no arraial do Senhor Bom Jesus de Cuiabá.

Além das pressões exercidas pelas autoridades daquela época, o medo dos gentios, sobretudo Paiaguá e Guaicuru, as epidemias que algumas vezes varreram a vila do Senhor Bom Jesus e as descobertas de ouro em outras paragens contribuíram de forma efetiva para o gradativo despovoamento de Cuiabá. Narram os cronistas que a partir dessa época tem-se o início do êxodo populacional.

Em princípios de 1728, a tal ponto chegou a situação de desespero entre os cuiabanos que pensaram em abandonar em massa a sua 
vila, voltando uns a São Paulo e indo outros para Goiás, de cujas riquezas chegavam constantemente notícias.

(...)

Partiram mais de mil pessoas, das quais morreram muitas pelos pousos e barrancas dos rios nas mãos dos índios. Taunay (195_, p. $62)$.

As incursões pelo interior da região de Cuiabá eram incessantes. Logo veio a notícia de novas descobertas de ouro em um lugar mais a oeste de Mato Grosso, e também, atendendo ordens de Portugal que queria ampliar e efetivar os seus domínios territoriais, foi criado um povoamento às margens do rio Guaporé. Esses fatos contribuíram para a elevação de Mato Grosso à condição de capitania. E para sediar a capitania foi criada a cidade de Mato Grosso às margens do referido rio Guaporé, com dois objetivos: fiscalizar o ouro e garantir a posse da terra para a coroa portuguesa. Esse episódio está narrado assim: "Em 1744, e à vista do que o informaram sobre as minas do Guaporé, resolveu D. João V elevar Mato Grosso a cabeça de capitania." Taunay (195_, p. 97).

O fascínio pelo ouro tangia as pessoas, e novamente, enfrentaram mais dificuldades de percurso para chegar às novas lavras. As viagens eram tão difíceis que por diversas vezes os cronistas reportam-se a elas. Transcreve-se uma descrição mais pormenorizada do trajeto desenvolvido pelas monções:

Segundo os cálculos de Lacerda e Almeida as distâncias fluviais sulcadas pelas monções atingia 531 léguas ou seja $3.504,6 \mathrm{~km}$. Assim se distribuíam 152 no Tietê, 29 no Paraná, 75 no Pardo, 17 no Camapoã, 40 no Coxim, 90 no Taquari, 39 no Paraguai, 25 no Porrudos e 64 no Cuiabá.

A esse colossal percurso aquático era preciso adicionar os 14 quilômetros do varadouro de Camapoã e os 155 quilômetros que medeiam de S. Paulo a Araraitaguaba. O total da jornada de S. Paulo às minas cuiabanas vinha a ser, pois, de 3.664 quilômetros.

De Cuiabá às minas guaporeanas mais noventa e três léguas a caminhar! (613,8 km).

Cento e treze saltos, cachoeiras e corredeiras a vencer: 55 no Tietê, 33 no Pardo, 24 no Coxim, uma no Taquari. No Pardo era muito freqüente verificar-se o espedaçamento de canoas. Taunay (195_, p. 47) 
A condição de efetivação de Mato Grosso como província, já independente de São Paulo, ocorreu em 1748, com a escolha pela coroa portuguesa do primeiro governador de província, mas a posse só ocorreu quase três anos depois.

Foi esta Província, como a de Goyaz, sujeita ao Governo de S. Paulo, até que, por Patente de 25 de Setembro de 1748 foi despachado primeiro e privativo Governador, o Capitão General dela o Ex. D. Antonio Rolim de Moura, Conde de Azambuja, de boa Memória que tomou posse em Cuyabá em 17 de janeiro de 1751. D'Allincourt (1914, p. 156).

Com a exaustão das lavras cuiabanas no século XIX e apesar do retorno de Cuiabá à condição de capital de Mato Grosso, foram longas décadas de distanciamento das outras regiões e estados brasileiros. As grandes distâncias e as poucas e precárias vias de acesso por terra muito contribuíram para a instalação e continuidade desse fato.

\subsubsection{Algumas características atuais do estado de Mato Grosso}

O estado de Mato Grosso localiza-se na região Centro-Oeste do Brasil. A região é formada por 03 (três) estados: Goiás, Mato Grosso, Mato Grosso do Sul e pelo Distrito Federal, Brasília. A extensão territorial de Mato Grosso corresponde a $54,8 \%$ da área total da região Centro-Oeste.

Mato Grosso sempre teve uma grande extensão territorial. Cedeu área para a formação de parte do estado de Rondônia e toda área do estado de Mato Grosso do Sul foi desmembrada do estado de Mato Grosso.

Atualmente Mato Grosso possui $903.397,51 \mathrm{~km}^{2}$. É o maior estado da região Centro-Oeste e o terceiro maior do Brasil. A capital do estado de Mato Grosso é Cuiabá. O estado de Mato Grosso está formado por 141 (cento e quarenta e um) municípios e estabelece limites com os estados: Rondônia, Pará, Amazonas, Tocantins, Goiás, Mato Grosso do Sul e com o país limítrofe: Bolívia. 
Apesar de todos os percalços ocorridos no passado, Mato Grosso seguiu, e segue firme, seu caminho a um futuro ainda mais promissor, mantendo-se como unidade federativa que sempre concedeu sua parcela de colaboração para a manutenção da integridade territorial brasileira.

O estado de Mato Grosso, no decorrer do século XX, começou a ampliar suas atividades econômicas. As atividades extrativistas deixaram de ter os destaques dos dois séculos anteriores e começou a re-direcionar as atividades produtivas para os demais setores econômicos: primário, secundário e terciário. Não apenas para a produção de culturas de subsistência, mas para grandes produções agrícolas, e logo depois, para o beneficiamento e comercialização desses produtos. Foi uma época tão empolgante que o estado de Mato Grosso chegou a receber o cognome de Celeiro do Brasil.

Com o êxito das atividades agropecuárias que parecem constituir a grande vocação mato-grossense, a produção de arroz, milho, feijão, mandioca, pecuária de corte e, mais recentemente, cana-de-açúcar, soja, algodão são contabilizados, em todas as safras, em milhares de toneladas. Isso mostra que Mato Grosso consolidou, de modo firme, sua posição de estado produtor de gêneros alimentícios.

O setor secundário, que era quase inexistente no início do século passado, ganhou força com a instalação de agroindústrias. Outros ramos da indústria vieram atraídas pela expressiva produção de grãos e de carnes em várias regiões do estado de Mato Grosso ou em busca de incentivos fiscais. Propiciaram, desse modo, geração de renda, empregos diretos e indiretos, isso já de meados para fim de 1900.

O setor terciário expandiu-se em função da evolução apresentada pelos outros dois setores econômicos, e desse modo, é um dos que mais gera empregos e cresce no estado de Mato Grosso.

Atualmente Mato Grosso está dividido em 05 (cinco) mesorregiões: CentroSul Mato-grossense, Nordeste Mato-grossense, Norte Mato-grossense, Sudeste Mato-grossense e Sudoeste Mato-grossense. As mesorregiões subdividem-se em microrregiões. São 22 (vinte e duas) microrregiões. Elas estão formadas assim:

- mesorregião Centro-Sul Mato-grossense: 
1. Alto Pantanal

2. Alto Paraguai

3. Cuiabá

4. Rosário Oeste

- mesorregião Nordeste Mato-grossense:

1. Canarana

2. Médio Araguaia

3. Norte Araguaia

- mesorregião Norte Mato-grossense:

1. Alta Floresta

2. Alto Teles Pires

3. Arinos

4. Aripuanã

5. Colíder

6. Paranatinga

7. Parecis

8. Sinop

- mesorregião Sudeste Mato-grossense:

1. Alto Araguaia

2. Primavera do Leste 
3. Rondonópolis

4. Tesouro

- mesorregião Sudoeste Mato-grossense

1. Alto Guaporé

2. Jauru

3. Tangará da Serra

Vale registrar pequena retrospectiva histórica com base em informações coletadas na SEPLAN-MT e no IBGE - Delegacia Regional de Mato Grosso, relativas à evolução político-adminstrativa do estado de Mato Grosso, apesar deste estudo não ter caráter diacrônico. Deve-se, porém, esclarecer que estão relacionados apenas os municípios que compõem o estado de Mato Grosso.

No século XVIII apenas 02 (dois) municípios foram criados. Em 1726, Cuiabá é elevada à categoria de município, desvinculando-se de São Paulo. Em 1746, Vila Bela da Santíssima Trindade, ainda com a denominação de Mato Grosso é elevado à categoria município ao ser desmembrado de Cuiabá. No decorrer de todo o século XIX foram criados os municípios de:

Cáceres

Diamantino

Nossa Senhora do Livramento
Poconé

Rosário Oeste

Santo Antônio de Leverger

Nas quatro primeiras décadas de 1900, foram criados mais 04 (quatro) municípios:
Alto Araguaia
Guiratinga
Barra do Garças
Poxoréu

Na década de 1940 a 1950 foram criados 03 (três) municípios: 
Barra do Bugres

Na década de 1950 a 1960 foram criados 14 (quatorze) municípios:

$\begin{array}{lll}\text { Acorizal } & \text { Chapada dos Guimarães } & \text { Ponte Branca } \\ \text { Alto Garças } & \text { Dom Aquino } & \text { Rondonópolis } \\ \text { Alto Paraguai } & \text { Itiquira } & \text { Torixoréu } \\ \text { Arenápolis } & \text { Jaciara } & \text { Tesouro } \\ \text { Barão de Melgaço } & \text { Nortelândia } & \end{array}$

Na década de 1960 a 1970 foram criados 05 (cinco) municípios:
Araguainha
Luciara
Porto dos Gaúchos
General Carneiro
Nobres

Na década de 1970 a 1980 foram criados 21 (vinte e um) municípios:

$\begin{array}{lll}\text { Água Boa } & \text { Mirassol D’Oeste } & \text { Salto do Céu } \\ \text { Alta Floresta } & \text { Nova Brasilândia } & \text { Santa Terezinha } \\ \text { Araputanga } & \text { Nova Xavantina } & \text { São Félix do Araguaia } \\ \text { Canarana } & \text { Paranatinga } & \text { São José do Rio Claro } \\ \text { Colíder } & \text { Pedra Preta } & \text { São José dos Quatro } \\ & & \text { Marcos } \\ \text { Jauru } & \text { Pontes e Lacerda } & \text { Sinop } \\ \text { Juscimeira } & \text { Rio Branco } & \text { Tangará da Serra }\end{array}$

Na década de 1980 a 1990 foram criados 41 (quarenta e um) municípios:

$\begin{array}{lll}\text { Alto Taquari } & \text { Indiavaí } & \text { Paranaíta } \\ \text { Apiacás } & \text { Itaúba } & \text { Peixoto de Azevedo } \\ \text { Araguaiana } & \text { Jangada } & \text { Porto Alegre do Norte } \\ \text { Brasnorte } & \text { Juara } & \text { Porto Esperidião } \\ \text { Campinápolis } & \text { Juína } & \text { Primavera do Leste } \\ \text { Campo Verde } & \text { Juruena } & \text { Reserva do Cabaçal } \\ \text { Campo Novo do Parecis } & \text { Lucas do Rio Verde } & \text { Ribeirão Cascalheira } \\ \text { Castanheira } & \text { Marcelândia } & \text { São José do Povo }\end{array}$




$\begin{array}{lll}\text { Cláudia } & \text { Matupá } & \text { Sorriso } \\ \text { Cocalinho } & \text { Nova Canaã do Norte } & \text { Tapurah } \\ \text { Comodoro } & \text { Nova Mutum } & \text { Terra Nova do Norte } \\ \text { Denise } & \text { Nova Olímpia } & \text { Vera } \\ \text { Figueirópolis D'Oeste } & \text { Novo Horizonte do Norte } & \text { Vila Rica } \\ \text { Guarantã do Norte } & \text { Novo São Joaquim } & \end{array}$

Na década de 1990 a 2000 foram criados 45 (quarenta e cinco) municípios:

$\begin{array}{lll}\text { Alto Boa Vista } & \text { Lambari D'Oeste } & \text { Querência } \\ \text { Bom Jesus do Araguaia } & \text { Nova Guarita } & \text { Ribeirãozinho } \\ \text { Campos de Júlio } & \text { Nova Lacerda } & \text { Rondolândia } \\ \text { Canabrava do Norte } & \text { Nova Marilândia } & \text { Santa Carmem } \\ \text { Carlinda } & \text { Nova Maringá } & \text { Santa Cruz do Xingu } \\ \text { Colniza } & \text { Nova Monte Verde } & \text { Santa Rita do Trivelato } \\ \text { Confresa } & \text { Nova Nazaré } & \text { Santo Afonso } \\ \text { Conquista D'Oeste } & \text { Nova Santa Helena } & \text { Santo Antônio do Leste } \\ \text { Cotriguaçu } & \text { Nova Ubiratã } & \text { São José do Xingu } \\ \text { Curvelândia } & \text { Nova Bandeirantes } & \text { São Pedro da Cipa } \\ \text { Feliz Natal } & \text { Novo Mundo } & \text { Sapezal } \\ \text { Gaúcha do Norte } & \text { Novo Santo Antônio } & \text { Serra Nova Dourada } \\ \text { Glória D'Oeste } & \text { Planalto da Serra } & \text { Tabaporã } \\ \text { Ipiranga do Norte } & \text { Pontal do Araguaia } & \text { União do Sul } \\ \text { Itanhangá } & \text { Porto Estrela } & \text { Vale de São Domingos }\end{array}$

Pretende-se que os dados apresentados corroborem com a tese da intensa ocupação demográfica que vem ocorrendo no estado de Mato Grosso. Para cá vieram pessoas de todas as partes do país, com o firme propósito de construir, em Mato Grosso, seus novos lares.

Em 1977, Mato Grosso cedeu parte de sua área para a criação de Mato Grosso do Sul. Assim, naquela época, o estado de Mato Grosso ficou com apenas 38 (trinta e oito) municípios. Atualmente Mato Grosso possui 141 (cento e quarenta e um) municípios. Portanto, em período de tempo pouco superior a 03 (três) décadas, 
o aumento de municípios, em termos absolutos, é de 103 (cento e três) municípios, correspondendo em nível percentual a 271,1\%.

Nesses últimos trinta anos ocorreram também crescimentos em todos os setores da economia mato-grossense. Destacam-se apenas mais dois aspectos com o intuito de acrescentar um exemplo a mais.

Com base nas pesquisas socioeconômicas do Anuário Estatístico de Mato Grosso - 2009, publicado pela SEPLAN - MT, os principais produtos agrícolas do estado de Mato Grosso foram: algodão, arroz, banana, cana-de-açúcar, feijão, mandioca, milho e soja. O volume da produção agrícola foi superior a 44.835 .803 toneladas. Os principais rebanhos foram: bovino, eqüino, ovino e suíno. Os rebanhos, nessa época, perfaziam um total de 28.524 .282 cabeças.

A população residente, recenseada em 2007 e divulgada pelo Instituto Brasileiro de Geografia e Estatística (IBGE), foi de 2.854.642 habitantes, sendo que 2.305.507 encontravam-se na zona urbana e 549.135 na zona rural. A densidade demográfica do estado de Mato Grosso atingiu o índice de 3,2 hab./km². A representatividade da população urbana foi de $80,8 \%$.

As possibilidades turísticas são muito expressivas, mas ainda não cuidadosamente exploradas, seja no potencial turístico, seja no aspecto de preservação ambiental. Esses dois aspectos precisam ser observados para que haja baixo impacto ambiental e, desse modo, seja possível preservar as belezas naturais, não só na mesorregião Sudeste Mato-grossense, como em todas as outras mesorregiões do estado de Mato Grosso.

Mato Grosso, ainda assim, destaca-se com áreas de grande potencial turístico, conhecido em nível nacional e, até mesmo, internacional: Pantanal Matogrossense, Chapada dos Guimarães, Chapada dos Parecis, região do rio Araguaia, vale do rio Guaporé, etc.

No Pantanal a fauna e a flora encantam pela quantidade e beleza exuberante. E ainda, seus animais, flores, árvores, etc. emprestam seus nomes para toponimizar acidentes na região: corixo Capivara, córrego Acorizal, baía Tucum, etc. As baías Chacororé e Siá Mariana são visitadas anualmente por milhares de turistas 
que se encantam com suas extensões, belezas e usufruem de suas águas para lazer e práticas de esportes aquáticos. A cachoeira Véu de Noiva, nas proximidades da divisa entre os municípios de Cuiabá e Chapada dos Guimarães, é um dos principais cartões postais de toda a região. A serra do Tapirapuã, no município de Rosário Oeste, atualmente é visitada por turistas e por praticantes de esportes radicais. As praias fluviais que margeiam o rio Araguaia são visitadas, anualmente, por milhares de turistas que se encantam com as soberbas paisagens. A beleza agreste do cerrado mato-grossense cativa com sua diversidade de animais, plantas e flores. Foram citados apenas alguns exemplos dos muitos que se encontram na mesorregião Centro-Sul Mato-grossense já pesquisada e na mesorregião Sudeste Mato-grossense, ora pesquisada, apenas para destacar e realçar o potencial turístico. 


\subsection{Mesorregião Sudeste Mato-grossense}

\subsubsection{Características gerais da mesorregião Sudeste Mato-grossense}

A mesorregião Sudeste Mato-grossense é uma das 05 (cinco) mesorregiões que compõe o estado de Mato Grosso, formada por 22 (vinte e dois) municípios, que estão agrupados em 04 (quatro) microrregiões. De acordo com a Resolução nº 05 de 10 de setembro de 2002 do Instituto Brasileiro de Geografia e Estatística (IBGE), a divisão geopolítica da mesorregião ficou assim estabelecida:

a) microrregião Alto Araguaia, formada pelos municípios:

- Alto Araguaia,

- Alto Garças,

- Alto Taquari;

b) microrregião Primavera do Leste, formada pelos municípios:

- Campo Verde,

- Primavera do Leste;

c) microrregião Rondonópolis, formada pelos municípios:

- Dom Aquino,

- Itiquira,

- Jaciara,

- Juscimeira,

- Pedra Preta, 
- Rondonópolis,

- São José do Povo,

- São Pedro da Cipa;

d) microrregião Tesouro, formada pelos municípios:

- Araguainha,

- General Carneiro,

- Guiratinga,

- Pontal do Araguaia,

- Ponte Branca,

- Poxoréu,

- Ribeirãozinho,

- Tesouro,

- Torixoréu.

Dentre os 141 (cento e quarenta e um) municípios mato-grossenses, constata-se que 24 (vinte e quatro) possuem altitude superior a 400 (quatrocentos) metros acima do nível do mar. A mesorregião Sudeste Mato-grossense possui 11 (onze) municípios que estão entre os que possuem as maiores altitudes do estado de Mato Grosso, o que Ihes propicia temperatura mais amena que na maioria dos municípios mato-grossenses. Os córregos, ribeirões e rios que irrigam com suas águas a mesorregião Sudeste Mato-grossense pertencem às bacias hidrográficas brasileiras: Amazônica, Araguaia-Tocantina e Pratina, com maior predominância de afluentes da bacia Araguaia-Tocantina. É uma região com grandes alternativas sociais, econômicas e turísticas. Neste início do século XXI elas estão centradas, principalmente, nas atividades agro-pecuárias, porém deve-se registrar que as atividades extrativas minerais ainda persistem na região. 
A extensão territorial da mesorregião Sudeste Mato-grossense, dados do Anuário Estatístico de Mato Grosso - 2009, publicado pela SEPLAN - MT, é de $71.887 \mathrm{~km}^{2}$. Com relação à extensão territorial é a menor mesorregião matogrossense. Ocupa 7,96 \% da área total do estado de Mato Grosso. Apesar disso, pode-se constatar que possui área maior que os estados brasileiros de Alagoas, Espírito Santo, Paraíba, Rio de Janeiro, Rio Grande do Norte e Sergipe e também, sua extensão territorial é maior que a de países como Bélgica, Costa Rica, Dinamarca, Holanda, Irlanda, Israel, dentre alguns outros.

Com base nas pesquisas socioeconômicas do Anuário Estatístico de Mato Grosso - 2009, publicado pela SEPLAN - MT, os principais produtos agrícolas da mesorregião Sudeste Mato-grossense foram: algodão, arroz, banana, cana-deaçúcar, feijão, mandioca, milho e soja. O volume da produção agrícola foi superior a 7.219.752 toneladas. Os principais rebanhos foram: bovino, eqüino, ovino e suíno. Os rebanhos, nessa época, perfaziam um total de 2.902 .521 cabeças.

A população residente, recenseada em 2007 e divulgada pelo Instituto Brasileiro de Geografia e Estatística (IBGE), foi de 406.054 habitantes, sendo que 349.420 encontravam-se na zona urbana e 56.634 na zona rural. A densidade demográfica estimada atingiu o índice de 5,6 hab. $/ \mathrm{km}^{2}$, com $86,1 \%$ de representatividade da população urbana. É o segundo maior índice de urbanização dentre as mesorregiões que compõem o estado de Mato Grosso.

A mesorregião Sudeste Mato-grossense limita-se com as seguintes mesorregiões: Centro-Sul Mato-grossense, Nordeste Mato-grossense, Norte Matogrossense e com os estados de Goiás e Mato Grosso do Sul.

A seguir, as características gerais da microrregião Alto Araguaia, e na seqüência, as características gerais dos municípios que a compõem, com suas respectivas relações de topônimos. 


\subsection{Microrregião Alto Araguaia}

\subsubsection{Características gerais da microrregião Alto Araguaia}

A microrregião Alto Araguaia é uma das 04 (quatro) microrregiões que compõe a mesorregião Sudeste Mato-grossense. Está formada por 03 (três) municípios: Alto Araguaia, Alto Garças e Alto Taquari. No final da terceira década do século $X X$, o município de Alto Araguaia foi elevado à categoria de município. O município de Alto Garças obteve sua emancipação político-administrativa na primeira metade da década de cinqüenta. Em 1986, criou-se o município de Alto Taquari com área desmembrada do município de Alto Araguaia.

Dentre os cursos d'água que irrigam as terras da microrregião Alto Araguaia apenas o rio Taquari, afluente do rio Paraguai e que estabelece divisa entre os estados de Mato Grosso e Mato Grosso do Sul, foi navegado pelos Bandeirantes em suas rotas fluviais, de idas e vindas, para as minas de Cuiabá e Mato Grosso.

A microrregião Alto Araguaia, com relação aos estudos toponímicos, apresenta um aspecto bastante singular. Os 03 (três) municípios que a compõem são classificados em uma mesma taxionomia, cardinotopônimos: Alto Araguaia, Alto Garças e Alto Taquari.

Toda região onde atualmente localiza-se a microrregião Alto Araguaia sempre foi muito rica tanto em terras férteis como em riquezas minerais, por isso despertou interesses e cobiças nas pessoas. Desde o início de seu povoamento por não autóctones, as terras foram utilizadas para produção agropecuária e extração mineral de ouro e diamante, mas principalmente de diamante.

Não há concordância entre os historiadores pesquisados quanto à primeira atividade produtiva da região, muito embora sejam concordantes com a data de início do povoamento. Alguns afirmam que, nas duas últimas décadas do século XIX, pessoas já perlustravam os rios Araguaia e Garças, bem como alguns afluentes, à 
procura de ouro e diamante. Outros afirmam que o início do povoamento da região ocorreu com a chegada de criadores de gado. Eles vieram de outros estados e aqui encontraram terras férteis, com formosas e extensas pastagens naturais.

Em 1890 o Governo Povisório do estado de Goiás tentou anexar, de forma arbitrária, extensa área que excedia bastante os limites atuais da microrregião Alto Araguaia, ao estado de Goiás. Aquele Governo chegou a mudar a toponímia do lugar. A disputa pela área entre os dois Estados perdurou por mais de três décadas. Finalmente, ficou decidido que toda área pertencia ao estado de Mato Grosso. $\mathrm{O}$ Governo Goiano queria expandir a fronteira oeste de seu estado, mas de preferência, com terras que contivessem calcário e ricas jazidas de diamante, como a região banhada pelos rios Araguaia, Garças e seus afluentes.

A região foi palco de disputas interestaduais, mas também, de disputas internas. As disputas pelo controle de áreas que continham ricas jazidas de diamante proporcionaram, por várias vezes, situações conflituosas que ameaçavam a vida dos habitantes e a estabilidade da região, exigindo interferências das autoridades estaduais constituídas, para pacificar os pontos conflitantes e buscar o restabelecimento da ordem econômico-social.

Com o passar das décadas, as rodovias estaduais e federais vieram e não só contribuiram com o desenvolvimento socioeconômico regional, como também, concretizaram a interligação dos três municípios com a capital Cuiabá e, conseqüentemente, com as regiões central e norte do estado de Mato Grosso, como também, com os estados de Goiás e Mato Grosso do Sul. Os trilhos da Ferronorte já chegaram à região e acenam com mais perspectivas de progresso regionalizado.

A extensão territorial da microrregião Alto Araguaia é de $10.593 \mathrm{~km}^{2}$, dados do Anuário Estatístico de Mato Grosso - 2009, publicado pela Secretaria de Estado de Planejamento e Coordenação Geral do Estado de Mato Grosso (SEPLAN - MT). É a terceira maior microrregião, em extensão territorial, da mesorregião Sudeste Mato-grossense e ocupa $14,74 \%$ de sua área total.

Com base nas pesquisas socioeconômicas do Anuário Estatístico de Mato Grosso - 2009, os principais produtos agrícolas da microrregião Alto Araguaia foram: 
algodão, arroz, banana, cana-de-açúcar, feijão, mandioca, milho e soja. O volume da produção agrícola foi superior a 840.826 toneladas. Os principais rebanhos foram: bovino, eqüino, ovino e suíno. Os rebanhos, nessa época, perfaziam um total de 259.767 cabeças.

A população residente, recenseada em 2007 e divulgada pelo Instituto Brasileiro de Geografia e Estatística (IBGE), foi de 28.980 habitantes, sendo que 25.151 encontravam-se na zona urbana e 3.829 na zona rural. A densidade demográfica atingiu o índice de 2,7 hab. $/ \mathrm{km}^{2}$ e a representatividade da população urbana foi superior a 86,8. A microrregião Alto Araguaia é a menos populosa da mesorregião Sudeste Mato-grossense.

A microrregião Alto Araguaia limita-se com as microrregiões Rondonópolis, Tesouro e os estados de Goiás e Mato Grosso do Sul. A seguir, as características gerais dos municípios que a compõem, com suas respectivas relações de topônimos. 


\subsubsection{Características gerais do município de Alto Araguaia}

O município de Alto Araguaia obteve sua autonomia político-administrativa em 1938, ao ser desmembrado do município de Cuiabá. A cidade de Alto Araguaia localiza-se à margem esquerda do rio Araguaia, do lado oposto localiza-se a cidade de Santa Rita do Araguaia, no estado de Goiás.

A extensão territorial do município de Alto Araguaia é de $5.538 \mathrm{~km}^{2}$, dados do Anuário Estatístico de Mato Grosso - 2009, publicado pela SEPLAN - MT. A altitude na cidade de Alto Araguaia é de 692 metros acima do nível do mar.

O topônimo Alto Araguaia possui estrutura híbrida, formado pela unidade lexical portuguesa alto + unidade lexical do tupi antigo araguaia. Neste caso a unidade lexical alto especifica que é área próxima à cabeceira ou nascente do rio com o qual compartilha o nome. Nos estudos toponímicos, é classificado taxionomicamente como cardinotopônimo.

Segundo Sampaio, a unidade lexical tupi tem as seguintes características: "ARAGUAYA, s. c. ará-guaya, os papagaios mansos" (1970, p. 174).

A lei $n^{\circ}$ 387, de 12 de abril de 1904, criou a freguesia do Registro do Araguaia que foi o primeiro topônimo de Alto Araguaia.

Em 12 de junho de 1915, a freguesia foi elevada à categoria de distrito de paz com o topônimo Santa Rita do Araguaia. O distrito foi criado pela Lei $n^{\circ} 696$, sob jurisdição do município de Cuiabá. A Resolução n 837 de 25 de outubro de 1921 elevou o distrito à categoria de município, mantendo a denominação. Em 1933 a sede do município de Santa Rita do Araguaia foi transferida para a vila do Lajeado por determinação do Decreto $n^{\circ} 291$ de 02 de agosto. O Decreto-lei no 208 de 26 de outubro de 1938 restabeleceu-lhe a condição de município mato-grossense, mas já com a denominação de Alto Araguaia.

O município era formado, naquela época, pelos distritos: Sede, Itiquira, Ribeirãozinho e São Vicente. Em 31 de dezembro de 1943, Alto Araguaia perdeu os 
distritos Ribeirãozinho e São Vicente, porém mais tarde adquiriu dois outros distritos: Alto Garças e Ponte Branca. Posteriormente, os distritos Alto Garças, Itiquira e Ponte Branca obtiveram emancipação político-administrativa.

Atualmente o município de Alto Araguaia está constituído pelos distritos: Sede e Buriti.

O distrito de Buriti foi criado pela Lei nº 4.386 de 16 de novembro de 1981.

Com base nas pesquisas socioeconômicas do Anuário Estatístico de Mato Grosso - 2009, publicado pela SEPLAN - MT, os principais produtos agrícolas do município de Alto Araguaia foram: algodão, arroz, banana, cana-de-açúcar, mandioca, milho e soja. O volume da produção agrícola foi superior a 80.251 toneladas. Os principais rebanhos foram: bovino, eqüino, ovino e suíno. Os rebanhos, nessa época, perfaziam um total de 171.946 cabeças.

A população residente, recenseada em 2007 e divulgada pelo Instituto Brasileiro de Geografia e Estatística (IBGE), foi de 13.790 habitantes, sendo que 11.681 encontravam-se na zona urbana e 2.109 na zona rural. A densidade demográfica atingiu o índice de 2,5 hab. $/ \mathrm{km}^{2}$ e a representatividade da população urbana foi superior a $84,7 \%$.

O município de Alto Araguaia localiza-se na mesorregião Sudeste Matogrossense e é um dos municípios que compõe a microrregião Alto Araguaia. Limitase com os municípios de Araguainha, Alto Garças, Alto Taquari, Itiquira e os estados de Goiás e Mato Grosso do Sul.

A seguir, anexam-se as relações dos topônimos do município Alto Araguaia, registrados no mapa elaborado pela Fundação de Pesquisas Cândido Rondon (FCR), que integra o corpus desta pesquisa. Os topônimos estão antecedidos pelos seus respectivos acidentes físicos e acidentes antrópicos, também identificados como elementos físicos e elementos humanos de uma paisagem. 
4.3.2.1 Relação dos acidentes físicos do município de Alto Araguaia, de seus topônimos e taxionomias.

\begin{tabular}{|c|c|c|c|}
\hline $\mathbf{N}^{\mathbf{0}}$ & Acidente & Topônimo & Taxionomia \\
\hline 01 & cabeceira do & Pontinha (I18, I19) & Hodotopônimo \\
\hline 02 & cabeceira do & Pontinha (I19, J19) & Hodotopônimo \\
\hline 03 & córrego do & Açude (AF7, AG7) & Hidrotopônimo \\
\hline 04 & córrego do & Açude (E20, F21) & Hidrotopônimo \\
\hline 05 & córrego & Açude (I14) & Hidrotopônimo \\
\hline 06 & córrego do & Açude (M10, M11) & Hidrotopônimo \\
\hline 07 & córrego do & Açude (M19, N19) & Hidrotopônimo \\
\hline 08 & córrego do & Açude (O13) & Hidrotopônimo \\
\hline 09 & córrego do & Açude do Félix Borges (M10, M11) & Hidrotopônimo \\
\hline 10 & córrego da & África (D22, D23) & Corotopônimo \\
\hline 11 & córrego & Água Amarela (AE4, AF4) & Hidrotopônimo \\
\hline 12 & córrego & Água Amarela (AH8) & Hidrotopônimo \\
\hline 13 & córrego & Água Amarela (T15, U15) & Hidrotopônimo \\
\hline 14 & córrego & Água Azul (AD9 a AD11) & Hidrotopônimo \\
\hline 15 & córrego & Água Azul (121, I22) & Hidrotopônimo \\
\hline 16 & córrego & Água Branca (AC10, AD10) & Hidrotopônimo \\
\hline 17 & córrego & Água Branca (S14, S15, R15) & Hidrotopônimo \\
\hline 18 & córrego & Água Emendada (P15, O16) & Hidrotopônimo \\
\hline 19 & córrego & Água Emendada (Q13, P14) & Hidrotopônimo \\
\hline 20 & córrego & Água Fria (AB8, AC8) & Hidrotopônimo \\
\hline 21 & córrego & Água Limpa (T15, U15) & Hidrotopônimo \\
\hline 22 & córrego & Água Limpa (H16 a T15) & Hidrotopônimo \\
\hline 23 & córrego & Água Vermelha (AE4, AF4) & Hidrotopônimo \\
\hline 24 & córrego & Aguadinha (AA4) & Hidrotopônimo \\
\hline 25 & córrego da & Aldeia (AE1) & Poliotopônimo \\
\hline 26 & córrego do & Angico (AD1, AD2, AE2) & Fitotopônimo \\
\hline 27 & córrego da & Anta (N17) & Zootopônimo \\
\hline 28 & córrego do & Arame (U14 a X11) & Ergotopônimo \\
\hline 29 & córrego do & Areado (AD6) & Litotopônimo \\
\hline
\end{tabular}


(continuação)

\begin{tabular}{|c|c|c|c|}
\hline $\mathbf{N}^{\mathbf{0}}$ & Acidente & Topônimo & Taxionomia \\
\hline 30 & córrego do & Areado (AE3) & Litotopônimo \\
\hline 31 & córrego & Areado (R8, S7) & Litotopônimo \\
\hline 32 & córrego & Ariranha $(07,08)$ & Zootopônimo \\
\hline 33 & córrego & Ariranha (V10) & Zootopônimo \\
\hline 34 & córrego & Atoladeira (P8) & Litotopônimo \\
\hline 35 & córrego & Bacuri $(\mathrm{J} 29, \mathrm{~J} 21)$ & Fitotopônimo \\
\hline 36 & córrego & Baguaçu (B18, B19) & Fitotopônimo \\
\hline 37 & córrego dos & Baianos (P12, P13) & Etnotopônimo \\
\hline 38 & córrego & Baixadão (G15) & Geomorfotopônimo \\
\hline 39 & córrego & Balsaminho $(\mathrm{J} 17, \mathrm{I} 17)$ & Fitotopônimo \\
\hline 40 & córrego do & Bálsamo (AG13 a AJ12) & Fitotopônimo \\
\hline 41 & córrego do & Bálsamo (I18 a L17) & Fitotopônimo \\
\hline 42 & córrego & Bandeira (Q19, R19) & Historiotopônimo \\
\hline 43 & córrego da & Barraca (AF2, AF3) & Ergotopônimo \\
\hline 44 & córrego da & Barraquinha (AE2, AE3) & Ergotopônimo \\
\hline 45 & córrego & Barreirinho (H22, G22) & Litotopônimo \\
\hline 46 & córrego do & Barreiro (AA7 a AD8) & Litotopônimo \\
\hline 47 & córrego do & Baú (D20, D21) & Ergotopônimo \\
\hline 48 & córrego & Biquinha (J19) & Hidrotopônimo \\
\hline 49 & córrego & Boiadeiro (R18 a O19) & Sociotopônimo \\
\hline 50 & córrego dos & Bois (P10 a R10) & Zootopônimo \\
\hline 51 & córrego & Bonito (L18) & Animotopônimo \\
\hline 52 & córrego & Bracinho (J18, L18) & Somatotopônimo \\
\hline 53 & córrego & Britador (E18, F18) & Ergotopônimo \\
\hline 54 & córrego & Buriti (Al10 a AH13) & Fitotopônimo \\
\hline 55 & córrego & Buriti Diferente (M8, N8) & Fitotopônimo \\
\hline 56 & córrego & Buritizinho (D16, D17) & Fitotopônimo \\
\hline 57 & córrego do & Burro (O19, P19) & Zootopônimo \\
\hline 58 & córrego do & Burro (P9, P10) & Zootopônimo \\
\hline 59 & córrego & Cabeceira Alta (F19) & Hidrotopônimo \\
\hline 60 & córrego & Cabeceira Atoladeira (C23) & Hidrotopônimo \\
\hline
\end{tabular}


(continuação)

\begin{tabular}{|c|c|c|c|}
\hline $\mathbf{N}^{\circ}$ & Acidente & Topônimo & Taxionomia \\
\hline 61 & córrego & Cabeceira Bonita $(\mathrm{H} 22, \mathrm{I} 22)$ & Hidrotopônimo \\
\hline 62 & córrego & Cabeceira Comprida (AE1) & Hidrotopônimo \\
\hline 63 & córrego & Cabeceira Comprida (AG4 a AF6) & Hidrotopônimo \\
\hline 64 & córrego & Cabeceira Comprida $(\mathrm{P} 15, \mathrm{O} 15)$ & Hidrotopônimo \\
\hline 65 & córrego & Cabeceira Comprida (S10, S11, R11) & Hidrotopônimo \\
\hline 66 & córrego & Cabeceira Comprida (S13) & Hidrotopônimo \\
\hline 67 & córrego & Cabeceira da Ronda (P14, Q14) & Hidrotopônimo \\
\hline 68 & córrego & Cabeceira da Ronda (R13) & Hidrotopônimo \\
\hline 69 & córrego & Cabeceira do Açude (D23, C22) & Hidrotopônimo \\
\hline 70 & córrego & Cabeceira do Formoso (U13, U14) & Hidrotopônimo \\
\hline 71 & córrego & Cabeceira do Tigre (O8) & Hidrotopônimo \\
\hline 72 & córrego da & Cachoeira (AF7, AG7) & Hidrotopônimo \\
\hline 73 & córrego da & Cachoeira (C21, B21) & Hidrotopônimo \\
\hline 74 & córrego & Cachoeirinha (M17) & Hidrotopônimo \\
\hline 75 & córrego da & Cambraia (U11) & Ergotopônimo \\
\hline 76 & córrego & Campo Bonito (N19, N20) & Fitotopônimo \\
\hline 77 & córrego & Cantagalo (V11) & Corotopônimo \\
\hline 78 & córrego & Capão Alto (I19) & Fitotopônimo \\
\hline 79 & córrego & Capão do Mato (L18) & Fitotopônimo \\
\hline 80 & córrego do & Capim (AD8) & Fitotopônimo \\
\hline 81 & córrego do & Cateto (P19) & Zootopônimo \\
\hline 82 & córrego & Catingueira (B15) & Fitotopônimo \\
\hline 83 & córrego da & Cava (M12, M13) & Geomorfotopônimo \\
\hline 84 & córrego do & Cavalo (AD2) & Zootopônimo \\
\hline 85 & córrego do & Cedro (P12, Q11) & Fitotopônimo \\
\hline 86 & córrego do & Cedro (P19) & Fitotopônimo \\
\hline 87 & córrego do & Cervo (AH9, Al9) & Zootopônimo \\
\hline 88 & córrego & Cervo (C18 a C22) & Zootopônimo \\
\hline 89 & córrego & Cervo ou Corgão $(\mathrm{V} 8$, V9, X8) & $\begin{array}{l}\text { Zootopônimo ou } \\
\text { Hidrotopônimo }\end{array}$ \\
\hline 90 & córrego da & Chapada (Z8) & Geomorfotopônimo \\
\hline 91 & córrego do & Cipó (M18) & Fitotopônimo \\
\hline
\end{tabular}


(continuação)

\begin{tabular}{|c|c|c|c|}
\hline $\mathbf{N}^{\circ}$ & Acidente & Topônimo & Taxionomia \\
\hline 92 & córrego do & Cobreiro (AH8, Al8) & Somatotopônimo \\
\hline 93 & córrego do & Cocho $(T 10, T 11)$ & Ergotopônimo \\
\hline 94 & córrego & Comprida (H23, G23) & Dimensiotopônimo \\
\hline 95 & córrego & Comprido (F17) & Dimensiotopônimo \\
\hline 96 & córrego & Coqueiro (AB3) & Fitotopônimo \\
\hline 97 & córrego do & Coqueiro (N17, M18) & Fitotopônimo \\
\hline 98 & córrego & Corregão (M18, M19) & Hidrotopônimo \\
\hline 99 & córrego & Diamante (A18, A19) & Litotopônimo \\
\hline 100 & córrego & Divisa (B17 a A20) & Cardinotopônimo \\
\hline 101 & córrego da & Divisa (E23, E24) & Cardinotopônimo \\
\hline 102 & córrego da & Divisa (V10) & Cardinotopônimo \\
\hline 103 & córrego dos & Dourados (P11, Q11, R10) & Zootopônimo \\
\hline 104 & córrego das & Éguas (B20) & Zootopônimo \\
\hline 105 & córrego & Encantado (C18, D19) & Animotopônimo \\
\hline 106 & córrego & Enfurnado (AG8, AG9) & Geomorfotopônimo \\
\hline 107 & córrego & Enfurnado (X13 a X15) & Geomorfotopônimo \\
\hline 108 & córrego da & Espora (Q9, R9) & Ergotopônimo \\
\hline 109 & córrego da & Estiva (R13 a Q15) & Sociotopônimo \\
\hline 110 & córrego da & Estivinha (R14, R15) & Sociotopônimo \\
\hline 111 & córrego do & Falcão (V13, X13) & Zootopônimo \\
\hline 112 & córrego & Ferruja (N8, M8, M9) & Cromotopônimo \\
\hline 113 & córrego & Ferruja $(\mathrm{T} 8, \mathrm{~T} 9)$ & Cromotopônimo \\
\hline 114 & córrego & Formiga (L15, M15) & Zootopônimo \\
\hline 115 & córrego & Formiguinha (S11) & Zootopônimo \\
\hline 116 & córrego & Fundo (AG7, AH7) & Dimensiotopônimo \\
\hline 117 & córrego & Fundo (C23, D24) & Dimensiotopônimo \\
\hline 118 & córrego & Fundo (M17 a J19) & Dimensiotopônimo \\
\hline 119 & córrego & Fundo (S8 a U9) & Dimensiotopônimo \\
\hline 120 & córrego & Furna do Teodoro (AD9, AE9) & Geomorfotopônimo \\
\hline 121 & córrego do & Garimpo (AA10, AA11) & Sociotopônimo \\
\hline 122 & córrego & Gatinho (AA12, Z12, Z13) & Zootopônimo \\
\hline
\end{tabular}


(continuação)

\begin{tabular}{|c|c|c|c|}
\hline $\mathbf{N}^{\circ}$ & Acidente & Topônimo & Taxionomia \\
\hline 123 & córrego da & Goiaba (M19) & Fitotopônimo \\
\hline 124 & córrego & Gordura (R16 a O19) & Somatotopônimo \\
\hline 125 & córrego da & Gralha (N11, O11) & Zootopônimo \\
\hline 126 & córrego & Grande (Z8, Z9) & Dimensiotopônimo \\
\hline 127 & córrego da & Grota (F22, G22) & Geomorfotopônimo \\
\hline 128 & córrego & Grota do Colonião (J18, L18) & Geomorfotopônimo \\
\hline 129 & córrego & Grotão (F20) & Geomorfotopônimo \\
\hline 130 & córrego do & Guampo (AG1 a AE2) & Somatotopônimo \\
\hline 131 & córrego & Gueiroba (V13, V14) & Fitotopônimo \\
\hline 132 & córrego da & Invernada (AE7, AE8) & Geomorfotopônimo \\
\hline 133 & córrego & Iracema $(Z 9, Z 10)$ & Antropotopônimo \\
\hline 134 & córrego da & Jaguatirica (N17) & Zootopônimo \\
\hline 135 & córrego & Jararaca (AC3, AD3) & Zootopônimo \\
\hline 136 & córrego & Jirau (M9) & Ergotopônimo \\
\hline 137 & córrego & Lagoinha (M11) & Hidrotopônimo \\
\hline 138 & córrego & Lajeadinho (AG14 a Al14) & Litotopônimo \\
\hline 139 & córrego & Lajeadinho (H16 a F19) & Litotopônimo \\
\hline 140 & córrego & Lajeado (AI9, AI10) & Litotopônimo \\
\hline 141 & córrego & Lajeado (C20, C21) & Litotopônimo \\
\hline 142 & córrego & Lajeado (H17, J16) & Litotopônimo \\
\hline 143 & córrego & Lajeado (L12 a J16) & Litotopônimo \\
\hline 144 & córrego & Laranjal (AB2, AB3) & Fitotopônimo \\
\hline 145 & córrego do & Lazinho (AE3, AE4) & Antropotopônimo \\
\hline 146 & córrego & Limoeiro (AC4, AD4) & Fitotopônimo \\
\hline 147 & córrego da & Lobeira (AF6, AG6) & Fitotopônimo \\
\hline 148 & córrego da & Lobeira (I18, H19) & Fitotopônimo \\
\hline 149 & córrego & Macaúba (L10, L11) & Fitotopônimo \\
\hline 150 & córrego do & Marco (Q19, Q20) & Ergotopônimo \\
\hline 151 & córrego & Marinheiro (AA11) & Sociotopônimo \\
\hline 152 & córrego & Marruás (H15, I14) & Zootopônimo \\
\hline 153 & córrego da & Mata (AB3) & Fitotopônimo \\
\hline
\end{tabular}


(continuação)

\begin{tabular}{|c|c|c|c|}
\hline $\mathbf{N}^{\circ}$ & Acidente & Topônimo & Taxionomia \\
\hline 154 & córrego da & Mata (AD7, AD8) & Fitotopônimo \\
\hline 155 & córrego da & Mata (AE6, AE7) & Fitotopônimo \\
\hline 156 & córrego & Matinha (E22) & Fitotopônimo \\
\hline 157 & córrego do & Mato (P8, P9) & Fitotopônimo \\
\hline 158 & córrego da & Matula (AF2) & Ergotopônimo \\
\hline 159 & córrego da & Matula (L13, L13) & Ergotopônimo \\
\hline 160 & córrego do & Maxixe (C24) & Fitotopônimo \\
\hline 161 & córrego do & Meio (AE4 a AG2) & Cardinotopônimo \\
\hline 162 & córrego do & Meio (N12, M12) & Cardinotopônimo \\
\hline 163 & córrego da & Melancia (V12, X12) & Fitotopônimo \\
\hline 164 & córrego do & Mesquita (H19) & Antropotopônimo \\
\hline 165 & córrego dos & Moleques (M11, M12) & Etnotopônimo \\
\hline 166 & córrego do & Monge (AI11, Al12, AJ11) & Sociotopônimo \\
\hline 167 & córrego & Monjolinho (O19) & Ergotopônimo \\
\hline 168 & córrego & Monjolo (E20, E21) & Ergotopônimo \\
\hline 169 & córrego & Monjolos (Z10, Z11) & Ergotopônimo \\
\hline 170 & córrego & Morro do Fogo (AG8) & Geomorfotopônimo \\
\hline 171 & córrego & Olaria (E21) & Sociotopônimo \\
\hline 172 & córrego do & Óleo (M20) & Ergotopônimo \\
\hline 173 & córrego do & Óleo (N18, O18) & Ergotopônimo \\
\hline 174 & córrego & Olho-d'água (F22) & Hidrotopônimo \\
\hline 175 & córrego da & Onça (AF7, AG6) & Zootopônimo \\
\hline 176 & córrego da & Onça (G21 a G23) & Zootopônimo \\
\hline 177 & córrego da & Onça $(Z 9, Z 10)$ & Zootopônimo \\
\hline 178 & córrego da & Paca (AD1 a AD5) & Zootopônimo \\
\hline 179 & córrego do & Paiva (T12) & Antropotopônimo \\
\hline 180 & córrego do & Paraíso (C23) & Hierotopônimo \\
\hline 181 & córrego & Paraíso (H17 a G21) & Hierotopônimo \\
\hline 182 & córrego & Paredão (H17 a L16) & Geomorfotopônimo \\
\hline 183 & córrego & Pau Terra (O15, P15) & Fitotopônimo \\
\hline 184 & córrego da & Pedra (AC6, AC7) & Litotopônimo \\
\hline
\end{tabular}


(continuação)

\begin{tabular}{|c|c|c|c|}
\hline $\mathbf{N}^{\mathbf{0}}$ & Acidente & Topônimo & Taxionomia \\
\hline 185 & córrego das & Pedras (AG4, AG5) & Litotopônimo \\
\hline 186 & córrego do & Peixe (AA8, AA9, AB9) & Zootopônimo \\
\hline 187 & córrego do & Pereira (E19) & Antropotopônimo \\
\hline 188 & córrego & Piçarrinha (H23, G23) & Litotopônimo \\
\hline 189 & córrego & Pindaibão (F22 a F24) & Fitotopônimo \\
\hline 190 & córrego & Pindaibão (I17, J16) & Fitotopônimo \\
\hline 191 & córrego da & Pinguela $(011,012)$ & Hodotopônimo \\
\hline 192 & córrego & Pinguelão (N10, O10, O9) & Hodotopônimo \\
\hline 193 & córrego & Pinguelinha (O10) & Hodotopônimo \\
\hline 194 & córrego & Piraputanga (AA9, AA9) & Zootopônimo \\
\hline 195 & córrego & Piraputanga (P15 a Q13) & Zootopônimo \\
\hline 196 & córrego & Piraputanga ou do Retiro (AD7) & $\begin{array}{l}\text { Zootopônimo ou } \\
\text { Sociotopônimo }\end{array}$ \\
\hline 197 & córrego & Pontal (M16) & Geomorfotopônimo \\
\hline 198 & córrego & Pontalzinho (T16, T17) & Geomorfotopônimo \\
\hline 199 & córrego da & Ponte (AD6, AD7) & Hodotopônimo \\
\hline 200 & córrego & Ponte de Terra (AB11) & Hodotopônimo \\
\hline 201 & córrego & Ponte de Terra (U8, U9) & Hodotopônimo \\
\hline 202 & córrego & Pontinha (J18 a D22) & Hodotopônimo \\
\hline 203 & córrego dos & Porcos (R14) & Zootopônimo \\
\hline 204 & córrego da & Porteira (AD5, AE6) & Ergotopônimo \\
\hline 205 & córrego da & Porteira (AG9, AG10) & Ergotopônimo \\
\hline 206 & córrego da & Porteira (D18, D19) & Ergotopônimo \\
\hline 207 & córrego da & Porteira (M10) & Ergotopônimo \\
\hline 208 & córrego & Potreirinho (Z14, AA14) & Ergotopônimo \\
\hline 209 & córrego & Potreiro (AF7, AG7) & Ergotopônimo \\
\hline 210 & córrego do & Potreiro (D23, D24) & Ergotopônimo \\
\hline 211 & córrego do & Potrinho (J17, L17) & Zootopônimo \\
\hline 212 & córrego & Pulador (AD3, AD4) & Hidrotopônimo \\
\hline 213 & córrego & Pulador (M11 a 09) & Hidrotopônimo \\
\hline 214 & córrego & Pulador (V8, V9) & Hidrotopônimo \\
\hline 215 & córrego & Puladorzinho (U8, U9) & Hidrotopônimo \\
\hline
\end{tabular}


(continuação)

\begin{tabular}{|c|c|c|c|}
\hline $\mathbf{N}^{\mathbf{0}}$ & Acidente & Topônimo & Taxionomia \\
\hline 216 & córrego & Quati (F17) & Zootopônimo \\
\hline 217 & córrego & Quebra-cabeça (E19) & Dirrematotopônimo \\
\hline 218 & córrego & Queixada (AA10, AB10) & Zootopônimo \\
\hline 219 & córrego & Queixada (AG8, AG9) & Zootopônimo \\
\hline 220 & córrego & Queixada (G16, F16) & Zootopônimo \\
\hline 221 & córrego & Quiçaça (AB3) & Fitotopônimo \\
\hline 222 & córrego & Rajada (AD7, AE8) & Cromotopônimo \\
\hline 223 & córrego & Ranchinho (T17 a S15) & Ecotopônimo \\
\hline 224 & córrego do & Rancho (N13 a L17) & Ecotopônimo \\
\hline 225 & córrego & Rancho Queimado (Z13, Z14) & Ecotopônimo \\
\hline 226 & córrego & Rego-d'água (U10, U11) & Hidrotopônimo \\
\hline 227 & córrego & Ressaca Grande (P9, P10, Q9) & Hidrotopônimo \\
\hline 228 & córrego & Ressaca Pequena (Q9) & Hidrotopônimo \\
\hline 229 & córrego & Retirinho (AE6, AE7) & Sociotopônimo \\
\hline 230 & córrego do & Retiro (S8, S9) & Sociotopônimo \\
\hline 231 & córrego & Retiro das Éguas (S11) & Sociotopônimo \\
\hline 232 & córrego & Retiro Velho (T14 a U11) & Sociotopônimo \\
\hline 233 & córrego & Riachão do Meio (E23, E24) & Hidrotopônimo \\
\hline 234 & córrego & Ribeirãozinho (AD2 a AC6) & Hidrotopônimo \\
\hline 235 & córrego & Ribeirãozinho (J11, J12) & Hidrotopônimo \\
\hline 236 & córrego & Ribeirãozinho (X13 a Z15) & Hidrotopônimo \\
\hline 237 & córrego & Rico (AC8) & Animotopônimo \\
\hline 238 & córrego & Rico (J19 a I22) & Animotopônimo \\
\hline 239 & córrego da & Roça (AC3, AB4) & Sociotopônimo \\
\hline 240 & córrego & Rochedo (AH9, $\mathrm{AH} 10)$ & Litotopônimo \\
\hline 241 & córrego do & Rodeio (U10, V10) & Sociotopônimo \\
\hline 242 & córrego do & Roncador (AF9 a AE11) & Hidrotopônimo \\
\hline 243 & córrego & Roncador (M16 a O17) & Hidrotopônimo \\
\hline 244 & córrego & Salva-vidas (AE5) & Sociotopônimo \\
\hline 245 & córrego & São Francisco (Z12 a Z10) & Hagiotopônimo \\
\hline 246 & córrego & São José (Q7 a S10) & Hagiotopônimo \\
\hline
\end{tabular}


(continuação)

\begin{tabular}{|c|c|c|c|}
\hline $\mathbf{N}^{\mathbf{0}}$ & Acidente & Topônimo & Taxionomia \\
\hline 247 & córrego & São Paulo (AH11, Al11) & Hagiotopônimo \\
\hline 248 & córrego do & Sapé (N19, O18) & Fitotopônimo \\
\hline 249 & córrego do & Sapinho (S18, R19) & Zootopônimo \\
\hline 250 & córrego & $\operatorname{Seco}(A B 12, A A 12, A A 13)$ & Hidrotopônimo \\
\hline 251 & córrego & Sucuri (O15, P15) & Zootopônimo \\
\hline 252 & córrego & Sucuri (R7, R8) & Zootopônimo \\
\hline 253 & córrego da & Sucuri (U8, U9) & Zootopônimo \\
\hline 254 & córrego & Taboca (L19, M19, M20) & Fitotopônimo \\
\hline 255 & córrego da & Taça (C20, D20) & Ergotopônimo \\
\hline 256 & córrego & Tapera (Q12, Q13, R13) & Ecotopônimo \\
\hline 257 & córrego da & Tapera (Q18, P18) & Ecotopônimo \\
\hline 258 & córrego da & Tapera $(\mathrm{H} 14, \mathrm{I} 13, \mathrm{I} 14)$ & Ecotopônimo \\
\hline 259 & córrego & Tortinho (P13, P14) & Morfotopônimo \\
\hline 260 & córrego do & Torto (N13 a U11) & Morfotopônimo \\
\hline 261 & córrego do & Trovão (M11 a 09) & Meteorotopônimo \\
\hline 262 & córrego & Tupaçuretã (AD1, AD2) & Hierotopônimo \\
\hline 263 & córrego da & Vaca (L19 a L21) & Zootopônimo \\
\hline 264 & córrego & Varginha (N11) & Geomorfotopônimo \\
\hline 265 & córrego dos & Veados (AA12, Z12) & Zootopônimo \\
\hline 266 & córrego & Vermelho (AA3 a AB6) & Cromotopônimo \\
\hline 267 & córrego & Vermelho (T11 a U16) & Cromotopônimo \\
\hline 268 & córrego do & Vicentão (O18, O19) & Antropotopônimo \\
\hline 269 & córrego & Vista Alegre (AA5, AA6) & Dirrematotopônimo \\
\hline 270 & córrego & Zé Abílio (F20, G21) & Antropotopônimo \\
\hline 271 & lagoa do & Cedro (P11, P12) & Fitotopônimo \\
\hline 272 & lagoa do & Ondino (V10, V11) & Antropotopônimo \\
\hline 273 & lagoa & São José (S10) & Hagiotopônimo \\
\hline 274 & lagoa do & Sapo (V15) & Zootopônimo \\
\hline 275 & lagoa & Seca (Q14) & Hidrotopônimo \\
\hline 276 & lagoa & Tapera (R13) & Ecotopônimo \\
\hline 277 & lagoa do & Veado (V8) & Zootopônimo \\
\hline
\end{tabular}


(continuação)

\begin{tabular}{|c|c|c|c|}
\hline $\mathbf{N}^{\mathbf{0}}$ & Acidente & Topônimo & Taxionomia \\
\hline 278 & morro da & Aguadinha (AF11) & Hidrotopônimo \\
\hline 279 & morro & Azul (AB6) & Cromotopônimo \\
\hline 280 & morro do & Caiá-quento (U13) & Ergotopônimo \\
\hline 281 & morro do & Chapéu (AE4) & Ergotopônimo \\
\hline 282 & morro da & Cruz (Q15) & Hierotopônimo \\
\hline 283 & morro do & Cruzeiro (E19, E20) & Hierotopônimo \\
\hline 284 & morro do & Filico (R12) & Antropotopônimo \\
\hline 285 & morro do & Fogo (AF9) & Igneotopônimo \\
\hline 286 & morro da & Gueiroba (AF12) & Fitotopônimo \\
\hline 287 & morro & Jerivá (U14) & Fitotopônimo \\
\hline 288 & morro do & Major (Z12) & Sociotopônimo \\
\hline 289 & morro da & Mesa (AE8) & Ergotopônimo \\
\hline 290 & morro dos & Moleques (M11, M12) & Etnotopônimo \\
\hline 291 & morro da & Neblina (U14) & Meteorotopônimo \\
\hline 292 & morro do & Pereira (E20) & Antropotopônimo \\
\hline 293 & morro do & Potreiro (T13) & Ergotopônimo \\
\hline 294 & morro do & Potreiro (AF7) & Ergotopônimo \\
\hline 295 & morro do & Roncador (AE9) & Hidrotopônimo \\
\hline 296 & morro & Solteiro (AB9) & Etnotopônimo \\
\hline 297 & morro & Vermelho (AB5) & Cromotopônimo \\
\hline 298 & morro & Vermelho (AB8) & Cromotopônimo \\
\hline 299 & morro & Vermelho (AF11) & Cromotopônimo \\
\hline 300 & riacho do & Caetano (E23, E24) & Antropotopônimo \\
\hline 301 & riacho da & Manilha (E23, E24) & Ergotopônimo \\
\hline 302 & riacho & Taboca (N19) & Fitotopônimo \\
\hline 303 & ribeirão & Arara (L11, M11) & Zootopônimo \\
\hline 304 & ribeirão & Arrependido (AG3 a AC6) & Animotopônimo \\
\hline 305 & ribeirão & Bonito (L11, L12, J12) & Animotopônimo \\
\hline 306 & ribeirão & Claro (I13 a N20) & Cromotopônimo \\
\hline 307 & ribeirão do & Correia (B15 a B24) & Antropotopônimo \\
\hline 308 & ribeirão do & Gato Preto (AB15 a X10) & Zootopônimo \\
\hline
\end{tabular}


(conclusão)

\begin{tabular}{l|l|ll}
\hline $\mathbf{N}^{\mathbf{2}}$ & \multicolumn{1}{|c}{ Acidente } & \multicolumn{1}{c}{ Topônimo } & \multicolumn{1}{c}{ Taxionomia } \\
\hline 309 & ribeirão da & Laje (AH15) & Litotopônimo \\
310 & ribeirão do & Sapo (AB16 a T19) & Zootopônimo \\
311 & rio & Araguaia (B25 a T19) & Zootopônimo \\
312 & rio & Araguainha (E18 a A24) & Zootopônimo \\
313 & rio & Ariranha (AE9 a N8) & Zootopônimo \\
314 & rio das & Garças (C15, C16) & Zootopônimo \\
315 & rio do & Peixe (AG1 a Z7) & Zootopônimo \\
316 & rio & Taquari (AG1 a AH15) & Fitotopônimo \\
317 & serra do & Burro (P9, P10, Q10, R10) & Zootopônimo \\
318 & serra do & Correia ou Café (B16, C17) & Antropotopônimo ou \\
319 & serra & Preta (AE10, AE11) & Fitotopônimo \\
320 & serra & Vermelha (AB14 a AG15) & Cromotopônimo \\
321 & serra & Vermelha (U14, U15, V14) & Cromotopônimo \\
322 & serra & Vermelha (E19 a H22) & Cromotopônimo \\
\hline
\end{tabular}

Fonte dos dados: Mapa da Fundação de Pesquisas Cândido Rondon (FCR), 1990 escala 1:100.000.

4.3.2.2 Relação dos acidentes humanos do município de Alto Araguaia, de seus topônimos e taxionomias.

\begin{tabular}{l|l|l|l}
\hline $\mathbf{N}^{\mathbf{0}}$ & \multicolumn{1}{c|}{ Acidente } & \multicolumn{1}{c}{ Topônimo } & \multicolumn{1}{c}{ Taxionomia } \\
\hline 01 & cidade de & Alto Araguaia $(\mathrm{O} 19, \mathrm{O} 20)$ & Cardinotopônimo \\
02 & distrito & Buriti (AI11) & Fitotopônimo \\
\hline
\end{tabular}

Fonte dos dados: Mapa da Fundação de Pesquisas Cândido Rondon (FCR), 1990 escala 1:100.000. 


\subsubsection{Características gerais do município de Alto Garças}

O município de Alto Garças obteve sua autonomia político-administrativa em 1953, ao ser desmembrado do município de Alto Araguaia. A cidade de Alto Garças localiza-se às margens do ribeirão Bonito.

A extensão territorial do município de Alto Garças é de $3.660 \mathrm{~km}^{2}$, dados do Anuário Estatístico de Mato Grosso - 2009, publicado pela SEPLAN - MT. A altitude na cidade de Alto Garças é de 754 metros acima do nível do mar.

O topônimo Alto Garças possui estrutura composta, formado por adjetivo + substantivo comum com desinência de plural -s. Também neste caso, a unidade lexical alto especifica que é área próxima à cabeceira ou nascente do rio com o qual compartilha o nome. Nos estudos toponímicos é classificado, taxionomicamente, como cardinotopônimo.

O primeiro topônimo do município de Alto Garças, ainda como pequeno aglomerado urbano, foi São Vicente. Pouco depois passou a ser denominado São Vicente do Bonito e mais tarde apenas Bonito. Este topônimo permaneceu até elevação do povoado à categoria de distrito.

O Decreto $\mathrm{n}^{\circ} 222$ de 03 de fevereiro de 1933 elevou Bonito à categoria de distrito, pertencente ao município de Alto Araguaia. Este topônimo foi modificado para Alto Garças conforme determinação do Decreto-lei estadual no 545 de 31 de dezembro de 1943. O distrito Alto Garças foi elevado à categoria de município em 10 de dezembro de 1953, pela Lei $n^{0} 660$.

Consta na bibliografia pesquisada, Enciclopédia dos Municípios Brasileiros (1958, p. 47, v. XXXV) que a Lei $n^{\circ} 675$, em 11 de dezembro de 1954, criou o distrito Cafelândia do Leste Mato-grossense pertencente ao município de Alto Garças. Em 05 de dezembro de 1977, a Lei no 3.967 extinguiu o referido distrito.

Pode-se observar, desde o início do povoamento, que houve a conjugação de atividades extrativas e agropecuárias nas terras que hoje compõem o município de 
Alto Garças. Uma de suas grandes riquezas foi o diamante. As atividades garimpeiras perduraram por várias décadas e atraíram grandes levas de aventureiros que sonhavam em adquirir o precioso metal.

Atualmente o município de Alto Garças está constituído apenas pelo distrito Sede.

Com base nas pesquisas socioeconômicas do Anuário Estatístico de Mato Grosso - 2009, publicado pela SEPLAN - MT, os principais produtos agrícolas do município de Alto Garças foram: algodão, arroz, banana, milho e soja. O volume da produção agrícola foi superior a 362.534 toneladas. Os principais rebanhos foram: bovino, eqüino, ovino e suíno. Os rebanhos, nessa época, perfaziam um total de 62.160 cabeças.

A população residente, recenseada em 2007 e divulgada pelo Instituto Brasileiro de Geografia e Estatística (IBGE), foi de 9.132 habitantes, sendo que 8.280 encontravam-se na zona urbana e 852 na zona rural. A densidade demográfica atingiu o índice de 2,5 hab. $/ \mathrm{km}^{2}$ e a representatividade da população urbana foi superior a $90,7 \%$.

O município de Alto Garças localiza-se na mesorregião Sudeste Matogrossense e é um dos municípios que compõe a microrregião Alto Araguaia. Limitase com os municípios de Alto Araguaia, Araguainha, Guiratinga, Itiquira, Pedra Preta e Ponte Branca.

A seguir, anexam-se as relações dos topônimos do município de Alto Garças registrados no mapa elaborado pela Fundação de Pesquisas Cândido Rondon (FCR), que integra o corpus desta pesquisa. Os topônimos estão antecedidos pelos seus respectivos acidentes físicos e acidentes antrópicos, também identificados como elementos físicos e elementos humanos de uma paisagem. 


\subsubsection{Relação dos acidentes físicos do município de Alto Garças, de seus} topônimos e taxionomias.

\begin{tabular}{|c|c|c|c|}
\hline $\mathbf{N}^{\mathbf{0}}$ & Acidente & Topônimo & Taxionomia \\
\hline 01 & córrego do & Açucrim $(\mathrm{J} 3, \mathrm{~L} 3)$ & Sociotopônimo \\
\hline 02 & córrego do & Açude (A19) & Hidrotopônimo \\
\hline 03 & córrego do & Açude (J4) & Hidrotopônimo \\
\hline 04 & córrego do & Açude $(011,012)$ & Hidrotopônimo \\
\hline 05 & córrego do & Açude (N15, N16) & Hidrotopônimo \\
\hline 06 & córrego do & Açude (Q10, P11) & Hidrotopônimo \\
\hline 07 & córrego do & Açude (S4, S5) & Hidrotopônimo \\
\hline 08 & córrego & Água Bonita (N5 a P4) & Hidrotopônimo \\
\hline 09 & córrego & Água Limpa (05) & Hidrotopônimo \\
\hline 10 & córrego & Água Quente (U10, T10) & Hidrotopônimo \\
\hline 11 & córrego & Água-emendada (O17 a N19) & Hidrotopônimo \\
\hline 12 & córrego das & Águas-emendadas (N1, M1) & Hidrotopônimo \\
\hline 13 & córrego & Águas-emendadas (O10, N11, N11) & Hidrotopônimo \\
\hline 14 & córrego & Amorim (F16, F17) & Antropotopônimo \\
\hline 15 & córrego do & Angá (P9) & Fitotopônimo \\
\hline 16 & córrego da & Anta (Q9, P10) & Zootopônimo \\
\hline 17 & córrego da & Areia (C21, D21, C20) & Litotopônimo \\
\hline 18 & córrego da & Areia (Q15, P15) & Litotopônimo \\
\hline 19 & córrego & Areiado $(\mathrm{O} 2, \mathrm{P} 2)$ & Litotopônimo \\
\hline 20 & córrego & Argola (H16, H17, G17) & Ergotopônimo \\
\hline 21 & córrego & Argolinha (G18 a E18) & Ergotopônimo \\
\hline 22 & córrego & Arrependido (M3 a I3) & Animotopônimo \\
\hline 23 & córrego da & Atoladeira (M3, N4) & Litotopônimo \\
\hline 24 & córrego & Atravessado (I8, H9) & Morfotopônimo \\
\hline 25 & córrego & Bandeira (P10) & Historiotopônimo \\
\hline 26 & córrego da & Barraca $(07,08)$ & Ergotopônimo \\
\hline 27 & córrego & Barreirinho (G15, G16) & Litotopônimo \\
\hline 28 & córrego & Barreiro (A18, B18) & Litotopônimo \\
\hline 29 & córrego & Barreiro $(\mathrm{J} 15, \mathrm{~J} 16)$ & Litotopônimo \\
\hline
\end{tabular}


(continuação)

\begin{tabular}{|c|c|c|c|}
\hline $\mathbf{N}^{\mathbf{0}}$ & Acidente & Topônimo & Taxionomia \\
\hline 30 & córrego do & Barro (G13, P13) & Litotopônimo \\
\hline 31 & córrego & Barro Preto (M13, M14) & Litotopônimo \\
\hline 32 & córrego & Boa Vista (G11 a J11) & Animotopônimo \\
\hline 33 & córrego & Boa Vista (L7 a O7) & Animotopônimo \\
\hline 34 & córrego & Boa Vista (N12 a 011) & Animotopônimo \\
\hline 35 & córrego dos & Bois (S11 a Q11) & Zootopônimo \\
\hline 36 & córrego & Bonito (R5 a S7) & Animotopônimo \\
\hline 37 & córrego & Buracão (L8 a N8) & Geomorfotopônimo \\
\hline 38 & córrego & Buriti Alto (D22) & Fitotopônimo \\
\hline 39 & córrego & Buriti Alto (R11, R12) & Fitotopônimo \\
\hline 40 & córrego & Buriti Diferente (V9, X10) & Fitotopônimo \\
\hline 41 & córrego & Buriti Torto (M5, M6) & Fitotopônimo \\
\hline 42 & córrego & Buritizinho (M20 a M17) & Fitotopônimo \\
\hline 43 & córrego da & Cabeceira $(14,15, \mathrm{J4})$ & Hidrotopônimo \\
\hline 44 & córrego & Cabeceira Comprida $(\mathrm{J5}, \mathrm{I6})$ & Hidrotopônimo \\
\hline 45 & córrego & Cabeceira Comprida (P12) & Hidrotopônimo \\
\hline 46 & córrego & Cabeceira Comprida (R2, R3) & Hidrotopônimo \\
\hline 47 & córrego & Cabeceira Comprida (R10) & Hidrotopônimo \\
\hline 48 & córrego & Cabeceira Comprida (S7, R7) & Hidrotopônimo \\
\hline 49 & córrego & Cabeceira da Caçada (T7, T8) & Hidrotopônimo \\
\hline 50 & córrego da & Cabeceira da Lagoa (Q9) & Hidrotopônimo \\
\hline 51 & córrego & Cabeceira da Macaúba (M3, M4) & Hidrotopônimo \\
\hline 52 & córrego & Cabeceira da Onça (S10, S11) & Hidrotopônimo \\
\hline 53 & córrego & Cabeceira da Picada (N11) & Hidrotopônimo \\
\hline 54 & córrego & Cabeceira da Samambaia $(013, \mathrm{P} 12)$ & Hidrotopônimo \\
\hline 55 & córrego & Cabeceira do Açude $(\mathrm{P} 8, \mathrm{Q} 8)$ & Hidrotopônimo \\
\hline 56 & córrego & Cabeceira do Chico Preto (Q8) & Hidrotopônimo \\
\hline 57 & córrego & Cabeceira do Corgão $(T 18$, S9) & Hidrotopônimo \\
\hline 58 & córrego & Cabeceira do Faustino (Q8) & Hidrotopônimo \\
\hline 59 & córrego & Cabeceira dos Peixinhos (O9) & Hidrotopônimo \\
\hline 60 & córrego & Cabeceira Funda (C22, C23) & Hidrotopônimo \\
\hline
\end{tabular}


(continuação)

\begin{tabular}{|c|c|c|c|}
\hline $\mathbf{N}^{\circ}$ & Acidente & Topônimo & Taxionomia \\
\hline 61 & córrego & Cacau (D17) & Fitotopônimo \\
\hline 62 & córrego & Cachoeira Vermelha (H4 a L8) & Hidrotopônimo \\
\hline 63 & córrego & Cafezinho (F21 a E18) & Fitotopônimo \\
\hline 64 & córrego & Caldeirão (B16, A17) & Hidrotopônimo \\
\hline 65 & córrego & Cambaúva (D17 a A20) & Fitotopônimo \\
\hline 66 & córrego & Campestre do Peba (M18) & Fitotopônimo \\
\hline 67 & córrego & Campestre Grande (M18) & Fitotopônimo \\
\hline 68 & córrego da & Cana (R4, S4) & Fitotopônimo \\
\hline 69 & córrego & Capão (G18, G19) & Fitotopônimo \\
\hline 70 & córrego & Capão Redondo (O5) & Fitotopônimo \\
\hline 71 & córrego & Cascavel (L1, M2) & Zootopônimo \\
\hline 72 & córrego & Catingueira (L17) & Fitotopônimo \\
\hline 73 & córrego do & Cavalo (O7 a N9) & Zootopônimo \\
\hline 74 & córrego do & Cervo (P14 a O16) & Zootopônimo \\
\hline 75 & córrego da & Chácara (P3) & Sociotopônimo \\
\hline 76 & córrego & Chiqueiro Velho (M19, N19) & Ergotopônimo \\
\hline 77 & córrego da & Coam (P8, Q8) & Zootopônimo \\
\hline 78 & córrego & Comprido (P9 a O11) & Dimensiotopônimo \\
\hline 79 & córrego das & Covas $(111, \mathrm{H} 11)$ & Geomorfotopônimo \\
\hline 80 & córrego & Curitiba (O3) & Fitotopônimo \\
\hline 81 & córrego da & Currutela (Q10) & Poliotopônimo \\
\hline 82 & córrego da & Currutela dos Casados (Q10) & Poliotopônimo \\
\hline 83 & córrego da & Divisa (T8) & Cardinotopônimo \\
\hline 84 & córrego da & Divisa (L3, L4, M4) & Cardinotopônimo \\
\hline 85 & córrego & Dois Irmãos (E16, E17) & Numerotopônimo \\
\hline 86 & córrego do & Elpidão (R2, R3) & Antropotopônimo \\
\hline 87 & córrego da & $\operatorname{Ema}(J 9,19)$ & Zootopônimo \\
\hline 88 & córrego & Esparramo (C21, B21) & Sociotopônimo \\
\hline 89 & córrego do & Felipe (P2, P3) & Antropotopônimo \\
\hline 90 & córrego & Ferruja (V10) & Cromotopônimo \\
\hline 91 & córrego & Figueira $(I 16, \mid 17)$ & Fitotopônimo \\
\hline
\end{tabular}


(continuação)

\begin{tabular}{|c|c|c|c|}
\hline $\mathbf{N}^{\circ}$ & Acidente & Topônimo & Taxionomia \\
\hline 92 & córrego das & Flores (P12, P13) & Fitotopônimo \\
\hline 93 & córrego das & Flores (P13, P14) & Fitotopônimo \\
\hline 94 & córrego & Fundo (L15, L16) & Dimensiotopônimo \\
\hline 95 & córrego & Fundo (N2, N3) & Dimensiotopônimo \\
\hline 96 & córrego & Fundo $(\mathrm{O} 14, \mathrm{~N} 14)$ & Dimensiotopônimo \\
\hline 97 & córrego & Furninha (G12, G13) & Geomorfotopônimo \\
\hline 98 & córrego & Galheiro (V10 a T11) & Zootopônimo \\
\hline 99 & córrego & Galhinho Comprido (R10, R11) & Fitotopônimo \\
\hline 100 & córrego do & Gato (L9, L10) & Zootopônimo \\
\hline 101 & córrego do & Gato (A21, A20) & Zootopônimo \\
\hline 102 & córrego & Gato Preto (F17) & Zootopônimo \\
\hline 103 & córrego & Grotão (N15, M15, M16) & Geomorfotopônimo \\
\hline 104 & córrego & Guampa (H16 a J18) & Somatotopônimo \\
\hline 105 & córrego & Guariroba (L13) & Fitotopônimo \\
\hline 106 & córrego do & Inácio (C21 a D18) & Antropotopônimo \\
\hline 107 & córrego do & Indaiá (H11, H12, I12) & Fitotopônimo \\
\hline 108 & córrego & Irara $(\mathrm{P} 8, \mathrm{P9})$ & Zootopônimo \\
\hline 109 & córrego do & Jacu (B21, C22) & Zootopônimo \\
\hline 110 & córrego & Jaguatirica (P9 a N11) & Zootopônimo \\
\hline 111 & córrego & Jaguatiriquinha (M9 a M11) & Zootopônimo \\
\hline 112 & córrego & Jaraguá (Q4, R4) & Hierotopônimo \\
\hline 113 & córrego & Jataí (G12) & Zootopônimo \\
\hline 114 & córrego & Jatobá (S9, S8, R8) & Fitotopônimo \\
\hline 115 & córrego & Jardim (P12) & Fitotopônimo \\
\hline 116 & córrego & Jirau (U11, V11) & Ergotopônimo \\
\hline 117 & córrego & Joventino (O14 a L17) & Antropotopônimo \\
\hline 118 & córrego & Júlio do Manezinho $(\mathrm{O} 1, \mathrm{O} 2)$ & Antropotopônimo \\
\hline 119 & córrego da & Lagoinha (P12, O12) & Hidrotopônimo \\
\hline 120 & córrego & Lajeadinho (O12 a M14) & Litotopônimo \\
\hline 121 & córrego & Lajeado (G16, G17) & Litotopônimo \\
\hline 122 & córrego do & Lobo (T11, T12, S12) & Zootopônimo \\
\hline
\end{tabular}


(continuação)

\begin{tabular}{|c|c|c|c|}
\hline $\mathbf{N}^{\circ}$ & Acidente & Topônimo & Taxionomia \\
\hline 123 & córrego do & Luisinho (R2, R3) & Antropotopônimo \\
\hline 124 & córrego & Macaúba (T12, U12) & Fitotopônimo \\
\hline 125 & córrego & Macaúbas (M19, N19) & Fitotopônimo \\
\hline 126 & córrego & Maravilha (N8, N9) & Animotopônimo \\
\hline 127 & córrego & Marimbondo $(\mathrm{O} 6, \mathrm{P} 6)$ & Zootopônimo \\
\hline 128 & córrego & Marruás (O4) & Zootopônimo \\
\hline 129 & córrego & Mateiro $(\mathrm{H} 13, \mathrm{H} 14)$ & Zootopônimo \\
\hline 130 & córrego do & Meio (R9) & Cardinotopônimo \\
\hline 131 & córrego & Morro da Mesa (D21 a E19) & Geomorfotopônimo \\
\hline 132 & córrego & Morro Redondo (C19, D20) & Geomorfotopônimo \\
\hline 133 & córrego da & Olaria (P6) & Sociotopônimo \\
\hline 134 & córrego da & Onça (A20, B20) & Zootopônimo \\
\hline 135 & córrego da & Onça (R3 a R5) & Zootopônimo \\
\hline 136 & córrego & Oncinha (L14, J14, J15) & Zootopônimo \\
\hline 137 & córrego da & Palha (C18) & Fitotopônimo \\
\hline 138 & córrego & Pantanalzinho (H7 a G9) & Litotopônimo \\
\hline 139 & córrego & Pedra Vermelha (P7, Q7) & Litotopônimo \\
\hline 140 & córrego das & Perdizes (N4) & Zootopônimo \\
\hline 141 & córrego das & Perdizes (N5, N6) & Zootopônimo \\
\hline 142 & córrego da & Picada (J12, L13) & Hodotopônimo \\
\hline 143 & córrego & Piloteiro (R7) & Sociotopônimo \\
\hline 144 & córrego & Pindaibinha (B22, B23) & Fitotopônimo \\
\hline 145 & córrego do & Pinhal $(16,17)$ & Fitotopônimo \\
\hline 146 & córrego da & Pontinha (P5, Q4, Q5) & Hodotopônimo \\
\hline 147 & córrego & Porteira (N20, M20) & Ergotopônimo \\
\hline 148 & córrego & Potreiro (D18, D19, E20) & Ergotopônimo \\
\hline 149 & córrego do & Pouso (S9, S10) & Sociotopônimo \\
\hline 150 & córrego da & Pratinha (I3 a L4) & Litotopônimo \\
\hline 151 & córrego & Pulador (P5) & Hidrotopônimo \\
\hline 152 & córrego & Pulador (T8) & Hidrotopônimo \\
\hline 153 & córrego & Quebra Pigarro (P16, O16) & Dirrematotopônimo \\
\hline
\end{tabular}


(continuação)

\begin{tabular}{|c|c|c|c|}
\hline $\mathbf{N}^{\circ}$ & Acidente & Topônimo & Taxionomia \\
\hline 154 & córrego & Queixada (J12, I12, I13) & Zootopônimo \\
\hline 155 & córrego & Queixada (E21, E20, F20) & Zootopônimo \\
\hline 156 & córrego & Queixada (Q13, Q14) & Zootopônimo \\
\hline 157 & córrego & Queixada (P4, Q4) & Zootopônimo \\
\hline 158 & córrego & Quilombo (M13, M14) & Sociotopônimo \\
\hline 159 & córrego do & Rafael (P2, Q2) & Antropotopônimo \\
\hline 160 & córrego da & Revolta (R13, R14) & Sociotopônimo \\
\hline 161 & córrego & Ribeirãozinho (S6, S7) & Hidrotopônimo \\
\hline 162 & córrego & Ribeirãozinho (T12 a T14) & Hidrotopônimo \\
\hline 163 & córrego da & Roça (Q11 a 014) & Sociotopônimo \\
\hline 164 & córrego & Rolador (M4 a L6) & Hidrotopônimo \\
\hline 165 & córrego & Rondinha (P15) & Sociotopônimo \\
\hline 166 & córrego & Rondinha (L5, J5) & Sociotopônimo \\
\hline 167 & córrego & São João (Q6) & Hagiotopônimo \\
\hline 168 & córrego & São Vicente (M11 a H14) & Hagiotopônimo \\
\hline 169 & córrego & Serradão (H13, G13, G14) & Geomorfotopônimo \\
\hline 170 & córrego da & Seriema (L7, M7) & Zootopônimo \\
\hline 171 & córrego & Sucupira (Q4) & Fitotopônimo \\
\hline 172 & córrego da & Sucuri (Q9) & Zootopônimo \\
\hline 173 & córrego da & Sucuri (R13, R14) & Zootopônimo \\
\hline 174 & córrego do & Tanque (J14 a H16) & Hidrotopônimo \\
\hline 175 & córrego & Tapera (P7, Q7) & Ecotopônimo \\
\hline 176 & córrego da & Tapera (R15) & Ecotopônimo \\
\hline 177 & córrego & Terra Vermelha (Q12, Q13) & Litotopônimo \\
\hline 178 & córrego & Tombador (A20 a A23) & Geomorfotopônimo \\
\hline 179 & córrego & Três Barras (R5, S5) & Numerotopônimo \\
\hline 180 & córrego da & Vaca $(\mathrm{J} 16, \mathrm{J17})$ & Zootopônimo \\
\hline 181 & córrego da & Vaca $(\mathrm{O} 2, \mathrm{O} 3)$ & Zootopônimo \\
\hline 182 & córrego & Valentina (E16, E17) & Antropotopônimo \\
\hline 183 & córrego & Viralino (016, O17) & Antropotopônimo \\
\hline 184 & lagoa dos & Patos $(\mathrm{J} 6, \mathrm{~J} 7)$ & Zootopônimo \\
\hline
\end{tabular}


(conclusão)

\begin{tabular}{|c|c|c|c|}
\hline $\mathbf{N}^{\mathbf{0}}$ & Acidente & Topônimo & Taxionomia \\
\hline 185 & morro & Galheiro (U10) & Zootopônimo \\
\hline 186 & morro da & Mesa (E19, E20) & Ergotopônimo \\
\hline 187 & ribeirão & Arara (Q7 a T13) & Zootopônimo \\
\hline 188 & ribeirão & Boa Esperança (U9 a S4) & Animotopônimo \\
\hline 189 & ribeirão & Bonito (O12 A I16) & Animotopônimo \\
\hline 190 & ribeirão & Café (C16 a H18) & Fitotopônimo \\
\hline 191 & ribeirão & Claro (R14) & Cromotopônimo \\
\hline 192 & ribeirão & Contendas (L13 a F15) & Sociotopônimo \\
\hline 193 & ribeirão da & Cutia (N9 a J9) & Zootopônimo \\
\hline 194 & ribeirão da & Mata (J7 a R7) & Fitotopônimo \\
\hline 195 & ribeirão da & Onça (J10 a F16) & Zootopônimo \\
\hline 196 & ribeirão & Pedreira (S13 a Q11) & Litotopônimo \\
\hline 197 & ribeirão da & Sobra (N9 a Q5) & Sociotopônimo \\
\hline 198 & ribeirão das & Velhas (S2 a N1) & Cronotopônimo \\
\hline 199 & rio & Araguainha (N19, O18) & Zootopônimo \\
\hline 200 & rio & Diamantino (A24 a D24) & Litotopônimo \\
\hline 201 & rio das & Garças (M17 a P16) & Zootopônimo \\
\hline 202 & rio & Itiquira (Q14 a S2) & Hidrotopônimo \\
\hline 203 & rio & Prata (G4 a M1) & Litotopônimo \\
\hline 204 & serra do & Bonito (L14, J14) & Animotopônimo \\
\hline 205 & serra do & Café (F17 a I18) & Fitotopônimo \\
\hline 206 & serra da & Estrela (B22 a E22) & Astrotopônimo \\
\hline
\end{tabular}

Fonte dos dados: Mapa da Fundação de Pesquisas Cândido Rondon (FCR), 1982 - escala 1:100.000. 
4.3.3.2 Relação dos acidentes humanos do município de Alto Garças, de seus topônimos e taxionomias.

\begin{tabular}{c|l|l|l}
\hline $\mathbf{N}^{\mathbf{0}}$ & \multicolumn{1}{c}{ Acidente } & \multicolumn{1}{c}{ Topônimo } & \multicolumn{1}{c}{ Taxionomia } \\
\hline 01 & cidade de & Alto Garças (N13) & Cardinotopônimo \\
02 & povoado & Cafelândia (D17) & Fitotopônimo \\
\hline
\end{tabular}

Fonte dos dados: Mapa da Fundação de Pesquisas Cândido Rondon (FCR), 1982 escala 1:100.000. 


\subsubsection{Características gerais do município de Alto Taquari}

O município de Alto Taquari obteve sua autonomia político-administrativa em 1986, ao ser desmembrado do município de Alto Araguaia. A cidade de Alto Taquari localiza-se às margens da rodovia MT-100.

O município de Alto Taquari possui $1.395 \mathrm{~km}^{2}$ de extensão territorial, dados do Anuário Estatístico de Mato Grosso - 2009, publicado pela SEPLAN - MT. A altitude na cidade de Alto Taquari é de 851 metros acima do nível do mar.

Alto Taquari é topônimo de estrutura híbrida, formado pela unidade lexical da língua portuguesa alto + unidade lexical da língua tupi taquari. Também neste caso, a unidade lexical alto especifica que é área próxima à cabeceira ou nascente do rio com o qual compartilha o nome. Nos estudos toponímicos, é classificado taxionomicamente como cardinotopônimo.

Segundo Sampaio, a unidade lexical tupi tem as seguintes características: “TAQUARí, c. taquara-í, a canna pequena, ou fina, o taquaril.” (1970, p. 285).

O rio Taquari nasce no estado de Mato Grosso e é tributário do rio Paraguai. Ele e seus afluentes são os únicos cursos d'água da microrregião Alto Araguaia que pertencem à bacia Pratina. Como já referido, as águas do rio Taquari foram navegadas pelos Bandeirantes e aventureiros que se dirigiam às minas de Cuiabá, porém, tudo indica que as terras do município não foram trilhadas por eles. O trecho desse rio, utilizado pela navegação bandeirante, encontra-se em área que hoje pertence ao estado de Mato Grosso do Sul.

A Lei estadual $n^{0} 1.118$ de 17 de outubro de 1958 criou o distrito de Taquari. Quase trinta anos depois e com várias demonstrações de interesse pela emancipação do distrito, inclusive com realizaçãdo de plebiscito, no qual os habitantes enfatizaram a veemente vontade de transformar o distrito em município. O distrito Alto Taquari foi elevado à categoria de município, pela Lei estadual $\mathrm{n}^{\circ}$ 4.993 de 13 de maio de 1986. 
Não foi possível constatar, nos livros pesquisados, a prática de atividades garimpeiras nas terras que atualmente compõem o município de Alto Taquari. Desde o início do povoamento daquelas paragens, as pessoas que para lá se dirigiram, dedicaram-se às atividades agropecuárias. Nas últimas décadas começaram a ser desenvolvidas algumas atividades no setor da agroindústria.

Atualmente o município de Alto Taquari está constituído apenas pelo distrito Sede.

Com base nas pesquisas socioeconômicas do Anuário Estatístico de Mato Grosso - 2009, publicado pela SEPLAN - MT, os principais produtos agrícolas do município de Alto Taquari foram: algodão, milho e soja. O volume da produção agrícola foi superior a 398.041 toneladas. Os principais rebanhos foram: bovino, eqüino, ovino e suíno. Os rebanhos, nessa época, perfaziam um total de 25.661 cabeças.

A população residente, recenseada em 2007 e divulgada pelo Instituto Brasileiro de Geografia e Estatística (IBGE), foi de 6.058 habitantes, sendo que 5.190 encontravam-se na zona urbana e 868 na zona rural. A densidade demográfica atingiu o índice de 4,3 hab. $/ \mathrm{km}^{2}$ e a representatividade da população urbana foi superior a $85,7 \%$.

O município de Alto Taquari localiza-se na mesorregião Sudeste Matogrossense e é um dos municípios que compõe a microrregião Alto Araguaia. Limitase com o município de Alto Araguaia e os estados de Goiás e Mato Grosso do Sul. Suas terras ocupam o ponto mais meridional do estado de Mato Grosso.

A seguir, anexam-se as relações dos topônimos do município de Alto Taquari, registrados no mapa elaborado pela Fundação de Pesquisas Cândido Rondon (FCR), que integram o corpus desta pesquisa. Os topônimos estão antecedidos pelos seus respectivos acidentes físicos e acidentes antrópicos, também identificados como elementos físicos e elementos humanos de uma paisagem. 
4.3.4.1 Relação dos acidentes físicos do município de Alto Taquari, de seus topônimos e taxionomias.

\begin{tabular}{|c|c|c|c|}
\hline $\mathrm{N}^{\mathbf{0}}$ & Acidente & Topônimo & Taxionomia \\
\hline 01 & córrego do & Açude (N6) & Hidrotopônimo \\
\hline 02 & córrego da & Antinha $(\mathrm{H} 8, \mathrm{I})$ & Zootopônimo \\
\hline 03 & córrego & Araguainha (O12 a M12) & Zootopônimo \\
\hline 04 & córrego do & Arame (N7) & Ergotopônimo \\
\hline 05 & córrego dos & Bois $(16,17)$ & Zootopônimo \\
\hline 06 & córrego do & Capão (E7, E8) & Fitotopônimo \\
\hline 07 & córrego & Carrilho (M5, M6) & Antropotopônimo \\
\hline 08 & córrego & Castigo $(18,19)$ & Sociotopônimo \\
\hline 09 & córrego & Comprido (G8) & Dimensiotopônimo \\
\hline 10 & córrego do & Esteio $(18,19)$ & Ergotopônimo \\
\hline 11 & córrego da & Furna (M10, M11) & Geomorfotopônimo \\
\hline 12 & córrego & Grande (G8) & Dimensiotopônimo \\
\hline 13 & córrego da & Jaguatirica (M7, N7) & Zootopônimo \\
\hline 14 & córrego & José Dutra $(16,17)$ & Antropotopônimo \\
\hline 15 & córrego do & Lobo (M7) & Zootopônimo \\
\hline 16 & córrego do & Mimoso (N7, O8) & Fitotopônimo \\
\hline 17 & córrego da & Oncinha (L5, L6) & Zootopônimo \\
\hline 18 & córrego & Pau de Terra (D7, C8) & Fitotopônimo \\
\hline 19 & córrego & Pontal (L7, M7) & Geomorfotopônimo \\
\hline 20 & córrego do & Prado (M5, M6) & Fitotopônimo \\
\hline 21 & córrego & Retalho $(19,110)$ & Ergotopônimo \\
\hline 22 & córrego & Taboca (M7) & Fitotopônimo \\
\hline 23 & córrego & Três Capões (G7 a F9) & Numerotopônimo \\
\hline 24 & córrego & Valinho (L6) & Geomorfotopônimo \\
\hline 25 & lagoa do & Açude $(\mathrm{N} 6, \mathrm{~N} 7)$ & Hidrotopônimo \\
\hline 26 & ribeirão & Furna (P11 a 05) & Geomorfotopônimo \\
\hline 27 & ribeirão & Guariroba (L9 a G9) & Fitotopônimo \\
\hline 28 & ribeirão da & Laje (N5 a I7) & Litotopônimo \\
\hline 29 & ribeirão do & Sapo (I5 a A8) & Zootopônimo \\
\hline
\end{tabular}




\begin{tabular}{l|l|l|l}
\hline $\mathbf{N}^{\mathbf{2}}$ & \multicolumn{1}{c}{ Acidente } & \multicolumn{1}{c}{ Topônimo } & \multicolumn{1}{c}{ (conclusão) } \\
\hline 30 & ribeirãozinho de & Cima (G7 a G9) & Cardinotopônimo \\
31 & rio & Araguaia (O11 a A8) & Zootopônimo \\
32 & rio & Taquari (J7 a O5) & Fitotopônimo \\
33 & serra & Morro Vermelho (P12, P13) & Geomorfotopônimo \\
34 & serra & Preta (N6, O6, O7) & Cromotopônimo \\
35 & serra & Vermelha (G4 a N7) & Cromotopônimo \\
\hline
\end{tabular}

Fonte dos dados: Mapa da Fundação de Pesquisas Cândido Rondon (FCR), 1988 - escala 1:100.000.

4.3.4.2 Relação do acidente humano do município de Alto Taquari, de seu topônimo e taxionomia.

\begin{tabular}{c|l|l|l}
\hline $\mathbf{N}^{\mathbf{0}}$ & \multicolumn{1}{|c|}{ Acidente } & \multicolumn{1}{c}{ Topônimo } & Taxionomia \\
\hline 01 & cidade de & Alto Taquari (J8) & Cardinotopônimo \\
\hline
\end{tabular}

Fonte dos dados: Mapa da Fundação de Pesquisas Cândido Rondon (FCR), 1988 - escala $1: 100.000$. 


\subsubsection{Análise toponímica da microrregião Alto Araguaia}

Encontram-se, no subitem anterior, as relações de topônimos de cada um dos municípios que compõe a microrregião Alto Araguaia. Essas relações agrupam os topônimos por acidentes físicos e por acidentes antrópicos. Permitem, também, uma visualização de todos topônimos em cada um dos municípios e subsidiam a análise. Nesta parte, apresenta-se o estudo toponímico da microrregião Alto Araguaia como um todo e dá-se ênfase às características toponímicas que mais se destacam nos municípios, de acordo com a proposta do Atlas Toponímico do Brasil (ATB).

Os topônimos de microrregião Alto Araguaia foram coletados, primeiramente, nos mapas dos municípios que a compõem. As cartas topográficas foram utilizadas, em caráter complementar, para ratificar os topônimos, divididos por município, pois ambos foram elaborados na escala de 1:100.000.

Registram-se 571 (quinhentos e setenta e um) topônimos de acidentes físicos e acidentes antrópicos na microrregião Alto Araguaia. São 327 (trezentos e vinte e sete) topônimos no município de Alto Araguaia, 208 (duzentos e oito) em Alto Garças e 36 (trinta e seis) em Alto Taquari.

Não há registro, na microrregião Alto Araguaia, de topônimos classificados nas taxionomias de natureza antrópica: axiotopônimos e mitotopônimos.

A microrregião Alto Araguaia é a terceira microrregião, da mesorregião Sudeste Mato-grossense, em volume de topônimos.

Encontram-se, nesta segunda parte, vários gráficos que permitem visualizar melhor a participação de cada município no total da taxionomia. Existe também, 01 (uma) tabela que contém todas taxionomias por município e por microrregião, em ordem decrescente de quantidade. Os valores estão em números absolutos e especificam a quantidade de topônimos por município e por taxionomia. As taxionomias que não possuem valores, na microrregião Alto Araguaia, estão especificadas com um traço. Os municípios foram colocados na parte superior da tabela, ou seja, na vertical e as taxionomias na horizontal. 
Quando ocorre o registro de topônimos em um único município da microrregião ou a quantidade de topônimos registrados na taxionomia for igual ou inferior a 05 (cinco) topônimos, não se apresenta gráfico para a taxionomia.

Com base na classificação por campos semânticos dos topônimos que compõem a microrregião Alto Araguaia, foram catalogadas 28 (vinte e oito) taxionomias, dentre elas destacam-se as 10 (dez) que apresentam, em valores absolutos, os maiores índices: 101 (cento e um) hidrotopônimos, 101 (cento e um) zootopônimos, 87 (oitenta e sete) fitotopônimos, 42 (quarenta e dois) ergotopônimos, 37 (trinta e sete) litotopônimos, 30 (trinta) sociotopônimos, 28 (vinte e oito) geomorfotopônimos, 25 (vinte e cinbco) antropotopônimos, 18 (dezoito) cromotopônimos e 15 (quinze) animotopônimos.

$\mathrm{Na}$ microrregião Alto Araguaia constam 571 (quinhentos e setenta e um) topônimos que denominam 563 (quinhentos e sessenta e três) acidentes físicos: cabeceiras, córregos, lagoas, morros, riachos, ribeirãozinho, ribeirões, rios, serras e 05 (cinco) acidentes antrópicos: distrito, povoado e municípios / cidades.

Constam, na microrregião Alto Araguaia, 03 (três) acidentes físicos com dupla denominação e localizam-se no município de Alto Araguaia.

A tabela dos topônimos, em números absolutos e por taxionomias, encontrase a seguir. O agrupamento dos topônimos foi realizado com base nas classificações taxionômicas desenvolvidas por Dick e uma que foi inserida na dissertação de mestrado (2005).

Para a elaboração deste estudo, a pesquisa foi desenvolvida por etapas: levantamento dos topônimos nos mapas e nas cartas topográficas respeitando, evidentemente, os limites legais de cada município; agrupamento dos topônimos por taxionomia; agrupamento dos topônimos de etimologia indígena, neste caso específico, topônimos de etimologia tupi e bororo; agrupamento das taxionomias por natureza, isto é, por natureza física e por natureza humana.

Na seqüência analisa-se, inicialmente, as taxionomias de natureza física, com 12 (doze) taxionomias num total de 404 (quatrocentas e quatro) ocorrências, em 
seguida, as de natureza antrópica com 16 (dezesseis) taxionomias num total de 167 (cento e sessenta e sete) ocorrências.

Para que haja melhor visualização das ocorrências taxionômicas da microrregião Alto Araguaia, estão inseridas no quadro a seguir, todas taxionomias já referidas pela pesquisadora Dick e a taxionomia igneotopônimo, inserida na dissertação de mestado (2005). As taxionomias que constam na microrregião Alto Araguaia estão com os valores em números absolutos e as que não constam estão referendadas por um traço. 
Tabela 1 - Topônimos da microrregião Alto Araguaia por municípios e taxionomias

\begin{tabular}{|c|c|c|c|c|c|}
\hline \multirow{2}{*}{$\mathrm{N}^{\mathrm{O}}$} & \multirow{2}{*}{ Taxionomia } & \multicolumn{3}{|c|}{ municípios } & \multirow{2}{*}{$\begin{array}{l}\text { microrregião } \\
\text { Alto Araguaia }\end{array}$} \\
\hline & & Alto Araguaia & Alto Garças & Alto Taquari & \\
\hline & Total & 327 & 208 & 36 & 571 \\
\hline 1 & Hidrotopônimos & 59 & 40 & 2 & 101 \\
\hline 2 & Zootopônimos & 52 & 41 & 8 & 101 \\
\hline 3 & Fitotopônimos & 46 & 34 & 7 & 87 \\
\hline 4 & Ergotopônimos & 31 & 8 & 3 & 42 \\
\hline 5 & Litotopônimos & 18 & 18 & 1 & 37 \\
\hline 6 & Sociotopônimos & 16 & 13 & 1 & 30 \\
\hline 7 & Geomorfotopônimos & 15 & 8 & 5 & 28 \\
\hline 8 & Antropotopônimos & 13 & 10 & 2 & 25 \\
\hline 9 & Cromotopônimos & 14 & 2 & 2 & 18 \\
\hline 10 & Animotopônimos & 6 & 9 & - & 15 \\
\hline 11 & Dimensiotopônimos & 7 & 4 & 2 & 13 \\
\hline 12 & Cardinotopônimos & 6 & 4 & 2 & 12 \\
\hline 13 & Hodotopônimos & 9 & 2 & - & 11 \\
\hline 14 & Ecotopônimos & 7 & 2 & - & 9 \\
\hline 15 & Hierotopônimos & 5 & 1 & - & 6 \\
\hline 16 & Hagiotopônimos & 4 & 2 & - & 6 \\
\hline 17 & Somatotopônimos & 4 & 1 & - & 5 \\
\hline 18 & Etnotopônimos & 4 & - & - & 4 \\
\hline 19 & Morfotopônimos & 2 & 1 & - & 3 \\
\hline 20 & Poliotopônimos & 1 & 2 & - & 3 \\
\hline 21 & Numerotopônimos & - & 2 & 1 & 3 \\
\hline 22 & Dirrematotopônimos & 2 & 1 & - & 3 \\
\hline 23 & Historiotopônimos & 1 & 1 & - & 2 \\
\hline 24 & Meteorotopônimos & 2 & - & - & 2 \\
\hline 25 & Corotopônimos & 2 & - & - & 2 \\
\hline 26 & Igneotopônimo & 1 & - & - & 1 \\
\hline
\end{tabular}


(conclusão)

\begin{tabular}{c|l|c|c|c|c}
\hline \multirow{2}{*}{$N^{0}$} & \multirow{2}{*}{ Taxionomia } & \multicolumn{3}{|c|}{ municípios } & microrregião \\
\cline { 3 - 5 } & & Alto Araguaia & Alto Garças & Alto Taquari & Alto Araguaia \\
\hline 27 & Astrotopônimo & - & 1 & - & 1 \\
28 & Cronotopônimo & - & 1 & - & 1 \\
29 & Axiotopônimo & - & - & - & - \\
30 & Mitotopônimo & - & - & - & - \\
\hline
\end{tabular}




\section{Taxionomias de natureza física da microrregião Alto Araguaia}

\section{Hidrotopônimos}

A taxionomia hidrotopônimos é a que apresenta maior quantidade de topônimos, juntamente com a taxionomia zootopônimos, na microrregião Alto Araguaia. Os hidrotopônimos perfazem 101 (cento e uma) ocorrências. As unidades lexicais que se referem a acidentes hidrográficos em geral, quando utilizadas para denominar acidentes físicos e acidentes antrópicos, são denominadas hidrotopônimos nos estudos toponímicos.

São 59 (cinqüenta e nove) hidrotopônimos no município de Alto Araguaia, 40 (quarenta) em Alto Garças e 02 (dois) em Alto Taquari. É a taxionomia que mais denomina acidentes no município de Alto Araguaia. Apresenta-se a seguir o gráfico desta taxionomia com os respectivos topônimos por município (GRÁFICO 1).

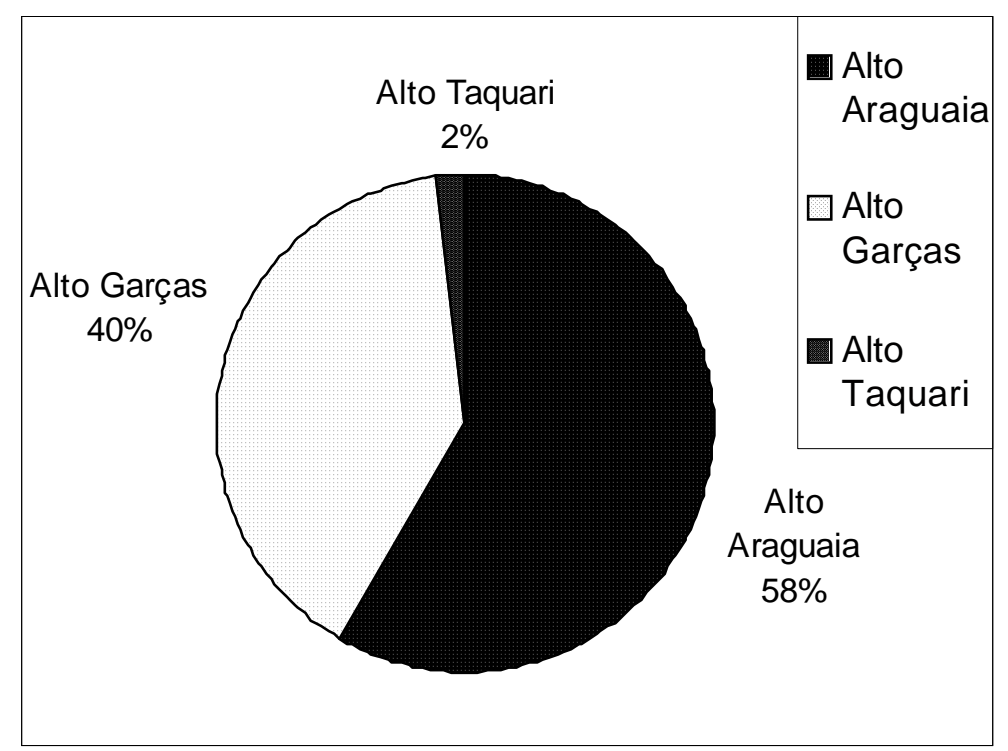

GRÁFICO 1 - Total dos hidrotopônimos da microrregião Alto Araguaia.

Registram-se, na microrregião Alto Araguaia, 03 (três) hidrotopônimos tupis e 98 (noventa e oito) portugueses. 
O município de Alto Araguaia possui 59 (cinqüenta e nove) hidrotopônimos portugueses. Alto Garças possui 03 (três) hidrotopônimos tupis e 37 (trinta e sete) portugueses. Alto Taquari possui 02 (dois) hidrotopônimos portugueses.

Os hidrotopônimos tupis, quanto à estrutura, subdividem-se em simples e híbridos. São 02 (dois) hidrotopônimos tupis híbridos e apresentam as seguintes características. Os hidrotopônimos Cabeceira da Macaúba e Cabeceira da Samambaia, formados pela unidade lexical portuguesa cabeça + sufixo -eira, indicador de quantidade, porção + conectivo + unidade lexical tupi, dão nomes a 02 (dois) córregos no município de Alto Garças. O hidrotopônimo tupi Itiquira é considerado, neste estudo, de estrutura simples. Nomeia 01 (um) rio que estabelece divisa entre os municípios de Alto Garças e Itiquira, por isso consta nas relações de topônimos dos dois municípios. A unidade lexical itiquira não está registrada no dicionário Houaiss, portanto, faz-se necessário inseri-la aqui.

Segundo Sampaio, a unidade lexical tupi tem as seguintes características: "ITIQUIRA, corr. y-tykyra, a água vertente, o minadouro." (1970, p. 230).

Considera-se, nesta pesquisa, que os hidrotopônimos portugueses da microrregião Alto Araguaia, quanto à estrutura, subdividem-se em simples e compostos. São 44 (quarenta e quatro) hidrotopônimos de estrutura simples e 54 (cinqüenta e quatro) hidrotopônimos de estrutura composta. Eles denominam acidentes físicos. Os 03 (três) municípios da microrregião Alto Araguaia possuem hidrotopônimos portugueses.

Os hidrotopônimos compostos Cabeceira da Caçada e Cabeceira da Picada, formados pela unidade lexical cabeceira + conectivo + unidade lexical derivada, denominam 02 (dois) córregos no município de Alto Garças. A primeira unidade lexical é cabeceira, já mencionada e as segundas são Caçada e Picada, formadas pelas unidades lexicais caçar e picar + sufixo -ada, indicador do efeito da ação. $O$ hidrotopônimo Cabeceira do Corgão, formado pela unidade lexical cabeceira + conectivo + unidade lexical corgo (forma sincopada de córrego) + sufixo -ão, indicador de aumentativo, dá nome a 01 (um) córrego em Alto Garças. 
Os hidrotopônimos Cabeceira da Lagoa, Cabeceira da Onça, Cabeceira da Ronda, Cabeceira do Açude e Cabeceira do Tigre, formados pela unidade lexical cabeceira + conectivo + substantivo comum, denominam 04 (quatro) córregos em Alto Araguaia e 03 (três) córregos em Alto Garças.

O hidrotopônimo Cabeceira do Formoso, formado pela unidade lexical cabeceira + conectivo + unidade lexical forma + sufixo -oso, indicador de abundância, cheio de, nomina 01 (um) córrego em Alto Araguaia. O hidrotopônimo Cabeceira dos Peixinhos, formado pela unidade lexical cabeceira + conectivo com desinência de plural $-s$ + unidade lexical peixe + sufixo -inho, formador de diminutivo com desinência de plural $-\mathrm{s}$, nomeia 01 (um) córrego em Alto Garças. O hidrotopônimo Cabeceira do Faustino, formado pela unidade lexical cabeceira + conectivo + substantivo próprio, toponimiza 01 (um) córrego em Alto Garças. O hidrotopônimo Cabeceira do Chico Preto, formado pela unidade lexical cabeceira + conectivo + hipocorístico composto, dá nome a 01 (um) córrego em Alto Garças.

Os hidrotopônimos Cabeceira Funda, Cabeceira Alta, Cabeceira Bonita e Cabeceira Comprida, formados pela unidade lexical cabeceira + adjetivo, dão nomes a 07 (sete) córregos em Alto Araguaia e a 06 (seis) córregos em Alto Garças. O hidrotopônimo Cabeceira Atoladeira, formado pela unidade lexical cabeceira + unidade lexical atolar + sufixo -ado + sufixo -eira, já citados, toponimiza 01 (um) córrego em Alto Araguaia. O hidrotopônimo Cachoeira Vermelha, formado pela unidade lexical cacho + sufixo -eira, indicador de quantidade + adjetivo, nomeia 01 (um) córrego em Alto Garças que estabelece divisa entre Alto Garças e Guiratinga, por isso consta nas relações de topônimos dos dois municípios.

Os hidrotopônimos Ressaca Grande e Ressaca Pequena, formados por substantivo comum + adjetivo, denominam 02 (dois) córregos. O hidrotopônimo Riachão do Meio, formado pela unidade lexical riacho, diminutivo irregular de rio + sufixo -ão, indicador de aumentativo + conectivo + substantivo comum, dá nome a 01 (um) córrego. Os hidrotopônimos Olho-d'água e Rego-d'água, substantivos compostos, singularizam 02 (dois) córregos. Todos localizam-se em Alto Araguaia. 
O hidrotopônimo Açude do Félix Borges, formado por substantivo comum + conectivo + nome próprio de pessoa + apelido de família, toponimiza 01 (um) córrego em Alto Araguaia.

Os hidrotopônimos Água Amarela, Água Azul, Água Branca, Água Fria, Água Limpa e Água Vermelha, formados por substantivo comum + adjetivo, denominam 11 (onze) córregos em Alto Araguaia. Os hidrotopônimos Água Bonita, Água Limpa e Água Quente dão nomes a 03 (três) córregos em Alto Garças.

Há um hidrotopônimo composto que apresenta variação de grafia e optou-se por respeitar a grafia registrada nos mapas que consta nas relações de topônimos, mas mantém, nesta parte, a forma dicionarizada. O hidrotopônimo Água-emendada, (ocorre também a grafia Água Emendada) nomeia 02 (dois) córregos em Alto Araguaia e 01 (um) córrego em Alto Garças. O hidrotopônimo Águas-emendadas, apresenta desinência de plural -s e denomina 02 (dois) córregos em Alto Garças.

Os hidrotopônimos de estrutura simples subdividem-se em derivados e não derivados. Alguns hidrotopônimos apresentam dupla sufixacão. O hidrotopônimo Aguadinha, formado pela unidade lexical água + sufixo -ada, indicador de conteúdo + sufixo -inha, indicador de diminutivo, nomeia 01 (um) córrego e 01 (um) morro no município de Alto Araguaia. O hidrotopônimo Cachoeirinha, formado pela unidade lexical cacho + sufixo -eiro + sufixo -inha, já descritos, dá nome a 01 (um) córrego em Alto Araguaia.

O hidrotopônimo Puladorzinho, formado pela unidade lexical pular + sufixo dor, indicador do agente de ação + sufixo -(z)inho, já mencionado, particulariza 01 (um) córrego em Alto Araguaia. O hidrotopônimo Ribeirãozinho, formado pela unidade lexical ribeiro + sufixo -ão, indicador de aumentativo + sufixo -(z)inho, já descrito, denomina 02 (dois) córregos em Alto Araguaia, 01 (um) córrego em Alto Garças e 01 (um) córrego que estabelece divisa entre Alto Araguaia e Alto Garças, por isso consta nas relações de topônimos dos dois municípios.

O hidrotopônimo Corgão, formado pela unidade lexical corgo (forma sincopada de córrego) + sufixo -ão, indicador de aumentativo, consta como segundo topônimo de 01 (um) córrego em Alto Araguaia. O hidrotopônimo Biquinha e 
Lagoinha, formados pelas unidades lexicais bica e lagoa + sufixo -(qu)inha, já descrito, denominam 02 (dois) córregos em Alto Araguaia e 01 (um) córrego em Alto Garças. Os hidrotopônimos Pulador, Rolador e Roncador, formados pelas unidades lexicais pular, rolar e roncar + sufixo -dor, já mencionado, nomeiam 03 (três) córregos em Alto Garças, 01(um) morro e 05 (cinco) córregos em Alto Araguaia.

O hidrotopônimo Cabeceira, formado pela unidade lexical cabeça + sufixo eira, já mencionado, dá nome a 01 (um) córrego em Alto Garças. O hidrotopônimo Cachoeira, formado pela unidade lexical cacho + sufixo -eira, já mencionado, denomina 02 (dois) córregos em Alto Araguaia. Os hidrotopônimos Caldeirão e Corregão, formados pelas unidades lexicais caldeira e córrego + sufixo -ão, indicador de aumentativo, particularizam, respectivamente, 01 (um) córrego em Alto Garças e 01 (um) córrego em Alto Araguaia. O hidrotopônimo Caldeirão estabelece divisa entre Alto Garças e Guiratinga, por isso consta nas relações de topônimos dos dois municípios.

O hidrotopônimo simples e não derivado Açude dá nome a 06 (seis) córregos no município de Alto Araguaia, a 05 (cinco) córregos em Alto Garças, a 01 (uma) lagoa e a 01 (um) córrego em Alto Taquari, e também, a 01 (um) córrego em Alto Garças que estabelece divisa entre Alto Garças e Guiratinga, por isso consta nas relações de topônimos dos dois municípios. O hidrotopônimo Seco nomeia 01 (um) córrego e o hidrotopônimo Seca denomina 01 (uma) lagoa, ambos em Alto Araguaia. O hidrotopônimo Tanque dá nome a 01 (um) córrego em Alto Garças.

Os hidrotopônimos, em geral, apresentam uma característica bastante peculiar, que recebe, nos estudos toponímicos, a denominação de toponimização do acidente físico. A microrregião Alto Araguaia possui 59 (cinqüenta e nove) acidentes físicos que foram denominados por unidades lexicais que, em um sintagma toponímico, exercem a função de termo genérico, ou seja, designam o acidente físico propriamente dito e antecedem o termo específico, isto é, a denominação do acidente ou topônimo.

O hidrotopônimo Açude dá nome a 13 (treze) córregos e 01 (uma) lagoa. Os hidrotopônimos Cabeceira, Cachoeira, Cachoeirinha, Corgão, Corregão, Lagoinha e Ribeirãozinho nomeiam 12 (doze) córregos. Vale anotar que há 01 (um) córrego 
toponimizado como Ribeirãozinho que estabelece divisa entre os municípios de Alto Araguaia e Alto Garças e, neste caso específico, foi contabilizado uma única vez. Os hidrotopônimos compostos Açude do Félix Borges, Cabeceira Alta, Cabeceira Atoladeira, Cabeceira Bonita, Cabeceira Comprida, Cabeceira Funda, Cabeceira da Caçada, Cabeceira da Lagoa, Cabeceira da Macaúba, Cabeceira da Onça, Cabeceira da Picada, Cabeceira da Ronda, Cabeceira da Samambaia, Cabeceira do Açude, Cabeceira do Chico Preto, Cabeceira do Corgão, Cabeceira do Faustino, Cabeceira do Formoso, Cabeceira do Tigre, Cabeceira dos Peixinhos, Cachoeira Vermelha e Riachão do Meio denominam 33 (trinta e três) córregos.

A produtividade toponímica dos hidrotopônimos, na microrregião Alto Araguaia, evidencia-se nos seguintes topônimos. O hidrotopônimo Açude nomina 06 (seis) córregos em Alto Araguaia, 05 (cinco) córregos em Alto Garças, 01 (um) córrego que estabelece divisa entre Alto Garças e Guiratinga, 01 (um) córrego e 01 (uma) lagoa em Alto Taquari, pode-se ainda acrescentar o hidrotopônimo Açude do Félix Borges que nomeia 01 (um) córrego em Alto Araguaia.

Os hidrotopônimos compostos, na microrregião Alto Araguaia, formados pela unidade lexical água seguida por um dos adjetivos: amarela, azul, bonita, branca, fria, limpa, quente e vermelha, denominam 11 (onze) córregos em Alto Araguaia e 03 (três) em Alto Garças. O hidrotopônimo Água-emendada nomeia 02 (dois) córregos em Alto Araguaia e 01 (um) córrego em Alto Garças. O hidrotopônimo Águasemendadas denomina 02 (dois) córregos em Alto Garças. O hidrotopônimo Aguadinha denomina 01 (um) córrego e 01 (um) morro em Alto Araguaia.

O hidrotopônimo Cabeceira toponimiza 01 (um) córrego em Alto Garças. A unidade lexical cabeceira seguida pelas unidades lexicais: alta, atoladeira, bonita, comprida, da caçada, da lagoa, da macaúba, da onça, da picada, da ronda, da samambaia, do açude, do Chico Preto, do corgão, do Faustino, do formoso, do tigre, dos peixinhos e funda nomeiam 13 (treze) córregos em Alto Araguaia e 17 (dezessete) córregos em Alto Garças.

O hidrotopônimo Cachoeira nomeia 02 (dois) córregos em Alto Araguaia. Pode-se ainda acrescentar o hidrotopônimo Cachoeirinha que dá nome a 01 (um) córrego em Alto Araguaia e o hidrotopônimo Cachoeira Vermelha que nomina 01 
(um) córrego em Alto Garças. O hidrotopônimo Lagoinha particulariza 01 (um) córrego em Alto Araguaia e outro em Alto Garças. O hidrotopônimo Roncador denomina 01 (um) morro e 02 (dois) córregos em Alto Araguaia. O hidrotopônimo Ribeirãozinho designa 02 (dois) córregos em Alto Araguaia, 01 (um) em Alto Garças e 01 (um) córrego que estabelece divisa entre Alto Araguaia e Alto Garças.

O hidrotopônimo Pulador nomeia 03 (três) córregos em Alto Araguaia e 02 (dois) em Alto Garças. Pode-se ainda acrescentar o hidrotopônimo Puladorzinho que toponimiza 01 (um) córrego em Alto Araguaia. Os hidrotopônimos compostos Ressaca Grande e Ressaca Pequena, cada um dá nome a 01 (um) córrego em Alto Araguaia. Os hidrotopônimos Seco e Seca denominam 01 (um) córrego e 01 (uma) lagoa em Alto Araguaia.

Os hidrotopônimos correspondem a $17,7 \%$ do total de topônimos da microrregião Alto Araguaia.

\section{Zootopônimos}

A taxionomia zootopônimos, na microrregião Alto Araguaia, também possui 101 (cento e uma) ocorrências. Nos estudos toponímicos, as unidades lexicais que se referem aos animais em geral, quando utilizadas para nomear acidentes físicos e acidentes antrópicos, são denominadas zootopônimos.

São 52 (cinqüenta e dois) zootopônimos em Alto Araguaia, 41 (quarenta e um) em Alto Garças e 08 (oito) zootopônimos em Alto Taquari. É a taxionomia que mais denomina acidentes nos municípios de Alto Garças e Alto Taquari. Apresentase a seguir o gráfico desta taxionomia com os respectivos percentuais por município (GRÁFICO 2). 


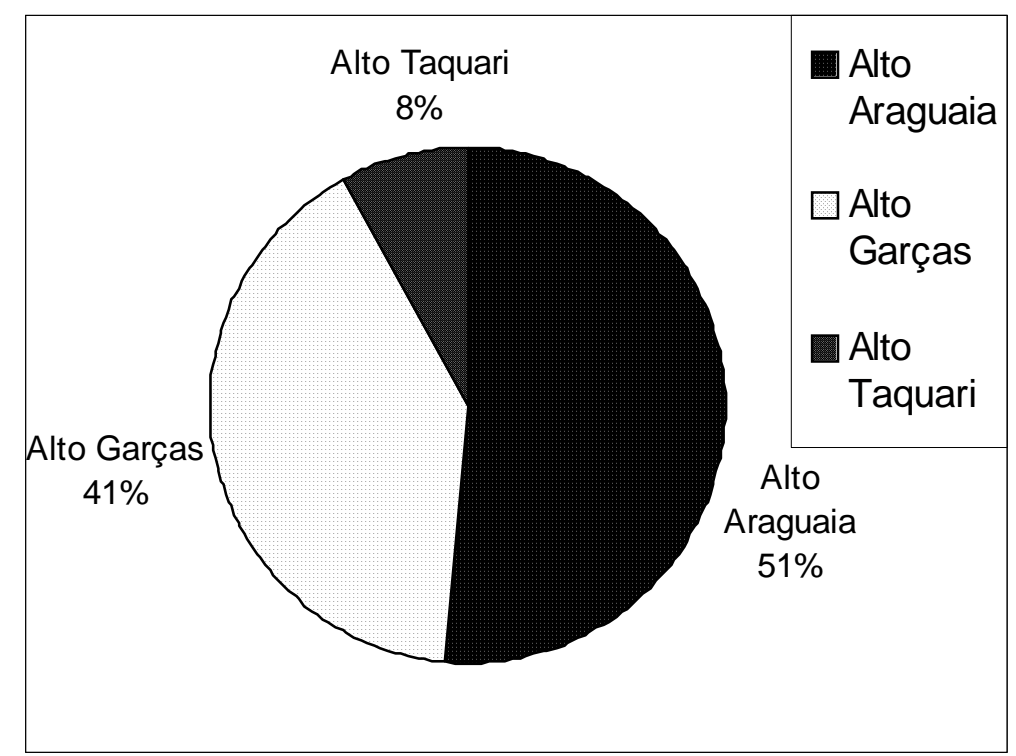

GRÁFICO 2 - Total dos zootopônimos da microrregião Alto Araguaia.

Dentre os zootopônimos registrados nos mapas e nas cartas topográficas, corpus desta pesquisa, dos municípios que compõem a microrregião Alto Araguaia, somente 12 (doze) zootopônimos se referem a animais domésticos. Dão nomes a 22 (vinte e dois) acidentes físicos, por exemplo: córregos dos Bois, serra do Burro, córrego do Cavalo, córrego das Éguas, córrego Gatinho, córrego do Gato, córrego Gato Preto, córrego Marruás, lagoa dos Patos, córrego dos Porcos, córrego do Potrinho e córrego da Vaca. Os demais zootopônimos se referem a animais silvestres, fator que evidencia a expressiva riqueza da fauna sudeste matogrossense, porém, deve-se observar que esta relação representa apenas uma pequena amostra da fauna do estado de Mato Grosso.

Os zootopônimos com base no habitat das espécies, na microrregião Alto Araguaia, em termos percentuais, subdividem-se em: 18,8\% se referem a animais que vivem preferencialmente no ar, como por exemplo: ribeirão Arara, córrego do Falcão, córrego do Jacu, córrego Marimbondo, lagoa dos Patos; 8,9\% são animais que vivem na água, como por exemplo: córrego Ariranha, córrego dos Dourados, córrego Piraputanga, córrego do Peixe e 72,3\% são animais que vivem em terra, tais como: córrego da Anta, serra do Burro, córrego do Cervo, córrego da Paca, córrego Queixada, ribeirão do Sapo.

Nesta taxionomia, na microrregião Alto Araguaia, computam-se 32 (trinta e dois) zootopônimos tupis, 01 (um) africano e 68 (sessenta e oito) portugueses. 
O município de Alto Araguaia possui 17 (dezessete) zootopônimos tupis e 35 (trinta e cinco) portugueses. Alto Garças possui 12 (doze) zootopônimos tupis, 01 (um) africano e 28 (vinte e oito) portugueses. Alto Taquari possui 03 (três) zootopônimos tupis e 05 (cinco) portugueses.

Considera-se, nesta pesquisa, que os zootopônimos tupis da microrregião Alto Araguaia, quanto à estrutura, subdividem-se em simples e híbridos. São 28 (vinte e oito) zootopônimos de estrutura simples e 04 (quatro) zootopônimos de estrutura híbrida. Eles denominam 32 (trinta e dois) acidentes físicos. Os 03 (três) municípios da microrregião Alto Araguaia possuem zootopônimos tupis.

O zootopônimo Araguainha, formado pela unidade lexical tupi araguaia + sufixo -inha, indicador de diminutivo da língua portuguesa, dá nome a 01 (um) córrego em Alto Taquari e a 01 (um) rio que estabelece divisa de Alto Araguaia com Alto Garças e com Araguainha, por isso consta nas relações de topônimos dos três municípios. O zootopônimo Jaguatiriquinha, formado pela unidade lexical tupi jaguatirica + sufixo -(qu)inha, já mencionado, nomeia 01 (um) córrego em Alto Garças.

Os zootopônimos tupis Ariranha, Cateto, Jaguatirica, Jararaca, Paca, Quati e Sucuri, neste estudo, são considerados de estrutura simples e denominam 10 (dez) córregos e 01 (um) rio. O zootopônimo Piraputanga dá nome a 02 (dois) córregos e é o primeiro topônimo de 01 (um) córrego. Todos localizam-se no município de Alto Araguaia. Os zootopônimos Coam, Cutia, Irara, Jacu, Jaguatirica, Jataí, Seriema e Sucuri nomeiam 08 (oito) córregos e 01 (um) ribeirão em Alto Garças. O zootopônimo Jaguatirica particulariza 01 (um) córrego em Alto Taquari.

O zootopônimo Araguaia dá nome a 01 (um) rio que consta nas relações de topônimos dos municípios de Alto Araguaia e Alto Taquari e estabelece divisa desses dois municípios com o estado de Goiás. O zootopônimo Arara dá nome a 01 (um) ribeirão que nasce no município de Alto Araguaia e deságua no município de Alto Garças, por isso consta nas relações de topônimos dos dois municípios.

O zootopônimo africano Marimbondo, neste estudo, é considerado de estrutura simples e dá nome a 01 (um) córrego em Alto Garças. 
Considera-se, nesta pesquisa, que os zootopônimos portugueses da microrregião Alto Araguaia, quanto à estrutura, subdividem-se em simples e compostos. São 65 (sessenta e cinco) zootopônimos de estrutura simples e 03 (três) zootopônimos de estrutura composta. Os 03 (três) municípios da microrregião Alto Araguaia possuem zootopônimos portugueses.

O zootopônimo composto Gato Preto, formado por substantivo comum + adjetivo, denomina 01 (um) ribeirão no município de Alto Araguaia e 02 (dois) córregos em Alto Garças.

Os zootopônimos simples e não derivados Anta, Burro, Cavalo, Falcão, Formiga, Gralha, Onça, Sapo, Vaca e Veado nomeiam 11 (onze) córregos, 02 (duas) lagoas e 01 (uma) serra. O zootopônimo Cervo nomina 02 (dois) córregos e é o primeiro topônimo de 01 (um) córrego. O zootopônimo Peixe dá nome a 01 (um) córrego e a 01 (um) rio. Todos localizam-se no município de Alto Araguaia. O rio do Peixe estabelece divisa entre o município de Alto Araguaia e o estado de Mato Grosso do Sul.

Os zootopônimos Anta, Cascavel, Cavalo, Cervo, Ema, Gato, Lobo, Onça e Vaca denominam 11 (onze) córregos e 01 (um) ribeirão em Alto Garças. O ribeirão da Onça estabelece divisa entre os municípios de Alto Garças e Guiratinga, por isso consta nas relações de topônimos dos dois municípios. O zootopônimo Lobo nomina 01 (um) córrego em Alto Taquari. O zootopônimo Sapo dá nome a 01 (um) ribeirão que estabelece divisa entre os municípios de Alto Araguaia e Alto Taquari, por isso consta nas relações de topônimos dos dois municípios.

O zootopônimo Marruás nomeia 01 (um) córrego em Alto Araguaia e 01 (um) córrego em Alto Garças. O vocábulo marruás não foi considerado, neste estudo, com desinência de plural -s porque é uma forma variante de marruá.

Constam ainda os zootopônimos simples e não derivados com desinência de plural -(e)s. Os zootopônimos Bois, Éguas, Porcos e Veados nomeiam 04 (quatro) córregos no município de Alto Araguaia. Os zootopônimos Bois, Patos e Perdizes denominam 03 (três) córregos e 01 (uma) lagoa em Alto Garças. O zootopônimo Bois dá nome a 01 (um) córrego em Alto Taquari. O zootopônimo Garças nomeia 01 
(um) rio que estabelece divisa entre os municípios de Alto Araguaia e Alto Garças, por isso consta nas relações de topônimos dos dois municípios.

Os zootopônimos simples que apresentam derivação Antinha, Formiguinha, Gatinho, Oncinha, Potrinho e Sapinho, formados pelas unidades lexicais anta, formiga, gato, onça, potro e sapo + sufixo -(gu)inho/a, indicador de diminutivo, denominam 04 (quatro) córregos no município de Alto Araguaia, 01 (um) córrego em Alto Garças e 02 (dois) córregos em Alto Taquari. O zootopônimo Queixada, formado pela unidade lexical queixo + sufixo -ada, indicador de grandeza, extensão, dá nome a 03 (três) córregos em Alto Araguaia, a 03 (três) córregos em Alto Garças e a 01 (um) córrego que estabelece divisa entre Alto Garças e Araguainha, por isso consta nas relações de topônimos dos dois municípios. Constam ainda os zootopônimos Galheiro e Mateiro, formados pelas unidades lexicais galho e mato + sufixo -eiro, indicador de naturalidade, origem e denominam 02 (dois) córregos e 01 (um) morro em Alto Garças.

O zootopônimo Dourados, formado pela unidade lexical dourar + sufixo -ado, indicador de um tanto + desinência de plural -s, dá nome a 01 (um) córrego no município de Alto Araguaia. Vale observar que o topônimo Dourados foi inserido nesta taxionomia porque está precedido, tanto no mapa quanto na carta topográfica, pelo conectivo dos. Se este topônimo não estivesse no plural e nem antecedido pelo referido conectivo seria classificado em outra taxionomia.

Pode-se constatar produtividade toponímica, nesta taxionomia, na microrregião Alto Araguaia. O zootopônimo Araguainha denomina 01 (um) córrego no município de Alto Taquari e 01 (um) rio que estabelece divisa de Alto Araguaia com Alto Garças e com Araguainha. O zootopônimo Ariranha dá nome a 02 (dois) córregos e a 01 (um) rio em Alto Araguaia. O zootopônimo Piraputanga designa 03 (três) córregos em Alto Araguaia. O zootopônimo Sucuri denomina 03 (três) córregos em Alto Araguaia e 02 (dois) em Alto Garças. O zootopônimo Jaguatirica nomeia 01 (um) córrego, em cada um dos três municípios da microrregião Alto Araguaia. $\mathrm{O}$ zootopônimo Jaguatiriquinha particulariza 01 (um) córrego em Alto Garças.

O zootopônimo Anta denomina 01 (um) córrego em Alto Araguaia e outro em Alto Garças. O zootopônimo Antinha toponimiza 01 (um) córrego em Alto Taquari. O 
zootopônimo Bois dá nome a 01 (um) córrego em cada um dos três municípios e o zootopônimo Burro denomina 01 (uma) serra e 02 (dois) córregos em Alto Araguaia. O zootopônimo Cervo nomeia 03 (três) córregos no município de Alto Araguaia e 01 (um) em Alto Garças.

O zootopônimo Galheiro nomeia 01 (um) córrego e 01 (um) morro em Alto Garças. O zootopônimo Gato Preto denomina 02 (dois) córregos em Alto Garças e 01 (um) ribeirão em Alto Araguaia. Pode-se ainda considerar o zootopônimo Gatinho e o zootopônimo Gato, cada um particulariza 01 (um) córrego, o primeiro em Alto Araguaia e o segundo em Alto Garças. Neste contexto, registram-se os zootopônimos Formiga e o zootopônimo Formiguinha que dão nome a 02 (dois) córregos no município de Alto Araguaia.

O zootopônimo Lobo denomina 01 (um) córrego em Alto Garças e outro em Alto Taquari. O zootopônimo Marruás dá nome a 01 (um) córrego em Alto Araguaia e a outro em Alto Garças. O zootopônimo Onça nomeia 03 (três) córregos em Alto Araguaia, 02 (dois) córregos e 01 (um) ribeirão em Alto Garças. O zootopônimo Oncinha nomina 01 (um) córrego em Alto Garças e outro em Alto Taquari.

O zootopônimo Perdizes denomina 02 (dois) córregos no município de Alto Garças. O zootopônimo Queixada denomina 03 (três) córregos em Alto Araguaia e 04 (quatro) em Alto Garças. O zootopônimo Peixe singulariza 01 (um) córrego em Alto Araguaia e 01 (um) rio que estabelece divisa entre o município de Alto Araguaia e o estado de Mato Grosso do Sul. O zootopônimo Sapo nomeia 01 (um) ribeirão que estabelece divisa entre os municípios de Alto Araguaia e Alto Taquari e 01 (uma) lagoa em Alto Araguaia. O zootopônimo Sapinho dá nome a 01 (um) córrego em Alto Araguaia. O zootopônimo Cavalo toponimiza 01 (um) córrego em Alto Araguaia e outro em Alto Garças.

Complementando a produtividade toponímica dos zootopônimos, na microrregião Alto Araguaia, o zootopônimo Vaca nomeia 01 (um) córrego em Alto Araguaia e 02 (dois) córregos em Alto Garças. Em Alto Araguaia, o zootopônimo Veado dá nome a 01 (uma) lagoa e o zootopônimo Veados nomina 01 (um) córrego. 
O zootopônimo Araguaia dá nome a 01 (um) rio que consta nas relações de topônimos dos municípios de Alto Araguaia e Alto Taquari e o zootopônimo Garças nomeia 01 (um) rio que consta nas relações de topônimos do municípios Alto Araguaia e Alto Garças, mas não são considerados produtivos porque estabelecem divisas entre eles. O zootopônimo Arara consta nas relações de topônimos dos municípios de Alto Araguaia e Alto Garças e se refere a 01 (um) ribeirão que nasce no município de Alto Araguaia e deságua em Alto Garças.

Os zootopônimos correspondem a $17,7 \%$ do total de topônimos da microrregião Alto Araguaia.

\section{Fitotopônimos}

As unidades lexicais que se referem aos elementos da flora, quando usadas para dar nomes a acidentes físicos e a acidentes antrópicos, são denominadas fitotopônimos nos estudos toponímicos. A taxionomia fitotopônimos apresenta 87 (oitenta e sete) ocorrências na microrregião Alto Araguaia.

São 46 (quarenta e seis) fitotopônimos no município de Alto Araguaia, 34 (trinta e quatro) em Alto Garças e 07 (sete) fitotopônimos em Alto Taquari. Apresenta-se a seguir o gráfico desta taxionomia com os respectivos percentuais por município (GRÁFICO 3). 


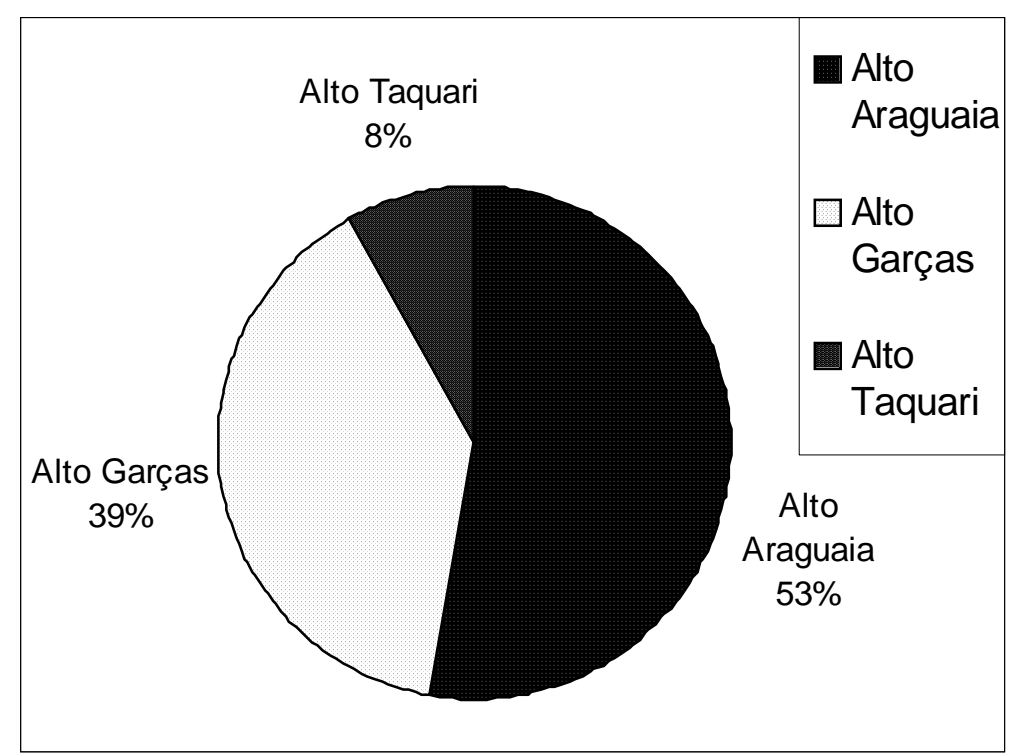

GRÁFICO 3 - Total dos fitotopônimos da microrregião Alto Araguaia.

Na microrregião Alto Araguaia pode-se constatar, ao observar a relação dos fitotopônimos, que a formação vegetal que possui maior representatividade é a dos fitotopônimos que indicam apenas um exemplar por espécie, por exemplo: Angá, Buriti, Cedro, Gueiroba, Melancia, Sapé, etc. e correspondem a 69,0\% do total dos fitotopônimos. Também ocorrem fitotopônimos que se referem a mais de um exemplar por espécie ou coletivo: Macaúbas, Flores, Laranjal, etc. e os que se referem a formações vegetais variadas, como por exemplo: Capão, Mata, Mato, correspondem a $5,7 \%$ e a $25 ; 3 \%$, respectivamente.

São 45 (quarenta e cinco) fitotopônimos tupis, 01 (um) africano e 41 (quarenta e um) portugueses.

O município de Alto Araguaia possui 22 (vinte e dois) fitotopônimos tupis, 01 (um) africano e 23 (vinte e três) portugueses. Alto Garças possui 19 (dezenove) fitotopônimos tupis e 15 (quinze) portugueses. Alto Taquari possui 04 (quatro) fitotopônimos tupis e 03 (três) portugueses.

Do total de 87 (oitenta e sete) fitotopônimos registrados verifica-se que 51,7\%, equivalentes a 45 (quarenta e cinco) ocorrências em número absoluto, são de etimologia indígena, neste caso específico, etimologia tupi. Os três municípios desta microrregião possuem fitotopônimos tupis. Ressalta-se ainda que alguns fitotopônimos tupis são bastante produtivos, pois denominam mais de um acidente por município. 
Considera-se, nesta pesquisa, que os fitotopônimos tupis da microrregião Alto Araguaia, quanto à estrutura, subdividem-se em simples e híbridos. São 28 (vinte e oito) fitotopônimos de estrutura simples e 17 (dezessete) fitotopônimos de estrutura híbrida. Eles denominam 44 (quarenta e quatro) acidentes físicos e 01 (um) acidente antrópico. Os 03 (três) municípios da microrregião Alto Araguaia possuem fitotopônimos tupis.

Os fitotopônimos Buritizinho e Pindaibinha, formados pelas unidades lexicais tupis buriti e pindaíba + sufixo -(z)inho/a, indicador de diminutivo da língua portuguesa, nomeiam, respectivamente, 01 (um) córrego que estabelece divisa entre os municípios de Alto Araguaia e Alto Garças, por isso consta nas relações de topônimos dos dois municípios e 01 (um) córrego em Alto Garças. O fitotopônimo Pindaibão, formado pela unidade lexical tupi pindaíba + sufixo -ão, indicador de aumentativo da língua portuguesa, denomina 02 (dois) córregos em Alto Araguaia.

O fitotopônimo Macaúbas, formado por unidade lexical tupi + desinência de plural -s da língua portuguesa, singulariza 01 (um) córrego em Alto Garças. O fitotopônimo Capão Alto, formado por unidade lexical tupi + unidade lexical portuguesa, nomina 01 (um) córrego no município de Alto Araguaia. Os fitotopônimos Buriti Alto, Buriti Torto e Capão Redondo, formados por unidade lexical tupi + unidade lexical portuguesa, nomeiam 04 (quatro) córregos em Alto Garças. O fitotopônimo Buriti Diferente, formado por unidade lexical tupi + unidade lexical portuguesa, dá nome a 01 (um) córrego que estabelece divisa entre Alto Araguaia e Alto Garças, por isso consta nas relações de topônimos dos dois municípios.

O fitotopônimo tupi Catingueira, formado pela unidade lexical tupi catinga + sufixo -eira, indicador de quantidade, porção da língua portuguesa, denomina 01 (um) córrego que estabelece divisa entre os municípios de Alto Araguaia e Alto Garças, por isso consta nas relações de topônimos dos dois municípios.

O fitotopônimo tupi Capão do Mato, formado por unidade lexical tupi + conectivo + unidade lexical portuguesa, nomeia 01 (um) córrego no município de Alto Araguaia. O fitotopônimo Campestre do Peba, formado pela unidade lexical portuguesa campo + sufixo -estre, indicador de relação + conectivo + unidade lexical tupi peba, dá nome a 01 (um) córrego em Alto Garças. 
Dentre os fitotopônimos tupis da microrregião Alto Araguaia, apenas um afixo tupi foi encontrado. Este afixo é o sufixo -tiba (variante de -tuba). Ele apresenta-se no fitotopônimo Curitiba e nomeia 01 (um) córrego no município de Alto Garças.

Os fitotopônimos tupis Bacuri, Baguaçu, Buriti, Capim, Cipó, Goiaba, Gueiroba (forma variante de Guariroba), Jerivá, Sapé e Taboca denominam 09 (nove) córregos, 01 (um) distrito, 01 (um) riacho e 02 (dois) morros no município de Alto Araguaia. Os fitotopônimos Angá (forma variante de ingá), Cambaúva, Capão, Guariroba, Indaiá, Jatobá e Sucupira dão nomes a 07 (sete) córregos em Alto Garças. Os fitotopônimos Capão, Guariroba e Taboca nomeiam 02 (dois) córregos e 01 (um) ribeirão em Alto Taquari.

O fitotopônimo Taquari dá nome a 01 (um) rio que estabelece divisa entre os municípios de Alto Araguaia e Alto Taquari, por isso consta nas relações de topônimos dos dois municípios. O fitotopônimo Macaúba dá nome a 01 (um) córrego que estabelece divisa entre os municípios de Alto Araguaia e Alto Garças, por isso consta nas relações de topônimos dos dois municípios.

Ocorre o registro de 01 (um) fitotopônimo africano no município de Alto Araguaia e, neste estudo, ele é considerado de estrutura simples. O fitotopônimo Maxixe denomina 01 (um) córrego.

Considera-se, nesta pesquisa, que os fitotopônimos portugueses da microrregião Alto Araguaia, quanto à estrutura, subdividem-se em simples e compostos. São 36 (trinta e seis) fitotopônimos de estrutura simples e 05 (cinco) fitotopônimos de estrutura composta. Eles denominam 40 (quarenta) acidentes físicos e 01 (um) acidente antrópico. Os 03 (três) municípios da microrregião Alto Araguaia possuem fitotopônimos portugueses.

Os fitotopônimos portugueses que possuem estrutura simples e não derivada Angico, Bálsamo, Cedro, Mata, Mato, Melancia e Quiçaça toponimizam 11 (onze) córregos e 01 (uma) lagoa no município de Alto Araguaia. Os fitotopônimos Cacau, Cana, Jardim, Mata e Palha nomeiam 04 (quatro) córregos e 01 (um) ribeirão em Alto Garças. O fitotopônimo Prado dá nome a 01 (um) córrego em Alto Taquari. 
O fitotopônimo Café denomina 01 (uma) serra e 01 (um) ribeirão no município de Alto Garças e ambos estabelecem divisas entre os municípios de Alto Garças e Araguainha, por isso constam nas relações de topônimos dos dois municípios. Essa mesma serra consta na relação de topônimos de Alto Araguaia, mas como segundo topônimo: serra do Correia ou Café.

O fitotopônimo Flores singulariza 02 (dois) córregos no município de Alto Garças. É o único fitotopônimo português da microrregião Alto Araguaia que apresenta desinência de plural -es.

Os fitotopônimos Balsaminho, Cafezinho e Matinha, formados pelas unidades lexicais bálsamo, café e mata + sufixo -(z)inho/a, formador de diminutivo, dão nomes a 02 (dois) córregos em Alto Araguaia e a 01 (um) córrego em Alto Garças.

Os fitotopônimos Coqueiro, Figueira, Limoeiro e Lobeira, formados pelas unidades lexicais coco, figo, limão e lobo + sufixo -(qu/gu)eiro/a, indicador de o que produz, nomeiam 05 (cinco) córregos no município de Alto Araguaia e 01 (um) em Alto Garças. Os fitotopônimos Laranjal e Pinhal, formados pelas unidades lexicais laranja e pinha + sufixo -al, indicador de plantações ou grande quantidade, dão nomes, respectivamente, a 01 (um) córrego em Alto Araguaia e a 01 (um) córrego em Alto Garças. O fitotopônimo Mimoso, formado pela unidade lexical mimo + sufixo -oso, indicador abundância, denomina 01 (um) córrego em Alto Taquari.

Existe 01 (um) fitotopônimo português com o afixo -lândia: povoado Cafelândia, formado pela unidade lexical portuguesa café + unidade lexical grega lândia, no município de Alto Garças. Neste estudo ele é considerado de estrutura simples, apesar de ser formado pela aglutinação já referida.

O fitotopônimo português de estrutura composta Campo Bonito, formado por substantivo comum + adjetivo e o fitotopônimo Campestre Grande, formado pela unidade lexical campo + sufixo -estre, indicador de relação + adjetivo, nomeiam, respectivamente, 01 (um) córrego em Alto Garças e 01 (um) córrego em Alto Araguaia. O fitotopônimo Galhinho Comprido, formado pela unidade lexical galho + sufixo -inho, formador de diminutivo + adjetivo, dá nome a 01 (um) córrego em Alto Garças. 
Os fitotopônimo Pau Terra, formado por substantivo comum + substantivo comum, singulariza 01 (um) córrego no município de Alto Araguaia e o fitotopônimo Pau de Terra, formado por substantivo comum + preposição + substantivo comum, nomeia 01 (um) córrego em Alto Taquari.

Constata-se produtividade toponímica, na taxionomia fitotopônimos da microrregião Alto Araguaia. O fitotopônimo tupi Buriti nomeia 01 (um) córrego e 01 (um) distrito no município de Alto Araguaia. O fitotopônimo Buriti Alto dá nome a 02 (dois) córregos em Alto Garças e, pode-se considerar também, o fitotopônimo Buriti Torto que particulariza 01 (um) córrego em Alto Garças. O fitotopônimo Buritizinho que denomina 01 (um) córrego que divide Alto Araguaia e Alto Garças.

O fitotopônimo Capão dá nome a 01 (um) córrego no município de Alto Garças e a outro em Alto Taquari. Pode-se ainda considerar os fitotopônimos Capão Alto, Capão do Mato e Capão Redondo que denominam 02 (dois) córregos em Alto Araguaia e 01 (um) córrego em Alto Garças.

O fitotopônimo tupi Guariroba e sua forma variante o fitotopônimo Gueiroba nominam 01 (um) morro e 01 (um) córrego em Alto Araguaia, 01 (um) córrego em Alto Garças e 01 (um) ribeirão em Alto Taquari. O fitotopônimo Macaúbas denomina 01 (um) córrego em Alto Garças e o fitotopônimo Macaúba dá nome a 01 (um) córrego que estabelece divisa entre Alto Araguaia e Alto Garças. O fitotopônimo Pindaibão nomeia 02 (dois) córregos em Alto Araguaia e o fitotopônimo Pindaibinha toponimiza 01 (um) córrego em Alto Garças. O fitotopônimo Taboca dá nome a 01 (um) córrego em Alto Taquari, a 01 (um) córrego e a 01 (um) riacho em Alto Araguaia.

O fitotopônimo Bálsamo denomina 02 (dois) córregos e o fitotopônimo Balsaminho nomeia 01 (um) córrego no município de Alto Araguaia. O fitotopônimo Café nomeia 01 (uma) serra em Alto Garças que também consta na relação de topônimos de Alto Araguaia e 01 (um) ribeirão, ambos estabelecem divisas entre os municípios de Alto Garças e Araguainha. Pode-se ainda considerar o fitotopônimo Cafezinho que nomeia 01 (um) córrego e o fitotopônimo Cafelândia que singulariza 01 (um) povoado, ambos em Alto Garças. O fitotopônimo Flores nomeia 02 (dois) córregos em Alto Garças. Os fitotopônimos Coqueiro e Lobeira denominam, cada 
um, 02 (dois) córregos em Alto Araguaia. O fitotopônimo Cedro dá nome a 02 (dois) córregos e a 01 (uma) lagoa em Alto Araguaia.

O fitotopônimo Mata denomina 01 (um) ribeirão no município de Alto Garças e 03 (três) córregos em Alto Araguaia. O fitotopônimo Mato nomina 01 (um) córrego e o fitotopônimo Matinha dá nome a 01 (um) córrego, ambos em Alto Araguaia. 0 fitotopônimo Pau Terra designa 01 (um) córrego em Alto Araguaia e o fitotopônimo Pau de Terra particulariza 01 (um) córrego em Alto Taquari. Se considerar a primeira unidade lexical, pode-se acrescentar os fitotopônimos Campestre do Peba e Campestre Grande, cada um nomeia 01 (um) córrego em Alto Garças.

Os fitotopônimos tupis Buriti Diferente e Catingueira nomeiam 02 (dois) que constam nas relações de topônimos dos municípios Alto Araguaia e Alto Garças, mas não são considerados produtivos porque estabelecem limites entre eles. $O$ fitotopônimo Taquari nomina 01 (um) rio que estabelece divisa entre os municípios de Alto Araguaia e Alto Taquari.

Os fitotopônimos correspondem a 15,2\% do total de topônimos da microrregião Alto Araguaia.

\section{Litotopônimos}

Registram-se 37 (trinta e sete) litotopônimos nos mapas dos municípios que compõem a microrregião Alto Araguaia. As unidades lexicais que se referem aos minerais em geral e a constituição do solo, quando usadas para dar nomes a acidentes físicos e a acidentes antrópicos, são classificadas nos estudos toponímicos como litotopônimos.

O município de Alto Araguaia possui 18 (dezoito) litotopônimos, Alto Garças também possui 18 (dezoito) litotopônimos e Alto Taquari possui 01 (um) litotopônimo. Apresenta-se a seguir o gráfico desta taxionomia com os respectivos percentuais por município (GRÁFICO 4). 


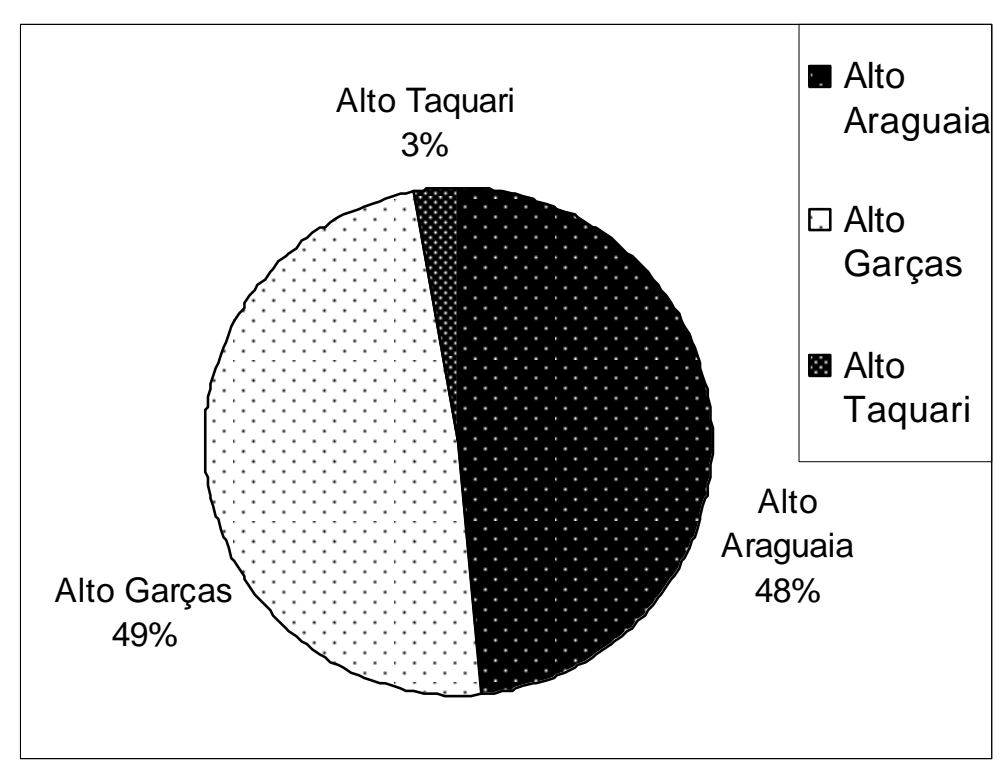

GRÁFICO 4 - Total dos litotopônimos da microrregião Alto Araguaia.

Os litotopônimos registrados na microrregião Alto Araguaia são portugueses.

Considera-se, nesta pesquisa, que os litotopônimos portugueses da microrregião Alto Araguaia, quanto à estrutura, subdividem-se em simples e compostos. São 34 (trinta e quatro) litotopônimos de estrutura simples e 03 (três) litotopônimos de estrutura composta. Eles denominam 37 (trinta e sete) acidentes físicos. Os 03 (três) municípios da microrregião Alto Araguaia possuem litotopônimos portugueses.

Os litotopônimos compostos Barro Preto, Pedra Vermelha e Terra Vermelha, formados por substantivo + adjetivo, denominam 03 (três) córregos no município de Alto Garças.

Os litotopônimos de estrutura simples subdividem-se em simples não derivados e simples com derivação. O litotopônimo Barreiro, formado pela unidade lexical barro + sufixo -eiro, indicador de quantidade, dá nome a 01 (um) córrego em Alto Araguaia, a 01 (um) córrego em Alto Garças e a 01 (um) córrego que estabelece divisa entre Alto Garças e Guiratinga, por isso consta nas relações de topônimos dos dois municípios. O litotopônimo Pedreira, formado pela unidade lexical pedra + sufixo -eira, já mencionado, denomina 01 (um) ribeirão no município de Alto Garças. 
Os litotopônimos Piçarrinha e Pratinha, formados pelas unidades lexicais piçarra e prata + sufixo -inha, formador de diminutivo, nomeiam, respectivamente, 01 (um) córrego em Alto Araguaia e 01 (um) córrego em Alto Garças.

Os litotopônimos Areado, Areiado (forma variante) e Lajeado, formados pelas unidades lexicais areia e laje + sufixo -ado, indicador de quantidade, porção, denominam 07 (sete) córregos no município de Alto Araguaia e 02 (dois) em Alto Garças. O litotopônimo Diamantino, formado pela unidade lexical diamante + sufixo ino, indicador de referência, relação, dá nome a 01 (um) rio em Alto Garças que estabelece divisa de Alto Garças com os municípios de Araguainha, Ponte Branca e Torixoréu, por isso consta nas relações de topônimos dos quatro municípios. O litotopônimo Rochedo, formado pela unidade lexical rocha + sufixo -edo, indicador de aumento, grandeza, singulariza 01 (um) córrego em Alto Araguaia.

Alguns litotopônimos apresentam dupla sufixação. O litotopônimo Barreirinho, formado pela unidade lexical barro + sufixo-eiro, já citado + sufixo -inho, formador de diminutivo, dá nome a 01 (um) córrego no município de Alto Araguaia e a 01 (um) córrego em Alto Garças. O litotopônimo Lajeadinho, formado pela unidade lexical laje + sufixo -ado + sufixo -inho, já citados, nominam 02 (dois) córregos em Alto Araguaia e 01 (um) córrego em Alto Garças.

O litotopônimo Atoladeira, formado por substantivo derivado atolar + sufixo ado + sufixo -eira, já citados, toponimiza 01 (um) córrego em Alto Araguaia e 01 (um) córrego em Alto Garças. O litotopônimo Pantanalzinho, formado pela unidade lexical pântano + sufixo -al, indicador de grande quantidade + sufixo -(z)inho, já citado, nomeia 01 (um) córrego em Alto Garças que estabelece divisa entre Alto Garças e Guiratinga, por isso consta nas relações de topônimos dos dois municípios.

Os litotopônimos simples e sem derivação Diamante e Pedra denominam 02 (dois) córregos no município de Alto Araguaia. Os litotopônimos Areia e Barro nomeiam 03 (três) córregos em Alto Garças.

O litotopônimo Laje dá nome a 01 (um) ribeirão que estabelece divisa entre os municípios de Alto Araguaia e Alto Taquari por isso consta nas relações de topônimos dos dois municípios. O litotopônimo Prata dá nome a 01 (um) rio em Alto 
Garças que estabelece divisa entre os municípios de Alto Garças e Pedra Preta, por isso consta nas relações de topônimos dos dois municípios. O litotopônimo Pedras apresenta desinência de plural -s e dá nome a 01 (um) córrego em Alto Araguaia.

A busca por metais preciosos fez-se presente nas atividades extrativas dos municípios de Alto Araguaia e Alto Garças, sobretudo a cata de diamantes, desde que os não-autóctones chegaram à região. Nesta pesquisa toponímica pode-se constatar que 04 (quatro) córregos e 01 (um) rio estão toponimizados com unidades lexicais que se referem a metais preciosos. O litotopônimo Prata dá nome a 01 (um) rio e o litotopônimo Pratinha nomeia 01(um) córrego, ambos localizam-se em Alto Garças. O litotopônimo Diamante nomeia 01 (um) córrego em Alto Araguaia e o litotopônimo Diamantino denomina 01 (um) rio em Alto Garças.

Ocorre produtividade toponímica, nesta taxionomia, na microrregião Alto Araguaia. O litotopônimo Areado nomeia 03 (três) córregos no município de Alto Araguaia e sua forma variante o litotopônimo Areiado dá nome a 01 (um) córrego em Alto Garças. O litotopônimo Areia denomina 02 (dois) córregos em Alto Garças. Os litotopônimos Atoladeira e Barreirinho toponimizam, cada um, 01 (um) córrego em Alto Araguaia e outro em Alto Garças. O litotopônimo Barreiro denomina 01 (um) córrego em Alto Araguaia e 02 (dois) em Alto Garças. O litotopônimo Lajeadinho nomeia 02 (dois) córregos em Alto Araguaia e 01 (um) em Alto Garças.

O litotopônimo Lajeado nomeia 04 (quatro) córregos no município de Alto Araguaia e 01 (um) córrego em Alto Garças. O litotopônimo Pedra dá nome a 01 (um) córrego e o litotopônimo Pedras particulariza 01 (um) córrego, ambos em Alto Araguaia. O litotopônimo Pedra Vermelha singulariza 01 (um) córrego em Alto Garças. O litotopônimo Prata denomina 01 (um) rio e o litotopônimo Pratinha dá nome a 01 (um) córrego, ambos em Alto Garças. O litotopônimo Barro dá nome a 01 (um) córrego e o litotopônimo Barro Preto também nomina 01 (um) córrego, ambos em Alto Garças. O litotopônimo Laje denomina 01 (um) ribeirão que estabelece divisa entre os municípios de Alto Araguaia e Alto Taquari, por isso não é considerado produtivo.

Os litotopônimos correspondem a 6,5\% do total de topônimos da microrregião Alto Araguaia. 


\section{Geomorfotopônimos}

As unidades lexicais que se referem às formações geomorfológicas em geral, quando usadas para dar nomes a acidentes físicos e a acidentes antrópicos, recebem nos estudos toponímicos, a denominação de geomorfotopônimos. Os geomorfotopônimos, na microrregião Alto Araguaia, perfazem o total de 28 (vinte e oito) ocorrências.

O município de Alto Araguaia possui 15 (quinze) geomorfotopônimos, Alto Garças 08 (oito) e Alto Taquari 05 (cinco). Apresenta-se a seguir o gráfico desta taxionomia com os respectivos percentuais por município (GRÁFICO 5).

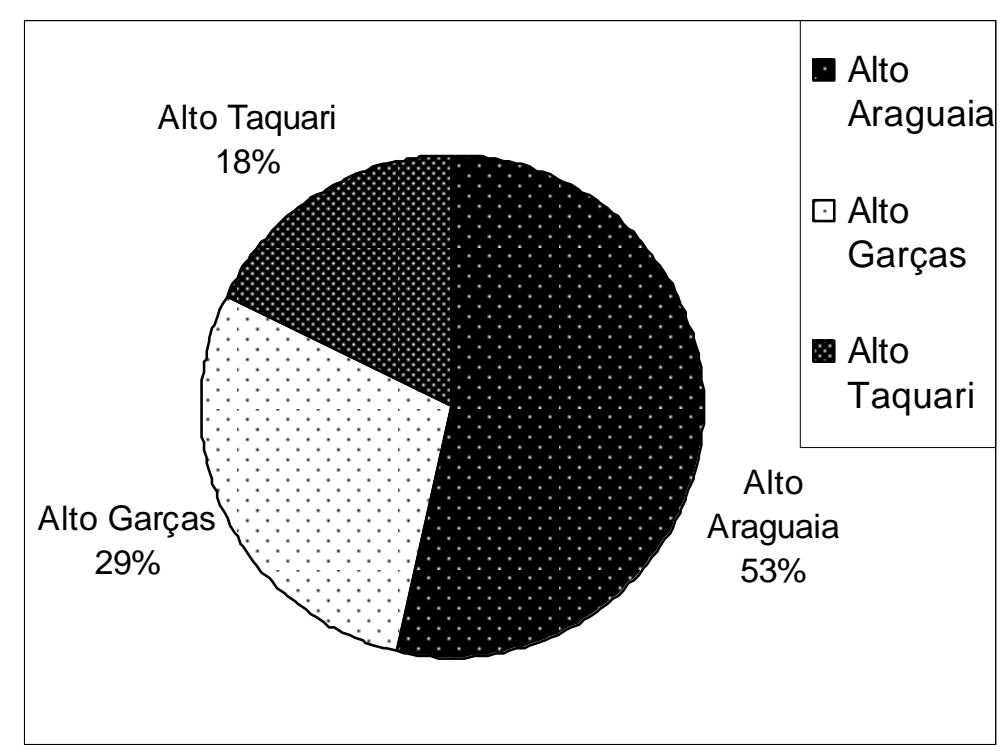

GRÁFICO 5 - Total dos geomorfotopônimos da microrregião Alto Araguaia.

Os geomorfotopônimos da microrregião Alto Araguaia são portugueses.

Considera-se, nesta pesquisa, que os geomorfotopônimos portugueses da microrregião Alto Araguaia, quanto à estrutura, subdividem-se em simples e compostos. São 22 (vinte e dois) geomorfotopônimos de estrutura simples e 06 (seis) geomorfotopônimos de estrutura composta. Eles denominam 28 (vinte e oito) acidentes físicos. Os 03 (três) municípios da microrregião Alto Araguaia possuem geomorfotopônimos portugueses. 
O geomorfotopônimo composto Furna do Teodoro, formado por substantivo comum + conectivo + substantivo próprio, singulariza 01 (um) córrego no município de Alto Araguaia. Os geomorfotopônimos Grota do Colonião e Morro do Fogo, formados por substantivo comum + conectivo do + substantivo comum, nomeiam 02 (dois) córregos, ambos localizam-se em Alto Araguaia.

O geomorfotopônimo Morro da Mesa, formado por substantivo comum + conectivo + substantivo comum, denomina 01 (um) córrego no município de Alto Garças. Os geomorfotopônimos compostos Morro Vermelho e Morro Redondo, formados por substantivo comum + adjetivo, denominam, respectivamente, 01 (uma) serra em Alto Taquari e 01 (um) córrego em Alto Garças.

Os geomorfotopônimos simples e não derivados Cava e Grota dão nomes a 02 (dois) córregos no município de Alto Araguaia. O geomorfotopônimo Furna nomeia 01 (um) ribeirão e 01 (um) córrego em Alto Taquari. O ribeirão Furna estabelece divisa entre o município de Alto Taquari e o estado de Mato Grosso do Sul. O geomorfotopônimo Covas apresenta desinência de plural -s e denomina 01 (um) córrego em Alto Garças.

Os geomorfotopônimos Buracão, Grotão e Paredão, formados pelas unidades lexicais buraco, grota e parede + sufixo -ão, indicador de aumentativo, denominam 02 (dois) córregos no município de Alto Araguaia e 02 (dois) córregos em Alto Garças. Os geomorfotopônimos Varginha, Furninha e Valinho, formados pelas unidades lexicais furna, vale e varja + sufixo -inho/a, indicador de diminutivo, nomeiam, respectivamente, 01 (um) córrego em Alto Araguaia, 01 (um) córrego em Alto Garças e 01 (um) córrego em Alto Taquari.

O geomorfotopônimo Pontal, formado pela unidade lexical ponta + sufixo -al, indicador de grande quantidade, denomina 01 (um) córrego em Alto Araguaia e 01 (um) córrego em Alto Taquari. O geomorfotopônimo Tombador, formado pela unidade lexical tombar + sufixo -dor, indicador do agente de ação, particulariza 01 (um) córrego em Alto Garças que estabelece divisa entre os municípios de Alto Garças e Guiratinga, por isso consta nas relações de topônimos dos dois municípios. 
Os geomorfotopônimos Chapada e Invernada, formados pelas unidades lexicais chapar e invernar + sufixo -ada, indicador de grandeza, extensão ou de tempo, nomeiam 02 (dois) córregos no município de Alto Araguaia. geomorfotopônimo Enfurnado, formado pela unidade lexical enfurnar + sufixo -ado, já referido, dá nome a 02 (dois) córregos em Alto Araguaia.

Alguns geomorfotopônimos apresentam dupla sufixação. O geomorfotopônimo Pontalzinho, formado pela unidade lexical ponta + sufixo -al + sufixo -(z)inho, já referidos, particulariza 01 (um) córrego em Alto Araguaia. Os geomorfotopônimos Baixadão e Serradão, formados pelas unidades lexicais baixar e serrar + sufixo -ada, já mencionado + sufixo -ão, indicador de aumentativo, nomeiam, respectivamente, 01 (um) córrego em Alto Araguaia e 01 (um) córrego em Alto Garças.

A taxionomia geomorfotopônimos é outra fonte de toponimização de acidentes físicos, pode-se exemplificar com os geomorfotopônimos Morro do Fogo, Morro da Mesa, Morro Redondo e Morro Vermelho que dão nomes a córregos. Os geomorfotopônimos Serradão e Chapada também denominam córregos na microrregião Alto Araguaia.

Pode-se constatar a ocorrência de produtividade toponímica, nesta taxionomia, na microrregião Alto Araguaia. O geomorfotopônimo Enfurnado denomina 02 (dois) córregos no município de Alto Araguaia. O geomorfotopônimo Furna dá nome a 01 (um) córrego e a 01 (um) ribeirão em Alto Taquari. O geomorfotopônimo Furninha toponimiza 01 (um) córrego em Alto Garças e pode-se acrescentar o geomorfotopônimo Furna do Teodoro que singulariza 01 (um) córrego em Alto Araguaia. O geomorfotopônimo Grota particulariza 01 (um) córrego em Alto Araguaia. O geomorfotopônimo Grotão denomina 01 (um) córrego em Alto Araguaia e outro em Alto Garças. O geomorfotopônimo Grota do Colonião dá nome a 01 (um) córrego em Alto Araguaia.

O geomorfotopônimo Pontal nomeia 01 (um) córrego no município de Alto Araguaia e outro em Alto Taquari. O geomorfotopônimo Pontalzinho dá nome a 01 (um) córrego em Alto Araguaia. Se considerar apenas a primeira unidade lexical do topônimo, ocorrem ainda os geomorfotopônimos Morro da Mesa e Morro Redondo 
que dão nomes, cada um, a 01 (um) córrego em Alto Garças. O geomorfotopônimo Morro Vermelho toponimiza 01 (uma) serra em Alto Taquari e o geomorfotopônimo Morro do Fogo denomina 01 (um) córrego em Alto Araguaia.

Os geomorfotopônimos correspondem a 4,9\% do total de topônimos da microrregião Alto Araguaia.

\section{Cromotopônimos}

Na microrregião Alto Araguaia registram-se 18 (dezoito) cromotopônimos. As unidades lexicais que se referem à escala cromática em geral, quando usadas para dar nomes a acidentes físicos e a acidentes antrópicos, são classificadas, nos estudos toponímicos, como cromotopônimos.

São 14 (quatorze) cromotopônimos no município de Alto Araguaia, 02 (dois) em Alto Garças e 02 (dois) em Alto Taquari. Apresenta-se a seguir o gráfico desta taxionomia com os respectivos percentuais por municípios (GRÁFICO 6).

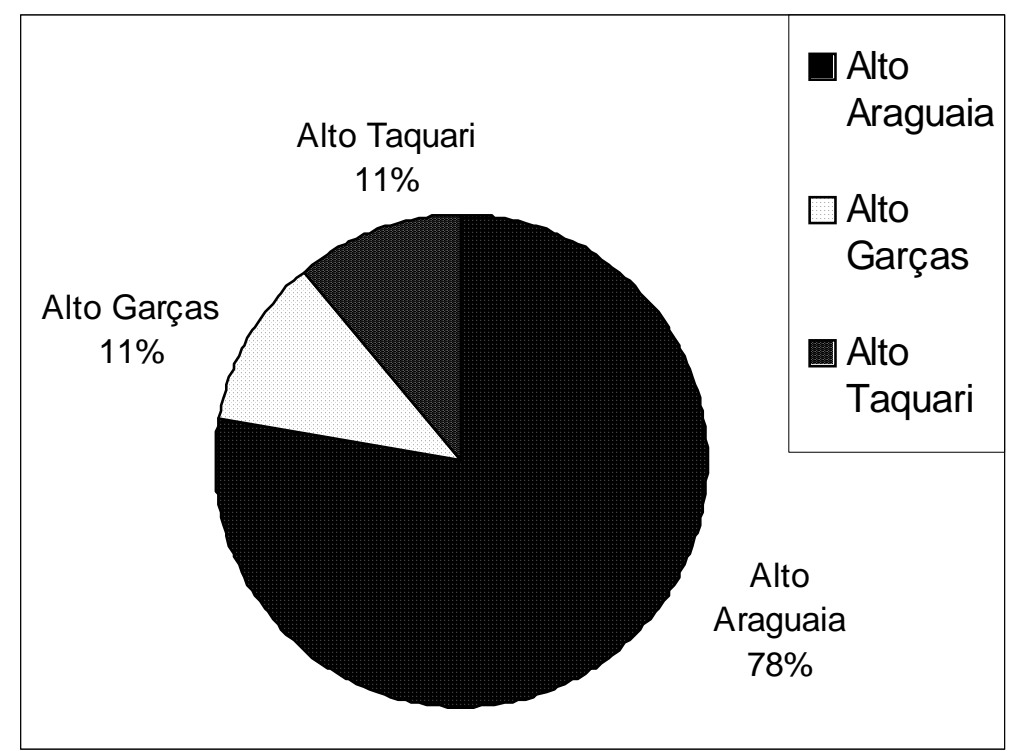

GRÁFICO 6 - Total dos cromotopônimos da microrregião Alto Araguaia.

Os cromotopônimos da microrregião Alto Araguaia são portugueses. 
Considera-se, nesta pesquisa, que os cromotopônimos portugueses da microrregião Alto Araguaia possuem estrutura simples. Eles denominam 18 (dezoito) acidentes físicos. Os 03 (três) municípios da microrregião Alto Araguaia possuem cromotopônimos portugueses.

O cromotopônimo Rajada apresenta derivação, formado pela unidade lexical rajar + sufixo -ada, indicador de um tanto, denomina 01 (um) córrego em Alto Araguaia. O cromotopônimo Ferruja está classificado nesta taxionomia por referir-se à cor amarelo-escuro da água, a qual algumas vezes também apresenta riscas de amarelo, ainda mais escuras, bem próximas à barranca do córrego e evidencia a forma regional da pronúncia da unidade lexical ferrugem. Denomina 01 (um) córrego em Alto Araguaia e 01 (um) córrego que estabelece divisa entre os municípios de Alto Araguaia e Alto Garças, por isso consta nas relações de topônimos dos dois municípios.

Os cromotopônimos Azul, Vermelha e Vermelho nomeiam 02 (dois) córregos, 04 (quatro) morros e 02 (duas) serras no município de Alto Araguaia. $O$ cromotopônimo Preta nomeia 01 (uma) serra e o cromotopônimo Vermelha também nomina 01 (uma) serra, ambas estabelecem divisas entre os municípios de Alto Araguaia e Alto Taquari, por isso constam nas relações de topônimos dos dois municípios. O cromotopônimo Claro dá nome a 01 (um) ribeirão que nasce no município de Alto Garças e deságua em Alto Araguaia, por isso consta nas relações de topônimos dos dois municípios.

O índice de produtividade dos cromotopônimos na microrregião Alto Araguaia é significativo. O cromotopônimo Ferruja dá nome a 01 (um) córrego no município de Alto Araguaia e a 01 (um) córrego que estabelece divisa entre os municípios de Alto Araguaia e Alto Garças. O cromotopônimo Vermelha denomina 02 (duas) serras em Alto Araguaia e 01 (uma) serra consta na relação de topônimos de dois municípios porque estabelece divisa entre os municípios de Alto Araguaia e Alto Taquari. O cromotopônimo Vermelho denomina 03 (três) morros e 02 (dois) córregos em Alto Araguaia. O cromotopônimo Claro dá nome a 01 (um) ribeirão que nasce em Alto Garças e deságua em Alto Araguaia, por isso não é considerado produtivo. 
O cromotopônimo Preta nomina 01 (uma) serra que consta na relação de topônimos dos municípios Alto Araguaia e Alto Taquari porque estabelece divisa entre eles e, por isso, não é considerado produtivo.

Os cromotopônimos correspondem a 3,1\% do total de topônimos da microrregião Alto Araguaia.

\section{Dimensiotopônimos}

Registram-se 13 (treze) dimensiotopônimos na microrregião Alto Araguaia. As unidades lexicais que se referem a características dimensionais, tais como: extensão, largura, grossura, altura, etc., quando utilizadas par dar nomes a acidentes físicos e a acidentes antrópicos, recebem nos estudos toponímicos, a denominação de dimensiotopônimos.

O município de Alto Araguaia possui 07 (sete) dimensiotopônimos, Alto Garças possui 04 (quatro) e Alto Taquari possui 02 (dois) dimensiotopônimos. Apresenta-se a seguir o gráfico desta taxionomia com os respectivos percentuais por município (GRÁFICO 7).

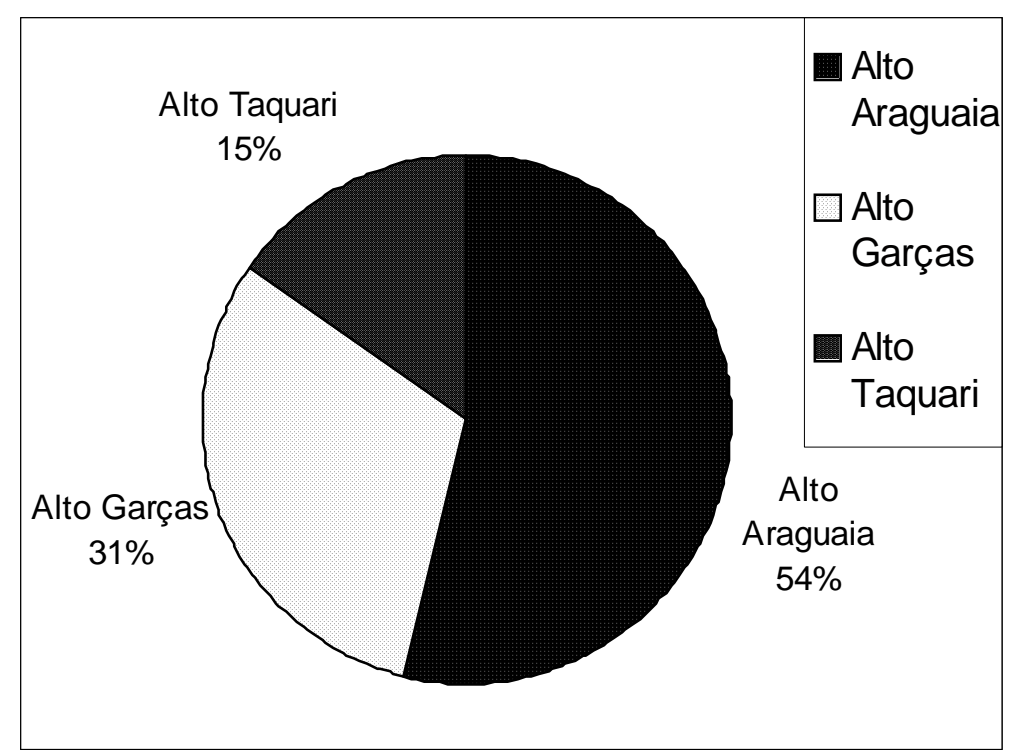

GRÁFICO 7 - Total dos dimensiotopônimos da microrregião Alto Araguaia. 
Os dimensiotopônimos da microrregião Alto Araguaia são portugueses.

Considera-se, nesta pesquisa, que os dimensiotopônimos portugueses da microrregião Alto Araguaia possuem estrutura simples. Eles denominam 13 (treze) acidentes físicos. Os 03 (três) municípios da microrregião Alto Araguaia possuem dimensiotopônimos.

Esta taxionomia apresenta, em geral, uma característica bastante pertinente, é formada, em sua maioria, por adjetivos que ao toponimizarem acidentes físicos e acidentes antrópicos, substantivam- se.

Os dimensiotopônimos Comprida, Comprido, Grande e Fundo dão nomes a 13 (treze) córregos.

O dimensiotopônimo Comprida singulariza 01 (um) córrego no município de Alto Araguaia. O dimensiotopônimo Comprido dá nome a 01 (um) córrego em Alto Araguaia, a 01 (um) córrego em Alto Garças e a 01 (um) córrego em Alto Taquari. $\mathrm{O}$ dimensiotopônimo Fundo denomina 04 (quatro) córregos em Alto Araguaia e 03 (três) córregos em Alto Garças. O dimensiotopônimo Grande nomeia 01 (um) córrego em Alto Araguaia e 01 (um) córrego em Alto Taquari.

São topônimos bastante produtivos, pode-se dizer que esta é outra característica que a taxionomia dimensiotopônimos geralmente apresenta.

Os dimensiotopônimos correspondem a 2,3\% do total de topônimos da microrregião Alto Araguaia.

\section{Cardinotopônimos}

As unidades lexicais que se referem às posições geográficas em geral, quando usadas para denominar acidentes físicos e acidentes antrópicos, recebem nos estudos toponímicos, a denominação de cardinotopônimos. Na microrregião Alto Araguaia, registram-se 12 (doze) topônimos nesta taxionomia. 
O município de Alto Araguaia possui 06 (seis) cardinotopônimos, Alto Garças 04 (quatro) e o município de Alto Taquari possui 02 (dois) cardinotopônimos. Apresenta-se a seguir o gráfico desta taxionomia com os respectivos percentuais por município (GRÁFICO 8).

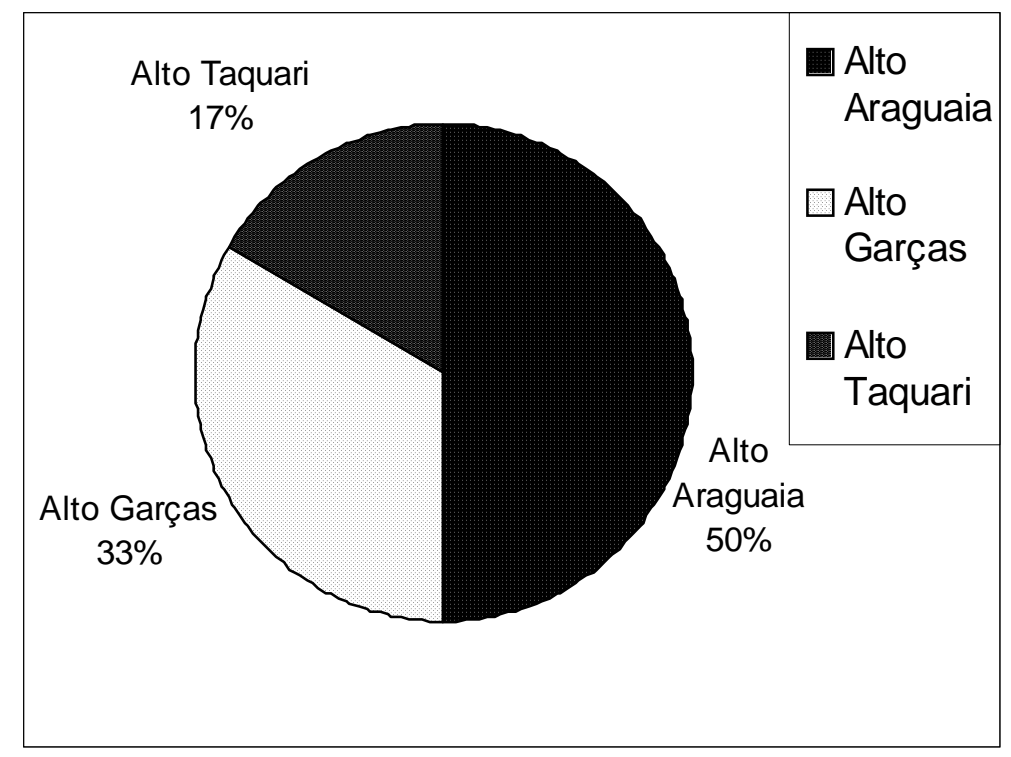

GRÁFICO 8 - Total dos cardinotopônimos da microrregião Alto Araguaia.

São 02 (dois) cardinotopônimos tupis e 10 (dez) portugueses.

Considera-se, nesta pesquisa, que os cardinotopônimos tupis possuem estrutura híbrida. Os cardinotopônimos Alto Araguaia e Alto Taquari, formados por unidade lexical portuguesa + unidade lexical tupi, denominam 02 (dois) municípios mato-grossenses.

Considera-se, nesta pesquisa, que os cardinotopônimos portugueses da microrregião Alto Araguaia, quanto à estrutura, subdividem-se em simples e composto. São 09 (nove) cardinotopônimos de estrutura simples e 01 (um) cardinotopônimo de estrutura composta. Eles denominam 09 (nove) acidentes físicos e 01 (um) acidente antrópico. Os 03 (três) municípios da microrregião Alto Araguaia possuem cardinotopônimos portugueses.

O cardinotopônimo composto Alto Garças, formado por adjetivo + substantivo comum com desinência de plural -s, dá nome a 01 (um) município mato-grossense. 
O cardinotopônimo Cima dá nome a 01 (um) ribeirãozinho no município de Alto Taquari. O cardinotopônimo Divisa denomina 03 (três) córregos no município de Alto Araguaia e 02 (dois) córregos em Alto Garças. O cardinotopônimo Meio nomeia 02 (dois) córregos em Alto Araguaia e 01 (um) córrego em Alto Garças.

Pode-se, portanto, constatar que a taxionomia cardinotopônimos apresenta produtividade toponímica na microrregião Alto Araguaia.

Os cardinotopônimos correspondem a 2,1\% do total de topônimos da microrregião Alto Araguaia.

\section{Morfotopônimos}

$\mathrm{Na}$ microrregião Alto Araguaia registram-se 03 (três) morfotopônimos. As unidades lexicais que se referem às formas geométricas, quando utilizadas para dar nomes a acidentes físicos e a acidentes antrópicos, são classificadas nos estudos toponímicos na taxionomia morfotopônimos.

O município de Alto Araguaia possui 02 (dois) morfotopônimos e Alto Garças possui 01 (um). Devido à pequena quantidade de morfotopônimos não se apresenta gráfico para esta taxionomia.

Os morfotopônimos são portugueses e possuem estrutura simples.

O morfotopônimo simples e não derivado Torto nomeia 01 (um) córrego. O morfotopônimo Tortinho, formado pela unidade lexical torto + sufixo -inho, formador de diminutivo, dá nome a 01 (um) córrego, ambos no município de Alto Araguaia. O morfotopônimo Atravessado, formado pela unidade lexical atravessar + sufixo -ado, indicador de qualidade ou estado, singulariza 01 (um) córrego em Alto Garças.

Os morfotopônimos correspondem a $0,5 \%$ do total de topônimos da microrregião Alto Araguaia. 


\section{Meteorotopônimos}

Registram-se, na microrregião Alto Araguaia, 02 (dois) meteorotopônimos. Nos estudos toponímicos são classificados como meteorotopônimos as unidades lexicais que se referem aos fenômenos atmosféricos, quando usadas para denominar acidentes físicos e acidentes antrópicos.

Os meteorotopônimos da microrregião Alto Araguaia localizam-se no município de Alto Araguaia, portanto não se apresenta gráfico para esta taxionomia.

Os meteorotopônimos Neblina e Trovão são portugueses e possuem estrutura simples. O meteorotopônimo Neblina dá nome a 01 (um) morro e o meteorotopônimo Trovão denomina 01 (um) córrego.

Os meteorotopônimos correspondem a 0,4\% do total de topônimos da microrregião Alto Araguaia.

\section{Igneotopônimo}

Na microrregião Alto Araguaia ocorre o registro de 01 (um) igneotopônimo. Nos estudos toponímicos são classificadas como igneotopônimos as unidades lexicais que se referem ao fogo, abrangendo todos os produtos resultantes de sua ação direta, quando usadas para denominar acidentes físicos e acidentes antrópicos.

O igneotopônimo da microrregião Alto Araguaia é português, possui estrutura simples e toponimiza 01 (um) morro no município de Alto Araguaia: morro do Fogo, portanto, não se apresenta gráfico para esta taxionomia.

O igneotopônimo corresponde a 0,2\% do total de topônimos da microrregião Alto Araguaia. 


\section{Astrotopônimo}

Registra-se, na microrregião Alto Araguaia, 01 (um) astrotopônimo. As unidades lexicais que se referem aos corpos celestes em geral, quando usadas para dar nomes a acidentes físicos e a acidentes antrópicos, recebem nos estudos toponímicos a denominação de astrotopônimos.

O astrotopônimo é português, possui estrutura simples e dá nome a 01 (uma) serra no município de Alto Garças: serra da Estrela, portanto, não se apresenta gráfico para esta taxionomia.

A serra da Estrela encontra-se em áreas dos municípios de Alto Garças e Guiratinga, por isso consta nas relações de topônimos dos dois municípios.

O astrotopônimo corresponde a 0,2\% do total de topônimos da microrregião Alto Araguaia. 


\section{Taxionomias de natureza antrópica da microrregião Alto Araguaia}

\section{Ergotopônimos}

$\mathrm{Na}$ microrregião Alto Araguaia constata-se a ocorrência de 42 (quarenta e dois) ergotopônimos. As unidades lexicais que se referem aos elementos de cultura material, quando usadas para dar nomes a acidentes físicos e a acidentes antrópicos, são denominadas ergotopônimos nos estudos toponímicos.

São 31 (trinta e um) ergotopônimos em Alto Araguaia, 08 (oito) em Alto Garças e 03 (três) em Alto Taquari. Apresenta-se a seguir o gráfico desta taxionomia com os respectivos percentuais por município (GRÁFICO 9).

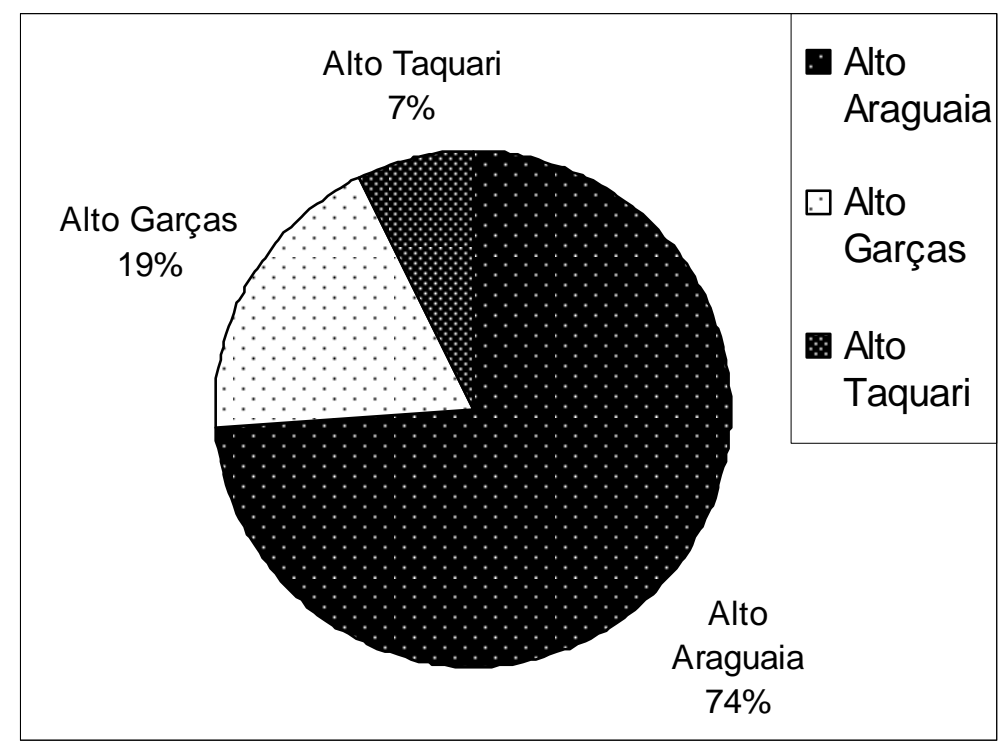

GRÁFICO 9 - Total dos ergotopônimos da microrregião Alto Araguaia.

Registram-se, na microrregião Alto Araguaia, 02 (dois) ergotopônimos tupis, 01 (um) bororo, 03 (três) africanos e 36 (trinta e seis) portugueses.

Considera-se, nesta pesquisa, que o ergotopônimo tupi possui estrutura simples. O ergotopônimo Jirau dá nome a 01 (um) córrego que consta na relação de topônimos de Alto Araguaia e de Alto Garças, porque estabelece divisa entre os dois municípios. 
Considera-se, nesta pesquisa, que o ergotopônimo bororo possui estrutura simples, apesar da grafia registrada no mapa e na carta conter hífen. O ergotopônimo bororo Caiá-quento dá nome a 01 (um) morro no município de Alto Araguaia. A unidade lexical borora está registrada na macroestrutura da Enciclopédia Bororo.

\begin{abstract}
Káia - * ká tamboril; ía $\mathbf{1}_{1}$, abertura [tamboril com abertura]. Designação: 1 . do pilão | É uma peça de madeira cilíndrica cava numa extremidade e ovoidal na outra. A concavidade é obtida por meio do fogo. É usada, estando o operador em pé ou assentado, para apiloar cereais, frutas e estipes das palmeiras. É primacial do clã dos Aróroe. Kédo - * kée, alimento; do $\mathbf{d o}_{1}$ suf. [fazer alimento]. Albisetti; Venturelli (1962, p. 701; 714).
\end{abstract}

Os ergotopônimos africanos, quanto à estrutura, subdividem-se em simples e híbridos. O ergotopônimo Monjolo possui estrutura simples e denomina 01 (um) córrego no município de Alto Araguaia. O ergotopônimo de estrutura híbrida Monjolos, formado pela unidade lexical africana monjolo + desinência de plural -s da língua portuguesa, dá nome a 01 (um) córrego em Alto Araguaia. O ergotopônimo Monjolinho, formado pela unidade lexical africana monjolo + sufixo -inho, indicador de diminutivo da língua portuguesa, nomeia 01 (um) córrego em Alto Araguaia.

Considera-se, nesta pesquisa, que os ergotopônimos portugueses da microrregião Alto Araguaia, quanto à estrutura, subdividem-se em simples e composto. São 35 (trinta e cinco) ergotopônimos de estrutura simples e 01 (um) ergotopônimo de estrutura composta. Eles denominam 36 (trinta e seis) acidentes físicos. Os 03 (três) municípios da microrregião Alto Araguaia possuem ergotopônimos portugueses.

O ergotopônimo composto Chiqueiro Velho, formado por substantivo comum + adjetivo, dá nome a 01 (um) córrego em Alto Garças.

Os ergotopônimos simples subdividem-se em simples não derivados e derivados. Os ergotopônimos não derivados Arame, Barraca, Baú, Cambraia, Chapéu, Cocho, Espora, Manilha, Marco, Matula, Mesa, Óleo e Taça denominam 12 (doze) córregos, 02 (dois) morros e 01 (um) riacho no município de Alto Araguaia. Os ergotopônimos Argola, Barraca e Mesa nomeiam 02 (dois) córregos e 01 morro 
em Alto Garças. Os ergotopônimos Arame, Esteiro e Retalho dão nomes a 03 (três) córregos em Alto Taquari.

Os ergotopônimos Argolinha e Barraquinha, formados pelas unidades lexicais argola e barraca + sufixo -(qu)inha, indicador de diminutivo, denominam 01 (um) córrego em Alto Araguaia e 01 (um) córrego em Alto Garças. O ergotopônimo Potreiro, formado pela unidade lexical potro + sufixo -eiro, indicador de lugar continente, denomina 01 (um) córrego em Alto Garças, 02 (dois) córregos e 02 (dois) morros em Alto Araguaia. O ergotopônimo Porteira, formado pela unidade lexical porta + sufixo -eira, indicador de quantidade ou aumento, denomina 03 (três) córregos em Alto Araguaia e 01 (um) córrego que estabelece divisa entre os municípios de Alto Araguaia e Alto Garças, por isso consta nas relações de topônimos dos dois municípios. O ergotopônimo Britador, formado pela unidade lexical britar + sufixo -dor, indicador de instrumento, dá nome a 01 (um) córrego em Alto Araguaia.

O ergotopônimo Potreirinho apresenta dupla sufixação, formado pela unidade lexical potro + sufixo -eiro + sufixo -inho, já mencionados, dá nome a 01 (um) córrego em Alto Araguaia.

Pode-se constatar produtividade toponímica, nesta taxionomia, na microrregião Alto Araguaia. Os ergotopônimos Matula e Óleo dão nomes, cada um, a 02 (dois) córregos no município de Alto Araguaia. O ergotopônimo Arame nomeia 01 (um) córrego em Alto Araguaia e outro em Alto Taquari. O ergotopônimo Mesa nomina 01 (um) morro em Alto Araguaia e outro em Alto Garças. O ergotopônimo Barraca denomina 01 (um) córrego em Alto Araguaia e 01 (um) córrego em Alto Garças. Pode-se ainda acrescentar o ergotopônimo Barraquinha que singulariza 01 (um) córrego em Alto Araguaia.

O ergotopônimo Porteira nomeia 03 (três) córregos no município de Alto Araguaia e 01 (um) córrego que estabelece divisa entre os municípios de Alto Araguaia e Alto Garças. O ergotopônimo Potreiro denomina 01 (um) córrego em Alto Garças, 02 (dois) morros e 02 (dois) córregos em Alto Araguaia. O ergotopônimo Potreirinho dá nome a 01 (um) córrego em Alto Araguaia. 
O ergotopônimo africano Monjolo denomina 01 (um) córrego, o ergotopônimo Monjolos dá nome a 01 (um) córrego e o ergotopônimo Monjolinho nomeia outro córrego, todos no município de Alto Araguaia. Pode-se ainda considerar o ergotopônimo Argola que nomeia 01 (um) córrego e o ergotopônimo Argolinha que também denomina 01 (um) córrego, ambos em Alto Garças. O ergotopônimo tupi Jirau singulariza 01 (um) córrego que consta nas relações de topônimos de Alto Araguaia e Alto Garças, mas não é considerado produtivo porque estabelece divisa entre os dois municípios.

Os ergotopônimos correspondem a 7,4\% do total de topônimos da microrregião Alto Araguaia.

\section{Sociotopônimos}

São 30 (trinta) sociotopônimos na microrregião Alto Araguaia. É a segunda taxionomia de natureza antrópica que mais denomina acidentes. As unidades lexicais que se referem às atividades sociais ou laborais, quando usadas para dar nomes a acidentes físicos e a acidentes antrópicos, são denominadas sociotopônimos nos estudos toponímicos.

O município de Alto Araguaia possui 16 (dezesseis) sociotopônimos, Alto Garças possui 13 (treze) e Alto Taquari possui 01 (um) sociotopônimo. Apresenta-se a seguir o gráfico desta taxionomia com os respectivos percentuais por município (GRÁFICO 10). 


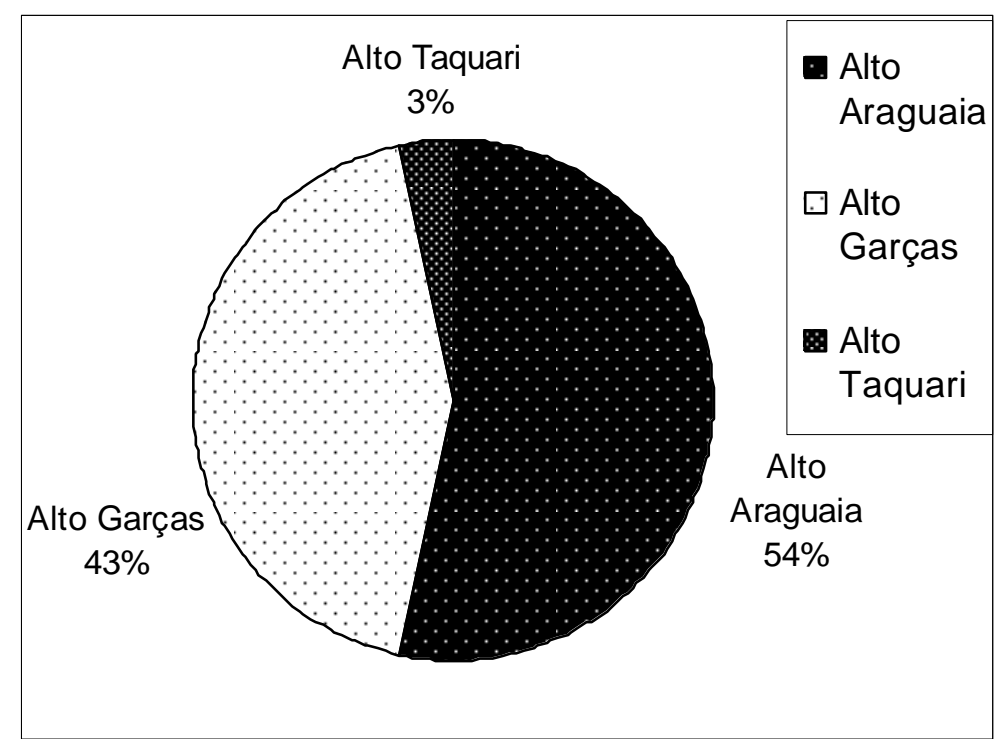

GRÁFICO 10 - Total dos sociotopônimos da microrregião Alto Araguaia.

Registram-se, na microrregião Alto Araguaia, 01 (um) sociotopônimo africano e 29 (vinte e nove) portugueses.

Considera-se, nesta pesquisa, que o sociotopônimo africano possui estrutura simples. O sociotopônimo Quilombo dá nome a 01 (um) córrego no município de Alto Garças.

Considera-se, nesta pesquisa, que os sociotopônimos portugueses da microrregião Alto Araguaia, quanto à estrutura, subdividem-se em simples e compostos. São 26 (vinte e seis) sociotopônimos de estrutura simples e 03 (três) sociotopônimos de estrutura composta. Eles denominam 29 (vinte e nove) acidentes físicos. Os 03 (três) municípios da microrregião Alto Araguaia possuem sociotopônimos portugueses.

O sociotopônimo composto Retiro das Éguas, formado por substantivo comum + conectivo com desinência de plural $-s+$ substantivo comum com desinência de plural $-\mathrm{s}$, nomeia 01 (um) córrego. O sociotopônimo Retiro Velho, formado por substantivo comum + adjetivo, dá nome a 01 (um) córrego. O sociotopônimo Salva-vidas, substantivo composto com desinência de plural $-\mathrm{s}$, denomina 01 (um) córrego. Todos localizam-se no município de Alto Araguaia.

Os sociotopônimos simples e não derivados Estiva, Garimpo, Major, Monge, Olaria, Roça e Rodeio nomeiam 06 (seis) córregos e 01 (um) morro no município de 
Alto Araguaia. O sociotopônimo Retiro nomina 01 (um) córrego, e também, é o segundo topônimo de 01 (um) córrego, ambos em Alto Araguaia. Os sociotopônimos Açucrim, Chácara, Esparramo, Olaria, Pouso, Revolta, Roça e Sobra denominam 07 (sete) córregos e 01 (um) ribeirão em Alto Garças. O sociotopônimo Castigo dá nome a 01 (um) córrego em Alto Taquari.

O sociotopônimo Contendas apresenta desinência de plural -s e dá nome a 01 (um) ribeirão no município de Alto Garças.

Os sociotopônimos Marinheiro e Piloteiro, formados pelas unidades lexicais marinha e piloto + sufixo -eiro, indicador de ofício, profissão, nomeiam, respectivamente, 01 (um) córrego em Alto Araguaia e 01 (um) córrego em Alto Garças. Os sociotopônimos Estivinha e Retirinho formados pelas unidades lexicais estiva e retiro + sufixo -inho/a, indicador de diminutivo, denominam 02 (dois) córregos em Alto Araguaia. O sociotopônimo Rondinha, formado pela unidade lexical ronda + sufixo -inha, já mencionado, dá nome a 02 (dois) córregos em Alto Garças.

O sociotopônimo Boiadeiro apresenta dupla sufixação, formado pela unidade lexical boi + sufixo ada, indicador de quantidade, porção + sufixo -eiro, já mencionado, dá nome a 01 (um) córrego no município de Alto Araguaia.

Os sociotopônimos também apresentam produtividade toponímica na microrregião Alto Araguaia. O sociotopônimo Retiro dá nome a 01 (um) córrego e é o segundo topônimo de outro córrego, ambos no município de Alto Araguaia. Pode-se considerar os sociotopônimos Retirinho, Retiro das Éguas e Retiro Velho que denominam, cada um, 01 (um) córrego em Alto Araguaia. Os sociotopônimos Olaria e Roça nomeiam, cada um, 01 (um) córrego em Alto Araguaia e 01 (um) córrego em Alto Garças. O sociotopônimo Rondinha nomina 02 (dois) córregos em Alto Garças. Os sociotopônimos Estiva e Estivinha toponimizam 02 (dois) córregos em Alto Araguaia.

Os sociotopônimos correspondem a 5,2\% do total de topônimos da microrregião Alto Araguaia. 


\section{Antropotopônimos}

Os nomes próprios individuais, quando usados para dar nomes a acidentes físicos e a acidentes antrópicos, são denominados antropotopônimos nos estudos toponímicos. Registram-se 25 (vinte e cinco) antropotopônimos nos levantamentos de topônimos realizados nos mapas e cartas topográficas dos municípios que compõem a microrregião Alto Araguaia.

São 13 (treze) antropotopônimos em Alto Araguaia, 10 (dez) em Alto Garças e 02 (dois) em Alto Taquari. Apresenta-se a seguir o gráfico desta taxionomia com os respectivos percentuais por município (GRÁFICO 11).

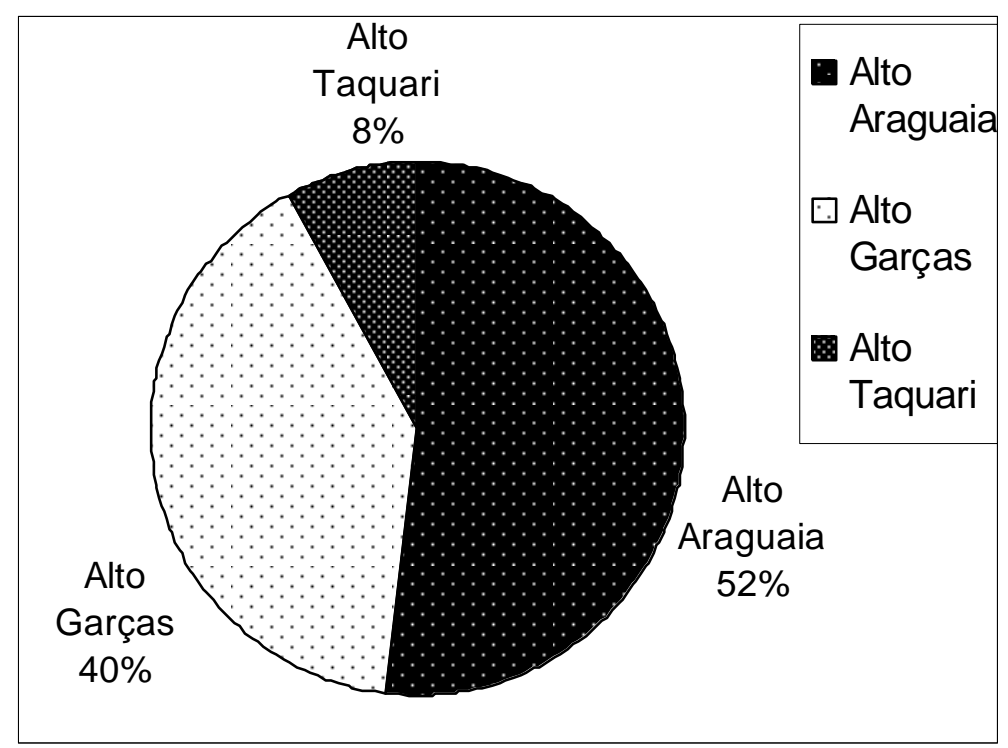

GRÁFICO 11 - Total dos antropotopônimos da microrregião Alto Araguaia.

São 01 (um) antropotopônimo tupi e 24 (vinte e quatro) portugueses na microrregião Alto Araguaia.

O antropotopônimo tupi Iracema é considerado, neste estudo, de estrutura simples e dá nome a 01 (um) córrego no município de Alto Araguaia.

Considera-se, nesta pesquisa, que os antropotopônimos portugueses da microrregião Alto Araguaia, quanto à estrutura, subdividem-se em simples e compostos. São 21 (vinte e um) antropotopônimos de estrutura simples e 03 (três) antropotopônimos de estrutura composta. Eles denominam 24 (vinte e quatro) 
acidentes físicos. Os 03 (três) municípios da microrregião Alto Araguaia possuem antropotopônimos portugueses.

Os antropotopônimos compostos subdividem-se em 03 (três) subgrupos:

a) nome próprio de pessoa + nome de família: José Dutra;

b) nome próprio de pessoa + conectivo + hipocorístico Mané + sufixo -(z)inho, indicador de diminutivo: Júlio do Manezinho;

c) hipocorístico + nome próprio de pessoa: Zé Abílio.

O antropotopônimo Zé Abílio dá nome a 01 (um) córrego em Alto Araguaia. O antropotopônimo Júlio do Manezinho denomina 01 (um) córrego em Alto Garças. O antropotopônimo José Dutra singulariza 01 (um) córrego em Alto Taquari.

Os hipocorísticos também apresentam subdivisões. Os antropotopônimos Elpidão e Vicentão, formados pelos nomes próprios de pessoa Elpídio e Vicente + sufixo -ão, formador de aumentativo, denominam, respectivamente, 01 (um) córrego no município de Alto Garças e 01 (um) córrego em Alto Araguaia. Os antropotopônimos Lazinho e Luisinho, formados pelos nomes próprios de pessoa Lázaro e Luís + sufixo -inho, formador de diminutivo, nominam 01 (um) córrego em Alto Araguaia e 01 (um) córrego em Alto Garças. O hipocorístico Filico toponimiza 01 (um) morro em Alto Araguaia.

Os antropotopônimos de estrutura simples Caetano, Felipe, Inácio, Joventino, Ondino, Rafael e Valentina são pré-nomes ou nome próprio de pessoa. Os antropotopônimos Amorim, Carrilho, Correia, Mesquita, Paiva, Pereira e Viralino são constituídos por nome de família ou sobrenome propriamente dito no Brasil.

Os antropotopônimos Caetano, Mesquita, Ondino, Paiva e Pereira nomeiam 03 (três) córregos, 01 (uma) lagoa, 01 (um) morro e 01 (um) riacho no município de Alto Araguaia. O antropotopônimo Correia dá nome a 01 (um) ribeirão e é o primeiro topônimo de 01 (uma) serra em Alto Araguaia. O ribeirão Correia estabelece divisa entre os municípios de Alto Araguaia e Araguainha, por isso consta nas relações de topônimos dos dois municípios. Os antropotopônimos Amorim, Felipe, Inácio, 
Joventino, Rafael, Valentina e Viralino denominam 07 (sete) córregos em Alto Garças. O antropotopônimo Carrilho dá nome a 01 (um) córrego em Alto Taquari.

São 02 (dois) antropotopônimos que apresentam produtividade toponímica na microrregião Alto Araguaia. O antropotopônimo Correia singulariza 01 (uma) serra e 01 (um) ribeirão. O antropotopônimo Pereira dá nome a 01 (um) morro e a 01 (um) córrego. Todos localizam-se no município de Alto Araguaia.

Os antropotopônimos correspondem a 4,4\% do total de topônimos da microrregião Alto Araguaia.

\section{Animotopônimos}

As unidades lexicais que se referem à vida psíquica das pessoas, quando usadas para dar nomes a acidentes físicos e a acidentes antrópicos, são classificados como animotopônimos nos estudos toponímicos. Registram-se 15 (quinze) animotopônimos na microrregião Alto Araguaia.

Não há registro de animotopônimo no mapa do município de Alto Taquari. São 06 (seis) animotopônimos em Alto Araguaia e 09 (nove) em Alto Garças. Apresenta-se a seguir o gráfico desta taxionomia com os respectivos percentuais por município (GRÁFICO 12). 


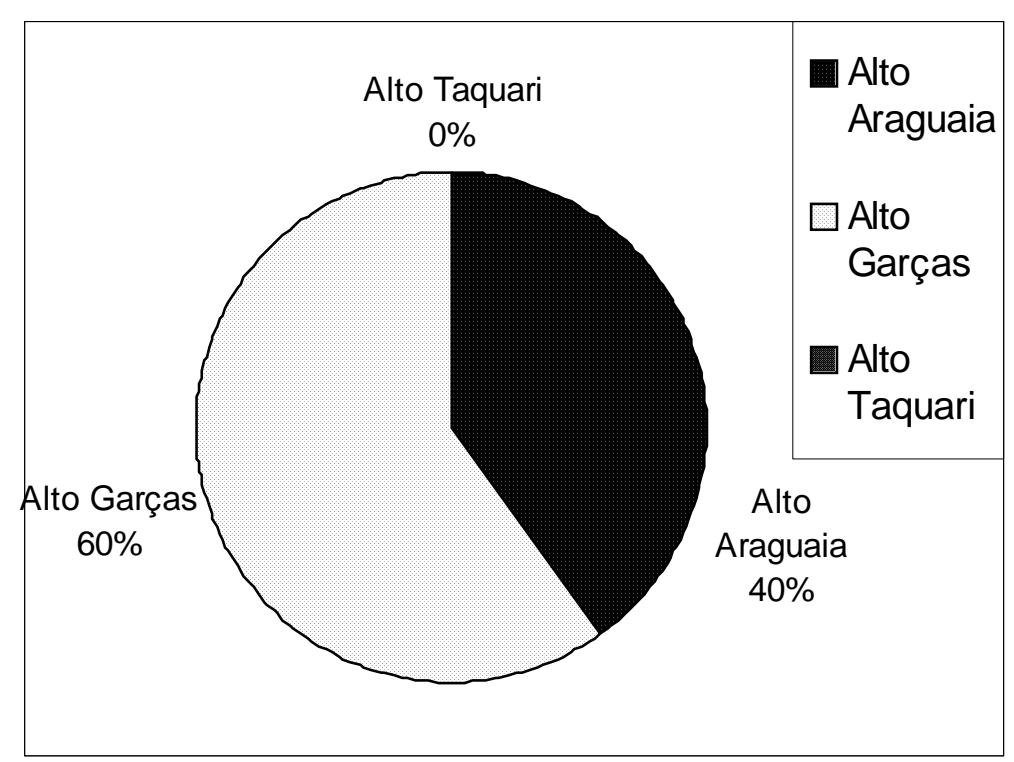

GRÁFICO 12 - Total dos animotopônimos da microrregião Alto Araguaia.

Os animotopônimos da microrregião Alto Araguaia são portugueses.

Considera-se, nesta pesquisa, que os animotopônimos portugueses da microrregião Alto Araguaia, quanto à estrutura, subdividem-se em simples e compostos. São 11 (onze) animotopônimos de estrutura simples e 04 (quatro) animotopônimos de estrutura composta. Eles denominam 15 (quinze) acidentes físicos.

O animotopônimo composto Boa Vista, formado por adjetivo + substantivo comum, dá nome a 03 (três) córregos no município de Alto Garças. O animotopônimo composto Boa Esperança, formado por adjetivo + unidade lexical esperar + sufixo -ança, indicador de qualidade ou estado, nomeia 01 (um) ribeirão em Alto Garças que estabelece divisa entre os municípios de Alto Garças e Itiquira, por isso consta nas relações de topônimos dos dois municípios.

Os animotopônimos simples subdividem-se em derivados e não derivados. animotopônimo Encantado, formado pela unidade lexical encantar + sufixo -ado, indicador de qualidade ou estado, dá nome a 01 (um) córrego em Alto Araguaia. O animotopônimo Arrependido, formado pela unidade lexical arrepender + sufixo-ido, indicador de resultado da ação, nomeia 01 (um) córrego em Alto Garças e 01 (um) ribeirão em Alto Araguaia. 
O animotopônimo simples e não derivado Maravilha nomeia 01 (um) córrego em Alto Garças e o animotopônimo Rico denomina 02 (dois) córregos em Alto Araguaia. O animotopônimo Bonito denomina 01 (uma) serra, 01 (um) córrego, 01 (um) ribeirão em Alto Garças, e também, 01 (um) córrego e 01 (um) ribeirão em Alto Araguaia.

Ocorre produtividade toponímica, nesta taxionomia, na microrregião Alto Araguaia. O animotopônimo Arrependido nomeia 01 (um) córrego no município de Alto Garças e 01 (um) ribeirão em Alto Araguaia. O animotopônimo Boa Vista dá nome a 03 (três) córregos em Alto Garças. O animotopônimo Bonito denomina 01 (uma) serra, 01 (um) córrego, 01 (um) ribeirão em Alto Garças e 01 (um) córrego e 01 (um) ribeirão em Alto Araguaia. O animotopônimo Rico singulariza 02 (dois) córregos em Alto Araguaia.

Os animotopônimos correspondem a 2,6\% do total de topônimos da microrregião Alto Araguaia.

\section{Hodotopônimos}

Registram-se, na microrregião Alto Araguaia, 11 (onze) hodotopônimos. As unidades lexicais que se referem às vias de comunicação rural ou urbana, quando utilizadas para dar nomes a acidentes físicos e a acidentes antrópicos são classificadas, nos estudos toponímicos, como hodotopônimos.

São 09 (nove) hodotopônimos no município de Alto Araguaia e 02 (dois) em Alto Garças. Não há registro de hodotopônimo no mapa do município de Alto Taquari. Apresenta-se a seguir o gráfico desta taxionomia com os respectivos percentuais por município (GRÁFICO 13). 


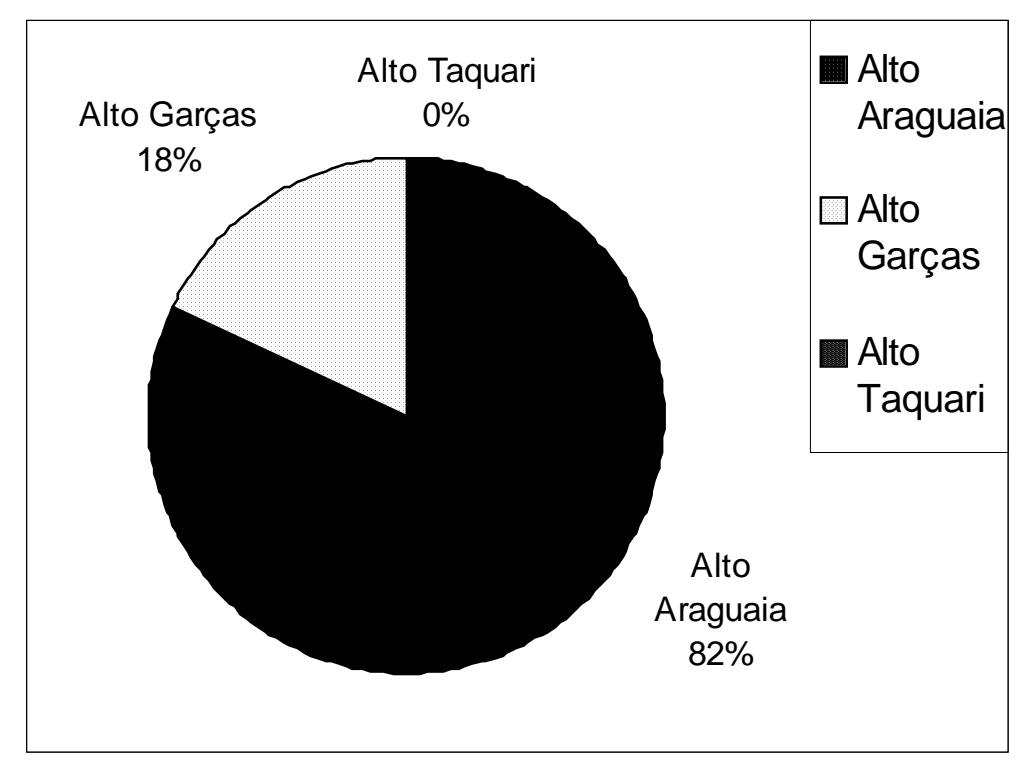

GRÁFICO 13 - Total dos hodotopônimos da microrregião Alto Araguaia.

Na microrregião Alto Araguaia os hodotopônimos são portugueses.

Considera-se, nesta pesquisa, que os hodotopônimos portugueses da microrregião Alto Araguaia, quanto à estrutura, subdividem-se em simples e compostos. São 09 (nove) hodotopônimos de estrutura simples e 02 (dois) hodotopônimos de estrutura composta. Eles denominam 11 (onze) acidentes físicos.

O hodotopônimo composto Ponte de Terra, formado por substantivo comum + preposição + substantivo comum, dá nome a 02 (dois) córregos no município de Alto Araguaia.

Os hodotopônimos Pinguela e Ponte possuem estrutura simples e não derivada, cada um nomeia 01 (um) córrego em Alto Araguaia.

O hodotopônimo Pinguelão, formado pela unidade lexical pinguela + sufixo ão, indicador de aumentativo, denomina 01 (um) córrego no município de Alto Araguaia. O hodotopônimo Picada, formado pela unidade lexical picar + sufixo -ada, indicador de efeito da ação, denomina 01 (um) córrego em Alto Garças. O hodotopônimo Pinguelinha, formado pela unidade lexical pinguela + sufixo -inha, indicador de diminutivo, nomeia 01 (um) córrego em Alto Araguaia. O hodotopônimo Pontinha, formado pela unidade lexical ponte + sufixo -inha, já mencionado, denomina 01 (um) córrego em Alto Garças, 02 (duas) cabeceiras e 01 (um) córrego em Alto Araguaia. 
Ocorre produtividade toponímica, nesta taxionomia, na microrregião Alto Araguaia. O hodotopônimo Potinha nomeia 02 (duas) cabeceiras e 01 (um) córrego no município de Alto Araguaia, e também, 01 (um) córrego em Alto Garças. O hodotopônimo Ponte dá nome a 01 (um) córrego em Alto Araguaia e o hodotopônimo Ponte de Terra toponimiza 02 (dois) córregos em Alto Araguaia.

Pode-se ainda considerar os hodotopônimos Pinguela, Pinguelinha e Pinguelão, cada um dá nome a 01 (um) córrego no município de Alto Araguaia.

Os hodotopônimos correspondem a 1,9\% do total de topônimos da microrregião Alto Araguaia.

\section{Ecotopônimos}

As unidades lexicais que se referem às habitações de um modo geral, quando usadas para dar nomes a acidentes físicos e a acidentes antrópicos, são classificadas nos estudos toponímicos como ecotopônimos. Registram-se, na microrregião Alto Araguaia, 09 (nove) ecotopônimos.

O município de Alto Araguaia possui 07 (sete) ecotopônimos e Alto Garças possui 02 (dois). Não há registro de ecotopônimo no município de Alto Taquari. Apresenta-se a seguir o gráfico desta taxionomia com os respectivos percentuais por município (GRÁFICO 14). 


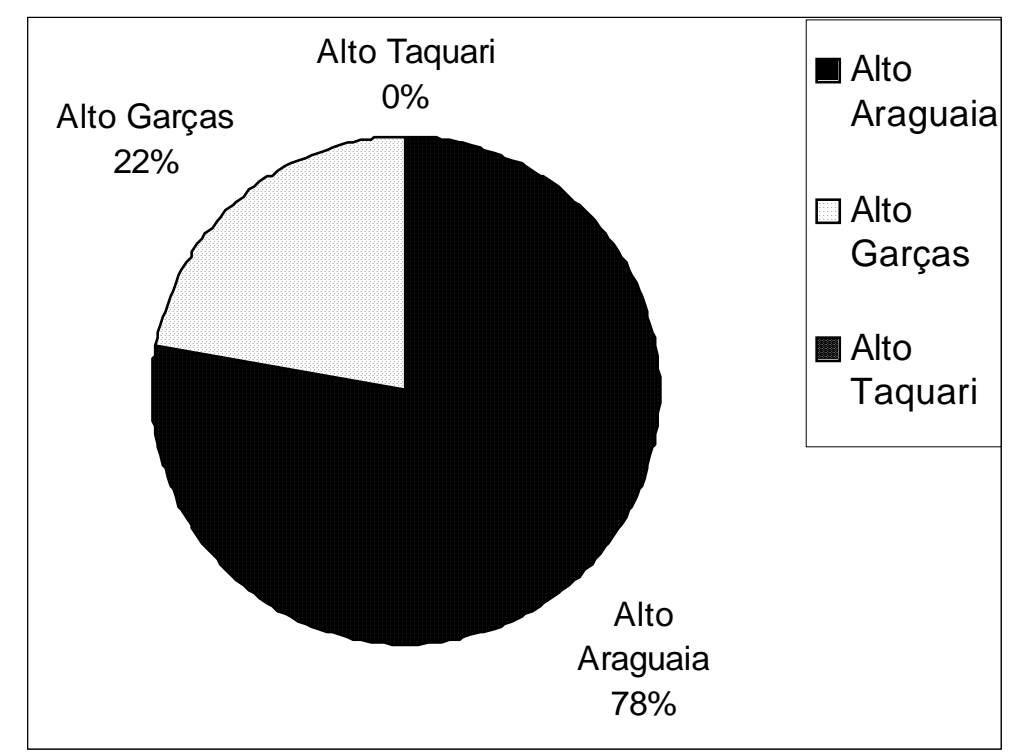

GRÁFICO 14 - Total dos ecotopônimos da microrregião Alto Araguaia.

Constam, na microrregião Alto Araguaia, 06 (seis) ecotopônimos tupis e 03 (três) portugueses.

Considera-se, nesta pesquisa, que o ecotopônimo tupi da microrregião Alto Araguaia possui estrutura simples. O ecotopônimo Tapera denomina 02 (dois) córregos e 01 (uma) lagoa no município de Alto Araguaia, 01 (um) córrego em Alto Garças e 01 (um) córrego que estabelece divisa entre os municípios de Alto Araguaia e Alto Garças, portanto, consta nas relações de topônimos dos dois municípios.

Considera-se, nesta pesquisa, que os ecotopônimos portugueses da microrregião Alto Araguaia, quanto à estrutura, subdividem-se em simples e composto.

O ecotopônimo português Rancho dá nome a 01 (um) córrego. O ecotopônimo Ranchinho, formado pela unidade lexical rancho + sufixo -inho, indicador de diminutivo, também nomeia 01 (um) córrego. O ecotopônimo composto Rancho Queimado, formado por substantivo comum + unidade lexical queimar + sufixo -ado, indicador do efeito da ação, denomina 01 (um) córrego. Todos localizam-se no município de Alto Araguaia.

Ocorre produtividade toponímica, nesta taxionomia, na microrregião Alto Araguaia. O ecotopônimo Tapera dá nome a 04 (quatro) córregos e a 01 (um) lagoa. 
Pode-se considerar os ecotopônimos Rancho, Ranchinho e Rancho Queimado que denominam 03 (três) córregos em Alto Araguaia.

Os ecotopônimos correspondem a 1,6\% do total de topônimos da microrregião Alto Araguaia.

\section{Hierotopônimos}

Registram-se, na microrregião Alto Araguaia, 06 (seis) hierotopônimos. As unidades lexicais que se referem aos nomes sagrados de diferentes crenças, às efemérides religiosas, às associações religiosas e aos locais de culto, quando usadas para dar nomes a acidentes físicos e a acidentes antrópicos são classificadas, nos estudos toponímicos, como hierotopônimos.

São 05 (cinco) hierotopônimos no município de Alto Araguaia e 01 (um) em Alto Garças. Não há registro de hierotopônimo no município de Alto Taquari. Apresenta-se a seguir o gráfico desta taxionomia com os respectivos percentuais por município (GRÁFICO 15).

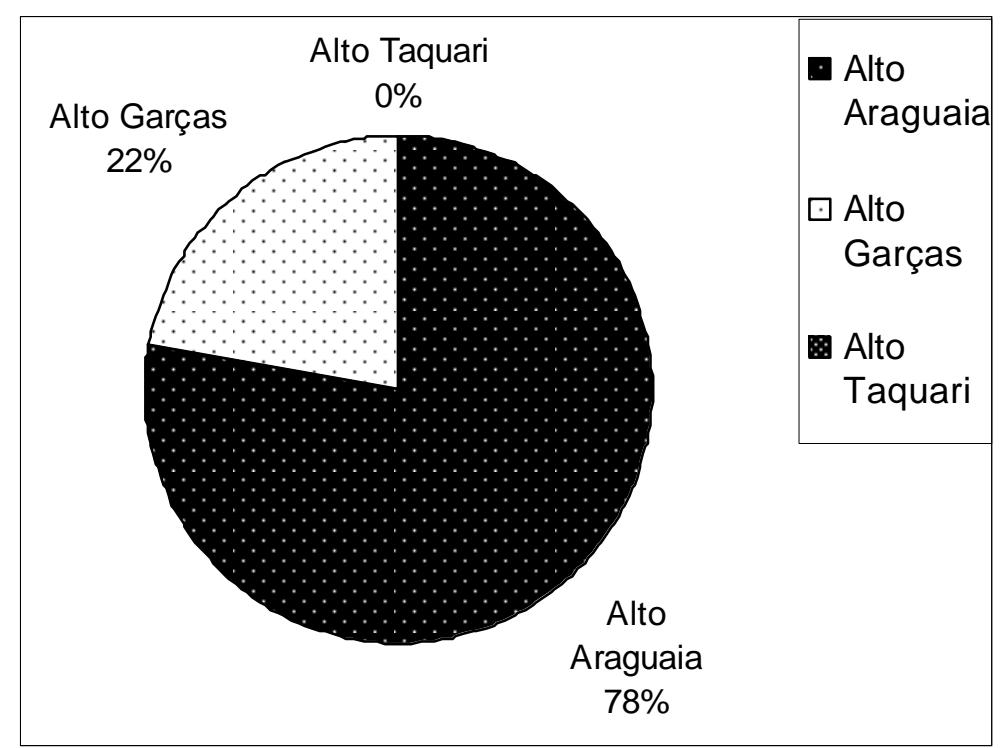

GRÁFICO 15 - Total dos hierotopônimos da microrregião Alto Araguaia.

São 02 (dois) hierotopônimos tupis e 04 (quatro) portugueses. 
Considera-se, nesta pesquisa, que os hierotopônimos tupis da microrregião Alto Araguaia possuem estrutura simples. O hierotopônimo tupi Tupaçuretã dá nome a 01 (um) córrego no município de Alto Araguaia. O hierotopônimo Jaraguá nomeia 01 (um) córrego no município de Alto Garças.

Segundo Sampaio, as unidades lexicais tupis jaraguá e tupaçuretã têm as seguintes características: "JARAGUÁ, corr. yara-guá, a baixa do senhor, o valle do dono. Pode ser corrupção de yara-quã que significa - o dedo de Deus, a ponta do Senhor." e "TUPANCERATAN, corr. tupã-cy-retã, a terra da mãe de Deus, o patrimônio de Nossa Senhora." (1970, p. 236; p. 330)

Considera-se, nesta pesquisa, que os hierotopônimos portugueses da microrregião Alto Araguaia possuem estrutura simples. O hierotopônimo Cruz denomina 01 (um) morro e o hierotopônimo Paraíso dá nome a 02 (dois) córregos. 0 hierotopônimo Cruzeiro, formado pela unidade lexical cruz + sufixo -eiro, indicador de aumento, nomeia 01 (um) morro. Todos localizam-se no município de Alto Araguaia.

Ocorre produtividade toponímica, nesta taxionomia, na microrregião Alto Araguaia. O hierotopônimo Paraíso denomina 02 (dois) córregos no município de Alto Araguaia. Pode-se acrescentar os hierotopônimos Cruz e Cruzeiro, cada um dá nome a 01 (um) morro em Alto Araguaia.

Os hierotopônimos correspondem a 1,0\% do total de topônimos da microrregião Alto Araguaia.

\section{Hagiotopônimos}

Registram-se 06 (seis) hagiotopônimos na microrregião Alto Araguaia. As unidades lexicais que se referem aos santos e santas da religião católico-romana, quando usadas para dar nomes a acidentes físicos e a acidentes antrópicos, são denominadas hagiotopônimos nos estudos toponímicos. 
Não consta, nos levantamentos cartográficos, hagiotopônimo no município de Alto Taquari. São 04 (quatro) hagiotopônimos no município de Alto Araguaia e 02 (dois) em Alto Garças. Apresenta-se a seguir o gráfico desta taxionomia com os respectivos percentuais por município (GRÁFICO 16).

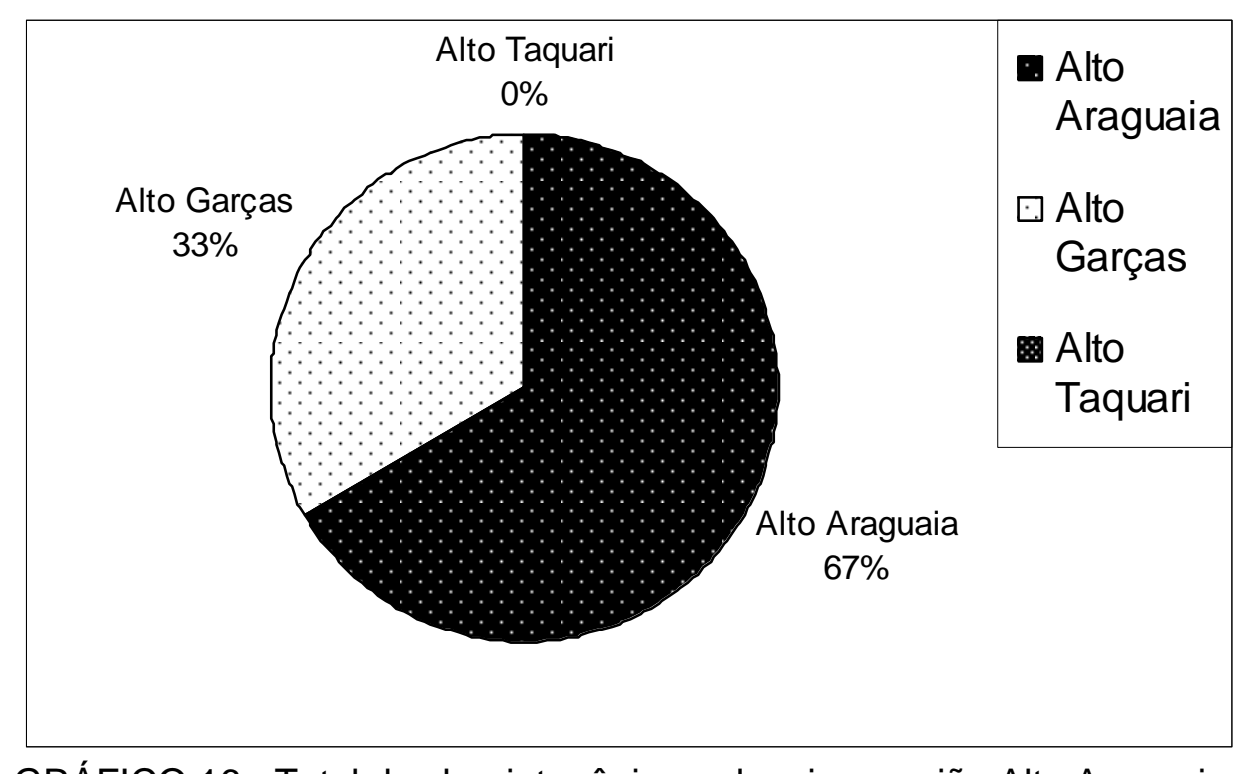

GRÁFICO 16 - Total dos hagiotopônimos da microrregião Alto Araguaia.

Os hagiotopônimos são portugueses e possuem estrutura composta.

O hagiotopônimo São José, formado por adjetivo + nome próprio de pessoa, dá nome a 01 (um) córrego e a 01 (uma) lagoa no município de Alto Araguaia. Os hagiotopônimos São Francisco e São Paulo, formados por adjetivo + nome próprio de pessoa, denominam 02 (dois) córregos no município de Alto Araguaia. Os hagiotopônimos São João e São Vicente, formados por adjetivo + nome próprio de pessoa, nomeiam 02 (dois) córregos no município de Alto Garças.

Apesar da pequena quantidade de hagiotopônimos, ocorre produtividade toponímica porque o hagiotopônimo São José dá nome a 01 (um) córrego e a 01 (uma) lagoa no município de Alto Araguaia.

Os hagiotopônimos correspondem a 1,0\% do total de topônimos da microrregião Alto Araguaia. 
Registram-se, nos mapas e nas cartas topográficas dos municípios que compõem a microrregião Alto Araguaia, 05 (cinco) somatotopônimos. As unidades lexicais que se referem à partes do corpo humano ou do corpo do animal, quando utilizadas para denominar acidentes físicos e acidentes antrópicos, são denominadas somatotopônimos nos estudos toponímicos.

O município de Alto Araguaia possui 04 (quatro) somatotopônimos e Alto Garças possui 01 (um). Não há registro de somatotopônimo no município de Alto Taquari. Devido à pequena quantidade de somatotopônimos não se apresenta gráfico para esta taxionomia.

Os somatotopônimos são portugueses e possuem estrutura simples.

Os somatotopônimos simples e não derivados Guampo e Guampa nomeiam, respectivamente, 01 (um) córrego no município de Alto Araguaia e 01 (um) córrego em Alto Garças. O somatotopônimo Bracinho, formado pela unidade lexical braço + sufixo -inho, indicador de diminutivo, denomina 01 (um) córrego. O somatotopônimo Cobreiro, formado pela unidade lexical cobra + sufixo -eiro, indicador de doença, dá nome a 01 (um) córrego. O somatotopônimo Gordura, formado pela unidade lexical gordo + sufixo -ura, indicador de ação ou resultado da ação, nomeia 01 (um) córrego. Todos localizam-se em Alto Araguaia.

Pode-se considerar como produtivos os somatotopônimos Guampo e Guampa, o primeiro denomina 01 (um) córrego no município de Alto Araguaia e o segundo nomeia 01 (um) córrego em Alto Garças.

Os somatotopônimos correspondem a $0,9 \%$ do total de topônimos da microrregião Alto Araguaia.

\section{Etnotopônimos}

Registram-se, na microrregião Alto Araguaia, 04 (quatro) etnotopônimos. Quando as unidades lexicais que se referem aos elementos étnicos, isolados ou não 
(povos, tribos, castas), dão nomes a acidentes físicos e a acidentes antrópicos, são denominadas etnotopônimos nos estudos toponímicos.

Apenas o município de Alto Araguaia possui etnotopônimos na microrregião Alto Araguaia, portanto, não se apresenta gráfico para esta taxionomia.

São 02 (dois) etnotopônimos africanos e 02 (dois) portugueses.

O etnotopônimo africano possui estrutura híbrida. O etnotopônimo Moleques, formado pela unidade lexical africana moleque + desinência de plural -s da língua portuguesa, denomina 01 (um) córrego e 01 (um) morro.

Os etnotopônimos portugueses possuem estrutura simples. O etnotopônimo Baianos, formado pela unidade lexical Bahia + sufixo -ano, indicador de naturalidade, origem + desinência de plural -s, dá nome a 01 (um) córrego. O etnotopônimo Solteiro nomeia 01 (um) morro.

$\mathrm{Na}$ microrregião Alto Araguaia, nesta taxionomia, o topônimo Moleques apresenta produtividade toponímica porque nomeia 01 (um) córrego e 01 (um) morro.

Os etnotopônimos correspondem a $0,7 \%$ do total de topônimos da microrregião Alto Araguaia.

\section{Poliotopônimos}

Constam 03 (três) poliotopônimos nos mapas e nas cartas topográficas dos municípios da microrregião Alto Araguaia. As unidades lexicais que se referem aos aglomerados humanos: vila, cidade, povoação, arraial, quando usadas para dar nomes a acidentes físicos e a acidentes antrópicos, recebem nos estudos toponímicos a denominação de poliotopônimos. 
O município de Alto Araguaia possui 01 (um) poliotopônimo e Alto Garças possui 02 (dois). Devido à pequena quantidade de somatotopônimos não se apresenta gráfico para esta taxionomia.

Os poliotopônimos da microrregião Alto Araguaia são portugueses e, quanto à estrutura, subdividem-se em simples e composto.

O poliotopônimo Aldeia dá nome a 01 (um) córrego em Alto Araguaia e o poliotopônimo Corrutela denomina 01 (um) córrego em Alto Garças.

O poliotopônimo composto Currutela dos Casados, formado por substantivo comum + conectivo com desinência de plural -s + unidade lexical casar + sufixo ado, indicador de qualidade ou estado com desinência de plural -s, nomeia 01 (um) córrego no município de Alto Garças.

Os poliotopônimos correspondem a 0,5\% do total de topônimos da microrregião Alto Araguaia.

\section{Numerotopônimos}

Os adjetivos numerais, quando usados para dar nomes a acidentes físicos e a acidentes antrópicos, são denominados, nos estud,os toponímicos, numerotopônimos. Registram-se, nos mapas dos municípios que compõem a microrregião Alto Araguaia, 03 (três) numerotopônimos.

O município de Alto Garças possui 02 (dois) numerotopônimos e Alto Taquari possui 01 (um). Não há registro de numerotopônimo no município de Alto Araguaia. Devido à pequena quantidade de somatotopônimos não se apresenta gráfico para esta taxionomia.

São 01 (um) numerotopônimo tupi e 02 (dois) portugueses. 
O numerotopônimo tupi possui estrutura híbrida. O numerotopônimo Três Capões, formado por unidade lexical portuguesa + unidade lexical tupi com desinência de plural -ões da língua portuguesa, dá nome a 01 (um) córrego em Alto Taquari.

Os numerotopônimos portugueses possuem estrutura composta. Os numerotopônimos Dois Irmãos e Três Barras, formados por numeral + substantivo comum com desinência de plural -s, nomeiam 02 (dois) córregos em Alto Garças.

Pode-se considerar que ocorre produtividade toponímica, nesta taxionomia, se observar a primeira unidade lexical dos numerotopônimos compostos. O numerotopônimo Três Capões nomeia 01 (um) córrego no município de Alto Taquari e o numerotopônimo Três Barras denomina 01 (um) córrego em Alto Garças.

Os numerotopônimos correspondem a 0,5\% do total de topônimos da microrregião Alto Araguaia.

\section{Dirrematotopônimos}

As denominações de acidentes físicos e de acidentes antrópicos, constituídas por frases ou enunciados lingüísticos, são classificadas nos estudos toponímicos na taxionomia dirrematotopônimos. Na microrregião Alto Araguaia registram-se 03 (três) dirrematotopônimos.

O município de Alto Araguaia possui 02 (dois) dirrematotopônimos, Alto Garças possui 01 (um) e não há registro de dirrematotopônimo em Alto Taquari. Devido à pequena quantidade de dirrematotopônimos não se apresenta gráfico para esta taxionomia.

Os dirrematotopônimos são portugueses, possuem estrutura composta e apresentam as seguintes subdivisões: 
a) dirrematotopônimos formados pelo presente do indicativo do verbo quebrar + substantivo comum: Quebra-cabeça e Quebra Pigarro;

b) dirrematotopônimo formado por substantivo comum + adjetivo: Vista Alegre;

O dirrematotopônimo Quebra-cabeça dá nome a 01 (um) córrego no município de Alto Araguaia. O dirrematotopônimo Vista Alegre nomeia 01 (um) córrego em Alto Araguaia. O dirrematotopônimo Quebra Pigarro denomina 01 (um) córrego em Alto Garças. Ressalta-se que foram respeitadas as grafias das fontes de pesquisa.

Os dirrematotopônimos correspondem a 0,5\% do total de topônimos da microrregião Alto Araguaia.

\section{Historiotopônimos}

As unidades lexicais relativas aos movimentos de cunho histórico-social e aos seus membros, assim como as datas correspondentes, quando usadas para dar nomes a acidentes físicos e a acidentes antrópicos, são denominadas historiotopônimos nos estudos toponímicos. Registram-se 02 (dois) historiotopônimos na microrregião Alto Araguaia.

O município de Alto Araguaia possui 01 (um) historiotopônimo e Alto Garças também possui 01 (um). Não há registro de historiotopônimo no município de Alto Taquari. Devido à pequena quantidade de somatotopônimos não se apresenta gráfico para esta taxionomia.

O historiotopônimo Bandeira é português, possui estrutura simples e nomeia 01 (um) córrego em Alto Araguaia e 01 (um) córrego em Alto Garças.

O historiotopônimo Bandeira apresenta produtividade toponímica porque dá nome a 02 (dois) córregos. 
Os historiotopônimos correspondem a 0,4\% do total de topônimos da microrregião Alto Araguaia.

\section{Corotopônimos}

As unidades lexicais que se referem a nomes de continentes, países, regiões, estados e cidades, quando usadas para nomear acidentes físicos e acidentes antrópicos, recebem nos estudos toponímicos a denominação de corotopônimos. Registram-se, na microrregião Alto Araguaia, 02 (dois) corotopônimos.

O município de Alto Araguaia possui 02 (dois) corotopônimos. Não há registro de corotopônimos nos municípios de Alto Garças e Alto Taquari. Devido à pequena quantidade de corotopônimos não se apresenta gráfico para esta taxionomia.

Os corotopônimos África e Cantagalo são portugueses, possuem estrutura simples e nomeiam 02 (dois) córregos no município de Alto Araguaia.

O corotopônimo corresponde a $0,4 \%$ do total de topônimos da microrregião Alto Araguaia.

\section{Cronotopônimo}

Registra-se, na microrregião Alto Araguaia, 01 (um) cronotopônimo. Nos estudos toponímicos são classificados como cronotopônimos as unidades lexicais que se referem ao tempo, quando usadas para dar nomes a acidentes físicos e a acidentes antrópicos.

O cronotopônimo localiza-se no município de Alto Garças. Devido ao registro único de cronotopônimo não se apresenta gráfico para esta taxionomia. 
O cronotopônimo Velhas é português, possui estrutura simples, apresenta desinência de plural -s e dá nome a 01 (um) ribeirão que estabelece divisa entre Alto Garças e Itiquira, por isso consta nas relações de topônimos dos dois municípios.

O cronotopônimo corresponde a $0,2 \%$ do total de topônimos da microrregião Alto Araguaia. 


\section{Considerações parciais}

Pode-se anotar, na conclusão da pesquisa dos topônimos alto-araguaienses, algumas observações quanto à análise dos topônimos agrupados por microrregião.

Do total de 571 (quinhentos e setenta e um) topônimos registrados na microrregião Alto Araguaia, 404 (quatrocentos e quatro) são de natureza física e 167 (cento e sessenta e sete) são de natureza antrópica.

Na microrregião Alto Araguaia os topônimos de natureza física classificam-se em 12 (doze) taxionomias. São 222 (duzentos e vinte e dois) no município de Alto Araguaia, 153 (cento e cinqüenta e três) em Alto Garças e 29 (vinte e nove) em Alto Taquari. Apresenta-se a seguir o gráfico dos topônimos de natureza física com os respectivos percentuais por município (GRÁFICO 17).

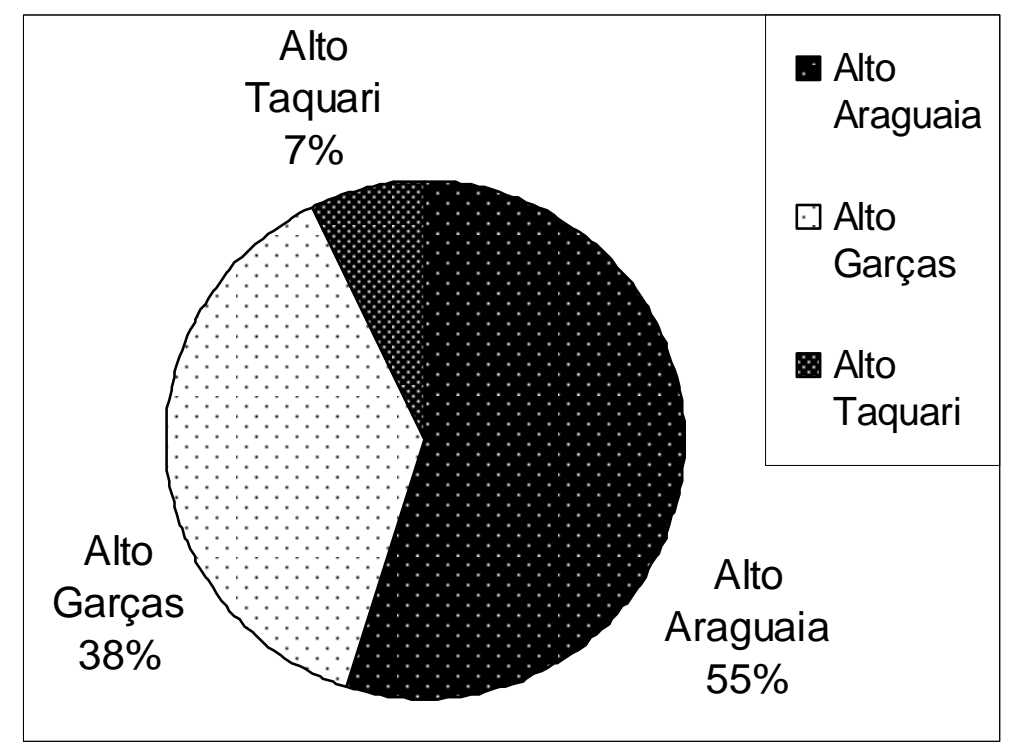

GRÁFICO 17 - Total dos topônimos de natureza física da microrregião Alto Araguaia.

Os topônimos de natureza humana classificam-se em 16 (dezesseis) taxionomias na microrregião Alto Araguaia. São 105 (cento e cinco) no município de Alto Araguaia, 55 (cinqüenta e cinco) em Alto Garças e 07 (sete) em Alto Taquari. Apresenta-se a seguir o gráfico dos topônimos de natureza humana com os respectivos percentuais por município (GRÁFICO 18). 


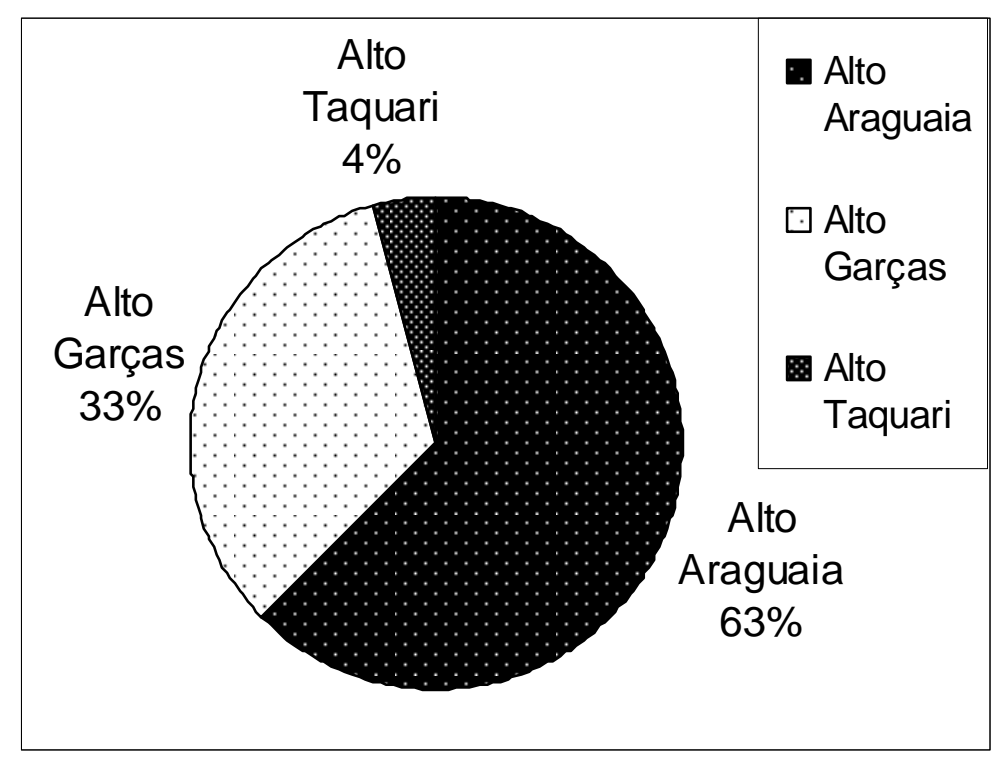

GRÁFICO 18 - Total dos topônimos de natureza antrópica da microrregião Alto Araguaia.

Constata-se que a representatividade dos topônimos de natureza física, na microrregião Alto Araguaia, é de $70,8 \%$, os topônimos de natureza humana correspondem a 29,2\%.

$\mathrm{Na}$ microrregião Alto Araguaia pode-se ainda observar a representatividade dos topônimos reunidos por grupos lingüísticos. São 01 (um) topônimo bororo, 08 (oito) africanos, 94 (noventa e quatro) topônimos tupis e 468 (quatrocentos e sessenta e oito) portugueses. Apresenta-se a seguir o gráfico dos topônimos por grupos lingüísticos com os respectivos percentuais por município (GRÁFICO 19).

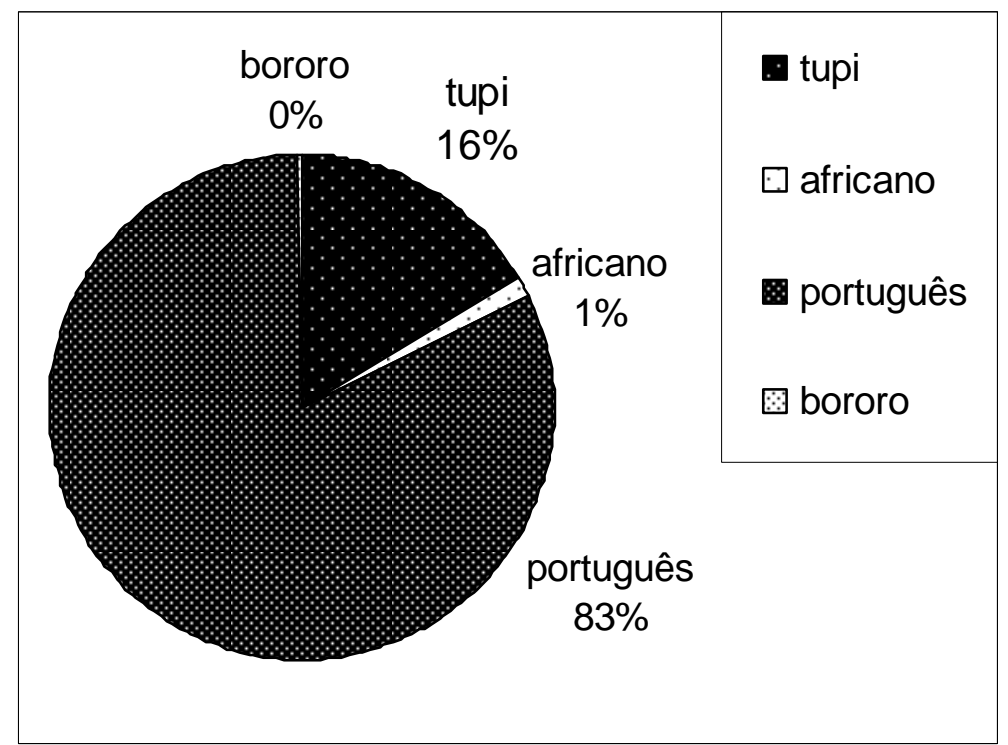

GRÁFICO 19 - Total dos topônimos por grupos lingüísticos da microrregião Alto Araguaia. 
Registram-se 82 (oitenta e dois) topônimos tupis nas taxionomias de natureza física: cardinotopônimos, fitotopônimos, hidrotopônimos e zootopônimos. São 12 (doze) topônimos tupis classificados nas taxionomias de natureza humana: antropotopônimos, ecotopônimos, ergotopônimos hierotopônimos e numerotopônimos. Eles representam $16,5 \%$ do total de topônimos da microrregião Alto Araguaia e correspondem, em termos absolutos, a 94 (noventa e quatro) ocorrências.

Registra-se 01 (um) topônimo bororo que corresponde a 0,2\% do total de topônimos da microrregião Alto Araguaia. O topônimo bororo está classificado na taxionomia ergotopônimo.

São 02 (dois) topônimos africanos classificados nas taxionomias de natureza física: fitotopônimos e zootopônimos. Registram-se 06 (seis) topônimos africanos nas taxionomias: ergotopônimos, etnotopônimos e sociotopônimos. São 08 (oito) topônimos africanos que correspondem a 1,4\% do total de topônimos da microrregião Alto Araguaia.

Na microrregião Alto Araguaia a representatividade de cada município no total dos topônimos alto-araguaienses define-se assim: 327 (trezentos e vinte e sete) topônimos no município de Alto Araguaia, 208 (duzentos e oito) em Alto Garças e 36 (trinta e seis) em Alto Taquari. Apresenta-se a seguir o gráfico do total geral dos topônimos da microrregião Alto Araguaia com os respectivos percentuais por município (GRÁFICO 20). 


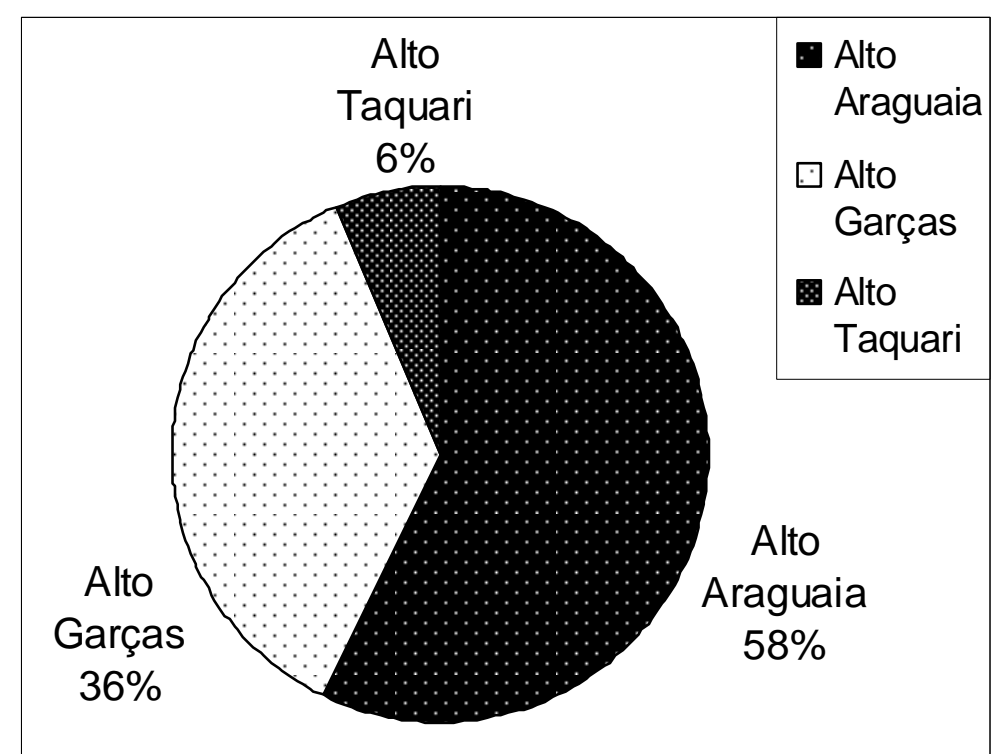

GRÁFICO 20 - Total geral dos topônimos da microrregião Alto Araguaia.

Não houve registro de topônimos, na microrregião Alto Araguaia, nas taxionomias axiotopônimos e mitotopônimos.

As taxionomias hidrotopônimos, zootopônimos, fitotopônimos e ergotopônimos são as mais representativas e correspondem a 58,0\% do total de topônimos da microrregião Alto Araguaia.

A microrregião Alto Araguaia, apesar do expressivo volume de topônimos, já referido, ocupa a terceira posição quanto ao número de topônimos. Os topônimos dos municípios Alto Araguaia, Alto Garças e Alto Taquari representam 24,3\% do total de topônimos da mesorregião Sudeste Mato-grossense. 


\subsection{Microrregião Primavera do Leste}

\subsubsection{Características gerais da microrregião Primavera do Leste}

A microrregião Primavera do Leste é uma das 04 (quatro) microrregiões que compõe a mesorregião Sudeste Mato-grossense. Está formada por 02 (dois) municípios: Campo Verde e Primavera do Leste. Ambos foram elevados à categoria de município na segunda metade da década de oitenta do século passado.

As terras que compõem a microrregião Primavera do Leste foram palmilhadas por bandeirantes e aventureiros que pretendiam alcançar a lendária serra dos Martírios. Depois foi percorrida pelos modernos bandeirantes para a instalação da linha telegráfica coordenada pelo marechal Rondon.

O povoamento da região iniciou-se com um grupo de pessoas que procurava terras apropriadas para práticas agropecuárias. A agricultura mecanizada proporcionou, aos dois municípios, destaques como produtores de grãos no estado de Mato Grosso. Vale ainda ressaltar que ambos apresentam promissoras perspectivas como grandes produtores de frutas, porque possuem terras com bons índices de fertilidade e altitudes elevadas que propiciam clima mais ameno. Eles já se destacam como municípios produtores de uvas, variedades desenvolvidas para cultivo em terras de cerrado.

Os projetos federais SUDAM e PROTERRA, criados para incentivar o setor primário da economia, deram suas cotas de contribuição para que pessoas se instalassem na região e lá construíssem base para garantir futuro promissor. O asfaltamento das rodovias federais que passam pela região: BR-070 e BR-364 influenciaram, de forma decisiva, para a continuidade dos labores agropecuários.

Os cursos d'água da microrregião Primavera do Leste contribuem com seus caudais para formar as bacias hidrográficas: Amazônica, Araguaia-tocantina e Pratina. 
A extensão territorial da microrregião Primavera do Leste é de $10.267 \mathrm{~km}^{2}$, dados do Anuário Estatístico de Mato Grosso - 2009, publicado pela SEPLAN - MT. Ocupa 14,3 \% da área total da mesorregião Sudeste Mato-grossense. É a quarta microrregião da mesorregião Sudeste Mato-grossense, em extensão territorial.

Com base nas pesquisas socioeconômicas do Anuário Estatístico de Mato Grosso - 2009, os principais produtos agrícolas da microrregião Primavera do Leste foram: algodão, arroz, banana, cana-de-açúcar, feijão, mandioca, milho e soja. O volume da produção agrícola foi superior a 1.624 .380 toneladas. Os principais rebanhos foram: bovino, eqüino, ovino e suíno. Os rebanhos, nessa época, perfaziam um total de 261.012 cabeças.

A população residente, recenseada em 2007 e divulgada pelo Instituto Brasileiro de Geografia e Estatística (IBGE), foi de 70.653 habitantes, sendo que 61.367 encontravam-se na zona urbana e 9.286 na zona rural. A densidade demográfica atingiu o índice de 6,9 hab. $/ \mathrm{km}^{2}$ e a representatividade da população urbana foi superior a 86,9\%. A microrregião Primavera do Leste é a segunda mais populosa da mesorregião Sudeste Mato-grossense. O índice de urbanização é o segundo maior dentre as microrregiões que compõem a mesorregião Sudeste Matogrossense.

A microrregião Primavera do Leste limita-se com as microrregiões Canarana, Cuiabá, Paranatinga, Rondonópolis e Tesouro. A seguir, as características gerais dos municípios que a compõem, com suas respectivas relações de topônimos. 


\subsubsection{Características gerais do município de Campo Verde}

O município de Campo Verde obteve sua autonomia político-administrativa em 1988, ao ser desmembrado dos municípios de Cuiabá e Dom Aquino. A cidade de Campo Verde localiza-se no entroncamento das rodovias federais: BR - 070 e BR $-364$.

O município de Campo Verde possui $4.795 \mathrm{~km}^{2}$ de extensão territorial, dados do Anuário Estatístico de Mato Grosso - 2009, publicado pela SEPLAN - MT. A altitude na cidade de Campo Verde é de 736 metros acima do nível do mar.

O topônimo Campo Verde possui estrutura composta, formado por substantivo comum + adjetivo. Nos estudos toponímicos é classificado, taxionomicamente, como fitotopônimo.

O início do povoamento, por não autóctones, em terras que atualmente constituem o município de Campo Verde, data da penúltima década do século XIX. Pessoas, de uma mesma família, vindas do estado de Minas Gerais ali se instalaram, porém o processo migratório que iria, posteriormente, proporcionar a instalação de uma nova unidade administrativa mato-grossense, iniciou-se na década de sessenta do século passado.

A cidade de Campo Verde começou a formar-se a partir do segundo aglomerado humano que desenvolveu-se em derredor de um posto de gasolina ao lado da BR-070, denominado Posto Paraná. Com posterior venda de lotes urbanos, uniu-se esse segundo aglomerado ao que encontrava-se um pouco mais distante: o primeiro loteamento denominado Jupiara.

Em 02 de outubro de 1985 foi criado o distrito de Campo Verde, pela Lei $n^{\circ}$ 898, que abrangia os loteamentos urbanos de Campo Real e Jupiara. O município de Campo Verde foi criado pela Lei n 5.314 de 04 de julho de 1988.

Atualmente o município de Campo Verde está constituído por 02 (dois) distritos: Sede e Coronel Ponce. 
O distrito de paz de Coronel Ponce foi criado pela Resolução no 814 em 08 de outubro de 1.920, anteriormente toponimizado Capim Branco e pertencia ao município de Cuiabá.

Com base nas pesquisas socioeconômicas do Anuário Estatístico de Mato Grosso - 2009, os principais produtos agrícolas do município de Campo Verde foram: algodão, arroz, banana, cana-de-açúcar, feijão, mandioca, milho e soja. O volume da produção agrícola foi superior a 991.419 toneladas. Os principais rebanhos foram: bovino, eqüino, ovino e suíno. Os rebanhos, nessa época, perfaziam um total de 159.517 cabeças.

A população residente, recenseada em 2007 e divulgada pelo Instituto Brasileiro de Geografia e Estatística (IBGE), foi de 25.924 habitantes, sendo que 20.244 encontravam-se na zona urbana e 5.680 na zona rural. A densidade demográfica atingiu o índice de 5,4 hab. $/ \mathrm{km}^{2}$ e a representatividade da população urbana foi superior a $78,1 \%$.

O município de Campo Verde localiza-se na mesorregião Sudeste Matogrossense e é um dos municípios que compõe a microrregião Primavera do Leste. Limita-se com os municípios de Chapada dos Guimarães, Cuiabá, Dom Aquino, Jaciara, Nova Brasilândia, Primavera do Leste, Poxoréu e Santo Antônio de Leverger.

A seguir, anexam-se as relações dos topônimos do município Campo Verde, registrados no mapa elaborado pela Fundação de Pesquisas Cândido Rondon (FCR), que integra o corpus desta pesquisa. Os topônimos estão antecedidos pelos seus respectivos acidentes físicos e acidentes antrópicos, também identificados como elementos físicos e elementos humanos de uma paisagem. 
4.4.2.1 Relação dos acidentes físicos do município de Campo Verde, de seus topônimos e taxionomias.

(continua)

\begin{tabular}{|c|c|c|c|}
\hline $\mathbf{N}^{0}$ & Acidente & Topônimo & Taxionomia \\
\hline 01 & cabeceira do & Buriti Comprido (N7, O7) & Fitotopônimo \\
\hline 02 & cabeceira do & Capão da Onça (R6, S6) & Fitotopônimo \\
\hline 03 & cabeceira do & Capão dos Porcos (Q6, R7) & Fitotopônimo \\
\hline 04 & cabeceira & Carambola (N7) & Fitotopônimo \\
\hline 05 & cabeceira do & Cascalho (C11 a D13) & Litotopônimo \\
\hline 06 & cabeceira dos & Compadres (Q8, R8) & Sociotopônimo \\
\hline 07 & cabeceira dos & Correios (S9, S10) & Sociotopônimo \\
\hline 08 & cabeceira do & Cupim Branco (I8 a I10) & Litotopônimo \\
\hline 09 & cabeceira & Formosa (E10 a I10) & Animotopônimo \\
\hline 10 & cabeceira & Granalta (H16 a J16) & Sociotopônimo \\
\hline 11 & cabeceira & Grande (P7) & Dimensiotopônimo \\
\hline 12 & cabeceira do & Jangada $(18, \mathrm{H} 9)$ & Ergotopônimo \\
\hline 13 & cabeceira & Ladinha (A20, B19) & Antropotopônimo \\
\hline 14 & cabeceira & Taturana (G15 a J15) & Zootopônimo \\
\hline 15 & cabeceira & Varjaria (N7) & Geomorfotopônimo \\
\hline 16 & cabeceira dos & Veados (P5, P6) & Zootopônimo \\
\hline 17 & córrego & Água Limpa (T2, T3) & Hidrotopônimo \\
\hline 18 & córrego & Areia (D10, D11) & Litotopônimo \\
\hline 19 & córrego & Aricá (V2 a T1) & Fitotopônimo \\
\hline 20 & córrego & Aricazinho (T2, T3) & Fitotopônimo \\
\hline 21 & córrego & Bacia $(010,011)$ & Hidrotopônimo \\
\hline 22 & córrego & Bahia (O4 a M5) & Corotopônimo \\
\hline 23 & córrego & Balisa (D25 a E23) & Ergotopônimo \\
\hline 24 & córrego & Barro Branco $(03, \mathrm{P3})$ & Litotopônimo \\
\hline 25 & córrego & Barro Preto (F19 a G21) & Litotopônimo \\
\hline 26 & córrego do & Bento (L5, L6) & Antropotopônimo \\
\hline 27 & córrego & Bela Vista (O10, P10) & Animotopônimo \\
\hline 28 & córrego & Boa Esperança (S8, T8, T9) & Animotopônimo \\
\hline 29 & córrego & Buriti (S10, S11) & Fitotopônimo \\
\hline
\end{tabular}


(continuação)

\begin{tabular}{|c|c|c|c|}
\hline $\mathbf{N}^{\mathbf{0}}$ & Acidente & Topônimo & Taxionomia \\
\hline 30 & córrego do & Buritizal (R10, R11) & Fitotopônimo \\
\hline 31 & córrego & Café (M11 a J14) & Fitotopônimo \\
\hline 32 & córrego & Cajazeiro (M5, M6) & Fitotopônimo \\
\hline 33 & córrego & Canjica (S2, T1) & Ergotopônimo \\
\hline 34 & córrego & Capão Comprido (V3 a T4) & Fitotopônimo \\
\hline 35 & córrego & Capão do Coração $(\mathrm{R} 7, \mathrm{R} 8, \mathrm{~S} 8)$ & Fitotopônimo \\
\hline 36 & córrego & Capão Grande (G21) & Fitotopônimo \\
\hline 37 & córrego & Capim Branco (P12, Q12) & Fitotopônimo \\
\hline 38 & córrego & Capitão Agostim (O13 a J16) & Axiotopônimo \\
\hline 39 & córrego & Cedro (Q9 a Q11) & Fitotopônimo \\
\hline 40 & córrego & Chita (P8 a M7) & Ergotopônimo \\
\hline 41 & córrego & Cupim (O15 a L20) & Litotopônimo \\
\hline 42 & córrego & Cupim Branco (I10 a I12) & Litotopônimo \\
\hline 43 & córrego & Curral Velho (Q13) & Ergotopônimo \\
\hline 44 & córrego & Galheiro (D15 a L22) & Zootopônimo \\
\hline 45 & córrego & Gariroba (C24 a G21) & Fitotopônimo \\
\hline 46 & córrego & Jacu (G16) & Zootopônimo \\
\hline 47 & córrego & Jacuba (D16 a J17) & Ergotopônimo \\
\hline 48 & córrego & Lagoa Comprida (A19, B19) & Hidrotopônimo \\
\hline 49 & córrego & Lajes (P9 a J10) & Litotopônimo \\
\hline 50 & córrego & Mambeca (E13 a I12) & Fitotopônimo \\
\hline 51 & córrego & Maricá (A19) & Fitotopônimo \\
\hline 52 & córrego & Morcego (P23) & Zootopônimo \\
\hline 53 & córrego & Mosquito (G20, F20) & Zootopônimo \\
\hline 54 & córrego & Mutum (D26, D27) & Zootopônimo \\
\hline 55 & córrego da & Onça $(E 26, F 27)$ & Zootopônimo \\
\hline 56 & córrego & Passa Três (D16 a J17) & Dirrematotopônimo \\
\hline 57 & córrego dos & Peixes (G7 a G9) & Zootopônimo \\
\hline 58 & córrego & Piraputanga (X6 a S13) & Zootopônimo \\
\hline 59 & córrego & Pocinho (S9, S10) & Hidrotopônimo \\
\hline 60 & córrego & Poço Azul (S8, T9) & Hidrotopônimo \\
\hline
\end{tabular}


(continuação)

\begin{tabular}{|c|c|c|c|}
\hline $\mathbf{N}^{\circ}$ & Acidente & Topônimo & Taxionomia \\
\hline 61 & córrego & Ponte Alta (M5 a J4) & Hodotopônimo \\
\hline 62 & córrego & Ponte Falsa (R3 a O2) & Hodotopônimo \\
\hline 63 & córrego & Pontinha (Q9, R9) & Hodotopônimo \\
\hline 64 & córrego do & Porco (T2, U2) & Zootopônimo \\
\hline 65 & córrego & Porrete (G19, F19, F20) & Ergotopônimo \\
\hline 66 & córrego & Potreiro (S2, T2) & Ergotopônimo \\
\hline 67 & córrego & Presidente (014, P14) & Sociotopônimo \\
\hline 68 & córrego & Pulador (N6, N7) & Hidrotopônimo \\
\hline 69 & córrego & Pulador (P11, O12) & Hidrotopônimo \\
\hline 70 & córrego & Quarta Cabeceira (Z5) & Numerotopônimo \\
\hline 71 & córrego & Quebra Litro (D22, E21) & Dirrematotopônimo \\
\hline 72 & córrego & Retiro (F19) & Sociotopônimo \\
\hline 73 & córrego & Roncador (O13 a R13) & Hidrotopônimo \\
\hline 74 & córrego & Segredo (E17) & Sociotopônimo \\
\hline 75 & córrego & Varjão (L5, L6) & Geomorfotopônimo \\
\hline 76 & córrego & Várzea (H25 a L24) & Geomorfotopônimo \\
\hline 77 & córrego & Veado (D22, D23) & Zootopônimo \\
\hline 78 & lagoa & Formosa (G9) & Animotopônimo \\
\hline 79 & morro da & Cruz (P12) & Hierotopônimo \\
\hline 80 & morro & Rapadura (Q12) & Ergotopônimo \\
\hline 81 & ribeirão & Chimbica (G25 a F27) & Ergotopônimo \\
\hline 82 & ribeirão & Claro (A21, B21) & Cromotopônimo \\
\hline 83 & rio dos & Bois (P4 a O7) & Zootopônimo \\
\hline 84 & rio da & Casca (R3 a O2) & Fitotopônimo \\
\hline 85 & rio & Cumbuco (A25 a D27) & Zootopônimo \\
\hline 86 & rio & Jangada (I8 a G6) & Ergotopônimo \\
\hline 87 & rio & Manso (Z2 a H12) & Animotopônimo \\
\hline 88 & rio das & Mortes (Z4 a L24) & Sociotopônimo \\
\hline 89 & rio & Roncador (C10 a B16) & Hidrotopônimo \\
\hline 90 & rio & São Lourenço (S8 a S13) & Hagiotopônimo \\
\hline 91 & serra & Dourada $(15,16 . \mathrm{J} 6)$ & Cromotopônimo \\
\hline
\end{tabular}


(conclusão)

\begin{tabular}{c|l|l|l}
\hline $\mathbf{N}^{\mathbf{0}}$ & \multicolumn{1}{|c}{ Acidente } & \multicolumn{1}{c}{ Topônimo } & \multicolumn{1}{c}{ Taxionomia } \\
\hline 92 & serra do & Finca-Faca (A18 a A24) & Dirrematotopônimo \\
93 & serra & São Lourenço (S4, R5, Q5) & Hagiotopônimo \\
\hline
\end{tabular}

Fonte dos dados: Mapa da Fundação de Pesquisas Cândido Rondon (FCR), 1990 - escala 1:100.000.

\subsubsection{Relação dos acidentes humanos do município de Campo Verde, de seus topônimos e taxionomias.}

\begin{tabular}{l|l|ll}
\hline $\mathbf{N}^{\mathbf{0}}$ & \multicolumn{1}{|c}{ Acidente } & \multicolumn{1}{c}{ Topônimo } & \multicolumn{1}{c}{ Taxionomia } \\
\hline 01 & cidade de & Campo Verde (P8, Q8) & Fitotopônimo \\
02 & distrito & Coronel Ponce (Q12) & Historiotopônimo \\
03 & localidade & Limeira (I8) & Fitotopônimo \\
\hline
\end{tabular}

Fonte dos dados: Mapa da Fundação de Pesquisas Cândido Rondon (FCR), 1990 - escala 1:100.000. 


\subsubsection{Características gerais do município de Primavera do Leste}

O município de Primavera do Leste obteve sua autonomia políticoadministrativa em 1986, ao ser desmembrado dos municípios de Barra do Garças, Cuiabá e Poxoréu. A cidade de Primavera do Leste localiza-se no entroncamento das rodovias BR - 070 e MT - 130.

O município de Primavera do Leste possui $5.472 \mathrm{~km}^{2}$ de extensão territorial, dados do Anuário Estatístico de Mato Grosso - 2009, publicado pela SEPLAN - MT. A altitude na cidade de Primavera do Leste é de 500 metros acima do nível do mar.

O topônimo Primavera do Leste possui estrutura composta, formado por substantivo comum + conectivo $[\mathrm{de}+\mathrm{o}]+$ substantivo comum. Nos estudos toponímicos é classificado, taxionomicamente, como meteorotopônimo.

O estabelecimento de famílias, que praticavam as lides com a terra, iniciou-se na década de sessenta do século passado. O começo do aglomerado urbano foi em 1979. A cidade de Primavera do Leste é, portanto, uma cidade planejada o que possibilita bastante um crescimento urbano controlado, e propicia também, maior aproveitamento de investimentos em toda extensão do município.

Pode-se dizer que o município de Primavera do Leste é um dos municípios mato-grossenses que retrata bons resultados proporcionados pela expansão da fronteira agrícola na região Centro-Oeste do Brasil, preconizada pelos governos federal e estadual a partir da segunda metade do século XX. Há no município de Primavera do Leste grande influência nas atividades agropecuárias de brasileiros vindos do sul do Brasil.

O distrito Primavera foi criado pela Lei no 4.351 em 25 de dezembro de 1981, subordinado administrativamente ao município de Poxoréu. O distrito foi elevado à categoria de município pela Lei $n^{0} 5.014$ de 13 de maio de 1986, com a denominação de Primavera do Leste.

Atualmente o município de Primavera do Leste está constituído apenas pelo distrito Sede. 
Com base nas pesquisas socioeconômicas do Anuário Estatístico de Mato Grosso - 2009, os principais produtos agrícolas do município de Primavera do Leste foram: algodão, arroz, feijão, mandioca, milho e soja. O volume da produção agrícola foi superior a 632.961 toneladas. Os principais rebanhos foram: bovino, eqüino, ovino e suíno. Os rebanhos, nessa época, perfaziam um total de 101.495 cabeças.

A população residente, recenseada em 2007 e divulgada pelo Instituto Brasileiro de Geografia e Estatística (IBGE), foi de 44.729 habitantes, sendo que 41.123 encontravam-se na zona urbana e 3.606 na zona rural. A densidade demográfica atingiu o índice de 8,2 hab. $/ \mathrm{km}^{2}$ e a representatividade da população urbana foi superior a $91,9 \%$.

O município de Primavera do Leste localiza-se na mesorregião Sudeste Matogrossense e é um dos municípios que compõe a microrregião Primavera do Leste. Limita-se com os municípios de Campo Verde, Dom Aquino, Nova Brasilândia, Paranatinga, Planalto da Serra, Poxoréu e Santo Antônio do Leste.

A seguir, anexam-se as relações dos topônimos do município Primavera do Leste, registrados no mapa elaborado pela Fundação de Pesquisas Cândido Rondon (FCR), que integra o corpus desta pesquisa. Os topônimos estão antecedidos pelos seus respectivos acidentes físicos e acidentes antrópicos, também identificados como elementos físicos e elementos humanos de uma paisagem. 
4.4.3.1 Relação dos acidentes físicos do município de Primavera do Leste, de seus topônimos e taxionomias.

(continua)

\begin{tabular}{|c|c|c|c|}
\hline $\mathrm{N}^{\mathbf{0}}$ & Acidente & Topônimo & Taxionomia \\
\hline 01 & cabeceira dos & Bois (AD8 a AB8) & Zootopônimo \\
\hline 02 & cabeceira do & Coité (AD10, AC9) & Fitotopônimo \\
\hline 03 & cabeceira & Escura (AD6 a AB6) & Cromotopônimo \\
\hline 04 & cabeceira do & Galheiro (F14, G14) & Zootopônimo \\
\hline 05 & cabeceira da & Lagoa Seca (AE12 a V11) & Hidrotopônimo \\
\hline 06 & cabeceira do & Marlo (AE12) & Antropotopônimo \\
\hline 07 & cabeceira dos & Perdidos (AD6 a AA8) & Animotopônimo \\
\hline 08 & cabeceira das & Traíras (AD9 a AA7) & Zootopônimo \\
\hline 09 & córrego da & Arara (E18) & Zootopônimo \\
\hline 10 & córrego & Cacimba Velha (E15, D16) & Hidrotopônimo \\
\hline 11 & córrego do & Coi (S13 a U15) & Fitotopônimo \\
\hline 12 & córrego & Corrente (M12 a Q12) / PRIM & Hidrotopônimo \\
\hline 13 & córrego & Fundo (J12 a R14) & Dimensiotopônimo \\
\hline 14 & córrego & Furnas (N17 a O20) & Geomorfotopônimo \\
\hline 15 & córrego & Garimpinho (I1 a L2) & Sociotopônimo \\
\hline 16 & córrego & Garimpinho (F12 a D11) & Sociotopônimo \\
\hline 17 & córrego & Guariba (J1) & Zootopônimo \\
\hline 18 & córrego & Matula (D18 a B18) & Ergotopônimo \\
\hline 19 & córrego & Mutum (P4, P5) & Zootopônimo \\
\hline 20 & córrego da & Onça (Q4, R5) & Zootopônimo \\
\hline 21 & córrego da & Onça (T12) & Zootopônimo \\
\hline 22 & córrego das & Pedras (F15 a F18) & Litotopônimo \\
\hline 23 & córrego do & Sapé (AF12, AF13) & Fitotopônimo \\
\hline 24 & córrego & Suspiro (H4 a Q10) & Somatotopônimo \\
\hline 25 & córrego & Várzea (V2 a T4) & Geomorfotopônimo \\
\hline 26 & córrego & Verde (J15 a Q19) & Cromotopônimo \\
\hline 27 & córrego & Xavante (E13 a B19) & Etnotopônimo \\
\hline 28 & ribeirão & Chimbica (S3 a U10) & Ergotopônimo \\
\hline 29 & ribeirão dos & Perdidos (AA8 a V10) & Animotopônimo \\
\hline
\end{tabular}


(conclusão)

\begin{tabular}{l|l|l|l}
\hline $\mathbf{N}^{\mathbf{0}}$ & \multicolumn{1}{c|}{ Acidente } & \multicolumn{1}{c}{ Topônimo } & \multicolumn{1}{c}{ Taxionomia } \\
\hline 30 & ribeirão & Quinze de Agosto (C22 a G15) & Cronotopônimo \\
31 & ribeirão & Sangradourozinho (Ae16 a T20) & Hidrotopônimo \\
32 & ribeirão do & Sapé (AF13 a U14) & Fitotopônimo \\
33 & rio & Coluene (F3 a B22) & S/C \\
34 & rio & Cumbuco (A1 a S18) & Zootopônimo \\
35 & rio das & Mortes (V2 a S20) & Sociotopônimo \\
36 & rio & Suspiro (G12 a S18) & Somatotopônimo \\
37 & serra do & Finca-Faca (J1, J2) & Dirrematotopônimo \\
38 & serra & Grande (AE7, AD8) & Dimensiotopônimo \\
\hline
\end{tabular}

Fonte dos dados: Mapa da Fundação de Pesquisas Cândido Rondon (FCR), 1990 - escala 1:100.000.

\subsubsection{Relação dos acidentes humanos do município de Primavera do Leste, de seus topônimos e taxionomias.}

\begin{tabular}{l|l|l|l}
\hline $\mathbf{N}^{\mathbf{0}}$ & \multicolumn{1}{c|}{ Acidente } & \multicolumn{1}{c}{ Topônimo } & \multicolumn{1}{c}{ Taxionomia } \\
\hline 01 & cidade de & Primavera do Leste (AD9) & Meteorotopônimo \\
02 & vila & União (S4) & Sociotopônimo \\
\hline
\end{tabular}

Fonte dos dados: Mapa da Fundação de Pesquisas Cândido Rondon (FCR), 1990 - escala 1:100.000. 


\subsubsection{Análise toponímica da microrregião Primavera do Leste}

Contém, a segunda parte deste capítulo, maior detalhamento das características dos topônimos registrados nos mapas e nas cartas topográficas que compõem o corpus desta pesquisa. Divide-se em vários subitens, para que se tenha melhor visualização das características toponímicas peculiares à microrregião Primavera do Leste. Constam todos acidentes físicos e acidentes antrópicos toponimizados e registrados dentro dos limites dos municípios que a compõem: Campo Verde e Primavera do Leste.

Na microrregião Primavera do Leste as cartas topográficas foram utilizadas em caráter complementar. Os topônimos foram coletados diretamente dos mapas. As cartas topográficas estão na mesma escala dos mapas e serviram para ratificar os topônimos por município.

São 136 (cento e trinta e seis) topônimos de acidentes físicos e de acidentes antrópicos na microrregião Primavera do Leste. O município de Campo Verde possui 96 (noventa e seis) topônimos e Primavera do Leste 40 (quarenta).

Inserem-se, nesta segunda parte, vários gráficos e 01 (uma) tabela. Constam, na tabela, todas taxionomias toponímicas por microrregião e por município, em ordem decrescente de quantidade. As taxionomias estão em números absolutos e especificam a quantidade de topônimos por taxionomia e por município. As taxionomias que não possuem topônimos, na microrregião Primavera do Leste são: astrotopônimos, cardinotopônimos, ecotopônimos, igneotopônimos, mitotopônimos, morfotopônimos e poliotopônimos. Essas taxionomias estão especificadas com traços. Constam também vários gráficos que permitem visualizar a proporção que o município ocupa no total da taxionomia.

Mantém-se, nesta tabela, a praticidade em uniformizar a apresentação dos dados. Os municípios foram colocados na parte superior da tabela, ou seja, na vertical e as taxionomias foram inseridas horizontalmente. Nas quadrículas estão relacionados, em valores absolutos, os totais de cada uma das taxionomias 
correspondentes a cada município. Desse modo, é fácil observar a quantidade de topônimos por município e por taxionomia, bem como, o total das taxionomias na microrregião Primavera do Leste. Estabeleceu-se, com relação a esta tabela, que a seqüência dos municípios obedece à ordem alfabética e que as taxionomias são inseridas por ordem decrescente de quantidades de topônimos.

A tabela e os gráficos, já mencionados, possibilitam a visualização da composição quantitativa dos topônimos por município e a representatividade das taxionomias em cada município. Eles também são importantes como elementos que subsidiam a análise das características toponímicas da microrregião Primavera do Leste, como um todo.

Quando, porém, a quantidade de topônimos for igual ou inferior a 04 (quatro) topônimos na taxionomia, se estiverem em partes iguais ou mais de 01 (um) topônimo em um só município não se apresenta gráfico para a taxionomia.

Na microrregião Primavera do Leste não consta acidente com dupla denominação.

Na microrregião Primavera do Leste constam 136 (cento e trinta e seis) acidentes toponimizados. Deste total, 131 (cento e trinta e um) topônimos dão nomes a: cabeceiras, córregos, lagoa, morros, ribeirões, rios e serras. São 05 (cinco) acidentes antrópicos toponimizados: distrito, localidade, vila, municípios / cidades.

A microrregião Primavera do Leste é a que possui menor quantidade de topônimos na mesorregião Sudeste Mato-grossense.

Seus topônimos estão classificados em 22 (vinte e duas) taxionomias. Com base nessas classificações, as 10 (dez) taxionomias, na microrregião Primavera do Leste, em valores absolutos, que mais agrupam topônimos são: 25 (vinte e cinco) fitotopônimos, 23 (vinte e três) zootopônimos, 13 (treze) ergotopônimos, 13 (treze) hidrotopônimos, 11 (onze) sociotopônimos, 09 (nove) litotopônimos, 07 (sete) animotopônimos, 05 (cinco) geomorfotopônimos, 05 (cinco) cromotopônimos e 04 (quatro) dirrematotopônimos. 
Para a elaboração da tabela que encontra-se a seguir, foi realizado, inicialmente, o levantamento dos topônimos nos mapas, em seguida, o levantamento foi ratificado nas cartas topográficas para a confirmação dos topônimos, ou melhor, dos sintagmas toponímicos em cada município. Os topônimos foram classificados taxionomicamente e agrupados, primeiro, por etimologia indígena, e depois, as taxionomias foram agrupadas por natureza física e por natureza antrópica.

$\mathrm{Na}$ seqüência analisam-se, inicialmente, as taxionomias de natureza física, com 08 (oito) taxionomias na microrregião Primavera do Leste, num total de 83 (oitenta e três) ocorrências e, em seguida, as de natureza antrópica com 15 (quinze) taxionomias, num total de 52 (cinqüenta e duas) ocorrências. Consta ainda 01 (um) topônimo não classificado taxionomicamente que está com a sigla S/C. 
Tabela 2 - Topônimos da microrregião Primavera do Leste por municípios e taxionomias

\begin{tabular}{|c|c|c|c|c|}
\hline \multirow[b]{2}{*}{$\mathrm{N}^{\mathrm{O}}$} & \multirow[b]{2}{*}{ Taxionomias } & \multicolumn{2}{|c|}{ municípios } & \multirow{2}{*}{$\begin{array}{c}\text { microrregião } \\
\text { Primavera do Leste }\end{array}$} \\
\hline & & $\begin{array}{l}\text { Campo } \\
\text { Verde }\end{array}$ & $\begin{array}{c}\text { Primavera do } \\
\text { Leste }\end{array}$ & \\
\hline & Total & 96 & 40 & 136 \\
\hline 01 & Fitotopônimos & 21 & 4 & 25 \\
\hline 02 & Zootopônimos & 14 & 9 & 23 \\
\hline 03 & Ergotopônimos & 11 & 2 & 13 \\
\hline 04 & Hidrotopônimos & 9 & 4 & 13 \\
\hline 05 & Sociotopônimos & 7 & 4 & 11 \\
\hline 06 & Litotopônimos & 8 & 1 & 9 \\
\hline 07 & Animotopônimos & 5 & 2 & 7 \\
\hline 08 & Geomorfotopônimos & 3 & 2 & 5 \\
\hline 09 & Cromotopônimos & 2 & 2 & 4 \\
\hline 10 & Dirrematotopônimos & 3 & 1 & 4 \\
\hline 11 & Dimensiotopônimos & 1 & 2 & 3 \\
\hline 12 & Antropotopônimos & 2 & 1 & 3 \\
\hline 13 & Hodotopônimos & 3 & - & 3 \\
\hline 14 & Somatotopônimos & - & 2 & 2 \\
\hline 15 & Hagiotopônimos & 2 & - & 2 \\
\hline 16 & Axiotopônimos & 1 & - & 1 \\
\hline 17 & Meteorotopônimo & - & 1 & 1 \\
\hline 18 & Corotopônimo & 1 & - & 1 \\
\hline 19 & Cronotopônimo & - & 1 & 1 \\
\hline 20 & Etnotopônimo & - & 1 & 1 \\
\hline 21 & Hierotopônimo & 1 & - & 1 \\
\hline 22 & Numerotopônimo & 1 & - & 1 \\
\hline 23 & Historiotopônimo & 1 & - & 1 \\
\hline 24 & Astrotopônimo & - & - & - \\
\hline 25 & Cardinotopônimo & - & - & - \\
\hline 26 & Ecotopônimo & - & - & - \\
\hline
\end{tabular}


(conclusão)

\begin{tabular}{l|l|c|c|c}
\hline \multirow{2}{*}{$N^{0}$} & \multirow{2}{*}{ Taxionomias } & \multicolumn{2}{|c|}{ municípios } & \multicolumn{2}{c}{$\begin{array}{c}\text { microrregião } \\
\text { Primavera do Leste }\end{array}$} \\
\cline { 3 - 4 } & $\begin{array}{c}\text { Campo } \\
\text { Verde }\end{array}$ & $\begin{array}{c}\text { Primavera do } \\
\text { Leste }\end{array}$ & \\
\hline 27 & Igneotopônimo & - & - & - \\
28 & Mitotopônimo & - & - & - \\
29 & Morfotopônimo & - & - & - \\
30 & Poliotopônimo & - & - & 1 \\
31 & S/C & - & 1 & \\
\hline
\end{tabular}




\section{Taxionomias de natureza física da microrregião Primavera do Leste}

\section{Fitotopônimos}

A taxionomia fitotopônimos é a que apresenta maior quantidade de topônimos na microrregião Primavera do Leste. As unidades lexicais que se referem aos elementos da flora, quando usadas para dar nomes a acidentes físicos e a acidentes antrópicos, são denominadas fitotopônimos nos estudos toponímicos. Classificamse, nesta taxionomia, 25 (vinte e cinco) topônimos.

São 21 (vinte e um) fitotopônimos no município de Campo Verde e 04 (quatro) em Primavera do Leste. É a taxionomia que mais denomina acidentes no município de Campo Verde. Apresenta-se a seguir o gráfico desta taxionomia com os respectivos percentuais por município. (GRÁFICO 21).

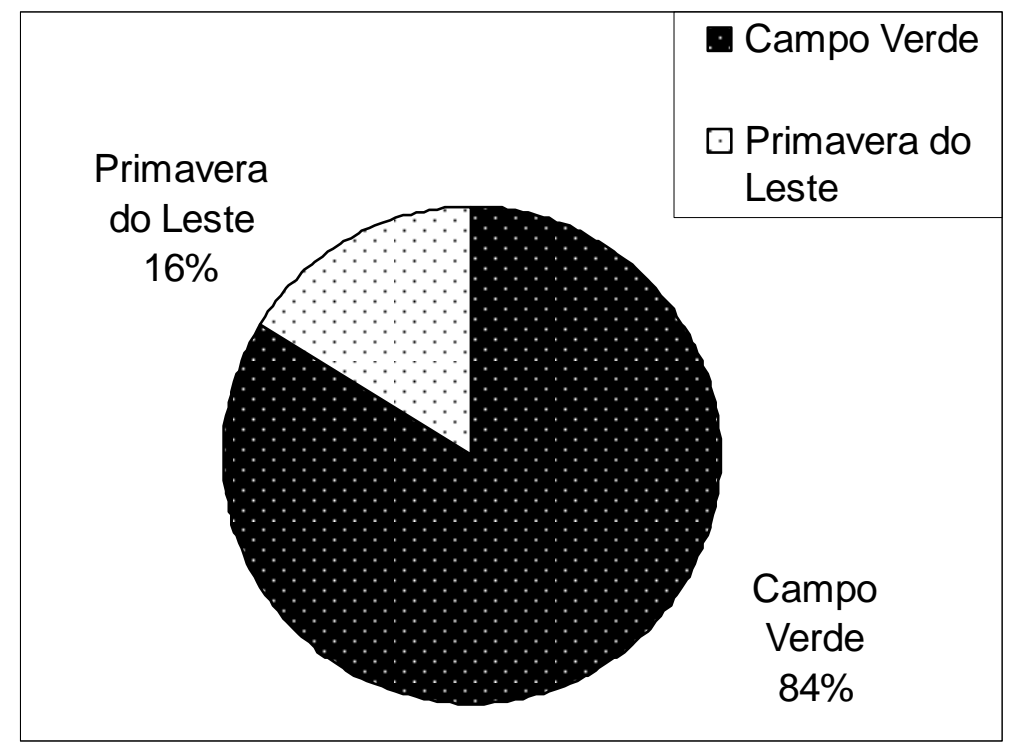

GRÁFICO 21 - Total dos fitotopônimos da microrregião Primavera do Leste.

Na microrregião Primavera do Leste, ao observar a relação dos fitotopônimos, pode-se constatar que dois tipos de formações vegetais se destacam. A ocorrência de fitotopônimos que se referem apenas um a exemplar da espécie, por exemplo: córrego Buriti, córrego Café, córrego Guariroba, córrego Cedro, cabeceira do Coité, 
etc. corresponde $72,0 \%$ do total dos fitotopônimos. A ocorrência de fitotopônimos que indicam formações vegetais variadas, como por exemplo: córrego Capão Comprido, córrego Capão Grande, município de Campo Verde, etc. corresponde a 24,0\%. A representatividade dos fitotopônimos que se referem a mais de um exemplo da espécie ou coletivo é de 4,0\%: córrego do Buritizal.

Registram-se, na microrregião Primavera do Leste, 16 (dezesseis) fitotopônimos tupis, 01 (um) fitotopônimo bororo e 08 (oito) portugueses.

O município de Campo Verde possui 13 (treze) fitotopônimos tupis e 08 (oito) portugueses. O município de Primavera do Leste possui 01 (um) fitotopônimo bororo e 03 (três) tupis.

Verifica-se, do total de 25 (vinte e cinco) fitotopônimos registrados na microrregião Primavera do Leste, que 64,0\% equivalente a 16 (dezesseis) ocorrências em número absoluto, são de etimologia tupi e 4,0\% equivalente a 01 (uma) ocorrência é de etimologia bororo.

Considera-se, nesta pesquisa, que os fitotopônimos tupis, quanto à estrutura, subdividem-se em simples e híbridos. São 07 (sete) de estrutura simples e 09 (nove) de estrutura híbrida. Eles denominam 16 (dezesseis) acidentes físicos. Os 02 (dois) municípios da microrregião Primavera do Leste possuem fitotopônimos tupis.

O fitotopônimo Coité dá nome a 01 (uma) cabeceira e o fitotopônimo Sapé denomina 01 (um) córrego e 01 (um) ribeirão no município de Primavera do Leste. Os fitotopônimos Buriti, Gariroba (forma variante de guariroba), Mambeca (forma variante de membeca) e Maricá nomeiam 04 (quatro) córregos em Campo Verde.

Os fitotopônimos tupis de estrutura híbrida Buriti Comprido, Capão Comprido, Capão Grande e Capim Branco, formados por unidade lexical tupi + unidade lexical portuguesa, nomeiam 01 (uma) cabeceira e 03 (três) córregos. Os fitotopônimos Capão da Onça, Capão do Coração e Capão dos Porcos, formados por unidade lexical tupi + conectivo da língua portuguesa + unidade lexical da língua portuguesa, denominam 02 (duas) cabeceiras e 01 (um) córrego. Deve-se observar que o fitotopônimo Capão dos Porcos apresenta desinência de plural -s no conectivo e no substantivo comum porco. O fitotopônimo Buritizal, formado pela unidade lexical 
buriti + sufixo -(z)al, indicador de grande quantidade da língua portuguesa, singulariza 01 (um) córrego. O fitotopônimo Cajazeiro, formado pela unidade lexical tupi cajá + sufixo -(z)eiro, indicador daquele que produz da língua portuguesa, dá nome a 01 (um) córrego. Todos localizam-se no município de Campo Verde.

O fitotopônimo bororo Coi nomeia 01 (um) córrego em Primavera do Leste e, considera-se neste estudo, que ele possui estrutura simples.

A unidade lexical bororo está registrada na macroestrutura da Enciclopédia Bororo: "Kói - * kó2, mau cheiro; í, árvore [árvore cuja entrecasca desprende mau cheiro]. Vard. de árvore." Albisetti; Venturelli (1962, p. 742).

Considera-se, nesta pesquisa, que os fitotopônimos portugueses da microrregião Primavera do Leste, quanto à estrutura, subdividem-se em simples e composto. São 07 (sete) fitotopônimos de estrutura simples e 01 (um) fitotopônimo de estrutura composta. Eles denominam 06 (seis) acidentes físicos e 02 (dois) acidentes antrópicos. Apenas o município de Campo Verde possui fitotopônimos portugueses.

O fitotopônimo Limeira, formado pela unidade lexical lima + sufixo -eira, já referido, denomina 01 (uma) localidade e o fitotopônimo Aricazinho, formado pela unidade lexical aricá + sufixo -(z)inho, indicador de diminutivo, nomeia 01 (um) córrego em Campo Verde.

Os fitotopônimos simples e não derivados Aricá, Café, Carambola, Casca e Cedro nomeiam 01 (uma) cabeceira, 01 (um) rio e 03 (três) córregos no município de Campo Verde. O córrego Aricá estabelece divisa entre os municípios de Campo Verde e Santo Antônio de Leverger. O rio da Casca estabelece divisa entre os municípios de Campo Verde e Chapada dos Guimarães.

O fitotopônimo composto Campo Verde, formado por substantivo comum + adjetivo, dá nome a 01 (um) município mato-grossense.

Ocorre produtividade toponímica, nesta taxionomia, na microrregião Primavera do Leste. O fitotopônimo Sapé singulariza 01 (um) córrego e 01 (um) ribeirão no município de Primavera do Leste. Pode-se ainda considerar os 
fitotopônimos Aricá e Aricazinho que dão nomes a 02 (dois) córregos em Campo Verde.

O fitotopônimo Buriti e os fitotopônimos Buriti Comprido e Buritizal nomeiam 02 (dois) córregos e 01 (uma) cabeceira em Campo Verde. Pode-se mencionar ainda, dentre os fitotopônimos tupis híbridos, aqueles cuja primeira unidade lexical é capão + unidade(s) lexical(is) portuguesas: Capão Comprido, Capão da Onça, Capão do Coração, Capão dos Porcos e Capão Grande que denominam 02 (duas) cabeceiras e 03 (três) córregos em Campo Verde.

Os fitotopônimos correspondem a 18,4\% do total de topônimos da microrregião Primavera do Leste.

\section{Zootopônimos}

Na microrregião Primavera do Leste a taxionomia zootopônimos é a segunda taxionomia de natureza física que mais apresenta topônimos. São 23 (vinte e três) ocorrências nesta taxionomia. Nos estudos toponímicos as unidades lexicais que se referem aos animais em geral, quando utilizadas para dar nomes a acidentes físicos e a acidentes antrópicos, são denominadas zootopônimos.

O município de Campo Verde possui 14 (quatorze) zootopônimos e Primavera do Leste possui 09 (nove). É a taxionomia que mais denomina acidentes no município de Primavera do Leste. Apresenta-se a seguir o gráfico desta taxionomia com os respectivos percentuais por município. (GRÁFICO 22). 


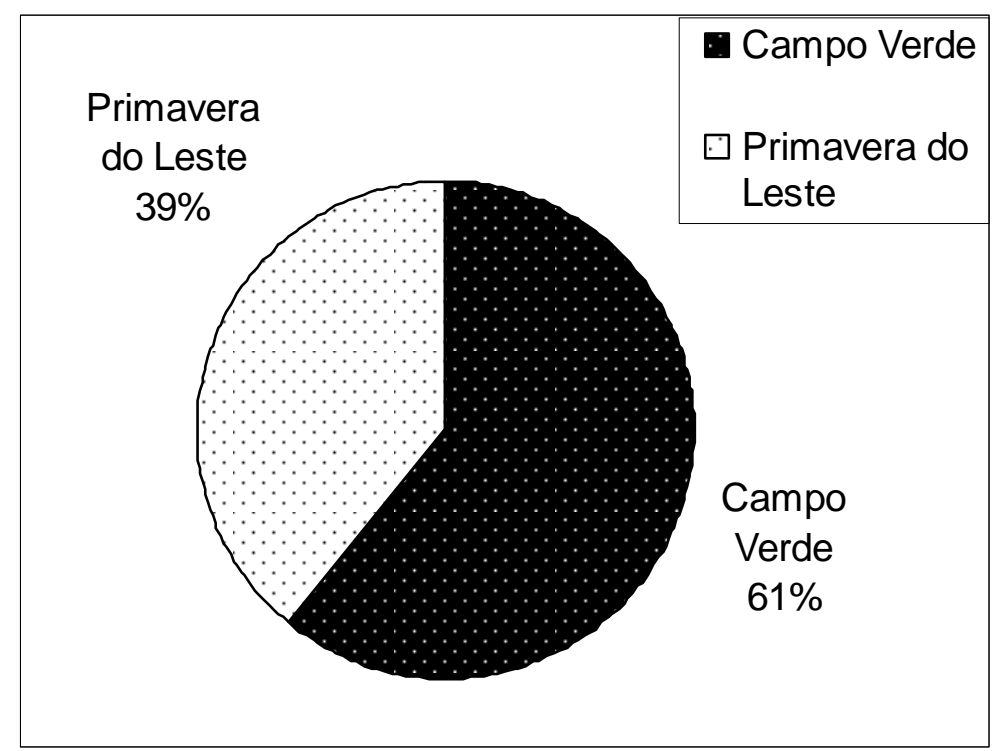

GRÁFICO 22 - Total dos zootopônimos da microrregião Primavera do Leste.

Dentre os zootopônimos registrados nos mapas e nas cartas topográficas do corpus desta pesquisa, nos municípios que compõem a microrregião Primavera do Leste, 03 (três) zootopônimos se referem a animais domésticos: Bois, Cumbuco e Porco. Os demais zootopônimos se referem a animais silvestres, tais como: Arara, Jacu, Mosquito, etc.

Quanto à divisão dos zootopônimos por habitat das espécies, pode-se constatar que 56,5\% dos zootopônimos especificam animais que vivem em terra firme: cabeceira dos Bois, córrego Galheiro, córrego Guariba, córrego da Onça, córrego do Porco e córrego Veado; 26,1\% designam animais que vivem, principalmente no ar: córrego da Arara, córrego Jacu, córrego Morcego, córrego Mosquito, córrego Mutum e 13,0\% se referem a animais que vivem na água: córrego dos Peixes, córrego Piraputanga e cabeceira das Traíras. O zootopônimo Taturana: cabeceira Taturana não foi classificado em nenhum habitat por não se adequar, com especificidade, em um deles e representa $4,4 \%$ do total dos zootopônimos.

Nesta taxionomia constatam-se 10 (dez) zootopônimos tupis e 13 (treze) portugueses.

O município de Campo Verde possui 05 (cinco) zootopônimos tupis e 09 (nove) portugueses. O município de Primavera do Leste possui 05 (cinco) zootopônimos tupis e 04 (quatro) portugueses. 
Considera-se, nesta pesquisa, que os zootopônimos tupis da microrregião Primavera do Leste, quanto à estrutura, subdividem-se em simples e híbridos. São 09 (nove) zootopônimos de estrutura simples e 01 (um) zootopônimo de estrutura híbrida. Eles denominam 10 (dez) acidentes físicos. Os 02 (dois) municípios da microrregião Primavera do Leste possuem zootopônimos tupis.

O zootopônimo tupi híbrido Traíras, formado pela unidade lexical tupi traíra + desinência -s de plural da língua portuguesa, nomeia 01 (uma) cabeceira no município de Primavera do Leste.

Considera-se, nesta pesquisa, que os zootopônimos tupis Arara, Cumbuco, Guariba, Jacu, Piraputanga e Taturana possuem estrutura simples. Os zootopônimos Arara e Guariba denominam 02 (dois) córregos no município de Primavera do Leste. Os zootopônimos Jacu, Piraputanga e Taturana dão nomes a 01 (uma) cabeceira e a 02 (dois) córregos em Campo Verde. O córrego Piraputanga estabelece divisa entre os municípios de Campo Verde e Jaciara, por isso consta nas relações de topônimos dos dois municípios.

O zootopônimo Mutum denomina 01 (um) córrego que estabelece divisa entre os municípios de Campo Verde e Primavera do Leste, por isso consta nas relações de topônimos de ambos. O zootopônimo tupi Cumbuco dá nome a 01 (um) rio que estabelece divisa entre Campo Verde e Primavera do Leste, por isso consta nas relações de topônimos dos dois municípios.

Considera-se, nesta pesquisa, que os zootopônimos portugueses da microrregião Primavera do Leste possuem estrutura simples. Eles denominam 13 (treze) acidentes físicos. Os 02 (dois) municípios da microrregião Primavera do Leste possuem zootopônimos portugueses.

Os zootopônimos simples e não derivados Morcego, Porco e Veado denominam 03 (três) córregos em Campo Verde. O córrego Morcego estabelece divisa entre os municípios de Campo Verde e Dom Aquino, por isso consta nas relações de topônimos dos dois municípios. O zootopônimo Onça denomina 01 (um) córrego no município de Primavera do Leste e 01 (um) córrego que estabelece divisa 
entre os municípios de Campo Verde e Primavera do Leste, por isso consta nas relações de topônimos dos dois municípios.

O zootopônimo simples Bois apresenta desinência -s de plural e nomeia 01 (uma) cabeceira no município de Primavera do Leste. Os zootopônimos Bois, Peixes e Veados também apresentam desinência de plural -s e denominam 01 (uma) cabeceira, 01 (um) córrego e 01 (um) rio em Campo Verde.

O zootopônimo Galheiro, formado pela unidade lexical galho + sufixo -eiro, indicador de quantidade, dá nome a 01 (um) córrego em Campo Verde e a 01 (uma) cabeceira em Primavera do Leste. O zootopônimo Mosquito, formado pela unidade lexical mosca + sufixo -(qu)ito, formador de diminutivo, dá nome a 01 (um) córrego em Campo Verde.

Pode-se constatar produtividade toponímica, nesta taxionomia, na microrregião Primavera do Leste. O zootopônimo Bois nomeia 01 (uma) cabeceira no município de Primavera do Leste e 01 (um) rio em Campo Verde. O zootopônimo Galheiro dá nome a 01 (uma) cabeceira em Primavera do Leste e a 01 (um) córrego em Campo Verde.

O zootopônimo Onça denomina 02 (dois) córregos, sendo que um deles estabelece divisa entre os municípios de Campo Verde e Primavera do Leste e, por isso, consta nas relações de topônimos dos dois municípios. Pode-se ainda considerar os zootopônimos Veado que nomeia 01 (um) córrego e o zootopônimo Veados que denomina 01 (uma) cabeceira, ambos em Campo Verde. Os zootopônimos Cumbuco e Mutum constam nas relações de topônimos dos dois municípios, mas não são considerados produtivos porque estabelecem divisas entre os municípios de Campo Verde e Primavera do Leste.

Os zootopônimos correspondem a 16,9\% do total de topônimos da microrregião Primavera do Leste. 


\section{Hidrotopônimos}

Os hidrotopônimos, na microrregião Primavera do Leste, perfazem 13 (treze) ocorrências. As unidades lexicais que se referem a acidentes hidrográficos em geral, quando utilizadas para denominar acidentes físicos e acidentes antrópicos, são classificadas nos estudos toponímicos, como hidrotopônimos.

São 09 (nove) hidrotopônimos em Campo Verde e 04 (quatro) no município de Primavera do Leste. Apresenta-se a seguir o gráfico desta taxionomia com os respectivos percentuais por município (GRÁFICO 23).

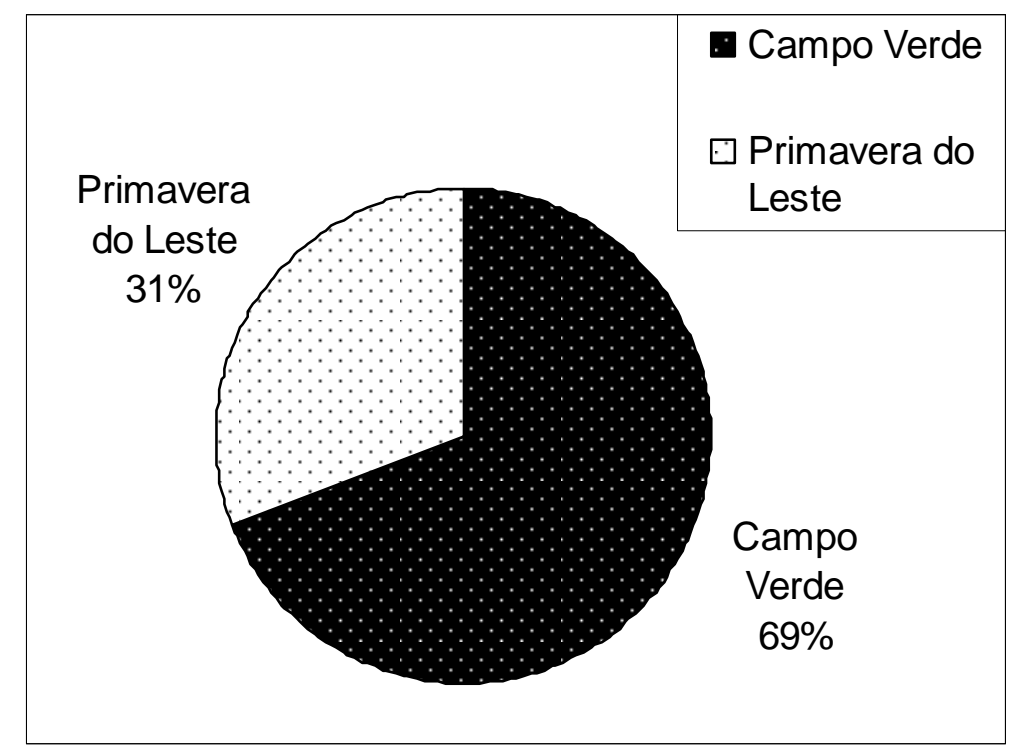

GRÁFICO 23 - Total dos hidrotopônimos da microrregião Primavera do Leste.

Registram-se, na microrregião Primavera, 01 (um) hidrotopônimo africano e 12 (doze) portugueses.

O hidrotopônimo africano Cacimba Velha possui estrutura híbrida, formado por unidade lexical africana + unidade lexical portuguesa e denomina 01 (um) córrego em Primavera do Leste.

Considera-se, nesta pesquisa, que os hidrotopônimos portugueses da microrregião Primavera do Leste, quanto à estrutura, subdividem-se em simples e compostos. São 08 (oito) hidrotopônimos de estrutura simples e 04 (quatro) hidrotopônimos de estrutura composta. Eles denominam 12 (doze) acidentes físicos. 
Os 02 (dois) municípios da microrregião Primavera do Leste possuem hidrotopônimos portugueses.

Os hidrotopônimos compostos Água Limpa, Lagoa Comprida e Poço Azul, formados por substantivo comum + adjetivo, nomeiam 03 (três) córregos no município de Campo Verde. O hidrotopônimo Lagoa Seca, formado por substantivo comum + adjetivo, dá nome a 01 (uma) cabeceira em Primavera do Leste.

Os hidrotopônimos de estrutura simples subdividem-se em simples com derivação e simples sem derivação. O hidrotopônimo Sangradourozinho apresenta dupla sufixação, formado pela unidade lexical sangrar + sufixo -douro, indicador de local onde se passa a ação + sufixo -(z)inho, indicador de diminutivo, dá nome a 01 (um) ribeirão no município de Primavera do Leste. O ribeirão Sangradourozinho estabelece divisa entre os municípios de Primavera do Leste e Poxoréu, por isso consta nas relações de topônimos dos dois municípios.

O hidrotopônimo Pulador, formado pela unidade lexical pular + sufixo -dor, indicador do agente de ação, dá nome a 02 (dois) córregos no município de Campo Verde. O hidrotopônimo Roncador, formado pela unidade lexical roncar + sufixo -dor, já mencionado, denomina 01 (um) córrego que estabelece divisa entre os municípios de Campo Verde e Dom Aquino, por isso consta nas relações de topônimos dos dois municípios e 01 (um) rio que estabelece divisa entre os municípios de Campo Verde e Chapada dos Guimarães.

O hidrotopônimo Pocinho, formado pela unidade lexical poço + sufixo -inho, já mencionado, nomeia 01 (um) córrego no município de Campo Verde. O hidrotopônimo Corrente, formado pela unidade lexical correr + sufixo -ente, indicador de lugar onde ocorre, dá nome a 01 (um) córrego em Primavera do Leste.

O hidrotopônimo Bacia possui estrutura simples, não derivada e denomina 01 (um) córrego no município de Campo Verde.

Ocorre produtividade toponímica, nesta taxionomia, na microrregião Primavera do Leste. O hidrotopônimo Pulador dá nome a 02 (dois) córregos e o hidrotopônimo Roncador denomina 01 (um) rio e 01 (um) córrego, no município de Campo Verde. 
Pode-se observar que na microrregião Primavera do Leste ocorre toponimização do acidente físico. As unidades lexicais que em um sintagma toponímico exercem a função de termo genérico, isto é, designam o acidente físico propriamente dito e antecedem o termo específico, nesta taxionomia tornam-se topônimos de acidentes físicos. A unidade lexical lagoa, no município de Campo Verde, nomeia 01 (um) acidente físico: córrego Lagoa Comprida e em Primavera do Leste denomina 01 (uma) cabeceira: cabeceira da Lagoa Seca. A unidade lexical bacia, toponimiza 01 (um) acidente físico em Campo Verde: córrego Bacia.

Os hidrotopônimos correspondem a $9,6 \%$ do total de topônimos da microrregião Primavera do Leste.

\section{Litotopônimos}

Registram-se 09 (nove) litotopônimos nos mapas dos municípios que compõem a microrregião Primavera do Leste. As unidades lexicais que se referem aos minerais em geral e à constituição do solo, quando usadas para dar nomes a acidentes físicos e a acidentes antrópicos, são classificadas nos estudos toponímicos como litotopônimos.

O município de Campo Verde possui 08 (oito) litotopônimos e Primavera do Leste possui 01 (um). Apresenta-se a seguir o gráfico desta taxionomia com os respectivos percentuais por município (GRÁFICO 24). 


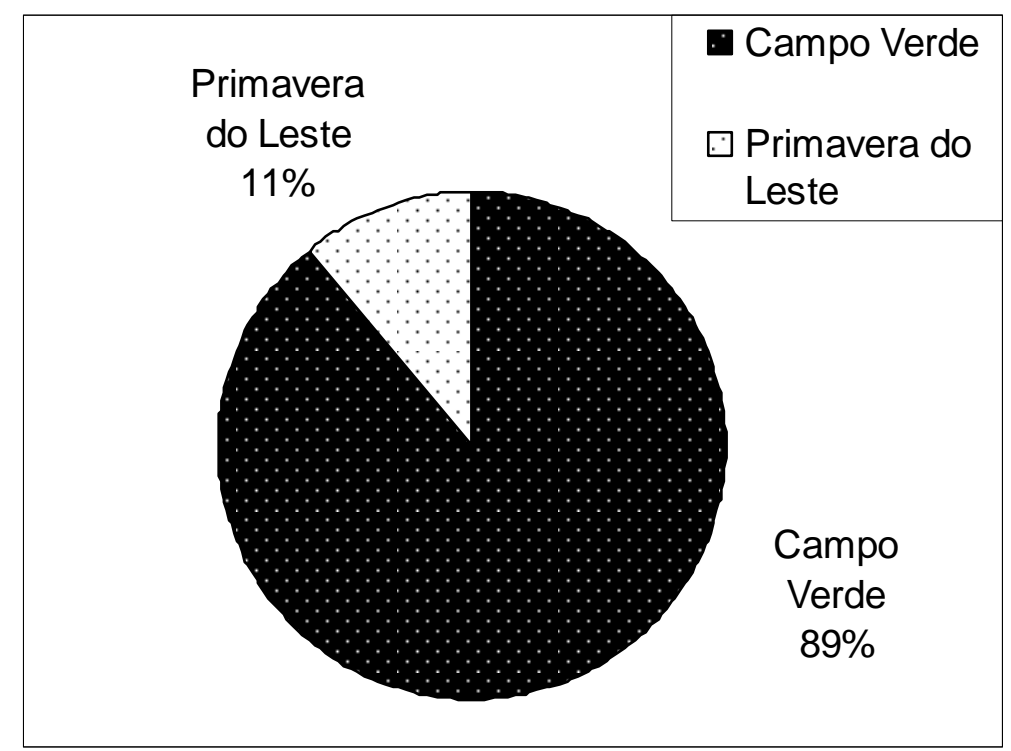

GRÁFICO 24 - Total dos litotopônimos da microrregião Primavera do Leste.

Na microrregião Primavera do Leste, registram-se 03 (três) litotopônimos tupis e 06 (seis) portugueses.

Considera-se, nesta pesquisa, que os litotopônimos tupis da microrregião Primavera do Leste, quanto à estrutura, subdividem-se em simples e híbrido. 0 litotopônimo Cupim possui estrutura simples e nomeia 01 (um) córrego que estabelece divisa entre os municípios de Campo Verde e Dom Aquino, por isso consta nas relações de topônimos dos dois municípios. O litotopônimo tupi de estrutura híbrida Cupim Branco, formado por unidade lexical tupi + unidade lexical portuguesa, dá nome a 01 (um) córrego e a 01 (uma) cabeceira. Todos localizam-se no município de Campo Verde.

Considera-se, nesta pesquisa, que os litotopônimos portugueses da microrregião Primavera do Leste, quanto à estrutura, subdividem-se em simples e compostos. São 04 (quatro) litotopônimos de estrutura simples e 02 (dois) litotopônimos de estrutura composta. Eles denominam 06 (seis) acidentes físicos. Os 02 (dois) municípios da microrregião Primavera do Leste possuem litotopônimos portugueses.

Os litotopônimos compostos Barro Branco e Barro Preto, formados por substantivo comum + adjetivo, nomeiam 02 (dois) córregos no município de Campo Verde. 
O litotopônimo simples e sem derivação Areia nomeia 01 (um) córrego no município de Campo Verde. O litotopônimo Cascalho, formado pela unidade lexical casca + sufixo -alho, indicador de diminutivo, denomina 01 (uma) cabeceira em Campo Verde. Os litotopônimos Lajes e Pedras apresentam desinência -s de plural. O primeiro denomina 01 (um) córrego em Campo Verde e o segundo dá nome a 01 (um) córrego em Primavera do Leste.

Ocorre produtividade toponímica, nesta taxionomia, na microrregião Primavera do Leste. O litotopônimo Cupim Branco nomeia 01 (um) córrego e 01 (uma) cabeceira no município de Campo Verde. Pode-se acrescentar o litotopônimo Cupim que dá nome a 01 (um) córrego em Campo Verde. Se considerar apenas a primeira unidade lexical, pode-se acrescentar ainda os litotopônimos Barro Branco e Barro Preto, cada um nomeia 01 (um) córrego em Campo Verde.

Os litotopônimos correspondem a 6,6\% do total de topônimos da microrregião Primavera do Leste.

\section{Geomorfotopônimos}

Os geomorfotopônimos, na microrregião Primavera do Leste, perfazem 05 (cinco) ocorrências. As unidades lexicais que se referem às formações geomorfológicas em geral, quando usadas para dar nomes a acidentes físicos e a acidentes antrópicos, recebem nos estudos toponímicos, a denominação de geomorfotopônimos.

Registram-se 03 (três) geomorfotopônimos no município de Campo Verde e 02 (dois) em Primavera do Leste. Apresenta-se a seguir o gráfico desta taxionomia com os respectivos percentuais por município (GRÁFICO 25). 


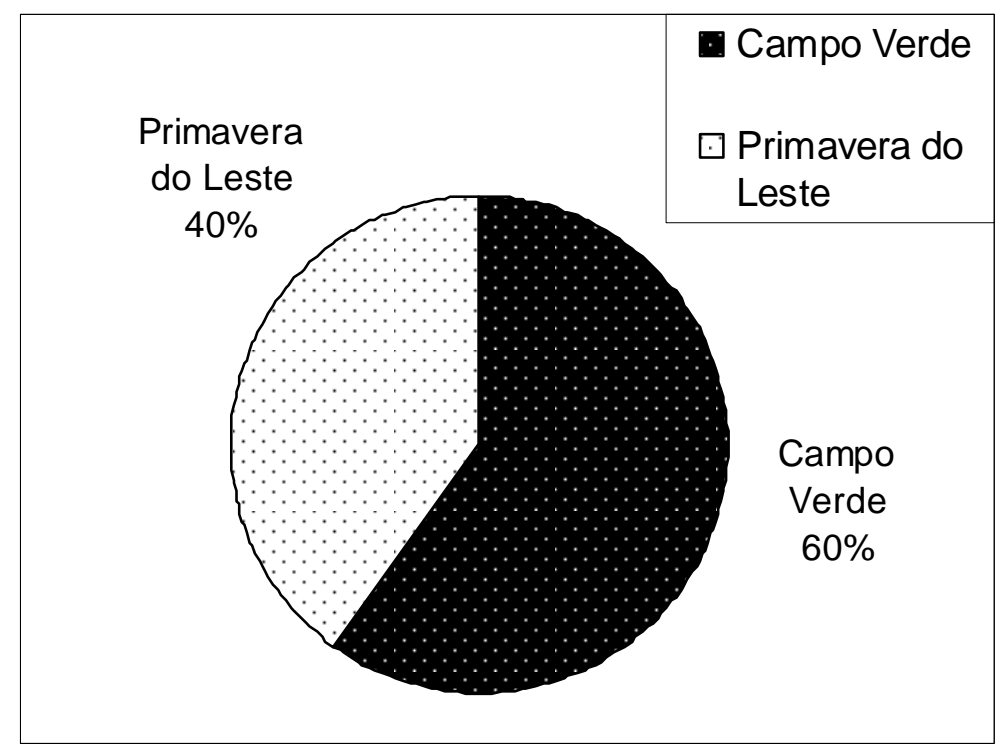

GRÁFICO 25 - Total dos geomorfotopônimos da microrregião Primavera do Leste.

Os geomorfotopônimos, na microrregião Primavera do Leste, são portugueses.

Considera-se, nesta pesquisa, que os geomorfotopônimos portugueses da microrregião Primavera do Leste possuem estrutura simples. Eles denominam 05 (cinco) acidentes físicos. Os 02 (dois) municípios da microrregião Primavera do Leste possuem geomorfotopônimos portugueses.

O geomorfotopônimo de estrutura simples e não derivado Furnas apresenta desinência -s de plural e dá nome a 01 (um) córrego em Primavera do Leste. O geomorfotopônimo Várzea dá nome a 01 (um) córrego que estabelece divisa entre os municípios de Campo Verde e Primavera do Leste, por isso consta nas relações de topônimos dos dois municípios.

O geomorfotopônimo Varjão, formado pela unidade lexical varja (forma variante de várzea) + sufixo -ão, indicador de aumentativo, denomina 01 (um) córrego. O geomorfotopônimo Varjaria, formado pela unidade lexical varja + sufixo aria, indicador de quantidade, porção, nomeia 01 (uma) cabeceira, ambos no município de Campo Verde.

Os geomorfotopônimos correspondem a 3,7\% do total de topônimos da microrregião Primavera do Leste. 


\section{Cromotopônimos}

$\mathrm{Na}$ microrregião Primavera do Leste registram-se 04 (quatro) cromotopônimos. As unidades lexicais que se referem à escala cromática em geral, quando usadas para dar nomes a acidentes físicos e a acidentes antrópicos, são classificadas, nos estudos toponímicos, como cromotopônimos.

O município de Campo Verde possui 02 (dois) cromotopônimos e Primavera do Leste também possui 02 (dois). Devido à pouca quantidade e à igualdade dos valores não se apresenta gráfico para esta taxionomia.

Os cromotopônimos da microrregião Primavera do Leste são portugueses e possuem estrutura simples.

O cromotopônimo Dourada é o único, dentre os simples, que apresenta derivação, formado pela unidade lexical dourar + sufixo -ada, indicador de um tanto, denomina 01 (uma) serra no município de Campo Verde. O cromotopônimo Claro dá nome a 01 (um) ribeirão em Campo Verde. Os cromotopônimos Escura e Verde nomeiam, respectivamente, 01 (uma) cabeceira e 01 (um) córrego em Primavera do Leste.

Os cromotopônimos correspondem a 3,0\% do total de topônimos da microrregião Primavera do Leste.

\section{Dimensiotopônimos}

Registram-se 03 (três) dimensiotopônimos na microrregião Primavera do Leste. As unidades lexicais que se referem a características dimensionais, tais como: extensão, largura, grossura, altura, etc., quando utilizadas para dar nomes a acidentes físicos e a acidentes antrópicos, recebem nos estudos toponímicos a denominação de dimensiotopônimos. 
O município de Campo Verde possui 01 (um) dimensiotopônimo e Primavera do Leste possui 02 (dois). Devido à baixa ocorrência de dimensiotopônimos não se apresenta gráfico para esta taxionomia.

Na microrregião Primavera do Leste os dimensiotopônimos são portugueses e possuem estrutura simples.

O dimensiotopônimo Fundo dá nome a 01 (um) córrego no município de Primavera do Leste e o dimensiotopônimo Grande denomina 01 (uma) cabeceira em Campo Verde e 01 (uma) serra em Primavera do Leste. A serra Grande estabelece divisa entre os municípios de Primavera do Leste e Poxoréu, por isso consta nas relações de topônimos dos dois municípios.

Pode-se observar, apesar da pequena quantidade de dimensiotopônimos, que esta taxionomia apresenta uma característica que lhe é bastante peculiar: alto índice de produtividade toponímica. Deve-se ressaltar também que os dimensiotopônimos, na sua grande maioria, possuem estrutura simples e não derivada. As unidades lexicais que toponimizam acidentes físicos ou antrópicos nesta taxionomia, em geral, pertencem à classe dos adjetivos.

Pode-se, portanto, constatar que apesar da baixa ocorrência de dimensiotopônimos na microrregião Primavera do Leste, o dimensiotopônimo Grande apresenta produtividade toponímica porque dá nome a 01 (uma) cabeceira em Campo Verde e a 01 (uma) serra em Primavera do Leste.

Os dimensiotopônimos correspondem a 2,2\% do total de topônimos da microrregião Primavera do Leste.

\section{Meteorotopônimo}

Na microrregião Primavera do Leste registra-se 01 (um) meteorotopônimo. Nos estudos toponímicos, classificam-se como meteorotopônimos as unidades 
lexicais que se referem aos fenômenos atmosféricos, quando usadas para denominar acidentes físicos e acidentes antrópicos.

O meteorotopônimo Primavera do Leste é português e possui estrutura composta, portanto, não se apresenta gráfico para esta taxionomia.

O meteorotopônimo Primavera do Leste, formado por substantivo comum + conectivo + substantivo comum, toponimiza 01 (um) município mato-grossense e também dá nome a microrregião Primavera do Leste.

O meteorotopônimo corresponde a $0,7 \%$ do total de topônimos da microrregião Primavera do Leste. 


\section{Taxionomias de natureza antrópica da microrregião Primavera do Leste}

\section{Ergotopônimos}

A taxionomia de natureza antrópica que mais se destaca, em números absolutos, na microrregião Primavera do Leste, é a taxionomia ergotopônimos com 13 (treze) ocorrências. As unidades lexicais que se referem aos elementos de cultura material, quando usadas para dar nomes a acidentes físicos e a acidentes antrópicos, são denominadas ergotopônimos nos estudos toponímicos.

O município de Campo Verde possui 11 (onze) ergotopônimos e Primavera do Leste possui 02 (dois). Apresenta-se a seguir o gráfico desta taxionomia com os respectivos percentuais por município (GRÁFICO 26).

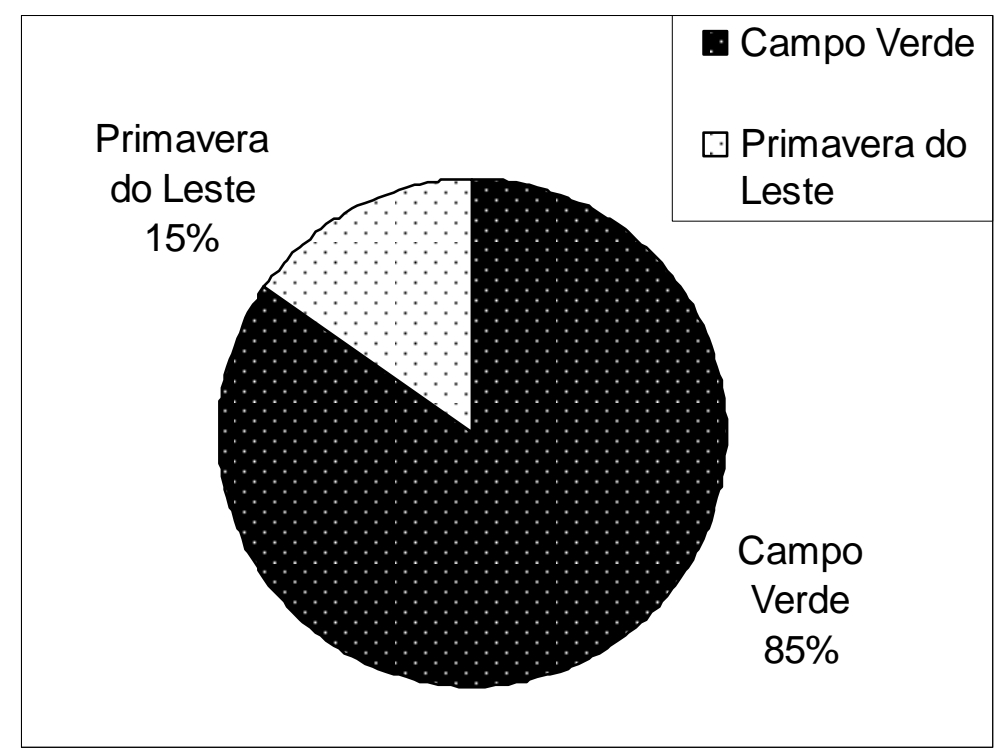

GRÁFICO 26 - Total dos ergotopônimos da microrregião Primavera do Leste.

Na microrregião Primavera do Leste registram-se 01 (um) ergotopônimo tupi, 03 (três) africanos e 09 (nove) portugueses.

Considera-se, neste estudo, que o ergotopônimo tupi possui estrutura simples. O ergotopônimo Jacuba dá nome a 01 (um) córrego em Campo Verde.

Considera-se, também, que os ergotopônimos africanos Canjica e Chimbica possuem estrutura simples. O ergotopônimo Canjica nomeia 01 (um) córrego que 
estabelece divisa entre os municípios de Campo Verde e Santo Antônio de Leverger. O ergotopônimo Chimbica denomina 01 (um) ribeirão que estabelece divisa entre os municípios Campo Verde e Primavera do Leste, por isso consta nas relações de topônimos dos dois municípios. Nos mapas dos municípios de Campo Verde e Primavera do Leste e na carta topográfica, o ergotopônimo Chimbica está grafado (com ch) e não ximbica (com x), forma dicionarizada.

Considera-se, nesta pesquisa, que os ergotopônimos portugueses da microrregião Primavera do Leste, quanto à estrutura, subdividem-se em simples e composto. São 08 (oito) ergotopônimos de estrutura simples e 01 (um) ergotopônimo composto. Eles nominam 09 (nove) acidentes físicos. Os 02 (dois) municípios da microrregião Primavera do Leste possuem ergotopônimos portugueses.

Os ergotopônimos simples e não derivados Balisa, Chita e Matula nomeiam 01 (um) córrego em Primavera do Leste e 02 (dois) córregos em Campo Verde. Deve-se registrar que no mapa e na carta topográfica, o ergotopônimo Balisa está grafado (com s) e não baliza (com z), forma dicionarizada. O ergotopônimo Jangada nomina 01 (uma) cabeceira e 01 (um) rio em Campo Verde. O ergotopônimo Jangada ao dar nome a cabeceira apresenta a elipse do substantivo comum rio porque o conectivo que antecede o substantivo feminino jangada está no masculino: cabeceira do Jangada. Com isso é possível inferir que o topônimo seria Rio Jangada. No mapa e na carta topográfica essa cabeceira é uma das cabeceiras que formam o rio Jangada.

O ergotopônimo Rapadura apresenta dupla sufixação, formado pela unidade lexical rapar + sufixo -ado, indicador de qualidade ou estado + sufixo -ura, indicador de ação ou resultado da ação, dá nome a 01 (um) morro. O ergotopônimo Potreiro, formado pela unidade lexical potro + sufixo -eiro, indicador de lugar continente, denomina 01 (um) córrego $\mathrm{O}$ ergotopônimo Porrete, formado pela unidade lexical porra + sufixo -ete, indicador de diminuição, nomeia 01 (um) córrego. Todos localizam-se em Campo Verde.

O ergotopônimo de estrutura composta Curral Velho, formado por substantivo comum + adjetivo, denomina 01 (um) córrego em Campo Verde. 
O ergotopônimo Jangada apresenta produtividade toponímica na microrregião Primavera do Leste. Dá nome a 01 (uma) cabeceira e a 01 (um) rio em Campo Verde.

Os ergotopônimos correspondem a 9,6\% do total de topônimos de microrregião Primavera do Leste.

\section{Sociotopônimos}

Na microrregião Primavera do Leste registram-se 11 (onze) sociotopônimos. As unidades lexicais que se referem às atividades sociais ou laborais, quando usadas para dar nomes a acidentes físicos e a acidentes antrópicos, são denominadas sociotopônimos nos estudos toponímicos.

O município de Campo Verde possui 07 (sete) sociotopônimos e Primavera do Leste 04 (quatro). Apresenta-se a seguir o gráfico desta taxionomia com os respectivos percentuais por município (GRÁFICO 27).

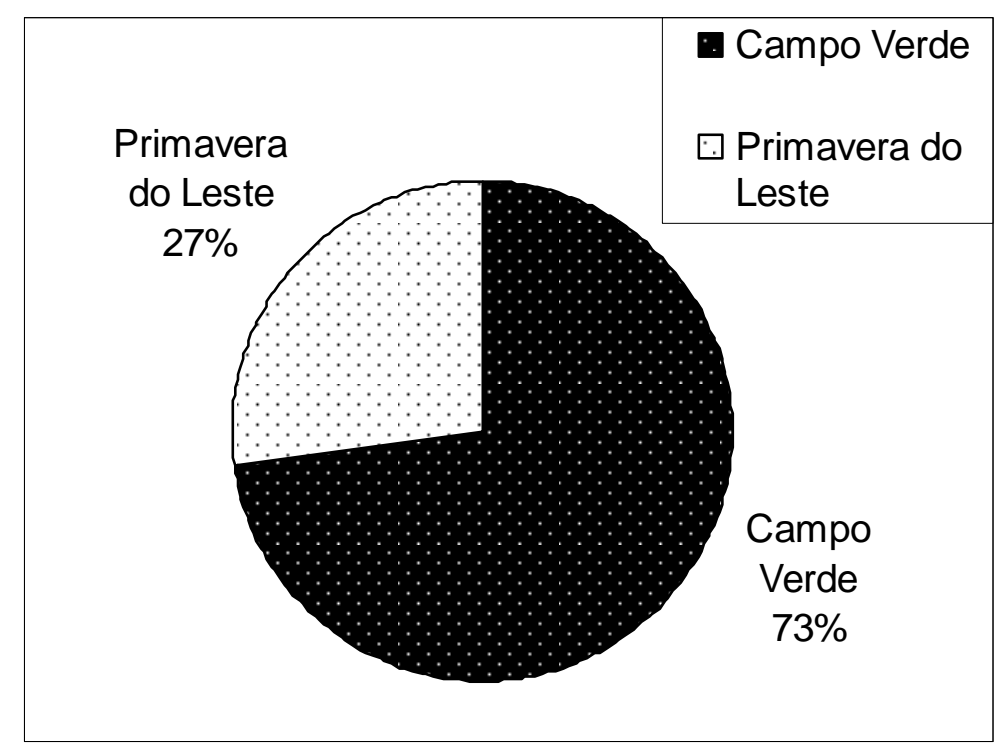

GRÁFICO 27 - Total dos sociotopônimos da microrregião Primavera do Leste.

Os sociotopônimos da microrregião Primavera do Leste são portugueses. 
Considera-se, nesta pesquisa, que os sociotopônimos portugueses da microrregião Primavera do Leste possuem estrutura simples. Eles denominam 10 (dez) acidentes físicos e 01 (um) acidente antrópico. Os 02 (dois) municípios da microrregião Primavera do Leste possuem sociotopônimos portugueses.

Os sociotopônimos de estrutura simples e não derivada Granalta, Presidente, Retiro e Segredo dão nomes a 01 (uma) cabeceira e a 03 (três) córregos no município de Campo Verde. O córrego Presidente estabelece divisa entre os municípios de Campo Verde e Dom Aquino, por isso consta nas relações de topônimos dos dois municípios. O sociotopônimo União denomina 01 (uma) vila em Primavera do Leste. Os sociotopônimos Compadres e Correios apresentam desinência -s de plural e denominam 02 (duas) cabeceiras em Campo Verde.

O sociotopônimo Mortes apresenta desinência de plural -s e dá nome a 01 (um) rio que estabelece divisa entre o município de Campo Verde e Dom Aquino, e também, estabelece divisa do município de Primavera do Leste com os municípios de Poxoréu e de Novo São Joaquim, portanto, consta nas relações de topônimos dos municípios Campo Verde, Dom Aquino, Primavera do Leste e Poxoréu.

O sociotopônimo Garimpinho, formado pela unidade lexical garimpo + sufixo inho, indicador de diminutivo, dá nome a 02 (dois) córregos no município de Primavera do Leste.

O sociotopônimo Garimpinho é o único sociotopônimo da microrregião Primavera do Leste que apresenta produtividade toponímica. O sociotopônimo Mortes consta na relação de topônimos dos dois municípios porque estabelece as divisas já mencionadas, portanto, não apresenta produtividade.

Os sociotopônimos correspondem a $8,1 \%$ do total de topônimos da microrregião Primavera do Leste.

\section{Animotopônimos}


Na microrregião Primavera do Leste registram-se 07 (sete) animotopônimos. As unidades lexicais que se referem à cultura espiritual, abrangendo a todos os produtos do psiquismo humano, quando usadas para dar nomes a acidentes físicos e a acidentes antrópicos, são denominadas animotopônimos nos estudos toponímicos.

O município de Campo Verde possui 05 (cinco) ocorrências e Primavera do Leste possui 02 (duas). Apresenta-se a seguir o gráfico desta taxionomia com os respectivos percentuais por município (GRÁFICO 28).

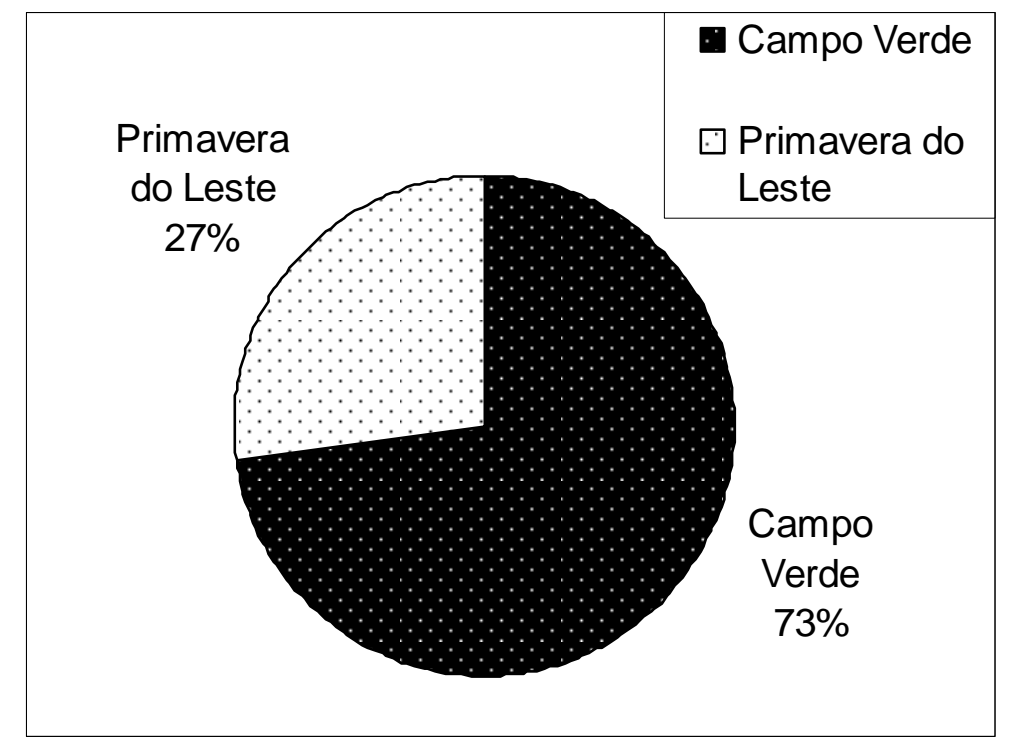

GRÁFICO 28 - Total dos animotopônimos da microrregião Primavera do Leste.

Os animotopônimos da microrregião Primavera do Leste são portugueses.

Considera-se, nesta pesquisa, que os animotopônimos portugueses da microrregião Primavera do Leste, quanto à estrutura, subdividem-se em simples e compostos. São 05 (cinco) animotopônimos de estrutura simples e 02 (dois) animotopônimos de estrutura composta. Eles denominam 07 (sete) acidentes físicos. Os 02 (dois) municípios da microrregião Primavera do Leste possuem animotopônimos portugueses.

O animotopônimo Bela Vista, formado por adjetivo + substantivo comum, dá nomes a 01 (um) córrego em Campo Verde. O animotopônimo composto Boa Esperança, formado por adjetivo + unidade lexical esperar + sufixo -ança, indicador de qualidade ou estado, nomeia a 01 (um) córrego em Campo Verde. 
O animotopônimo simples e não derivado Manso denomina 01 (um) rio no município de Campo Verde. O animotopônimo Formosa, formado pela unidade lexical forma + sufixo -osa, indicador de abundância, denomina 01 (uma) cabeceira e 01 (uma) lagoa em Campo Verde. O animotopônimo Perdidos, formado pela unidade lexical perder + sufixo -ido, indicador do resultado da ação, apresenta desinência -s de plural e nomeia 01 (uma) cabeceira e 01 (um) ribeirão no município de Primavera do Leste. Ambos estabelecem divisas entre os municípios de Primavera do Leste e Poxoréu, por isso constam nas relações de topônimos dos dois municípios.

Ocorre produtividade toponímica, nesta taxionomia, na microrregião Primavera do Leste. O animotopônimo Formosa dá nome a 01 (uma) cabeceira e a 01 (uma) lagoa no município de Campo Verde. O animotopônimo Perdidos denomina 01 (uma) cabeceira e 01 (um) ribeirão em Primavera do Leste.

Os animotopônimos correspondem a 5,2\% do total de topônimos da microrregião Primavera do Leste.

\section{Dirrematotopônimos}

As denominações de acidentes físicos e de acidentes antrópicos, constituídas por frases ou enunciados lingüísticos, recebem nos estudos toponímicos a denominação de dirrematotopônimos. Na microrregião Primavera do Leste registram-se 04 (quatro) dirrematotopônimos.

O município de Campo Verde possui 03 (três) dirrematotopônimos e Primavera do Leste possui 01 (um). Devido à pequena quantidade de dirrematotopônimos não se apresenta gráfico para esta taxionomia

Os dirrematotopônimos da microrregião Primavera do Leste são portugueses, possuem estrutura composta e apresentam as seguintes subdivisões:

a) dirrematotopônimos formados por verbo + substantivo: Finca-Faca e Quebra Litro; 
b) dirrematotopônimo formado por verbo + numeral cardinal: Passa Três.

O dirrematotopônimo Finca-Faca dá nome a 01 (uma) serra que encontra-se em áreas dos municípios de Campo Verde e Primavera do Leste, por isso consta nas relações de topônimos dos dois municípios, e também, estabelece divisa do município de Campo Verde com os municípios de Chapada dos Guimarães e Nova Brasilândia. Os dirrematotopônimos Passa Três e Quebra Litro nomeiam 02 (dois) córregos no município de Campo Verde.

Os dirrematotopônimos correspondem a 3,0\% do total de topônimos da microrregião Primavera do Leste.

\section{Antropotopônimos}

Na microrregião Primavera do Leste pode-se constatar a ocorrência de 03 (três) antropotopônimos. Os nomes próprios individuais, quando usados para dar nomes a acidentes físicos e a acidentes antrópicos, são denominados antropotopônimos nos estudos toponímicos.

São 02 (dois) antropotopônimos no município de Campo Verde e 01 (um) em Primavera do Leste. Devido à pequena quantidade de antropotopônimos, não se apresenta gráfico para esta taxionomia.

Os antropotopônimos da microrregião Primavera do Leste são portugueses e possuem estrutura simples.

O antropotopônimo Bento denomina 01 (um) córrego no município de Campo Verde.

O antropotopônimo Ladinha, hipocorístico de Geralda, nomeia 01 (uma) cabeceira, no município de Campo Verde.

O antropotopônimo Marlo dá nome a 01 (uma) cabeceira em Primavera do Leste. 
Os antropotopônimos correspondem a 2,2\% do total de topônimos da microrregião Primavera do Leste.

\section{Hodotopônimos}

Registram-se, na microrregião Primavera do Leste, 03 (três) hodotopônimos. As unidades lexicais que se referem às vias de comunicação rural ou urbana, quando utilizadas para dar nomes a acidentes físicos e a acidentes antrópicos, são classificadas nos estudos toponímicos como hodotopônimos.

O município de Campo Verde possui 03 (três) hodotopônimos, portanto, não se apresenta gráfico para esta taxionomia.

Os hodotopônimos da microrregião Primavera do Leste são portugueses e, quanto à estrutura, subdividem-se em compostos e simples.

Os hodotopônimos compostos Ponte Alta e Ponte Falsa, formados por substantivo + adjetivo, denominam 02 (dois) córregos. O córrego Ponte Alta estabelece divisa entre os municípios de Campo Verde e Chapada dos Guimarães. O hodotopônimo Pontinha, formado pela unidade lexical ponte + sufixo -inha, indicador de diminutivo, dá nome a 01 (um) córrego.

Ocorre produtividade toponímica na microrregião Primavera do Leste se considerar apenas a primeira unidade lexical dos hodotopônimos compostos Ponte Alta e Ponte Falsa, que nomeiam 02 (dois) córregos.

Os hodotopônimos correspondem a 2,2\% do total de topônimos da microrregião Primavera do Leste.

\section{Somatotopônimo}


As unidades lexicais que se referem à partes do corpo humano e do animal, quando usadas para denominar acidentes físicos e acidentes antrópicos, são denominadas somatotopônimos nos estudos toponímicos. $\mathrm{Na}$ microrregião Primavera do Leste registra-se 01 (um) somatotopônimo que dá nome a 02 (dois) acidentes físicos.

O município de Primavera do Leste possui o somatotopônimo, portanto não se apresenta gráfico para esta taxionomia.

O somatotopônimo da microrregião Primavera do Leste é português e possui estrutura simples.

O somatotopônimo Suspiro denomina 01 (um) córrego e 01 (um) rio. O rio Suspiro estabelece divisa do município de Primavera do Leste com o município de Novo São Joaquim.

Apesar da pequena quantidade de somatotopônimos, constata-se que ocorre produtividade toponímica, nesta taxionomia, na microrregião Primavera do Leste. O somatotopônimo Suspiro dá nome a 01 (um) córrego e a 01 (um) rio.

O somatotopônimo corresponde a 1,5\% do total de topônimos da microrregião Primavera do Leste.

\section{Hagiotopônimo}

Na microrregião Primavera do Leste registra-se 01 (um) hagiotopônimo que denomina 02 (dois) acidentes físicos. As unidades lexicais que se referem aos santos e santas da religião católico-romana, quando usadas para dar nomes a acidentes físicos e a acidentes antrópicos, são denominadas hagiotopônimos nos estudos toponímicos.

O município de Campo Verde registra o hagiotopônimo, portanto, não se apresenta gráfico para esta taxionomia. 
O hagiotopônimo da microrregião Primavera do Leste é português e possui estrutura composta.

O hagiotopônimo São Lourenço formado por adjetivo + substantivo próprio, dá nome a 01 (uma) serra e a 01 (um) rio que estabelece divisa entre os municípios de Campo Verde e Dom Aquino, por isso consta nas relações de topônimos dos dois municípios. Constata-se que, apesar da pequena quantidade de hagiotopônimo, ocorre produtividade toponímica nesta taxionomia.

O hagiotopônimo corresponde a 1,5\% do total de topônimos da microrregião Primavera do Leste.

\section{Axiotopônimo}

Nos mapas dos municípios da microrregião Primavera do Leste registra-se 01 (um) axiotopônimo. As unidades lexicais que se referem aos títulos e dignidade de que se fazem acompanhar os nomes próprios individuais, quando usadas para dar nomes a acidentes físicos e a acidentes antrópicos, são denominadas axiotopônimos nos estudos toponímicos.

O município de Campo Verde ocorre o registro de 01 (um) axiotopônimo, portanto, não se apresenta gráfico para esta taxionomia.

O axiotopônimo da microrregião Primavera do Leste é português e possui estrutura composta. O axiotopônimo Capitão Agostim, formado por substantivo comum + nome próprio de pessoa, dá nome a 01 (um) córrego.

O axiotopônimo corresponde a 0,7\% do total de topônimos da microrregião Primavera do Leste.

\section{Corotopônimo}


Na microrregião Primavera do Leste registra-se 01 (um) corotopônimo. As unidades lexicais que se referem a nomes de continentes, países, regiões, estados e cidades, quando usadas para dar nomes a acidentes físicos e a acidentes antrópicos, recebem nos estudos toponímicos a denominação de corotopônimos.

O município de Campo Verde registra 01 (um) corotopônimo, portanto, não se apresenta gráfico para esta taxionomia.

O corotopônimo da microrregião Primavera do Leste é português e possui estrutura simples. O corotopônimo Bahia nomeia 01 (um) córrego que estabelece divisa entre os municípios de Campo Verde e Chapada dos Guimarães.

O corotopônimo corresponde a $0,7 \%$ do total de topônimos da microrregião Primavera do Leste.

\section{Cronotopônimo}

A microrregião Primavera do Leste possui 01 (um) cronotopônimo. As unidades lexicais que encerram indicadores cronológicos, quando usadas para dar nomes a acidentes físicos e a acidentes antrópicos, são classificadas, nos estudos toponímicos, como cronotopônimos.

O município de Primavera do Leste registra 01 (um) cronotopônimo, portanto, não se apresenta gráfico para esta taxionomia.

O cronotopônimo Quinze de Agosto é português e possui estrutura composta. O cronotopônimo Quinze de Agosto, formado por numeral + preposição + substantivo comum, dá nome a 01 (um) ribeirão que estabelece divisa entre os municípios de Primavera do Leste e Novo São Joaquim.

O cronotopônimo corresponde a $0,7 \%$ do total de topônimos da microrregião Primavera do Leste. 


\section{Etnotopônimo}

As unidades lexicais se referem aos elementos étnicos, isolados ou não (povos, tribos, castas), quando usadas para dar nomes a acidentes físicos e a acidentes antrópicos, são denominadas etnotopônimos nos estudos toponímicos. Registra-se 01 (um) etnotopônimo na microrregião Primavera do Leste.

O município de Primavera do Leste possui 01 (um) etnotopônimo, portanto, não se apresenta gráfico para esta taxionomia.

O etnotopônimo da microrregião Primavera do Leste é português e possui estrutura simples. O etnotopônimo Xavante denomina 01 (um) córrego no município de Primavera do Leste.

O etnotopônimo corresponde a $0,7 \%$ do total de topônimos da microrregião Primavera do Leste.

\section{Hierotopônimo}

As unidades lexicais que se referem aos nomes sagrados de diferentes crenças, às efemérides religiosas, às associações religiosas e aos locais de cultos, quando usadas para dar nomes a acidentes físicos e a acidentes antrópicos, são denominadas hierotopônimos nos estudos toponímicos. Registra-se 01 (um) hierotopônimo na microrregião Primavera do Leste.

O município de Campo Verde registra 01 (um) hierotopônimo, portanto, não se apresenta gráfico para esta taxionomia.

O hierotopônimo da microrregião Primavera do Leste é português e possui estrutura simples. O hierotopônimo Cruz nomeia 01 (um) morro. 
O hierotopônimo corresponde a $0,7 \%$ do total de topônimos da microrregião Primavera do Leste.

\section{Numerotopônimo}

Os adjetivos numerais, quando usados para dar nomes a acidentes físicos e a acidentes antrópicos, são denominados numerotopônimos nos estudos toponímicos. Registra-se 01 (um) numerotopônimo na microrregião Primavera do Leste.

O município de Campo Verde registra 01 (um) numerotopônimo, portanto, não se apresenta gráfico para esta taxionomia.

O numerotopônimo da microrregião Primavera do Leste é português e possui estrutura composta. O numerotopônimo composto Quarta Cabeceira, formado por numeral ordinal + unidade lexical cabeça + sufixo -eira, indicador de quantidade, dá nome a 01 (um) córrego.

O numerotopônimo corresponde a $0,7 \%$ do total de topônimos da microrregião Primavera do Leste.

\section{Historiotopônimo}

Registra-se 01 (um) historiotopônimo na microrregião Primavera do Leste. As unidades lexicais relativas aos movimentos de cunho histórico-social e aos seus membros, assim como as datas correspondentes, quando usadas para dar nomes a acidentes físicos e a acidentes antrópicos, são denominadas historiotopônimos nos estudos toponímicos.

O município de Campo Verde possui 01 (um) historiotopônimo, portanto, não se apresenta gráfico para esta taxionomia. 
O historiotopônimo da microrregião Primavera do Leste é português e possui estrutura composta. O historiotopônimo Coronel Ponce, formado por substantivo comum + nome de família, nomeia 01 (um) distrito no município de Campo Verde. O historiotopônimo é uma homenagem ao cuiabano Generoso Paes Leme de Sousa Ponce que foi Voluntário da Pátria na guerra contra o Paraguai, e também, ardoroso abolicionista, deputado provincial do Império, deputado à Assembléia Nacional Constituinte, deputado federal, presidente de Estado e senador da República.

O historiotopônimo corresponde a 0,7\% do total de topônimos da microrregião Primavera do Leste.

\section{Topônimo sem classificação}

O topônimo Coluene, ainda sem classificação taxionômica, está com a sigla S/C e consta na relação de topônimos do município de Primavera do Leste.

O topônimo Coluene dá nome a 01 (um) rio que estabelece divisa do município de Primavera do Leste com os municípios de Nova Brasilândia e Paranatinga.

O topônimo ainda sem classificação taxionômica corresponde a 0,7\% do total de topônimos da microrregião Primavera do Leste. 


\section{Considerações Parciais}

Estas considerações parciais objetivam apresentar alguns aspectos dos topônimos da microrregião Primavera do Leste, agrupados por microrregião, em uma visão de conjunto.

Do total de 136 (cento e trinta e seis) topônimos registrados na microrregião Primavera do Leste, 83 (oitenta e três) são de natureza física, 52 (cinqüenta e dois) topônimos de natureza antrópica e 01 (um) está sem classificação taxionômica.

Os topônimos de natureza física da microrregião Primavera do Leste estão classificados em 08 (oito) taxionomias e observa-se a seguinte distribuição por município: 58 (cinqüenta e oito) no município de Campo Verde e 25 (vinte e cinco) em Primavera do Leste. Apresenta-se a seguir o gráfico dos topônimos de natureza física com os respectivos percentuais por município (GRÁFICO 29).

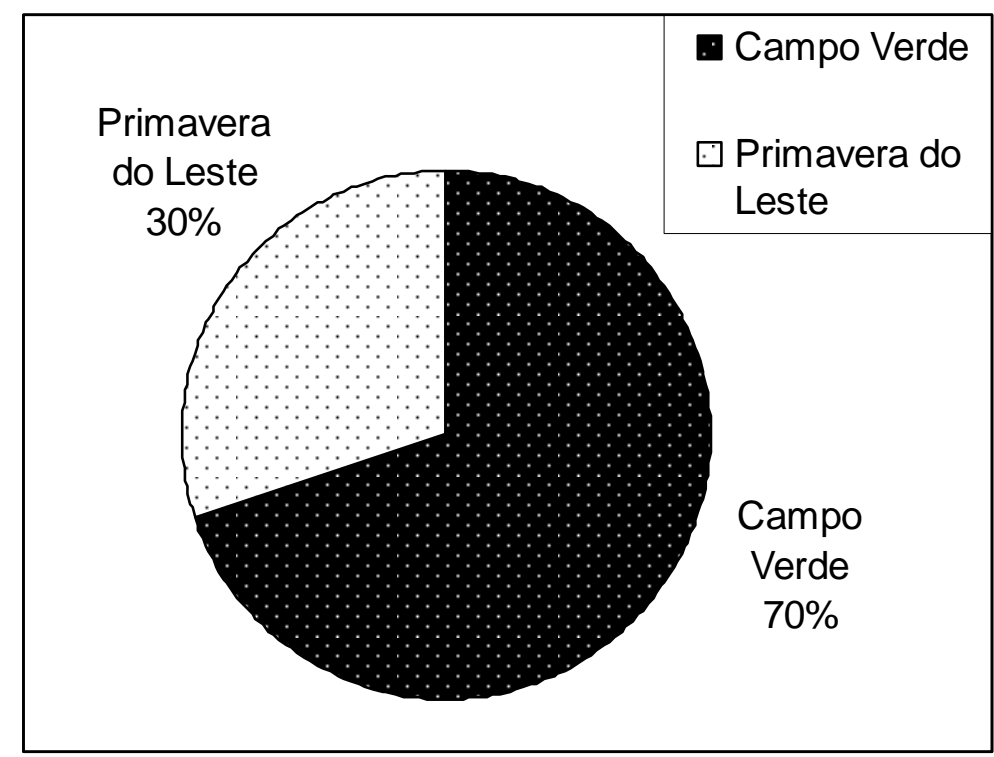

GRÁFICO 29 - Total dos topônimos de natureza física da microrregião Primavera do Leste.

Nos mapas e nas cartas topográficas da microrregião Primavera do Leste os topônimos estão classificados em 15 (quinze) taxionomias de natureza antrópica e apresentam a seguinte distribuição: 38 (trinta e oito) no município de Campo Verde e 14 (quatorze) em Primavera do Leste. Apresenta-se a seguir o gráfico dos topônimos de natureza antrópica com os respectivos percentuais por município (GRÁFICO 30). 


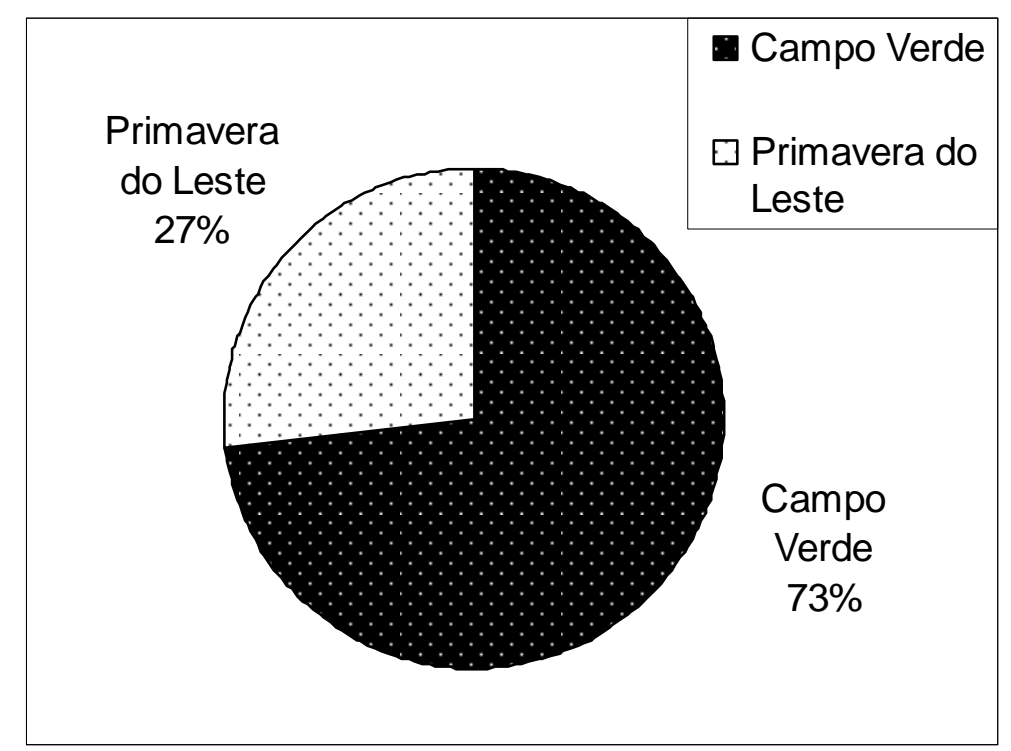

GRÁFICO 30 - Total dos topônimos de natureza antrópica da microrregião Primavera do Leste.

A representatividade dos topônimos de natureza física no total de topônimos da microrregião Primavera do Leste é de 61,1\%. Os topônimos de natureza antrópica possuem menor representatividade e correspondem a 38,2\%. O topônimo ainda sem classificação taxionômica corresponde a 0,7\%.

Os topônimos da microrregião Primavera do Leste foram agrupados por grupos lingüísticos. São 30 (trinta) topônimos tupis, 01 (um) bororo, 04 (quatro) africanos, 01 (um) topônimo ainda sem classificação lingüística e 100 (cem) portugueses Apresenta-se a seguir o gráfico dos topônimos por grupos lingüísticos com os respectivos percentuais por microrregião (GRÁFICO 31). 


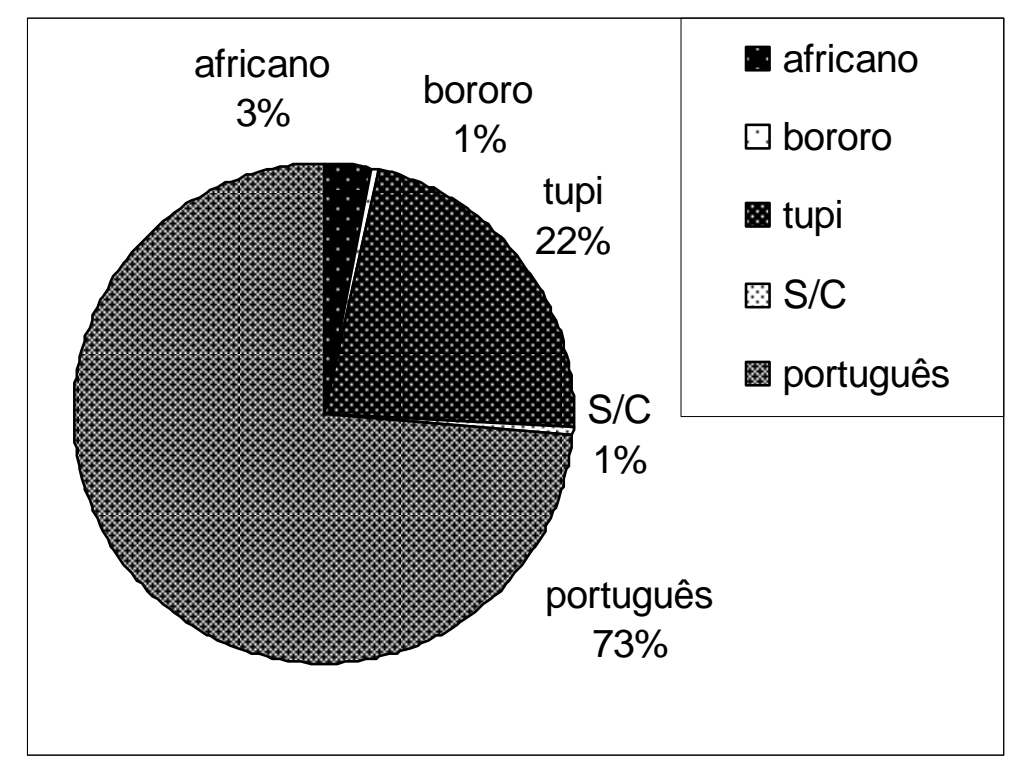

GRÁFICO 31 - Total dos topônimos por grupos lingüísticos da microrregião Primavera do Leste.

Registram-se 29 (vinte e nove) topônimos tupis nas taxionomias de natureza física: fitotopônimos, litotopônimos e zootopônimos. Há 01 (um) topônimo tupi na taxionomia de natureza antrópica: ergotopônimos. São 30 (trinta) topônimos tupis e representam 22,1\% do total de topônimos da microrregião Primavera do Leste.

Há somente 01 (um) topônimo bororo que está classificado na taxionomia fitotopônimos e representa $0,7 \%$ do total de topônimos.

São 03 (três) topônimos africanos classificados na taxionomia de natureza antrópica: ergotopônimos e 01 (um) classificado na taxionomia de natureza física: hidrotopônimos. Eles correspondem a 2,9\% do total de topônimos da microrregiãoPrimavera do Leste.

A participação dos municípios, em números absolutos, no total de topônimos da microrregião Primavera do Leste é de 96 (noventa e seis) topônimos em Campo Verde e de 40 (quarenta) em Primavera do Leste. Apresenta-se a seguir o gráfico do total de topônimos com os respectivos percentuais por município (GRÁFICO 32). 


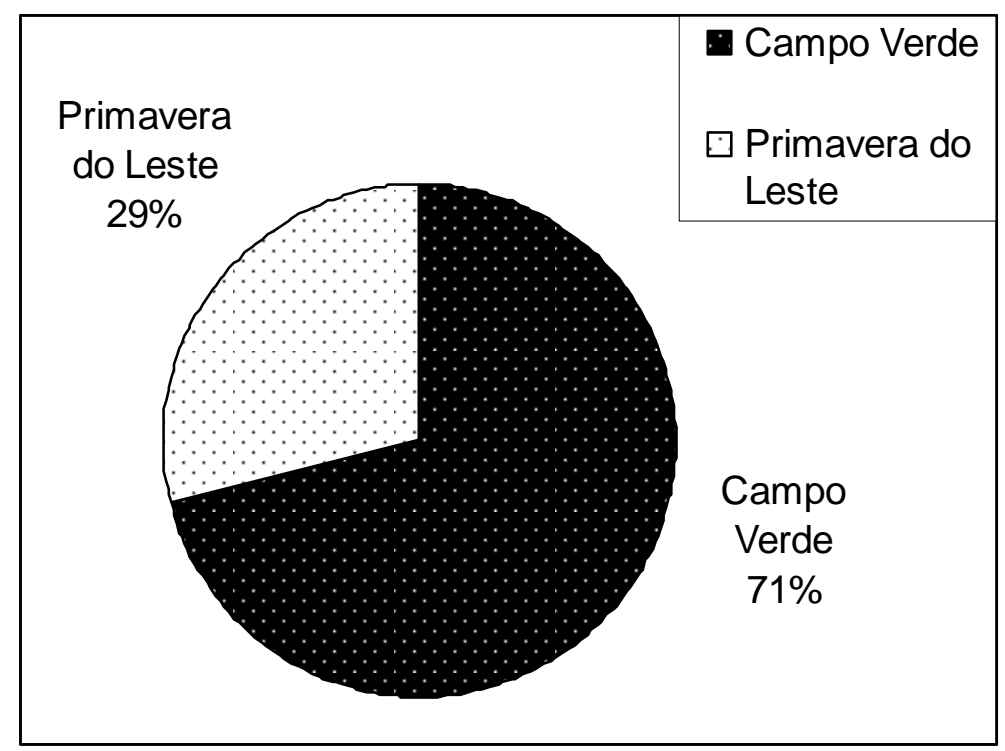

GRÁFICO 32 - Total geral dos topônimos da microrregião Primavera do Leste.

$\mathrm{Na}$ microrregião Primavera do Leste não há topônimo classificado nas taxionomias de natureza física: astrotopônimos, cardinotopônimos, igneotopônimos e morfotopônimos e nas taxionomias de natureza antrópica: ecotopônimos, mitotopônimos e poliotopônimos.

Os topônimos classificados nas taxionomias fitotopônimos, zootopônimos, hidrotopônimos e ergotopônimos são os que apresentam-se em maior quantidade, representam 54,4\% do total de topônimos da microrregião Primavera do Leste e evidenciam a força desses quatro campos semânticos nas denominações dos acidentes.

A microrregião Primavera do Leste é a que apresenta menor volume de topônimos. Os topônimos dos municípios de Campo Verde e Primavera do Leste representam 5,8\% do total de topônimos da mesorregião Sudeste Mato-grossense. 


\subsection{Microrregião Rondonópolis}

\subsubsection{Características gerais da microrregião Rondonópolis}

A microrregião Rondonópolis é uma das 04 (quatro) microrregiões que compõe a mesorregião Sudeste Mato-grossense. Está formada por 08 (oito) municípios: Dom Aquino, Itiquira, Jaciara, Juscimeira, Pedra Preta, Rondonópolis, São José do Povo e São Pedro da Cipa. Os municípios que compõem a microrregião Rondonópolis foram emancipados no decorrer da segunda metade do século XX. Na década de cinqüenta Dom Aquino, Itiquira, Jaciara e Rondonópolis foram elevados à categoria de município. Os municípios de Juscimeira e Pedra Preta emanciparam-se, respectivamente, em 1979 e 1976. O município de São José do Povo obteve sua autonomia político-administrativa em 1989 e São Pedro da Cipa em 1981.

As áreas dos municípios que constituem, atualmente, a microrregião Rondonópolis sempre foram habitadas por índios da nação Bororo. Eles vivem ainda na região, mas agora em reserva indígena.

Os cursos d'água da microrregião Rondonópolis contribuem com seus caudais para a formação das bacias hidrográficas brasileiras: Araguaia-tocantina e Pratina.

Os municípios que compõem a microrregião Rondonópolis foram formados por destemidos aventureiros que para lá se dirigiram, sozinhos ou acompanhados de suas famílias, em busca de novas alternativas de vida. Ao chegar, eles por motivos específicos a cada um, decidiram-se por uma subdivisão natural, enquanto uns se dedicaram às práticas agropecuárias, outros optaram pelo extrativismo mineral, sobretudo à garimpagem de diamantes e alguns outros foram exercer atividades no setor terciário. 
A extensão territorial da microrregião Rondonópolis é de $23.854 \mathrm{~km}^{2}$, dados do Anuário Estatístico de Mato Grosso - 2009, publicado pela SEPLAN - MT. Ocupa $33,18 \%$ da área total da mesorregião Sudeste Mato-grossense. É a segunda microrregião em extensão territorial.

Com base nas pesquisas socioeconômicas do Anuário Estatístico de Mato Grosso - 2009, os principais produtos agrícolas da microrregião Rondonópolis foram: algodão, arroz, banana, cana-de-açúcar, feijão, mandioca, milho e soja. O volume da produção agrícola foi superior a 3.650.310 toneladas. Os principais rebanhos foram: bovino, eqüino, ovino e suíno. Os rebanhos, nessa época, perfaziam um total de 1.362.068 cabeças.

A população residente, recenseada em 2007 e divulgada pelo Instituto Brasileiro de Geografia e Estatística (IBGE), foi de 252.949 habitantes, sendo que 223.514 encontravam-se na zona urbana e 29.435 na zona rural. A densidade demográfica atingiu o índice de 10,6 hab. $/ \mathrm{km}^{2}$ e a representatividade da população urbana foi superior a 88,4\%. A microrregião Rondonópolis é a mais populosa da mesorregião Sudeste Mato-grossense e possui o terceiro maior índice de urbanização dentre as microrregiões que compõem a mesorregião Sudeste Matogrossense.

A microrregião Rondonópolis limita-se com as microrregiões Alto Araguaia, Cuiabá, Primavera, Tesouro e o estado de Mato Grosso do Sul. A seguir, as características gerais dos municípios que a compõem, com suas respectivas relações de topônimos. 


\subsubsection{Características gerais do município de Dom Aquino}

O município de Dom Aquino obteve sua autonomia político-administrativa em 1958, ao ser desmembrado do município de Poxoréu. A cidade de Dom Aquino localiza-se às margens do córrego Mutum.

A extensão territorial do município de Dom Aquino é de $2.205 \mathrm{~km}^{2}$, dados do Anuário Estatístico de Mato Grosso - 2009, publicado pela SEPLAN - MT. A altitude na cidade de Dom Aquino é de 283 metros acima do nível do mar.

O primeiro aglomerado urbano, no atual município de Dom Aquino, foi formado por garimpeiros de diamantes que o denominaram Mutum. Com o decorrer dos anos a vocação econômica do lugar direcionou-se para a agropecuária.

Em 17 de novembro de 1958 foi criado o distrito de Mutum pela Lei $n^{0} 1.127$, ainda no município de Poxoréu. O distrito foi elevado à categoria de município pela Lei $\mathrm{n}^{\circ} 1.196$ em 22 de dezembro de 1958, mas o município só foi instalado em $1^{\circ} \mathrm{de}$ janeiro de 1963. O topônimo do município foi alterado para Dom Aquino em 24 de setembro de 1965 , pela Lei $n^{\circ} 2.482$.

O topônimo Dom Aquino possui estrutura composta, formado por substantivo comum + substantivo próprio. Nos estudos toponímicos é classificado, taxionomicamente, como historiotopônimo. Este topônimo é homenagem a Dom Francisco de Aquino Correia, bispo, arcebispo, poeta, escritor e governador matogrossense. Dom Aquino foi Fundador e Presidente de Honra da Academia Matogrossense de Letras, Membro Efetivo do Instituto Histórico e Geográfico Brasileiro e Membro Efetivo da Academia Brasileira de Letras. Foi, também, o autor do Hino a Mato Grosso.

Atualmente o município de Dom Aquino está constituído por 02 (dois) distritos: Sede e Entre Rios.

O distrito de Entre Rios foi criado pela Lei no 3.731 de 04 de junho de 1976, pertencente ao município de Dom Aquino. 
Com base nas pesquisas socioeconômicas do Anuário Estatístico de Mato Grosso - 2009, os principais produtos agrícolas do município de Dom Aquino foram: algodão, arroz, cana-de-açúcar, mandioca, milho e soja. O volume da produção agrícola foi superior a 308.752 toneladas. Os principais rebanhos foram: bovino, eqüino, ovino e suíno. Os rebanhos, nessa época, perfaziam um total de 89.638 cabeças.

A população residente, recenseada em 2007 e divulgada pelo Instituto Brasileiro de Geografia e Estatística (IBGE), foi de 8.261 habitantes, sendo que 6.683 encontravam-se na zona urbana e 1.578 na zona rural. A densidade demográfica atingiu o índice de $3,7 \mathrm{hab} . / \mathrm{km}^{2}$ e a representatividade da população urbana foi superior a $80,9 \%$.

O município de Dom Aquino localiza-se na mesorregião Sudeste Matogrossense e é um dos municípios que compõe a microrregião Rondonópolis. Limitase com os municípios de Campo Verde, Jaciara, Poxoréu, Primavera do Leste e São Pedro da Cipa.

A seguir, anexam-se as relações dos topônimos do município de Dom Aquino, registrados no mapa elaborado pela Fundação de Pesquisas Cândido Rondon (FCR) que integra o corpus desta pesquisa. Os topônimos estão antecedidos pelos seus respectivos acidentes físicos e acidentes antrópicos, também identificados como elementos físicos e elementos humanos de uma paisagem. 
4.5.2.1 Relação dos acidentes físicos do município de Dom Aquino, de seus topônimos e taxionomias.

\begin{tabular}{|c|c|c|c|}
\hline $\mathbf{N}^{0}$ & Acidente & Topônimo & Taxionomia \\
\hline 01 & cabeceira da & Cotia (E14, F13) & Zootopônimo \\
\hline 02 & cabeceira do & Encontro (E12) & Sociotopônimo \\
\hline 03 & cabeceira do & Esparramo (E12) & Sociotopônimo \\
\hline 04 & cabeceira & Verde $(07, \mathrm{P} 7)$ & Cromotopônimo \\
\hline 05 & córrego & Água Limpa (F10) & Hidrotopônimo \\
\hline 06 & córrego & Água Quente (L2) & Hidrotopônimo \\
\hline 07 & córrego & Alcantilado (L13) & Geomorfotopônimo \\
\hline 08 & córrego & Alecrim $(\mathrm{H} 6)$ & Fitotopônimo \\
\hline 09 & córrego & Baiano (F5, F6) & Etnotopônimo \\
\hline 10 & córrego & Barracão (N3, N4) & Ergotopônimo \\
\hline 11 & córrego & Barroso (O5 a P3) & Litotopônimo \\
\hline 12 & córrego do & Café (Q5) & Fitotopônimo \\
\hline 13 & córrego & Cercadinho (E2, E3) & Ergotopônimo \\
\hline 14 & córrego & Chibiu (L3, L4) & Litotopônimo \\
\hline 15 & córrego & Chico Nunes (E6 a B14) & Antropotopônimo \\
\hline 16 & córrego & Coruja (M5) & Zootopônimo \\
\hline 17 & córrego da & Cotia (P4, Q4) & Zootopônimo \\
\hline 18 & córrego & Cupim (D4 a A9) & Litotopônimo \\
\hline 19 & córrego do & Engano (I8) & Animotopônimo \\
\hline 20 & córrego & Esparramo (E13 a B14) & Sociotopônimo \\
\hline 21 & córrego & Estiva (G6) & Sociotopônimo \\
\hline 22 & córrego & Formoso (F10, F11) & Animotopônimo \\
\hline 23 & córrego & Fundo $(13,14)$ & Dimensiotopônimo \\
\hline 24 & córrego & Fundo $(\mathrm{J} 3, \mathrm{~J} 4)$ & Dimensiotopônimo \\
\hline 25 & córrego & Grota Feia $(\mathrm{H} 2, \mathrm{H} 3)$ & Geomorfotopônimo \\
\hline 26 & córrego & Grotão (N4, O3) & Geomorfotopônimo \\
\hline 27 & córrego & Lajinha (19) & Litotopônimo \\
\hline 28 & córrego & Lambança (H7 a F12) & Sociotopônimo \\
\hline 29 & córrego & Lambancinha (F13, E13) & Sociotopônimo \\
\hline
\end{tabular}


(continuação)

\begin{tabular}{|c|c|c|c|}
\hline $\mathbf{N}^{\circ}$ & Acidente & Topônimo & Taxionomia \\
\hline 30 & córrego & Lambari (L5, L6) & Zootopônimo \\
\hline 31 & córrego & Lavrinha Verde (G10) & Sociotopônimo \\
\hline 32 & córrego & Mata Cavalo $(\mathrm{N5}, \mathrm{N6})$ & Dirrematotopônimo \\
\hline 33 & córrego & Monjolo (N6, N7) & Ergotopônimo \\
\hline 34 & córrego & Morcego (F5 a G2) & Zootopônimo \\
\hline 35 & córrego & Morcego (G7) & Zootopônimo \\
\hline 36 & córrego & Mutum (M5 a N2) & Zootopônimo \\
\hline 37 & córrego & Pombas (L9) & Zootopônimo \\
\hline 38 & córrego & Ponte de Barro (G2 a F4) & Hodotopônimo \\
\hline 39 & córrego & Ponte de Pedra (G13, F14) & Hodotopônimo \\
\hline 40 & córrego dos & Porcos (15) & Zootopônimo \\
\hline 41 & córrego & Ponteiro (F5 a I5) & Ergotopônimo \\
\hline 42 & córrego & Potreiro (N8 a O11) & Ergotopônimo \\
\hline 43 & córrego da & Prata (P5) & Litotopônimo \\
\hline 44 & córrego & Presidente (D3) & Sociotopônimo \\
\hline 45 & córrego & Preto (G8) & Cromotopônimo \\
\hline 46 & córrego & Progresso (O5 a P3) & Animotopônimo \\
\hline 47 & córrego & Quati (J11) & Zootopônimo \\
\hline 48 & córrego do & Rapa (L11) & Sociotopônimo \\
\hline 49 & córrego & Ribeirão (J11 a H10) & Hidrotopônimo \\
\hline 50 & córrego & Rico $(C 9, D 9)$ & Animotopônimo \\
\hline 51 & córrego & Roncador (F2) & Hidrotopônimo \\
\hline 52 & córrego & São Bento (M9 a M6) & Hagiotopônimo \\
\hline 53 & córrego & São Domingos (M8 a N10) & Hagiotopônimo \\
\hline 54 & córrego & São José $(I 10,111)$ & Hagiotopônimo \\
\hline 55 & córrego & São Luiz $(H 9,19)$ & Hagiotopônimo \\
\hline 56 & córrego & Serival $(E 2, E 3)$ & Antropotopônimo \\
\hline 57 & córrego das & Tropas $(\mathrm{H} 6, \mathrm{H} 7)$ & Zootopônimo \\
\hline 58 & córrego dos & Veados (P4, Q4) & Zootopônimo \\
\hline 59 & lagoa & Formosa (D10) & Animotopônimo \\
\hline 60 & morro do & Baú ou do Chibiu (L6) & $\begin{array}{l}\text { Ergotopônimo ou } \\
\text { Litotopônimo }\end{array}$ \\
\hline
\end{tabular}


(conclusão)

\begin{tabular}{lllll}
\hline $\mathbf{N}^{\mathbf{0}}$ & \multicolumn{1}{c}{ Acidente } & \multicolumn{1}{c}{ Topônimo } & \multicolumn{1}{c}{ Taxionomia } \\
\hline 61 & morro do & Cervo (L8) & Zootopônimo \\
62 & morro do & Perigo (P5, P6) & Animotopônimo \\
63 & morro das & Pombas (P8) & Zootopônimo \\
64 & morro & Rapadura (J3) & Ergotopônimo \\
65 & morro & Santo Antônio (O7, O8) & Hagiotopônimo \\
66 & ribeirão & Parnaíba (J10 a F13) & Hidrotopônimo \\
67 & ribeirão das & Pombas (R4 a P10) & Zootopônimo \\
68 & rio das & Mortes (A9 a B14) & Sociotopônimo \\
69 & rio & São Lourenço (H2 a R4) & Hagiotopônimo \\
70 & serra dos & Acidentados (I2, J2) & Sociotopônimo \\
71 & serra da & Conceição (N8, N9) & Antropotopônimo \\
72 & serra do & Morcego (E3, F2, F3) & Zootopônimo \\
73 & serra das & Parnaíbas (M6, M7, L7) & Hidrotopônimo \\
74 & serra da & Pimenta (I2, I3) & Fitotopônimo \\
75 & serra da & Piteira (H2, H3) & Fitotopônimo \\
\hline
\end{tabular}

Fonte dos dados: Mapa da Fundação de Pesquisas Cândido Rondon (FCR) - 1984 - escala 1:100.000.

4.5.2.2 Relação dos acidentes humanos do município de Dom Aquino, de seus topônimos e taxionomias.

\begin{tabular}{l|l|ll}
\hline $\mathbf{N}^{\mathbf{0}}$ & \multicolumn{1}{c}{ Acidente } & \multicolumn{1}{c}{ Topônimo } & \multicolumn{1}{c}{ Taxionomia } \\
\hline 01 & cidade de & Dom Aquino (M3 a N4) & Historiotopônimo \\
02 & distrito & Entre Rios (P5) & Cardinotopônimo \\
\hline
\end{tabular}

Fonte dos dados: Mapa da Fundação de Pesquisas Cândido Rondon (FCR) - 1984 - escala 1:100.000. 


\subsubsection{Características gerais do município de Itiquira}

O município de Itiquira obteve sua autonomia político-administrativa em 1953, ao ser desmembrado dos municípios de Alto Araguaia e Poxoréu. A cidade de Itiquira localiza-se à margem direita do rio Itiquira.

A extensão territorial do município de Itiquira é de $8.639 \mathrm{~km}^{2}$ dados do Anuário Estatístico de Mato Grosso - 2009, publicado pela SEPLAN - MT. A altitude na cidade de Itiquira é de 522 metros acima do nível do mar.

O topônimo Itiquira possui estrutura simples. Nos estudos toponímicos é classificado, taxionomicamente, como hidrotopônimo.

Segundo Sampaio, a unidade lexical tupi itiquira tem as seguintes características: "ITIQUIRA, corr. y-tykyra, a água vertente, o minadouro." (1970, p. 230)

O município de Itiquira está muito próximo do Pantanal Mato-grossense e isto pode ser observado em alguns acidentes físicos com características específicas desse importante sistema ecológico brasileiro. Toda área que hoje constitui o município de Itiquira foi habitada por povos indígenas. Relatam alguns historiadores que essa área também foi palmilhada por bandeirantes no decorrer do século XVIII.

A povoação, onde atualmente encontra-se o município de Itiquira, começou a ser formada por ajuntamento de garimpeiros, ainda na primeira metade do século XX. Um pequeno núcleo habitacional composto por pessoas que se dedicam a exploração de diamantes é denominado corrutela, no estado de Mato Grosso. Inicialmente a povoação de Itiquira estava integrada ao município de Coxim, pela Lei $\mathrm{n}^{\circ} 13$ de 25 de abril de 1935, que hoje pertence ao estado de Mato Grosso do Sul. Mas a localidade foi elevada a categoria de sede de distrito pela Lei $n^{\circ} 127$ de 20 de outubro de 1937, quando já integrava o município de Santa Rita do Araguaia.

Itiquira passou a categoria de município em $1^{\circ}$ de dezembro de 1953 com a Lei $n^{\circ} 654$, desmembrando-se do município de Alto Araguaia. 
Atualmente o município de Itiquira está constituído apenas pelo distrito Sede.

Com base nas pesquisas socioeconômicas do Anuário Estatístico de Mato Grosso - 2009, os principais produtos agrícolas do município de Itiquira foram: algodão, arroz, mandioca, milho e soja. O volume da produção agrícola foi superior a 1.058.704 toneladas. Os principais rebanhos foram: bovino, eqüino, ovino e suíno. Os rebanhos, nessa época, perfaziam um total de 284.098 cabeças.

A população residente, recenseada em 2007 e divulgada pelo Instituto Brasileiro de Geografia e Estatística (IBGE), foi de 12.159 habitantes, sendo que 3.867 encontravam-se na zona urbana e 8.292 na zona rural. A densidade demográfica atingiu o índice de $1,6 \mathrm{hab} . / \mathrm{km}^{2}$ e a representatividade da população urbana foi superior a $31,8 \%$.

O município de Itiquira localiza-se na mesorregião Sudeste Mato-grossense e é um dos municípios que compõe a microrregião Rondonópolis. Limita-se com os municípios de Alto Garças, Barão de Melgaço, Pedra Preta, Rondonópolis, Santo Antônio de Leverger e o estado de Mato Grosso do Sul.

A seguir, anexam-se as relações dos topônimos do município Itiquira, registrados nas cartas topográficas ${ }^{3}$ elaboradas pela Diretoria de Serviço Geográfico (DSG) e Instituto Brasileiro de Geografia e Estatística (IBGE) que integram o corpus desta pesquisa. Os topônimos estão antecedidos pelos seus respectivos acidentes físicos e acidentes antrópicos, também identificados como elementos físicos e elementos humanos de uma paisagem.

\footnotetext{
${ }^{3}$ As dez cartas topográficas que abrangem a área geográfica do município de Itiquira são: Pedra Preta (326), Alto Garças (327), Porto Coqueiro (335), Fazenda Três Marias (336), Córrego Cachoeira (337), Itiquira (338), Rio Itiquira (339), Morro Formoso (345), Córrego Benjamim (346) e Serra Preta (347).

O número que está entre parênteses, após o nome de cada carta topográfica, corresponde ao número que está colocado, entre parênteses, logo após o topônimo nas relações dos topônimos do município, para facilitar a sua localização na respectiva carta.
} 
4.5.3.1 Relação dos acidentes físicos do município de Itiquira, de seus topônimos e taxionomias. 
(continuação)

\begin{tabular}{|c|c|c|c|}
\hline $\mathbf{N}^{\mathbf{0}}$ & Acidente & Topônimo & Taxionomia \\
\hline 30 & córrego dos & Bois (327 - O1) & Zootopônimo \\
\hline 31 & córrego & Bom Jardim (338 - I18, I19) & Animotopônimo \\
\hline 32 & córrego & Buriti (337 - Z23) & Fitotopônimo \\
\hline 33 & córrego das & Cabaças (339 - H3) & Fitotopônimo \\
\hline 34 & córrego & Cabeceira Comprida (339 - J2 a H3) & Hidrotopônimo \\
\hline 35 & córrego & Cabeceira Seca (339 - 13) & Hidrotopônimo \\
\hline 36 & córrego & Cachoeira (337 - G8 a L26) & Hidrotopônimo \\
\hline 37 & córrego & Café (338 - M12, N11) & Fitotopônimo \\
\hline 38 & córrego & Cambota (339 - D4 a F5) & Somatotopônimo \\
\hline 39 & córrego do & Camilo $(339-\mathrm{H} 1, \mathrm{H} 2)$ & Antropotopônimo \\
\hline 40 & córrego & Campo Alegre (339 - H1) & Fitotopônimo \\
\hline 41 & córrego da & Capoeira (339 - F3) & Fitotopônimo \\
\hline 42 & córrego & Capoeirinha (338 - M24, N24, N25) & Fitotopônimo \\
\hline 43 & córrego do & Castelo (339 - E7, F7) & Ecotopônimo \\
\hline 44 & córrego do & Cedro (347 - A18 a B12) & Fitotopônimo \\
\hline 45 & córrego & $\begin{array}{l}\text { Cemitério (336 - AC27 a AC23 / } 337 \text { - } \\
A A 2, A B 1)\end{array}$ & Sociotopônimo \\
\hline 46 & córrego & Cervo (338 - L23, L24, J24) & Zootopônimo \\
\hline 47 & córrego da & Cobra (339 - F4) & Zootopônimo \\
\hline 48 & córrego & Confusão (337 - I10, I11) & Sociotopônimo \\
\hline 49 & córrego da & Confusão (339 - F2 a G5) & Sociotopônimo \\
\hline 50 & córrego & Congonhas (338 - N20, N21) & Fitotopônimo \\
\hline 51 & córrego & Curral de Vara (337 - J24, 125) & Ergotopônimo \\
\hline 52 & córrego & Duas Pontes (337 - G2 a J8) & Numerotopônimo \\
\hline 53 & córrego do & Enganinho (339 - G2) & Animotopônimo \\
\hline 54 & córrego da & Espora (339 - G4, G5) & Ergotopônimo \\
\hline 55 & córrego & Estreito (337 - U24, V24) & Dimensiotopônimo \\
\hline 56 & córrego da & Faísca (339 - B1) & Igneotopônimo \\
\hline 57 & córrego do & Feixe $(339-\mathrm{H} 3)$ & Ergotopônimo \\
\hline 58 & córrego & Fundo (337 - U3 a V7) & Dimensiotopônimo \\
\hline 59 & córrego & Fundo (338 - M13) & Dimensiotopônimo \\
\hline 60 & córrego & Fundo (339 - H1, G1) & Dimensiotopônimo \\
\hline
\end{tabular}


(continuação)

\begin{tabular}{|c|c|c|c|}
\hline $\mathbf{N}^{\mathbf{0}}$ & Acidente & Topônimo & Taxionomia \\
\hline 61 & córrego & Furninha (338 - F9, G9) & Geomorfotopônimo \\
\hline 62 & córrego & Gordura (337 - AD18, AC19) & Somatotopônimo \\
\hline 63 & córrego & $\begin{array}{l}\text { Grande (337 - AE3 a AC6 / } 345 \text { - F22, } \\
\text { E22, E23) }\end{array}$ & Dimensiotopônimo \\
\hline 64 & córrego da & Ilha $(339-\mathrm{H} 5)$ & Geomorfotopônimo \\
\hline 65 & córrego & Indaial (338 - AB25) & Fitotopônimo \\
\hline 66 & córrego da & Invernada (339 - F3, G3) & Geomorfotopônimo \\
\hline 67 & córrego & Jaraguá (337 - U9, T9) & Hierotopônimo \\
\hline 68 & córrego do & Jorge (339- M2, M3) & Antropotopônimo \\
\hline 69 & córrego & Lajeadinho (339 - J1, L3) & Litotopônimo \\
\hline 70 & córrego & Lajeado (337 - AC15, AC16) & Litotopônimo \\
\hline 71 & córrego & Linchal (336 - U27, T26 / 337 - U1 a S4) & Ergotopônimo \\
\hline 72 & córrego & Macaúba (339 - E4, F4) & Fitotopônimo \\
\hline 73 & córrego & Mangaba (337 - S9, S10, T10) & Fitotopônimo \\
\hline 74 & córrego do & Matão (337 - G25, H25) & Fitotopônimo \\
\hline 75 & córrego & Mata-Pasta (336 - AC22 a X22) & Fitotopônimo \\
\hline 76 & córrego & Mateirinha (338 - F12, F13) & Zootopônimo \\
\hline 77 & córrego da & Matinha (339 - D3, E3) & Fitotopônimo \\
\hline 78 & córrego do & Mato (337 - P24, Q24) & Fitotopônimo \\
\hline 79 & córrego do & Moedor (339 - D5, F5) & Ergotopônimo \\
\hline 80 & córrego do & Mutum (339 - G3, H3) & Zootopônimo \\
\hline 81 & córrego do & Mutum (339 - I1) & Zootopônimo \\
\hline 82 & córrego & Olaria (339 - A2, B2) & Sociotopônimo \\
\hline 83 & córrego & Olho-d'água (339 - F1) & Hidrotopônimo \\
\hline 84 & córrego da & Onça (339 - A2) & Zootopônimo \\
\hline 85 & córrego da & Onça (339 - E7, F7) & Zootopônimo \\
\hline 86 & córrego da & Onça (339 - 14) & Zootopônimo \\
\hline 87 & córrego do & Pântano (338 - G24, G25) & Litotopônimo \\
\hline 88 & córrego & Paraíso (339 - D1) & Hierotopônimo \\
\hline 89 & córrego & Pau Terra (339 - F4, G4) & Fitotopônimo \\
\hline 90 & córrego das & Pedras (339 - 13) & Litotopônimo \\
\hline 91 & córrego & Pedregulho (337 - V14, V15) & Litotopônimo \\
\hline
\end{tabular}


(continuação)

\begin{tabular}{|c|c|c|c|}
\hline $\mathbf{N}^{\circ}$ & Acidente & Topônimo & Taxionomia \\
\hline 92 & córrego do & Piquenique (339 - G3) & Sociotopônimo \\
\hline 93 & córrego & Pita (337 - V22) & Fitotopônimo \\
\hline 94 & córrego & $\begin{array}{l}\text { Ponta do Resolvido (338 - AE14 a } \\
\text { AD15) }\end{array}$ & Geomorfotopônimo \\
\hline 95 & córrego & Pontal $(339-12,13)$ & Geomorfotopônimo \\
\hline 96 & córrego & Ponte de Pedra (338 - E12, E13) & Hodotopônimo \\
\hline 97 & córrego & Ponte de Pedra (338 - U15, U16) & Hodotopônimo \\
\hline 98 & córrego & Porteira (338 - G26) & Ergotopônimo \\
\hline 99 & córrego & $\begin{array}{l}\text { Posto Duzentos (336 - M26, N27 / } 337 \\
\text { O3, O4, O5) }\end{array}$ & Sociotopônimo \\
\hline 100 & córrego do & Potreiro (339 - H1, I1) & Ergotopônimo \\
\hline 101 & córrego & Prata (338 - M8) & Litotopônimo \\
\hline 102 & córrego & Queixada (337 - AA11, AA12) & Zootopônimo \\
\hline 103 & córrego do & Queixada (338 - U22, V22) & Zootopônimo \\
\hline 104 & córrego & Queixada $(339-14,15)$ & Zootopônimo \\
\hline 105 & córrego & Rego-d'água (339 - G3, G4) & Hidrotopônimo \\
\hline 106 & córrego & Resolvido (338 - A25 a D26) & Sociotopônimo \\
\hline 107 & córrego & Resolvido (347 - A13, B13) & Sociotopônimo \\
\hline 108 & córrego & Retirinho (339 - E2) & Sociotopônimo \\
\hline 109 & córrego & Retirinho (339 - E2, F2) & Sociotopônimo \\
\hline 110 & córrego & Retirinho $(339$ - H4) & Sociotopônimo \\
\hline 111 & córrego & Retiro (337 - Z10 a N10) & Sociotopônimo \\
\hline 112 & córrego & $\begin{array}{l}\text { Rio Novo (336 - T27 a T13 / } 337 \text { - S1 a } \\
\text { P8) }\end{array}$ & Hidrotopônimo \\
\hline 113 & córrego & Roncador (338 - Q19, R20) & Hidrotopônimo \\
\hline 114 & córrego & São Domingos (337 - M8 a N2) & Hagiotopônimo \\
\hline 115 & córrego & São João (338 - J16, J17) & Hagiotopônimo \\
\hline 116 & córrego & Sapé (338 - L26) & Fitotopônimo \\
\hline 117 & córrego do & Sapé (339 - F1) & Fitotopônimo \\
\hline 118 & córrego & Sete da Pedra (337 - AC23, AD23) & Numerotopônimo \\
\hline 119 & córrego & Sozinho (338- S1 a S16) & Cardinotopônimo \\
\hline 120 & córrego & Sucuri (337 - AD26 / 338 - AA1, AB1) & Zootopônimo \\
\hline 121 & córrego & Sucuri $(339-\mathrm{J} 2, \mathrm{~J} 3)$ & Zootopônimo \\
\hline
\end{tabular}


(continuação)

\begin{tabular}{|c|c|c|c|}
\hline $\mathbf{N}^{\circ}$ & Acidente & Topônimo & Taxionomia \\
\hline 122 & córrego da & Taboca (339 - B2) & Fitotopônimo \\
\hline 123 & córrego & Triunfo (339 - D4, E4) & Animotopônimo \\
\hline 124 & córrego da & Vaca $(339-\mathrm{N} 1, \mathrm{~N} 2)$ & Zootopônimo \\
\hline 125 & córrego da & Velhinha $(339-\mathrm{G} 3)$ & Cronotopônimo \\
\hline 126 & córrego do & Vigilato $(339$ - E8, F8) & Antropotopônimo \\
\hline 127 & ilha do & Rio Velho $(336-\mathrm{N} 18, \mathrm{~N} 19)$ & Hidrotopônimo \\
\hline 128 & lagoa & Seca (326 - AB25) & Hidrotopônimo \\
\hline 129 & morretes da & Pedra de Fogo (338 - C23 a C25) & Litotopônimo \\
\hline 130 & morrinho da & Baliza (338 - B23, B24) & Ergotopônimo \\
\hline 131 & morro da & Cruz $(339-12)$ & Hierotopônimo \\
\hline 132 & morro & Formoso (345 - B12) & Animotopônimo \\
\hline 133 & morro da & Louca (336 - AE25, AE26) & Somatotopônimo \\
\hline 134 & morro da & Onça (339 - 14) & Zootopônimo \\
\hline 135 & porto & Chinelo (345 - C13) & Ergotopônimo \\
\hline 136 & ribeirão & Boa Esperança (339 - C4 a F9) & Animotopônimo \\
\hline 137 & ribeirão & $\begin{array}{l}\text { Comprido (338 - AE6 a S24 / } 347 \text { - A5, } \\
\text { B4) }\end{array}$ & Dimensiotopônimo \\
\hline 138 & ribeirão do & Engano (339 - E1 a J4) & Animotopônimo \\
\hline 139 & ribeirão & $\begin{array}{l}\text { Pedra de Fogo (338 - D25 a I27 / } 339 \text { - } \\
\text { C1, D1) }\end{array}$ & Litotopônimo \\
\hline 140 & ribeirão & $\begin{array}{l}\text { Ponte de Pedra (337 - D16 a G27 / } 338 \text { - } \\
\text { E1 a B18) }\end{array}$ & Hodotopônimo \\
\hline 141 & ribeirão & Resolvido (347 - C13 a E9) & Sociotopônimo \\
\hline 142 & ribeirão & Sozinho (337 - R14 a T27) & Cardinotopônimo \\
\hline 143 & ribeirão das & Velhas (327 - N1, O1 / 339 - A1 a D2) & Cronotopônimo \\
\hline 144 & rio & $\begin{array}{l}\text { Correntes (337 - AE17 a AE26 / } 338 \text { - } \\
\text { AD1, AD2 / } 339 \text { - N1 a G9 / } 345 \text { - J19 a } \\
\text { H26 / } 346 \text { - H1 a A18 / } 347 \text { - A2 a A25) }\end{array}$ & Hidrotopônimo \\
\hline 145 & rio & $\begin{array}{l}\text { Itiquira (336 - U1 a G27 / } 337 \text { - G1 a } \\
\text { O27 / } 338 \text { - O1 a I27 / } 339 \text { - D1 a C4) }\end{array}$ & Hidrotopônimo \\
\hline 146 & rio & $\begin{array}{l}\text { Piquiri (335 - AC21 a U27 I } 336 \text { - AD1, } \\
\text { AE3 / } 345 \text { - A3 a I19) }\end{array}$ & Hidrotopônimo \\
\hline 147 & serra do & Espigão Mestre (338 - J10 a L14) & Geomorfotopônimo \\
\hline 148 & serra & São Jerônimo (337 - AE7 a E9) & Hagiotopônimo \\
\hline 149 & serra & Solteira (345 - E17 a C19) & Etnotopônimo \\
\hline 150 & serrinha do & Lobo (338 - A22) & Zootopônimo \\
\hline
\end{tabular}


(conclusão)

\begin{tabular}{c|l|l|l}
\hline $\mathbf{N}^{\mathbf{2}}$ & \multicolumn{1}{c|}{ Acidente } & \multicolumn{1}{c}{ Topônimo } & \multicolumn{1}{c}{ Taxionomia } \\
\hline 151 & vazante & Descarrega (336 - AA19 a AC21) & Sociotopônimo \\
152 & vazante das & $\begin{array}{l}\text { Piranhas (335 - Z27 a V24 / 336 - V1 a } \\
\text { AE14) }\end{array}$ & Zootopônimo \\
153 & vazante & Riozinho (336 - J27 a V18) & Hidrotopônimo \\
\hline
\end{tabular}

Fonte dos dados: Carta topográfica da Diretoria de Serviço Geográfico (DSG), Ministério do Exército, 1976 - escala 1:100.000.

Carta topográfica do Instituto Brasileiro de Geográfica e Estatística (IBGE), 1976 - escala 1:100.000.

Mapa da Fundação de Pesquisas Cândido Rondon (FCR), 1983 - escala $1: 250.000$.

\subsubsection{Relação do acidente humano do município de Itiquira, de seu topônimo e taxionomia.}

\begin{tabular}{c|l|l|l}
\hline $\mathbf{N}^{\mathbf{0}}$ & \multicolumn{1}{|c|}{ Acidente } & \multicolumn{1}{c}{ Topônimo } & \multicolumn{1}{c}{ Taxionomia } \\
\hline 01 & cidade de & Itiquira (338 - M19) & Hidrotopônimo \\
\hline
\end{tabular}

Fonte dos dados: Carta topográfica da Diretoria de Serviço Geográfico (DSG), Ministério do Exército, 1976 - escala 1:100.000.

Carta topográfica do Instituto Brasileiro de Geográfica e Estatística (IBGE), 1976 - escala 1:100.000.

Mapa da Fundação de Pesquisas Cândido Rondon (FCR), 1983 - escala $1: 250.000$. 


\subsubsection{Características gerais do município de Jaciara}

O município de Jaciara obteve sua autonomia político-administrativa em 1958, ao ser desmembrado dos municípios de Cuiabá e Poxoréu. A cidade de Jaciara localiza-se às margens da rodovia federal BR - 364.

O município de Jaciara possui $1.659 \mathrm{~km}^{2}$ de extensão territorial, dados do Anuário Estatístico de Mato Grosso - 2009, publicado pela SEPLAN - MT. A altitude na cidade de Jaciara é de 367 metros acima do nível do mar.

O topônimo Jaciara possui estrutura simples, formado pela aglutinação das unidades lexicais tupis jaci e ara. Nos estudos toponímicos é classificado, taxionomicamente, como astrotopônimo. Segundo Sampaio, as unidades lexicais tupis possuem as seguintes características:

JACY, corr. ya-cy, a mãe dos frutos, a lua; o mês lunar; o ornato feito de um pedaço de conha branca e telhado em forma de crescente. ARA, s. o dia, o tempo; idade, vez; o que está no alto, em cima, de cima, na eminência: o mundo. (1970, p. 173; 233)

A chegada do chamado 'homem branco' à região de Jaciara começou nas décadas finais do século XIX. Eles se instalaram nas produtivas terras e se dedicaram a produzir gêneros alimentícios. O povoamento, propriamente dito, teve seu início no final da primeira metade do século $X X$, com o incentivo dado pelo Governo Federal ao processo de colonização, visando expandir a fronteira agrícola do país e minimizar a disputa pela posse da terra nas regiões Sul e Sudeste.

A Lei no 695 de 12 de dezembro de 1953 criou o distrito de Jaciara, no município de Cuiabá. O município de Jaciara foi implantado cinco anos depois pela Lei $n^{\circ} 1.188$ de 20 de dezembro de 1958. No final da década de setenta, o município de Jaciara cedeu área para a criação do município de Juscimeira e na década de noventa, novamente, voltou a ceder área para a criação do município de São Pedro da Cipa. 
Atualmente o município de Jaciara está constituído por 03 (três) distritos: Sede, Jatobá e Selma.

O distrito de Jatobá foi criado pela Lei no 2.128 em 21 de janeiro de 1964, pertencente ao município de Jaciara.

O distrito de Selma foi criado pela Lei n² 2.078 em 14 de dezembro de 1963, pertencente ao município de Jaciara.

Com base nas pesquisas socioeconômicas do Anuário Estatístico de Mato Grosso - 2009, os principais produtos agrícolas do município de Jaciara foram: algodão, arroz, cana-de-açúcar, feijão, mandioca, milho e soja. O volume da produção agrícola foi superior a 1.224.079 toneladas. Os principais rebanhos foram: bovino, eqüino, ovino e suíno. Os rebanhos, nessa época, perfaziam um total de 79.515 cabeças.

A população residente, recenseada em 2007 e divulgada pelo Instituto Brasileiro de Geografia e Estatística (IBGE), foi de 24.945 habitantes, sendo que 22.996 encontravam-se na zona urbana e 1.949 na zona rural. A densidade demográfica atingiu o índice de 15,0 hab. $/ \mathrm{km}^{2}$ e a representatividade da população urbana foi superior a $92,2 \%$.

O município de Jaciara localiza-se na mesorregião Sudeste Mato-grossense e é um dos municípios que compõe a microrregião Rondonópolis. Limita-se com os municípios de Campo Verde, Dom Aquino, Juscimeira, Santo Antônio de Leverger e São Pedro da Cipa.

A seguir, anexam-se as relações dos topônimos do município de Jaciara, registrados no mapa elaborado pela Secretaria de Estado de Planejamento e Coordenação Geral do Estado de Mato Grosso (SEPLAN - MT) que integra o corpus desta pesquisa. Os topônimos estão antecedidos pelos seus respectivos acidentes físicos e acidentes antrópicos, também identificados como elementos físicos e elementos humanos de uma paisagem. 


\subsubsection{Relação dos acidentes físicos do município de Jaciara, de seus} topônimos e taxionomias.

\begin{tabular}{|c|c|c|c|}
\hline $\mathbf{N}^{\mathbf{0}}$ & Acidente & Topônimo & Taxionomia \\
\hline 01 & cachoeira da & Fumaça $(\mathrm{J8}, \mathrm{J9})$ & Igneotopônimo \\
\hline 02 & córrego & Água Branca (C7, D8, D7) & Hidrotopônimo \\
\hline 03 & córrego & Água Grande (H8, 19) & Hidrotopônimo \\
\hline 04 & córrego & Areia $(\mathrm{C} 7, \mathrm{C} 8)$ & Litotopônimo \\
\hline 05 & córrego & Bela Vista (H7, G7, G8) & Animotopônimo \\
\hline 06 & córrego & Bela Vista (M6, L6) & Animotopônimo \\
\hline 07 & córrego & Bento Ribeiro (B6, B7, B8) & Antropotopônimo \\
\hline 08 & córrego & Brilhante (F2 a L6) & Cromotopônimo \\
\hline 09 & córrego dos & Bagres (F9, E9) & Zootopônimo \\
\hline 10 & córrego & Cachoeirinha (17 a J9) & Hidrotopônimo \\
\hline 11 & córrego & Chiquinha Maciel (F4 a D8) & Antropotopônimo \\
\hline 12 & córrego & Formoso (M1, M2) & Animotopônimo \\
\hline 13 & córrego & Fortaleza (F6 a G9) & Corotopônimo \\
\hline 14 & córrego & Fundo (M8, M9, M10) & Dimensiotopônimo \\
\hline 15 & córrego & Furnas (F7 a E9) & Geomorfotopônimo \\
\hline 16 & córrego & Granja (C4) & Sociotopônimo \\
\hline 17 & córrego & Grotão I (B7, C8) & Geomorfotopônimo \\
\hline 18 & córrego & Grotão II (F7, G8) & Geomorfotopônimo \\
\hline 19 & córrego & Iapu (N1, N2) & Zootopônimo \\
\hline 20 & córrego & Jacarezinho (F9, G9) & Zootopônimo \\
\hline 21 & córrego & Jatobá (E3 a C5) & Fitotopônimo \\
\hline 22 & córrego do & Jurita (E5 a E7) & Antropotopônimo \\
\hline 23 & córrego & Olho d'Água (G4 a H5) & Hidrotopônimo \\
\hline 24 & córrego & Piraputanga (D1 a A9) & Zootopônimo \\
\hline 25 & córrego & Saia Branca (O1 a L6) & Ergotopônimo \\
\hline 26 & córrego & $\operatorname{Seco}(A 7)$ & Hidrotopônimo \\
\hline 27 & córrego & Sobradinho (D6, D7, D8) & Ecotopônimo \\
\hline 28 & córrego & Tozadinha (G4, G5) & Sociotopônimo \\
\hline 29 & córrego & Verde (I1 a L4) & Cromotopônimo \\
\hline
\end{tabular}


(conclusão)

\begin{tabular}{|l|l|l|l|}
\hline $\mathbf{N}^{\mathbf{2}}$ & \multicolumn{1}{|c|}{ Acidente } & \multicolumn{1}{c|}{ Topônimo } & \multicolumn{1}{c|}{ Taxionomia } \\
\hline 30 & córrego & Vinte e Sete $(\mathrm{H} 9)$ & Numerotopônimo \\
31 & morro & Melado $(\mathrm{C} 5, \mathrm{C} 6)$ & Ergotopônimo \\
32 & ribeirão & Tenente Amaral (H1 a L9) & Axiotopônimo \\
33 & rio & Prata (P1 a O9) & Litotopônimo \\
34 & rio & São Lourenço (A9 a O10) & Hagiotopônimo \\
35 & serra do & Roncador (D5 a B6) & Hidrotopônimo \\
\hline
\end{tabular}

Fonte dos dados: Mapa da Secretaria de Estado de Planejamento e Coordenação Geral do Estado de Mato Grosso (SEPLAN - MT), 1993 - escala 1:100.000.

\subsubsection{Relação dos acidentes humanos do município de Jaciara, de seus topônimos e taxionomias.}

\begin{tabular}{llll}
\hline $\mathbf{N}^{\mathbf{0}}$ & \multicolumn{1}{c}{ Acidente } & Topônimo & \multicolumn{1}{c}{ Taxionomia } \\
\hline 01 & cidade de & Jaciara (J9) & Astrotopônimo \\
02 & distrito & Jatobá (B6) & Fitotopônimo \\
03 & distrito & Selma (A8) & Antropotopônimo \\
\hline
\end{tabular}

Fonte dos dados: Mapa da Secretaria de Estado de Planejamento e Coordenação Geral do Estado de Mato Grosso (SEPLAN - MT), 1993 - escala 1:100.000. 


\subsubsection{Características gerais do município de Juscimeira}

O município de Juscimeira obteve sua autonomia político-administrativa em 1979 ao ser desmembrado do município de Jaciara. A cidade de Juscimeira localizase às margens da rodovia federal BR - 364 .

O município de Juscimeira possui $2.205 \mathrm{~km}^{2}$ de extensão territorial, dados do Anuário Estatístico de Mato Grosso - 2009, publicado pela SEPLAN - MT. A altitude na cidade de Juscimeira é de 251 metros acima do nível do mar.

O topônimo Juscimeira possui estrutura simples, formado pela aglutinação de parte das unidades lexicais Juscelândia e Limeira. Nos estudos toponímicos é classificado, taxionomicamente, como dirrematotopônimo.

O primeiro topônimo do lugar foi Garimpos, pertencia ao município de Poxoréu e, já naquela época, possuía a condição de distrito. Em 21 de janeiro de 1964 a Lei no 2.135 modificou o topônimo do distrito para Juscelândia. Nessa época, havia outro povoado, muito próximo a Juscelândia, denominado Limeira. De acordo com fontes consultadas, ambos formavam um único núcleo urbano. A Lei $n^{\circ} 3.761$ de 29 de junho de 1976 alterou, novamente, a denominação do distrito para Juscimeira, mas já pertencente ao município de Jaciara.

O distrito de Juscimeira foi elevado à categoria de município pela Lei $n^{\circ} 4.148$ de 10 de dezembro de 1979, com área desmembrada do município de Jaciara.

Atualmente o município de Juscimeira está constituído por 04 (quatro) distritos: Sede, Irenápolis, Santa Elvira e São Lourenço de Fátima.

O distrito de Irenapólis foi criado pela Lei no 2.120 em 21 de janeiro de 1964.

O distrito de Santa Elvira foi criado pela Lei no 3.763 em 29 de junho de 1976.

O distrito de São Lourenço de Fátima foi criado pela Lei no 673 em 11 de dezembro de 1953. 
Os fatores que mais contribuíram para transformar o distrito em município foram a qualidade de suas terras, a construção e o asfaltamento da BR-364. Uma das culturas que mais contribui para a receita do município é a cana-de-açúcar.

Com base nas pesquisas socioeconômicas do Anuário Estatístico de Mato Grosso - 2009, os principais produtos agrícolas do município de Juscimeira foram: algodão, arroz, banana, cana-de-açúcar, mandioca, milho e soja. O volume da produção agrícola foi superior a 359.171 toneladas. Os principais rebanhos foram: bovino, eqüino, ovino e suíno. Os rebanhos, nessa época, perfaziam um total de 150.858 cabeças.

A população residente, recenseada em 2007 e divulgada pelo Instituto Brasileiro de Geografia e Estatística (IBGE), foi de 11.830 habitantes, sendo que 8.701 encontravam-se na zona urbana e 3.129 na zona rural. A densidade demográfica atingiu o índice de $5,4 \mathrm{hab} . / \mathrm{km}^{2}$ e a representatividade da população urbana foi superior a $73,6 \%$.

O município de Juscimeira localiza-se na mesorregião Sudeste Matogrossense e é um dos municípios que compõe a microrregião Rondonópolis. Limitase com os municípios de Jaciara, Poxoréu, Rondonópolis, Santo Antônio de Leverger e São Pedro da Cipa.

A seguir, anexam-se as relações dos topônimos do município de Juscimeira, registrados no mapa elaborado pela Fundação de Pesquisas Cândido Rondon (FCR), que integra o corpus desta pesquisa. Os topônimos estão antecedidos pelos seus respectivos acidentes físicos e acidentes antrópicos, também identificados como elementos físicos e elementos humanos de uma paisagem. 
4.5.5.1 Relação dos acidentes físicos do município de Juscimeira, de seus topônimos e taxionomias. 
(continuação)

\begin{tabular}{|c|c|c|c|}
\hline $\mathbf{N}^{\circ}$ & Acidente & Topônimo & Taxionomia \\
\hline 29 & córrego & Fundo (I11 a L11) & Dimensiotopônimo \\
\hline 30 & córrego & Gambá (J7, J8) & Zootopônimo \\
\hline 31 & córrego & Gavião (H2, H3) & Zootopônimo \\
\hline 32 & córrego & Grota Vermelha (E15, G15) & Geomorfotopônimo \\
\hline 33 & córrego & Ibo (N1 a L8) & Zootopônimo \\
\hline 34 & córrego do & Jacu (C19) & Zootopônimo \\
\hline 35 & córrego & Marimbondinho (M7) & Zootopônimo \\
\hline 36 & córrego & Marimbondo (M6, M7) & Zootopônimo \\
\hline 37 & córrego & Motorista $(05,06)$ & Sociotopônimo \\
\hline 38 & córrego & Mulateiro (D12, E12) & Zootopônimo \\
\hline 39 & córrego & Pantanalzinho (F11, G11) & Litotopônimo \\
\hline 40 & córrego & Panturra (E11, E12) & Somatotopônimo \\
\hline 41 & córrego do & Pão (N7) & Ergotopônimo \\
\hline 42 & córrego & Piteira (H8 a G10) & Fitotopônimo \\
\hline 43 & córrego & Piteirinha (H9, G9) & Fitotopônimo \\
\hline 44 & córrego & Pontinha (L10, L9) & Hodotopônimo \\
\hline 45 & córrego & Pulador (C14, D14) & Hidrotopônimo \\
\hline 46 & córrego & Pulador (G14, F13, F12) & Hidrotopônimo \\
\hline 47 & córrego do & Rasga $(\mathrm{J} 6, \mathrm{~J} 7, \mathrm{~L} 7)$ & Antropotopônimo \\
\hline 48 & córrego & Recifezinho (B18) & Geomorfotopônimo \\
\hline 49 & córrego & Russão (M1 a N3) & Etnotopônimo \\
\hline 50 & córrego & São Bento (C15, D15) & Hagiotopônimo \\
\hline 51 & córrego & Seriema $(15, \mathrm{J5})$ & Zootopônimo \\
\hline 52 & córrego & Sucuri (G10 a E10) & Zootopônimo \\
\hline 53 & córrego & Tugore (L9 a H15) & Fitotopônimo \\
\hline 54 & morro & Areia (A20, B21) & Litotopônimo \\
\hline 55 & morro & Vermelho (C18) & Cromotopônimo \\
\hline 56 & rio & Areia (C1 a E8) & Litotopônimo \\
\hline 57 & rio & Prata (H1 a G9) & Litotopônimo \\
\hline 58 & rio & São Lourenço (E8 a S6) & Hagiotopônimo \\
\hline 59 & serra & Beleza (J6 a J8) & Animotopônimo \\
\hline
\end{tabular}


(conclusão)

\begin{tabular}{l|c|c|c}
\hline $\mathbf{N}^{\mathbf{0}}$ & Acidente & Topônimo & Taxionomia \\
\hline 60 & serra do & Colorado $(\mathrm{O} 6, \mathrm{O} 7, \mathrm{~N} 7)$ & Cromotopônimo \\
\hline
\end{tabular}

Fonte dos dados: Mapa da Fundação de Pesquisas Cândido Rondon (FCR), 1986 - escala 1:100.000.

4.5.5.2 Relação dos acidentes humanos do município de Juscimeira, de seus topônimos e taxionomias.

\begin{tabular}{l|l|ll}
\hline $\mathbf{N}^{\mathbf{2}}$ & \multicolumn{1}{c}{ Acidente } & \multicolumn{1}{c}{ Topônimo } & \multicolumn{1}{c}{ Taxionomia } \\
\hline 01 & cidade de & Juscimeira (E9, E10) & Dirrematotopônimo \\
02 & distrito & Irenópolis (E11) & Antropotopônimo \\
03 & distrito & Santa Elvira (H12) & Hagiotopônimo \\
04 & distrito & São Lourenço de Fátima (M8) & Hagiotopônimo \\
05 & localidade & Placa de Santo Antônio (G10, G11) & Dirrematotopônimo
\end{tabular}

Fonte dos dados: Mapa da Fundação de Pesquisas Cândido Rondon (FCR), 1986 - escala 1:100.000. 


\subsubsection{Características gerais do município de Pedra Preta}

O município de Pedra Preta obteve sua autonomia político-administrativa em 1976, ao ser desmembrado do município de Rondonópolis. A cidade de Pedra Preta localiza-se às margens do córrego Águas Claras.

O município de Pedra Preta possui $4.193 \mathrm{~km}^{2}$ de extensão territorial, dados do Anuário Estatístico de Mato Grosso - 2009, publicado pela SEPLAN - MT. A altitude na cidade de Pedra Preta é de 248 metros acima do nível do mar.

O topônimo Pedra Preta possui estrutura composta, formado por substantivo comum + adjetivo. Nos estudos toponímicos é classificado, taxionomicamente, como litotopônimo.

A Lei no 2.133 de 21 de janeiro de 1964 criou o distrito de paz de Pedra Preta. O município de Pedra Preta foi criado pela Lei $n^{\circ} 3.688$ de 13 de maio de 1976, com área desmembrada do município de Rondonópolis.

O município de Pedra Preta, como alguns municípios da microrregião Rondonópolis, teve seu início em um projeto de colonização de terras, desenvolvido na década de cinqüenta do século passado. Consta que no início do povoamento da região, onde atualmente encontra-se o município de Pedra Preta, não havia a mínima infraestrutura para as famílias que se aventuraram a viver naquelas paragens. Todos dependiam da cidade de Rondonópolis, inclusive para se guarnecerem de gêneros alimentícios.

Pode-se dizer que o município de Pedra Preta, como vários municípios matogrossenses, saltou etapas no processo de conquista de sua emancipação políticoadministrativa. Pouco mais de duas décadas foi o intervalo entre o início do povoamento e a criação do município. A ocorrência desse fato deve-se, principalmente, ao expressivo fluxo migratório recebido pelo estado de Mato Grosso, na segunda metade do século $X X$. 
O município de Pedra Preta está constituído por 02 (dois) distritos: Sede e São José do Planalto.

O distrito de São José do Planalto foi criado pela Lei $n^{0} 3.750$ de 18 de junho de 1976, anteriormente toponimizado como Birro.

Com base nas pesquisas socioeconômicas do Anuário Estatístico de Mato Grosso - 2009, os principais produtos agrícolas do município de Pedra Preta foram: algodão, arroz, banana, cana-de-açúcar, feijão, mandioca, milho e soja. O volume da produção agrícola foi superior a 274.387 toneladas. Os principais rebanhos foram: bovino, eqüino, ovino e suíno. Os rebanhos, nessa época, perfaziam um total de 298.365 cabeças.

A população residente, recenseada em 2007 e divulgada pelo Instituto Brasileiro de Geografia e Estatística (IBGE), foi de 15.638 habitantes, sendo que 11.165 encontravam-se na zona urbana e 4.473 na zona rural. A densidade demográfica atingiu o índice de $3,7 \mathrm{hab} . / \mathrm{km}^{2}$ e a representatividade da população urbana foi superior a $71,4 \%$.

O município de Pedra Preta localiza-se na mesorregião Sudeste Matogrossense e é um dos municípios que compõe a microrregião Rondonópolis. Limitase com os municípios de Altas Garças, Guiratinga, Itiquira, Rondonópolis e São José do Povo.

A seguir, anexam-se as relações dos topônimos do município de Pedra Preta, registrados nas cartas topográficas ${ }^{4}$ elaboradas pelo Departamento de Serviço Geográfico (DSG) e Instituto Brasileiro de Geografia e Estatística (IBGE), que integram o corpus desta pesquisa. Os topônimos estão antecedidos pelos seus respectivos acidentes físicos e acidentes antrópicos, também identificados como elementos físicos e elementos humanos de uma paisagem.

\footnotetext{
${ }^{4}$ As seis cartas topográficas que abrangem a área geográfica do município de Pedra Preta são: Jarudore (313), Anhumas (325), Pedra Preta (326), Alto Garças (327) Córrego Cachoeira (337), Itiquira (338).

O número que está entre parênteses, após o nome de cada carta topográfica, corresponde ao número que está colocado, entre parênteses, logo após o topônimo nas relações dos topônimos do município, para facilitar a sua localização na respectiva carta.
} 
4.5.6.1 Relação dos acidentes físicos do município de Pedra Preta, de seus topônimos e taxionomias.

(continua)

\begin{tabular}{|c|c|c|c|}
\hline $\mathbf{N}^{\mathbf{0}}$ & Acidente & Topônimo & Taxionomia \\
\hline 01 & cabeceira do & Açude (326 - U21 a R24) & Hidrotopônimo \\
\hline 02 & cabeceira da & Gibóia (338 - C3 a C8) & Zootopônimo \\
\hline 03 & córrego do & Açude (326 - U5, V4) & Hidrotopônimo \\
\hline 04 & córrego & Água Bonita (327 - F4) & Hidrotopônimo \\
\hline 05 & córrego & Água Fria (325 - P23, Q23) & Hidrotopônimo \\
\hline 06 & córrego & Águas Claras (326 - H1) & Hidrotopônimo \\
\hline 07 & córrego & Anhumas (325 - AB21, AB22) & Zootopônimo \\
\hline 08 & córrego da & Anta (326 - L22, M22) & Zootopônimo \\
\hline 09 & córrego d' & Anta (327-B2, C2) & Zootopônimo \\
\hline 10 & córrego da & Arnica $(327-\mathrm{H} 2)$ & Fitotopônimo \\
\hline 11 & córrego da & Arnica (327 - H3) & Fitotopônimo \\
\hline 12 & córrego & Azulão (326 - AC5, AC6 / 338 - A8 a C8) & Cromotopônimo \\
\hline 13 & córrego & Baixadão (326 - F2, F3, F4) & Geomorfotopônimo \\
\hline 14 & córrego & Barreiro (337 - B26, B25) & Litotopônimo \\
\hline 15 & córrego do & $\begin{array}{l}\text { Birro (325 - AD21 a AD27 / } 337 \text { - A17 a } \\
\text { B15) }\end{array}$ & Zootopônimo \\
\hline 16 & córrego dos & Bois (327 - E2, D2) & Zootopônimo \\
\hline 17 & córrego & Borá (325 - AA22 a V24) & Zootopônimo \\
\hline 18 & córrego & Buritizal (327 - C3, D3, D4) & Fitotopônimo \\
\hline 19 & córrego & Buritizal (327 - F1) & Fitotopônimo \\
\hline 20 & córrego & Cabeceira do Pontal (337 - A20 a B22) & Hidrotopônimo \\
\hline 21 & córrego & Cachoeirinha (326 - L1) & Hidrotopônimo \\
\hline 22 & córrego & Cambaúva (326 - V9, V10) & Fitotopônimo \\
\hline 23 & córrego & Cangussu (325 - T20 a Q26) & Zootopônimo \\
\hline 24 & córrego & Canoa (326 - AB1, AC3 / 338 - A3, B3) & Ergotopônimo \\
\hline 25 & córrego & Confusão (325 - L21, L22) & Sociotopônimo \\
\hline 26 & córrego & Confusão (326 - T1) & Sociotopônimo \\
\hline 27 & córrego & Corgão (326 - O24 a H27) & Hidrotopônimo \\
\hline 28 & córrego & Dobradinho (326 - Z3) & Ergotopônimo \\
\hline 29 & córrego do & Engano (325 - D25 a G27) & Animotopônimo \\
\hline
\end{tabular}


(continuação)

\begin{tabular}{|c|c|c|c|}
\hline $\mathbf{N}^{\circ}$ & Acidente & Topônimo & Taxionomia \\
\hline 30 & córrego & Espraiado (327 - E4) & Hidrotopônimo \\
\hline 31 & córrego da & Fazenda (326 - AC13, AD13) & Sociotopônimo \\
\hline 32 & córrego & Furninha (327 - F3) & Geomorfotopônimo \\
\hline 33 & córrego das & Garças (326 - V24 a T26 / 327 - J1) & Zootopônimo \\
\hline 34 & córrego & Garimpo (325 - V21, V22) & Sociotopônimo \\
\hline 35 & córrego do & Garimpo (326 - AC15, AC16) & Sociotopônimo \\
\hline 36 & córrego & Garrucha (326 - Z9, AA9) & Ergotopônimo \\
\hline 37 & córrego do & Goiano (326 - Q15) & Etnotopônimo \\
\hline 38 & córrego & Grotão (326 - J4, L5) & Geomorfotopônimo \\
\hline 39 & córrego da & Invernada (327 - G2, H2) & Geomorfotopônimo \\
\hline 40 & córrego do & Jaó (326 - V1 / 325 - Z26) & Zootopônimo \\
\hline 41 & córrego & João Irara (326 - S16) & Antropotopônimo \\
\hline 42 & córrego & Lagoa (326 - U15) & Hidrotopônimo \\
\hline 43 & córrego & Lajeadinho (326 - R21 a R26) & Litotopônimo \\
\hline 44 & córrego & Lajeadinho (326 - Z15, Z16) & Litotopônimo \\
\hline 45 & córrego da & Mata (325 - P23, Q23) & Fitotopônimo \\
\hline 46 & córrego & Mesa (326 - T17, S18) & Ergotopônimo \\
\hline 47 & córrego & Monogobinho (326 - H21, H22) & Fitotopônimo \\
\hline 48 & córrego & Monogobo (326 - C19 a L19) & Fitotopônimo \\
\hline 49 & córrego & Olaria (326 - N13, N14, O15) & Sociotopônimo \\
\hline 50 & córrego & Olho-d’Água (327 - F1, E1) & Hidrotopônimo \\
\hline 51 & córrego da & Onça $(327$ - F4, F5) & Zootopônimo \\
\hline 52 & córrego da & Onça (337 - D25) & Zootopônimo \\
\hline 53 & córrego do & Ouro (327 - D1) & Litotopônimo \\
\hline 54 & córrego do & Ouro (327 - E4, F4) & Litotopônimo \\
\hline 55 & córrego & Pedra Preta (325 - J25, L25) & Litotopônimo \\
\hline 56 & córrego do & Pedro (326 - S3, T3) & Antropotopônimo \\
\hline 57 & córrego & Perdido (326 - I12) & Animotopônimo \\
\hline 58 & córrego da & Pinguela (326 - L10 a Q12) & Hodotopônimo \\
\hline 59 & córrego & Piraputanga (327 - B1 / 326 - F25, E26) & Zootopônimo \\
\hline 60 & córrego dos & Porcos (326 - T4) & Zootopônimo \\
\hline
\end{tabular}


(continuação)

\begin{tabular}{|c|c|c|c|}
\hline $\mathbf{N}^{\mathbf{0}}$ & Acidente & Topônimo & Taxionomia \\
\hline 61 & córrego & Potreirinho (327 - E2, D2) & Ergotopônimo \\
\hline 62 & córrego & Queixada (327 - G3) & Zootopônimo \\
\hline 63 & córrego & Retiro Velho (327 - D1, C1) & Sociotopônimo \\
\hline 64 & córrego & Salobro (326 - AD1 / 338 - A1, B1) & Hidrotopônimo \\
\hline 65 & córrego da & $\begin{array}{l}\text { São Domingos (326 - M1 / } 325 \text { - N25, } \\
\text { M26) }\end{array}$ & Hagiotopônimo \\
\hline 66 & córrego do & Sapế (327 - G3, H3) & Fitotopônimo \\
\hline 67 & córrego & Seco $(326-$ B24, B25) & Hidrotopônimo \\
\hline 68 & córrego & $\operatorname{Seco}(327-A 1)$ & Hidrotopônimo \\
\hline 69 & córrego da & Serra (326 - V9) & Geomorfotopônimo \\
\hline 70 & córrego & Submarino (325 - Z25, AA25) & Ergotopônimo \\
\hline 71 & córrego & Sucuri $(325-123,125)$ & Zootopônimo \\
\hline 72 & córrego da & Vaca (327 - G4) & Zootopônimo \\
\hline 73 & córrego da & $\begin{array}{l}\text { Vertente Comprida (325 - AD23, AD24 / } \\
337 \text { - A23, A24) }\end{array}$ & Geomorfotopônimo \\
\hline 74 & morro do & Bugio (326 - T10, T11) & Zootopônimo \\
\hline 75 & morro da & Cruz (326 - AC11, AC12) & Hierotopônimo \\
\hline 76 & morro & Ilha da Esperança (326 - X2, X3, X4) & Geomorfotopônimo \\
\hline 77 & morro da & Máquina (326 - O15, P16) & Ergotopônimo \\
\hline 78 & morro da & Mesa (326 - AA15, AA16) & Ergotopônimo \\
\hline 79 & morro da & Mesa (326 - D24) & Ergotopônimo \\
\hline 80 & morro da & Petrovina (326 - N14, N15) & Antropotopônimo \\
\hline 81 & ribeirão & Corgão (327 - A1 a F1) & Hidrotopônimo \\
\hline 82 & ribeirão & Lajeadinho (327 - H1 a H4) & Litotopônimo \\
\hline 83 & ribeirão & $\begin{array}{l}\text { Ponte de Pedra (337 - E20 a E27 / } 338 \text { - } \\
\text { E1 a F1) }\end{array}$ & Hodotopônimo \\
\hline 84 & ribeirão & Potreirinho (327 - D3 a B3) & Ergotopônimo \\
\hline 85 & ribeirão & Potreiro(327 - D2, D3) & Ergotopônimo \\
\hline 86 & rio & Jurigão (326 - AC23 a O1) & Fitotopônimo \\
\hline 87 & rio & $\begin{array}{l}\text { Jurigue (325 - D26, D27 / } 326 \text { - D1 a } \\
\text { Q3) }\end{array}$ & Fitotopônimo \\
\hline 88 & rio & $\begin{array}{l}\text { Juriguinho (325 - P27 a AA27 / } 326 \text { - P1 } \\
\text { a AE13 / } 338 \text { - B12, B13, A13) }\end{array}$ & Fitotopônimo \\
\hline 89 & rio & $\begin{array}{l}\text { Prata (313 - AE19 a AE27 / } 327 \text { - A1 a } \\
\text { J1 / } 313 \text { - AE16, AE17) }\end{array}$ & Litotopônimo \\
\hline
\end{tabular}


(conclusão)

\begin{tabular}{l|l|l|l}
\hline $\mathbf{N}^{\circ}$ & \multicolumn{1}{c|}{ Acidente } & \multicolumn{1}{c}{ Topônimo } & \multicolumn{1}{c}{ Taxionomia } \\
\hline 90 & serra da & Gibóia (338 - C3 a C8) & Zootopônimo \\
91 & serra & Jega-Jega (326 - E23, E24) & Ergotopônimo \\
92 & serra da & Mesa (326 - Q16, R17) & Ergotopônimo \\
93 & serra da & Petrovina (326- AC23 a O26) & Antropotopônimo \\
94 & serra da & Saudade (326 - AD20, AC21) & Animotopônimo \\
95 & serra & Solteira (326 - S15, S16) & Etnotopônimo \\
\hline
\end{tabular}

Fonte dos dados: Carta topográfica da DSG - Diretoria de Serviço Geográfico (DSG), Ministério do Exército, 1976 - escala 1:100.000.

Carta topográfica do Instituto Brasileiro de Geográfica e Estatística (IBGE), 1976 - escala 1:100.000.

Mapa da Fundação de Pesquisas Cândido Rondon (FCR), 1983 - escala 1:250.000.

\subsubsection{Relação dos acidentes humanos do município de Pedra Preta, de seus topônimos e taxionomias.}

\begin{tabular}{lllll}
\hline $\mathbf{N}^{\mathbf{0}}$ & Acidente & \multicolumn{1}{c}{ Topônimo } & \multicolumn{1}{c}{ Taxionomia } \\
\hline 01 & cidade & Pedra Preta (326-G1) & Litotopônimo \\
02 & distrito & São José do Planalto (325-AD24, AD25) & Hagiotopônimo \\
03 & povoado & Nova Araçatuba (326-Q7) & Cronotopônimo \\
04 & povoado & Petrovina (326 - N16) & Antropotopônimo
\end{tabular}

Fonte dos dados: Carta topográfica da DSG - Diretoria de Serviço Geográfico (DSG), Ministério do Exército, 1976 - escala 1:100.000.

Carta topográfica do Instituto Brasileiro de Geográfica e Estatística (IBGE), 1976 - escala 1:100.000.

Mapa da Fundação de Pesquisas Cândido Rondon (FCR), 1983 - escala 1:250.000. 


\subsubsection{Características gerais do município de Rondonópolis}

O município de Rondonópolis obteve sua autonomia político-administrativa em 1953, ao ser desmembrado do município de Poxoréu. A cidade de Rondonópolis localiza-se às margens do rio Vermelho.

A extensão territorial do município de Rondonópolis é de $4.165 \mathrm{~km}^{2}$, dados do Anuário Estatístico de Mato Grosso - 2009, publicado pela SEPLAN - MT. A altitude na cidade de Rondonópolis é de 227 metros acima do nível do mar.

O topônimo Rondonópolis possui estrutura simples, formado pela aglutinação do substantivo próprio Rondon + sufixo -polis, unidade lexical da língua grega, usada no Brasil como indicativo de cidade, donde "cidade de Rondon". A estrutura do topônimo não afetou seu campo semântico. Nos estudos toponímicos é classificado, taxionomicamente, como historiotopônimo.

O primeiro agrupamento humano que deu origem ao município denominavase Rio Vermelho e, só em 1919, foi alterado para Rondonópolis.

Rondonópolis foi elevado à categoria de distrito pelo Decreto-Lei Estadual $n^{0}$ 208 de 26 de outubro de 1938. O município de Rondonópolis foi criado pela Lei $n^{\circ}$ 666 de 10 de dezembro de 1953 com desmembramento do município de Poxoréu.

Atualmente o município de Rondonópolis está constituído por 05 (cinco) distritos: Sede, Anhumas, Nova Galiléia, Boa Vista e Vila Operária.

O distrito de Anhumas foi criado pela Lei $n^{0} 2.130$ de 21 de janeiro de 1964, pertencente ao município de Rondonópolis.

O distrito de Nova Galiléia foi criado pela Lei nº 3.753 de 18 de junho de 1976, pertencente ao município de Rondonópolis.

O distrito de Boa Vista foi criado pela Lei no 3.720 de 04 de junho de 1976, pertencente ao município de Rondonópolis. 
O distrito de Vila Operária foi criado pela Lei nº 3.766 de 30 de junho de 1976, pertencente ao município de Rondonópolis.

Com base nas pesquisas socioeconômicas do Anuário Estatístico de Mato Grosso - 2009, os principais produtos agrícolas do município de Rondonópolis foram: algodão, arroz, banana, cana-de-açúcar, feijão, mandioca, milho e soja. O volume da produção agrícola foi superior a 273.029 toneladas. Os principais rebanhos foram: bovino, eqüino, ovino e suíno. Os rebanhos, nessa época, perfaziam um total de 378.227 cabeças.

A população residente, recenseada em 2007 e divulgada pelo Instituto Brasileiro de Geografia e Estatística (IBGE), foi de 172.783 habitantes, sendo que 164.969 encontravam-se na zona urbana e 7.814 na zona rural. A densidade demográfica atingiu o índice de 18,2 hab. $/ \mathrm{km}^{2}$ e a representatividade da população urbana foi superior a $95,5 \%$.

O município de Rondonópolis localiza-se na mesorregião Sudeste Matogrossense e é um dos municípios que compõe a microrregião Rondonópolis. Limitase com os municípios de Itiquira, Juscimeira, Poxoréu, Santo Antônio de Leverger e São Pedro da Cipa.

A seguir, anexam-se as relações dos topônimos do município Rondonópolis, registrados no mapa elaborado pela Fundação de Pesquisas Cândido Rondon (FCR) que integra o corpus desta pesquisa. Os topônimos estão antecedidos pelos seus respectivos acidentes físicos e acidentes antrópicos, também identificados como elementos físicos e elementos humanos de uma paisagem. 
4.5.7.1 Relação dos acidentes físicos do município de Rondonópolis, de seus topônimos e taxionomias.

(continua)

\begin{tabular}{|c|c|c|c|}
\hline $\mathbf{N}^{\mathbf{0}}$ & Acidente & Topônimo & Taxionomia \\
\hline 01 & cabeceira & Água Bonita (Z8, AA8) & Hidrotopônimo \\
\hline 02 & cabeceira & Bonita (C13, B12) & Animotopônimo \\
\hline 03 & cabeceira da & Zorra $(A C 9, A B 9)$ & Sociotopônimo \\
\hline 04 & chapada de & Cima da Serra (P5) & Cardinotopônimo \\
\hline 05 & córrego do & Açude (AB9, AC9) & Hidrotopônimo \\
\hline 06 & córrego & Água da Queixada (V8, V9) & Hidrotopônimo \\
\hline 07 & córrego & Água Fria (G6 a F4) & Hidrotopônimo \\
\hline 08 & córrego & Água Limpa (L4, L5, L6) & Hidrotopônimo \\
\hline 09 & córrego & Aguiar (V3) & Antropotopônimo \\
\hline 10 & córrego & Alagoano (H17, G17) & Etnotopônimo \\
\hline 11 & córrego & Aldeia (E10, D9) & Poliotopônimo \\
\hline 12 & córrego & Aldeinha (E10, E11) & Poliotopônimo \\
\hline 13 & córrego & Anhumas (Z8 a X7) & Zootopônimo \\
\hline 14 & córrego & Apoial (S10 a O11) & Zootopônimo \\
\hline 15 & córrego & Arareau (B13 a N10) & Zootopônimo \\
\hline 16 & córrego & Ararial $(\mathrm{N} 3, \mathrm{O} 2)$ & Zootopônimo \\
\hline 17 & córrego & Areia $(\mathrm{H} 2, \mathrm{I} 2)$ & Litotopônimo \\
\hline 18 & córrego & Babaçu (I13 a J15) & Fitotopônimo \\
\hline 19 & córrego & Bagaréu (A13 a H16) & Dimensiotopônimo \\
\hline 20 & córrego & Baixadão (N12, N13) & Geomorfotopônimo \\
\hline 21 & córrego & Bajara (L15, M13) & Zootopônimo \\
\hline 22 & córrego & Bananal (D10, D11) & Fitotopônimo \\
\hline 23 & córrego & Barreirão (J7 a L5) & Litotopônimo \\
\hline 24 & córrego & Barreirinho $(\mathrm{J9}, \mathrm{J} 10)$ & Litotopônimo \\
\hline 25 & córrego & Barreiro (E8) & Litotopônimo \\
\hline 26 & córrego & Baunilha (I5) & Fitotopônimo \\
\hline 27 & córrego do & Bento (J12, L12) & Antropotopônimo \\
\hline 28 & córrego & Beroaba (C10 a A14) & Ergotopônimo \\
\hline 29 & córrego & Berigue (J16 a T15) & Somatotopônimo \\
\hline
\end{tabular}


(continuação)

\begin{tabular}{|c|c|c|c|}
\hline $\mathbf{N}^{\circ}$ & Acidente & Topônimo & Taxionomia \\
\hline 30 & córrego & Beriguinho (L15, L14) & Somatotopônimo \\
\hline 31 & córrego do & Birro (AE7 a $A C 7)$ & Zootopônimo \\
\hline 32 & córrego & Boa Vista (E5 a F7) & Animotopônimo \\
\hline 33 & córrego & Bocodoro (F10, G10) & Zootopônimo \\
\hline 34 & córrego & Buriti $(Z 4, Z 5)$ & Fitotopônimo \\
\hline 35 & córrego & Buriti $(\mathrm{H} 5, \mathrm{H} 6)$ & Fitotopônimo \\
\hline 36 & córrego & Buriti (Q8 a P11) & Fitotopônimo \\
\hline 37 & córrego & Buriti (S7 a R9) & Fitotopônimo \\
\hline 38 & córrego & Cachoeirinha (N8) & Hidrotopônimo \\
\hline 39 & córrego & Campo Limpo $(19,110)$ & Fitotopônimo \\
\hline 40 & córrego & Campo Novo (J5, L4) & Fitotopônimo \\
\hline 41 & córrego & Cascalhinho (G4 a E9) & Litotopônimo \\
\hline 42 & córrego & Cascalho $(\mathrm{N} 15, \mathrm{O} 15)$ & Litotopônimo \\
\hline 43 & córrego & Cateto (D14, D15) & Zootopônimo \\
\hline 44 & córrego & Comprido (AB6 a X6) & Dimensiotopônimo \\
\hline 45 & córrego & Corguinho $(12, \mathrm{~F} 13)$ & Hidrotopônimo \\
\hline 46 & córrego & Esparramo $(07, \mathrm{~N} 8)$ & Sociotopônimo \\
\hline 47 & córrego da & Estiva (F11, D14) & Sociotopônimo \\
\hline 48 & córrego & Furninha (J8) & Geomorfotopônimo \\
\hline 49 & córrego do & Gaúcho (M16) & Etnotopônimo \\
\hline 50 & córrego da & Grota (G13, G14, G15) & Geomorfotopônimo \\
\hline 51 & córrego & Grota $(I 11, \mid 10, J 10)$ & Geomorfotopônimo \\
\hline 52 & córrego da & Grota Seca (E13 a F11) & Geomorfotopônimo \\
\hline 53 & córrego do & Iko $(T 7, T 8)$ & Antropotopônimo \\
\hline 54 & córrego & Jaboti $(018, \mathrm{P} 18)$ & Zootopônimo \\
\hline 55 & córrego & Jatobá (L4, M4) & Fitotopônimo \\
\hline 56 & córrego & Jirau da Onça $(\mathrm{J} 13, \mathrm{~J} 14)$ & Ergotopônimo \\
\hline 57 & córrego da & Lagoa (V8, V9) & Hidrotopônimo \\
\hline 58 & córrego & Lajeadinho (G9 a L10) & Litotopônimo \\
\hline 59 & córrego & Lourencinho (Q8 a M10) & Antropotopônimo \\
\hline 60 & córrego & Macaco (D11 a B13) & Zootopônimo \\
\hline
\end{tabular}


(continuação)

\begin{tabular}{|c|c|c|c|}
\hline $\mathbf{N}^{\circ}$ & Acidente & Topônimo & Taxionomia \\
\hline 61 & córrego & Macaco (D10, D11) & Zootopônimo \\
\hline 62 & córrego & Macaco (H10 a L10) & Zootopônimo \\
\hline 63 & córrego & Macaíba (E13 a I12) & Fitotopônimo \\
\hline 64 & córrego da & Mamona (D11, D10) & Fitotopônimo \\
\hline 65 & córrego & Mangaba (I6) & Fitotopônimo \\
\hline 66 & córrego & Manilha (P11, O11) & Ergotopônimo \\
\hline 67 & córrego & Marajá (P10 a O11) & Fitotopônimo \\
\hline 68 & córrego & Matinha (D10 a E12) & Fitotopônimo \\
\hline 69 & córrego & Medeirão (M17, N17) & Antropotopônimo \\
\hline 70 & córrego & Miau (M4 a L7) & Somatotopônimo \\
\hline 71 & córrego & Miséria (N21, N22) & Sociotopônimo \\
\hline 72 & córrego & Monogobo (N21, O21) & Fitotopônimo \\
\hline 73 & córrego da & Onça (R7, R8, R9) & Zootopônimo \\
\hline 74 & córrego & Paga (Q18 a O17) & Hidrotopônimo \\
\hline 75 & córrego da & Palha (G12, H11) & Fitotopônimo \\
\hline 76 & córrego & Pedra de Fogo (E7, E8) & Litotopônimo \\
\hline 77 & córrego & Piabagre (N2, N3) & Zootopônimo \\
\hline 78 & córrego & Pinguela $(E 9, D 8)$ & Hodotopônimo \\
\hline 79 & córrego & Piqui $(\mathrm{H} 10, \mathrm{H} 11)$ & Fitotopônimo \\
\hline 80 & córrego & Pitaluga (L12, M12) & Antropotopônimo \\
\hline 81 & córrego & Piteira ou Candinho Mineiro (D8 a D10) & $\begin{array}{l}\text { Fitotopônimo ou } \\
\text { Antropotopônimo }\end{array}$ \\
\hline 82 & córrego & Ponte de Pedra $(\mathrm{J} 12, \mathrm{~J} 13)$ & Hodotopônimo \\
\hline 83 & córrego & Pontinha (G2 a E5) & Hodotopônimo \\
\hline 84 & córrego & Queixada (L8) & Zootopônimo \\
\hline 85 & córrego do & Retiro (M8) & Sociotopônimo \\
\hline 86 & córrego & Sapé $(H 2, H 3)$ & Fitotopônimo \\
\hline 87 & córrego do & Sapé (AB8 a Z7) & Fitotopônimo \\
\hline 88 & córrego & Seco (M16 a M13) & Hidrotopônimo \\
\hline 89 & córrego & Sete Voltas $(\mathrm{O} 18, \mathrm{P} 17)$ & Numerotopônimo \\
\hline 90 & córrego & Sucuri (M8) & Zootopônimo \\
\hline 91 & córrego & Sucuri (R11 a Q12) & Zootopônimo \\
\hline
\end{tabular}


(conclusão)

\begin{tabular}{|c|c|c|c|}
\hline $\mathbf{N}^{\mathbf{0}}$ & Acidente & Topônimo & Taxionomia \\
\hline 92 & córrego & Trubial (I2 a H6) & Somatotopônimo \\
\hline 93 & córrego & Tugore (E5 a C10) & Fitotopônimo \\
\hline 94 & córrego da & Vereda Grande (E7, D7) & Hodotopônimo \\
\hline 95 & córrego & Vertente (I8) & Geomorfotopônimo \\
\hline 96 & córrego & Votuporanga (N14, N15) & Meteorotopônimo \\
\hline 97 & morro & Aldeia (E10) & Poliotopônimo \\
\hline 98 & morro & Bagaro (D10) & Ergotopônimo \\
\hline 99 & morro & Cateto (C13, C14) & Zootopônimo \\
\hline 100 & morro da & Cutia (E11) & Zootopônimo \\
\hline 101 & morro & Grande (E9) & Dimensiotopônimo \\
\hline 102 & morro & Mão Dada (C13) & Dirrematotopônimo \\
\hline 103 & morro & Naboreiro (D13) & Zootopônimo \\
\hline 104 & morro do & Papagaio (D7) & Zootopônimo \\
\hline 105 & morro & Pirogueiro (D13) & Zootopônimo \\
\hline 106 & morro & Três Coqueiros (D7) & Numerotopônimo \\
\hline 107 & ribeirão & Ponte de Pedra (AA4 a T5) & Hodotopônimo \\
\hline 108 & rio & Areia ou Coqueial (H16, H17) & $\begin{array}{l}\text { Litotopônimo ou } \\
\text { Zootopônimo }\end{array}$ \\
\hline 109 & rio & Jurigue (R10 a N11) & Fitotopônimo \\
\hline 110 & rio & São Lourenço (G2 a M1) & Hagiotopônimo \\
\hline 111 & rio & Tadarimana (N13 a M19) & Fitotopônimo \\
\hline 112 & rio & Vermelho (M1 a G16) & Cromotopônimo \\
\hline 113 & serra do & Brigadeiro $(\mathrm{O} 2, \mathrm{P} 2)$ & Sociotopônimo \\
\hline 114 & serra & Formosa (Q21, Q22) & Animotopônimo \\
\hline 115 & serra da & Onça $(18,19)$ & Zootopônimo \\
\hline 116 & serra & Santa Joana $(\mathrm{O} 2, \mathrm{~N} 2)$ & Hagiotopônimo \\
\hline 117 & serra & São Jerônimo (T4, S4) & Hagiotopônimo \\
\hline
\end{tabular}

Fonte dos dados: Mapa da Fundação de Pesquisas Cândido Rondon (FCR), 1984 - escala 1:100.000. 
4.5.7.2 Relação dos acidentes humanos do município de Rondonópolis, de seus topônimos e taxionomias.

\begin{tabular}{llll}
\hline $\mathbf{N}^{\mathbf{0}}$ & \multicolumn{1}{c|}{ Acidente } & \multicolumn{1}{c}{ Topônimo } & \multicolumn{1}{c}{ Taxionomia } \\
\hline 01 & cidade de & Rondonópolis (L8 a M11) & Historiotopônimo \\
02 & distrito & Anhumas (X9) & Zootopônimo \\
03 & distrito & Boa Vista (E6) & Animotopônimo \\
04 & distrito & Nova Galiléia (P17) & Cronotopônimo \\
05 & distrito & Vila Operária (J9, J10) & Poliotopônimo \\
06 & colônia & Paulista (I14) & Etnotopônimo \\
07 & vila & Bueno (F13) & Antropotopônimo \\
08 & vila & Cardinal (H9) & Cardinotopônimo \\
09 & vila & Cruzeiro ou Mata Grande (J11) & Hierotopônimo ou \\
10 & vila & Naboreiro (G15, G16) & Fitotopônimo \\
11 & vila & Paulista (M12) & Zootopônimo \\
12 & povoado & Bajara ou Rio Vermelho & Etnotopônimo \\
13 & povoado & Três Pontes (I13) & Zootopônimo ou \\
14 & terra indígena & Tadarimana (M10 a M16) & Hidrotopônimo \\
\hline
\end{tabular}

Fonte dos dados: Mapa da Fundação de Pesquisas Cândido Rondon (FCR), 1984 - escala 1:100.000. 


\subsubsection{Características gerais do município de São José do Povo}

O município de São José do Povo obteve sua autonomia políticoadministrativa em 1989, ao ser desmembrado do município de Rondonópolis. A cidade de São José do Povo localiza-se entre os córregos da Cana e Retiro.

O município de São José do Povo possui $444 \mathrm{~km}^{2}$ de extensão territorial, dados do Anuário Estatístico de Mato Grosso - 2009, publicado pela SEPLAN - MT. A altitude na cidade de São José do Povo é de 281 metros acima do nível do mar.

O topônimo São José do Povo possui estrutura composta, formado por adjetivo + substantivo próprio + conectivo $[\mathrm{de}+\mathrm{o}]+$ substantivo comum. Nos estudos toponímicos é classificado, taxionomicamente, como hagiotopônimo.

São José do Povo foi elevado à categoria de distrito pela Lei $n^{\circ} 3.733$ de 04 de junho de 1976. Em 04 de julho de 1989 foi elevado à categoria de município pela Lei $n^{\circ} 5.486$, que o desmembrou do município de Rondonópolis. Deve-se ressaltar que este é um dos municípios que possui menor extensão territorial no estado de Mato Grosso. Na emancipação político-administrativa sua área total correspondia a menos de $10 \%$ da área total do município de Rondonópolis, do qual se desmembrou.

Atualmente o município de São José do Povo está constituído apenas pelo distrito Sede.

Com base nas pesquisas socioeconômicas do Anuário Estatístico de Mato Grosso - 2009, os principais produtos agrícolas do município de São José do Povo foram: arroz, mandioca e milho. O volume da produção agrícola foi superior a 6.826 toneladas. Os principais rebanhos foram: bovino, eqüino, ovino e suíno. Os rebanhos, nessa época, perfaziam um total de 65.272 cabeças.

A população residente, recenseada em 2007 e divulgada pelo Instituto Brasileiro de Geografia e Estatística (IBGE), foi de 3.305 habitantes, sendo que 1.512 encontravam-se na zona urbana e 1.793 na zona rural. A densidade 
demográfica atingiu o índice de 7,4 hab. $/ \mathrm{km}^{2}$ e a representatividade da população urbana foi superior a $45,7 \%$.

O município de São José do Povo localiza-se na mesorregião Sudeste Matogrossense e é um dos municípios que compõe a microrregião Rondonópolis. Limitase com os municípios de Guiratinga, Pedra Preta, Poxoréu e Rondonópolis.

A seguir, anexam-se as relações dos topônimos do município de São José do Povo, registrados nas cartas topográficas ${ }^{5}$ elaboradas pelo Departamento de Serviço Geográfico (DSG) e Instituto Brasileiro de Geografia e Estatística (IBGE), que integram o corpus desta pesquisa. Os topônimos estão antecedidos pelos seus respectivos acidentes físicos e acidentes antrópicos, também identificados como elementos físicos e elementos humanos de uma paisagem.

\footnotetext{
${ }^{5}$ As duas cartas topográficas que abrangem a área geográfica do município de São José do Povo são: Guiratinga (314) e Pedra Preta (326).

O número que está entre parênteses, após o nome de cada carta topográfica, corresponde ao número que está colocado, entre parênteses, logo após o topônimo nas relações dos topônimos do município, para facilitar a sua localização na respectiva carta.
} 
4.5.8.1 Relação dos acidentes físicos do município de São José do Povo, de seus topônimos e taxionomias.

\begin{tabular}{|c|c|c|c|}
\hline $\mathrm{N}^{\mathbf{0}}$ & Acidente & Topônimo & Taxionomia \\
\hline 01 & córrego & Alagoano (313 - U8) & Etnotopônimo \\
\hline 02 & córrego & Barrinha (326 - B11) & Hidrotopônimo \\
\hline 03 & córrego & Bonito (313 - T14 a V18) & Animotopônimo \\
\hline 04 & córrego & Brilhante (326 - E13, E14) & Cromotopônimo \\
\hline 05 & córrego da & Cana (313 - AB13, AC13) & Fitotopônimo \\
\hline 06 & córrego do & Gaúcho (313 - AE8) & Etnotopônimo \\
\hline 07 & córrego & Jatupe (313 - U10 a V12) & Fitotopônimo \\
\hline 08 & córrego & Medeirão (313 - AD7 / 326 - A7, B6) & Antropotopônimo \\
\hline 09 & córrego & Moreiral (313 - AB16) & Antropotopônimo \\
\hline 10 & córrego & Paga (326 - C8 a H18) & Hidrotopônimo \\
\hline 11 & córrego & Peroba (313 - V12) & Fitotopônimo \\
\hline 12 & córrego & Retiro (313 - AC12) & Sociotopônimo \\
\hline 13 & córrego & Salvação (326 - A13, B13) & Hierotopônimo \\
\hline 14 & córrego & Seco (313 - Z7, Z8) & Hidrotopônimo \\
\hline 15 & córrego & Sucuri (313 - V14) & Zootopônimo \\
\hline 16 & rio & Areia (313 - T9 a T16) & Litotopônimo \\
\hline 17 & rio & Prata (313 - AE12, / 326 - A11 a C6) & Litotopônimo \\
\hline 18 & rio & Tadarimana (313 - AE12, / 326 - A11 a C6) & Fitotopônimo \\
\hline
\end{tabular}

Fonte dos dados: Carta topográfica da Diretoria de Serviço Geográfico (DSG), Ministério do Exército, 1976 - escala 1:100.000.

Carta topográfica do Instituto Brasileiro de Geográfica e Estatística (IBGE), 1976 - escala 1:100.000. 
4.5.8.2 Relação dos acidentes humanos do município de São José do Povo, de seus topônimos e taxionomias.

\begin{tabular}{l|l|c|c}
\hline$N^{\mathbf{0}}$ & \multicolumn{1}{c}{ Acidente } & \multicolumn{1}{c}{ Topônimo } & Taxionomia \\
\hline 01 & cidade de & São José do Povo (313 - AD13) & Hagiotopônimo \\
02 & povoado & Nova Catanduva (326 - D9, D10) & Cronotopônimo \\
\hline
\end{tabular}

Fonte dos dados: Carta topográfica da Diretoria de Serviço Geográfico (DSG), Ministério do Exército, 1976 - escala 1:100.000.

Carta topográfica do Instituto Brasileiro de Geográfica e Estatística (IBGE), 1976 - escala 1:100.000. 


\subsubsection{Características gerais do município de São Pedro da Cipa}

O município de São Pedro da Cipa obteve sua autonomia políticoadministrativa em 1991, ao ser desmembrado dos municípios de Jaciara e Dom Aquino. A cidade de São Pedro da Cipa localiza-se às margens da rodovia federal BR - 364.

O município de São Pedro da Cipa possui $344 \mathrm{~km}^{2}$ de extensão territorial, dados do Anuário Estatístico de Mato Grosso - 2009, publicado pela SEPLAN - MT. A altitude na cidade de São Pedro da Cipa é de 264 metros acima do nível do mar.

O topônimo São Pedro da Cipa possui estrutura composta, formado por adjetivo + substantivo próprio + conectivo [de + a] + sigla. Nos estudos toponímicos é classificado, taxionomicamente, como hagiotopônimo.

Dentre os municípios da microrregião Rondonópolis e que surgiram após processo de colonização de terras, o município de São Pedro da Cipa é o único que conserva em seu topônimo o registro do nome da colonizadora que deu início ao processo de loteamento e povoamento de parte da região. A sigla CIPA é composta pelas iniciais das unidades lexicais Companhia Industrial Pastoril e Agrícola que se instalou naquelas terras na década de cinqüenta do século $X X$.

Deve-se ressaltar, porém, que o primeiro povoamento teve como motivação inicial o garimpo de diamantes. As pedras preciosas eram procuradas nas margens dos cursos d'água que deságuam no rio São Lourenço. Em verdade, o povoamento do distrito de Pombas, que tem origem garimpeira, é bem anterior ao povoamento do distrito Sede do município.

Em 27 de novembro de 1958 a Lei no 1.130 criou o distrito de São Pedro da Cipa, no município de Poxoréu. São Pedro da Cipa foi elevado à categoria de município, trinta e três anos mais tarde, em 20 de dezembro de 1991 pela Lei n $^{\circ}$ 5.906. 
Atualmente o município de São Pedro da Cipa está constituído por 02 (dois) distritos: Sede e Pombas. É o município de menor extensão territorial do estado de Mato Grosso.

O distrito de Pombas foi criado pela Lei no 1.120 de 17 de outubro de 1958 e pertencia ao município de Poxoréu. Após a criação do município de São Pedro da Cipa, passou a pertencer ao novo município.

Com base nas pesquisas socioeconômicas do Anuário Estatístico de Mato Grosso - 2009, os principais produtos agrícolas da microrregião foram: cana-deaçúcar e mandioca. O volume da produção agrícola foi superior a 145.362 toneladas. Os principais rebanhos foram: bovino, eqüino, ovino e suíno. Os rebanhos, nessa época, perfaziam um total de 16.095 cabeças.

A população residente, recenseada em 2007 e divulgada pelo Instituto Brasileiro de Geografia e Estatística (IBGE), foi de 4.028 habitantes, sendo que 3.621 encontravam-se na zona urbana e 407 na zona rural. A densidade demográfica atingiu o índice de 11,7 hab./ $\mathrm{km}^{2}$ e a representatividade da população urbana foi superior a $89,9 \%$.

O município de São Pedro da Cipa localiza-se na mesorregião Sudeste Matogrossense e é um dos municípios que compõe a microrregião Rondonópolis. Limitase com os municípios de Dom Aquino, Jaciara, Juscimeira e Poxoréu.

A seguir, anexam-se as relações dos topônimos do município São Pedro da Cipa, registrados no mapa da Fundação de Pesquisa Cândido Rondon (FCR), que integra o corpus desta pesquisa. Os topônimos estão antecedidos pelos seus respectivos acidentes físicos e acidentes antrópicos, também identificados como elementos físicos e elementos humanos de uma paisagem. 
4.5.9.1 Relação dos acidentes físicos do município de São Pedro da Cipa, de seus topônimos e taxionomias.

\begin{tabular}{|c|c|c|c|}
\hline $\mathbf{N}^{\mathbf{0}}$ & Acidente & Topônimo & Taxionomia \\
\hline 01 & córrego do & Borges (B11, B12) & Antropotopônimo \\
\hline 02 & córrego & Buriti $(B 7, B 8)$ & Fitotopônimo \\
\hline 03 & córrego & Campinas (D7, C8) & Fitotopônimo \\
\hline 04 & córrego & Canavial das Pombas (D3, D4, E3) & Fitotopônimo \\
\hline 05 & córrego & Caninana I (E4, E5, E6) & Zootopônimo \\
\hline 06 & córrego & Caninana II (D4, E4) & Zootopônimo \\
\hline 07 & córrego & Chico Preto (C11, D11) & Antropotopônimo \\
\hline 08 & córrego & Corguinho (A12 a D11) & Hidrotopônimo \\
\hline 09 & córrego do & Doido (C6, C7, D7) & Somatotopônimo \\
\hline 10 & córrego da & Forma (C10, D10) & Ergotopônimo \\
\hline 11 & córrego & Lajinha (D7, C8) & Litotopônimo \\
\hline 12 & córrego & Mateiro (C5, D6) & Zootopônimo \\
\hline 13 & córrego & Piçarra (D9, E9) & Litotopônimo \\
\hline 14 & córrego & Pontal (F3) & Geomorfotopônimo \\
\hline 15 & córrego & Pulador (C9, D9) & Hidrotopônimo \\
\hline 16 & córrego & São Bento (D10) & Hagiotopônimo \\
\hline 17 & córrego & São Domingos (C11, D11) & Hagiotopônimo \\
\hline 18 & córrego & São Paulo (A9 a A11) & Hagiotopônimo \\
\hline 19 & córrego & Seco (D4, E4) & Hidrotopônimo \\
\hline 20 & córrego & Sete (A9) & Numerotopônimo \\
\hline 21 & morro & Baliza (C10) & Ergotopônimo \\
\hline 22 & morro & Baliza (C11) & Ergotopônimo \\
\hline 23 & morro do & Gavião (D10) & Zootopônimo \\
\hline 24 & ribeirão das & Pombas (D3 a A9) & Zootopônimo \\
\hline 25 & rio & Areia (F3) & Litotopônimo \\
\hline 26 & rio & São Lourenço (D3 a F3) & Hagiotopônimo \\
\hline
\end{tabular}

Fonte dos dados: Mapa da Fundação de Pesquisas Cândido Rondon (FCR), 1991 - escala 1:100.000. 
4.5.9.2 Relação do acidente humano do município de São Pedro da Cipa, de seu topônimo e taxionomia.

\begin{tabular}{l|l|l|l}
\hline $\mathbf{N}^{\mathbf{0}}$ & \multicolumn{1}{c|}{ Acidente } & \multicolumn{1}{c}{ Topônimo } & \multicolumn{1}{c}{ Taxionomia } \\
\hline 01 & cidade de & São Pedro da Cipa (E3, E4) & Hagiotopônimo \\
02 & distrito & Pombas (B8) & Zootopônimo \\
\hline
\end{tabular}

Fonte dos dados: Mapa da Fundação de Pesquisas Cândido Rondon (FCR), 1991 - escala 1:100.000. 


\subsubsection{Análise toponímica da microrregião Rondonópolis}

Encontram-se, na primeira parte, as relações de topônimos dos municípios que compõem a microrregião Rondonópolis. As relações agrupam os topônimos por acidentes físicos e por acidentes antrópicos. Permitem a visualização dos topônimos, registrados nos mapas e nas cartas topográficas, dos municípios que compõem o corpus desta pesquisa.

A segunda parte contém maior detalhamento das características dos topônimos registrados nos mapas e nas cartas topográficas. Está dividida em vários subitens a fim de que se tenha uma visualização ampla e, dentro do possível, mais pormenorizada das características toponímicas peculiares da microrregião Rondonópolis.

Os 08 (oito) municípios que compõem a microrregião Rondonópolis estão cartografados em 19 (dezenove) cartas topográficas, na escala de 1:100.000. Para o levantamento dos topônimos utilizou-se, em caráter preliminar, 05 (cinco) mapas municipais na escala de 1:100.000. Os topônimos dos municípios de Itiquira, Pedra Preta e São José do Povo foram coletados em 13 (treze) cartas topográficas, em caráter preliminar, ou seja, os topônimos foram coletados diretamente nas referidas cartas topográficas.

Inserem-se, nesta segunda parte, uma tabela e vários gráficos. A tabela apresenta a quantificação das taxionomias toponímicas, por ordem decrescente de valor, contendo respectivamente, os municípios já citados, por ordem alfabética. As taxionomias toponímicas estão em números absolutos e especificam a quantidade de topônimos por taxionomia, por município e por microrregião. As taxionomias que não possuem topônimos estão marcadas com traços. Os gráficos permitem visualizar a proporção ocupada, em cada taxionomia, pelos municípios da microrregião Rondonópolis.

Quando, porém, ocorre o registro de topônimos em quantidade inferior ou igual a 05 (cinco) na taxionomia ou de mais de 01 (um) topônimo em um ou dois 
municípios, no caso específico da microrregião Rondonópolis, não se apresenta gráfico para a taxionomia.

Registram-se, na microrregião Rondonópolis, 04 (quatro) acidentes físicos e 02 (dois) acidentes antrópicos com dupla denominação. Esses topônimos são conservados pelos habitantes da região e/ou órgãos oficiais, por isso constam nos mapas e nas cartas topográficas dos municípios de Dom Aquino, Juscimeira e Rondonópolis. Como exemplo, pode-se citar o córrego Corgão ou do Boi no município de Juscimeira e a vila Cruzeiro ou Mata Grande em Rondonópolis. No cômputo geral dos topônimos, todos foram considerados.

Deve-se ressaltar que na microrregião Rondonópolis, de forma mais específica, ocorre uma característica bastante peculiar. Há 01 (um) córrego que estabelece divisa entre os municípios de Juscimeira e Rondonópolis que no percurso entre a nascente até a foz recebe 03 (três) topônimos diferentes. Esse aspecto não foi considerado tripla denominação porque, tanto no mapa quanto na carta topográfica, não consta a conjunção alternativa ou que, geralmente, caracteriza a dupla ou a tripla denominação de um acidente físico. Há também 01 (um) rio, com essa característica, que estabelece divisa entre os municípios de Rondonópolis e São José do Povo. Esse rio, no percurso entre a nascente e a foz, recebe duas toponimizações. Pode-se, portanto, por essas constatações considerar que, nestes dois casos, foram denominados trechos desses acidentes físicos.

A tabela que totaliza os topônimos foi elaborada para atender, principalmente, a dois objetivos. O primeiro é a visualização dos topônimos agrupados por taxionomia, por município, e conseqüentemente, por microrregião. O segundo objetivo é subsidiar a análise toponímica, quantitativamente nos vários denotativos, mas principalmente tupi e bororo.

São 618 (seiscentos e dezoito) topônimos na microrregião Rondonópolis. Vale ressaltar, uma vez mais, que dentre os acidentes físicos e antrópicos, 06 (seis) possuem dupla denominação e todos estão computados no total de topônimos. Constam também 02 (dois) acidentes físicos que estabelecem divisas entre dois municípios e possuem mais de um trecho, de seus percursos, toponimizado. São, deste total, 579 (quinhentos e setenta e nove) topônimos que denominam acidentes 
físicos: baía, cabeceiras, cachoeira, chapada, córregos, ilha, lagoas, morretes, morrinho, morros, porto, ribeirões, rios, serras, serrinha e vazantes. São 33 (trinta e três) topônimos que nomeiam acidentes humanos ou antrópicos: colônias, distritos, terra indígena, vilas, povoados, localidade e municípios / cidades.

Os topônimos da microrregião Rondonópolis foram classificados em 28 (vinte e oito) taxionomias. As 10 (dez) taxionomias que mais agrupam topônimos, em valores absolutos, são: 108 (cento e oito) zootopônimos, 82 (oitenta e dois) fitotopônimos, 78 (setenta e oito) hidrotopônimos, 49 (quarenta e nove) litotopônimos, 44 (quarenta e quatro) ergotopônimos, 44 (quarenta e quatro) sociotopônimos, 29 (vinte e nove) antropotopônimos, 28 (vinte e oito) animotopônimos, 28 (vinte e oito) geomorfotopônimos e 25 (vinte e cinco) hagiotopônimos.

Na microrregião Rondonópolis não há topônimos, registrados nos mapas e nas cartas topográficas, na taxionomia de natureza antrópica: mitotopônimos e na taxionomia de natureza física: morfotopônimos.

A tabela de topônimos, em números absolutos por municípios e por taxionomias, encontra-se a seguir. O agrupamento dos topônimos foi realizado com base nas classificações taxionômicas desenvolvidas por Dick (1992, 31-34) e a taxionomia igneotopônimo inserida na dissertação de mestrado (2005). Para a elaboração deste estudo, a pesquisa foi desenvolvida em três fases: levantamento dos topônimos nos mapas e nas cartas topográficas respeitando, evidentemente, os limites legais e atuais de cada município; o agrupamento dos topônimos por taxionomia e o agrupamento das taxionomias por natureza, isto é, por natureza física e por natureza antrópica.

Na seqüência analisa-se, inicialmente, as taxionomias de natureza física, com 11 (onze) taxionomias na microrregião Rondonópolis, com um total de 378 (trezentas e setenta e oito) ocorrências e, em seguida, as taxionomias de natureza antrópica com 17 (dezessete) taxionomias, com um total de 240 (duzentas e quarenta) ocorrências. 
Tabela 3 - Topônimos da microrregião Rondonópolis por municípios e taxionomias.

(continua)

\begin{tabular}{|c|c|c|c|c|c|c|c|c|c|c|}
\hline \multirow[b]{2}{*}{$\mathrm{N}^{\mathrm{o}}$} & \multirow[b]{2}{*}{ Taxionomias } & \multicolumn{8}{|c|}{ municípios } & \multirow{2}{*}{$\begin{array}{l}\text { microrregião } \\
\text { Rondonópolis }\end{array}$} \\
\hline & & $\begin{array}{l}\text { Dom } \\
\text { Aquino }\end{array}$ & Itiquira & Jaciara & Juscimeira & $\begin{array}{l}\text { Pedra } \\
\text { Preta }\end{array}$ & $\begin{array}{l}\text { Rondonó- } \\
\text { polis }\end{array}$ & $\begin{array}{l}\text { São } \\
\text { José do } \\
\text { Povo }\end{array}$ & $\begin{array}{l}\text { São } \\
\text { Pedro } \\
\text { da Cipa }\end{array}$ & \\
\hline 01 & Zootopônimos & 16 & 21 & 4 & 14 & 19 & 27 & 1 & 6 & 108 \\
\hline 02 & Fitotopônimos & 4 & 22 & 2 & 9 & 12 & 26 & 4 & 3 & 82 \\
\hline 04 & Litotopônimos & 6 & 13 & 2 & 5 & 9 & 9 & 2 & 3 & 49 \\
\hline 05 & Ergotopônimos & 7 & 12 & 2 & 3 & 13 & 4 & - & 3 & 44 \\
\hline 06 & Sociotopônimos & 11 & 15 & 2 & 2 & 7 & 6 & 1 & - & 44 \\
\hline 07 & Antropotopônimos & 3 & 3 & 4 & 2 & 5 & 8 & 2 & 2 & 29 \\
\hline 11 & Hodotopônimos & 2 & 4 & - & 1 & 2 & 5 & - & - & 14 \\
\hline 12 & Dimensiotopônimos & 2 & 6 & 1 & 1 & - & 3 & - & - & 13 \\
\hline 13 & Etnotopônimos & 1 & 1 & - & 1 & 2 & 4 & 2 & - & 11 \\
\hline 14 & Somatotopônimos & - & 3 & - & 2 & - & 4 & - & 1 & 10 \\
\hline 15 & Cromotopônimos & 2 & - & 2 & 2 & 1 & 1 & 1 & - & 9 \\
\hline
\end{tabular}


(conclusão)

\begin{tabular}{|c|c|c|c|c|c|c|c|c|c|c|}
\hline \multirow[b]{2}{*}{$\mathrm{N}^{\mathrm{O}}$} & \multirow[b]{2}{*}{ Taxionomias } & \multicolumn{8}{|c|}{ municípios } & \multirow{2}{*}{$\begin{array}{l}\text { microrregião } \\
\text { Rondonópolis }\end{array}$} \\
\hline & & $\begin{array}{l}\text { Dom } \\
\text { Aquino }\end{array}$ & Itiquira & Jaciara & Juscimeira & $\begin{array}{l}\text { Pedra } \\
\text { Preta }\end{array}$ & $\begin{array}{l}\text { Rondonó- } \\
\text { polis }\end{array}$ & \begin{tabular}{|l|} 
São \\
José do \\
Povo
\end{tabular} & $\begin{array}{l}\text { São } \\
\text { Pedro } \\
\text { da Cipa }\end{array}$ & \\
\hline 17 & Hierotopônimos & - & 3 & - & 1 & 1 & 1 & 1 & - & 7 \\
\hline 18 & Cardinotopônimos & 1 & 2 & - & - & - & 2 & - & - & 5 \\
\hline 20 & Dirrematotopônimos & 1 & - & - & 2 & - & 1 & - & - & 4 \\
\hline 21 & Poliotopônimos & - & - & - & - & - & 4 & - & - & 4 \\
\hline 22 & Igneotopônimos & - & 2 & 1 & - & - & - & - & - & 3 \\
\hline 23 & Historiotopônimos & 1 & - & - & 1 & - & 1 & - & - & 3 \\
\hline 27 & Axiotopônimo & - & - & 1 & - & - & - & - & - & 1 \\
\hline 28 & Astrotopônimo & - & - & 1 & - & - & - & - & - & 1 \\
\hline 29 & Mitotopônimo & - & - & - & - & - & - & - & - & - \\
\hline 30 & Morfotopônimo & - & - & - & - & - & - & - & - & - \\
\hline
\end{tabular}




\section{Taxionomias de natureza física da microrregião Rondonópolis}

\section{Zootopônimos}

As unidades lexicais que se referem aos elementos da fauna em geral, quando utilizadas para nominar acidentes físicos e acidentes antrópicos, recebem nos estudos toponímicos, a denominação de zootopônimos. É a taxionomia que mais denomina acidentes na microrregião Rondonópolis. Registram-se 108 (cento e oito) zootopônimos.

São 16 (dezesseis) zootopônimos no município de Dom Aquino, 21 (vinte e um) em Itiquira, 04 (quatro) em Jaciara, 14 (quatorze) em Juscimeira, 19 (dezenove) em Pedra Preta, 27 (vinte e sete) em Rondonópolis, 01 (um) em São José do Povo e 06 (seis) em São Pedro da Cipa. É a taxionomia que mais denomina acidentes nos municípios de Dom Aquino, Juscimeira, Pedra Preta, Rondonópolis e São Pedro da Cipa. Apresenta-se a seguir o gráfico desta taxionomia com os respectivos percentuais por municípios (GRÁFICO 33).

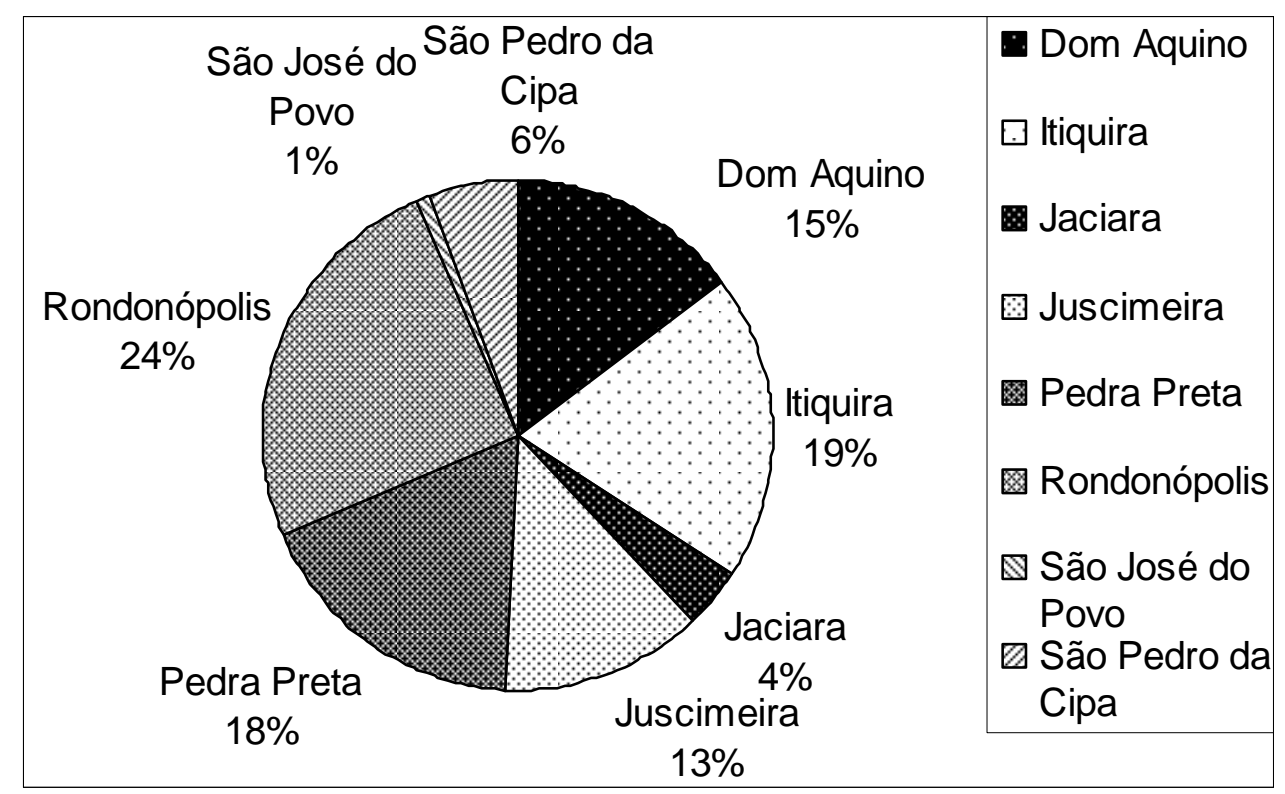

GRÁFICO 33 - Total dos zootopônimos da microrregião Rondonópolis. 
Constata-se que, do total dos zootopônimos registrados na microrregião Rondonópolis, 09 (nove) zootopônimos referem-se a animais domésticos. O zootopônimo Boi é o segundo topônimo de 01 (um) córrego no município de Juscimeira. O zootopônimo Bois denomina 01 (um) córrego em Itiquira e outro em Pedra Preta. O zootopônimo Porcos nomeia 01 (um) córrego em Dom Aquino e outro em Pedra Preta. O zootopônimo Vaca toponimiza 01 (um) córrego em Itiquira e outro em Pedra Preta. No município de Juscimeira o zootopônimo Mulateiro singulariza 01 (um) córrego. Pode-se ainda citar o zootopônimo Tropas que foi inserido nesta taxionomia por considerar que se refere ao conjunto de animais. $O$ zootopônimo Tropas dá nome a 01 (um) córrego em Dom Aquino.

Com base no habitat das espécies, em termos percentuais, na microrregião Rondonópolis, os zootopônimos subdividem-se: 30,6\% são animais que vivem no ar, como por exemplo: distrito Anhumas, córrego Coruja, morro do Gavião, córrego do Jacu; 10,2\% especificam animais que vivem na água, como por exemplo: córrego dos Bagres, córrego Lambari, vazante das Piranhas, córrego Piraputanga e 58,3\% se referem a animais que vivem no solo, tais como: córrego da Anta, córrego do Boi, córrego Cateto, morro da Onça. O zootopônimo Bicho representa 0,9\% do total dos zootopônimos e não está classificado em nenhum habitat citado.

Constam, na microrregião Rondonópolis, 40 (quarenta) zootopônimos tupis, 13 (treze) bororos, 02 (dois) africanos e 53 (cinqüenta e três) portugueses.

O município de Dom Aquino possui 05 (cinco) zootopônimos tupis e 11 (onze) portugueses. O município de Itiquira possui 06 (seis) zootopônimos tupis e 15 (quinze) portugueses. O município de Jaciara possui 04 (quatro) zootopônimos tupis. O município de Juscimeira possui 06 (seis) zootopônimos tupis, 02 (dois) bororos, 02 (dois) africanos e 04 (quatro) portugueses.

O município de Pedra Preta possui 08 (oito) zootopônimos tupis e 11 (onze) portugueses. O município de Rondonópolis possui 08 (oito) zootopônimos tupis, 11 (onze) bororos e 08 (oito) portugueses. O município de São José do Povo possui 01 (um) zootopônimo tupi. O município de São Pedro da Cipa possui 02 (dois) zootopônimos tupis e 04 (quatro) portugueses. 
Considera-se, nesta pesquisa, que os zootopônimos tupis da microrregião Rondonópolis, quanto à estrutura, subdividem-se em simples e híbridos. São 31 (trinta e um) zootopônimos de estrutura simples e 09 (nove) zootopônimos de estrutura híbrida. Eles denominam 39 (trinta e nove) acidentes físicos e 01 (um) acidente antrópico. Os 08 (oito) municípios da microrregião Rondonópolis possuem zootopônimos tupis.

Os zootopônimos Anhumas, Bagres e Piranhas, formados pelas unidades lexicais tupis anhuma, bagre e piranha + desinência de plural $-s$ da língua portuguesa, toponimizam 01 (uma) vazante no município de Itiquira, 01 (um) córrego em Jaciara, 01 (um) córrego que nasce em Pedra Preta e deságua em Rondonópolis, por isso consta nas relações de topônimos dos dois municípios e 01 (um) distrito no município de Rondonópolis.

Os zootopônimos tupis Caninana I e Caninana II, formados pela unidade lexical tupi caninana + algarismo romano, denominam 01 (um) córrego que estabelece divisa entre os municípios de Juscimeira e São Pedro da Cipa, por isso consta nas relações de topônimos dos dois municípios e 01 (um) córrego em São Pedro da Cipa. O zootopônimo tupi Jacarezinho, formado pela unidade lexical tupi jacaré + sufixo -(z)inho, formador de diminutivo da língua portuguesa, dá nome a 01 (um) córrego em Jaciara.

Os zootopônimos tupis de estrutura simples Cotia (grafia registrada no mapa e na carta topográfica), Lambari, Mutum e Quati nomeiam 01 (uma) cabeceira e 04 (quatro) córregos no município de Dom Aquino. A cabeceira da Cotia estabelece divisa entre os municípios de Dom Aquino e Poxoréu, por isso consta nas relações de topônimos dos dois municípios. Os zootopônimos Mutum, Piquiri e Sucuri dão nomes a 04 (quatro) córregos e a 01 (um) rio no município de Itiquira. O rio Piquiri estabelece divisa entre o município de Itiquira e o estado de Mato Grosso do Sul.

Os zootopônimos lapu e o zootopônimo Piraputanga denominam 02 (dois) córregos no município de Jaciara. O córrego Piraputanga estabelece divisa entre os municípios de Jaciara e Campo Verde, por isso consta nas relações de topônimos dos dois municípios. Segundo Sampaio, a unidade lexical tupi iapu possui as 
seguintes características: "IAPÚ, corr. ya-pú, aquelle que é ruidoso, o individuo barulhento. A ave conhecida (Cassicus)." (1970, p.235)

Os zootopônimos Caititu, Gambá, Jacu, Seriema e Sucuri nomeiam 05 (cinco) córregos em Juscimeira. O zootopônimo Sucuri dá nome a 01 (um) córrego em São José do Povo. Os zootopônimos Borá, Cangussu e Gibóia (grafia registrada na carta topográfica), Jaó e Piraputanga nomeiam 01 (uma) cabeceira, 04 (quatro) córregos e 01 (uma) serra no município de Pedra Preta. Os zootopônimos Cateto, Cutia, Jaboti e Sucuri denominam 02 (dois) morros e 03 (três) córregos em Rondonópolis. Registra-se ainda o zootopônimo Sucuri que dá nome a 01 (um) córrego que estabelece divisa entre os municípios de Pedra Preta e Rondonópolis, por isso consta nas relações de topônimos dos dois municípios.

Considera-se, nesta pesquisa, que os zootopônimos bororos da microrregião Rondonópolis possuem estrutura simples. São 13 (treze) zootopônimos de estrutura simples que denominam 11 (onze) acidentes físicos e 02 (dois) acidentes antrópicos. São 02 (dois) municípios da microrregião Rondonópolis que possuem zootopônimos bororos: Juscimeira e Rondonópolis.

Os zootopônimos Bacureréu e Ibo denominam 02 (dois) córregos no município de Juscimeira. O córrego lbo nasce em Santo Antônio de Leverger e deságua em Juscimeira. Os zootopônimos Apoial, Arareau, Ararial, Bocodoro, Naboreiro, Piabagre e Pirogueiro nomeiam 05 (cinco) córregos, 02 (dois) morros e 01 (uma) vila. O córrego Piabagre nasce em Rondonópolis e deságua em Santo Antônio de Leverger. O zootopônimo Bajara dá nome 01 (um) córrego e é o primeiro topônimo de 01 (um) povoado. O zootopônimo Coqueial é o segundo topônimo de 01 (um) rio que estabelece divisa entre os municípios de Rondonópolis e Poxoréu. Todos localizam-se em Rondonópolis. Deve-se anotar que a unidade lexical bororo Ararial é forma variante de Arareau.

As unidades lexicais ibo, naboreiro e pirogueiro, registradas na Enciclopédia Bororo, tem as seguintes características: "Uíbo - * ui, traíra; bó 3 agua [cór. da traíra]. Cór. afl. da dir. do c. m. do Pogúbo Ceréu, rio São Lourenço, Oíbo Grande." Albisetti; Venturelli (1962, p. 959), "Naburéri - * nabúre 2 , ararapiranga; rí1, morro [morro da ararapiranga]: morro Naburere." Albisetti; Venturelli (1962, p. 811) e 
"Pirojéri - piróje, andorinha; rí, morro [morro das andorinhas]. Morro na margem direita do Pogúbo, r. Vermelho." Albisetti; Venturelli (1962, p. 871)

As unidades lexicais apoial, arareau, bacureréu, bajara, bocodoro, coqueial e piabagre estão registradas na Enciclopédia Bororo:

Apue-E-iáo - * ápue, pacas; e, (d)elas; iáo, localidade [rib. das pacas]. Rib. afl. da esq. do Jérigi, rib. Jorigue, cór. Apoiau. Albisetti; Venturelli (1962, p. 83).

Arároe E-iáo - * arároe, piraputangas; e (d)elas; iáo, lugar [cór. das piraputangas]. Designação: 1 . de um cór. afl. da esq. do c. i. do Pogúbo Ceréu, r. São Lourenço: cór Arareau; 2. de um cór. afl. da dir. do c. m. do r. Correntes; 3. de um cór. afl. do Pogúbo, r. Vermelho, na cidade de Rondonópolis: cór Arareau. Albisetti; Venturelli (1962, p. 87)

Bakure $_{1}$ - * ? Designação: 1. de uma vard. de macaco branco de hábitos noturnos (Aotes sp.). Réu - * $\mathbf{r e}_{2}$, existência; $\mathbf{u}$, aquilo [aquilo que é]. Esta f. usada sempre como sufixo indica posse e semelhança. Albisetti; Venturelli (1962, p. 214; p. 901)

Bái Jarí - * bái ${ }_{2}$, urubu; ji, (d)ele; iári, toca [toca do urubu]. Designação: 1. de um cór. afl. da esq. do Jakoreuge E-iáo, r. das Garças, pouco a montante da foz do Kujibo Pó Rurureu, rib. Barreiro; 2. de um cór. afl. do c. i. do Okóge-E-iáo, ribeirão Cogueiau. Albisetti; Venturelli (1962, p. 203)

Bokodóri - * bo, carapaça; kódo, cesta; rí 1 , grandeza [animal com carapaça como grande cesta]. Designação: 1. do tatu-canastra (Priodontes gigantus); 2. de coleópteros mutilídeos indistintamente. Albisetti; Venturelli (1962, p. 505)

Okóge E-iáo - * okóge, dourados; e, (d)êles; iáo, localidade [cór. dos dourados]. Designação: 1. de um cór. afl. do c. m. do Pogúbo, r. Vermelho: rib. Areia ou Floriano ou Coqueiau; 2. de um cór. afl. da esq. do Biagaréu, cór. Biagaréu: cór. Kogueau. Albisetti; Venturelli (1962, p. 831)

Ipíe Baga - * ipíe, ariranha; bága, córrego [cór. da ariranha]. Designação: 1. de um cór. afl. da dir. do Arároe E-iao ${ }_{1}$, cór. Arareau: cór. Piebaga; 2. de um cór. afl. da dir. do c. $m$. do Pogúbo, r. Vermelho: cór. Ipieboga. Albisetti; Venturelli (1962, p. 643)

Considera-se, nesta pesquisa, que os zootopônimos africanos, quanto à estrutura, subdividem-se em simples e híbrido. O zootopônimo africano Marimbondo possui estrutura simples e dá nome a 01 (um) córrego. O zootopônimo Marimbondinho possui estrutura híbrida, formado pela unidade lexical africana 
marimbondo + sufixo -inho, indicador de diminutivo da língua portuguesa e denomina 01 (um) córrego. Ambos localizam-se no município de Juscimeira.

Considera-se, nesta pesquisa, que os zootopônimos portugueses da microrregião Rondonópolis possuem estrutura simples. Eles denominam 52 (cinqüenta e dois) acidentes físicos e 01 (um) acidente antrópico. Os municípios de Jaciara e São José do Povo não possuem zootopônimos portugueses.

O zootopônimo Mateiro, formado pela unidade lexical mata + sufixo -eiro, indicador de naturalidade, denomina 01 (um) córrego no município de São Pedro da Cipa. O zootopônimo Queixada, formado pela unidade lexical queixo + sufixo -ada, indicador de grandeza ou extensão, nomeia 03 (três) córregos em Itiquira, 01 (um) córrego em Pedra Preta e 01 (um) córrego em Rondonópolis.

Os zootopônimos Mateirinha e Mulateiro apresentam dupla sufixação. O zootopônimo Mateirinha, formado pela unidade mata + sufixo -eira + sufixo -inha, já mencionados, dá nome a 01 (um) córrego no município de Itiquira. O zootopônimo Mulateiro, formado pela unidade lexical mula + sufixo -ato, indicador de qualidade ou estado + sufixo -eiro, já mencionado nomina 01 (um) córrego em Juscimeira.

Os zootopônimos Cervo, Coruja e Morcego nomeiam 03 (três) córregos, 01 (um) morro e 01 (uma) serra no município de Dom Aquino. Um dos córregos denominado Morcego estabelece divisa entre os municípios de Dom Aquino e Campo Verde, por isso consta nas relações de topônimos dos dois municípios. Os zootopônimos Anta, Cervo, Cobra, Lobo, Onça, Papagaio e Vaca denominam 02 (duas) cabeceiras, 06 (seis) córregos, 01 (um) morro e 01 (uma) serrinha em Itiquira. Os zootopônimos Bicho e Gavião dão nomes a 02 (dois) córregos em Juscimeira. O zootopônimo Boi é o segundo topônimo de 01 (um) córrego em Juscimeira.

Os zootopônimos Anta, Bugio, Onça e Vaca denominam 05 (cinco) córregos e 01 (um) morro em Pedra Preta. Os zootopônimos Macaco, Onça e Papagaio nomeiam 04 (quatro) córregos, 01 (um) morro e 01 (uma) serra em Rondonópolis. 0 zootopônimo Gavião singulariza 01 (um) morro em São Pedro da Cipa. 
O zootopônimo Birro singulariza 01 (um) córrego que estabelece divisa entre os municípios de Pedra Preta e Rondonópolis, por isso consta nas relações de topônimos dos dois municípios.

Alguns zootopônimos simples, na microrregião Rondonópolis, apresentam desinência de plural $-\mathrm{s}$. Os zootopônimos Pombas, Porcos, Tropas e Veados denominam 01 (um) morro e 04 (quatro) córregos no município de Dom Aquino. $\mathrm{O}$ zootopônimo Pombas também dá nome a 01 (um) distrito em São Pedro da Cipa e a 01 (um) ribeirão que estabelece divisa entre os municípios de Dom Aquino e São Pedro da Cipa, por isso consta nas relações de topônimos dos dois municípios. O zootopônimo Bois dá nome a 01 (um) córrego em Itiquira. Os zootopônimos Bois, Garças e Porcos nomeiam 03 (três) córregos em Pedra Preta.

Ocorre produtividade toponímica, nesta taxionomia, na microrregião Rondonópolis. O zootopônimo Anhumas denomina 01 (um) distrito em Rondonópolis e 01 (um) córrego que nasce em Pedra Preta e deságua em Rondonópolis, por isso consta nas relações de topônimos dos dois municípios. O zootopônimo Cateto dá nome a 01 (um) morro e a 01 (um) córrego em Rondonópolis. O zootopônimo Cotia toponimiza 01 (uma) cabeceira e 01 (um) córrego em Dom Aquino e o zootopônimo Cutia singulariza 01 (um) morro em Rondonópolis. O zootopônimo Gibóia nomeia 01 (uma) cabeceira e 01 (uma) serra em Pedra Preta.

O zootopônimo Mutum dá nome a 01 (um) córrego no município de Dom Aquino e a 02 (dois) córregos em Itiquira. O zootopônimo Piraputanga denomina 01 (um) córrego em Jaciara e outro em Pedra Preta. O zootopônimo Sucuri nomeia 02 (dois) córregos em Itiquira, 01 (um) córrego em Juscimeira, 01 (um) córrego em Rondonópolis, 01 (um) córrego em São José do Povo e 01 (um) córrego que consta nas relações de topônimos de Pedra Preta e Rondonópolis, porque estabelece divisa entre os dois municípios.

O zootopônimo bororo Naboreiro denomina 01 (um) morro e 01 (uma) vila. O zootopônimo Bajara nomina 01 (um) córrego e é o primeiro topônimo de 01 (um) povoado. O zootopônimo Arareau nomeia 01 (um) córrego e sua forma variante o zootopônimo Ararial dá nome a 01 (um) córrego. Todos localizam-se em Rondonópolis 
O zootopônimo Queixada toponimiza 03 (três) córregos no município de Itiquira, 01 (um) córrego em Pedra Preta e outro em Rondonópolis. O zootopônimo Anta dá nome a 01 (uma) cabeceira em Itiquira e a 02 (dois) córregos em Pedra Preta. O zootopônimo Cervo denomina 01 (um) morro em Dom Aquino e 01 (um) córrego em Itiquira. O zootopônimo Gavião singulariza 01 (um) córrego em Juscimeira e 01 (um) morro em São Pedro da Cipa. O zootopônimo Macaco dá nome a 03 (três) córregos em Rondonópolis. O zootopônimo Morcego nomeia 02 (dois) córregos e 01 (uma) serra em Dom Aquino.

O zootopônimo Onça nomeia 03 (três) córregos e 01 (um) morro no município de Itiquira, 02 (dois) córregos em Pedra Preta, 01 (um) córrego e 01 (uma) serra em Rondonópolis. O zootopônimo Papagaio toponimiza 01 (uma) cabeceira em Itiquira e 01 (um) morro em Rondonópolis. O zootopônimo Vaca dá nome a 01 (um) córrego em Itiquira e a outro em Pedra Preta. O zootopônimo Pombas denomina 01 (um) morro e 01 (um) córrego em Dom Aquino, 01 (um) distrito em São Pedro da Cipa e 01 (um) ribeirão que consta nas relações de topônimos dos municípios de Dom Aquino e São Pedro da Cipa, porque estabelece divisa entre os dois municípios. O zootopônimo Porcos denomina 01 (um) córrego em Dom Aquino e outro em Pedra Preta.

Pode-se ainda acrescentar os zootopônimos Caninana I e Caninana II que dão nomes, respectivamente, a 01 (um) córrego que consta nas relações de topônimos de Juscimeira e São Pedro da Cipa porque estabelece divisa entre os dois municípios e a 01 (um) córrego em São Pedro da Cipa. Os zootopônimos Marimbondo e Marimbondinho nominam 02 (dois) córregos em Juscimeira. O zootopônimo Mateiro singulariza 01 (um) córrego em São Pedro da Cipa e o zootopônimo Mateirinha denomina 01 (um) córrego em Itiquira. O zootopônimo Boi é a segunda denominação de 01 (um) córrego em Juscimeira e o zootopônimo Bois designa 01 (um) córrego em Itiquira e outro em Pedra Preta.

O zootopônimo Birro dá nome a 01 (um) córrego que estabelece divisa entre os municípios de Pedra Preta e Rondonópolis, por isso não é considerado produtivo.

Os zootopônimos correspondem a 17,5 \% do total de topônimos da microrregião Rondonópolis. 


\section{Fitotopônimos}

As unidades lexicais que se referem aos elementos da flora em geral, quando utilizadas para denominar acidentes físicos e acidentes antrópicos, recebem nos estudos toponímicos a denominação de fitotopônimos. Registram-se 82 (oitenta e dois) fitotopônimos na microrregião Rondonópolis.

São 04 (quatro) fitotopônimos no município de Dom Aquino, 22 (vinte e dois) em Itiquira, 02 (dois) em Jaciara, 09 (nove) em Juscimeira, 12 (doze) em Pedra Preta, 26 (vinte e seis) em Rondonópolis, 04 (quatro) em São José do Povo e 03 (três) em São Pedro da Cipa. É a taxionomia, no município de São José do Povo, que mais denomina acidentes. Apresenta-se a seguir o gráfico desta taxionomia com os respectivos percentuais por municípios (GRÁFICO 34).

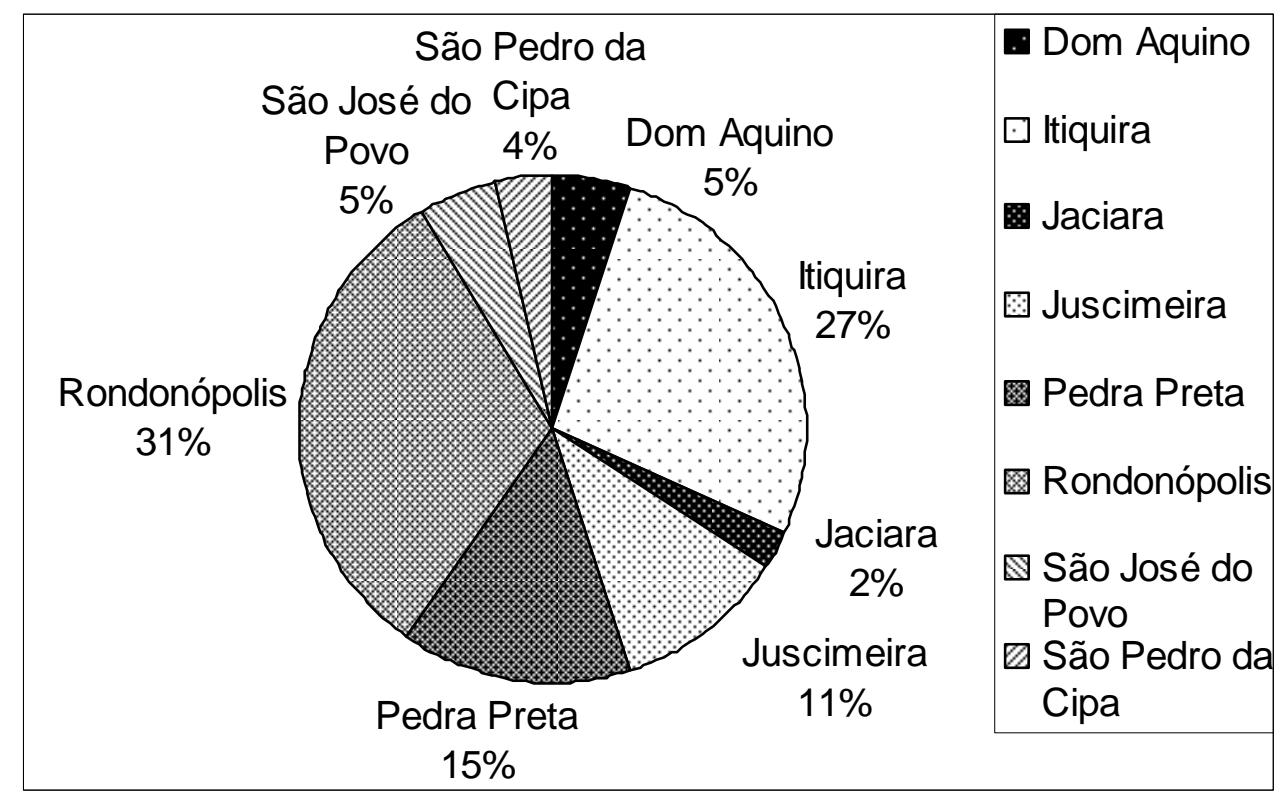

GRÁFICO 34 - Total dos fitotopônimos da microrregião Rondonópolis.

Na microrregião Rondonópolis pode-se constatar, ao observar a relação dos fitotopônimos, que a formação vegetal que possui maior representatividade é a que indica apenas um exemplar por espécie, por exemplo: Arnica, Babaçu, Mamona, Mangaba, etc. Eles correspondem a $67,1 \%$ do total dos fitotopônimos. Também ocorrem fitotopônimos que se referem a mais de um exemplar por espécie ou coletivo: Bananal, Buritizal, Congonhas, Indaial, etc. e representam 14,6\%. Os que 
se referem a formações vegetais variadas, como por exemplo: Campina, Capoeira, Cerradinho, Mata correspondem a 18,3\% do total dos fitotopônimos.

São 34 (trinta e quatro) fitotopônimos tupis, 13 (treze) bororos, 01 (um) africano e 34 (trinta e quatro) portugueses.

O município de Dom Aquino possui 04 (quatro) fitotopônimos portugueses. O município de Itiquira possui 12 (doze) fitotopônimos tupis e 10 (dez) portugueses. O município de Jaciara possui 02 (dois) fitotopônimos tupis. O município de Juscimeira possui 02 (dois) fitotopônimos tupis, 01 (um) bororo e 06 (seis) portugueses.

O município de Pedra Preta possui 04 (quatro) fitotopônimos tupis, 05 (cinco) bororos e 03 (três) portugueses. O município de Rondonópolis possui 12 (doze) fitotopônimos tupis, 05 (cinco) bororos, 01 (um) africano e 08 (oito) portugueses. 0 município de São José do Povo possui 01 (um) fitotopônimo tupi, 02 (dois) bororos e 01 (um) português. O município de São Pedro da Cipa possui 01 (um) fitotopônimo tupi e 02 (dois) portugueses.

São 82 (oitenta e dois) fitotopônimos registrados na microrregião Rondonópolis, deste total verifica-se que 41,5\% equivalente a 34 (trinta e quatro) ocorrências em número absoluto, são de etimologia tupi e 15,8\% equivalente a 13 (treze) ocorrências são de etimologia bororo.

Considera-se, nesta pesquisa, que os fitotopônimos tupis da microrregião Rondonópolis, quanto à estrutura, subdividem-se em simples e híbridos. São 29 (vinte e nove) fitotopônimos de estrutura simples e 05 (cinco) de estrutura híbrida. Eles denominam 33 (trinta e três) acidentes físicos e 01 (um) acidente antrópico. São 07 (sete) municípios da microrregião Rondonópolis que possuem fitotopônimos tupis. Não há registro de fitotopônimo tupi no município de Dom Aquino.

Os fitotopônimos tupis de estrutura híbrida Buritizal e Indaial, formados pelas unidades lexicais tupis buriti e indaiá + sufixo -(z)al, indicador de plantações da língua portuguesa, dão nomes a 01 (um) córrego no município de Itiquira e a 02 (dois) córregos em Pedra Preta. O fitotopônimo Capoeirinha, formado pela unidade lexical tupi capoeira + sufixo -inha, formador de diminutivo da língua portuguesa, nomeia 01 (um) córrego em Itiquira. O fitotopônimo Congonhas, formado pela 
unidade lexical tupi congonha + desinência de plural $-\mathrm{s}$ da língua portuguesa, singulariza 01 (um) córrego em Itiquira.

Os fitotopônimos tupis de estrutura simples Acaiá, Buriti, Capoeira, Guanandi, Macaúba (forma variante), Mangaba, Sapé (forma variante) e Taboca denominam 01 (uma) cabeceira e 08 (oito) córregos no município de Itiquira. O fitotopônimo Jatobá dá nome a 01 (um) distrito e a 01 (um) córrego em Jaciara. Os fitotopônimos Buriti e Cambará nominam 02 (dois) córregos em Juscimeira.

Os fitotopônimos Cambaúva e Sapê nomeiam 02 (dois) córregos no município de Pedra Preta. Os fitotopônimos Babaçu, Buriti, Jatobá, Macaíba, Mangaba, Marajá, Piqui e Sapé denominam 12 (doze) córregos em Rondonópolis. O fitotopônimo Peroba particulariza 01 (um) córrego em São José do Povo. O fitotopônimo Buriti dá nome a 01 (um) córrego em São Pedro da Cipa. Respeitou-se as grafias dos mapas e das cartas topográficas.

O fitotopônimo africano Mamona dá nome a 01 (um) córrego no município de Rondonópolis e, neste estudo, é considerado de estrutura simples.

Considera-se, nesta pesquisa, que os fitotopônimos bororos da microrregião Rondonópolis, quanto à estrutura, subdividem-se em simples e híbridos. São 10 (dez) fitotopônimos de estrutura simples e 03 (três) fitotopônimos de estrutura híbrida. Eles denominam 12 (doze) acidentes físicos e 01 (um) acidente antrópico. São 04 (quatro) municípios da microrregião Rondonópolis que possuem fitotopônimos bororos: Juscimeira, Pedra Preta, Rondonópolis e São José do Povo.

O fitotopônimo bororo de estrutura simples Tugore dá nome ao segundo trecho de 01 (um) córrego que estabelece divisa entre Rondonópolis e Juscimeira, por isso consta nas relações de topônimos dos dois municípios. Os zootopônimos Jurigue e Monogobo nomeiam, respectivamente, 01 (um) rio e 01 (um) córrego que estabelecem divisa entre os municípios de Pedra Preta e Rondonópolis, por isso constam nas relações de topônimos dos dois municípios.

O zootopônimo Jatupe dá nome a 01 (um) córrego no município de São José do Povo. O zootopônimo Tadarimana denomina 01 (uma) terra indígena em Rondonópolis e o segundo trecho de 01 (um) rio que divide os municípios de 
Rondonópolis e São José do Povo, por isso consta nas relações de topônimos dos dois municípios.

As unidades lexicais jurigue, jatupe e monogobo, registradas na Enciclopédia Bororo, possuem as seguintes características: "Jatúgo í - * jatúgo, cajá; í, árvore [árvore do cajá]. Cajazeiro (Spondias lútea)" Albisetti; Venturelli (1962, p. 687); "Jérigi - * ji, sua; erígi, lenha sêca [cór. da lenha sêca]. Cór. afl. da esq. do c. i. do Pogúbo, r. Vermelho, perto da cidade de Rondonópolis: cór. Jorigue." Albisetti; Venturelli (1962, p. 688); "Nonógo - * ? Designação global de duas vards. de urucu: Bixa orellana e Bixa sp." Albisetti; Venturelli (1962, p. 815) e "Bo - son. de pó e ders. Água." Albisetti; Venturelli (1962, p. 278)

As unidades lexicais tadarimana e tugore estão registradas na Enciclopédia Bororo:

Tadári umána - * tadári, tubérculo comestível; u, (d)êle; mána irmão maior [tubérculo do qual o tadári umána é irmão maior]. Vard. de tubérculo da floresta um pouco menor que o tadári. - * $\mathrm{c}$. a. [r. do tubérculo comestível] r. afl. da esq. do Pogúbo, r. Vermelho, a montante da atual cidade de Rondonópolis: r. Tadarimana. Albisetti; Albisetti; Venturelli (1962, p. 917).

Tugóri - * ? Designação: 1. de uma vard. de grande árvore das margens dos rios de cujas frutas são avidíssimos certos peixes 2 . de um rib. afl. da esq. do c. s. do Pogúbo Ceréu, r. São Lourenço: Tugore; 3. de uma elevação na margem esq. do c. s. do Pogúbo Ceréu, r. São Lourenço: Tugore. Albisetti; Venturelli (1962, p. 955)

Os fitotopônimos bororos de estrutura híbrida Juriguinho e Monogobinho, formados pelas unidades lexicais bororas jurigue e monogobo + sufixo -inho, indicador de diminutivo na língua portuguesa, dão nomes a 01 (um) córrego e a 01 (um) rio no município de Pedra Preta. O fitotopônimo Jurigão, formado pela unidade lexical borora jurigue + sufixão -ão, indicador de aumentativo da língua portuguesa, singulariza 01 (um) rio em Pedra Preta.

Considera-se, nesta pesquisa, que os fitotopônimos portugueses da microrregião Rondonópolis, quanto à estrutura, subdividem-se em simples e compostos. São 27 (vinte e sete) fitotopônimos de estrutura simples e 07 (sete) fitotopônimos de estrutura composta. Eles denominam 33 (trinta e três) acidentes 
físicos e 01 (um) acidente antrópico. O município de Jaciara não possui fitotopônimo português.

Os fitotopônimos Coqueiro e Piteira, formados pelas unidades lexicais coco e pita + sufixo -(qu)eiro/a, indicador do que produz, o primeiro nomeia 01 (um) córrego em Juscimeira que estabelece divisa entre os municípios de Juscimeira e Santo Antônio de Leverger. O fitotopônimo Piteira denomina 01 (uma) serra no município de Dom Aquino, 01 (um) córrego em Juscimeira e é o primeiro topônimo de 01 (um) córrego em Rondonópolis. Os fitotopônimos Cerradinho e Piteirinha apresentam dupla sufixação. O fitotopônimo Cerradinho, formado pela unidade lexical cerrar + sufixo -ado, indicador do efeito da ação + sufixo -inho, já mencionado, particulariza 01 (um) córrego em Juscimeira. O fitotopônimo Piteirinha, formado pela unidade lexical pita + sufixo -eira + sufixo -inha, já mencionados, nomeia 01 (um) córrego em Juscimeira.

O fitotopônimo Bananal, formado pela unidade lexical banana + sufixo -al, indicador de plantações, toponimiza 01 (um) córrego no município de Rondonópolis. O fitotopônimo Matinha, formado pela unidade lexical mata + sufixo -inha, já mencionado, dá nome a 01 (um) córrego em Itiquira e a 01 (um) córrego em Rondonópolis. O fitotopônimo Matão, formado pela unidade lexical mata + sufixo ão, já mencionado, denomina 01 (um) córrego em Itiquira. O fitotopônimo Campina, formado pela unidade lexical campo + sufixo -ina, indicador de origem, naturalidade, dá nome a 01 (um) córrego em São Pedro da Cipa. O fitotopônimo Campinas apresenta desinência de plural -s e nomeia 01 (um) córrego em Juscimeira.

Os fitotopônimos simples e não derivados Alecrim, Café e Pimenta denominam 02 (dois) córregos e 01 (uma) serra no município de Dom Aquino. Os fitotopônimos Café, Cedro, Mato e Pita dão nomes a 04 (quatro) córregos em Itiquira. O fitotopônimo Mata toponimiza 01 (uma) cabeceira em Juscimeira. Os fitotopônimos Arnica e Mata nominam 03 (três) córregos em Pedra Preta. Os fitotopônimos Baunilha e Palha nomeiam 02 (dois) córregos em Rondonópolis . O fitotopônimo Cana particulariza 01 (um) córrego em São José do Povo. 0 fitotopônimo Cabaças apresenta desinência de plural -s e nomeia 01 (um) córrego em Itiquira. 
Os fitotopônimos compostos Campo Alegre, Campo Limpo e Campo Novo, formados por substantivo comum + adjetivo, dão nomes a 01 (um) córrego no município de Itiquira e a 02 (dois) córregos em Rondonópolis. O fitotopônimo Mata Grande, formado por substantivo comum + adjetivo, é o segundo topônimo de 01 (uma) vila em Rondonópolis. O fitotopônimo Canavial das Pombas, formado pela unidade lexical cana + sufixo -(vi)al, indicador de plantações + conectivo com desinência de plural $-s+$ substantivo comum com desinência de plural $-s$, dá nome a 01 (um) córrego em São Pedro da Cipa. O fitotopônimo composto Mata-Pasta (grafia registrada no mapa e na carta topográfica), nomeia 01 (um) córrego em Itiquira. O fitotopônimo Pau Terra, formado por substantivo comum + substantivo comum, denomina 01 (um) córrego em Itiquira.

Ocorre produtividade toponímica, nesta taxionomia, na microrregião Rondonópolis. O fitotopônimo Arnica dá nome a 02 (dois) córregos no município de Pedra Preta. O fitotopônimo Café nomeia 01 (um) córrego em Dom Aquino e outro em Itiquira. O fitotopônimo Campina toponimiza 01 (um) córrego em São Pedro da Cipa e o fitotopônimo Campinas denomina 01 (um) córrego em Juscimeira. 0 fitotopônimo Pita nomeia 01 (um) córrego em Itiquira. O fitotopônimo Piteira denomina 01 (uma) serra em Dom Aquino, 01 (um) córrego em Juscimeira e 01 (um) córrego em Rondonópolis. O fitotopônimo Piteirinha singulariza 01 (um) córrego em Juscimeira.

O fitotopônimo Mato dá nome a 01 (um) córrego no município de Itiquira e o fitotopônimo Mata denomina 01 (uma) cabeceira em Juscimeira e 01 (um) córrego em Pedra Preta. O fitotopônimo Matinha nomeia 01 (um) córrego em Itiquira e 01 (um) córrego em Rondonópolis. O fitotopônimo Matão designa 01 (um) córrego em Itiquira e o fitotopônimo Mata Grande particulariza 01 (uma) vila em Rondonópolis. Se considerar apenas a primeira unidade lexical do topônimo composto, pode-se ainda acrescentar o fitotopônimo Campo Alegre que denomina 01 (um) córrego em Itiquira. Os fitotopônimos Campo Limpo e Campo Novo que nominam 02 (dois) córregos em Rondonópolis.

O fitotopônimo Buriti nomina 01 (um) córrego no município de Itiquira, 01 (um) córrego em Juscimeira, 04 (quatro) córregos em Rondonópolis e 01 (um) córrego em São Pedro da Cipa. O fitotopônimo Buritizal dá nome a 02 (dois) córregos em Pedra 
Preta. O fitotopônimo Jatobá toponimiza 01 (um) córrego em Rondonópolis, 01 (um) córrego e 01 (um) distrito em Jaciara. O fitotopônimo Macaíba denomina 01 (um) córrego em Rondonópolis e o fitotopônimo Macaúba singulariza 01 (um) córrego em Itiquira. O fitotopônimo Mangaba nomeia 01 (um) córrego no município de Itiquira e 01 (um) córrego em Rondonópolis.

O fitotopônimo Sapê dá nome a 01 (um) córrego em Pedra Preta. O fitotopônimo Sapé nomeia 02 (dois) córregos em Itiquira e 02 (dois) córregos em Rondonópolis. O fitotopônimo Tadarimana nomina 01 (uma) terra indígena e 0 primeiro trecho de 01 (um) rio que consta nas relações de topônimos dos municípios de Rondonópolis e São José do Povo, porque estabelece divisa entre os dois municípios.

Pode-se ainda considerar produtivos os fitotopônimos Capoeira e Capoeirinha que denominam 02 (dois) córregos no município de Itiquira. O fitotopônimo Jurigue dá nome a 01 (um) rio que consta nas relações de topônimos dos municípios de Pedra Preta e Rondonópolis porque estabelece divisa entre os dois municípios. O fitotopônimo Juriguinho que denomina 01 (um) rio e o fitotopônimo Jurigão que dá nome a 01 (um) rio, ambos em Pedra Preta. O fitotopônimo Monogobo singulariza 01 (um) córrego que consta nas relações de topônimos dos municípios de Pedra Preta e Rondonópolis porque estabelece divisa entre os dois municípios. O fitotopônimo Monogobinho particulariza 01 (um) córrego em Pedra Preta.

O fitotopônimo Tugore denomina o segundo trecho de 01 (um) córrego que consta nas relações de topônimos dos municípios de Juscimeira e Rondonópolis, mas não é considerado produtivo porque estabelece divisa entre eles.

Os fitotopônimos correspondem a 13,3 \% do total de topônimos da microrregião Rondonópolis.

\section{Hidrotopônimos}


As unidades lexicais que se referem a acidentes hídricos, quando utilizadas para dar nomes a acidentes físicos e a acidentes antrópicos, recebem nos estudos toponímicos a denominação de hidrotopônimos. Registram-se 78 (setenta e oito) hidrotopônimos na microrregião Rondonópolis.

São 06 (seis) hidrotopônimos no município de Dom Aquino, 25 (vinte e cinco) em Itiquira, 06 (seis) em Jaciara, 09 (nove) em Juscimeira, 15 (quinze) em Pedra Preta, 11 (onze) em Rondonópolis, 03 (três) em São José do Povo e 03 (três) em São Pedro da Cipa. É a taxionomia que mais denomina acidentes nos municípios de Itiquira e Jaciara. Apresenta-se a seguir o gráfico desta taxionomia com os respectivos percentuais por municípios (GRÁFICO 35).

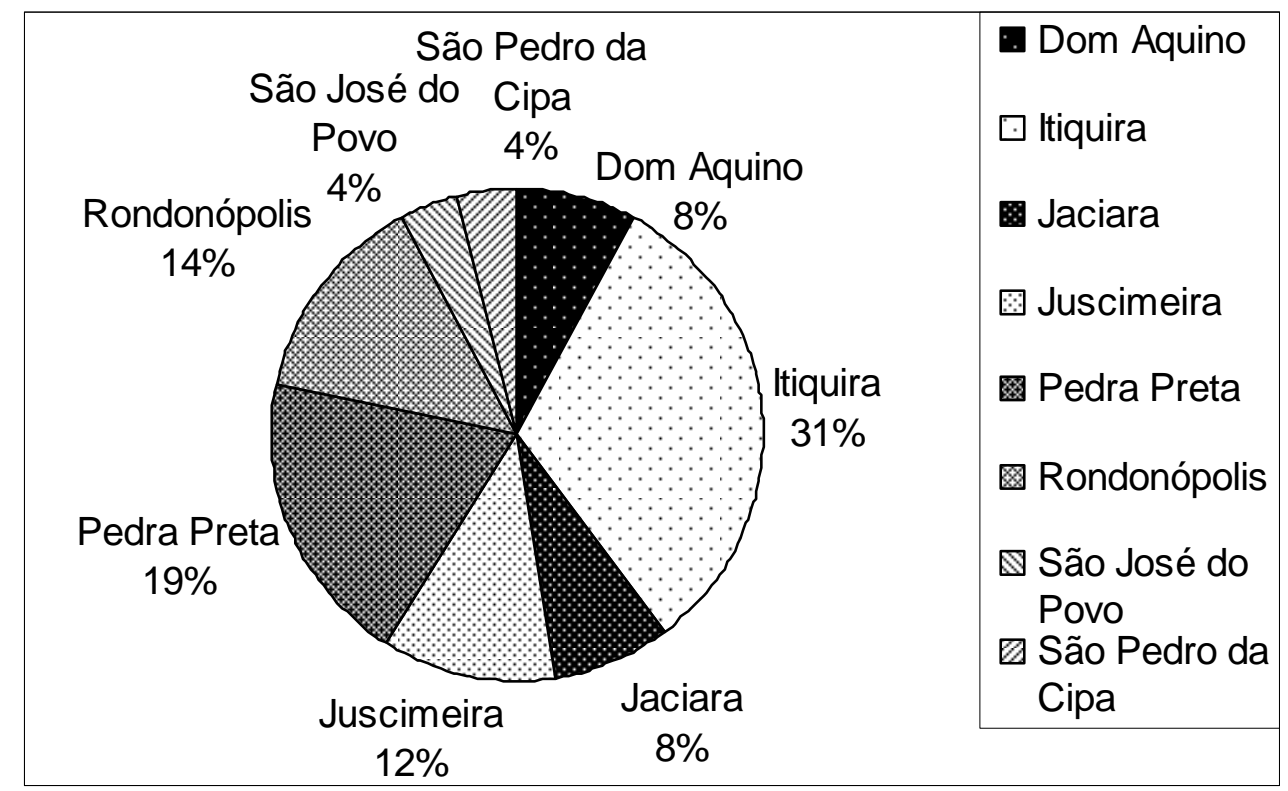

GRÁFICO 35 - Total dos hidrotopônimos da microrregião Rondonópolis.

Constam, na microrregião Rondonópolis, 04 (quatro) hidrotopônimos tupis, 02 (dois) bororos e 72 (setenta e dois) portugueses.

Considera-se, nesta pesquisa, que os hidrotopônimos tupis subdividem-se, quanto à estrutura, em simples e híbrido. Os hidrotopônimos Itiquira e Parnaíba possuem estrutura simples. O hidrototopônimo Parnaíba denomina 01 (um) ribeirão no município de Dom Aquino que estabelece divisa entre os municípios de Dom Aquino e Poxoréu, por isso consta nas relações de topôninos dos dois municípios. O hidrotopônimo Itiquira nomeia 01 (um) município mato-grossense e 01 (um) rio que estabelece divisa do município de Itiquira com os municípios de Alto Garças e Santo 
Antônio de Leverger, por isso consta nas relações de topônimos dos municípios de Itiquira e Alto Garças. O hidrotopônimo tupi de estrutura híbrida Parnaíbas, formado pela unidade lexical tupi parnaíba + desinência de plural -s da língua portuguesa, dá nome a 01 (uma) serra em Dom Aquino.

Segundo Sampaio, as unidades lexicais tupis itiquira e parnaíba possuem as seguintes características: "ITIQUIRA, corr. y-tykyra, a água vertente, o minadouro" (1970, p. 230). "PARNAHIBA, v. Paranahyba." (1970, p. 259). "PARANAHYBA, corr.paranã-ayba, o grande caudal ruim, ou impraticavel. Goyaz, Matto Grosso. Alt. Parnahyba." (1970, p. 260).

Considera-se, nesta pesquisa, que o hidrotopônimo bororo Paga possui estrutura simples e denomina 01 (um) córrego que consta nas relações de topônimos dos municípios de Rondonópolis e São José do Povo, porque estabelece divisa entre os dois municípios.

A unidade lexical paga está registrada na Enciclopédia Bororo e possui as seguintes características: "Pága - $^{*}$ po, água; ága $\mathbf{a}_{\mathbf{1}}$ cabeleira [água como longa cabeleira]. Córrego, riacho." Albisetti; Venturelli (1962, p. 853).

Considera-se, nesta pesquisa, que os hidrotopônimos portugueses da microrregião Rondonópolis, quanto à estrutura, subdividem-se em simples e compostos. São 42 (quarenta e dois) hidrotopônimos de estrutura simples e 30 (trinta) hidrotopônimos de estrutura composta. Eles denominam 71 (setenta e um) acidentes físicos e 01 (um) acidente antrópico. Os 08 (oito) municípios da microrregião Rondonópolis possuem hidrotopônimos portugueses.

O hidrotopônimo composto Açude do Luiz, formado por substantivo comum + conectivo + substantivo próprio, dá nome a 01 (um) córrego no município de Itiquira. O hidrotopônimo Água da Queixada, formado por substantivo comum + conectivo + unidade lexical queixo + sufixo -ada, indicador de grandeza, extensão, nomeia 01 (um) córrego em Rondonópolis.

O hidrotopônimo Cabeceira do Pontal, formado pela unidade lexical cabeça + sufixo -eira, indicador de quantidade, porção + conectivo + unidade lexical ponta + sufixo -al, indicador de grande quantidade, nomina 01 (um) córrego em Pedra Preta. 
Os hidrotopônimos Cabeceira Comprida e Cabeceira Seca, formados pela unidade lexical cabeceira, já mencionada + adjetivo, nomeiam 02 (dois) córregos em Itiquira.

Os hidrotopônimos compostos, formados por substantivo comum + adjetivo, Água Limpa e Água Quente denominam 02 (dois) córregos no município de Dom Aquino. Os hidrotopônimos Água Bonita, Água Fria, Rio Novo e Rio Velho denominam 03 (três) córregos e 01 (uma) ilha em Itiquira. Os hidrotopônimos Água Branca e Água Grande toponimizam 02 (dois) córregos em Jaciara. O hidrotopônimo Águas Claras, formado por substantivo comum + adjetivo, com desinência de plural -s, nomeia 01 (um) córrego em Pedra Preta. O hidrotopônimo Água Enterrada, formado por substantivo comum + unidade lexical enterrar + sufixo -ada, indicador do efeito da ação, nomina 01 (um) córrego em Itiquira. O hidrotopônimo Rego-d'água dá nome a 01 (um) córrego em Itiquira.

Os hidrotopônimos Água Bonita, Água Clara e Água Quente dão nomes a 03 (três) córregos no município de Juscimeira. Os hidrotopônimos Água Bonita e Água Fria nomeiam 02 (dois) córregos em Pedra Preta. Os hidrotopônimos Água Bonita, Água Fria e Água Limpa nomeiam 01 (uma) cabeceira e 02 (dois) córregos em Rondonópolis. O hidrotopônimo Rio Vermelho é o segundo topônimo de 01 (um) povoado em Rondonópolis

Dois hidrotopônimos compostos apresentam variações de grafia nos mapas e nas cartas topográficas. Optou-se por respeitar as grafias registradas que constam nas relações de topônimos, mas mantêm-se, nesta parte, as formas dicionarizadas. O hidrotopônimo Água-emendada, (ocorre também a grafia Água Emendada), dá nome a 02 (dois) córregos em Itiquira. O hidrotopônimo Olho-d'água (ocorrem também as grafias Olho d’Água e Olho-d'Água) toponimiza 01 (um) córrego em Itiquira, 01 (um) córrego em Jaciara e 01 (um) córrego em Pedra Preta.

Os hidrotopônimos simples e não derivados Açude, Limpa e Seca denominam 02 (duas) cabeceiras, 01 (uma) lagoa e 02 (dois) córregos no município de Itiquira. 0 hidrotopônimo Seco dá nome a 01 (um) córrego em Jaciara. O hidrotopônimo Açude singulariza 01 (um) córrego em Juscimeira. Os hidrotopônimos Açude, Lagoa, Salobro e Seco nomeiam 01 (uma) cabeceira e 05 (cinco) córregos em Pedra Preta. Os hidrotopônimos Açude e Lagoa nominam 02 (dois) córregos em Rondonópolis. 0 
hidrotopônimo Seco nomeia 01 (um) córrego em São Pedro da Cipa e 01 (um) córrego que estabelece divisa entre os municípios de Rondonópolis e São José do Povo, por isso consta nas relações de topônimos dos dois municípios.

Os hidrotopônimos Barrinha, Corguinho e Riozinho, formados pelas unidades lexicais barra, corgo (forma sincopada de córrego) e rio + sufixo -(z)inho/a, formador de diminutivo, nomeiam 01 (uma) vazante no município de Itiquira, 01 (um) córrego em São José do Povo, 01 (um) córrego em Rondonópolis e 01 (um) córrego que estabelece divisa entre os municípios de Juscimeira e São Pedro da Cipa, por isso consta nas relações de topônimos dos dois municípios.

Os hidrotopônimos Caldeirão e Ribeirão, formados pelas unidades lexicais caldeira e ribeiro + sufixo -ão, formador de aumentativo, nomeiam, respectivamente, 01 (uma) cabeceira em Itiquira e 01 (um) córrego em Dom Aquino que estabelece divisa entre os municípios de Dom Aquino e Poxoréu, por isso consta nas relaçoes de topônimos dos dois municípios. O hidrotopônimo Corgão, formado pela unidade lexical corgo + sufixo -ão, já mencionado, é o primeiro topônimo de 01 (um) córrego em Juscimeira e dá nome a 01 (um) córrego e 01 (um) ribeirão em Pedra Preta

Os hidrotopônimos Roncador, formado pela unidade lexical roncar + sufixo dor, indicador do agente de ação, denomina 01 (um) córrego no município de Itiquira, 01 (uma) serra em Jaciara e 01 (um) córrego em Dom Aquino que estabelece divisa entre os municípios de Dom Aquino e Campo Verde, por isso conta nas relações de topônimos dos dois municípios. O hidrotopônimo Pulador, formado pela unidade lexical pular + sufixo -dor, já mencionado, nomeia01 (um) córrego em Juscimeira e 01 (um) córrego que nasce em São Pedro da Cipa e deságua no município de Juscimeira, por isso consta nas relações de topônimos dos dois municípios.

O hidrotopônimo Cachoeira, formado pela unidade cacho + sufixo -eira, indicador de quantidade, nomeia 01 (uma) cabeceira e 01 (um) córrego no município de Itiquira. O hidrotopônimo Espraiado, formado pela unidade lexical espraiar + sufixo -ado, indicador do efeito da ação, dá nome a 01 (um) córrego em Pedra Preta. O hidrotopônimo Correntes, formado pela unidade lexical correr + sufixo ente, indicador de lugar onde ocorre + desinência de plural -s, dá nome a 01 (um) 
rio em Itiquira. Esse rio estabelece divisa entre o município de Itiquira e o estado de Mato Grosso do Sul.

O hidrotopônimo Cachoeirinha apresenta dupla sufixação, formado pela unidade lexical cacho + sufixo -eira + sufixo -inha, já mencionados, denomina 01 (um) córrego em Jaciara, 01 (um) córrego em Juscimeira, 01 (um) córrego em Pedra Preta e 01 (um) córrego em Rondonópolis.

$\mathrm{Na}$ microrregião Rondonópolis os hidrotopônimos também apresentam a característica de toponimização do acidente físico. Constam 30 (trinta) acidentes físicos e 01 (um) acidente antrópico denominados por unidades lexicais que, em um sintagma toponímico, exercem a função de termo genérico, ou seja, designam o acidente físico propriamente dito e antecedem o termo específico, isto é, a denominação do acidente.

Os hidrotopônimos simples e não derivados Açude e Lagoa dão nomes a 02 (duas) cabeceiras e a 07 (sete) córregos. Os hidrotopônimos simples e que apresentam derivação Cachoeira, Cachoeirinha, Corgão, Corguinho e Ribeirão nomeiam 01 (uma) cabeceira, 12 (doze córregos), 01 (uma) vazante e 01 (um) ribeirão. Neste contexto, o hidrotopônimo que estabelece divisa entre municípios foi computado uma só vez: o hidrotopônimo Corguinho nomina 01 (um) córrego que divide Juscimeira e São Pedro da Cipa. Os hidrotopônimos de estrutura composta Açude do Luiz, Cabeceira Comprida, Cabeceira do Pontal, Cabeceira Seca, Rio Novo, Rio Velho e Rio Vermelho denominam 05 (cinco) córregos, 01 (uma) ilha e 01 (um) povoado.

Constata-se produtividade toponímica, nesta taxionomia, na microrregião Rondonópolis. O hidrotopônimo Cachoeira nomeia 01 (uma) cabeceira e 01 (um) córrego no município de Itiquira. O hidrotopônimo Cachoeirinha denomina 01 (um) córrego em Jaciara, 01 (um) córrego em Juscimeira, 01 (um) córrego em Pedra Preta e outro em Rondonópolis. O hidrotopônimo Corgão dá nome a 01 (um) córrego em Juscimeira, a 01 (um) córrego e a 01 (um) ribeirão em Pedra Preta. O hidrotopônimo Corguinho singulariza 01 (um) córrego em Rondonópolis e 01 (um) córrego que estabelece divisa entre os municípios de Juscimeira e São Pedro da Cipa. 
O hidrotopônimo Pulador dá nome a 01 (um) córrego no município de Juscimeira e a 01 (um) córrego que nasce no município de São Pedro da Cipa e deságua em Juscimeira. O hidrotopônimo Roncador denomina 01 (um) córrego em Dom Aquino, 01 (um) córrego em Itiquira e 01 (uma) serra em Jaciara. O hidrotopônimo Açude nomeia 01 (uma) cabeceira e 02 (dois) córregos em Itiquira, 01 (uma) cabeceira e 01 (um) córrego em Pedra Preta, 01 (um) córrego em Juscimeira e 01 (um) córrego em Rondonópolis. Pode-se considerar o hidrotopônimo Açude do Luiz que singulariza 01 (um) córrego em Itiquira.

O hidrotopônimo Lagoa denomina 01 (um) córrego no município de Pedra Preta e outro em Rondonópolis. O hidrotopônimo Seca singulariza 01 (uma) lagoa em Itiquira e o hidrotopônimo Seco nomeia 01 (um) córrego em Jaciara, 02 (dois) córregos em Pedra Preta, 01 (um) córrego em São Pedro da Cipa e 01 (um) córrego que estabelece divisa entre os municípios de Rondonópolis e São José do Povo.

O hidrotopônimo Água Bonita toponimiza 01 (uma) cabeceira no município de Rondonópolis, 01 (um) córrego em Itiquira, 01 (um) córrego em Juscimeira e 01 (um) córrego em Pedra Preta. O hidrotopônimo Água Fria nomeia 01 (um) córrego em Itiquira, 01 (um) córrego em Pedra Preta e outro em Rondonópolis. O hidrotopônimo Água Quente dá nome a 01 (um) córrego em Dom Aquino e a outro em Juscimeira. O hidrotopônimo Água Limpa denomina 01 (um) córrego em Dom Aquino e outro em Rondonópolis. O hidrotopônimo Água-emendada singulariza 02 (dois) córregos em Itiquira. O hidrotopônimo Olho-d'água toponimiza 01 (um) córrego em Itiquira, 01 (um) córrego em Jaciara e outro em Pedra Preta. O hidrotopônimo Água Clara denomina 01 (um) córrego em Juscimeira e o hidrotopônimo Águas Claras toponimiza 01 (um) córrego em Pedra Preta.

Se considerar a primeira unidade lexical do topônimo composto pode-se ainda acrescentar os hidrotopônimos Água Branca e Água Grande que denominam 02 (dois) córregos no município de Jaciara. O hidrotopônimo Água Enterrada nomeia 01 (um) córrego em Itiquira e o hidrotopônimo Água da Queixada singulariza 01 (um) córrego em Rondonópolis. Os hidrotopônimos Cabeceira Comprida e Cabeceira Seca nomeiam 02 (dois) córregos em Itiquira. O hidrotopônimo Cabeceira do Pontal particulariza 01 (um) córrego em Pedra Preta. O hidrotopônimo Rio Novo dá nome a 01 (um) córrego e o hidrotopônimo Rio Velho nomeia 01 (uma) ilha, ambos em 
Itiquira. O hidrotopônimo Rio Vermelho é o segundo topônimo de 01 (um) povoado em Rondonópolis.

O hidrotopônimo Itiquira denomina 01 (um) rio e 01 (um) município matogrossense. O hidrotopônimo Parnaíba dá nome a 01 (um) ribeirão e o hidrotopônimo Parnaíbas nomeia 01 (uma) serra, ambos em Dom Aquino. O hidrotopônimo bororo Paga nomina 01 (um) córrego que consta nas relações de topônimos de Rondonópolis e São José do Povo, mas não é considerado produtivo porque estabelece divisa entre os dois municípios.

Os hidrotopônimos correspondem a $12,6 \%$ do total de topônimos da microrregião Rondonópolis.

\section{Litotopônimos}

As unidades lexicais que se referem aos elementos geológicos, quando utilizadas para denominar acidentes físicos e acidentes antrópicos, recebem nos estudos toponímicos a denominação de litotopônimos. Registram-se 49 (quarenta e nove) litotopônimos na microrregião Rondonópolis.

São 06 (seis) litotopônimos no município de Dom Aquino, 13 (treze) em Itiquira, 02 (dois) em Jaciara, 05 (cinco) em Juscimeira, 09 (nove) em Pedra Preta, 09 (nove) em Rondonópolis, 02 (dois) em São José do Povo e 03 (três) em São Pedro da Cipa. Apresenta-se a seguir o gráfico desta taxionomia com os respectivos percentuais por municípios (GRÁFICO 36). 


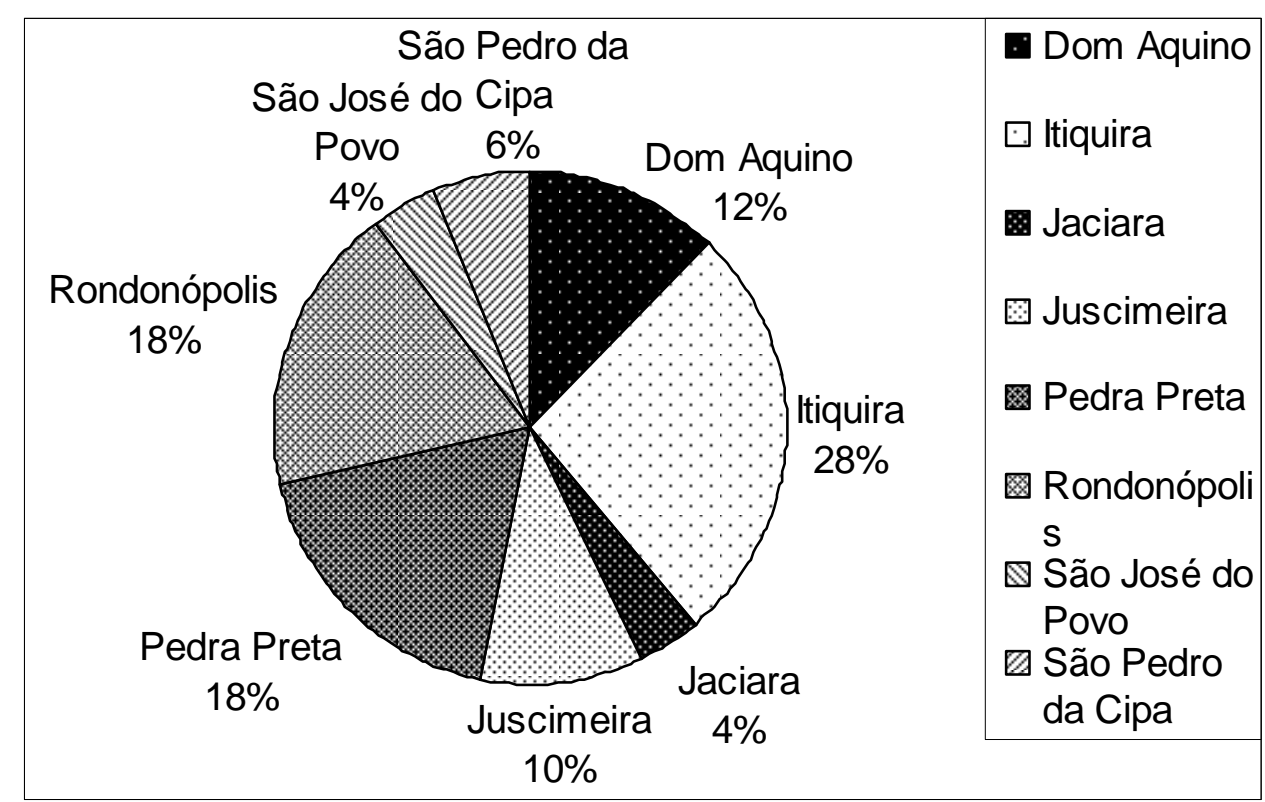

GRÁFICO 36 - Total dos litotopônimos da microrregião Rondonópolis.

São 01 (um) litotopônimo tupi e 48 (quarenta e oito) litotopônimos portugueses na microrregião Rondonópolis.

Considera-se, nesta pesquisa, que o litotopônimo tupi Cupim possui estrutura simples. Ele dá nome a 01 (um) córrego no município de Dom Aquino que estabelece divisa entre os municípios de Dom Aquino e Campo Verde, por isso consta nas relações de topônimos dos dois municípios.

Considera-se, nesta pesquisa, que os litotopônimos portugueses, quanto à estrutura, subdividem-se em simples e compostos. São 42 (quarenta e dois) litotopônimos de estrutura simples e 06 (seis) litotopônimos de estrutura composta. Eles denominam 47 (quarenta e sete) acidentes físicos e 01 (um) antrópico. Os 08 (oito) municípios da microrregião Rondonópolis possuem litotopônimos portugueses.

Os litotopônimos compostos Barro Amarelo e Pedra Preta, formados por substantivo comum + adjetivo, dão nomes a 01 (um) córrego no município de Juscimeira, a 01 (um) córrego em Pedra Preta e a 01 (um) município matogrossense. O litotopônimo Pedra de Fogo, formado por substantivo comum + preposição + substantivo comum, nomeia 01 (um) córrego em Rondonópolis, 01 (um) morrete e 01 (um) ribeirão em Itiquira. 
Os litotopônimos simples subdividem-se em simples sem derivação e simples com derivação. O litotopônimo simples e sem derivação Chibiu (grafia registrada no mapa e na carta topográfica) denomina 01 (um) córrego no município de Dom Aquino e é o segundo topônimo de 01 (um) morro em Dom Aquino. O litotopônimo Pântano dá nome a 01 (um) córrego em Itiquira. O litotopônimo Ouro denomina 02 (dois) córregos em Pedra Preta. O litotopônimo Piçarra dá nome a 01 (um) córrego em São Pedro da Cipa. O litotopônimo Pedras apresenta desinência de plural -s e singulariza 01 (uma) baía e 01 (um) córrego em Itiquira.

O litotopônimo Areia nomeia 01 (um) morro no município de Juscimeira que estabelece divisa entre os municípios de Juscimeira e Poxoréu, 01 (um) rio que estabelece divisa entre os municípios de Juscimeira e São Pedro da Cipa, 01 (um) rio que consta nas relações de topônimos dos municípios de Rondonópolis e São José do Povo e esse rio estabelece divisa desses dois municípios com o município de Poxoréu, por isso consta nas relações de topônimos dos referidos municípios. No município de Rondonópolis consta como o primeiro topônimo desse rio. 0 litotopônimo Areia também dá nome a 01 (um) córrego em Itiquira, a 01 (um) córrego em Jaciara e a 01 (um) córrego em Rondonópolis.

O litotopônimo Prata denomina 01 (um) córrego no município de Dom Aquino, 01 (um) córrego em Itiquira e 01 (um) rio que consta nas relações de topônimos de quatro municípios da microrregião Rondonópolis: Jaciara, Juscimeira, Pedra Preta e São José do Povo.

Pode-se observar, nesta taxionomia, que alguns litotopônimos apresentam dupla sufixação. O litotopônimo Barreirinho, formado pela unidade lexical barro + sufixo -eiro, indicador de quantidade porção + sufixo -inho, indicador de diminutivo, dá nome a 02 (dois) córregos em Itiquira e a 01 (um) córrego em Rondonópolis. 0 litotopônimo Cascalhinho, formado pela unidade lexical casca + sufixo -alho, indicador de diminutivo + sufixo -inho, já mencionado, nomeia 01 (um) córrego em Rondonópolis.

O litotopônimo Lajeadinho, formado pela unidade lexical laje + sufixo -ado, indicador de quantidade, porção + sufixo -inho, já mencionado, denomina 01 (um) córrego em Itiquira, 01 (um) córrego em Rondonópolis, 02 (dois) córregos e 01 (um) 
ribeirão em Pedra Preta. O litotopônimo Pantanalzinho, formado pela unidade lexical pântano + sufixo -al, indicador de grande quantidade + sufixo -inho, já mencionado, denomina 01 (um) córrego no município de Juscimeira. O litotopônimo Barreirão, formado pela unidade lexical barro + sufixo -eiro, já mencionado + sufixo -ão, indicador de aumentativo, denomina 01 (um) córrego em Rondonópolis.

O litotopônimo Lajeado, formado pela unidade lexical laje + sufixo -ado, já mencionado, singulariza 01 (um) córrego em Itiquira. O litotopônimo Lajinha, formado pela unidade lexical laje + sufixo -inha, já mencionado, dá nome a 01 (um) córrego em Dom Aquino e a 01 (um) córrego em São Pedro da Cipa. O litotopônimo Cascalho, formado pela unidade lexical casca + sufixo -alho, indicador de diminutivo, toponimiza 01 (um) córrego em Rondonópolis. O litotopônimo Pedregulho, formado pela unidade lexical pedra + sufixo -(eg)ulho, indicador de coleção, nomeia 01 (um) córrego em Itiquira.

O litotopônimo Barroso, formado pela unidade lexical barro + sufixo -oso, indicador de abundância, dá nome a 01 (um) córrego no município de Dom Aquino. O litotopônimo Atolador, formado pela unidade lexical atolar + sufixo -dor, indicador de qualidade ou estado, toponimiza 01 (um) córrego em Itiquira. O litotopônimo Barreiro, formado pela unidade lexical barro + sufixo -eiro, já mencionado, nomeia 01 (um) córrego em Pedra Preta e 01 (um) córrego em Rondonópolis.

Ocorre produtividade toponímica, nesta taxionomia, na microrregião Rondonópolis. O litotopônimo Areia denomina 01 (um) córrego no município de Itiquira, 01 (um) córrego em Jaciara, 01 (um) córrego em Rondonópolis, 01 (um) morro em Juscimeira, 01 (um) rio que consta nas relações de topônimo de Rondonópolis e São José do Povo e outro rio que consta nas relações de topônimos de Juscimeira e São Pedro da Cipa. O litotopônimo Pedras dá nome a 01 (uma) baía e a 01 (um) córrego em Itiquira. O litotopônimo Pedra de Fogo toponimiza 01 (um) córrego em Rondonópolis, 01 (um) morrete e 01 (um) ribeirão no município de Itiquira. O litotopônimo Pedra Preta dá nome a 01 (um) córrego em Pedra Preta e a 01 (um) município mato-grossense.

O litotopônimo Chibiu denomina 01 (um) córrego e 01 (um) morro no município de Dom Aquino. O litotopônimo Ouro nomeia 02 (dois) córregos em Pedra 
Preta. O litotopônimo Prata toponimiza 01 (um) córrego em Dom Aquino, 01 (um) córrego em Itiquira e 01 (um) rio que consta nas relações de topônimos de quatro municípios: Jaciara, Juscimeira, Pedra Preta e São José do Povo.

O litotopônimo Barreirinho dá nome a 02 (dois) córregos em Itiquira e a 01 (um) córrego em Rondonópolis. O litotopônimo Barreiro denomina 01 (um) córrego em Pedra Preta e 01 (um) córrego em Rondonópolis. O litotopônimo Barreirão singulariza 01 (um) córrego em Rondonópolis. O litotopônimo Lajeadinho nomeia 01 (um) córrego em Itiquira, 01 (um) córrego em Rondonópolis, 02 (dois) córregos e 01 (um) ribeirão em Pedra Preta. O litotopônimo Lajinha denomina 01 (um) córrego em Dom Aquino e outro em São Pedro da Cipa. Pode-se ainda acrescentar o litotopônimo Lajeado que dá nome a 01 (um) córrego em Itiquira. O litotopônimo Cascalho que particulariza 01 (um) córrego e o litotopônimo Cascalhinho que nomeia 01 (um) córrego, ambos em Rondonópolis.

Os litotopônimos correspondem a 7,9\% do total de topônimos da microrregião Rondonópolis.

\section{Geomorfotopônimos}

As unidades lexicais que se referem às formas geomorfológicas da superfície terrestre, quando usadas para dar nomes a acidentes físicos e a acidentes antrópicos, recebem nos estudos toponímicos a denominação de geomorfotopônimos. Registram-se 28 (vinte e oito) geomorfotopônimos na microrregião Rondonópolis.

São 03 (três) geomorfotopônimos no município de Dom Aquino, 06 (seis) em Itiquira, 03 (três) em Jaciara, 02 (dois) em Juscimeira, 07 (sete) em Pedra Preta, 06 (seis) em Rondonópolis e 01 (um) em São Pedro da Cipa. O município de São José do Povo não possui geomorfotopônimo. Apresenta-se a seguir o gráfico desta taxionomia com os respectivos percentuais por municípios (GRÁFICO 37). 


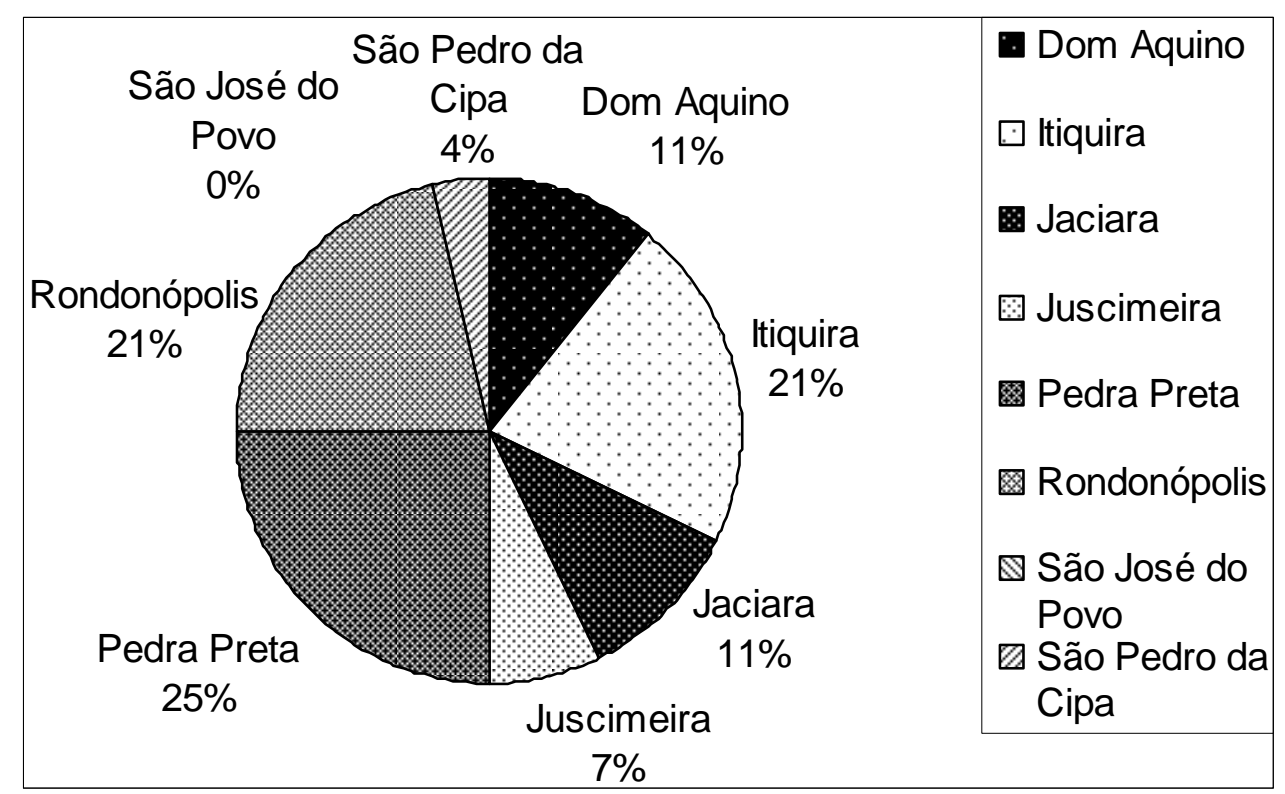

GRÁFICO 37 - Total dos geomorfotopônimos da microrregião Rondonópolis.

Os geomorfotopônimos da microrregião Rondonópolis são portugueses.

Considera-se, nesta pesquisa, que os geomorfotopônimos da microrregião Rondonópolis, quanto à estrutura, subdividem-se em simples e compostos. São 19 (dezenove) geomorfotopônimos de estrutura simples e 09 (nove) geomorfotopônimos de estrutura composta. Eles denominam 28 (vinte e oito) acidentes físicos.

Os geomorfotopônimos de estrutura composta Grota Feia, Grota Seca e Grota Vermelha, formados por substantivo comum + adjetivo, dão nomes, respectivamente, a 01 (um) córrego no município de Dom Aquino, a 01 (um) córrego em Rondonópolis e a 01 (um) córrego em Juscimeira. O geomorfotopônimo Espigão Mestre, formado pela unidade lexical espiga + sufixo -ão, formador de aumentativo + adjetivo, singulariza 01 (uma) serra em Itiquira. O geomorfotopônimo Vertente Comprida, formado pela unidade lexical verter + sufixo -ente, indicador de lugar onde ocorre + adjetivo, nomeia 01 (um) córrego em Pedra Preta.

Os geomorfotopônimos Grotão I e Grotão II, formados pela unidade lexical grota + sufixo -ão, já mencionado + algarismo romano, denominam 02 (dois) córregos em Jaciara. O geomorfotopônimo Ilha da Esperança, formado por substantivo comum + conectivo + unidade lexical esperar + sufixo -ança, indicador de qualidade ou estado, particulariza 01 (um) morro em Pedra Preta. O 
geomorfotopônimo Ponta do Resolvido, formado por substantivo comum + conectivo + unidade lexical resolver + sufixo -ido, indicador do resultado da ação, denomina 01 (um) córrego em Itiquira.

Os geomorfotopônimos simples subdividem-se em derivados e não derivados. O geomorfotopônimo simples e não derivado Ilha dá nome a 01 (um) córrego no município de Itiquira. O geomorfotopônimo Serra toponimiza 01 (um) córrego em Pedra Preta. O geomorfotopônimo Grota denomina 02 (dois) córregos em Rondonópolis. O geomorfotopônimo Furnas apresenta desinência de plural -s e dá nome a 01 (um) córrego em Jaciara.

O geomorfotopônimo Baixadão apresenta dupla sufixação, formado pela unidade lexical baixar + sufixo -ada, + sufixo -ão, já mencionados, dá nome a 01 (um) córrego que estabelece divisa entre os municípios de Pedra Preta e Rondonópolis, por isso consta nas relações de topônimos dos dois municípios.

O geomorfotopônimo Alcantilado, formado pela unidade lexical alcantilar + sufixo -ado, indicador de grandeza ou extensão, dá nome a 01 (um) córrego no município de Dom Aquino que estabelece divisa entre os municípios de Dom Aquino e Poxoréu, por isso consta nas relações de topônimos dos dois municípios. O geomorfotopônimo Grotão, já mencionado, nomeia 01 (um) córrego em Dom Aquino e 01 (um) córrego em Pedra Preta. O geomorfotopônimo Vertente, formado pela unidade lexical verter + sufixo -ente, já mencionado, denomina 01 (um) córrego em Rondonópolis.

Os geomorfotopônimos Furninha e Recifezinho, formados pelas unidade lexicais furna e recife + sufixo -(z)inho, indicador de diminutivo, denominam 01 (um) córrego em Itiquira, 01 (um) córrego em Juscimeira, 01 (um) córrego em Pedra Preta e 01 (um) córrego em Rondonópolis. O geomorfotopônimo Pontal, formado pela unidade lexical ponta + sufixo -al, indicador de grande quantidade, toponimiza 01 (um) córrego em Itiquira e 01 (um) córrego em São Pedro da Cipa. O geomorfotopônimo Invernada, formado pela unidade lexical invernar + sufixo -ada, indicador de tempo, nomeia 01 (um) córrego em Itiquira e 01 (um) córrego em Pedra Preta. 
Os topônimos classificados nesta taxionomia também apresentam a característica de toponimização do acidente físico, ou seja, o termo genérico do sintagma toponímico passa a exercer a função de topônimo. Os geomorfotopônimos Ilha e Espigão Mestre denominam, respectivamente, 01 (um) córrego e 01 (uma) serra no município de Itiquira. O geomorfotopônimo Serra nomeia 01 (um) córrego e o geomorfotopônimo Ilha da Esperança dá nome a 01 (um) morro, ambos em Pedra Preta.

Ocorre produtividade toponímica, nesta taxionomia, na microrregião Rondonópolis. O geomorfotopônimo Grota dá nome a 02 (dois) córregos no município de Rondonópolis. O geomorfotopônimo Grotão nomeia 01 (um) córrego em Dom Aquino e outro em Pedra Preta. Os geomorfotopônimos Grotão I e Grotão II singularizam 02 (dois) córregos em Jaciara. Se considerar a primeira unidade lexical do topônimo pode-se ainda acrescentar os geomorfotopônimos Grota Feia, Grota Seca e Grota Vermelha que nomeiam, respectivamente, 01 (um) córrego em Dom Aquino, 01 (um) córrego em Rondonópolis e outro em Juscimeira.

O geomorfotopônimo Furninha toponimiza 01 (um) córrego em Itiquira, 01 (um) córrego em Pedra Preta e outro em Rondonópolis. O geomorfotopônimo Furnas dá nome a 01 (um) córrego em Jaciara. O geomorfotopônimo Invernada denomina 01 (um) córrego em Itiquira e outro em Pedra Preta. O geomorfotopônimo Pontal dá nome a 01 (um) córrego em Itiquira e a outro em São Pedro da Cipa.

O geomorfotopônimo Ilha particulariza 01 (um) córrego em Itiquira e o geomorfotopônimo Ilha da Esperança dá nome a 01 (um) morro em Pedra Preta. O geomorfotopônimo Vertente singulariza 01 (um) córrego em Rondonópolis e o geomorfotopônimo Vertente Comprida nomeia 01 (um) córrego em Pedra Preta. O geomorfotopônimo Baixadão denomina 01 (um) córrego que consta nas relações de topônimos de Pedra Preta e Rondonópolis porque estabelece divisa entre eles, por isso não é considerado produtivo.

Os geomorfotopônimos correspondem a 4,5\% do total de topônimos da microrregião Rondonópolis. 


\section{Dimensiotopônimos}

As unidades lexicais que se referem às dimensões dos acidentes, como extensão, comprimento, largura, grossura, espessura, altura, etc., quando utilizadas para dar nomes a acidentes físicos e a acidentes antrópicos, recebem nos estudos toponímicos a denominação de dimensiotopônimos. Registram-se 13 (treze) dimensiotopônimos na microrregião Rondonópolis.

São 02 (dois) dimensiotopônimos no município de Dom Aquino, 06 (seis) em Itiquira, 01 (um) em Jaciara, 01 (um) em Juscimeira e 03 (três) em Rondonópolis. Os municípios de Pedra Preta, São José do Povo e São Pedro da Cipa não possuem dimensiotopônimos. Apresenta-se a seguir o gráfico desta taxionomia com os respectivos percentuais por municípios (GRÁFICO 38).

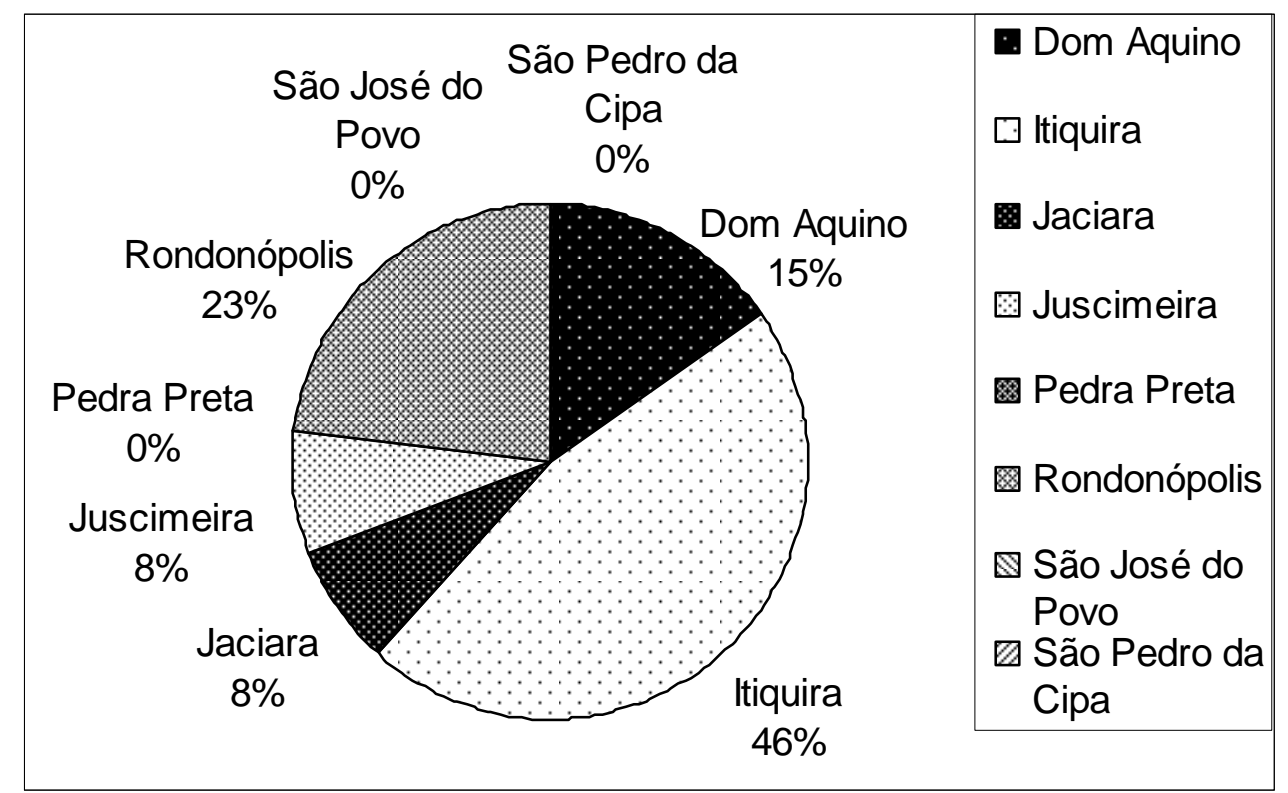

GRÁFICO 38 - Total dos dimensiotopônimos da microrregião Rondonópolis.

Constam, na microrregião Rondonópolis, 01 (um) dimensiotopônimo bororo e 12 (doze) dimensiotopônimos portugueses.

Considera-se, nesta pesquisa, que o dimensiotopônimo bororo Bagaréu possui estrutura simples. Ele dá nome a 01 (um) córrego no município de Rondonópolis que estabelece divisa entre os municípios de Rondonópolis e Poxoréu, por isso consta nas relações de topônimos desses municípios. 
A unidade lexical bagaréu está registrada na Enciclopédia Bororo: "Biagaréu * biága, pequenos; réu, suf. poss. O pequeno, o reduzido. - * c.a. [pequeno curso d'água]. Cór. afl. da dir. do c. m. do Pogúbo, rio Vermelho: c. Biagoréu." Albisetti; Venturelli (1962, p. 27).

Considera-se, nesta pesquisa, que os dimensiotopônimos portugueses da microrregião Rondonópolis possuem estrutura simples. Eles denominam 12 (doze) acidentes físicos.

Os dimensiotopônimos Comprido, Estreito, Fundo e Grande denominam 02 (dois) córregos no município de Dom Aquino, 05 (cinco) córregos e 01 (um) ribeirão em Itiquira, 01 (um) córrego em Jaciara, 01 (um) córrego em Juscimeira, 01 (um) córrego e 01 (um) morro em Rondonópolis.

Ocorre produtividade toponímica, nesta taxionomia, na microrregião Rondonópolis. O dimensiotopônimo Comprido dá nome a 01 (um) ribeirão no município de Itiquira e a 01 (um) córrego em Rondonópolis. O dimensiotopônimo Fundo nomeia 02 (dois) córregos em Dom Aquino, 03 (três) córregos em Itiquira, 01 (um) córrego em Jaciara e 01 (um) córrego em Juscimeira. O dimensiotopônimo Grande denomina 01 (um) córrego em Itiquira e 01 (um) morro em Rondonópolis.

Os dimensiotopônimos correspondem a 2,1\% do total de topônimos da microrregião Rondonópolis.

\section{Cromotopônimos}

As unidades lexicais que evidenciam as tonalidades, quando usadas para dar nomes a acidentes físicos e a acidentes antrópicos, recebem nos estudos toponímicos a denominação de cromotopônimos. Registram-se 09 (nove) cromotopônimos na microrregião Rondonópolis.

São 02 (dois) cromotopônimos no município de Dom Aquino, 02 (dois) em Jaciara, 02 (dois) em Juscimeira, 01 (um) em Pedra Preta, 01 (um) em Rondonópolis 
e 01 (um) em São José do Povo. Os municípios de Itiquira e São Pedro da Cipa não possuem cromotopônimos. Apresenta-se a seguir o gráfico desta taxionomia com os respectivos percentuais por municípios (GRÁFICO 39).

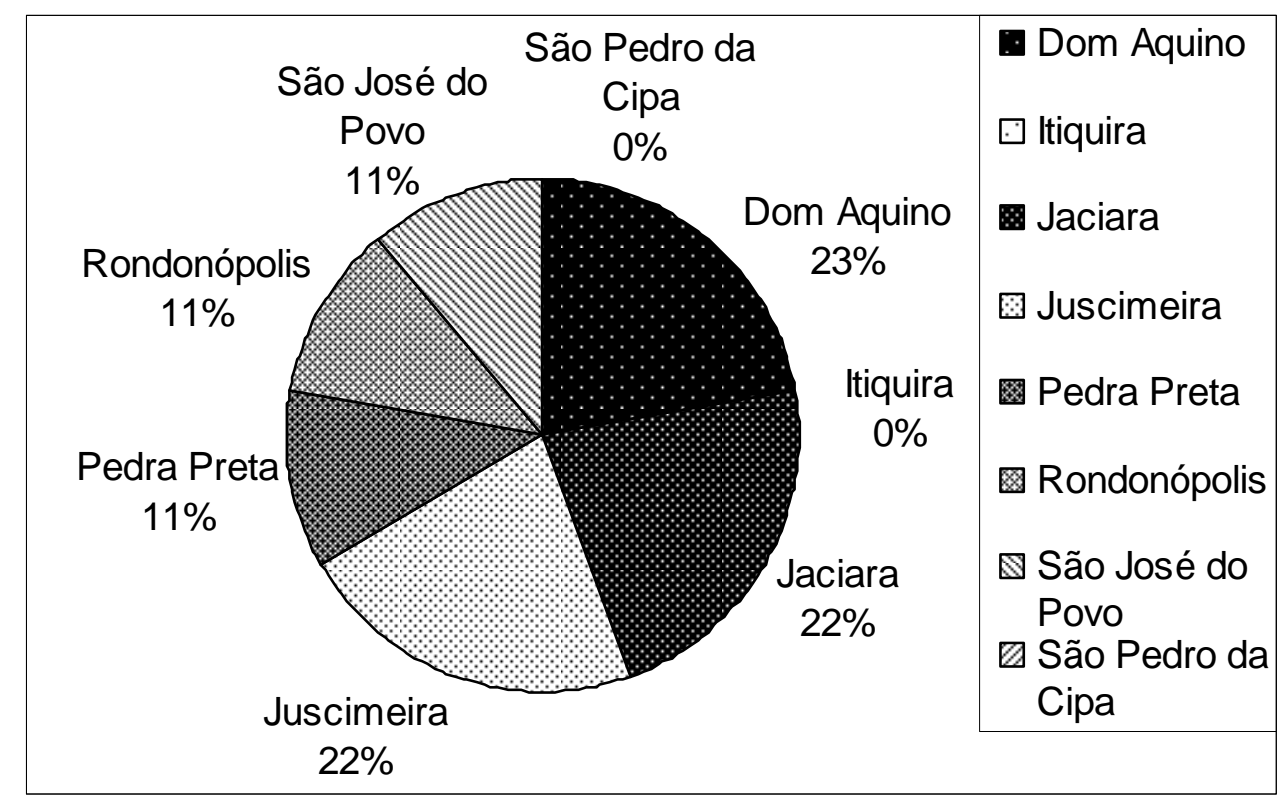

GRÁFICO 39 - Total dos cromotopônimos da microrregião Rondonópolis.

Os cromotopônimos da microrregião Rondonópolis são portugueses.

Considera-se, nesta pesquisa, que os cromotopônimos portugueses da microrregião Rondonópolis possuem estrutura simples. Eles denominam 09 (nove) acidentes físicos.

Os cromotopônimos Preto, Verde e Vermelho nomeiam 01 (uma) cabeceira e 01 (um) córrego em Dom Aquino, 01 (um) córrego em Jaciara, 01 (um) morro em Juscimeira e 01 (um) rio em Rondonópolis. O rio Vermelho é o mesmo rio de Poxoréu, por isso consta nas relações de topônimos de ambos.

O cromotopônimo Azulão, formado pela unidade lexical azul + sufixo -ão, formador de aumentativo, dá nome a 01 (um) córrego no município de Pedra Preta. O cromotopônimo Brilhante, formado pelo verbo brilhar + sufixo -ante, indicador do agente da ação, denomina 01 (um) córrego em Jaciara e 01 (um) córrego em São José do Povo. O cromotopônimo Colorado, formado pelo verbo colorar + sufixo ado, indicador do efeito da ação, singulariza 01 (uma) serra em Juscimeira. 
Constata-se produtividade toponímica, nesta taxionomia, na microrregião Rondonópolis. O cromotopônimo Brilhante nomeia 01 (um) córrego no município de Jaciara e outro em São José do Povo. O cromotopônimo Verde denomina 01 (uma) cabeceira em Dom Aquino e 01 (um) córrego em Jaciara. O cromotopônimo Vermelho dá nome a 01 (um) morro em Juscimeira e a 01 (um) rio em Rondonópolis.

Os cromotopônimos correspondem a 1,5\% do total de topônimos da microrregião Rondonópolis.

\section{Cardinotopônimos}

As unidades lexicais que denotam direções ou localização específica, quando utilizadas para dar nomes a acidentes físicos e a acidentes antrópicos, recebem nos estudos toponímicos a denominação de cardinotopônimos. Registram-se 05 (cinco) cardinotopônimos na microrregião Rondonópolis.

São 01 (um) cardinotopônimo no município de Dom Aquino, 02 (dois) em Itiquira e 02 (dois) em Rondonópolis. Os municípios de Jaciara, Juscimeira, Pedra Preta, São José do Povo e São Pedro da Cipa não possuem cardinotopônimos. Devido à pequena quantidade de cardinotopônimos não se apresenta gráfico para esta taxionomia.

Os cardinotopônimos da microrregião Rondonópolis são portugueses e, quanto à estrutura, subdividem-se em simples e compostos.

O cardinotopônimo composto Cima de Serra, formado por substantivo comum + preposição + substantivo comum, dá nome a 01 (uma) chapada no município de Rondonópolis. O cardinotopônimo Entre Rios, formado por preposição + substantivo comum com desinência de plural -s, nomeia 01 (um) distrito em Dom Aquino.

O cardinotopônimo português de estrutura simples Cardinal denomina 01 (uma) vila no município de Rondonópolis. O cardinotopônimo Sozinho, formado pela 
unidade lexical só + sufixo -(z)inho, formador de diminutivo, nomeia 01 (um) ribeirão e 01 (um) córrego, ambos em Itiquira.

Apesar da pequena quantidade de cardinotopônimos constata-se a ocorrência de produtividade toponímica, nesta taxionomia, na microrregião Rondonópolis. O cardinotopônimo Sozinho toponimiza 01 (um) ribeirão e 01 (um) córrego no município de Itiquira.

Os cardinotopônimos correspondem a $0,8 \%$ do total de topônimos da microrregião Rondonópolis.

\section{Igneotopônimos}

Nos estudos toponímicos são classificados como igneotopônimos as unidades lexicais relativas ao fogo ou resultantes da ação do fogo, quando usadas para dar nomes a acidentes físicos e a acidentes antrópicos. Registram-se 03 (três) igneotopônimos na microrregião Rondonópolis.

O município de Itiquira possui 02 (dois) igneotopônimos e o município de Jaciara possui 01 (um) igneotopônimo. Os municípios de Dom Aquino, Juscimeira, Pedra Preta, Rondonópolis, São José do Povo e São Pedro da Cipa não possuem igneotopônimos. Devido à pequena quantidade de igneotopônimos não se apresenta gráfico para esta taxionomia

Os igneotopônimos da microrregião Rondonópolis são portugueses e possuem estrutura simples.

Os igneotopônimos simples e não derivados Faísca e Fogo nomeiam 01 (uma) cabeceira e 01 (um) córrego no município de Itiquira. O igneotopônimo Fumaça, formado pela unidade lexical fumo + sufixo -aça, indicador de aumento, dá nome a 01 (um) cachoeira em Jaciara. 
Os igneotopônimos correspondem a 0,5\% do total de topônimos da microrregião Rondonópolis.

\section{Meteorotopônimos}

As unidades lexicais que se referem aos fenômenos climáticos, quando utilizadas para dar nomes a acidentes físicos e a acidentes antrópicos, recebem nos estudos toponímicos a denominação de meteorotopônimos. Registram-se 02 (dois) meteorotopônimos na microrregião Rondonópolis.

O município de Itiquira possui 01 (um) meteorotopônimo e Rondonópolis também possui 01 (um). Os municípios de Dom Aquino, Jaciara, Juscimeira, Pedra Preta, São José do Povo e São Pedro da Cipa não possuem meteorotopônimos. Devido à pequena quantidade de meteorotopônimos não se apresenta gráfico para esta taxionomia.

A microrregião Rondonópolis possui 01 (um) meteorotopônimo tupi e 01 (um) português.

Considera-se, nesta pesquisa, que o meteorotopônimo tupi Votuporanga possui estrutura simples, formado pela aglutinação das unidades lexicais votu + poranga e dá nome a 01 (um) córrego no município de Rondonópolis.

Segundo Sampaio, as unidades lexicais tupis votu e poranga possuem as seguintes características: "VOTU, corr. botú, corr. yby-tú, o vento, o sopro do ar. Atl. Ubutúra, Butura, Botura, Votura." e "MORANGA, o mesmo que poranga, bello, formoso, bonito, excellente." (1970, p. 251; 302)

O meteorotopônimo português Chuva possui estrutura simples e nomeia 01 (uma) cabeceira no município de Itiquira.

Os meteorotopônimos correspondem a 0,3\% do total de topônimos da microrregião Rondonópolis. 


\section{Astrotopônimo}

As unidades lexicais que se referem aos astros celestes em geral, quando utilizadas para dar nomes a acidentes físicos e a acidentes antrópicos, são denominadas astrotopônimos nos estudos toponímicos. Registra-se 01 (um) astrotopônimo na microrregião Rondonópolis.

O município de Jaciara possui 01 (um) astrotopônimo. Devido à unicidade de astrotopônimo não se apresenta gráfico para esta taxionomia.

O astrotopônimo Jaciara é tupi e considera-se, nesta pesquisa, que ele possui estrutura simples.

Segundo Sampaio, as unidades lexicais tupis possuem as seguintes características:

JACY, corr. ya-cy, a mãe dos frutos, a lua; o mês lunar; o ornato feito de um pedaço de conha branca e telhado em forma de crescente. ARA, s. o dia, o tempo; idade, vez; o que está no alto, em cima, de cima, na eminência: o mundo. (1970, p. 173; 233)

O astrotopônimo Jaciara dá nome a 01 (um) município mato-grossense.

O astrotopônimo corresponde a $0,2 \%$ do total de topônimos da microrregião Rondonópolis. 


\section{Taxionomias de nature za antrópica da microrregião Rondonópolis}

\section{Ergotopônimos}

As unidades lexicais que se referem aos elementos da cultura material, quando utilizadas para dar nomes a acidentes físicos e a acidentes antrópicos, recebem nos estudos toponímicos a denominação de ergotopônimos. Registram-se 44 (quarenta e quatro) ergotopônimos na microrregião Rondonópolis.

São 07 (sete) ergotopônimos no município de Dom Aquino, 12 (doze) em Itiquira, 02 (dois) em Jaciara, 03 (três) em Juscimeira, 13 (treze) em Pedra Preta, 04 (quatro) em Rondonópolis e 03 (três) em São Pedro da Cipa. O município de São José do Povo não possui ergotopônimo. Apresenta-se a seguir o gráfico desta taxionomia com os respectivos percentuais por municípios (GRÁFICO 40).

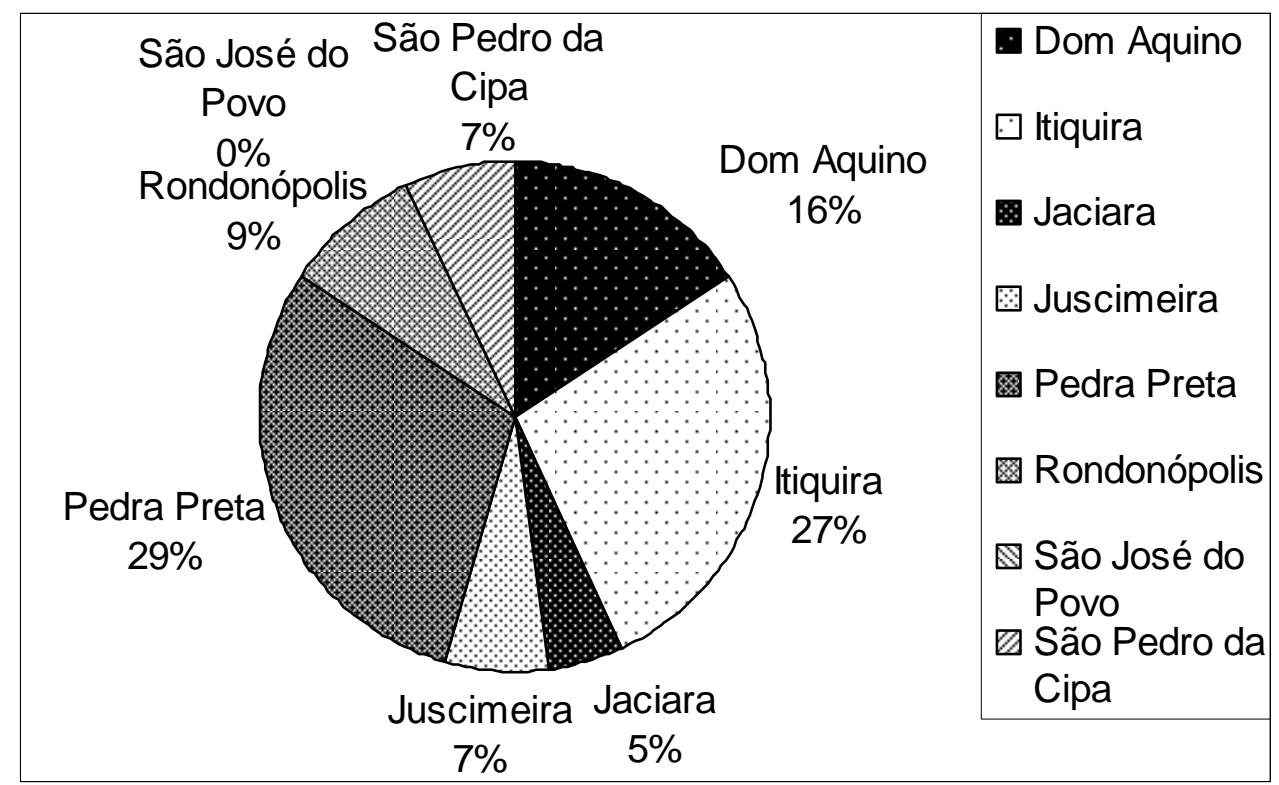

GRÁFICO 40 - Total dos ergotopônimos da microrregião Rondonópolis.

São 01 (um) ergotopônimo tupi, 04 (quatro) bororos, 01 (um) africano e 38 (trinta e oito) portugueses na microrregião Rondonópolis. 
O ergotopônimo tupi Jirau da Onça possui estrutura híbrida, formado por unidade lexical tupi + conectivo português + unidade lexical portuguesa e dá nome a 01 (um) córrego no município de Rondonópolis.

Considera-se, nesta pesquisa, que os ergotopônimos bororos possuem estrutura simples. O ergotopônimo Beroaba dá nome ao primeiro trecho de 01 (um) córrego que estabelece divisa entre os municípios de Juscimeira e Rondonópolis, por isso consta nas relações de topônimos dos dois municípios. A unidade lexical beroaba está registrada na Enciclopédia Bororo:

Bóro - * ? Designação: 1. de um caramujo de carapaça alongada; Wábo - vel. son. de bápo e ders. Coração, maracá; Bápo á - * bápo, maracá; á (1962, p. 216; 515; 967).

O ergotopônimo Jega-Jega nomeia 01 (um) serra em Pedra Preta. O ergotopônimo Jega-Jega foi classificado como de etimologia bororo e nesta taxionomia, após definição obtida em Cuiabá - MT com o índio bororo F, depois confirmada pelo índio bororo IR e por BEM e OCG. Eles asseveram que este topônimo é uma forma variante de Jaga-Jaga e possui o seguinte significado: "JagaJaga degrau, escada." (2009).

Classificou-se, nesta pesquisa, o topônimo Bagaro como ergotopônimo. O topônimo desse morro está registrado no mapa elaborado pelo Marechal Cândido Rondon como Baraga. Conclui-se que houve divergência de grafia na elaboração da carta topográfica um quarto de século mais tarde. O ergotopônimo Bagaro nomeia 01 (um) morro no município de Rondonópolis. A unidade lexical borora bagaro está registrada na Enciclopédia Bororo:

Aobaragári - * áo, sumidade; barága (=baragára), prego com tufo de penas; $\mathbf{r i}_{1}$, morro [morro tendo na sumidade vegetação semelhante a um tufo de penas]. Morro nas nascentes do Arároe Eiáo $_{3}$, cór Arareau: morro Barága. Albisetti; Venturelli (1962, p. 72) 
Considera-se, nesta pesquisa, que o ergotopônimo africano Monjolo possui estrutura simples. Ele denomina 01 (um) córrego no município de Dom Aquino.

Considera-se, nesta pesquisa, que os ergotopônimos portugueses da microrregião Rondonópolis, quanto à estrutura, subdividem-se em simples e compostos. São 36 (trinta e seis) ergotopônimos de estrutura simples e 02 (dois) ergotopônimos de estrutura composta. Eles denominam 38 (trinta e oito) acidentes físicos.

O ergotopônimo composto Curral de Vara, formado por substantivo comum + preposição + substantivo comum, nomeia 01 (um) córrego no município de Itiquira. O ergotopônimo Saia Branca, formado por substantivo comum + adjetivo, singulariza 01 (um) córrego que deságua em Jaciara e nasce em Santo Antônio de Leverger.

O ergotopônimo simples e não derivado Baú dá nome a 01 (um) morro no município de Dom Aquino. É o primeiro topônimo desse morro. Os ergotopônimos Anzol, Baliza, Barraca, Chinelo, Espora, Feixe e Linchal denominam 01 (uma) cabeceira, 04 (quatro) córregos, 01 (um) morrinho e 01 (um) porto em Itiquira. $\mathrm{O}$ ergotopônimo Pão nomina 01 (um) córrego em Juscimeira.

Os ergotopônimos Canoa, Garrucha, Máquina e Mesa toponimizam 03 córregos, 03 (três) morros e 01 (uma) serra no município de Pedra Preta. O ergotopônimo Manilha singulariza 01 (um) córrego em Rondonópolis. O ergotopônimo Baliza nomeia 02 (dois) morros em São Pedro da Cipa. O ergotopônimo Forma dá nome a 01 (um) córrego que nasce no município de Juscimeira e deságua em São Pedro da Cipa, por isso consta nas relações de topônimos dos dois municípios.

Os ergotopônimos Ponteiro, Porteira e Potreiro, formados pelas unidades lexicais ponta, porta e potro + sufixo -eiro/a, indicador de aumento, de instrumento ou de lugar continente, dão nomes a 02 (dois) córregos no município de Dom Aquino, a 02 (dois) córregos em Itiquira e a 01 (um) ribeirão em Pedra Preta. $\mathrm{O}$ ergotopônimo Barracão, formado pela unidade lexical barraca + sufixo -ão, indicador de aumentativo, denomina 01 (um) córrego em Dom Aquino. O ergotopônimo Melado, formado pela unidade lexical melar + sufixo -ado, indicador de qualidade ou 
estado, singulariza 01 (um) morro em Jaciara. O ergotopônimo Moedor, formado pela unidade lexical moer + sufixo -dor, indicador de instrumento, nomeia 01 (um) córrego em Itiquira.

O ergotopônimo Rapadura apresenta dupla sufixação, formado pela unidade lexical rapar + sufixo -ado, indicador de qualidade ou estado + sufixo -ura, indicador do resultado da ação, denomina 01 (um) morro no município de Dom Aquino. O ergotopônimo Submarino, formado pelo prefixo sub-, indicador de posição inferior + unidade lexical mar + sufixo -ino, indicador de relação, dá nome a 01 (um) córrego em Pedra Preta.

Os ergotopônimos Barreirinha, Cercadinho, Dobradinho e Potreirinho possuem dupla sufixação. Os ergotopônimos Barreirinha e Potreirinho, formados pelas unidades lexicais barra e potro + sufixo -eiro, já mencionado + sufixo -inho/a, formador de diminutivo, nomeiam 01 (um) córrego em Itiquira, 01 (um) córrego e 01 (um) ribeirão em Pedra Preta. Os ergotopônimos Cercadinho e Dobradinho, formados pelas unidades lexicais cercar e dobrar + sufixo -ado e sufixo -inho, já mencionados, denominam 01 (um) córrego em Dom Aquino e 01 (um) córrego em Pedra Preta.

Ocorre produtividade toponímica, nesta taxionomia, na microrregião Rondonópolis. O ergotopônimo Potreiro nomeia 01 (um) córrego no município de Dom Aquino, 01 (um) córrego em Itiquira e 01 (um) ribeirão em Pedra Preta. 0 ergotopônimo Potreirinho designa 01 (um) córrego e 01 (um) ribeirão em Pedra Preta. O ergotopônimo Baliza dá nome a 01 (um) morrinho em Itiquira e a 02 (dois) morros em São Pedro da Cipa.

O ergotopônimo Mesa nomeia 01 (um) córrego, 02 (dois) morros e 01 (uma) serra em Pedra Preta. Pode-se ainda acrescentar o ergotopônimo Barraca que denomina 01 (um) córrego em Itiquira e o ergotopônimo Barracão que toponimiza 01 (um) córrego em Dom Aquino. O ergotopônimo Forma não é considerado produtivo porque dá nome a 01 (um) córrego que nasce no município São Pedro da Cipa e deságua no município de Juscimeira. O ergotopônimo Beroaba nomina o primeiro trecho de 01 (um) córrego que divide Juscimeira e Rondonópolis, por isso não é considerado produtivo. 
Os ergotopônimos correspondem a 7,1\% do total de topônimos da microrregião Rondonópolis.

\section{Sociotopônimos}

As unidades lexicais que se referem às atividades sociais ou laborais, quando utilizadas para dar nomes a acidentes físicos e a acidentes antrópicos, recebem nos estudos toponímicos a denominação de sociotopônimos. Registram-se 44 (quarenta e quatro) sociotopônimos na microrregião Rondonópolis.

São 11 (onze) sociotopônimos no município de Dom Aquino, 15 (quinze) em Itiquira, 02 (dois) em Jaciara, 02 (dois) em Juscimeira, 07 (sete) em Pedra Preta, 06 (seis) em Rondonópolis e 01 (um) em São José do Povo. O município de São Pedro da Cipa não possui sociotopônimo. Apresenta-se a seguir o gráfico desta taxionomia com os respectivos percentuais por municípios (GRÁFICO 41).

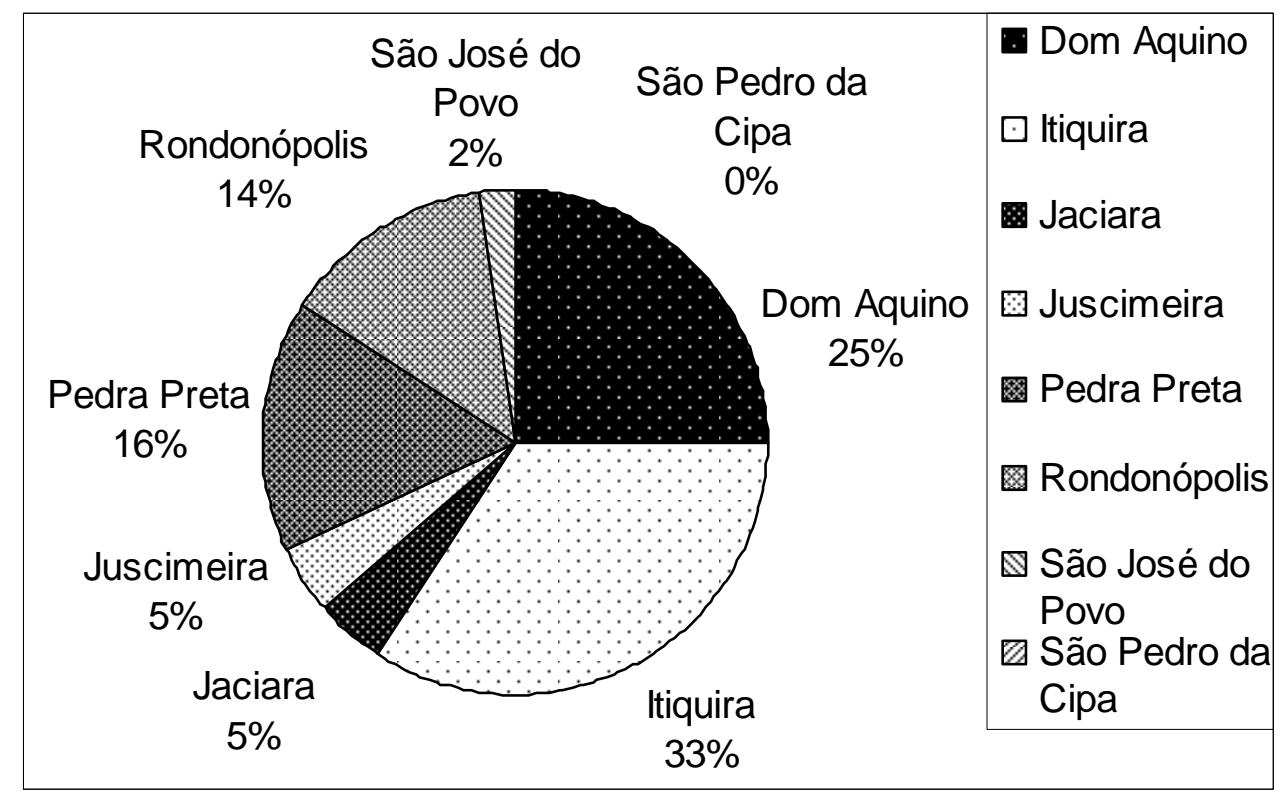

GRÁFICO 41 - Total dos sociotopônimos da microrregião Rondonópolis.

Os sociotopônimos da microrregião Rondonópolis são portugueses. 
Considera-se, nesta pesquisa, que os sociotopônimos portugueses da microrregião Rondonópolis, quanto à estrutura, subdividem-se em simples e compostos. São 40 (quarenta) sociotopônimos de estrutura simples e 04 (quatro) sociotopônimos de estrutura composta. Eles denominam 44 (quarenta e quatro) acidentes físicos.

O sociotopônimo composto Lavrinha Verde, formado por unidade lexical lavrar + sufixo -inha, indicador de diminutivo + adjetivo, nomeia 01 (um) córrego no município de Dom Aquino. O sociotopônimo Posto Duzentos, formado por substantivo comum + numeral cardinal, dá nome a 01 (um) córrego em Itiquira. 0 sociotopônimo Retiro Velho, formado por substantivo comum + adjetivo, denomina 01 (uma) cabeceira em Itiquira e 01 (um) córrego em Pedra Preta.

Os sociotopônimos de estrutura simples subdividem-se em simples não derivados e simples com derivação. O sociotopônimo Confusão, formado pela unidade lexical confuso + sufixo -ão, indicador de aumentativo, nomeia 02 (dois) córregos no município de Itiquira e 02 (dois) córregos em Pedra Preta. O sociotopônimo Motorista, formado pela unidade lexical motor + sufixo -ista, indicador de profissão, denomina 01 (um) córrego no município de Juscimeira. 0 sociotopônimo Resolvido, formado pela unidade lexical resolver + sufixo -ido, indicador do resultado da ação, nomeia 02 (dois) córregos e 01 (um) ribeirão em Itiquira. O sociotopônimo Lambança, formado pela unidade lexical lamber + sufixo ança, indicador de resultado da ação, toponimiza 01 (um) córrego em Dom Aquino.

Alguns sociotopônimos, na microrregião Rondonópolis, apresentam dupla sufixação. O sociotopônimo Lambancinha, formado pela unidade lexical lamber + sufixo -ança, já mencionado + sufixo -inha, formador de diminutivo, singulariza 01 (um) córrego no município de Dom Aquino. O sociotopônimo Tozadinha (grafia registrada no mapa e na carta topográfica), formado pela unidade lexical tosar + sufixo -ada, indicador do efeito da ação + sufixo -inha, já mencionado, denomina 01 (um) córrego em Jaciara. O sociotopônimo Brigadeiro, formado pela unidade lexical brigar + sufixo -ada, mencionado acima + sufixo -eiro, indicador de profissão, dá nome a 01 (uma) serra em Rondonópolis que estabelece divisa entre os municípios de Rondonópolis e Santo Antônio de Leverger. 
O sociotopônimo Retirinho, formado pela unidade lexical retiro + sufixo -inho, já mencionado, toponimiza 03 (três) córregos no município de Itiquira. O sociotopônimo Acidentados, formado pela unidade lexical acidentar + sufixo -ado, já mencionado + desinência de plural -s, dá nome a 01 (uma) serra em Dom Aquino. O sociotopônimo Descarrega, formado pelo prefixo des-, indicador de ação contrária + verbo carregar no presente do indicativo, nomeia 01 (uma) vazante em Itiquira.

Os sociotopônimos simples e não derivados Encontro, Esparramo, Estiva, Presidente e Rapa, denominam 02 (duas) cabeceiras e 04 (quatro) córregos no município de Dom Aquino. O córrego Presidente estabelece divisa entre os municípios de Dom Aquino e Campo Verde, por isso consta nas relações de topônimos dos dois municípios. O córrego Esparramo estabelece divisa entre os municípios de Dom Aquino e Poxoréu, por isso consta nas relações de topônimos dos dois municípios. Os sociotopônimos Cemitério, Olaria, Piquenique e Retiro toponimizam 04 (quatro) córregos em Itiquira.

O sociotopônimo Granja particulariza 01 (um) córrego no município de Jaciara. O sociotopônimo Almoço dá nome a 01 (uma) cabeceira em Juscimeira. Os sociotopônimos Fazenda, Garimpo e Olaria nominam 04 (quatro) córregos em Pedra Preta. Os sociotopônimos Esparramo, Estiva, Miséria, Retiro e Zorra nomeiam 01 (uma) cabeceira e 04 (quatro) córregos em Rondonópolis. O sociotopônimo Retiro toponimiza 01 (um) córrego em São José do Povo. O sociotopônimo Mortes apresenta desinência $-\mathrm{s}$ de plural e dá nome a 01 (um) rio no município de Dom Aquino que estabelece divisa entre os municípios de Dom Aquino e Primavera do Leste, por isso consta nas relações de topônimos dos dois municípios.

Ocorre produtividade toponímica, nesta taxionomia, na microrregião Rondonópolis. O sociotopônimo Retiro Velho singulariza 01 (uma) cabeceira em Itiquira e 01 (um) córrego no município de Pedra Preta. O sociotopônimo Confusão dá nome a 02 (dois) córregos em Itiquira e a 02 (dois) em Pedra Preta. O sociotopônimo Resolvido nomina 02 (dois) córregos e 01 (um) ribeirão em Itiquira. 0 sociotopônimo Retirinho nomeia 03 (três) córregos em Itiquira. O sociotopônimo Retiro denomina 01 (um) córrego em Itiquira, 01 (um) córrego em Rondonópolis e outro em São José do Povo. 
O sociotopônimo Esparramo dá nome a 01 (um) córrego no município de Rondonópolis, a 01 (uma) cabeceira e a 01 (um) córrego em Dom Aquino. $\mathrm{O}$ sociotopônimo Garimpo denomina 02 (dois) córregos em Pedra Preta. $\mathrm{O}$ sociotopônimo Estiva designa 01 (um) córrego em Dom Aquino e outro em Rondonópolis. O sociotopônimo Olaria nomeia 01 (um) córrego em Itiquira e outro em Pedra Preta. Pode-se acrescentar o sociotopônimo Lambança que particulariza 01 (um) córrego e o sociotopônimo Lambancinha que nomina 01 (um) córrego, ambos no município de Dom Aquino.

Os sociotopônimos correspondem a 7,1 \% do total de topônimos da microrregião Rondonópolis.

\section{Antropotopônimos}

As unidades lexicais que se referem aos nomes de pessoas, quando utilizadas para nomear acidentes físicos e acidentes antrópicos, recebem nos estudos toponímicos a denominação de antropotopônimos. Registram-se 29 (vinte e nove) antropotopônimos na microrregião Rondonópolis.

São 03 (três) antropotopônimos no município de Dom Aquino, 03 (três) em Itiquira, 04 (quatro) em Jaciara, 02 (dois) em Juscimeira, 05 (cinco) em Pedra Preta, 08 (oito) em Rondonópolis, 02 (dois) em São José do Povo e 02 (dois) em São Pedro da Cipa. Apresenta-se a seguir o gráfico desta taxionomia com os respectivos percentuais por municípios (GRÁFICO 42). 


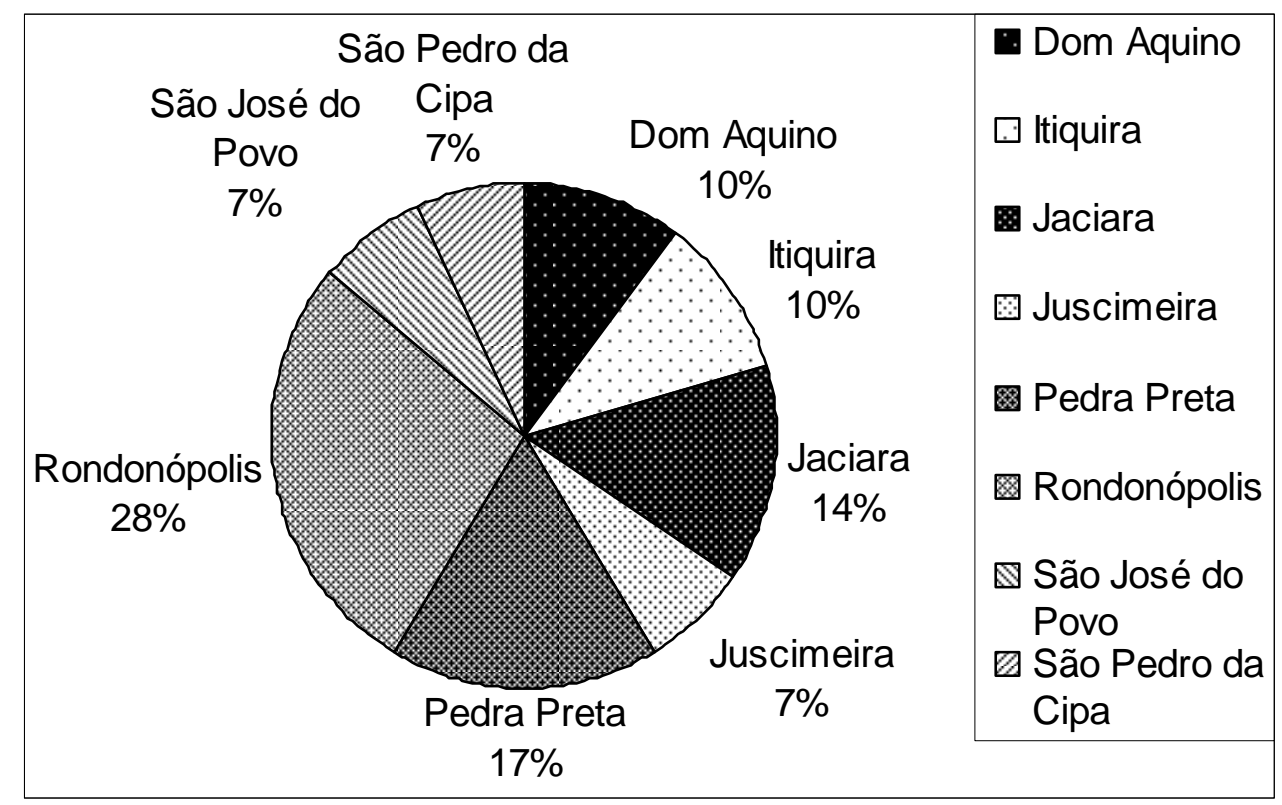

GRÁFICO 42 - Total dos antropotopônimos da microrregião Rondonópolis.

São 01 (um) antropotopônimo tupi e 28 (vinte e oito) portugueses na microrregião Rondonópolis.

O antropotopônimo tupi João Irara possui estrutura híbrida, formado por nome próprio de pessoa da língua portuguesa + unidade lexical tupi, toponimiza 01 (um) córrego no município de Pedra Preta.

Considera-se, nesta pesquisa, que os antropotopônimos portugueses da microrregião Rondonópolis, quanto à estrutura, subdividem-se em simples e compostos. São 23 (vinte e três) antropotopônimos de estrutura simples e 05 (cinco) antropotopônimos de estrutura composta. Eles denominam 24 (vinte e quatro) acidentes físicos e 04 (quatro) acidentes antrópicos. Os 08 (oito) municípios da microrregião Rondonópolis possuem antropotopônimos portugueses.

Os antropotopônimos compostos apresentam as seguintes formações:
a) hipocorístico + apelido de família: Chico Nunes e Chiquinha Maciel;
b) nome próprio + apelido de família: Bento Ribeiro;
c) hipocorístico + hipocorístico: Candinho Mineiro e Chico Preto. 
O antropotopônimo composto Chico Nunes dá nome a 01 (um) córrego no município de Dom Aquino.

Os antropotopônimos Bento Ribeiro e Chiquinha Maciel toponimizam 02 (dois) córregos em Jaciara.

O antropotopônimo Candinho Mineiro é o segundo topônimo de 01 (um) córrego em Rondonópolis.

O antropotopônimo Chico Preto nomeia 01 (um) córrego em São Pedro da Cipa.

Os antropotopônimos simples subdividem-se em simples não derivados e simples com derivação. O antropotopônimo derivado Lourencinho, formado por nome próprio de pessoa Lourenço + sufixo -inho, indicador de diminutivo, dá nome a 01 (um) córrego no município de Rondonópolis. O antropotopônimo Medeirão, formado pelo apelido de família Medeiros + sufixo -ão, formador de aumentativo, toponimiza 01 (um) córrego que estabelece limite entre os municípios de Rondonópolis e São José do Povo, por isso consta nas relações de topônimos dos dois municípios.

Deve-se observar que, nesta pesquisa, considerou-se antropotopônimos derivados somente os que apresentam o sufixo -inho, indicador de diminutivo e o sufixo -ão, indicador de aumentativo.

O antropotopônimo Serival dá nome a 01 (um) córrego no município de Dom Aquino e o antropotopônimo Vigilato toponimiza 01 (um) córrego em Itiquira. 0 antropotopônimo Rasga denomina 01 (um) córrego em Juscimeira e o antropotopônimo Petrovina nomeia 01 (um) morro, 01 (um) povoado e 01 (uma) serra em Pedra Preta. Os antropotopônimos Aguiar, Bueno e Pitaluga denominam 02 (dois) córregos e 01 (uma) vila em Rondonópolis. O córrego Aguiar nasce em Rondonópolis e deságua em Santo Antônio de Leverger. O antropotopônimo Borges nomina 01 (um) córrego em São Pedro da Cipa. O antropotopônimo Moreiral designa 01 (um) córrego em São José do Povo que estabelece divisa entre os municípios de São José do Povo e Guiratinga, por isso consta nas relações de topônimos dos dois municípios. 
O antropotopônimo Conceição nomina 01 (uma) serra no município de Dom Aquino. Os antropotopônimos Jurita e Selma dão nomes, respectivamente, a 01 (um) córrego e a 01 (um) distrito em Jaciara. Os antropotopônimos Camilo e Jorge denominam 02 (dois) córregos em Itiquira. O antropotopônimo Pedro singulariza 01 (um) córrego em Pedra Preta. Os antropotopônimos Bento e Iko nomeiam 02 (dois) córregos em Rondonópolis.

O antropotopônimo Irenópolis é considerado, nesta pesquisa, de estrutura simples, formado pela aglutinação do nome próprio de pessoa Irene + sufixo -polis, unidade lexical da língua grega, usada no Brasil como indicativo de cidade. 0 antropotopônimo Irenópolis nomeia 01 (um) distrito no município de Juscimeira.

Há ocorrência de produtividade toponímica, nesta taxionomia, na microrregião Rondonópolis. O antropotopônimo Petrovina denomina 01 (um) morro, 01 (um) povoado e 01 (uma) serra no município de Pedra Preta. Pode-se ainda considerar o antropotopônimo Bento que nomeia 01 (um) córrego em Rondonópolis e o antropotopônimo Bento Ribeiro que denomina 01 (um) córrego em Jaciara.

Os antropotopônimos correspondem a 4,7\% do total de topônimos da microrregião Rondonópolis.

\section{Animotopônimos}

As unidades lexicais que se referem à vida espiritual, abrangendo a todos os produtos do psiquismo humano, quando utilizadas para dar nomes a acidentes físicos e a acidentes antrópicos, recebem nos estudos toponímicos a denominação de animotopônimos. Registram-se 28 (vinte e oito) animotopônimos na microrregião Rondonópolis.

São 06 (seis) animotopônimos no município de Dom Aquino, 07 (sete) em Itiquira, 03 (três) em Jaciara, 04 (quatro) em Juscimeira, 03 (três) em Pedra Preta, 04 (quatro) em Rondonópolis e 01 (um) em São José do Povo. O município de São 
Pedro da Cipa não possui animotopônimo. Apresenta-se a seguir o gráfico desta taxionomia com os respectivos percentuais por municípios (GRÁFICO 43).

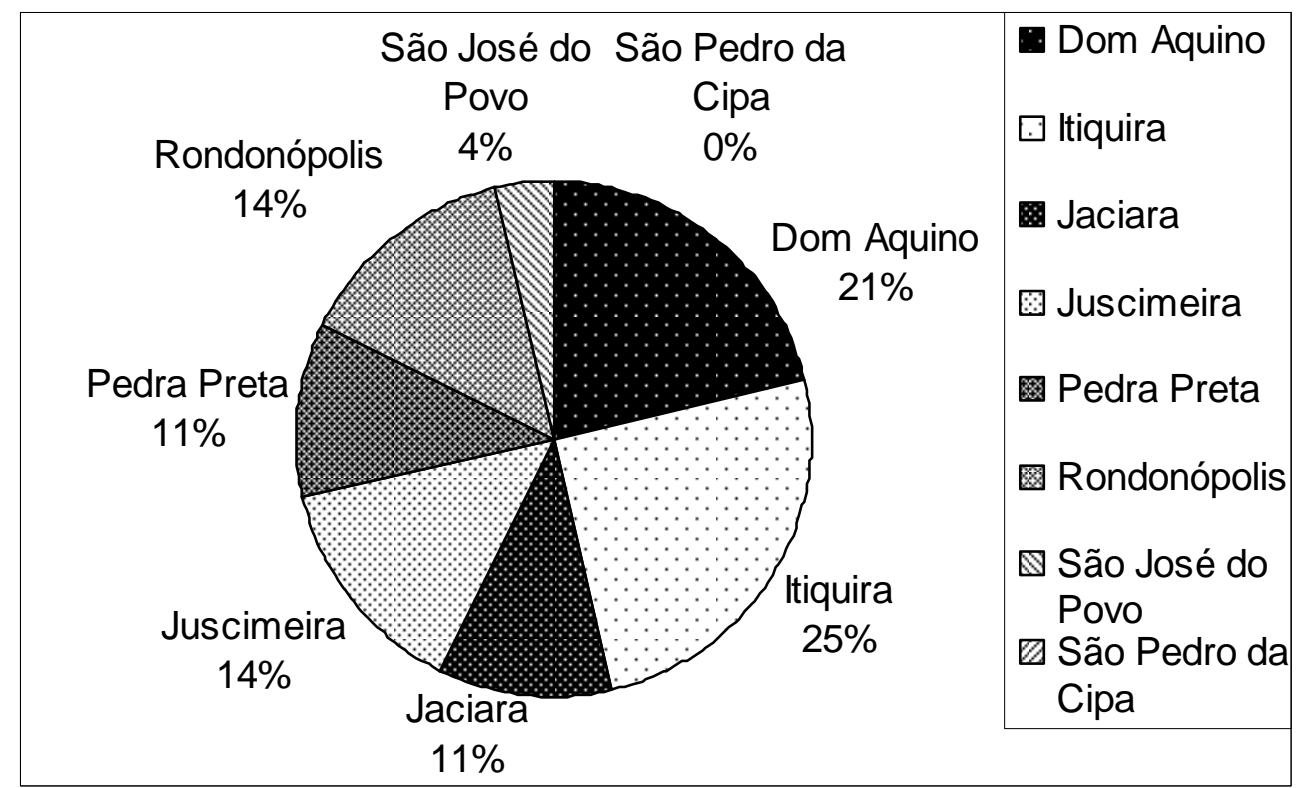

GRÁFICO 43 - Total dos animotopônimos da microrregião Rondonópolis.

Os animotopônimos da microrregião Rondonópolis são portugueses.

Considera-se, nesta pesquisa, que os animotopônimos portugueses da microrregião Rondonópolis, quanto à estrutura, subdividem-se em simples e compostos. São 21 (vinte e um) animotopônimos de estrutura simples e 07 (sete) animotopônimos de estrutura composta. Eles denominam 27 (vinte e sete) acidentes físicos e 01 (um) acidentes antrópico.

Os animotopônimos compostos Bela Vista, Boa Vista e Bom Jardim, formados por adjetivo + substantivo comum, denominam 02 (dois) córregos no município de Jaciara, 01 (um) córrego em Itiquira, 01 (um) córrego e 01 (um) distrito em Rondonópolis. O animotopônimo Boa Esperança, formado por adjetivo + unidade lexical esperar + sufixo -ança, indicador de qualidade ou estado, dá nome a 01 (um) córrego e a 01 (um) ribeirão em Itiquira. O ribeirão Boa Esperança estabelece divisa entre os municípios de Itiquira e Alto Garças, por isso consta nas relações de topônimos dos dois municípios.

Os animotopônimos simples e não derivados Engano, Perigo, Progresso e Rico nominam 03 (três) córregos e 01 (um) morro no município de Dom Aquino. Os animotopônimos Engano e Triunfo particularizam 01 (um) córrego e 01 (um) ribeirão 
em Itiquira. Os animotopônimos Alegre e Beleza nomeiam 02 (dois) córregos e 01 (uma) serra em Juscimeira. Os animotopônimos Engano e Saudade dão nomes a 01 (um) córrego e 01 (uma) serra em Pedra Preta. O animotopônimo Bonita toponimiza 01 (uma) cabeceira em Rondonópolis. O animotopônimo Bonito denomina 01 (um) córrego em São José do Povo que estabelece divisa entre os municípios de São José do Povo e Guiratinga, por isso consta nas relações de topônimos dos dois municípios.

Os animotopônimos Belezinha e Enganinho, formados pelas unidades lexicais beleza e engano + sufixo -inho/a, formador de diminutivo, denominam, respectivamente, 01 (um) córrego no município de Juscimeira e 01 (um) córrego em Itiquira. Os animotopônimos Formosa e Formoso, formados pela unidade lexical forma + sufixo -oso/a, indicador de abundância, nomeiam 01 (uma) lagoa e 01 (um) córrego em Dom Aquino, 01 (um) morro em Itiquira, 01 (um) córrego em Jaciara e 01 (uma) serra em Rondonópolis. O animotopônimo Perdido, formado pela unidade lexical perder + sufixo -ido, indicador do resultado da ação, dá nome a 01 (um) córrego em Pedra Preta.

Ocorre produtividade toponímica, nesta taxionomia, na microrregião Rondonópolis. O animotopônimo Bela Vista nomeia 02 (dois) córregos no município de Jaciara e o animotopônimo Boa Esperança denomina 01 (um) córrego e 01 (um) ribeirão em Itiquira. O animotopônimo Boa Vista dá nome a 01 (um) córrego e a 01 (um) distrito em Rondonópolis. O animotopônimo Formosa toponimiza 01 (uma) lagoa em Dom Aquino e 01 (uma) serra em Rondonópolis. O animotopônimo Formoso nomeia 01 (um) córrego em Dom Aquino, 01 (um) morro em Itiquira e 01 (um) córrego em Jaciara.

O animotopônimo Beleza dá nome a 01 (um) córrego e a 01 (uma) serra no município de Juscimeira. O animotopônimo Belezinha designa 01 (um) córrego em Juscimeira. O animotopônimo Bonita nomina 01 (uma) cabeceira em Rondonópolis e o animotopônimo Bonito toponimiza 01 (um) córrego em São José do Povo. O animotopônimo Engano nomeia 01 (um) córrego em Dom Aquino, 01 (um) ribeirão em Itiquira e 01 (um) córrego em Pedra Preta. O animotopônimo Enganinho denomina 01 (um) córrego em Itiquira. 
Os animotopônimos correspondem a 4,5\% do total de topônimos da microrregião Rondonópolis.

\section{Hagiotopônimos}

As unidades lexicais que se referem aos santos e santas da hagiologia católico-romana, quando utilizadas para dar nomes a acidentes físicos e a acidentes antrópicos, recebem nos estudos toponímicos a denominação de hagiotopônimos. Registram-se 25 (vinte e cinco) hagiotopônimos na microrregião Rondonópolis.

São 06 (seis) hagiotopônimos no município de Dom Aquino, 03 (três) em Itiquira, 01 (um) em Jaciara, 04 (quatro) em Juscimeira, 02 (dois) em Pedra Preta, 03 (três) em Rondonópolis, 01 (um) em São José do Povo e 05 (cinco) em São Pedro da Cipa. Apresenta-se a seguir o gráfico desta taxionomia com os respectivos percentuais por municípios (GRÁFICO 44).

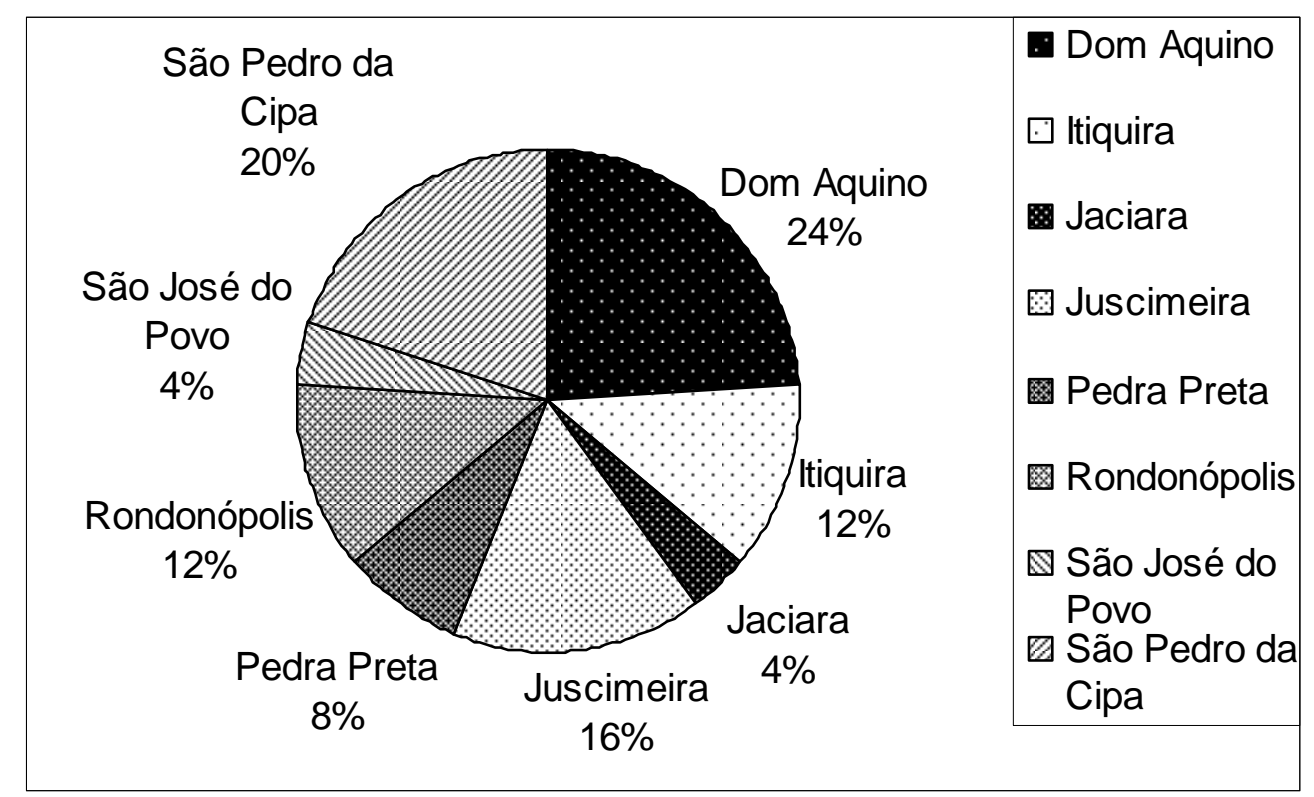

GRÁFICO 44 - Total dos hagiotopônimos da microrregião Rondonópolis.

Os hagiotopônimos da microrregião Rondonópolis são portugueses.

Considera-se, nesta pesquisa, que os hagiotopônimos da microrregião Rondonópolis possuem estrutura composta. Eles denominam 20 (vinte) acidentes 
físicos e 05 (cinco) acidentes antrópicos. Os 08 (oito) municípios da microrregião Rondonópolis possuem hagiotopônimos portugueses.

O hagiotopônimo São José do Povo, formado por adjetivo + substantivo próprio masculino + conectivo + substantivo comum, toponimiza 01 (um) município mato-grossense. O hagiotopônimo São Lourenço de Fátima, formado por adjetivo + substantivo próprio masculino + preposição + substantivo próprio feminino, nomeia 01 (um) distrito em Juscimeira. O hagiotopônimo São Pedro da Cipa, formado por adjetivo + substantivo próprio masculino + conectivo + sigla, denomina 01 (um) município mato-grossense. O hagiotopônimo São José do Planalto, formado por adjetivo + substantivo próprio masculino + conectivo + substantivo comum, formado pela aglutinação das unidades lexicais plano + alto, dá nome a 01 (um) distrito em Pedra Preta.

Os hagiotopônimos femininos Santa Elvira e Santa Joana, formados por adjetivo + substantivo próprio, denominam 01 (um) distrito no município de Juscimeira e 01 (uma) serra em Rondonópolis. A serra Santa Joana estabelece divisa entre os municípios de Rondonópolis e Santo Antônio de Leverger.

O hagiotopônimo Santo Antônio dá nome a 01 (um) morro no município de Dom Aquino. Os hagiotopônimos São Domingos, São João, São José e São Luiz nomeiam 03 (três) córregos no município de Dom Aquino, 02 (dois) córregos em Itiquira, 01 (um) córrego em Pedra Preta e 01 (um) córrego em São Pedro da Cipa. O hagiotopônimo São Bento nomina 01 (um) córrego em Dom Aquino e 01 (um) córrego que nasce em São Pedro da Cipa e deságua em Juscimeira, por isso consta nas relações de topônimos dos dois municípios. O hagiotopônimo São Paulo toponimiza 01 (um) córrego em São Pedro da Cipa que estabelece divisa entre os municípios de São Pedro da Cipa e Poxoréu, por isso consta nas relações de topônimos dos dois municípios.

O hagiotopônimo São Jerônimo dá nome a 01 (uma) serra que consta nas relações de topônimos do município de Itiquira e de Rondonópolis, pois encontra-se em áreas dos dois municípios e estabelece divisa entre Rondonópolis e Santo Antônio de Leverger. O hagiotopônimo São Lourenço toponimiza 01 (um) rio que consta nas relações de topônimos de Dom Aquino, Jaciara, Juscimeira, 
Rondonópolis e São Pedro da Cipa. O rio São Lourenço estabelece divisa do município de Jaciara com Dom Aquino e com São Pedro da Cipa e do município de Juscimeira com Jaciara e com Rondonópolis.

Ocorre produtividade toponímica, nesta taxionomia, na microrregião Rondonópolis. O hagiotopônimo São Bento denomina 01 (um) córrego em Dom Aquino, 01 (um) córrego que nasce em São Pedro da Cipa e deságua em Juscimeira. O hagiotopônimo São Domingos nomeia 01 (um) córrego em Dom Aquino, 01 (um) córrego em Itiquira, 01 (um) córrego em Pedra Preta e outro em São Pedro da Cipa.

Pode-se ainda considerar os hagiotopônimos São José, São José do Planalto e São José do Povo que dão nomes a 01 (um) córrego no município de Dom Aquino, a 01 (um) distrito em Pedra Preta e a 01 (um) município mato-grossense. O hagiotopônimo São Lourenço dá nome a 01 (um) rio que consta nas relações de topônimos de cinco municípios, mas não é considerado produtivo porque estabelece divisa entre eles. O hagiotopônimo São Lourenço de Fátima particulariza 01 (um) distrito em Juscimeira. O hagiotopônimo São Jerônimo também não é considerado produtivo porque dá nome a 01 (uma) serra que consta nas relações de topônimos de Itiquira e Rondonópolis.

Os hagiotopônimos correspondem a 4,0\% do total de topônimos da microrregião Rondonópolis.

\section{Hodotopônimos}

As unidades lexicais que se referem às vias de comunicação rurais ou urbanas, quando utilizadas para dar nomes a acidentes físicos e a acidentes antrópicos, recebem nos estudos toponímicos a denominação de hodotopônimos. Registram-se 14 (quatorze) hodotopônimos na microrregião Rondonópolis. 
São 02 (dois) hodotopônimos no município de Dom Aquino, 04 (quatro) em Itiquira, 01 (um) em Juscimeira, 02 (dois) em Pedra Preta e 05 (cinco) em Rondonópolis. Os municípios de Jaciara, São José do Povo e São Pedro da Cipa não possuem hodotopônimos. Apresenta-se a seguir o gráfico desta taxionomia com os respectivos percentuais por municípios (GRÁFICO 45).

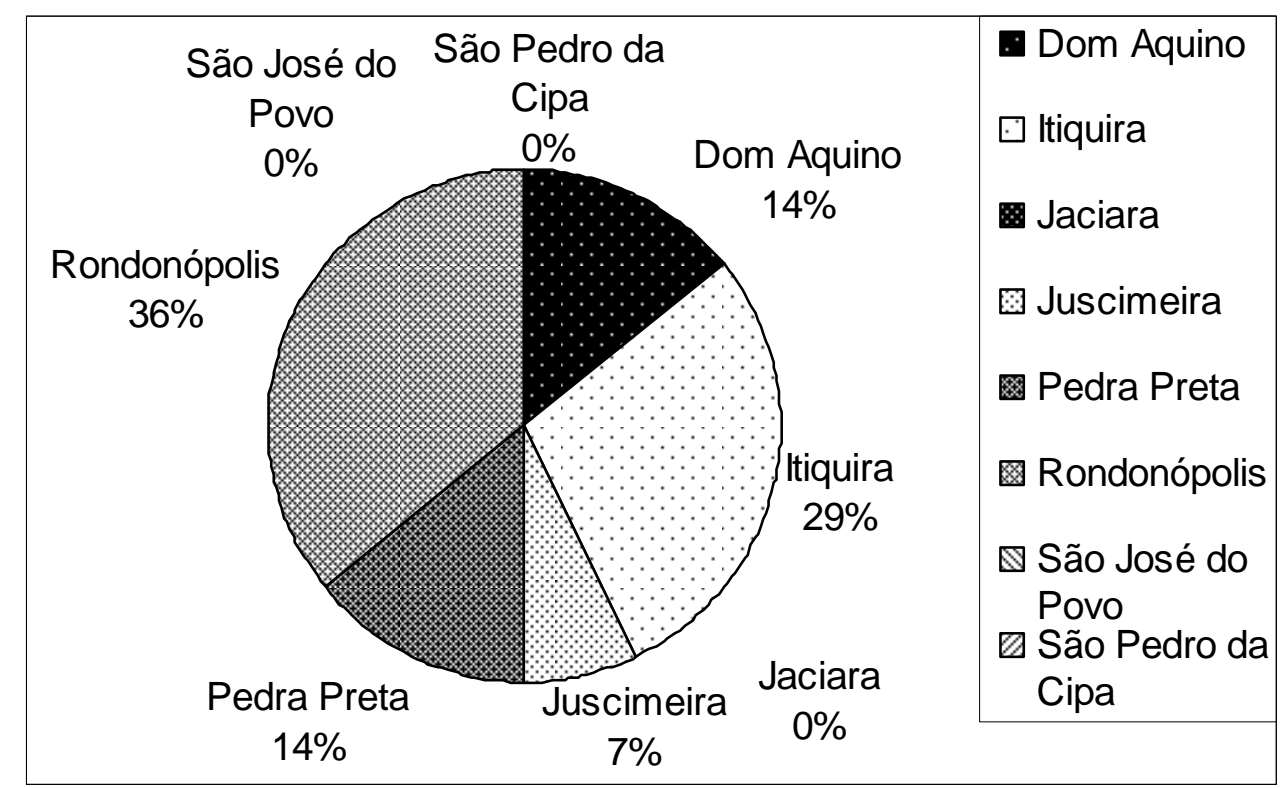

GRÁFICO 45 - Total dos hodotopônimos da microrregião Rondonópolis.

Os hodotopônimos da microrregião Rondonópolis são portugueses.

Considera-se, nesta pesquisa, que os hodotopônimos da microrregião Rondonópolis, quanto à estrutura, subdividem-se em simples e compostos. São 05 (cinco) hodotopônimos de estrutura simples e 09 (nove) hodotopônimos de estrutura composta. Eles denominam 14 (quatorze) acidentes físicos.

Os hodotopônimos de estrutura simples e não derivada Atalho e Pinguela dão nomes a 01 (um) córrego no município de Itiquira, a 01 (um) córrego em Pedra Preta e a 01 (um) córrego em Rondonópolis.

O hodotopônimo Pontinha, formado pela unidade lexical ponte + sufixo -inha, indicador de diminutivo, nomeia o terceiro trecho de 01 (um) córrego que estabelece divisa entre os municípios de Juscimeira e Rondonópolis, por isso consta nas relações de topônimos dos dois municípios. 
O hodotopônimo de estrutura composta Vereda Grande, formado por substantivo comum + adjetivo, singulariza 01 (um) córrego no município de Rondonópolis. Os hodotopônimos Ponte de Barro e Ponte de Pedra, formados por substantivo comum + preposição + substantivo comum, denominam 01 (um) córrego em Dom Aquino, 02 (dois) córregos em Itiquira, 01 (um) córrego em Rondonópolis e 01 (um) ribeirão que consta nas relações de topônimos dos municípios de Itiquira, Pedra Preta e Rondonópolis porque estabelece divisa entre os municípios de Itiquira e Pedra Preta e deságua em Rondonópolis. E também, dá nome a 01 (um) córrego em Dom Aquino que estabelece divisa entre Dom Aquino e Poxoréu, por isso consta nas relações de topônimos dos dois municípios.

Ocorre produtividade toponímica, nesta taxionomia, na microrregião Rondonópolis. O hodotopônimo Pinguela dá nome a 01 (um) córrego no município de Pedra Preta e a outro em Rondonópolis. O hodotopônimo Ponte de Pedra nomeia 01 (um) ribeirão que consta nas relações de topônimos dos municípios de Itiquira, Pedra Preta e Rondonópolis, 01 (um) córrego em Dom Aquino, 02 (dois) córregos em Itiquira e 01 (um) córrego em Rondonópolis.

O hodotopônimo Pontinha denomina 01 (um) córrego que estabelece divisa entre os municípios de Juscimeira e Rondonópolis, por isso não é considerado produtivo.

Os hodotopônimos correspondem a 2,3\% do total de topônimos da microrregião Rondonópolis.

\section{Etnotopônimos}

As unidades lexicais que se referem a elementos étnicos, isolados ou não (povos, tribos, castas), quando utilizadas para denominar acidentes físicos e acidentes antrópicos, recebem nos estudos toponímicos a denominação de etnotopônimos. Registram-se 11 (onze) etnotopônimos na microrregião Rondonópolis. 
São 01 (um) etnotopônimo no município de Dom Aquino, 01 (um) em Itiquira, 01 (um) em Juscimeira, 02 (dois) em Pedra Preta, 04 (quatro) em Rondonópolis e 02 (dois) em São José do Povo. Os municípios de Jaciara e São Pedro da Cipa não possuem etnotopônimos. Apresenta-se a seguir o gráfico desta taxionomia com os respectivos percentuais por municípios (GRÁFICO 46).

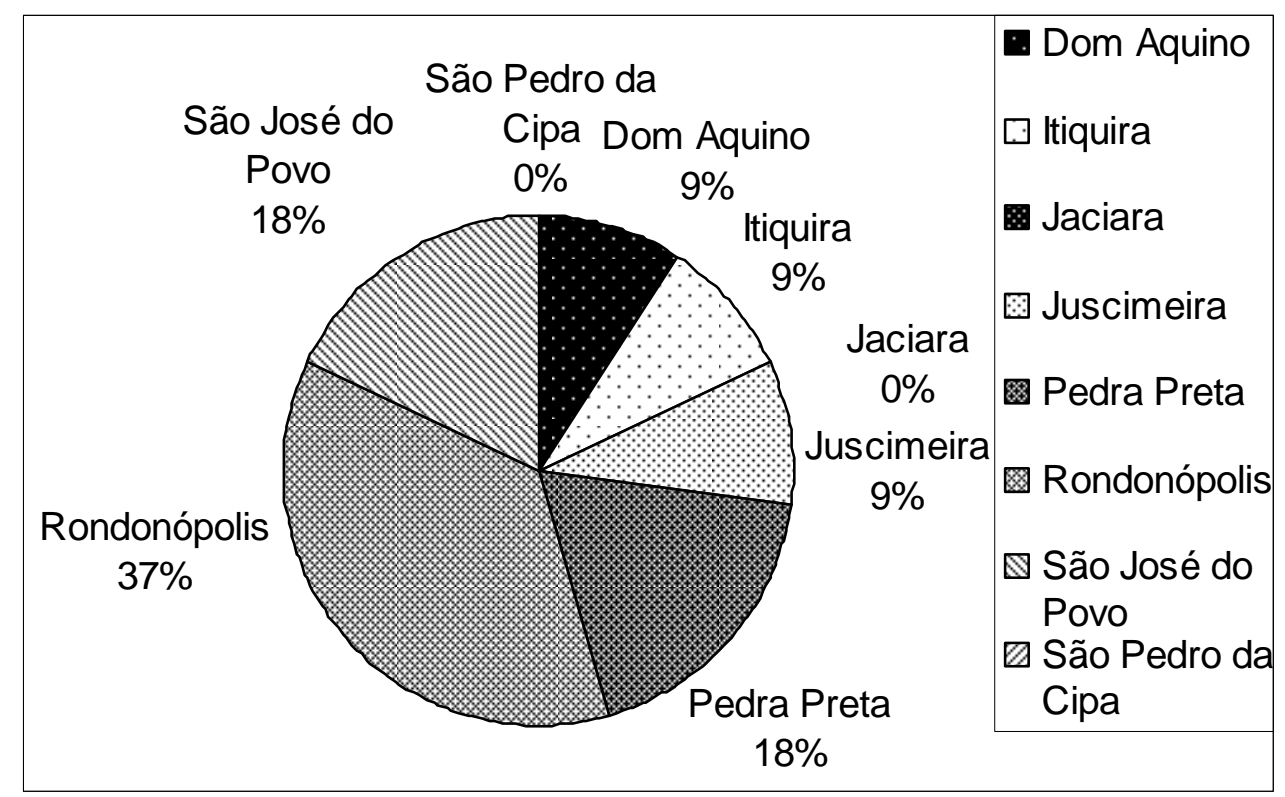

GRÁFICO 46 - Total dos etnotopônimos da microrregião Rondonópolis.

São 01 (um) etnotopônimo tupi e 10 (dez) portugueses na microrregião Rondonópolis.

O etnotopônimo tupi Goiano, formado pela unidade lexical tupi Goiás + sufixo -ano, indicador de naturalidade, origem da língua portuguesa, possui estrutura híbrida e dá nome a 01 (um) córrego no município de Pedra Preta.

Segundo Sampaio, a unidade lexical tupi tem as seguintes características: "GOYAZ, V. Goyá. GOYÁ, corr. guayá, c. guá-yá, o indivíduo semelhante, parecido, ou gente da mesma raça. Documentos antigos falam em guayás e guayazes, designando uma nação selvagem." (1970, p. 206).

Considera-se, nesta pesquisa, que os etnotopônimos portugueses da microrregião Rondonópolis, possuem estrutura simples. Eles denominam 08 (oito) acidentes físicos e 02 (dois) acidentes antrópicos. 
Os etnotopônimos Alagoano e Baiano, formados pelas unidades lexicais Alagoas e Bahia + sufixo -ano, indicador de naturalidade, denominam 01 (um) córrego em Dom Aquino e 01 (um) córrego que estabelece divisa entre os municípios de Rondonópolis e São José do Povo e, por isso, consta nas relações de topônimos dos dois municípios. O etnotopônimo Paulista, formado pelas unidades lexicais do topônimo São Paulo + sufixo -ista, indicador de naturalidade, dá nome a 01 (uma) colônia e a 01 (uma) vila em Rondonópolis. O etnotopônimo Russão, formado pela unidade lexical Rússia + sufixo -ão, formador de aumentativo, singulariza 01 (um) córrego em Juscimeira.

O etnotopônimo simples e não derivado Gaúcho toponimiza 01 (um) córrego que estabelece divisa entre os municípios de Rondonópolis e São José do Povo, por isso consta nas relações de topônimos dos dois municípios. O etnotopônimo Solteira nomeia 01 (uma) serra em Itiquira e 01 (uma) serra em Pedra Preta.

Ocorre produtividade toponímica, nesta taxionomia, na microrregião Rondonópolis. O etnotopônimo Paulista denomina 01 (uma) colônia e 01 (uma) vila no município de Rondonópolis. O etnotopônimo Solteira dá nome a 01 (uma) serra em Itiquira e a outra em Pedra Preta.

Os etnotopônimos correspondem a 1,8\% do total de topônimos da microrregião Rondonópolis.

\section{Somatotopônimos}

As unidades lexicais que se referem à partes do corpo humano ou do animal, quando utilizadas para denominar acidentes físicos e acidentes antrópicos, recebem nos estudos toponímicos a denominação de somatotopônimos. Registram-se 10 (dez) somatotopônimos na microrregião Rondonópolis.

São 03 (três) somatotopônimos no município de Itiquira, 02 (dois) em Juscimeira, 04 (quatro) em Rondonópolis e 01 (um) em São Pedro da Cipa. Os 
municípios de Dom Aquino, Jaciara, Pedra Preta e São José do Povo não possuem somatotopônimos. Apresenta-se a seguir o gráfico desta taxionomia com os respectivos percentuais por municípios (GRÁFICO 47).

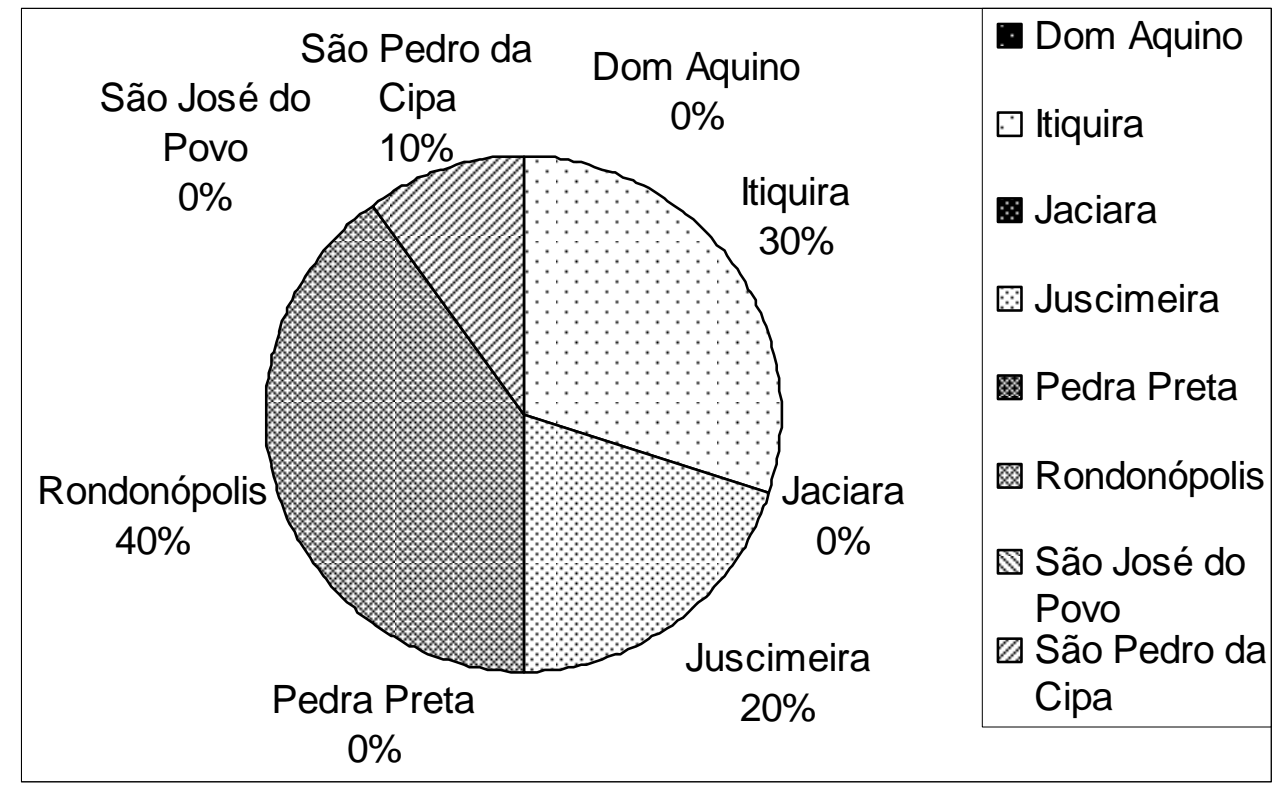

GRÁFICO 47 - Total dos somatotopônimos da microrregião Rondonópolis.

Registram-se, na microrregião Rondonópolis, 03 (três) somatotopônimos bororos e 07 (sete) portugueses.

Considera-se, nesta pesquisa, que os somatotopônimos bororos, quanto à estrutura, classificam-se como simples e híbrido. Os somatotopônimos bororos simples Berigue e Trubial singularizam 02 (dois) córregos. O somatotopônimo bororo híbrido Beriguinho, formado pela unidade lexical borora berigue + sufixo -inho, indicador de diminutivo da língua portuguesa, dá nome a 01 (um) córrego. Todos localizam-se no município de Rondonópolis.

As unidades lexicais berigue e trubial estão registradas na Enciclopédia Bororo: "Bíri Ki Páru - * bíri $\mathbf{2}_{2}$ pele; kí2, secura; páru, princípio [foz do cór. da pele sêca]. Cór. afl. da esq. do c. m. do Pogúbo, r. Vermelho, cór. Birigue." e "Aturébe Eiáo - aturébe, conchinhas; e, (d)elas; iáo, localidade [cór. das conchinhas]. Cór. afl. da esq. do c. m. do Pogúbo Ceréu, r. São Lourenço: cór. Tribiau." Albisetti; Venturelli (1962, p. 183; 277) 
Considera-se, nesta pesquisa, que os somatotopônimos portugueses da microrregião Rondonópolis possuem estrutura simples. Eles denominam 07 (sete) acidentes físicos.

Os somatotopônimos simples e sem derivação Cambota (forma sincopada de cambalhota), Doido, Louca, Miau e Panturra nomeiam 01 (um) córrego e 01 (um) morro no município de Itiquira, 01 (um) córrego em Juscimeira, 01 (um) córrego em Rondonópolis e 01 (um) córrego em São Pedro da Cipa.

O somatotopônimo derivado Canceira (grafia registrada no mapa e na carta topográfica), formado pela unidade lexical cansar + sufixo -eira, indicador de estado, denomina 01 (um) córrego em Juscimeira. O somatotopônimo Gordura, formado pela unidade lexical gordo + sufixo -ura, indicador de qualidade ou estado, dá nome a 01 (um) córrego em Itiquira.

Os somatotopônimos correspondem a 1,6\% do total de topônimos da microrregião Rondonópolis.

\section{Numerotopônimos}

As unidades lexicais que se referem aos adjetivos numerais, quando utilizadas para denominar acidentes físicos e acidentes antrópicos, recebem nos estudos toponímicos a denominação de numerotopônimos. Registram-se 08 (oito) numerotopônimos na microrregião Rondonópolis.

São 02 (dois) numerotopônimos no município de Itiquira, 01 (um) em Jaciara, 01 (um) em Juscimeira, 03 (três) em Rondonópolis e 01 (um) em São Pedro da Cipa. Os municípios de Dom Aquino, Pedra Preta e São José do Povo não possuem numerotopônimos. Apresenta-se a seguir o gráfico desta taxionomia com os respectivos percentuais por municípios (GRÁFICO 48). 


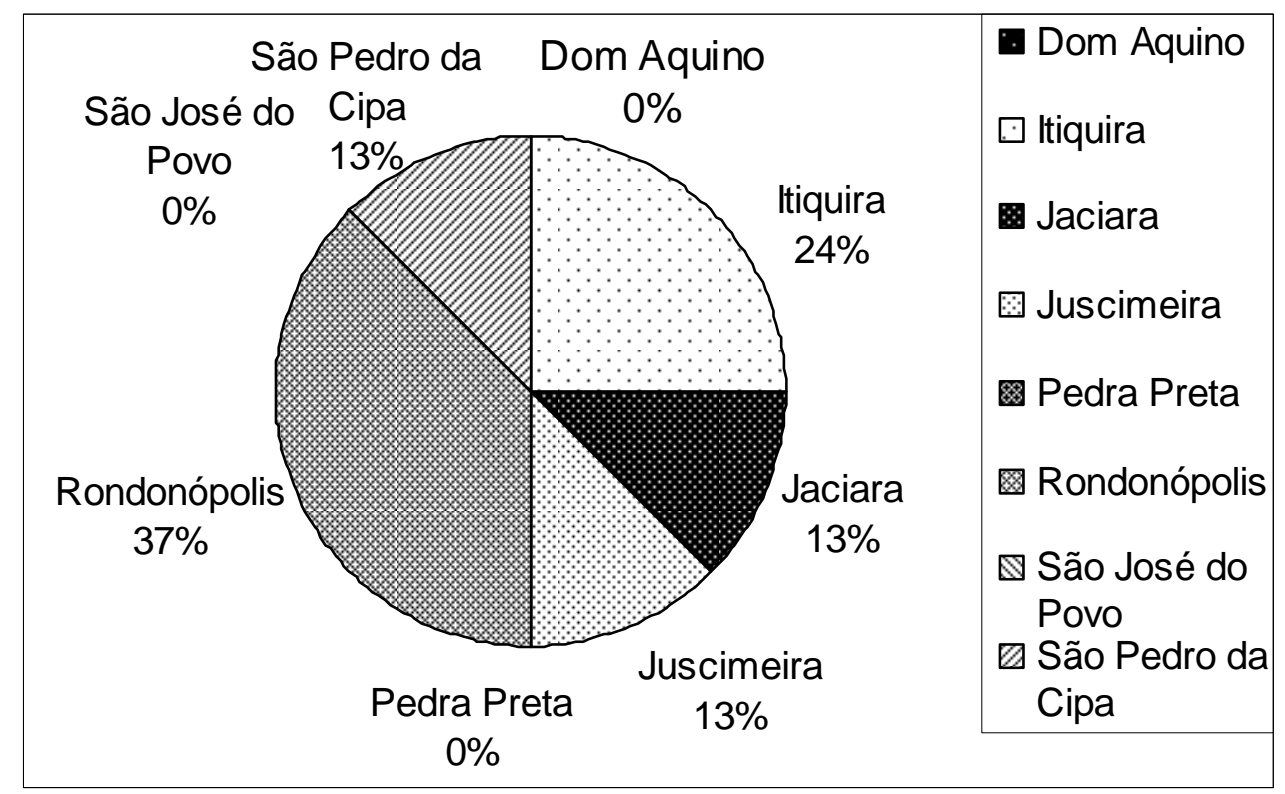

GRÁFICO 48 - Total dos numerotopônimos da microrregião Rondonópolis.

Os numerotopônimos da microrregião Rondonópolis são portugueses.

Considera-se, nesta pesquisa, que os numerotopônimos da microrregião Rondonópolis, quanto à estrutura, subdividem-se em simples e compostos. São 01 (um) numerotopônimo de estrutura simples e 07 (sete) numerotopônimos de estrutura composta. Eles denominam 07 (sete) acidentes físicos e 01 (um) acidente antrópico.

O numerotopônimo simples e não derivado Sete dá nome a 01 (um) córrego no município de São Pedro da Cipa. O córrego Sete estabelece divisa entre os municípios de São Pedro da Cipa e Poxoréu, por isso consta nas relações de topônimos dos dois municípios.

Os numerotopônimos de estrutura composta Dois Córregos, Duas Pontes, Sete Voltas e Três Pontes, formados por numeral + substantivo comum com desinência de plural -s, denominam 01 (um) córrego no município de Itiquira, 01 (um) córrego em Juscimeira, 01 (um) córrego e 01 (um) povoado em Rondonópolis. O numerotopônimo Três Coqueiros, formado por numeral + unidade lexical coco + sufixo -(qu)eiro com desinência de plural -s, dá nome a 01 (um) morro em Rondonópolis. 
O numerotopônimo Sete de Pedra, formado por numeral + preposição + substantivo comum, dá nome a 01 (um) córrego no município de Itiquira. O numeral cardinal Vinte e Sete nomeia 01 (um) córrego em Jaciara.

Pode-se considerar que ocorre produtividade toponímica, nesta taxionomia, se observar a primeira unidade lexical dos numerotopônimos compostos. $O$ numerotopônimo Três Pontes nomeia 01 (um) povoado e o numerotopônimo Três Coqueiros denomina 01 (um) morro, ambos no município de Rondonópolis. O numerotopônimo Sete nomeia 01 (um) córrego em São Pedro da Cipa, o numerotopônimo Sete de Pedra singulariza 01 (um) córrego em Itiquira e o numerotopônimo Sete Voltas nomina 01 (um) córrego em Rondonópolis.

Os numerotopônimos correspondem a 1,3\% do total de topônimos da microrregião Rondonópolis.

\section{Hierotopônimos}

As unidades lexicais que se referem aos nomes sagrados de diferentes crenças: cristã, hebraica, maometana, etc., às efemérides religiosas, às associações religiosas, aos locais de culto, quando utilizadas para denominar acidentes físicos e acidentes antrópicos, recebem nos estudos toponímicos a denominação de hierotopônimos. Registram-se 07 (sete) hierotopônimos na microrregião Rondonópolis.

São 03 (três) hierotopônimos no município de Itiquira, 01 (um) em Juscimeira, 01 (um) em Pedra Preta, 01 (um) em Rondonópolis e 01 (um) em São José do Povo. Os municípios de Dom Aquino, Jaciara e São Pedro da Cipa não possuem hierotopônimos. Apresenta-se a seguir o gráfico desta taxionomia com os respectivos percentuais por municípios (GRÁFICO 49). 


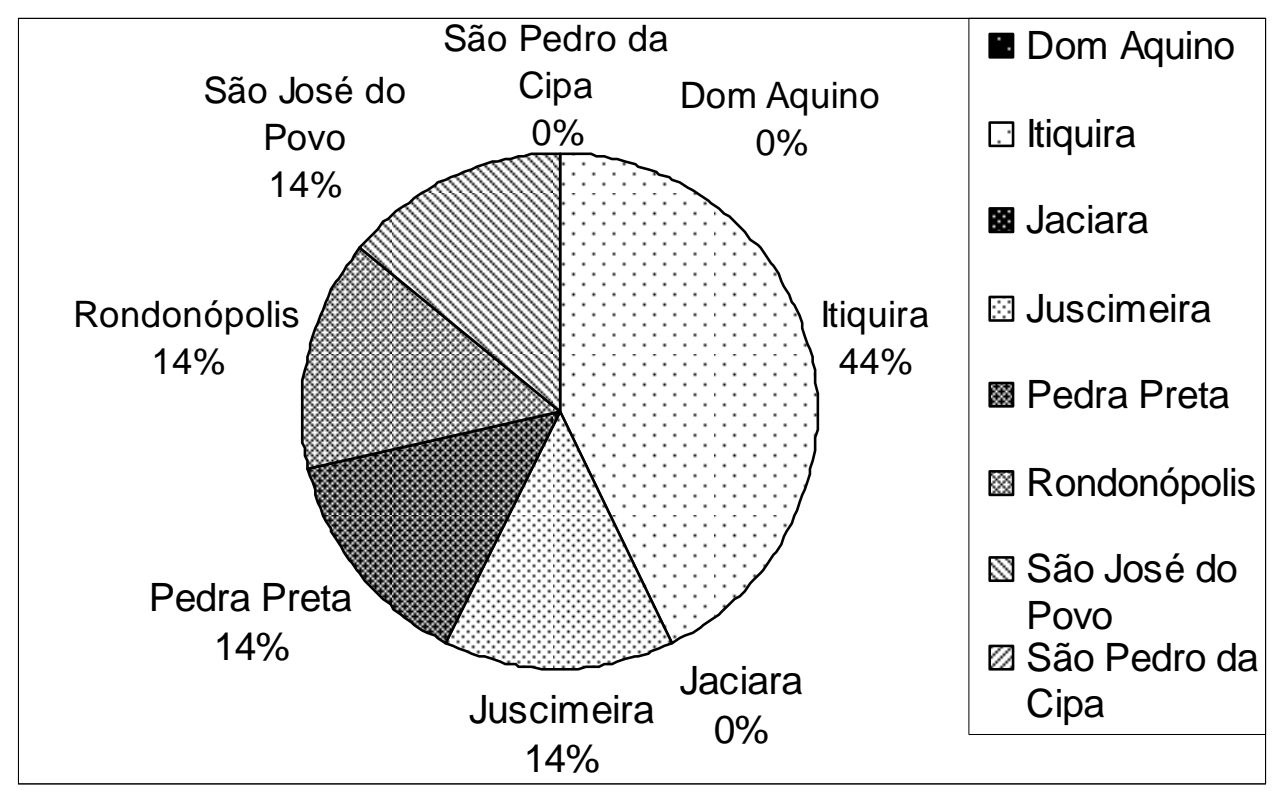

GRÁFICO 49 - Total dos hierotopônimos da microrregião Rondonópolis.

São 01 (um) hierotopônimo tupi e 06 (seis) portugueses na microrregião Rondonópolis.

Considera-se, nesta pesquisa, que o hierotopônimo tupi possui estrutura simples. O hierotopônimo Jaraguá dá nome a 01 (um) córrego no município de Itiquira.

Segundo Sampaio, a unidade lexical tupi jaraguá possui as seguintes características: "JARAGUÁ, corr. yara-guá, a baixa do senhor, o valle do dono. Pode ser corrupção de yara-quã que significa - o dedo de Deus, a ponta do Senhor." (1970, p. 236).

Considera-se, nesta pesquisa, que os hierotopônimos portugueses da microrregião Rondonópolis possuem estrutura simples. Eles denominam 05 (cinco) acidentes físicos e 01 (um) acidente antrópico.

Os hierotopônimos Cruz e Paraíso denominam 01 (um) córrego e 01 (um) morro em Itiquira. O hierotopônimo Cruz dá nome a 01 (um) morro em Pedra Preta

O hierotopônimo Cruzinha, formado pela unidade lexical cruz + sufixo -inha, indicador de diminutivo, dá nome a 01 (um) córrego em Juscimeira. O hierotopônimo Cruzeiro, formado pela unidade lexical cruz + sufixo -eiro, indicador de aumento, é o primeiro topônimo de 01 (uma) vila em Rondonópolis. O hierotopônimo Salvação, 
formado pela unidade lexical salvar + sufixo -ção, indicador da ação ou resultado da ação, nomeia 01 (um) córrego em São José do Povo.

Ocorre produtividade toponímica, nesta taxionomia, na microrregião Rondonópolis. O hierotopônimo Cruz nomeia 01 (um) morro em Itiquira e outro em Pedra Preta e, pode-se ainda acrescentar, o hierotopônimo Cruzinha que denomina 01 (um) córrego em Juscimeira e o hierotopônimo Cruzeiro que é o primeiro topônimo de 01 (uma) vila em Rondonópolis.

Os hierotopônimos correspondem a 1,1\% do total de topônimos da microrregião Rondonópolis.

\section{Cronotopônimos}

As unidades lexicais que se referem a indicadores cronológicos como novo/nova, velho/velha, quando utilizadas para denominar acidentes físicos e acidentes antrópicos, recebem nos estudos toponímicos a denominação de cronotopônimos. Registram-se 05 (cinco) cronotopônimos na microrregião Rondonópolis.

São 02 (dois) cronotopônimos no município de Itiquira, 01 (um) em Pedra Preta, 01 (um) em Rondonópolis e 01 (um) em São José do Povo. Os municípios de Dom Aquino, Jaciara, Juscimeira e São Pedro da Cipa não possuem cronotopônimos. Devido à pequena quantidade de topônimos não se apresenta gráfico para esta taxionomia.

São 02 (dois) cronotopônimos tupis e 03 (três) portugueses na microrregião Rondonópolis.

Os cronotopônimos tupis possuem estrutura híbrida. Os cronotopônimos Nova Araçatuba e Nova Catanduva, formados por unidade lexical portuguesa + unidade lexical tupi, dão nomes a 01 (um) povoado no município de Pedra Preta e a 01 (um) povoado em São José do Povo. 
Segundo Sampaio, as unidades lexicais tupis araçatuba e catanduva possuem as seguintes características: "ARAÇATUBA, corr. araçá-tyba, o sitio dos araçás, onde há araçás em abundancia. Alt. Araçatiba." e "CATANDUVA, córr.caatã-dyba, o local do matto ralo, ou do cerrado; terreno seco com matto de inferior qualidade." (1970, p. 173; 194)

Considera-se, nesta pesquisa, que os cronotopônimos portugueses subdividem-se em simples e composto. O cronotopônimo composto português Nova Galiléia, formado por adjetivo + substantivo próprio, nomeia 01 (um) distrito no município de Rondonópolis.

O cronotopônimo simples Velhas apresenta desinência de plural $-s$ e dá nome a 01 (um) ribeirão no município de Itiquira que estabelece divisa entre Itiquira e Alto Garças, por isso consta nas relações de topônimos dos dois municípios. O cronotopônimo Velhinha, formado pela unidade lexical velha + sufixo -inha, indicador de diminutivo, nomeia 01 (um) córrego em Itiquira.

Pode-se considerar que ocorre produtividade toponímica, na taxionomia cronotopônimos. O cronotopônimo Velhas denomina 01 (um) ribeirão e o cronotopônimo Velhinha dá nome a 01 (um) córrego, ambos em Itiquira. Os cronotopônimos Nova Galiléia, Nova Araçatuba e Nova Catanduva nomeiam 01 (um) distrito em Rondonópolis, 01 (um) povoado em Pedra Preta e 01 (um) povoado em São José do Povo.

Os cronotopônimos correspondem a $0,8 \%$ do total de topônimos da microrregião Rondonópolis.

\section{Dirrematotopônimos}

As unidades lexicais que constituem frases ou enunciados lingüísticos, quando utilizadas para denominar acidentes físicos e acidentes antrópicos, recebem 
nos estudos toponímicos a denominação de dirrematotopônimos. Registram-se 04 (quatro) dirrematotopônimos na microrregião Rondonópolis.

O município de Dom Aquino possui 01 (um) dirrematotopônimo, Juscimeira possui 02 (dois) e Rondonópolis possui 01 (um) dirrematotopônimo. Os municípios de Itiquira, Jaciara, Pedra Preta, São José do Povo e São Pedro da Cipa não possuem dirrematotopônimos. Devido à pequena quantidade de topônimos não se apresenta gráfico para esta taxionomia

Os dirrematotopônimos da microrregião Rondonópolis são portugueses.

Considera-se, nesta pesquisa, que os dirrematotopônimos, quanto à estrutura, subdividem-se em simples e compostos.

O dirrematotopônimo Juscimeira possui estrutura simples, formado pela aglutinação de parte das unidades lexicais: substantivo próprio Juscelino + substantivo derivado limeira, toponimiza 01 (um) município mato-grossense.

Os dirrematotopônimos compostos apresentam as seguintes subdivisões:

a) dirrematotopônimo formado por substantivo comum + particípio (feminino) do verbo dar: Mão Dada;

b) dirrematotopônimo formado por verbo matar no presente do indicativo + substantivo comum: Mata Cavalo;

c) dirrematotopônimo formado por substantivo comum + preposição + adjetivo + substantivo próprio: Placa de Santo Antônio.

O dirrematotopônimo Mão Dada nomeia 01 (um) morro no município de Rondonópolis e o dirrematotopônimo Mata Cavalo dá nome a 01 (um) córrego em Dom Aquino. O dirrematotopônimo Placa de Santo Antônio denomina 01 (uma) localidade em Juscimeira.

Os dirrematotopônimos correspondem a $0,7 \%$ do total de topônimos da microrregião Rondonópolis. 


\section{Poliotopônimos}

As unidades lexicais que se referem aos aglomerados urbanos como vila, aldeia, cidade, povoação, arraial, quando usadas para denominar acidentes físicos e acidentes antrópicos, recebem nos estudos toponímicos a denominação de poliotopônimos. Registram-se 04 (quatro) poliotopônimos na microrregião Rondonópolis.

O município de Rondonópolis possui 04 (quatro) poliotopônimos. Os municípios de Dom Aquino, Itiquira, Jaciara, Juscimeira, Pedra Preta, São José do Povo e São Pedro da Cipa não possuem poliotopônimos. Devido à pequena quantidade de topônimos não se apresenta gráfico para esta taxionomia

Os poliotopônimos da microrregião Rondonópolis são portugueses e, quanto à estrutura, subdividem em simples e composto.

O poliotopônimo simples e não derivado Aldeia nomeia 01 (um) córrego e 01 (um) morro. O poliotopônimo Aldeinha, formado pela unidade lexical aldeia + sufixo inha, indicador de diminutivo, dá nome a 01 (um) córrego.

O poliotopônimo composto Vila Operária, formado por substantivo comum + adjetivo, dá nome a 01 (um) distrito.

Apesar da pequena quantidade de poliotopônimos pode-se constatar que ocorre produtividade, nesta taxionomia, na microrregião Rondonópolis. O poliotopônimo Aldeia denomina 01 (um) morro e 01 (um) córrego. O poliotopônimo Aldeinha dá nome a 01 (um) córrego, no município de Rondonópolis.

Os poliotopônimos correspondem a $0,7 \%$ do total de topônimos da microrregião Rondonópolis.

\section{Historiotopônimo}


As unidades lexicais que se referem aos movimentos de cunho históricosocial e aos seus membros, assim como as datas correspondentes, quando utilizadas para denominar acidentes físicos e acidentes antrópicos, recebem nos estudos toponímicos a denominação de historiotopônimos. Registram-se 03 (três) historiotopônimos na microrregião Rondonópolis.

O município de Dom Aquino possui 01 (um) historiotopônimo, Juscimeira possui 01 (um) e Rondonópolis também possui 01 (um) historiotopônimo. Os municípios de Itiquira, Jaciara, Pedra Preta, São José do Povo e São Pedro da Cipa não possuem historiotopônimos. Devido à pequena quantidade de topônimos não se apresenta gráfico para esta taxionomia

Os historiotopônimos da microrregião Rondonópolis são portugueses e subdividem-se, quanto à estrutura, em simples e composto.

O historiotopônimo Bandeirante, formado pela unidade lexical bandeira + sufixo -ante, indicador do agente da ação, nomeia 01 (um) córrego em Juscimeira.

O historiotopônimo Rondonópolis é considerado, neste estudo, de estrutura simples, formado pela aglutinação do nome de família Rondon + unidade lexical grega -polis. O historiotopônimo Rondonópolis toponimiza 01 (um) município matogrossense e uma das microrregiões que compõem a mesorregião Sudeste Matogrossense. O historiotopônimo Rondonópolis é uma homenagem do povo matogrossense ao eminente sertanista brasileiro Marechal Cândido Mariano da Silva Rondon.

O historiotopônimo Dom Aquino possui estrutura composta, formado por substantivo comum + substantivo próprio e nomeia 01 (um) município matogrossense. O historiotopônimo é uma homenagem a Francisco de Aquino Correia. Dom Aquino foi arcebispo católico, governador de Mato Grosso, fundador da Academia Mato-grossense de Letras e Membro Efetivo da Academia Brasileira de Letras.

O historiotopônimo corresponde a 0,5\% do total de topônimos da microrregião Rondonópolis. 


\section{Ecotopônimos}

As unidades lexicais que se referem às habitações de um modo geral, quando utilizadas para denominar acidentes físicos e acidentes antrópicos, recebem nos estudos toponímicos a denominação de ecotopônimos. Registram-se 02 (dois) ecotopônimos na microrregião Rondonópolis.

O município de Itiquira possui 01 (um) ecotopônimo e Jaciara também possui 01 (um) ecotopônimo. Os municípios de Dom Aquino, Juscimeira, Pedra Preta, Rondonópolis, São José do Povo e São Pedro da Cipa não possuem ecotopônimos. Devido à pequena quantidade de topônimos não se apresenta gráfico para esta taxionomia

Os ecotopônimos da microrregião Rondonópolis são portugueses e possuem estrutura simples.

O ecotopônimo simples e não derivado Castelo nomeia 01 (um) córrego em de Itiquira. O ecotopônimo Sobradinho apresenta dupla sufixação, formado pela unidade lexical sobrar + sufixo -ado, indicador de grandeza ou extensão + sufixo inho, indicador de diminutivo, dá nome a 01 (um) córrego em Jaciara.

Os ecotopônimos correspondem a $0,3 \%$ do total de topônimos da microrregião Rondonópolis.

\section{Axiotopônimo}

As unidades lexicais que se referem aos títulos e dignidades de que se fazem acompanhar os nomes próprios individuais, quando utilizadas para denominar acidentes físicos e acidentes antrópicos, recebem nos estudos toponímicos a denominação de axiotopônimos. Registra-se 01 (um) axiotopônimo na microrregião Rondonópolis. 
O município de Jaciara possui 01 (um) axiotopônimo. Os municípios de Dom Aquino, Itiquira, Juscimeira, Pedra Preta, Rondonópolis, São José do Povo e São Pedro da Cipa não possuem axiotopônimos. Devido à unicidade de topônimo não se apresenta gráfico para esta taxionomia

O axiotopônimo da microrregião Rondonópolis é português e possui estrutura composta.

O axiotopônimo Tenente Amaral, formado por substantivo comum + substantivo próprio, dá nome a 01 (um) ribeirão no município de Jaciara.

O axiotopônimo corresponde a $0,2 \%$ do total de topônimos da microrregião Rondonópolis.

\section{Corotopônimo}

As unidades lexicais que se referem aos nomes de cidades, estados países, regiões, continentes, quando utilizadas para denominar acidentes físicos e acidentes antrópicos, recebem nos estudos toponímicos a denominação de corotopônimos. Registra-se 01 (um) corotopônimo na microrregião Rondonópolis.

O município de Jaciara possui 01 (um) corotopônimo. Os municípios de Dom Aquino, Itiquira, Juscimeira, Pedra Preta, Rondonópolis, São José do Povo e São Pedro da Cipa não possuem corotopônimos. Devido à unicidade de topônimo não se apresenta gráfico para esta taxionomia

O corotopônimo da microrregião Rondonópolis é português e possui estrutura simples. O corotopônimo Fortaleza nomeia 01 (um) córrego em Jaciara.

O corotopônimo corresponde a $0,2 \%$ do total de topônimos da microrregião Rondonópolis. 


\section{Considerações parciais}

Nos estudos toponímicos da microrregião Rondonópolis pode-se constatar algumas características específicas no que se refere ao agrupamento dos topônimos.

Do total de 618 (seiscentos e dezoito) topônimos registrados na microrregião Rondonópolis, 378 (trezentos e setenta e oito) são de natureza física e 240 (duzentos e quarenta) são de natureza antrópica.

A distribuição dos topônimos de natureza física, por município, na microrregião Rondonópolis, em números absolutos, apresenta os seguintes valores: 40 (quarenta) topônimos no município de Dom Aquino, 98 (noventa e oito) em Itiquira, 22 (vinte e dois) em Jaciara, 42 (quarenta e dois) em Juscimeira, 63 (sessenta e três) em Pedra Preta, 86 (oitenta e seis) em Rondonópolis, 11 (onze) em São José do Povo e 16 (dezesseis) em São Pedro da Cipa. Apresenta-se a seguir o gráfico dos topônimos de natureza física com os respectivos percentuais por município (GRÁFICO 50).

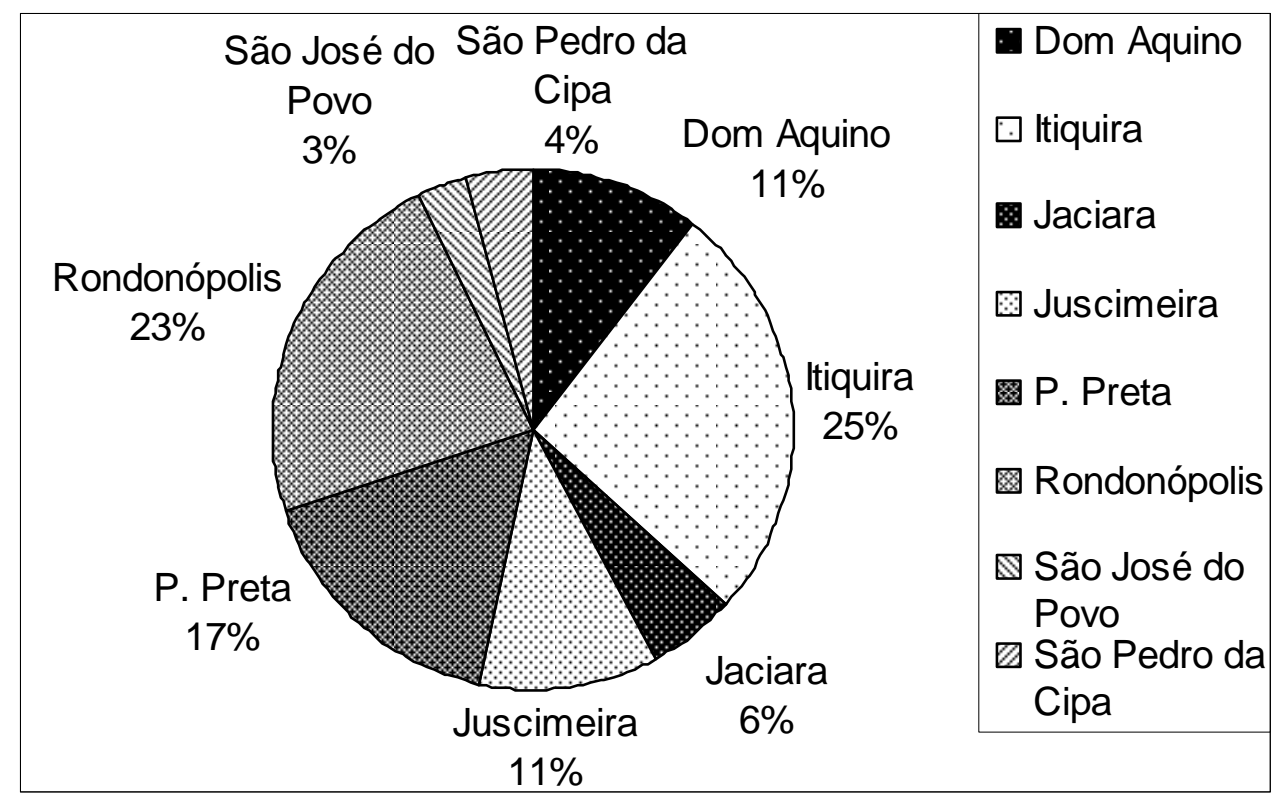

GRÁFICO 50 - Total dos topônimos de natureza física da microrregião Rondonópolis.

Os topônimos de natureza antrópica, por município, na microrregião Rondonópolis, em números absolutos, apresentam-se assim: 38 (trinta e oito) 
topônimos no município de Dom Aquino, 56 (cinqüenta e seis) em Itiquira, 16 (dezesseis) em Jaciara, 24 (vinte e quatro) em Juscimeira, 36 (trinta e seis) em Pedra Preta, 49 (quarenta e nove) em Rondonópolis, 09 (nove) em São José do Povo e 12 (doze) São Pedro da Cipa. Apresenta-se a seguir, o gráfico dos topônimos de natureza antrópica com os respectivos percentuais por município (GRÁFICO 51).

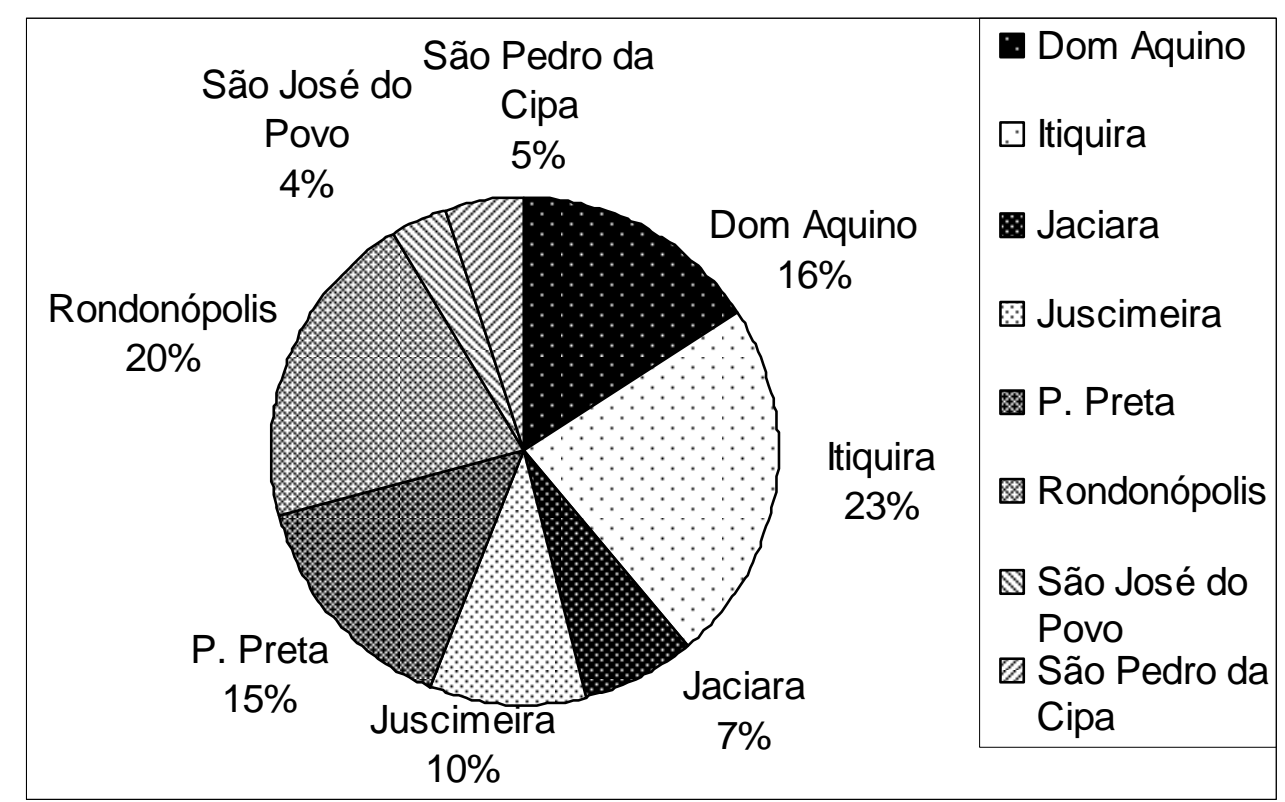

GRÁFICO 51 - Total dos topônimos de natureza antrópica da microrregião Rondonópolis.

Pode-se constatar que a representatividade dos topônimos de natureza física, na microrregião Rondonópolis, é de $61,2 \%$ e os topônimos de natureza humana correspondem a $38,8 \%$.

Os topônimos da microrregião Rondonópolis foram agrupados por grupos lingüísticos. Constam 87 (oitenta e sete) topônimos tupis, 36 (trinta e seis) topônimos bororos, 04 (quatro) topônimos africanos e 491 (quatrocentos e noventa e um) topônimos portugueses. Apresenta-se a seguir o gráfico dos topônimos classificados por grupos lingüísticos com os respectivos percentuais na microrregião Rondonópolis (GRÁFICO 52). 


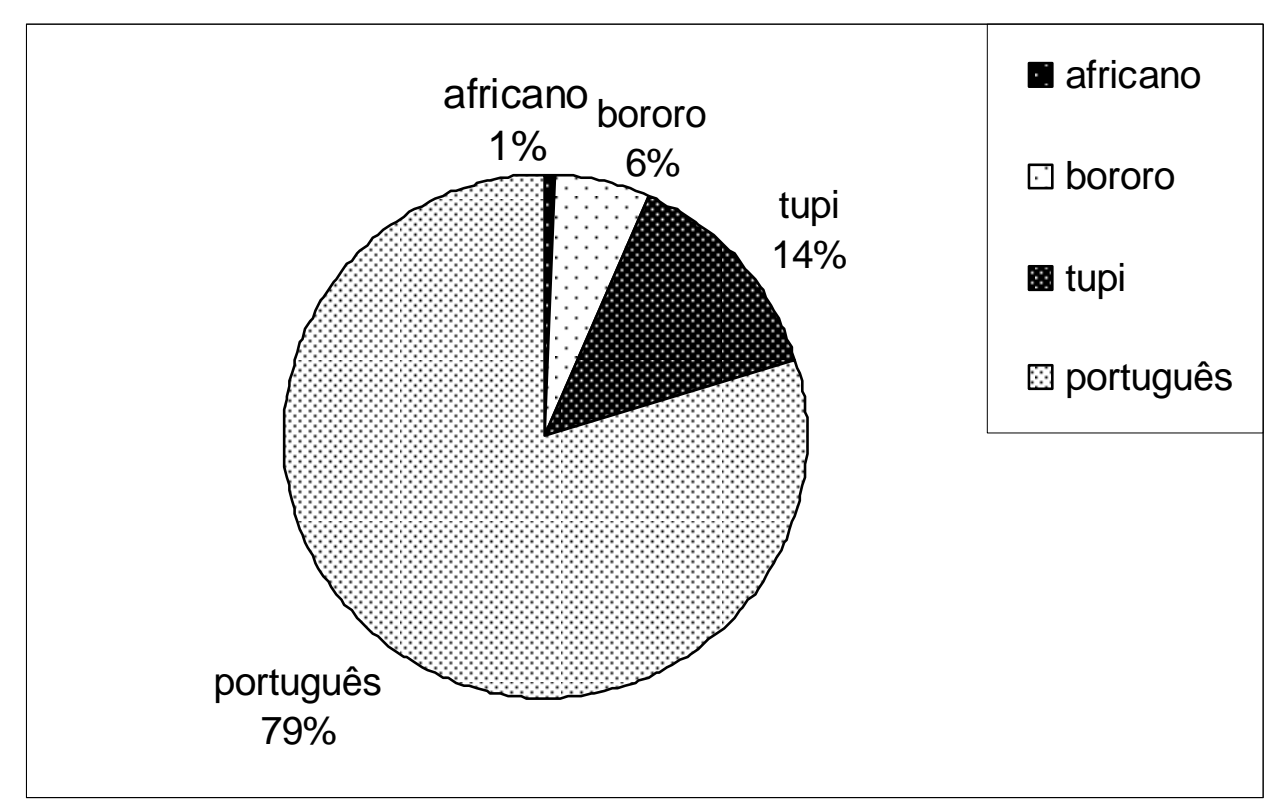

GRÁFICO 52 - Total dos topônimos por grupos lingüísticos da microrregião Rondonópolis.

Registram-se 81 (oitenta e um) topônimos tupis nas taxionomias de natureza física: astrotopônimos, fitotopônimos, hidrotopônimos, litotopônimos, meteorotopônimos e zootopônimos. São 06 (seis) topônimos tupis classificados nas taxionomias de natureza antrópica: antropotopônimos, cronotopônimos, ergotopônimos e hierotopônimos. Os topônimos de etimologia tupi representam 14,1 \% do total de topônimos e correspondem, em termos absolutos, a 87 (oitenta e sete) ocorrências.

São 36 (trinta e seis) topônimos de etimologia bororo e correspondem a 5,8\% do total de topônimos da microrregião Rondonópolis. São 29 (vinte e nove) topônimos classificados nas taxionomias de natureza física: dimensiotopônimos, fitotopônimos, hidrotopônimos e zootopônimos. Registram-se 07 (sete) topônimos nas taxionomias de natureza antrópica: ergotopônimos e somatotopônimos.

Os topônimos de etimologia africana correspondem a $0,6 \%$ do total de topônimos da microrregião Rondonópolis, com 04 (quatro) ocorrências. A taxionomia de natureza antrópica que registra topônimo nessa etimologia é ergotopônimos e as taxionomias de natureza física são: fitotopônimos e zootopônimos.

Constam 78 (setenta e oito) topônimos no município de Dom Aquino, 154 (cento e cinqüenta e quatro) em Itiquira, 38 (trinta e oito) em Jaciara, 66 (sessenta e seis) em Juscimeira, 99 (noventa e nove) em Pedra Preta, 135 (cento e trinta e 
cinco) em Rondonópolis, 20 (vinte) em São José do Povo e 28 (vinte e oito) em São Pedro da Cipa, registrados nos mapas e nas cartas topográficas dos municípios. Apresenta-se a seguir o gráfico do total de topônimos com os respectivos percentuais por município (GRÁFICO 53).

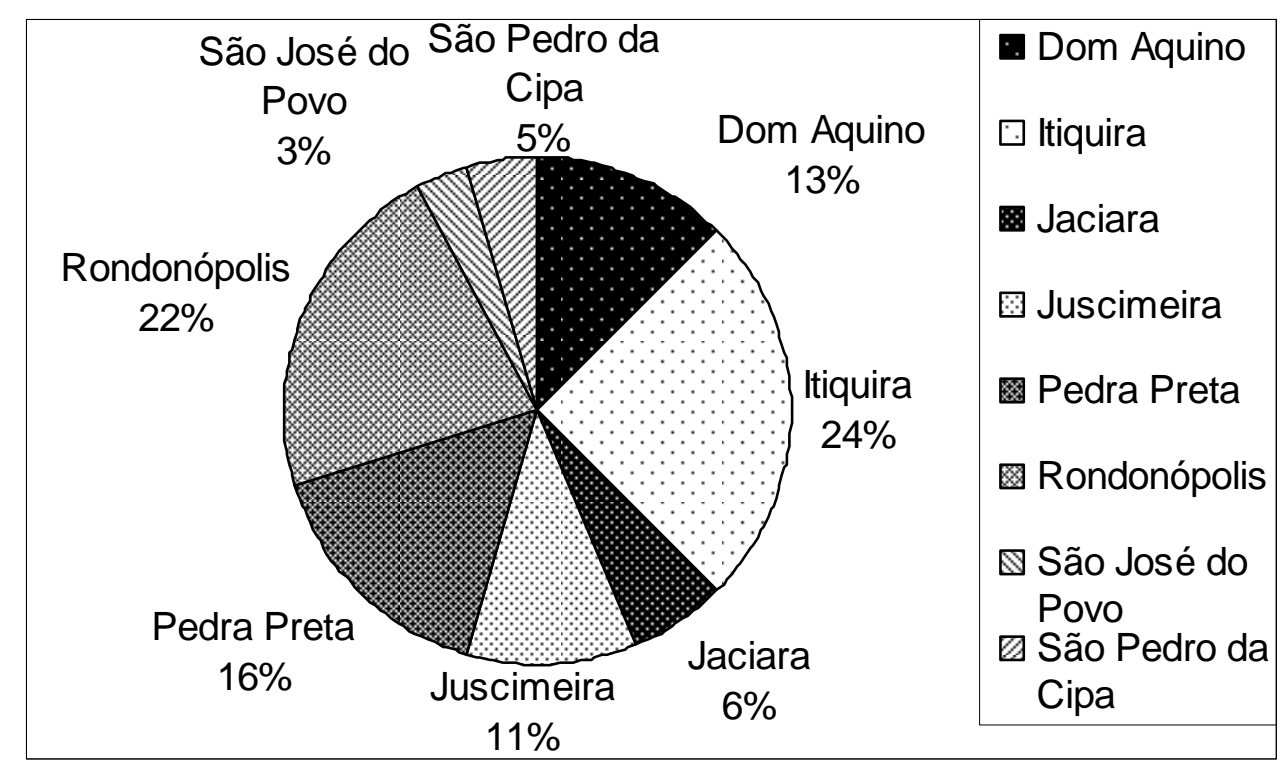

GRÁFICO 53 - Total geral dos topônimos da microrregião Rondonópolis.

Na microrregião Rondonópolis não ocorre registro de topônimos nas taxionomias mitotopônimos e morfotopônimos.

As taxionomias zootopônimos fitotopônimos, hidrotopônimos e litotopônimos são as que mais possuem topônimos. Eles correspondem a 51,3\% do total de topônimos da microrregião Rondonópolis.

A microrregião Rondonópolis é a segunda microrregião em volume de topônimos. A quantidade dos topônimos rondonopolitanos representa $26,3 \%$ do total de topônimos da mesorregião Sudeste Mato-grossense. 


\subsection{Microrregião Tesouro}

\subsubsection{Características gerais da microrregião Tesouro}

A microrregião Tesouro é uma das 04 (quatro) microrregiões que compõe a mesorregião Sudeste Mato-grossense. Está formada por 09 (nove) municípios: Araguainha, General Carneiro, Guiratinga, Pontal do Araguaia, Ponte Branca, Poxoréu, Ribeirãozinho, Tesouro e Torixoréu. Os municípios que compõem a microrregião Tesouro conseguiram emancipação político-administrativa no decorrer do século XX. Os municípios de Guiratinga e Poxoréu, na terceira década do século passado, foram elevados à categoria de município. Os municípios de Ponte Branca, Tesouro e Torixoréu emanciparam-se nos primeiros anos da década de cinqüenta. Dez anos depois, os municípios de Araguainha e General Carneiro obtiveram emancipação político-administrativa. Os municípios de Pontal do Araguaia e Ribeirãozinho foram elevados à categoria de município em 1991.

Pode-se dizer que, praticamente, todos municípios da microrregião Tesouro compunham a área diamantífera da região leste do estado de Mato Grosso. Os diamantes dessa região eram extraídos em grande quantidade e possuíam tão boa qualidade que para lá arrebanharam pessoas dos quatro cantos do Brasil. Segundo alguns historiadores e também pessoas idosas que vivem e/ou viveram naquela região, dali saíram muitas centenas de arrobas do mais puro diamante. Eles eram vendidos em Cuiabá, mas principalmente, nos grandes centos urbanos do Brasil, para onde seguiam, não raras vezes, em aviões.

Nos municípios diamantíferos as atividades agropecuárias exerciam, no auge da exploração e cata de diamantes, na maioria das vezes, papel secundário porque a esperança de conseguir um 'bamburo', ou seja, encontrar sozinho ou em sociedade uma grande quantidade de diamantes de boa qualidade, contaminava praticamente a todos que lá chegavam. 
O processo de extração de diamantes exige o uso de muita água, degrada o solo e compromete seriamente o meio ambiente, como por exemplo, os devios dos cursos naturais de córregos e ribeirões.

Os cursos d'água da microrregião Tesouro contribuem com seus caudais para formar a bacia hidrográfica Araguaia-tocantina e Pratina.

A extensão territorial da microrregião Tesouro é de $27.173 \mathrm{~km}^{2}$, dados do Anuário Estatístico do Estado de Mato Grosso - 2009, publicado pela SEPLAN - MT. Ocupa $37,8 \%$ da área total da mesorregião Sudeste Mato-grossense. É a microrregião que possui maior extensão territorial.

Com base nas pesquisas socioeconômicas do Anuário Estatístico de Mato Grosso - 2009, os principais produtos agrícolas da microrregião Tesouro foram: algodão, arroz, banana, cana-de-açúcar, feijão, mandioca, milho e soja. O volume da produção agrícola foi superior a 1.104.236 toneladas. Os principais rebanhos foram: bovino, eqüino, ovino e suíno. Os rebanhos, nessa época, perfaziam um total de 1.019.674 cabeças.

A população residente, recenseada em 2007 e divulgada pelo Instituto Brasileiro de Geografia e Estatística (IBGE), foi de 53.472 habitantes, sendo que 39.388 encontravam-se na zona urbana e 14.084 na zona rural. A densidade demográfica atingiu o índice de 2,0 hab. $/ \mathrm{km}^{2}$ e a representatividade da população urbana foi superior a 73,7\%. A microrregião Tesouro é a terceira mais populosa da mesorregião Sudeste Mato-grossense e possui o quarto índice de urbanização dentre as microrregiões que compõem a mesorregião Sudeste Mato-grossense.

A microrregião Tesouro limita-se com as microrregiões Alto Araguaia, Canarana, Médio Araguaia, Primavera do Leste, Rondonópolis e o estado de Goiás. 


\subsubsection{Características gerais do município de Araguainha}

O município de Araguainha obteve sua autonomia político-administrativa em 1963, ao ser desmembrado do município de Ponte Branca. A cidade de Araguainha localiza-se à margem esquerda do rio Araguainha.

O município de Araguainha possui $689 \mathrm{~km}^{2}$ de extensão territorial, dados do Anuário Estatístico de Mato Grosso - 2009, publicado pela SEPLAN - MT. A altitude na cidade de Araguainha é de 462 metros acima do nível do mar.

O topônimo Araguainha possui estrutura híbrida, formado pela unidade lexical tupi araguaia + sufixo -inha, indicador de diminutivo da língua portuguesa. Nos estudos toponímicos é classificado, taxionomicamente, como zootopônimo.

Segundo Sampaio, a unidade lexical tupi araguaia possui as seguintes características: "ARAGUAYA, s. c. ará-guaya, os papagaios mansos." (1970, p. 174)

Consta que a primeira denominação do aglomerado humano, que se formou naquela região garimpeira, denominava-se Couto Magalhães. O advogado José Vieira Couto de Magalhães foi governador da província de Mato Grosso. Quando o município de Ponte Branca foi criado, criou-se também um distrito em 12 de dezembro de 1953, pela Lei $n^{\circ}$ 693. O topônimo do novo distrito era Araguainha que substituiu o topônimo Couto Magalhães.

Como vários outros municípios da microrregião Tesouro, a chegada do chamado 'homem branco' nas terras que hoje pertencem ao município de Araguainha foi motivada pela procura de pedras preciosas, sobretudo diamante. Eles também pretendiam assegurar com suas presenças, o direito de defender a atividade de extração de diamantes. Desde o início do povoamento as atividades agropecuárias exerceram papel complementar.

Em 11 de novembro de 1963, a Lei no 1946 criou o município de Araguainha.

Atualmente o município de Araguainha está constituído apenas pelo distrito Sede. 
Como, em geral, ocorre em municípios que foram criados sobre alicerces de atividades garimpeiras, com o passar dos anos e o conseqüente rareamento das pedras preciosas, Araguainha suportou, nas últimas décadas, acentuado processo emigratório. Houve significativo decréscimo populacional, fator que propicia pesado ônus para as pessoas que optaram por permanecer no município.

Com base nas pesquisas socioeconômicas do Anuário Estatístico de Mato Grosso - 2009, os principais produtos agrícolas do município de Araguainha foram: arroz, cana-de-açúcar e soja. O volume da produção agrícola foi superior a 1.823 toneladas. Os principais rebanhos foram: bovino, eqüino, ovino e suíno. Os rebanhos, nessa época, perfaziam um total de 28.307 cabeças.

A população residente, recenseada em 2007 e divulgada pelo Instituto Brasileiro de Geografia e Estatística (IBGE), foi de 1.117 habitantes, sendo que 968 encontravam-se na zona urbana e 149 na zona rural. A densidade demográfica atingiu o índice de 1,6 hab./ $\mathrm{km}^{2}$ e a representatividade da população urbana foi superior a $86,7 \%$.

O município de Araguainha localiza-se na mesorregião Sudeste Matogrossense e é um dos municípios que compõe a microrregião Tesouro. Limita-se com os municípios de Alto Araguaia, Alto Garças, Ponte Branca e o estado de Goiás.

A seguir, anexam-se as relações dos topônimos do município de Araguainha, registrados no mapa elaborado pela Fundação de Pesquisas Cândido Rondon (FCR), que integra o corpus desta pesquisa. Os topônimos estão antecedidos pelos seus respectivos acidentes físicos e acidentes antrópicos, também identificados como elementos físicos e elementos humanos de uma paisagem. 
4.6.2.1 Relação dos acidentes físicos do município de Araguainha, de seus topônimos e taxionomias.

(continua)

\begin{tabular}{|c|c|c|c|}
\hline $\mathbf{N}^{\mathbf{0}}$ & Acidente & Topônimo & Taxionomia \\
\hline 01 & córrego do & Açude $(\mathrm{H} 7, \mathrm{H} 8)$ & Hidrotopônimo \\
\hline 02 & córrego & Água-emendada (F7) & Hidrotopônimo \\
\hline 03 & córrego & Água-suja (G2, G3) & Hidrotopônimo \\
\hline 04 & córrego da & Arnica $(\mathrm{H} 11, \mathrm{I11})$ & Fitotopônimo \\
\hline 05 & córrego & Avoadeira (G2 a H4) & Zootopônimo \\
\hline 06 & córrego & Balão (C6, D6) & Ergotopônimo \\
\hline 07 & córrego & Barreirão (D7 a 16) & Litotopônimo \\
\hline 08 & córrego & Barreiro (D7) & Litotopônimo \\
\hline 09 & córrego & Barreiro (F8, F9, G9) & Litotopônimo \\
\hline 10 & córrego & Barreirinho (D7) & Litotopônimo \\
\hline 11 & córrego & Barreirinho (F3 a I6) & Litotopônimo \\
\hline 12 & córrego & Barreirinho $(\mathrm{I} 7, \mathrm{H} 7)$ & Litotopônimo \\
\hline 13 & córrego & Baunilha $(\mathrm{C} 6, \mathrm{C} 7)$ & Fitotopônimo \\
\hline 14 & córrego & Bela Vista (F7, G7, G8) & Animotopônimo \\
\hline 15 & córrego & Boa Vista $(18, \mathrm{H} 8)$ & Animotopônimo \\
\hline 16 & córrego & Boqueirão (H10, G10) & Geomorfotopônimo \\
\hline 17 & córrego & Buriti $(18, \mathrm{~J} 8)$ & Fitotopônimo \\
\hline 18 & córrego & Buritizinho (F7, F8) & Fitotopônimo \\
\hline 19 & córrego & Cabeceira Comprida (G7 a H9) & Hidrotopônimo \\
\hline 20 & córrego & Cafezinho (E5, E4) & Fitotopônimo \\
\hline 21 & córrego & Capoeira (H10, H11. G11) & Fitotopônimo \\
\hline 22 & córrego & Correia Dantas (F8 a G10) & Antropotopônimo \\
\hline 23 & córrego & Coxo $(I 10, \mathrm{J10})$ & Somatotopônimo \\
\hline 24 & córrego & Cutia (H10, G10) & Zootopônimo \\
\hline 25 & córrego & Função $(\mathrm{H} 11, \mathrm{I1})$ & Sociotopônimo \\
\hline 26 & córrego & Fundo (F8 a G10) & Dimensiotopônimo \\
\hline 27 & córrego & Fuzil $(F 6, G 6)$ & Ergotopônimo \\
\hline 28 & córrego & João Gomes (H2, H3) & Antropotopônimo \\
\hline 29 & córrego & Juca (19) & Antropotopônimo \\
\hline
\end{tabular}


(conclusão)

\begin{tabular}{l|l|l|l}
\hline $\mathbf{N}^{\mathbf{0}}$ & \multicolumn{1}{c|}{ Acidente } & \multicolumn{1}{c}{ Topônimo } & \multicolumn{1}{c}{ Taxionomia } \\
\hline 30 & córrego & Lajeadinho (G4 a I5) & Litotopônimo \\
31 & córrego & Lajeado (I9, J9) & Litotopônimo \\
32 & córrego & Marreco (C8 a E8) & Zootopônimo \\
33 & córrego & Matula (F4, G5) & Ergotopônimo \\
34 & córrego & Pindaíba (D6, E6) & Fitotopônimo \\
35 & córrego & Poção (B6, B7) & Hidrotopônimo \\
36 & córrego & Ponte de Pedra (E6, E7) & Hodotopônimo \\
37 & córrego & Queixada (D5) & Zootopônimo \\
38 & córrego & Retinta (B6, C7) & Cromotopônimo \\
39 & córrego do & Retiro (I10) & Sociotopônimo \\
40 & córrego do & Retirinho (I10, I11, J11) & Sociotopônimo \\
41 & córrego & Seco (I10 a I12) & Hidrotopônimo \\
42 & córrego da & Serra (G10, H10) & Geomorfotopônimo \\
43 & córrego & Sete Voltas (F10 a I12) & Numerotopônimo \\
44 & córrego do & Veado (G3) & Zootopônimo \\
45 & ribeirão & Bisca (F8 a J9) & Sociotopônimo \\
46 & ribeirão & Café (H2 a E4) & Fitotopônimo \\
47 & ribeirão & Correia (J1 a J9) & Antropotopônimo \\
48 & ribeirão das & Pedras (F7 a I7) & Litotopônimo \\
49 & ribeirão & São João (E7, E8, F8) & Hagiotopônimo \\
50 & rio & Araguaia (J10 a I12) & Zootopônimo \\
51 & rio & Araguainha (J9, J10) & Zootopônimo \\
52 & rio & Diamantino (D5 a A6) & Litotopônimo \\
53 & serra da & Arnica (G10 a I10) & Fitotopônimo \\
54 & serra do & Café (H2 a E4) & Fitotopônimo \\
\hline
\end{tabular}

Fonte dos dados: Mapa da Fundação de Pesquisas Cândido Rondon (FCR), 1982 - escala 1:100.000. 
4.6.2.2 Relação dos acidentes humanos do município de Araguainha, de seus topônimos e taxionomias.

\begin{tabular}{lllll}
\hline $\mathbf{N}^{\mathbf{0}}$ & \multicolumn{1}{c|}{ Acidente } & \multicolumn{1}{c}{ Topônimo } & \multicolumn{1}{c}{ Taxionomia } \\
\hline 01 & cidade de & Araguainha (J9) & Zootopônimo \\
02 & localidade & Buriti (I8, 19) & Fitotopônimo \\
03 & localidade & Garcês (H6) & Antropotopônimo \\
\hline
\end{tabular}

Fonte dos dados: Mapa da Fundação de Pesquisas Cândido Rondon (FCR), 1982 - escala $.1: 100.000$. 


\subsubsection{Características gerais do município de General Carneiro}

O município de General Carneiro obteve sua autonomia político-administrativa em 1963, ao ser desmembrado dos municípios de Barra do Garças e Tesouro. A cidade de General Carneiro localiza-se às margens da rodovia federal BR - 070.

O município de General Carneiro possui $3.721 \mathrm{~km}^{2}$ de extensão territorial, dados do Anuário Estatístico de Mato Grosso - 2009, publicado pela SEPLAN - MT. A altitude na cidade de General Carneiro é de 343 metros acima do nível do mar.

O topônimo General Carneiro possui estrutura composta, formado por substantivo comum + substantivo próprio. Nos estudos toponímicos é classificado, taxionomicamente, como axiotopônimo. Este topônimo é homenagem prestada ao General Gomes Carneiro.

A área que corresponde atualmente ao município de General Carneiro foi habitada inicialmente, de acordo com historiadores da região, por dois povos autóctones: Xavante e Bororo. O denominado 'homem branco' chegou à região no princípio do século XIX.

Os primeiros povoamentos ocorreram com a chegada dos garimpeiros que para lá se dirigiram à procura de diamantes. Assim foi criada a localidade Barreiro Grande, primeiro topônimo do lugar. Em 1892 chegou ao local uma expedição comandada pelo tenente-coronel Antonio Ernesto Gomes Carneiro, com a determinação de instalar uma linha telegráfica entre os estados de Goiás e Mato Grosso.

Em 18 de novembro de 1958 foi criado o distrito de General Carneiro pela Lei $n^{\circ}$ 1.158. O distrito foi elevado, cinco anos depois, à categoria de município pela Lei $\mathrm{n}^{\circ} 2.051$ de 03 de dezembro de 1963.

Atualmente o município de General Carneiro está constituído apenas pelo distrito Sede. 
Aconteceram, no decorrer dos anos, diversas escaramuças entre pessoas da localidade com índios Bororo, ocasionando mortes de ambos os lados. Existem relatos que mais de 500 (quinhentos) indígenas morreram. Ainda hoje existem, no município, as reservas indígenas Sangradouro e Meruri.

Com base nas pesquisas socioeconômicas do Anuário Estatístico de Mato Grosso - 2009, os principais produtos agrícolas do município de General Carneiro foram: algodão, arroz, cana-de-açúcar, mandioca, milho e soja. O volume da produção agrícola foi superior a 285.667 toneladas. Os principais rebanhos foram: bovino, eqüino, ovino e suíno. Os rebanhos, nessa época, perfaziam um total de 113.860 cabeças.

A população residente, recenseada em 2007 e divulgada pelo Instituto Brasileiro de Geografia e Estatística (IBGE), foi de 4.803 habitantes, sendo que 2.390 encontravam-se na zona urbana e 2.413 na zona rural. A densidade demográfica atingiu o índice de $1,3 \mathrm{hab} . / \mathrm{km}^{2}$ e a representatividade da população urbana foi superior a $49,8 \%$.

O município de General Carneiro localiza-se na mesorregião Sudeste Matogrossense e é um dos municípios que compõe a microrregião Tesouro. Limita-se com os municípios de Barra do Garças, Novo São Joaquim, Pontal do Araguaia, Poxoréu e Tesouro.

A seguir, anexam-se as relações dos topônimos do município General Carneiro, registrados no mapa elaborado pela Fundação de Pesquisas Cândido Rondon (FCR), que integra o corpus desta pesquisa. Os topônimos estão antecedidos pelos seus respectivos acidentes físicos e acidentes antrópicos, também identificados como elementos físicos e elementos humanos de uma paisagem. 
4.6.3.1 Relação dos acidentes físicos do município de General Carneiro, de seus topônimos e taxionomias.

\begin{tabular}{|c|c|c|c|}
\hline $\mathbf{N}^{\mathbf{0}}$ & Acidente & Topônimo & Taxionomia \\
\hline 01 & cabeceira do & Açude (L6, L7, M7) & Hidrotopônimo \\
\hline 02 & cabeceira & Atoladeira (J27, L27) & Litotopônimo \\
\hline 03 & cabeceira do & Barreiro $(\mathrm{J} 17, \mathrm{I} 18)$ & Litotopônimo \\
\hline 04 & cabeceira & Comprida $(16,17)$ & Dimensiotopônimo \\
\hline 05 & cabeceira & Comprida (L26) & Dimensiotopônimo \\
\hline 06 & cabeceira da & Invernada (L7, L8) & Geomorfotopônimo \\
\hline 07 & cabeceira da & Lagoa $(17,18)$ & Hidrotopônimo \\
\hline 08 & cabeceira do & Limão (L7, L8) & Fitotopônimo \\
\hline 09 & cabeceira da & Torrinha $(128, \mathrm{~J} 28)$ & Ergotopônimo \\
\hline 10 & córrego do & Açude (N24) & Hidrotopônimo \\
\hline 11 & córrego & Água Emendada (M29 a M31) & Hidrotopônimo \\
\hline 12 & córrego & Água Limpa (G19, F13, E14) & Hidrotopônimo \\
\hline 13 & córrego das & Areias (M10 a L8) & Litotopônimo \\
\hline 14 & córrego & Barreirinho (M10, J11) & Litotopônimo \\
\hline 15 & córrego & Barreirinho (N25, M25, M26) & Litotopônimo \\
\hline 16 & córrego & Beija-flor (N21, N20) & Zootopônimo \\
\hline 17 & córrego & Boqueirãozinho (A21, B20) & Geomorfotopônimo \\
\hline 18 & córrego & Borá (I19, H20) & Zootopônimo \\
\hline 19 & córrego & Botina (J30, L30) & Ergotopônimo \\
\hline 20 & córrego & Buritirana (F15, F16) & Fitotopônimo \\
\hline 21 & córrego & Buritizal (G18) & Fitotopônimo \\
\hline 22 & córrego & Butuie $(\mathrm{J} 19, \mathrm{~J} 20)$ & Fitotopônimo \\
\hline 23 & córrego & Cachoeirinha $(\mathrm{J} 15, \mathrm{I15}, \mathrm{I16})$ & Hidrotopônimo \\
\hline 24 & córrego & Cachoeirinha (M22 a M25) & Hidrotopônimo \\
\hline 25 & córrego & Cacimbinha (M29 a M31) & Hidrotopônimo \\
\hline 26 & córrego do & Café $(\mathrm{H} 7, \mathrm{H} 8)$ & Fitotopônimo \\
\hline 27 & córrego & Canagora (N24, O24) & Somatotopônimo \\
\hline 28 & córrego do & Cedro (N2) & Fitotopônimo \\
\hline 29 & córrego do & Cervo (M7) & Zootopônimo \\
\hline
\end{tabular}


(continuação)

\begin{tabular}{|c|c|c|c|}
\hline $\mathbf{N}^{\circ}$ & Acidente & Topônimo & Taxionomia \\
\hline 30 & córrego & Corisco (M8, N9) & Meteorotopônimo \\
\hline 31 & córrego & Couto (L27, M27, M26) & Antropotopônimo \\
\hline 32 & córrego & Coval $(G 9$, G10, F10) & Geomorfotopônimo \\
\hline 33 & córrego & Cristalino (G17, G18) & Litotopônimo \\
\hline 34 & córrego das & Éguas (O29, P29) & Zootopônimo \\
\hline 35 & córrego do & Eixo (H30 a J31) & Ergotopônimo \\
\hline 36 & córrego do & Engano (H14 a E16) & Animotopônimo \\
\hline 37 & córrego da & Expedição $(\mathrm{N} 8, \mathrm{OB})$ & Sociotopônimo \\
\hline 38 & córrego da & Forma (G20, F19, E19) & Ergotopônimo \\
\hline 39 & córrego & Fundo (N28, O28) & Dimensiotopônimo \\
\hline 40 & córrego & Fundo $(07, N 7, N 8)$ & Dimensiotopônimo \\
\hline 41 & córrego & Fundo (G18, H18) & Dimensiotopônimo \\
\hline 42 & córrego & Furninha $(\mathrm{J} 14, \mathrm{~J} 15)$ & Geomorfotopônimo \\
\hline 43 & córrego & Grotão (L29 a M31) & Geomorfotopônimo \\
\hline 44 & córrego & Jacuba(O27, N28) & Ergotopônimo \\
\hline 45 & córrego & Jatobá (L18, J18, J19) & Fitotopônimo \\
\hline 46 & córrego & Jeriguiga (L21 a J23) & Fitotopônimo \\
\hline 47 & córrego & Lagoinha (G11, H11) & Hidrotopônimo \\
\hline 48 & córrego da & Lama (I10) & Litotopônimo \\
\hline 49 & córrego & Landi $(117, \mathrm{H} 16)$ & Fitotopônimo \\
\hline 50 & córrego & Luizão (L25, M25) & Antropotopônimo \\
\hline 51 & córrego & Magalhães (030, O31) & Antropotopônimo \\
\hline 52 & córrego da & Matinha $(\mathrm{J} 7, \mathrm{~J} 8)$ & Fitotopônimo \\
\hline 53 & córrego do & Meio (E12 a G12) & Cardinotopônimo \\
\hline 54 & córrego & Mortandade (M1 a O4) & Sociotopônimo \\
\hline 55 & córrego & Nova Olinda (F17, E17, E18) & Cronotopônimo \\
\hline 56 & córrego & Olaria $(\mathrm{N} 30, \mathrm{~N} 31)$ & Sociotopônimo \\
\hline 57 & córrego & Pântano (J10 a I8) & Litotopônimo \\
\hline 58 & córrego & Paredãozinho (H17 a J17) & Geomorfotopônimo \\
\hline 59 & córrego da & Pedra $(127,128)$ & Litotopônimo \\
\hline 60 & córrego da & Pedra (M2 a G3) & Litotopônimo \\
\hline
\end{tabular}


(conclusão)

\begin{tabular}{l|l|l|l}
\hline $\mathbf{N}^{0}$ & \multicolumn{1}{|c|}{ Acidente } & \multicolumn{1}{c}{ Topônimo } & \multicolumn{1}{c}{ Taxionomia } \\
\hline 61 & córrego & Pindaibão (M6 a E6) & Fitotopônimo \\
62 & córrego & Pindaibinha (L6 a H6) & Fitotopônimo \\
63 & córrego & Pontinha (O2, O3) & Hodotopônimo \\
64 & córrego & Presente (L23 a M25) & Sociotopônimo \\
65 & córrego do & Retiro (N24 a P24) & Sociotopônimo \\
66 & córrego da & Ritinha (J26, I26) & Antropotopônimo \\
67 & córrego & Rocoeial ou Ariraiau (L18 a P21) & Zootopônimo ou \\
68 & córrego & Sucuri (I10, I11) & Fitotopônimo \\
69 & córrego & Sucuri (J2, L2, L3) & Zootopônimo \\
70 & córrego & Tarigameridoda (L20, J21) & Zootopônimo \\
71 & córrego & Tinteiro (O2 a R4) & Ergotopônimo \\
72 & córrego & Toricujago (M21 a P21) & Ergotopônimo \\
73 & morro & Paredão Grande (J12) & Litotopônimo \\
74 & ribeirão & Barigajau(L23 a P30) & Geomorfotopônimo \\
75 & ribeirão & Couro de Porco (N4 a D6) & Litotopônimo \\
76 & ribeirão & Macacos (N7 a D9) & Somatotopônimo \\
77 & ribeirão & Paredão Grande (J13 a C17) & Zootopônimo \\
78 & ribeirão & Samambaia (N10 a F11) & Geomorfotopônimo \\
79 & ribeirão & Sangradouro Grande (T5 a D6) & Fitotopônimo \\
80 & rio & Barreiro (I17 a P31) & Hidrotopônimo \\
81 & rio das & Garças (P21 a P31) & Litotopônimo \\
82 & rio das & Mortes (D6 a C17) & Zootopônimo \\
\hline
\end{tabular}

Fonte dos dados: Mapa da Fundação de Pesquisas Cândido Rondon (FCR), 1990 - escala 1:100.000. 
4.6.3.2 Relação dos acidentes humanos do município de General Carneiro, de seus topônimos e taxionomias.

\begin{tabular}{llll}
\hline $\mathbf{N}^{\mathbf{0}}$ & \multicolumn{1}{c|}{ Acidente } & \multicolumn{1}{c}{ Topônimo } & \multicolumn{1}{c}{ Taxionomia } \\
\hline 01 & cidade de & General Carneiro (O30, O31) & Axiotopônimo \\
02 & colônia & São José (M1, M2) & Hagiotopônimo \\
03 & vila & Paredão Grande (L13) & Geomorfotopônimo \\
04 & terra indígena & Meruri (L20 a L26) & Zootopônimo \\
05 & terra indígena & Sangradouro (R1 a D6) & Hidrotopônimo \\
\hline
\end{tabular}

Fonte dos dados: Mapa da Fundação de Pesquisas Cândido Rondon (FCR), 1990 - escala $1: 100.000$. 


\subsubsection{Características gerais do município de Guiratinga}

O município de Guiratinga obteve sua autonomia político-administrativa em 1938, ao ser desmembrado do município de Santa Rita do Araguaia, atual Alto Araguaia. A cidade de Guiratinga localiza-se no entroncamento das rodovias estatuais MT - 110 e MT - 270.

A extensão territorial do município de Guiratinga é de $5.358 \mathrm{~km}^{2}$, dados do Anuário Estatístico de Mato Grosso - 2009, publicado pela SEPLAN - MT. A altitude na cidade de Guiratinga é de 510 metros acima do nível do mar.

Os indígenas da nação autóctone Bororo foram, até finais do século XIX, os habitantes das terras que atualmente constituem o município de Guiratinga. Já os primeiros não autóctones chegaram a partir de 1890 com o intuito inicial de encontrar terras para estabelecer fazendas para cria e engorda de gado. Eles, porém, logo descobriram a existência de diamantes. Essa descoberta, como sempre ocorre, proporcionou a chegada de milhares de pessoas fascinadas pela possibilidade de encontrar o precioso metal.

Atualmente a atividade de extração de diamante encontra-se em declínio, apesar da persistência de garimpeiros que ainda insistem em trabalhar no garimpo, em busca das pedras preciosas. Na proporção que houve a diminuição das atividades extrativas, ocorreu também um decréscimo populacional, pode-se até mesmo dizer, que o processo emigratório no município de Guiratinga foi bem acentuado nas décadas de setenta e oitenta do século passado. Atualmente a principal atividade econômica do município é a agropecuária, com base nas terras agricultáveis e na altitude que proporcionam colheitas produtivas.

O topônimo Guiratinga possui estrutura simples, formado pela aglutinação das unidades lexicais tupis: guira + tinga. Nos estudos toponímicos é classificado, taxionomicamente, como zootopônimo. 
Segundo Sampaio, a unidade lexical tupi guiratinga possui as seguintes características: "GUIRATINGA, c. guirá-tinga, o pássaro branco, a garça." (1970, p. 213)

O primeiro topônimo do município de Guiratinga foi Lageado (grafia do documento), criado pelo Decreto-lei $n^{\circ} 145$ de 29 de março de 1938. O topônimo foi alterado para Guiratinga em 31 de dezembro de 1943 pelo Decreto-lei nº 545.

Até o mês de junho de 2003, o município de Guiratinga estava constituído por 05 (cinco) distritos: Sede, Alcantilado, Buriti, Estrela do Leste e Vale Rico. Em 28 de julho de 2003 a Lei no 750 extingiu os distritos de Buriti e Estrela do Leste.

Atualmente o município de Guiratinga está constituído por 03 (três) distritos: Sede, Alcantilado e Vale Rico.

O distrito de Alcantilado foi criado pelo Decreto $n^{\circ} 384$ de 13 de agosto de 1934 e pertencia, inicialmente, ao município de Santa Rita do Araguaia.

O distrito de Buriti, criado pela Lei $n^{0} 1.157$ de 17 de novembro de 1958 no município de Guiratinga, foi extinto pela Lei no 750 de 28 de julho de 2003,.

O distrito de Estrela do Leste, criado pela Lei no 1.169 de 12 de novembro de 1958 no município de Guiratinga, foi extinto pela Lei no 750 de 28 de julho de 2003.

O distrito de Vale Rico foi criado pela Lei n 2.911 de 06 de janeiro de 1969. Essa lei retirou a condição de distrito de Toriparu e elevou o patrimônio de Vale Rico a condição de distrito.

Com base nas pesquisas socioeconômicas do Anuário Estatístico de Mato Grosso - 2009, os principais produtos agrícolas do município de Guiratinga foram: algodão, arroz, banana, cana-de-açúcar, feijão, mandioca, milho e soja. O volume da produção agrícola foi superior a 308.375 toneladas. Os principais rebanhos foram: bovino, eqüino, ovino e suíno. Os rebanhos, nessa época, perfaziam um total de 150.759 cabeças.

A população residente, recenseada em 2007 e divulgada pelo Instituto Brasileiro de Geografia e Estatística (IBGE), foi de 13.883 habitantes, sendo que 
11.542 encontravam-se na zona urbana e 2.341 na zona rural. A densidade demográfica atingiu o índice de 2,4 hab. $/ \mathrm{km}^{2}$ e a representatividade da população urbana foi superior a $83,1 \%$.

O município de Guiratinga localiza-se na mesorregião Sudeste Matogrossense e é um dos municípios que compõe a microrregião Tesouro. Limita-se com os municípios de Alto Garças, Pedra Preta, Pontal do Araguaia, Poxoréu, São José do Povo, Tesouro e Torixoréu.

A seguir, anexam-se as relações dos topônimos do município de Guiratinga, registrados nas cartas topográficas ${ }^{6}$ elaboradas pela Diretoria de Serviço Geográfico (DSG) e pelo Instituto Brasileiro de Geografia e Estatística (IBGE), que integram o corpus desta pesquisa. Os topônimos estão antecedidos pelos seus respectivos acidentes físicos e acidentes antrópicos, também identificados como elementos físicos e elementos humanos de uma paisagem.

\footnotetext{
${ }^{6}$ As sete cartas topográficas que abrangem a área geográfica do município de Guiratinga são: Colônia Meruri (297), Jarudore (313), Guiratinga (314), Buriti (315), Torixoréu (316), Alto Garças (327) e Araguainha (328).

O número que está entre parênteses, após o nome de cada carta topográfica, corresponde ao número que está colocado, entre parênteses, logo após o topônimo nas relações dos topônimos do município, para facilitar a sua localização na respectiva carta.
} 
4.6.4.1 Relação dos acidentes físicos do município de Guiratinga, de seus topônimos e taxionomias. 
(continuação)

\begin{tabular}{|c|c|c|c|}
\hline $\mathbf{N}^{\circ}$ & Acidente & Topônimo & Taxionomia \\
\hline 30 & córrego & Barracão $(314-18,19)$ & Ergotopônimo \\
\hline 31 & córrego & Barracão Queimado (314 - M9, M10) & Ergotopônimo \\
\hline 32 & córrego & Barreirão (314 - J2 a L5) & Litotopônimo \\
\hline 33 & córrego & Barreirinho $(314-08)$ & Litotopônimo \\
\hline 34 & córrego & Barreirinho (314 - J2 a 15) & Litotopônimo \\
\hline 35 & córrego & Barreiro (314 - M9, N9) & Litotopônimo \\
\hline 36 & córrego & Barreiro (313 - AC26 / 314 - N1, N2) & Litotopônimo \\
\hline 37 & córrego & Barreiro $(314-\mathrm{N} 10,09)$ & Litotopônimo \\
\hline 38 & córrego & Barreiro (315 - N7 a O5) & Litotopônimo \\
\hline 39 & córrego & Barreiro (327 - B5, B6) & Litotopônimo \\
\hline 40 & córrego & Barreiro $(327-\mathrm{B} 9, \mathrm{C} 8, \mathrm{C} 9)$ & Litotopônimo \\
\hline 41 & córrego & Barro Branco $(315-\mathrm{J} 7,17)$ & Litotopônimo \\
\hline 42 & córrego & Bateia (327 - A3) & Ergotopônimo \\
\hline 43 & córrego & Boa Esperança (315 - E3, F3) & Animotopônimo \\
\hline 44 & córrego & Boi Baio (315 - A12) & Zootopônimo \\
\hline 45 & córrego & Boiadeiro (327 - C13 / 328 - A1, B1) & Sociotopônimo \\
\hline 46 & córrego & Bonfim (314 - M6, M7) & Antropotopônimo \\
\hline 47 & córrego & Bonito (313 - T14 A X18) & Animotopônimo \\
\hline 48 & córrego & Bonito (315 - D12, D13) & Animotopônimo \\
\hline 49 & córrego & Borá (314 - L10, L11, L12) & Zootopônimo \\
\hline 50 & córrego & Buracão (315 - E8) & Geomorfotopônimo \\
\hline 51 & córrego & Buracão (315 - I3) & Geomorfotopônimo \\
\hline 52 & córrego & Buriti (314 - 18) & Fitotopônimo \\
\hline 53 & córrego & Buritizal $(314-J 3,14)$ & Fitotopônimo \\
\hline 54 & córrego & Buritizal (315 - B12, C12) & Fitotopônimo \\
\hline 55 & córrego & Buritizinho (314 - H9) & Fitotopônimo \\
\hline 56 & córrego & Buritizinho (315 - A11) & Fitotopônimo \\
\hline 57 & córrego & Cabeceira Alta (314 - H2) & Hidrotopônimo \\
\hline 58 & córrego & Cabeceira Alta (327 - E7) & Hidrotopônimo \\
\hline 59 & córrego & Cabeceira Comprida (327 - C7) & Hidrotopônimo \\
\hline 60 & córrego & Cabeceira da Serra (327 - D10) & Hidrotopônimo \\
\hline
\end{tabular}


(continuação)

\begin{tabular}{|c|c|c|c|}
\hline $\mathbf{N}^{\mathbf{0}}$ & Acidente & Topônimo & Taxionomia \\
\hline 61 & córrego da & Cabeceira do Açude (327 - C10, C11) & Hidrotopônimo \\
\hline 62 & córrego & Cabeceira do Martim $(315-\mathrm{H} 6,17)$ & Hidrotopônimo \\
\hline 63 & córrego & Cabeceira do Olho-d'água (327 - E7, E8) & Hidrotopônimo \\
\hline 64 & córrego & Cabeceira do Peixe (314 - 010, 011) & Hidrotopônimo \\
\hline 65 & córrego & Cabeceira do Varjão $(315$ - J8, J9) & Hidrotopônimo \\
\hline 66 & córrego & Cachoeira Vermelha (327 - H4 a G6) & Hidrotopônimo \\
\hline 67 & córrego & Cachoeirinha (327 - B11, B12) & Hidrotopônimo \\
\hline 68 & córrego & Cacimba (315 - 15) & Hidrotopônimo \\
\hline 69 & córrego & Cadela (315 - E2) & Zootopônimo \\
\hline 70 & córrego & Cafezal $(315-\mathrm{N} 4, \mathrm{N5})$ & Fitotopônimo \\
\hline 71 & córrego & Caicai (314 - E7 a 19) & Zootopônimo \\
\hline 72 & córrego & Caixão (314 - O10) & Ergotopônimo \\
\hline 73 & córrego & Caixão (327 - A10, A11) & Ergotopônimo \\
\hline 74 & córrego & Caldeirão (315 - A10, B10) & Hidrotopônimo \\
\hline 75 & córrego & Caldeirão (315 - O4 / 328 - A2, A3) & Hidrotopônimo \\
\hline 76 & córrego & Caldeirão (327 - B10, B11) & Hidrotopônimo \\
\hline 77 & córrego & Cambaúva (315 - J1 a 14) & Fitotopônimo \\
\hline 78 & córrego & Canivete (314 - 011, 012) & Ergotopônimo \\
\hline 79 & córrego & Capão Verde (314 - J11) & Fitotopônimo \\
\hline 80 & córrego da & Cobra (327 - A10, B10) & Zootopônimo \\
\hline 81 & córrego das & Cobrinhas (327 - B10, B11) & Zootopônimo \\
\hline 82 & córrego da & Comprida (327 - B5, C6) & Dimensiotopônimo \\
\hline 83 & córrego & Corgão (314 - J13, L13) & Hidrotopônimo \\
\hline 84 & córrego & Corguinho (314 - H11) & Hidrotopônimo \\
\hline 85 & córrego & Cristal (327 - C11, C12) & Litotopônimo \\
\hline 86 & córrego & Cupim (315 - 18) & Litotopônimo \\
\hline 87 & córrego da & Divisa (314 - H10, I10) & Cardinotopônimo \\
\hline 88 & córrego da & Divisa $(314-19,110)$ & Cardinotopônimo \\
\hline 89 & córrego & Dois Córregos (327 - G5, G6) & Numerotopônimo \\
\hline 90 & córrego & Dois Galhos (315 - M5, N5) & Numerotopônimo \\
\hline 91 & córrego & Dois Irmãos (313 - AA17 a AA19) & Numerotopônimo \\
\hline
\end{tabular}


(continuação)

\begin{tabular}{|c|c|c|c|}
\hline $\mathbf{N}^{\circ}$ & Acidente & Topônimo & Taxionomia \\
\hline 92 & córrego & Engenho de Serra (314 - M8, M9) & Sociotopônimo \\
\hline 93 & córrego & Esbarrancado $(315-18,19)$ & Geomorfotopônimo \\
\hline 94 & córrego & Esparramado $(315$ - I6, J6) & Hidrotopônimo \\
\hline 95 & córrego & Esparramado $(315-17, \mathrm{~J} 7)$ & Hidrotopônimo \\
\hline 96 & córrego do & Estreito (315 - F6, E7) & Geomorfotopônimo \\
\hline 97 & córrego & Estrela (314 - H12, H13 / 315 - H1) & Astrotopônimo \\
\hline 98 & córrego da & Fazenda Divisa (315 - C11) & Sociotopônimo \\
\hline 99 & córrego & Fazenda Velha (314 - L10, L9) & Sociotopônimo \\
\hline 100 & córrego da & Forma (328 - D1, D2) & Ergotopônimo \\
\hline 101 & córrego & Formiga $(315-\mathrm{J} 7, \mathrm{~J} 8)$ & Zootopônimo \\
\hline 102 & córrego & Fundo (314 - F8 a H10) & Dimensiotopônimo \\
\hline 103 & córrego da & Furna $(314-14)$ & Geomorfotopônimo \\
\hline 104 & córrego das & Furnas (314 - N1, N2) & Geomorfotopônimo \\
\hline 105 & córrego & Furnas (327 - D6, E7) & Geomorfotopônimo \\
\hline 106 & córrego & Galante (315 - N2 a N15) & Sociotopônimo \\
\hline 107 & córrego & Galantinho (315 - M5, M6, M7) & Sociotopônimo \\
\hline 108 & córrego & Galheiro (314 - H2) & Zootopônimo \\
\hline 109 & córrego & Galheiro $(315$ - 15, I6, 17) & Zootopônimo \\
\hline 110 & córrego & Gemedor (315 - O2 / 328 - B1 / 327 - C13) & Somatotopônimo \\
\hline 111 & córrego do & Grotão (313 - Z18 a T22) & Geomorfotopônimo \\
\hline 112 & córrego & Grotão (314 - O1) & Geomorfotopônimo \\
\hline 113 & córrego & Grotão (315 - D12, D13 / 316 - B1, C1) & Geomorfotopônimo \\
\hline 114 & córrego & Grotão (327 - D13) & Geomorfotopônimo \\
\hline 115 & córrego & Grotão de Cima (315 - C12, C13) & Geomorfotopônimo \\
\hline 116 & córrego & Grotinha (314 - M2) & Geomorfotopônimo \\
\hline 117 & córrego & Grotinha (314 - M3) & Geomorfotopônimo \\
\hline 118 & córrego & Guariroba (314 - M3, M4) & Fitotopônimo \\
\hline 119 & córrego & Honorino (314 - L8) & Antropotopônimo \\
\hline 120 & córrego & Invernada (315 - A10) & Geomorfotopônimo \\
\hline 121 & córrego do & Ioiô (314 - N13 / 315 - N1) & Sociotopônimo \\
\hline 122 & córrego & Jatobá (314 - L12) & Fitotopônimo \\
\hline
\end{tabular}


(continuação)

\begin{tabular}{|c|c|c|c|}
\hline $\mathbf{N}^{\circ}$ & Acidente & Topônimo & Taxionomia \\
\hline 123 & córrego & Jatobá (327 - C13 / 328 - C1 a C3) & Fitotopônimo \\
\hline 124 & córrego & Jatobazinho (314 - N11) & Fitotopônimo \\
\hline 125 & córrego & Jenipapo (328 - A1) & Fitotopônimo \\
\hline 126 & córrego do & Jorge (314 - O2 / 327 - A1) & Antropotopônimo \\
\hline 127 & córrego & Jurucuba (314 - 02, O3 / 327 - O2, O3) & Ergotopônimo \\
\hline 128 & córrego & Kidi (314 - O4 a O6 / 327 - A4, A5) & Antropotopônimo \\
\hline 129 & córrego & Lajeadinho (314 - F11, F12, F13) & Litotopônimo \\
\hline 130 & córrego & Lajeadinho (314 - N9, N10) & Litotopônimo \\
\hline 131 & córrego & Lajeadinho (314 - H10, H11) & Litotopônimo \\
\hline 132 & córrego & Lajeadinho (314 - L6 a J8) & Litotopônimo \\
\hline 133 & córrego & Lajeadinho (315 - N2) & Litotopônimo \\
\hline 134 & córrego & Lajeado (314 - D12, D13 / 315 - D1) & Litotopônimo \\
\hline 135 & córrego & Lajeado (314 - M10, M11) & Litotopônimo \\
\hline 136 & córrego & Laranjeira (315 - A12) & Fitotopônimo \\
\hline 137 & córrego do & Leandro (315 - C8) & Antropotopônimo \\
\hline 138 & córrego & Limão (315 - A7 a B12) & Fitotopônimo \\
\hline 139 & córrego & Mangabeira (327 - A12) & Fitotopônimo \\
\hline 140 & córrego & Mata-cachorro (315 - J7) & Dirrematotopônimo \\
\hline 141 & córrego & Mateirinho (314 - I6) & Zootopônimo \\
\hline 142 & córrego & Mateiro (315 - A10) & Zootopônimo \\
\hline 143 & córrego & Matinha (314 - J11) & Fitotopônimo \\
\hline 144 & córrego da & Matinha (315 - L3, M4) & Fitotopônimo \\
\hline 145 & córrego do & Meio (314 - M8, M9) & Cardinotopônimo \\
\hline 146 & córrego do & Meio (315 - M2 a L5) & Cardinotopônimo \\
\hline 147 & córrego do & Meio (327 - A2, A3) & Cardinotopônimo \\
\hline 148 & córrego & Melancia (314 - H6) & Fitotopônimo \\
\hline 149 & córrego & Membeca (327 - E8, E9) & Fitotopônimo \\
\hline 150 & córrego da & Mesa (314 - M4, N4) & Ergotopônimo \\
\hline 151 & córrego da & Moitinha (327 - D13) & Fitotopônimo \\
\hline 152 & córrego do & Moleque (314 - M10) & Etnotopônimo \\
\hline 153 & córrego & Monjolo (315 - L4) & Ergotopônimo \\
\hline
\end{tabular}


(continuação)

\begin{tabular}{|c|c|c|c|}
\hline $\mathbf{N}^{\circ}$ & Acidente & Topônimo & Taxionomia \\
\hline 154 & córrego & Moreiral (313 - Z18 a AE14) & Antropotopônimo \\
\hline 155 & córrego & Moreninha $(314-15,16)$ & Etnotopônimo \\
\hline 156 & córrego & Morro Alto (315 - D4, E4) & Geomorfotopônimo \\
\hline 157 & córrego do & Morro Chato (315 - B7, B8) & Geomorfotopônimo \\
\hline 158 & córrego do & Morro Grande (315 - C9, C10) & Geomorfotopônimo \\
\hline 159 & córrego & Mortandade (315 - F6) & Sociotopônimo \\
\hline 160 & córrego & Mosquito (313 - AC22 a AD16) & Zootopônimo \\
\hline 161 & córrego & Mumbeca (314 - G7) & Fitotopônimo \\
\hline 162 & córrego & Mutum (314 - J9) & Zootopônimo \\
\hline 163 & córrego & Ojasto (314 - M3. M4, N4) & Antropotopônimo \\
\hline 164 & córrego & Olaria $(315-N 1, N 2)$ & Sociotopônimo \\
\hline 165 & córrego & Olho d'Água (327 - L7) & Hidrotopônimo \\
\hline 166 & córrego do & Ourino (328 - C1, C2, D1) & Antropotopônimo \\
\hline 167 & córrego & Panela (315 -F6 a F10) & Ergotopônimo \\
\hline 168 & córrego & Pantanalzinho (327 - H6 a F9) & Litotopônimo \\
\hline 169 & córrego das & Pedras $(315-19, \mathrm{~J} 10)$ & Litotopônimo \\
\hline 170 & córrego & Pedregulho (315 - A9) & Litotopônimo \\
\hline 171 & córrego da & Pedreira (315 - F8, E8, E9) & Litotopônimo \\
\hline 172 & córrego do & Peixe (314 - L6, L7) & Zootopônimo \\
\hline 173 & córrego do & Pelego (327 - C10, D11) & Ergotopônimo \\
\hline 174 & córrego & Piau (314 - G4 a 18) & Zootopônimo \\
\hline 175 & córrego & Piau (315 - A9) & Zootopônimo \\
\hline 176 & córrego & Pindaíba (315 - D11, C11) & Fitotopônimo \\
\hline 177 & córrego & Pindaíbão (314 - L2, L3) & Fitotopônimo \\
\hline 178 & córrego & Pindaibão (315 - D10, D11, E11) & Fitotopônimo \\
\hline 179 & córrego & Pindaibão (327 - C12, C13) & Fitotopônimo \\
\hline 180 & córrego & Pindaibão (327 - D10, D11) & Fitotopônimo \\
\hline 181 & córrego & Pindaibinha $(314-\mathrm{H} 3,12)$ & Fitotopônimo \\
\hline 182 & córrego & Pindaibal (315 - D112, D13) & Fitotopônimo \\
\hline 183 & córrego do & Pio (327 - A2, A3) & Antropotopônimo \\
\hline 184 & córrego & Pirapitanga (314 - 12 a H4) & Zootopônimo \\
\hline
\end{tabular}


(continuação)

\begin{tabular}{|c|c|c|c|}
\hline $\mathbf{N}^{\circ}$ & Acidente & Topônimo & Taxionomia \\
\hline 185 & córrego & Pirapitanguinha $(314-\mathrm{H} 3, \mathrm{I})$ & Zootopônimo \\
\hline 186 & córrego & Ponte Alta (315 - L5, M6) & Hodotopônimo \\
\hline 187 & córrego & Ponte de Terra (315 - M7, M8) & Hodotopônimo \\
\hline 188 & córrego & Ponteirinho $(314-\mathrm{J} 4, \mathrm{~J} 5)$ & Ergotopônimo \\
\hline 189 & córrego & Ponteiro (314 - M4) & Ergotopônimo \\
\hline 190 & córrego da & Porca (314 - N12, N13) & Zootopônimo \\
\hline 191 & córrego & Portão (314 - M6 a M8) & Ergotopônimo \\
\hline 192 & córrego da & Porteira (315 - M1 a L3) & Ergotopônimo \\
\hline 193 & córrego da & Porteira (327 - D12, C13) & Ergotopônimo \\
\hline 194 & córrego & Potreiro (315 - L8, L9) & Ergotopônimo \\
\hline 195 & córrego & Pouso Alegre (314 - F6 a I5) & Sociotopônimo \\
\hline 196 & córrego dos & Pretos (314 - J12, I12) & Etnotopônimo \\
\hline 197 & córrego & Pulador (315 - F6) & Hidrotopônimo \\
\hline 198 & córrego & Queixada (327 - A11, A12) & Zootopônimo \\
\hline 199 & córrego & Queixada (327 - C7) & Zootopônimo \\
\hline 200 & córrego & Queixada ou Divisinha (315 - D7, C7, C8) & $\begin{array}{l}\text { Zootopônimo ou } \\
\text { Cardinotopônimo }\end{array}$ \\
\hline 201 & córrego & Retirinho (314 - E13 / 315 - E1, F2) & Sociotopônimo \\
\hline 202 & córrego do & Retiro (314 - E12, F13 / 315 - E1, F2) & Sociotopônimo \\
\hline 203 & córrego do & Retiro (314 - G6, G7) & Sociotopônimo \\
\hline 204 & córrego & Retiro (314 - L1 a L4) & Sociotopônimo \\
\hline 205 & córrego & Retiro (314 - N11, N12) & Sociotopônimo \\
\hline 206 & córrego do & Ribeirão (315 - D9, E10) & Hidrotopônimo \\
\hline 207 & córrego da & Roça (297 - AD22, AC22 / 315 - A11) & Sociotopônimo \\
\hline 208 & córrego da & Roça (315 - E6 a E12) & Sociotopônimo \\
\hline 209 & córrego & Rola Burro (315 - G6 a H9) & Dirrematotopônimo \\
\hline 210 & córrego do & Roque (315 - L5, M5) & Antropotopônimo \\
\hline 211 & córrego & Rusguento (315 - D10, E10) & Sociotopônimo \\
\hline 212 & córrego & Samambaia $(315-11, \mathrm{~J} 1)$ & Fitotopônimo \\
\hline 213 & córrego & Santo Antônio (314 - N2 a L2) & Hagiotopônimo \\
\hline 214 & córrego & São Miguel (315 - E8, F7) & Hagiotopônimo \\
\hline 215 & córrego & Saturnino (314 - G3, G4) & Antropotopônimo \\
\hline
\end{tabular}


(continuação)

\begin{tabular}{|c|c|c|c|}
\hline $\mathbf{N}^{\mathbf{0}}$ & Acidente & Topônimo & Taxionomia \\
\hline 216 & córrego & Saturno (315 - L7, L8, M8) & Astrotopônimo \\
\hline 217 & córrego & Sucuri (314 - L13) & Zootopônimo \\
\hline 218 & córrego & Sucuri $(315$ - L6, L7) & Zootopônimo \\
\hline 219 & córrego da & Taboca (314 - G11, G12 / 315 - G1, G2) & Fitotopônimo \\
\hline 220 & córrego & Tarumã (313 - AA24, Z25) & Fitotopônimo \\
\hline 221 & córrego & Tarumãzinho (313 - AB26 / 314 - M1) & Fitotopônimo \\
\hline 222 & córrego & Teixeirinha (314 - L9) & Antropotopônimo \\
\hline 223 & córrego & Tombador (314 - M11, M12) & Geomorfotopônimo \\
\hline 224 & córrego & Tombador (315 - N7, N8) & Geomorfotopônimo \\
\hline 225 & córrego da & Vaca (315 - D9, C9) & Zootopônimo \\
\hline 226 & córrego da & Vaca (327 - B8, B9) & Zootopônimo \\
\hline 227 & córrego do & Vão (314 - F5) & Hodotopônimo \\
\hline 228 & córrego & Varjão (314 - O13 / 315 - O1 / 328 - A1) & Geomorfotopônimo \\
\hline 229 & córrego & Vilela (314 - 17) & Antropotopônimo \\
\hline 230 & córrego da & Vitória (314 - F5, F4) & Animotopônimo \\
\hline 231 & morro & Alto (315 - E6, D6) & Cardinotopônimo \\
\hline 232 & morro da & Arnica (314 - F8) & Fitotopônimo \\
\hline 233 & morro & Barracão (314 - I10) & Ergotopônimo \\
\hline 234 & morro & Chato (315 - B7) & Morfotopônimo \\
\hline 235 & morro da & Divisa $(314-\mathrm{J} 11)$ & Cardinotopônimo \\
\hline 236 & morro do & Espinhaço (315 - D10, D11) & Geomorfotopônimo \\
\hline 237 & morro da & Mesa (314 - M4) & Ergotopônimo \\
\hline 238 & morro da & Mesa (314 - 17) & Ergotopônimo \\
\hline 239 & morro & Pão de Açúcar (313 - T17, T18) & Corotopônimo \\
\hline 240 & ribeirão & $\begin{array}{l}\text { Água-suja (314 - L13 a O12 / } 327 \text { - A12 a } \\
\text { D11) }\end{array}$ & Hidrotopônimo \\
\hline 241 & ribeirão & Aldeia (314 - F6 a G11) & Poliotopônimo \\
\hline 242 & ribeirão & Cascavel (327 - D5 a C7) & Zootopônimo \\
\hline 243 & ribeirão & $\begin{array}{l}\text { Chico França (314 - L12, M13 / } 315 \text { - L1 a } \\
\text { I4) }\end{array}$ & Antropotopônimo \\
\hline 244 & ribeirão da & Divisa (315 - D6 a C13 / 316 - C1) & Cardinotopônimo \\
\hline 245 & ribeirão da & Estrela (315 - G3 a D2) & Astrotopônimo \\
\hline 246 & ribeirão & Floriano (314 - L2 a M5) & Antropotopônimo \\
\hline
\end{tabular}


(conclusão)

\begin{tabular}{l|lll}
\hline $\mathbf{N}^{\mathbf{2}}$ & \multicolumn{1}{c|}{ Acidente } & \multicolumn{1}{c}{ Topônimo } & \multicolumn{1}{c}{ Taxionomia } \\
\hline 247 & ribeirão da & Forma (327 - C9 a E9) & Ergotopônimo \\
248 & ribeirão do & Mosquito (314 - O8 a N9 / 327 - A8 a C7) & Zootopônimo \\
249 & ribeirão da & Onça (327 - G9 a E13) & Zootopônimo \\
250 & ribeirão & Ponte de Pedra (315 - 17 a H9) & Hodotopônimo \\
251 & ribeirão & Taboca (314 - O6 a J8 / 327 - A5, A6) & Fitotopônimo \\
252 & rio & Areia (313 - T15 A V27 / 314 - J1 a F2) & Litotopônimo \\
253 & rio & Bandeira (314 - O9 a G11 / 327 - A9 a E8) & Historiotopônimo \\
254 & rio & Diamantino (315 - D13 a O9 / 316 - D1, D2) & Litotopônimo \\
255 & rio das & Garças (314 - D12 a M13 / 315 - M1, O2 / & Zootopônimo \\
256 & rio & Prata (327 - A1 a G4 / 313 - AE17 a AE27) & Litotopônimo \\
257 & serra da & Divisa (315 - C10) & Cardinotopônimo \\
258 & serra da & Estrela (315 - G3 a J3) & Astrotopônimo \\
259 & serra de & Santo Antônio (314 - N2, N3) & Hagiotopônimo \\
260 & serra da & Saudade (314 - N4 a M6) & Animotopônimo \\
261 & serra do & Tonhá (314 - O4 / 327 - A4) & Antropotopônimo \\
\hline
\end{tabular}

Fonte dos dados: Carta topográfica da Diretoria de Serviço Geográfico (DSG), Ministério do Exército, 1976 - escala 1:100.000.

Carta topográfica do Instituto Brasileiro de Geográfica e Estatística (IBGE), 1976 - escala 1:100.000.

Mapa da Fundação de Pesquisas Cândido Rondon (FCR), 1983 - escala $1: 250.000$. 
4.6.4.2 Relação dos acidentes humanos do município de Guiratinga, de seus topônimos e taxionomias.

\begin{tabular}{llll}
\hline $\mathbf{N}^{\mathbf{0}}$ & \multicolumn{1}{c|}{ Acidente } & \multicolumn{1}{c}{ Topônimo } & \multicolumn{1}{c}{ Taxionomia } \\
\hline 01 & cidade de & Guiratinga (314 - I7) & Zootopônimo \\
02 & distrito & Alcantilado $(314-\mathrm{M} 13)$ & Geomorfotopônimo \\
03 & distrito & Vale Rico $(313-$ Z19) & Geomorfotopônimo \\
04 & localidade & Buriti (315 - N2) & Fitotopônimo \\
05 & localidade & Estrela do Leste (314 - I11) & Astrotopônimo \\
06 & localidade & Toriparu (314 - L3) & Geomorfotopônimo \\
07 & vila & Nova (314 - F9) & Cronotopônimo \\
\hline
\end{tabular}

Fonte dos dados: Carta topográfica da Diretoria de Serviço Geográfico (DSG), Ministério do Exército, 1976 - escala 1:100.000.

Carta topográfica do Instituto Brasileiro de Geográfica e Estatística (IBGE), 1976 - escala 1:100.000.

Mapa da Fundação de Pesquisas Cândido Rondon (FCR), 1983 - escala $1: 250.000$. 


\subsubsection{Características gerais do município de Pontal do Araguaia}

O município de Pontal do Araguaia obteve sua autonomia políticoadministrativa em 1991, ao ser desmembrado dos municípios Guiratinga e Torixoréu. A cidade de Pontal do Araguaia localiza-se à margem esquerda do rio Araguaia e à margem direita do rio das Garças.

O município de Pontal do Araguaia possui $2.755 \mathrm{~km}^{2}$ de extensão territorial, dados do Anuário Estatístico de Mato Grosso - 2009, publicado pela SEPLAN - MT. A altitude na cidade de Pontal do Araguaia é de 300 metros acima do nível do mar.

O município de Pontal do Araguaia também teve seu início com as atividades garimpeiras na região, porém, deve-se ressaltar que devido à fertilidade de suas terras, pode-se dizer que ao mesmo tempo, ocorreu a implantação de atividades agropecuárias que fixaram as pessoas na localidade e que proporcionavam aos garimpeiros os meios de sustentação básica para que se mantivessem na garimpagem de diamantes.

Como todos municípios que margeiam o rio Araguaia, Pontal do Araguaia tem terras duplamente ricas - terras férteis para atividades agropecuárias e terras propícias para prática de atividades extrativas minerais. Por possuir pedras preciosas, a área do município de Pontal do Araguaia, foi alvo de cobiça de Governadores do estado de Goiás. Eles, durante várias décadas, mantiveram a ambição de ampliar os limites territoriais do estado de Goiás, apropriando-se de ampla extensão de terras que sempre pertenceram por direito legítimo ao estado de Mato Grosso. Posteriormene houve a ratificação dos direitos para o estado de Mato Grosso pelo Governo Federal.

O topônimo Pontal do Araguaia possui estrutura híbrida, formado pela unidade lexical portuguesa pontal + conectivo do + unidade lexical tupi araguaia. Nos estudos toponímicos é classificado, taxionomicamente, como geomorfotopônimo. 
Segundo Sampaio, a unidade lexical tupi araguaia possui as seguintes características: "ARAGUAYA, s. c. ará-guaya, os papagaios mansos." (1970, p. 174)

O município de Pontal do Araguaia foi criado pela Lei $\mathrm{n}^{\circ} 5.907$ de 20 de dezembro de 1991.

Atualmente o município de Pontal do Araguaia está constituído apenas pelo distrito Sede.

Com base nas pesquisas socioeconômicas do Anuário Estatístico de Mato Grosso - 2009, os principais produtos agrícolas do município de Pontal do Araguaia foram: cana-de-açúcar e mandioca. O volume da produção agrícola foi superior a 3.209 toneladas. Os principais rebanhos foram: bovino, eqüino, ovino e suíno. Os rebanhos, nessa época, perfaziam um total de 123.255 cabeças.

A população residente, recenseada em 2007 e divulgada pelo Instituto Brasileiro de Geografia e Estatística (IBGE), foi de 4.966 habitantes, sendo que 4.033 encontravam-se na zona urbana e 933 na zona rural. A densidade demográfica atingiu o índice de $1,8 \mathrm{hab} . \mathrm{km}^{2}$ e a representatividade da população urbana foi superior a $81,2 \%$.

O município de Pontal do Araguaia localiza-se na mesorregião Sudeste Matogrossense e é um dos municípios que compõe a microrregião Tesouro. Limita-se com os municípios de Barra do Garças, General Carneiro, Guiratinga, Tesouro, Torixoréu e o estado de Goiás.

A seguir, anexam-se as relações dos topônimos do município Pontal do Araguaia, registrados no mapa elaborado pela Fundação de Pesquisas Cândido Rondon (FCR), que integra o corpus desta pesquisa. Os topônimos estão antecedidos pelos seus respectivos acidentes físicos e acidentes antrópicos, também identificados como elementos físicos e elementos humanos de uma paisagem. 
4.6.5.1 Relação dos acidentes físicos do município de Pontal do Araguaia, de seus topônimos e taxionomias.

(continua)

\begin{tabular}{|c|c|c|c|}
\hline $\mathbf{N}^{\mathbf{0}}$ & Acidente & Topônimo & Taxionomia \\
\hline 01 & cabeceira do & Açude (G4) & Hidrotopônimo \\
\hline 02 & cabeceira & Boa Esperança (C8, B7) & Animotopônimo \\
\hline 03 & cabeceira do & Escondido (E14, E15) & Sociotopônimo \\
\hline 04 & cabeceira do & Grotão (G4) & Geomorfotopônimo \\
\hline 05 & cabeceira & Guaraína (D7, D8) & Zootopônimo \\
\hline 06 & cabeceira do & Joca (D14, E13) & Antropotopônimo \\
\hline 07 & córrego do & Açude (F17, F18) & Hidrotopônimo \\
\hline 08 & córrego & Araci (C10 a A10) & Antropotopônimo \\
\hline 09 & córrego & Areia $(I 13, \mathrm{~J} 14)$ & Litotopônimo \\
\hline 10 & córrego & Ariranha (C10 a E12) & Zootopônimo \\
\hline 11 & córrego & Atoladeiro (F13, E13, E14) & Litotopônimo \\
\hline 12 & córrego & Babilônia (H16 a E19) & Corotopônimo \\
\hline 13 & córrego & Barreirão $(I 15, \mathrm{J14})$ & Litotopônimo \\
\hline 14 & córrego & Baunilha (G21) & Fitotopônimo \\
\hline 15 & córrego & Boca para Cima (D11, D12) & Dirrematotopônimo \\
\hline 16 & córrego & Boca para Cima (J4 a M4) & Dirrematotopônimo \\
\hline 17 & córrego & Buriti Alegre (H9 a J9) & Fitotopônimo \\
\hline 18 & córrego & Buritirana (H19, G19) & Fitotopônimo \\
\hline 19 & córrego & Buritizinho (G17, H17) & Fitotopônimo \\
\hline 20 & córrego & Cabeceira do Sangue (F21) & Hidrotopônimo \\
\hline 21 & córrego & Cabeceira Verde (L13) & Hidrotopônimo \\
\hline 22 & córrego & Cachoeirão (I3 a I5) & Hidrotopônimo \\
\hline 23 & córrego & Cachoeirinha (F7 a 17) & Hidrotopônimo \\
\hline 24 & córrego & Caga-fogo $(I 19, I 20, J 20)$ & Zootopônimo \\
\hline 25 & córrego & Caixão (H13 a J18) & Ergotopônimo \\
\hline 26 & córrego & Cajá (H17, G17) & Fitotopônimo \\
\hline 27 & córrego & Caldeirão (H11, I11) & Hidrotopônimo \\
\hline 28 & córrego & Cambaúva (I18 a L19) & Fitotopônimo \\
\hline 29 & córrego & Campeiro (E6, E7) & Zootopônimo \\
\hline
\end{tabular}


(continuação)

\begin{tabular}{|c|c|c|c|}
\hline $\mathbf{N}^{\circ}$ & Acidente & Topônimo & Taxionomia \\
\hline 30 & córrego & Canoeiro $(\mathrm{H} 20)$ & Sociotopônimo \\
\hline 31 & córrego & Capivara $(\mathrm{H} 2)$ & Zootopônimo \\
\hline 32 & córrego & Capoeira (L5) & Fitotopônimo \\
\hline 33 & córrego do & Cervo $(\mathrm{H} 20, \mathrm{I} 20, \mathrm{I} 21)$ & Zootopônimo \\
\hline 34 & córrego & Chupador (B9, A9) & Geomorfotopônimo \\
\hline 35 & córrego das & Cobras (D12, C11) & Zootopônimo \\
\hline 36 & córrego & Corgão (A4 a D4) & Hidrotopônimo \\
\hline 37 & córrego & Curral Velho (D11, D12) & Ergotopônimo \\
\hline 38 & córrego & D'Antas (G15, F15, F14) & Zootopônimo \\
\hline 39 & córrego da & Égua $(\mathrm{J4}, \mathrm{J5})$ & Zootopônimo \\
\hline 40 & córrego & Farinha $(13,14)$ & Ergotopônimo \\
\hline 41 & córrego & Feio (H9 a I9) & Animotopônimo \\
\hline 42 & córrego & Fervedor (D6, E6) & Hidrotopônimo \\
\hline 43 & córrego & Figueira $(\mathrm{H} 16, \mathrm{H} 17, \mathrm{I17})$ & Fitotopônimo \\
\hline 44 & córrego & Figura $(16,17)$ & Morfotopônimo \\
\hline 45 & córrego & Fortaleza $(\mathrm{J} 13, \mathrm{~J} 14)$ & Corotopônimo \\
\hline 46 & córrego & Fundo (F8 a E11) & Dimensiotopônimo \\
\hline 47 & córrego & Fundo $(\mathrm{H} 2)$ & Dimensiotopônimo \\
\hline 48 & córrego da & Furna $(\mathrm{H} 9,19)$ & Geomorfotopônimo \\
\hline 49 & córrego das & Galinhas $(\mathrm{H} 9,18,19)$ & Zootopônimo \\
\hline 50 & córrego & Gordura $(\mathrm{H} 4, \mathrm{l} 4)$ & Somatotopônimo \\
\hline 51 & córrego & Grota Funda (H19 a H21) & Geomorfotopônimo \\
\hline 52 & córrego & Grotão $(\mathrm{J} 3, \mathrm{~L} 3)$ & Geomorfotopônimo \\
\hline 53 & córrego dos & Índios (G8 a C13) & Etnotopônimo \\
\hline 54 & córrego & Invernada (L5, L6) & Geomorfotopônimo \\
\hline 55 & córrego & Jaboti (G16, G17) & Zootopônimo \\
\hline 56 & córrego & Jaraguazinho (G7, H6) & Hierotopônimo \\
\hline 57 & córrego & Jauru $(I 15, \mathrm{~J} 15)$ & Zootopônimo \\
\hline 58 & córrego & Jia $(H 17)$ & Zootopônimo \\
\hline 59 & córrego & Lajeado (I10, J10) & Litotopônimo \\
\hline 60 & córrego & Lajinha (G18) & Litotopônimo \\
\hline
\end{tabular}


(continuação)

\begin{tabular}{|c|c|c|c|}
\hline $\mathbf{N}^{0}$ & Acidente & Topônimo & Taxionomia \\
\hline 61 & córrego & Laranjeira (H2 a J1) & Fitotopônimo \\
\hline 62 & córrego da & Lata (G19) & Ergotopônimo \\
\hline 63 & córrego & Limão (J1) & Fitotopônimo \\
\hline 64 & córrego & Limeira $(I 16, \mid 17)$ & Fitotopônimo \\
\hline 65 & córrego & Mangabeira (F17, E17) & Fitotopônimo \\
\hline 66 & córrego & Marimbondo $(15,16)$ & Zootopônimo \\
\hline 67 & córrego & Marimbondo (F16, E16) & Zootopônimo \\
\hline 68 & córrego da & Mata (H17 a J17) & Fitotopônimo \\
\hline 69 & córrego do & Mato $(I 11, \mid 12)$ & Fitotopônimo \\
\hline 70 & córrego & Monte Negro (H18 a F20) & Geomorfotopônimo \\
\hline 71 & córrego & Novo (C11, B11, B12) & Cronotopônimo \\
\hline 72 & córrego da & Onça (C8 a A8) & Zootopônimo \\
\hline 73 & córrego da & Onça $(J 19, \mathrm{~J} 20)$ & Zootopônimo \\
\hline 74 & córrego das & Palhas $(110,111)$ & Fitotopônimo \\
\hline 75 & córrego & Pedrão (J16) & Antropotopônimo \\
\hline 76 & córrego do & Pedrinho (L16, L17) & Antropotopônimo \\
\hline 77 & córrego & Piau (A6 a D8) & Zootopônimo \\
\hline 78 & córrego & Pindaibão (E6 a G6) & Fitotopônimo \\
\hline 79 & córrego & Pindaibal $(14,15)$ & Fitotopônimo \\
\hline 80 & córrego & Poção (G21, F21) & Hidrotopônimo \\
\hline 81 & córrego & Ponte de Pedra (H12, H13) & Hodotopônimo \\
\hline 82 & córrego & Retirinho $(115, \mathrm{~J} 16)$ & Sociotopônimo \\
\hline 83 & córrego do & Rela-Rela (G13, H14) & Dirrematotopônimo \\
\hline 84 & córrego & Santa Arlinda $(I 14, \mathrm{~J} 14)$ & Hagiotopônimo \\
\hline 85 & córrego & Santo Antônio (F13, G12) & Hagiotopônimo \\
\hline 86 & córrego & São José (F20) & Hagiotopônimo \\
\hline 87 & córrego & Sossego $(\mathrm{H} 19, \mathrm{G} 19)$ & Animotopônimo \\
\hline 88 & córrego & Sucuri (F2, E2) & Zootopônimo \\
\hline 89 & córrego & Tronqueira $(E 3, E 4)$ & Fitotopônimo \\
\hline 90 & córrego & Vaca Morta $(J 19$, L19) & Zootopônimo \\
\hline 91 & córrego da & Vaca $(\mathrm{J} 2, \mathrm{~L} 2)$ & Zootopônimo \\
\hline
\end{tabular}


(conclusão)

\begin{tabular}{l|lll}
\hline $\mathbf{N}^{\mathbf{2}}$ & \multicolumn{1}{c|}{ Acidente } & \multicolumn{1}{c}{ Topônimo } & \multicolumn{1}{c}{ Taxionomia } \\
\hline 92 & córrego & Veado (F16, F17) & Zootopônimo \\
93 & morro da & Cruz (H17) & Hierotopônimo \\
94 & morro da & Mesa (F2) & Ergotopônimo \\
95 & ribeirão & Barreirinho (H13 a D15) & Litotopônimo \\
96 & ribeirão & Capivara (H2 a l6) & Zootopônimo \\
97 & ribeirão da & Divisa (J1 a M3) & Hagiotopônimo \\
98 & ribeirão & São José (F3 a J7) & Hagiotopônimo \\
99 & ribeirão & São José (G1 a A2) & Hagiotopônimo \\
100 & rio & Araguaia (M17 a E22) & Zootopônimo \\
101 & rio & Diamantino (M3 a M17) & Litotopônimo \\
102 & rio das & Garças (E22 a A2) & Zootopônimo \\
103 & serra dos & Índios (H10, I10) & Etnotopônimo \\
104 & serra dos & Pretos (I18, H18) & Etnotopônimo \\
\hline
\end{tabular}

Fonte dos dados: Mapa da Fundação de Pesquisas Cândido Rondon (FCR), 1990 - escala 1:100.000.

\subsubsection{Relação dos acidentes humanos do município de Pontal do Araguaia, de seus topônimos e taxionomias.}

\begin{tabular}{l|l|l|l}
\hline $\mathbf{N}^{\mathbf{0}}$ & \multicolumn{1}{c|}{ Acidente } & \multicolumn{1}{c}{ Topônimo } & \multicolumn{1}{c}{ Taxionomia } \\
\hline 01 & cidade de & Pontal do Araguaia (F22) & Geomorfotopônimo \\
02 & localidade & Atoladeira (E13) & Litotopônimo
\end{tabular}

Fonte dos dados: Mapa da Fundação de Pesquisas Cândido Rondon (FCR), 1990 - escala 1:100.000. 


\subsubsection{Características gerais do município de Ponte Branca}

O município de Ponte Branca obteve sua autonomia político-administrativa em 1953, ao ser desmembrado do município de Alto Araguaia. A cidade de Ponte Branca localiza-se à margem esquerda do rio Araguaia.

A extensão territorial do município de Ponte Branca é de $668 \mathrm{~km}^{2}$, dados do Anuário Estatístico de Mato Grosso - 2009, publicado pela SEPLAN - MT. A altitude na cidade de Ponte Branca é de 424 metros acima do nível do mar.

No final do século XIX chegaram às terras que hoje pertencem ao município de Ponte Branca as primeiras pessoas não autóctones. Eles logo perceberam que eram terras muito ricas e proporcionavam com abundância tudo aquilo que os fazendeiros sonham: terra fértil e água em abundância. Inicialmente, para eles as atividades garimpeiras, existentes em toda aquela região, não despertavam interesse.

A partir de 1935, a pequena povoação que já era conhecida pelo topônimo Alcantilado do Araguaia, começou a receber migrantes que tinham por principal objetivo encontrar diamantes nos leitos dos acidentes hídricos da região e no seu rico subsolo. Desse modo, Alcantilado do Araguaia integrou, efetivamente, a chamada "área diamantífera" da região do rio Araguaia.

O topônimo Ponte Branca possui estrutura composta, formado por substantivo comum + adjetivo. Nos estudos toponímicos é classificado, taxionomicamente, como hodotopônimo.

Em 31 de dezembro de 1943 pelo Decreto no 545, Ponte Branca tornou-se distrito, pertencente ao município de Alto Araguaia. A Lei $n^{\circ} 652$ de 10 de dezembro de 1953 elevou o distrito à categoria de município.

Atualmente o município de Ponte Branca está constituído apenas pelo distrito Sede. 
Com base nas pesquisas socioeconômicas do Anuário Estatístico de Mato Grosso - 2009, os principais produtos agrícolas do município de Ponte Branca foram: arroz, cana-de-açúcar, mandioca, milho e soja. O volume da produção agrícola foi superior a 1.468 toneladas. Os principais rebanhos foram: bovino, eqüino, ovino e suíno. Os rebanhos, nessa época, perfaziam um total de 28.206 cabeças.

A população residente, recenseada em 2007 e divulgada pelo Instituto Brasileiro de Geografia e Estatística (IBGE), foi de 1.794 habitantes, sendo que 1.533 encontravam-se na zona urbana e 261 na zona rural. A densidade demográfica atingiu o índice de $1,0 \mathrm{hab} . \mathrm{km}^{2}$ e a representatividade da população urbana foi superior a $85,4 \%$.

O município de Ponte Branca localiza-se na mesorregião Sudeste Matogrossense e é um dos municípios que compõe a microrregião Tesouro. Limita-se com os municípios de Araguainha, Ribeirãozinho, Torixoréu e o estado de Goiás.

A seguir, anexam-se as relações dos topônimos do município de Ponte Branca, registrados no mapa elaborado pela Fundação de Pesquisas Cândido Rondon (FCR), que integra o corpus desta pesquisa. Os topônimos estão antecedidos pelos seus respectivos acidentes físicos e acidentes antrópicos, também identificados como elementos físicos e elementos humanos de uma paisagem. 
4.6.6.1 Relação dos acidentes físicos do município de Ponte Branca, de seus topônimos e taxionomias.

\begin{tabular}{|c|c|c|c|}
\hline $\mathrm{N}^{\mathbf{0}}$ & Acidente & Topônimo & Taxionomia \\
\hline 01 & córrego do & Açude (B2, B3, A2) & Hidrotopônimo \\
\hline 02 & córrego & Antinha (A1 a A3) & Zootopônimo \\
\hline 03 & córrego do & Arame (D6 a C10) & Ergotopônimo \\
\hline 04 & córrego & Barreirinho $(\mathrm{H} 7, \mathrm{H} 8)$ & Litotopônimo \\
\hline 05 & córrego & Barreiro (F7, H8) & Litotopônimo \\
\hline 06 & córrego do & Brejão (D5 a F6) & Litotopônimo \\
\hline 07 & córrego & Buritizal (F9) & Fitotopônimo \\
\hline 08 & córrego & Cabeceira Alta (G9, F9) & Hidrotopônimo \\
\hline 09 & córrego & Cabeceira da Cruz (B3, B4) & Hidrotopônimo \\
\hline 10 & córrego & Cabeceira da Cruz (B5, B6) & Hidrotopônimo \\
\hline 11 & córrego & Cabeceira do Açude (C3 a C5) & Hidrotopônimo \\
\hline 12 & córrego da & Cabeceirinha (F6, G6) & Hidrotopônimo \\
\hline 13 & córrego & Campo Alto (B1, B2) & Fitotopônimo \\
\hline 14 & córrego do & Casal (D4 a E5) & Sociotopônimo \\
\hline 15 & córrego & Cascavel (A2, B2) & Zootopônimo \\
\hline 16 & córrego & Cervo (F8, G8) & Zootopônimo \\
\hline 17 & córrego & Escondido (E11, E12) & Sociotopônimo \\
\hline 18 & córrego & Esbarrancado (B3, B4) & Geomorfotopônimo \\
\hline 19 & córrego & Fazenda Velha (C4, C5) & Sociotopônimo \\
\hline 20 & córrego & Fortuna (D10, B10) & Sociotopônimo \\
\hline 21 & córrego da & Irara (B6) & Zootopônimo \\
\hline 22 & córrego & Lagoa (E9) & Hidrotopônimo \\
\hline 23 & córrego & Lixa (D6, D7) & Ergotopônimo \\
\hline 24 & córrego do & Mangue $(B 7, C 7, C 6)$ & Fitotopônimo \\
\hline 25 & córrego & Marreco (C3 a F4) & Zootopônimo \\
\hline 26 & córrego & Marreco (D5, E5) & Zootopônimo \\
\hline 27 & córrego & Mata Redonda (D11) & Fitotopônimo \\
\hline 28 & córrego do & Mato (E10 a G10) & Fitotopônimo \\
\hline 29 & córrego do & Morro Alto (E9) & Geomorfotopônimo \\
\hline
\end{tabular}


(conclusão)

\begin{tabular}{|c|c|c|c|}
\hline $\mathbf{N}^{\mathbf{0}}$ & Acidente & Topônimo & Taxionomia \\
\hline 30 & córrego & Olaria $(E 3, D 4)$ & Sociotopônimo \\
\hline 31 & córrego & Olaria (E9) & Sociotopônimo \\
\hline 32 & córrego das & Pedras (G7) & Litotopônimo \\
\hline 33 & córrego & Poção (C3) & Hidrotopônimo \\
\hline 34 & córrego & Ponte de Terra $(\mathrm{C} 3, \mathrm{C} 4, \mathrm{~B} 4)$ & Hodotopônimo \\
\hline 35 & córrego & Pousinho (D11, E11) & Sociotopônimo \\
\hline 36 & córrego do & Pouso (E10 a E12) & Sociotopônimo \\
\hline 37 & córrego & Quatro Passagens (E6 a E8) & Numerotopônimo \\
\hline 38 & córrego & Raiz (D3) & Fitotopônimo \\
\hline 39 & córrego & Retinta $(\mathrm{C} 2, \mathrm{C} 3)$ & Cromotopônimo \\
\hline 40 & córrego & Retirinho (E10, D9) & Sociotopônimo \\
\hline 41 & córrego & Seco $(C 7)$ & Hidrotopônimo \\
\hline 42 & córrego da & Serra $(E 10, F 10)$ & Geomorfotopônimo \\
\hline 43 & córrego & Sete Voltas (F5 a I8) & Numerotopônimo \\
\hline 44 & córrego & Taperão (B5) & Ecotopônimo \\
\hline 45 & morro & Alto $(\mathrm{E} 9, \mathrm{E} 10)$ & Cardinotopônimo \\
\hline 46 & morro do & Pontal (E5) & Geomorfotopônimo \\
\hline 47 & ribeirão & São João (F4 a C12) & Hagiotopônimo \\
\hline 48 & rio & Araguaia (I8 a C12) & Zootopônimo \\
\hline 49 & rio & Diamantino (A1, B1) & Litotopônimo \\
\hline 50 & rio & São Domingos (A3 a B7) & Hagiotopônimo \\
\hline 51 & serra do & Brejão (C5, D5, E5) & Litotopônimo \\
\hline 52 & serra do & Casal $(\mathrm{E} 6, \mathrm{E} 7)$ & Sociotopônimo \\
\hline 53 & serra do & Marreco (D4, D5, C5) & Zootopônimo \\
\hline 54 & serra & Pedras Altas $(\mathrm{E} 6, \mathrm{E} 7)$ & Litotopônimo \\
\hline 55 & serra & Quatro Passagens (D6 a D8) & Numerotopônimo \\
\hline
\end{tabular}

Fonte dos dados: Mapa da Fundação de Pesquisas Cândido Rondon (FCR), 1982 - escala 1:100.000. 
4.6.6.2 Relação dos acidentes humanos do município de Ponte Branca, de seus topônimos e taxionomias.

\begin{tabular}{l|llll}
\hline $\mathbf{N}^{\mathbf{0}}$ & \multicolumn{1}{|c|}{ Acidente } & Topônimo & Taxionomia \\
\hline 01 & cidade de & Ponte Branca (G10) & Hodotopônimo \\
02 & localidade & Pouso (E11) & Sociotopônimo \\
\hline
\end{tabular}

Fonte dos dados: Mapa da Fundação de Pesquisas Cândido Rondon (FCR), 1982 - escala 1:100.000. 


\subsubsection{Características gerais do município de Poxoréu}

O município de Poxoréu obteve sua autonomia político-administrativa em 1938, ao ser desmembrado do município de Cuiabá. A cidade de Poxoréu localiza-se às margens do rio Poxoréo.

A extensão territorial do município de Poxoréu é de $6.923 \mathrm{~km}^{2}$, dados do Anuário Estatístico de Mato Grosso - 2009, publicado pela SEPLAN - MT. A altitude na cidade de Poxoréu é de 360 metros acima do nível do mar.

A extração diamantífera foi, durante várias décadas, a principal fonte de recurso da região, principalmente porque os diamantes procedentes do município de Poxoréu possuíam beleza e grande qualidade. Os labores desenvolvidos na agricultura, na pecuária e as atividades do comércio, que eram exercidos paralelamente, davam o suporte necessário para o prosseguimento da vida em Poxoréu e nas áreas circunvizinhas.

O topônimo Poxoréu possui estrutura simples, formado pela aglutinação das unidades lexicais bororo po + xoréu. Nos estudos toponímicos é classificado, taxionomicamente, como hidrotopônimo. A unidade lexical poxoréu está registrada na Enciclopédia Bororo:

Pó Ceréu - * pó, água; ceréu, o escuro [r. de águas escuras]. Designação: 1 . do curso superior do Pogúbo, $r$. Vermelho até a foz do Porubí, r. Porube Aidjau. Nas proximidades de Jurodóri Boróro é também denominado r. São João. Com seu c. s. atravessa a cidade de Poxoreu; 2. de um r. afl. do c. i. do Pogúbo, r. Vermelho: r. Dr. Correia ou r. Ponte de Pedra ou r. Poxoreu. Albisetti; Venturelli (1962, p. 879)

O Decreto-lei no 131 de 16 de fevereiro de 1932 criou o distrito de Poxoréu, pertencente ao município de Cuiabá. O Decreto no 139 de 05 de março de 1938 elevou o distrito à condição de município. 
Deve-se registrar que em 07 de julho de 1967 a Lei $n^{0} 120$ alterou a grafia do topônimo do município para Poxoréo. Em 25 de maio de 2005, a Câmara Municipal de Poxoréo aprovou e o Prefeito Municipal sancionou a Lei no 976 que restabeleceu a grafia Poxoréu. Esta lei foi publicada no Diário Oficial do Estado de Mato Grosso em 06 de junho de 2005, p. 25.

Atualmente o município de Poxoréu está constituído por 05 (cinco) distritos: Sede, Alto Coité, Aparecida do Leste, Jarudore e Paraíso do Leste.

O distrito de paz de Alto Coité foi criado pela Lei no 185 de 16 de novembro de 1948, pertencente ao município de Poxoréu.

O distrito de Aparecida do Leste foi criado pela Lei $n^{\circ} 2.923$ de 06 de janeiro de 1969, pertencente ao município de Poxoréu.

O distrito policial de Jarudore foi criado pelo Decreto-lei $n^{\circ} 831$ de 29 de dezembro de 1949, pertencente ao município de Poxoréu.

O distrito de paz de Paraíso do Leste foi criado pela Lei $n^{\circ} 681$ de 11 de dezembro de 1953, com desmembramento do distrito de paz de Toriparu, mas pertencente ao município de Poxoréu.

Com base nas pesquisas socioeconômicas do Anuário Estatístico de Mato Grosso - 2009, os principais produtos agrícolas do município de Poxoréu foram: algodão, arroz, banana, cana-de-açúcar, mandioca, milho e soja. O volume da produção agrícola foi superior a 290.366 toneladas. Os principais rebanhos foram: bovino, eqüino, ovino e suíno. Os rebanhos, nessa época, perfaziam um total de 330.206 cabeças.

A população residente, recenseada em 2007 e divulgada pelo Instituto Brasileiro de Geografia e Estatística (IBGE), foi de 17.592 habitantes, sendo que 12.154 encontravam-se na zona urbana e 5.438 na zona rural. A densidade demográfica atingiu o índice de $1,4 \mathrm{hab} . / \mathrm{km}^{2}$ e a representatividade da população urbana foi superior a $69,1 \%$. 
O município de Poxoréu localiza-se na mesorregião Sudeste Mato-grossense e é um dos municípios que compõe a microrregião Tesouro. Limita-se com os municípios de Dom Aquino, General Carneiro, Guiratinga, Juscimeira, Novo São Joaquim, Primavera do Leste, Rondonópolis, Santo Antônio do Leste, São José do Povo, São Pedro da Cipa e Tesouro.

A seguir, anexam-se as relações dos topônimos do município de Poxoréu, registrados nas cartas topográficas ${ }^{7}$ elaboradas pela Diretoria de Serviço Geográfico (DSG) e pelo Instituto Brasileiro de Geografia e Estatística (IBGE), que integram o corpus desta pesquisa. Os topônimos estão antecedidos pelos seus respectivos acidentes físicos e acidentes antrópicos, também identificados como elementos físicos e elementos humanos de uma paisagem.

\footnotetext{
${ }^{7}$ As oito cartas topográficas que abrangem a área geográfica do município de Poxoréu são: Galheiro (275), Fazenda Luciana (276), Lagoa do Cervo (277), Dom Aquino (294), Poxoréo (295), Batovi (296), Jarudore (313) e Guiratinga (314),

O número que está entre parênteses, após o nome de cada carta topográfica, corresponde ao número que está colocado, entre parênteses, logo após o topônimo nas relações dos topônimos do município, para facilitar a sua localização na respectiva carta.
} 
4.6.7.1 Relação dos acidentes físicos do município de Poxoréu, de seus topônimos e taxionomias. 
(continuação)

\begin{tabular}{|c|c|c|c|}
\hline $\mathbf{N}^{0}$ & Acidente & Topônimo & Taxionomia \\
\hline 29 & córrego & Bororo (295 - V4) & Etnotopônimo \\
\hline 30 & córrego dos & Bugres (295 - R12, R13) & Etnotopônimo \\
\hline 31 & córrego & Buracão (296 - N4, M5) & Geomorfotopônimo \\
\hline 32 & córrego da & Cabeceira da Merenda (314 - F1) & Hidrotopônimo \\
\hline 33 & córrego & Cabeceira do Areia (314 - C5) & Hidrotopônimo \\
\hline 34 & córrego & Cachoeira (314 - A1, B1) & Hidrotopônimo \\
\hline 35 & córrego & Cachoerinha (313 - C24, C25 / 314 - A1) & Hidrotopônimo \\
\hline 36 & córrego & Calango (314 - G1 a I2) & Zootopônimo \\
\hline 37 & córrego & Caldeirão (314 - D2) & Hidrotopônimo \\
\hline 38 & córrego & Catete (296 - R7 a T2) & Zootopônimo \\
\hline 39 & córrego da & Clarineta (296 - R4 a M5) & Ergotopônimo \\
\hline 40 & córrego & D'anta (313 - F24, F25) & Zootopônimo \\
\hline 41 & córrego do & Desvio (295 - S17, R17) & Hodotopônimo \\
\hline 42 & córrego & Divisa (313 - U25, U26) & Cardinotopônimo \\
\hline 43 & córrego do & Domingos (313 - G8) & Antropotopônimo \\
\hline 44 & córrego & Duas Barras (313 - F19, G19) & Numerotopônimo \\
\hline 45 & córrego da & Ema (314 - E2) & Zootopônimo \\
\hline 46 & córrego & Encantado (277 - V9, X10) & Animotopônimo \\
\hline 47 & córrego & Engano (313 - T12) & Animotopônimo \\
\hline 48 & córrego & Esparramo (275 - AE24 a Z27) & Sociotopônimo \\
\hline 49 & córrego da & Faísca (314 - E1) & Igneotopônimo \\
\hline 50 & córrego da & Forma (314 - A2, A3, B3) & Ergotopônimo \\
\hline 51 & córrego & Fumaça (313 - H17, H18) & Igneotopônimo \\
\hline 52 & córrego & Fundo (314 - I1) & Dimensiotopônimo \\
\hline 53 & córrego & Furninha (295 - R25, S25) & Geomorfotopônimo \\
\hline 54 & córrego & Galante (314 - E2) & Sociotopônimo \\
\hline 55 & córrego & Grande (295 - S17 a AE18) & Dimensiotopônimo \\
\hline 56 & córrego & Grande (313 - E7 a G5) & Dimensiotopônimo \\
\hline 57 & córrego & Grotão (313 - P5 a R7) & Geomorfotopônimo \\
\hline 58 & córrego & Iguaçu (313 - C22, C23) & Hidrotopônimo \\
\hline 59 & córrego & Inveja (296 - Q6, R6) & Animotopônimo \\
\hline
\end{tabular}


(continuação)

\begin{tabular}{|c|c|c|c|}
\hline $\mathbf{N}^{\mathbf{0}}$ & Acidente & Topônimo & Taxionomia \\
\hline 60 & córrego & Jaboti (277 - R8 a Q11) & Zootopônimo \\
\hline 61 & córrego do & Jácomo (294 - V25, V26 / 295 - U1, T1 ) & Antropotopônimo \\
\hline 62 & córrego & Jatobá (313 - N19, N20) & Fitotopônimo \\
\hline 63 & córrego & João Leite (314 - E5) & Antropotopônimo \\
\hline 64 & córrego & $\begin{array}{l}\text { Lambari (295 - AD4, AD5 / } 313 \text { - A5 a } \\
\text { L11) }\end{array}$ & Zootopônimo \\
\hline 65 & córrego & Limoeiro (314 - J1) & Fitotopônimo \\
\hline 66 & córrego do & Macaco $(296-$ L4, J5) & Zootopônimo \\
\hline 67 & córrego & Mangaba (295 - P27) & Fitotopônimo \\
\hline 68 & córrego da & Mata $(296-$ M3, L5) & Fitotopônimo \\
\hline 69 & córrego da & Matinha (296 - L3 a H4) & Fitotopônimo \\
\hline 70 & córrego do & Meio (294 - H25, G27) & Cardinotopônimo \\
\hline 71 & córrego do & Meio (313 - H7) & Cardinotopônimo \\
\hline 72 & córrego dos & Negros (313 - S24, S25) & Etnotopônimo \\
\hline 73 & córrego & Olaria (314 - E1) & Sociotopônimo \\
\hline 74 & córrego da & Onça (313 - C14 a F15) & Zootopônimo \\
\hline 75 & córrego do & Ouro (313 - R23) & Litotopônimo \\
\hline 76 & córrego & $\begin{array}{l}\text { Palmeira (294 - L27, M27 / } 295 \text { - M1, } \\
\text { N1) }\end{array}$ & Fitotopônimo \\
\hline 77 & córrego & Paraíso (314 - A4 / 296 - AE10 a AB9) & Hierotopônimo \\
\hline 78 & córrego & Pedra de Fogo (314 - E11) & Litotopônimo \\
\hline 79 & córrego & Perigo (295 - AC23) & Animotopônimo \\
\hline 80 & córrego & Piobogue (313 - L7 a O10) & Zootopônimo \\
\hline 81 & córrego & Ponte de Pedra (313 - M26) & Hodotopônimo \\
\hline 82 & córrego & Ponte de Pedra (294 - E24, F23) & Hodotopônimo \\
\hline 83 & córrego & Poruba (295 - J13 a N17) & Zootopônimo \\
\hline 84 & córrego do & Pouso (314 - G1) & Sociotopônimo \\
\hline 85 & córrego & Pulador (313 - A23, A24) & Hidrotopônimo \\
\hline 86 & córrego & Retiro Velho (295 - S23, R23) & Sociotopônimo \\
\hline 87 & córrego & Ribeirão (294 - G19, L20) & Hidrotopônimo \\
\hline 88 & córrego & Rico $(295-18,19)$ & Animotopônimo \\
\hline 89 & córrego da & Roça (313 - A6, B7) & Sociotopônimo \\
\hline 90 & córrego & São Carlos (296 - U4 a Z6) & Hagiotopônimo \\
\hline
\end{tabular}


(continuação)

\begin{tabular}{|c|c|c|c|}
\hline $\mathbf{N}^{\circ}$ & Acidente & Topônimo & Taxionomia \\
\hline 91 & córrego & São João (294 - J25 / 295 - H1 a M6) & Hagiotopônimo \\
\hline 92 & córrego & São Lucas (296 - X12 a AC5 & Hagiotopônimo \\
\hline 93 & córrego & São Paulo (294 - Z19, X20) & Hagiotopônimo \\
\hline 94 & córrego & São Paulo (295 - S21, S22) & Hagiotopônimo \\
\hline 95 & córrego & São Pedro (294 - U20) & Hagiotopônimo \\
\hline 96 & córrego & São Pedro (295 - Q9, R9, R10) & Hagiotopônimo \\
\hline 97 & córrego & Sete (294 - AA19 a X22) & Numerotopônimo \\
\hline 98 & córrego do & Sucuri (296 - O3 a M1) & Zootopônimo \\
\hline 99 & córrego & Sucuri (314 - B1, B2, C1) & Zootopônimo \\
\hline 100 & córrego & Sucurizinho (314 - E1) & Zootopônimo \\
\hline 101 & córrego & Tejuco (314 - H1) & Litotopônimo \\
\hline 102 & córrego & $\begin{array}{l}\text { Toca da Onça (314 - A2, A3 / } 296 \text { - AE5, } \\
\text { AD4) }\end{array}$ & Geomorfotopônimo \\
\hline 103 & córrego & Tombador (313 - N11 a N14) & Geomorfotopônimo \\
\hline 104 & córrego do & $\begin{array}{l}\text { Trabalho (313 - H25, H26 / } 314 \text { - D1 a } \\
\text { B3) }\end{array}$ & Sociotopônimo \\
\hline 105 & córrego do & Urubu $(314-F 1)$ & Zootopônimo \\
\hline 106 & córrego da & Vaca (314 - A1) & Zootopônimo \\
\hline 107 & córrego & Vaca Morta $(296$ - J5, J6) & Zootopônimo \\
\hline 108 & córrego & Vitória (314 - F5) & Animotopônimo \\
\hline 109 & lagoa do & Cervo (277 - R8, R9) & Zootopônimo \\
\hline 110 & morro & Areia (295 - Z2, Z3) & Litotopônimo \\
\hline 111 & morro & Janela (313 - P13, P14) & Ergotopônimo \\
\hline 112 & morro & Jarudore (313 - N11, N12) & Zootopônimo \\
\hline 113 & morro & Natal (313 - E8) & Hierotopônimo \\
\hline 114 & morro dos & Pinga (295 - X1, X2) & Antropotopônimo \\
\hline 115 & morro do & Touro (313 - H7) & Zootopônimo \\
\hline 116 & morro & Troale (313 - N15, N16) & Antropotopônimo \\
\hline 117 & ribeirão das & Almas (277 - AE1 a Q5) & Hierotopônimo \\
\hline 118 & ribeirão das & $\begin{array}{l}\text { Alminhas (295 - H26, I27 / } 296-\mathrm{F} 1 \mathrm{a} \\
\text { A1) }\end{array}$ & Hierotopônimo \\
\hline 119 & ribeirão & $\begin{array}{l}\text { Dourado (313 - E19 a J27 / } 314 \text { - D1, } \\
\text { D2) }\end{array}$ & Cromotopônimo \\
\hline 120 & ribeirão das & Malas (296 - G4 a S1) & Ergotopônimo \\
\hline
\end{tabular}


(conclusão)

\begin{tabular}{|c|c|c|c|}
\hline $\mathbf{N}^{\circ}$ & Acidente & Topônimo & Taxionomia \\
\hline 121 & ribeirão & Parnaíba (294 - G21,G22) & Hidrotopônimo \\
\hline 122 & ribeirão dos & Perdidos (276 - AD8 a T14) & Animotopônimo \\
\hline 123 & ribeirão das & Pombas (294 - X16, X17) & Zootopônimo \\
\hline 124 & ribeirão & $\begin{array}{l}\text { Sangradouro Grande (277 - AE5 a U15 / } \\
296 \text { - A5 a T14) }\end{array}$ & Hidrotopônimo \\
\hline 125 & ribeirão & $\begin{array}{l}\text { Sangradourozinho (276 - S27 a AE26 / } \\
277 \text { - S1 a P6 / } 295 \text { - M22 a G25) }\end{array}$ & Hidrotopônimo \\
\hline 126 & rio & Areia ou Coqueial (313 - T6 a U27) & $\begin{array}{l}\text { Litotopônimo ou } \\
\text { Zootopônimo }\end{array}$ \\
\hline 127 & rio & Coité (295 - Q8 a C16) & Fitotopônimo \\
\hline 128 & rio das & Mortes (276 - Z1 a T14 / 277 - P6 a U15) & Sociotopônimo \\
\hline 129 & rio & $\begin{array}{l}\text { Paraíso (295 - AC27 a AE21 / } 313 \text { - G13 } \\
\text { a A20 / } 296 \text { - AC1 a Z12) }\end{array}$ & Hierotopônimo \\
\hline 130 & rio do & $\begin{array}{l}\text { Peixe (295 - T25 a AE17 / } 313 \text { - A18 a } \\
\text { C19 / } 296 \text { - V1, V2) }\end{array}$ & Zootopônimo \\
\hline 131 & rio & $\begin{array}{l}\text { Poxoréo (295 - S7 a AC10 / } 313 \text { - A10 a } \\
\text { G13) }\end{array}$ & Hidrotopônimo \\
\hline 132 & rio & $\begin{array}{l}\text { Poxoreozinho (294 - N25, N26 / } 295 \text { - } \\
\text { N1 a U7) }\end{array}$ & Hidrotopônimo \\
\hline 133 & rio & São João (313 - H13 a M11) & Hagiotopônimo \\
\hline 134 & rio & Vermelho (313 - N11 a T6) & Cromotopônimo \\
\hline 135 & serra das & Araras (313 - O21, P21) & Zootopônimo \\
\hline 136 & serra & Grande (295 - D3 a D11) & Dimensiotopônimo \\
\hline 137 & serra da & Saudade (314 - F5 a C5) & Animotopônimo \\
\hline
\end{tabular}

Fonte dos dados: Carta topográfica da Diretoria de Serviço Geográfico (DSG), Ministério do Exército, 1976 - escala 1:100.000.

Carta topográfica do Instituto Brasileiro de Geográfica e Estatística (IBGE), 1976 - escala 1:100.000.

Mapa da Fundação de Pesquisas Cândido Rondon (FCR), 1983 - escala $1: 250.000$. 
4.6.7.2 Relação dos acidentes humanos do município de Poxoréu, de seus topônimos e taxionomias.

\begin{tabular}{|c|c|c|c|}
\hline $\mathbf{N}^{\mathbf{0}}$ & Acidente & Topônimo & Taxionomia \\
\hline 01 & cidade de & Poxoréu (295 - T6, T7, U8) & Hidrotopônimo \\
\hline 02 & distrito & Alto Coité (295 - O9, P9) & Cardinotopônimo \\
\hline 03 & distrito & Jarudore (313 - M10, M11) & Zootopônimo \\
\hline 04 & distrito & Paraíso do Leste (313 - E18) & Hierotopônimo \\
\hline 05 & distrito & $\begin{array}{l}\text { Aparecida do Leste (295 - AF 14, AF13 / } \\
313 \text { - A13, A14) }\end{array}$ & Antropotopônimo \\
\hline 06 & terra indígena & Jarudore (313 - M10 a M14) & Zootopônimo \\
\hline 07 & terra indígena & Sangradouro (296 - G1 a A12) & Hidrotopônimo \\
\hline
\end{tabular}

Fonte dos dados: Carta topográfica da Diretoria de Serviço Geográfico (DSG), Ministério do Exército, 1976 - escala 1:100.000.

Carta topográfica do Instituto Brasileiro de Geográfica e Estatística (IBGE), 1976 - escala 1:100.000.

Mapa da Fundação de Pesquisas Cândido Rondon (FCR), 1983 - escala $1: 250.000$. 


\subsubsection{Características gerais do município de Ribeirãozinho}

O município de Ribeirãozinho obteve sua autonomia político-administrativa em 1991, ao ser desmembrado do município de Ponte Branca. A cidade de Ribeirãozinho localiza-se às margens do córrego Ribeirãozinho.

O município de Ribeirãozinho possui $623 \mathrm{~km}^{2}$ de extensão territorial, dados do Anuário Estatístico de Mato Grosso - 2009, publicado pela SEPLAN - MT. A altitude na cidade de Ribeirãozinho é de 477 metros acima do nível do mar.

O topônimo Ribeirãozinho possui estrutura simples, formado pela unidade lexical ribeiro + sufixo -ão + sufixo -(z)inho. Nos estudos toponímicos é classificado, taxionomicamente, como hidrotopônimo.

As terras que atualmente constituem a extensão territorial do município de Ribeirãozinho começaram a ser palmilhadas, por povos não autóctones, nas duas últimas décadas do século XIX, quando alguns garimpeiros passaram por lá em busca de promissoras jazidas diamantíferas. Esses grupos, porém, não permaneceram naquelas terras.

Ocorreu, ao final da segunda década do século $X X$, o estabelecimento de várias famílias provenientes de outros estados brasileiros. Ali chegaram com o intuito de adquirir terras agricultáveis para desenvolver atividades agropecuárias e dar prosseguimento à continuidade do núcleo familiar que já tinham formado.

O pequeno aglomerado humano foi firmando-se com o decorrer dos anos e, por isso, conseguiu ser elevado à categoria de distrito, pela primeira vez, em 30 de outubro de 1935, pelo Decreto no 11, porém perdeu essa condição em 1943. Somente quinze anos depois, em 21 de novembro de 1958, a localidade de Ribeirãozinho obteve pela Lei $n^{\circ} 1.170$, novamente, a categoria de distrito, mas jurisdicionado ao município de Ponte Branca. A Lei nº 5.910 de 20 de dezembro de 1991 elevou Ribeirãozinho à categoria de município. 
Atualmente o município de Ribeirãozinho está constituído apenas pelo distrito Sede:

Com base nas pesquisas socioeconômicas do Anuário Estatístico de Mato Grosso - 2009, os principais produtos agrícolas do município de Ribeirãozinho foram: arroz, cana-de-açúcar, mandioca, milho e soja. O volume da produção agrícola foi superior a 36.155 toneladas. Os principais rebanhos foram: bovino, eqüino, ovino e suíno. Os rebanhos, nessa época, perfaziam um total de 33.229 cabeças.

A população residente, recenseada em 2007 e divulgada pelo Instituto Brasileiro de Geografia e Estatística (IBGE), foi de 2.107 habitantes, sendo que 1.497 encontravam-se na zona urbana e 610 na zona rural. A densidade demográfica atingiu o índice de $3,4 \mathrm{hab} . / \mathrm{km}^{2}$ e a representatividade da população urbana foi superior a $71,1 \%$.

O município de Ribeirãozinho localiza-se na mesorregião Sudeste Matogrossense e é um dos municípios que compõe a microrregião Tesouro. Limita-se com os municípios de Ponte Branca, Torixoréu e o estado de Goiás.

A seguir, anexam-se as relações dos topônimos do município Ribeirãozinho, registrados no mapa elaborado pela Fundação de Pesquisas Cândido Rondon (FCR), que integra o corpus desta pesquisa. Os topônimos estão antecedidos pelos seus respectivos acidentes físicos e acidentes antrópicos, também identificados como elementos físicos e elementos humanos de uma paisagem. 
4.6.8.1 Relação dos acidentes físicos do município de Ribeirãozinho, de seus topônimos e taxionomias.

\begin{tabular}{|c|c|c|c|}
\hline $\mathbf{N}^{0}$ & Acidente & Topônimo & Taxionomia \\
\hline 01 & córrego do & Açude (F5) & Hidrotopônimo \\
\hline 02 & córrego & Baixada (E7, E8) & Geomorfotopônimo \\
\hline 03 & córrego & Barriga (H5, G5) & Somatotopônimo \\
\hline 04 & córrego dos & Bois (F7, F8) & Zootopônimo \\
\hline 05 & córrego & Borá (H4, G4, G5) & Zootopônimo \\
\hline 06 & córrego & Buritizal (E6 a D8) & Fitotopônimo \\
\hline 07 & córrego & Campo Alegre (G5 a E4) & Fitotopônimo \\
\hline 08 & córrego & Cocal (D7, C7, C8) & Fitotopônimo \\
\hline 09 & córrego & Confusa (H3 a F4) & Animotopônimo \\
\hline 10 & córrego & Confuso (G5 a E5) & Animotopônimo \\
\hline 11 & córrego & Galante (F6) & Sociotopônimo \\
\hline 12 & córrego & Grotão $(13,14)$ & Geomorfotopônimo \\
\hline 13 & córrego & Igrejinha (F9, E9) & Hierotopônimo \\
\hline 14 & córrego & Invernada (G8, G9, H9) & Geomorfotopônimo \\
\hline 15 & córrego & Iraras (J1 a H2) & Zootopônimo \\
\hline 16 & córrego & Jaguatirica ou Bacuri $(\mathrm{I3}, \mathrm{H} 2, \mathrm{H} 3)$ & $\begin{array}{l}\text { Zootopônimo ou } \\
\text { Fitotopônimo }\end{array}$ \\
\hline 17 & córrego & Jaguatirica $(15,16)$ & Zootopônimo \\
\hline 18 & córrego & Luizinho $(\mathrm{H} 7, \mathrm{I8})$ & Antropotopônimo \\
\hline 19 & córrego do & Mangue $(I 1, H 1, H 2)$ & Fitotopônimo \\
\hline 20 & córrego do & Mato (H4, G4, G5) & Fitotopônimo \\
\hline 21 & córrego & Moderno (E6) & Cronotopônimo \\
\hline 22 & córrego & Olaria (F8, E8) & Sociotopônimo \\
\hline 23 & córrego & Peixe (G6 a 17) & Zootopônimo \\
\hline 24 & córrego & Pontinha (I3 a G3) & Hodotopônimo \\
\hline 25 & córrego & Pulador (D6, C6) & Hidrotopônimo \\
\hline 26 & córrego & Quati (B7, B8) & Zootopônimo \\
\hline 27 & córrego & Rainha (G4) & Sociotopônimo \\
\hline 28 & córrego & Rainha (F5, E5) & Sociotopônimo \\
\hline
\end{tabular}


(conclusão)

\begin{tabular}{l|lll}
\hline $\mathbf{N}^{\mathbf{2}}$ & \multicolumn{1}{c|}{ Acidente } & \multicolumn{1}{c}{ Topônimo } & \multicolumn{1}{c}{ Taxionomia } \\
\hline 29 & córrego & Ribeirãozinho (G5 a D8) & Hidrotopônimo \\
30 & córrego & Seco $(\mathrm{I} 1, \mathrm{J1})$ & Hidrotopônimo \\
31 & córrego & Varjão $(\mathrm{H} 6, \mathrm{I6})$ & Geomorfotopônimo \\
32 & ribeirão & São João (J4 a I7) & Hagiotopônimo \\
33 & rio & Araguaia (J7 a A8) & Zootopônimo \\
34 & rio & São Domingos (I1 a A8) & Hagiotopônimo \\
35 & serra do & Poço Velho (C7, B7) & Hidrotopônimo \\
36 & serra do & Quati (B7, B8) & Zootopônimo \\
\hline
\end{tabular}

Fonte dos dados: Mapa da Fundação de Pesquisas Cândido Rondon (FCR), 1991 - escala 1:100.000.

4.6.8.2 Relação do acidente humano do município de Ribeirãozinho, de seu topônimo e taxionomia.

\begin{tabular}{c|c|c|c}
\hline $\mathbf{N}^{\mathbf{0}}$ & Acidente & Topônimo & Taxionomia \\
\hline 01 & cidade de & Ribeirãozinho (G8) & Hidrotopônimo \\
\hline
\end{tabular}

Fonte dos dados: Mapa da Fundação de Pesquisas Cândido Rondon (FCR), 1991 - escala $1: 100.000$ 


\subsubsection{Características gerais do município de Tesouro}

O município de Tesouro obteve sua autonomia político-administrativa em 1953, ao ser desmembrado do município de Guiratinga. A cidade de Tesouro localiza-se à margem esquerda do rio das Garças.

A extensão territorial do município de Tesouro é de $4.017 \mathrm{~km}^{2}$, dados do Anuário Estatístico de Mato Grosso - 2009, publicado pela SEPLAN - MT. A altitude na cidade de Tesouro é de 410 metros acima do nível do mar.

O topônimo Tesouro possui estrutura simples. Nos estudos toponímicos é classificado, taxionomicamente, como sociotopônimo.

Os Bororo foram, segundo historiadores pesquisados, os primeiros a viver na área territorial onde hoje encontra-se o município de Tesouro. A partir dos anos finais do século XIX, os primeiros exploradores não autóctones chegaram a região. Alguns sonhavam em encontrar terras férteis para desenvolver atividades agropecuárias, mas grande parte dos exploradores pretendia desenvolver a prática do extrativismo vegetal com a extração do látex das mangabeiras, a qual poucos se dedicaram. A mangabeira é planta do Cerrado Brasileiro e naquela época existia em profusão, mas atualmente, corre o risco de extinção.

O grande sonho dos exploradores que ali chegaram era o extrativismo mineral. Sonhavam com a descoberta de grandes veios diamantíferos, como já ocorria em várias outras áreas circunvizinhas e que thes possibilitaria usufruir as regalias proporcionadas pelo comércio das preciosas pedras. A chegada de tantas pessoas para trabalhar no garimpo propiciou a instalação de pequenos aglomerados humanos, desses porém, poucos permaneceram.

Em 19 de outubro de 1937 o povoado de Tesouro foi elevado à categoria de distrito pela Lei $n^{0} 116$, pertencendo ao município de Alto Araguaia, que naquela época era toponimizado Santa Rita do Araguaia. O município de Tesouro foi criado pela Lei no 664 de 10 de dezembro de 1953. 
Atualmente o município de Tesouro está constituído por 03 (três) distritos: Sede, Batovi e Caçununga.

O distrito de Batovi foi criado pela Lei no 175 de 18 de outubro de 1948, pertencia, naquela época, ao município de Guiratinga.

O distrito de Caçununga foi criado pelo Decreto $n^{0} 372$ de 05 de junho de 1934 e, naquela época, integrava o município de Santa Rita do Araguaia.

Com base nas pesquisas socioeconômicas do Anuário Estatístico de Mato Grosso - 2009, os principais produtos agrícolas do município de Tesouro foram: arroz, mandioca, milho e soja. O volume da produção agrícola foi superior a 138.000 toneladas. Os principais rebanhos foram: bovino, eqüino, ovino e suíno. Os rebanhos, nessa época, perfaziam um total de 82.009 cabeças.

A população residente, recenseada em 2007 e divulgada pelo Instituto Brasileiro de Geografia e Estatística (IBGE), foi de 3.109 habitantes, sendo que 2.303 encontravam-se na zona urbana e 806 na zona rural. A densidade demográfica atingiu o índice de $0,6 \mathrm{hab} . / \mathrm{km}^{2}$ e a representatividade da população urbana foi superior a $74,1 \%$.

O município de Tesouro localiza-se na mesorregião Sudeste Mato-grossense e é um dos municípios que compõe a microrregião Tesouro. Limita-se com os municípios de General Carneiro, Guiratinga, Pontal do Araguaia e Poxoréu.

A seguir, anexam-se as relações dos topônimos do município Tesouro, registrados no mapa elaborado pela Secretaria de Estado de Planejamento e Coordenação Geral do Estado de Mato Grosso (SEPLAN - MT), que integra o corpus desta pesquisa. Os topônimos estão antecedidos pelos seus respectivos acidentes físicos e acidentes antrópicos, também identificados como elementos físicos e elementos humanos de uma paisagem. 
4.6.9.1 Relação dos acidentes físicos do município de Tesouro, de seus topônimos e taxionomias.

(continua)

\begin{tabular}{|c|c|c|c|}
\hline $\mathbf{N}^{\mathbf{0}}$ & Acidente & Topônimo & Taxionomia \\
\hline 01 & cabeceira do & Açude (G9 a H11) & Hidrotopônimo \\
\hline 02 & córrego & Água Bonita (M9 a O10) & Hidrotopônimo \\
\hline 03 & córrego & Água Bonita (R4) & Hidrotopônimo \\
\hline 04 & córrego & Água Bonita (A14, B13) & Hidrotopônimo \\
\hline 05 & córrego & Água Emendada (F8 a E11) & Hidrotopônimo \\
\hline 06 & córrego & Água Limpa (R5, S5) & Hidrotopônimo \\
\hline 07 & córrego & Água Suja $(\mathrm{O} 3, \mathrm{P3})$ & Hidrotopônimo \\
\hline 08 & córrego & Aldeia (O14 a E15) & Poliotopônimo \\
\hline 09 & córrego & Antinha (P4, Q4, Q5) & Zootopônimo \\
\hline 10 & córrego & Antinha (Q7) & Zootopônimo \\
\hline 11 & córrego & Areia $(\mathrm{E} 5, \mathrm{F5})$ & Litotopônimo \\
\hline 12 & córrego & Aroeira (A12) & Fitotopônimo \\
\hline 13 & córrego & Avuadeira (Q12 a 011) & Zootopônimo \\
\hline 14 & córrego & Bandeirinha (N5, N6) & Historiotopônimo \\
\hline 15 & córrego & Barreirão (C16 a G16) & Litotopônimo \\
\hline 16 & córrego & Barreiro (Q11 a O11) & Litotopônimo \\
\hline 17 & córrego & Barreiro (S7, S8) & Litotopônimo \\
\hline 18 & córrego & Barro Duro (A11, B11, B12) & Litotopônimo \\
\hline 19 & córrego & Boa Esperança (P5, P6) & Animotopônimo \\
\hline 20 & córrego & Boa Fé (F4) & Animotopônimo \\
\hline 21 & córrego & Boa Vista (R7, S8) & Animotopônimo \\
\hline 22 & córrego & Bom Jesus (O6, P6) & Hierotopônimo \\
\hline 23 & córrego da & Bomba (R14, R15) & Ergotopônimo \\
\hline 24 & córrego & Borá (P2, P3) & Zootopônimo \\
\hline 25 & córrego & Buracão (R3, R4) & Geomorfotopônimo \\
\hline 26 & córrego & Buriti (O14) & Fitotopônimo \\
\hline 27 & córrego & Buritirana (C17, C18, D18) & Fitotopônimo \\
\hline 28 & córrego & Buritirana (P8, P9) & Fitotopônimo \\
\hline 29 & córrego & Cabeceira do Açude (R14 a R15) & Hidrotopônimo \\
\hline
\end{tabular}


(continuação)

\begin{tabular}{|c|c|c|c|}
\hline $\mathbf{N}^{\circ}$ & Acidente & Topônimo & Taxionomia \\
\hline 30 & córrego & Cachoeirinha (F10, G10) & Hidrotopônimo \\
\hline 31 & córrego & Cachoeirinha ( $\mathrm{H} 5$ a H7) & Hidrotopônimo \\
\hline 32 & córrego & Cachoeirinha (Q5, R5) & Hidrotopônimo \\
\hline 33 & córrego & Cadela (Q12, R12) & Zootopônimo \\
\hline 34 & córrego & Celebra $(\mathrm{N} 9, \mathrm{O9})$ & Sociotopônimo \\
\hline 35 & córrego & Cuiabano (P4, P5, O5) & Etnotopônimo \\
\hline 36 & córrego & Dantas (Q4 a P9) & Antropotopônimo \\
\hline 37 & córrego & Divisinha (H20 a E22) & Cardinotopônimo \\
\hline 38 & córrego & Engano (M3 a O3) & Animotopônimo \\
\hline 39 & córrego do & Estreito (P16) & Geomorfotopônimo \\
\hline 40 & córrego & Fazendinha (L15 a N17) & Sociotopônimo \\
\hline 41 & córrego & Ferrugem (N6, M6, M7) & Cromotopônimo \\
\hline 42 & córrego & Fundo (L4, L5) & Dimensiotopônimo \\
\hline 43 & córrego da & Furna (N3) & Geomorfotopônimo \\
\hline 44 & córrego & Galheiro $(015,016)$ & Zootopônimo \\
\hline 45 & córrego & Garapa (O7, P7) & Ergotopônimo \\
\hline 46 & córrego & Garimpeiro (Q4, R4) & Sociotopônimo \\
\hline 47 & córrego & Grotão (D17 a E19) & Geomorfotopônimo \\
\hline 48 & córrego & Grotão (O4) & Geomorfotopônimo \\
\hline 49 & córrego & Inferninho (L20 a J19) & Mitotopônimo \\
\hline 50 & córrego do & Inferninho (Q13, Q14, P13) & Mitotopônimo \\
\hline 51 & córrego & Jacu (L7 a I9) & Zootopônimo \\
\hline 52 & córrego & Jatobá (M12 a H12) & Fitotopônimo \\
\hline 53 & córrego & Jirau (A12 a E11) & Ergotopônimo \\
\hline 54 & córrego & João Batista (B13, B14) & Antropotopônimo \\
\hline 55 & córrego da & Laje (R15, R16) & Litotopônimo \\
\hline 56 & córrego & Lajeadinho (C14 a D16) & Litotopônimo \\
\hline 57 & córrego & Lajeadinho (O16 a L15) & Litotopônimo \\
\hline 58 & córrego & Lajeado (Q9, Q10) & Litotopônimo \\
\hline 59 & córrego da & Laura $(\mathrm{O} 8, \mathrm{P} 8)$ & Antropotopônimo \\
\hline 60 & córrego & Malhador (R14) & Litotopônimo \\
\hline
\end{tabular}


(continuação)

\begin{tabular}{l|l|l|l}
\hline$N^{\circ}$ & \multicolumn{1}{c}{ Acidente } & \multicolumn{1}{c}{ Topônimo } & \multicolumn{1}{|c}{ Taxionomia } \\
\hline 61 & córrego & Mangue (O3, P3) & Fitotopônimo \\
62 & córrego & Manjerona (C17, D17, D16) & Fitotopônimo \\
63 & córrego & Mata da Onça (S15, R14) & Fitotopônimo \\
64 & córrego & Matuta (P13) & Sociotopônimo \\
65 & córrego do & Meio (N14, M13) & Cardinotopônimo \\
66 & córrego & Monjolo (Q14, Q15) & Ergotopônimo \\
67 & córrego & Morro Alto (R13, R14) & Geomorfotopônimo \\
68 & córrego & Morro da Mesa (E17 a F20) & Geomorfotopônimo \\
69 & córrego & Morro do Chapéu (R7, R8) & Geomorfotopônimo \\
70 & córrego do & Onofre (P15, O15) & Antropotopônimo \\
71 & córrego & Paulo Afonso (P9, P10) & Antropotopônimo \\
72 & córrego & Pião (O7, P7) & Ergotopônimo \\
73 & córrego & Pião (Q14 a O13) & Ergotopônimo \\
74 & córrego & Pindaibão (F15) & Fitotopônimo \\
75 & córrego & Pitangi (R6) & Fitotopônimo \\
76 & córrego & Ponte de Terra (O4, P4, O5) & Hodotopônimo \\
77 & córrego da & Porteira (R15, Q15) & Ergotopônimo \\
78 & córrego do & Pouso (M8 a O7) & Sociotopônimo \\
79 & córrego & Pulador (M10, N10, N11) & Hidrotopônimo \\
80 & córrego & Queixada (N10, N11) & Zootopônimo \\
81 & córrego & Revoltoso (A16 a C16) & Sociotopônimo \\
82 & córrego & Rocoeial ou Ariraiau (B17 a E20) & Zootopônimo ou \\
83 & córrego & Rolete (I21, I22) & Fitotopônimo \\
84 & córrego & Salgadeira (M5, N5) & Ergotopônimo \\
85 & córrego & Santa Maria (N1, N2) & Sociotopônimo \\
86 & córrego & Santa Maria (L3 a N4) & Hagiotopônimo \\
87 & córrego & Serrinha (R6, R7) & Hagiotopônimo \\
88 & córrego & Sucuri (M5 a L8) & Geomorfotopônimo \\
89 & córrego & Sucuri (R5, S5) & Zootopônimo \\
90 & córrego & Tapera (S14, R15) & Zootopônimo \\
91 & córrego & Tesouro (Q8, Q9) & Ecotopônimo \\
& & & Sociotopôno \\
\hline
\end{tabular}


(conclusão)

\begin{tabular}{l|l|l|l}
\hline $\mathbf{N}^{0}$ & \multicolumn{1}{c|}{ Acidente } & \multicolumn{1}{c}{ Topônimo } & \multicolumn{1}{c}{ Taxionomia } \\
\hline 92 & córrego & Tourinho (E4 a F7) & Zootopônimo \\
93 & córrego & Três Barras (I13, H14) & Numerotopônimo \\
94 & córrego & Três Irmãos (H4 a I8) & Numerotopônimo \\
95 & córrego & Varjão (Q8, Q9) & Geomorfotopônimo \\
96 & córrego da & Volta (O13, O12, N13) & Morfotopônimo \\
97 & córrego do & Zinco (O6) & Ergotopônimo \\
98 & morro do & Chapéu (Q6) & Ergotopônimo \\
99 & morro & Redondo (P6) & Morfotopônimo \\
100 & morro & Três Irmãos (G6, G7) & Numerotopônimo \\
101 & ribeirão & Aldeia (S6, S7) & Poliotopônimo \\
102 & ribeirão & Cambaúva (L9 a I10) & Fitotopônimo \\
103 & ribeirão & Confusão (M17 a G18) & Sociotopônimo \\
104 & ribeirão da & Divisa (R16 a P17) & Cardinotopônimo \\
105 & ribeirão da & Estrela (Q13 a M13) & Astrotopônimo \\
106 & ribeirão & Pratinha (G3 a H11) & Litotopônimo \\
107 & ribeirão & São José (L22 a G22) & Hagiotopônimo \\
108 & rio & Areiado (E6 a G13) & Litotopônimo \\
109 & rio & Batovi (I4 a G18) & Fitotopônimo \\
110 & rio & Caçununga (O2 a P9) & Zootopônimo \\
111 & rio das & Garças (T8 a E20) & Zootopônimo \\
112 & serra da & Saudade (O2 a Q2) & Animotopônimo \\
\hline
\end{tabular}

Fonte dos dados: Mapa da Secretaria de Estado de Planejamento e Coordenação Geral do Estado de Mato Grosso (SEPLAN - MT), 1990 - escala 1:100.000. 
4.6.9.2 Relação dos acidentes humanos do município de Tesouro, de seus topônimos e taxionomias.

\begin{tabular}{l|lll}
\hline $\mathbf{N}^{\mathbf{0}}$ & \multicolumn{1}{c}{ Acidente } & \multicolumn{1}{c}{ Topônimo } & \multicolumn{1}{c}{ Taxionomia } \\
\hline 01 & cidade de & Tesouro (P9) & Sociotopônimo \\
02 & distrito & Batovi (I10) & Fitotopônimo \\
03 & distrito & Caçununga (O6) & Zootopônimo \\
04 & localidade & Monchão Dourado (N5) & Litotopônimo \\
\hline Fonte dos dados: & Mapa da Secretaria de Estado de Planejamento e Coordenação Geral \\
& \multicolumn{2}{c}{ do Estado de Mato Grosso (SEPLAN - MT), 1990 - escala 1:100.000. }
\end{tabular}




\subsubsection{Características gerais do município de Torixoréu}

O município de Torixoréu obteve sua autonomia político-administrativa em 1953, ao ser desmembrado do município de Guiratinga. A cidade de Torixoréu localiza-se à margem esquerda do rio Araguaia.

A extensão territorial do município de Torixoréu é de $2.398 \mathrm{~km}^{2}$, dados do Anuário Estatístico de Mato Grosso - 2009, publicado pela SEPLAN - MT. A altitude na cidade de Torixoréu é de 335 metros acima do nível do mar.

O topônimo Torixoréu possui estrutura simples, formado pela aglutinação das unidades lexicais bororo tóri + xoréu. Nos estudos toponímicos é classificado, taxionomicamente, como geomorfotopônimo.

A unidade lexical torixoréu está registrada na Enciclopédia Bororo: "Tóri Coréu - * tóri, rocha; coréu, o escuro [morro escuro]. Pequena elevação nas proximidades da atual cidade de Torixoréu, na margem esquerda do Oroaríbo Kuriréu, r. Araguaia." e Ceréu - vart. de coréu e ders. * cé, prêto; réu, suf. poss. O prêto, o escuro. ex. Pó Ceréu, Água a Escura i.e. rio Escuro: rio Poxoreu. Albisetti; Venturelli (1962, p. 536; 925)

Torixoréu, como a grande maioria dos municípios que compõem a microrregião Tesouro, foi habitado primeiramente pelos Bororo, povo autóctone que vivia em toda aquela região.

Com a chegada de pessoas vindas de vários estados do Brasil e de garimpeiros que já haviam passado por várias localidades garimpeiras da região, as atividades de garimpo, nas terras do atual município de Torixoréu, implantaram-se de forma intensiva. No início do povoamento os garimpeiros descobriram vários monchões - local onde são encontradas grandes quantidades de diamantes. Segundo historiadores, desses monchões foram extraídos quilates de diamantes aos milhares. 
O primeiro topônimo do povoado foi Balizinha, criado pelo Decreto $n^{0} 318$ de 19 de outubro de 1933. No ano seguinte, em 25 de maio de 1934, pelo Decreto $\mathrm{n}^{\circ}$ 319 foi instalado o distrito de paz.

O município de Torixoréu foi criado pela Lei $n^{\circ} 665$ de 10 de dezembro de 1953.

Atualmente o município de Torixoréu está constituído apenas pelo distrito Sede.

Com base nas pesquisas socioeconômicas do Anuário Estatístico de Mato Grosso - 2009, os principais produtos agrícolas do município de Torixoréu foram: cana-de-açúcar, feijão, mandioca, milho e soja. O volume da produção agrícola foi superior a 39.173 toneladas. Os principais rebanhos foram: bovino, eqüino, ovino e suíno. Os rebanhos, nessa época, perfaziam um total de 129.843 cabeças.

A população residente, recenseada em 2007 e divulgada pelo Instituto Brasileiro de Geografia e Estatística (IBGE), foi de 4.101 habitantes, sendo que 2.968 encontravam-se na zona urbana e 1.133 na zona rural. A densidade demográfica atingiu o índice de $0,8 \mathrm{hab} . / \mathrm{km}^{2}$ e a representatividade da população urbana foi superior a $72,4 \%$.

O município de Torixoréu localiza-se na mesorregião Sudeste Mato-grossense e é um dos municípios que compõe a microrregião Tesouro. Limita-se com os municípios de Araguainha, Guiratinga, Pontal do Araguaia, Ponte Branca, Ribeirãozinho, Tesouro e estado de Goiás.

A seguir, anexam-se as relações dos topônimos do município Torixoréu, registrados no mapa elaborado pela Secretaria de Estado de Planejamento e Coordenação Geral do Estado de Mato Grosso (SEPLAN - MT), que integra o corpus desta pesquisa. Os topônimos estão antecedidos pelos seus respectivos acidentes físicos e acidentes antrópicos, também identificados como elementos físicos e elementos humanos de uma paisagem. 
4.6.10.1 Relação dos acidentes físicos do município de Torixoréu, de seus topônimos e taxionomias.

\begin{tabular}{|c|c|c|c|}
\hline $\mathrm{N}^{\mathrm{o}}$ & Acidente & Topônimo & Taxionomia \\
\hline 01 & córrego & Água Bela (D11, C11, C12) & Hidrotopônimo \\
\hline 02 & córrego & Água Bonita (E13 a C16) & Hidrotopônimo \\
\hline 03 & córrego & Água-emendada (C11) & Hidrotopônimo \\
\hline 04 & córrego & Águas Belas (F12 a D15) & Hidrotopônimo \\
\hline 05 & córrego & Antinha (E9) & Zootopônimo \\
\hline 06 & córrego & Antinha (P2 a O4) & Zootopônimo \\
\hline 07 & córrego & Areado (O3) & Litotopônimo \\
\hline 08 & córrego & Areia (B11, B12) & Litotopônimo \\
\hline 09 & córrego & Areia (E15 a G15) & Litotopônimo \\
\hline 10 & córrego & Aroeira (C10, B9) & Fitotopônimo \\
\hline 11 & córrego & Aroeirinha (C11, B12) & Fitotopônimo \\
\hline 12 & córrego & Arraia $(\mathrm{J} 6, \mathrm{~L} 6)$ & Zootopônimo \\
\hline 13 & córrego dos & Baianos (L3) & Etnotopônimo \\
\hline 14 & córrego & Bálsamo $(05,06)$ & Fitotopônimo \\
\hline 15 & córrego & Bálsamo $(05,06)$ & Fitotopônimo \\
\hline 16 & córrego & Barreirão (F17) & Litotopônimo \\
\hline 17 & córrego & Barreirinho $(\mathrm{F} 7, \mathrm{~F} 8)$ & Litotopônimo \\
\hline 18 & córrego & Barreirinho $(\mathrm{O} 1, \mathrm{O} 2)$ & Litotopônimo \\
\hline 19 & córrego & Barreirinho (C18, C19) & Litotopônimo \\
\hline 20 & córrego & Barreiro (C9, D10) & Litotopônimo \\
\hline 21 & córrego & Barreiro (E11 a B13) & Litotopônimo \\
\hline 22 & córrego & Barreiro (F8, F9) & Litotopônimo \\
\hline 23 & córrego da & Bezerra $(19, \mathrm{~J} 10)$ & Zootopônimo \\
\hline 24 & córrego & Boa Aguada (B18, C18) & Animotopônimo \\
\hline 25 & córrego & Boa Esperança (N6 a N9) & Animotopônimo \\
\hline 26 & córrego & Boa Vista (C18, D18) & Animotopônimo \\
\hline 27 & córrego do & Boi (F17, F18) & Zootopônimo \\
\hline 28 & córrego & Buritirana $(\mathrm{J4}, \mathrm{I5})$ & Fitotopônimo \\
\hline 29 & córrego & Buritizinho (N10) & Fitotopônimo \\
\hline
\end{tabular}


(continuação)

\begin{tabular}{|c|c|c|c|}
\hline $\mathbf{N}^{\circ}$ & Acidente & Topônimo & Taxionomia \\
\hline 30 & córrego & Cabaças (L11, L12) & Fitotopônimo \\
\hline 31 & córrego & Cabeceira (F5, E5) & Hidrotopônimo \\
\hline 32 & córrego & Cabeçudo (F14, G14) & Somatotopônimo \\
\hline 33 & córrego & Cabritinha (L11) & Zootopônimo \\
\hline 34 & córrego & Cachoeira (L2 a N3) & Hidrotopônimo \\
\hline 35 & córrego & Cai-cai (C10, C11) & Zootopônimo \\
\hline 36 & córrego & Cambaúva (F4, E4, E5) & Fitotopônimo \\
\hline 37 & córrego & Cambaúva (H11, I11) & Fitotopônimo \\
\hline 38 & córrego da & Campeira $(08,09)$ & Zootopônimo \\
\hline 39 & córrego & Capão Redondo (M9, N9) & Fitotopônimo \\
\hline 40 & córrego & Capim Branco (E15 a E18) & Fitotopônimo \\
\hline 41 & córrego & Cardão (D17) & Fitotopônimo \\
\hline 42 & córrego & Caxixe (M1) & Zootopônimo \\
\hline 43 & córrego & Cerradão (E14, E15) & Fitotopônimo \\
\hline 44 & córrego da & Comprida $(19, \mid 10, \mathrm{~J} 10)$ & Dimensiotopônimo \\
\hline 45 & córrego & Conquista $(\mathrm{J9}, 19)$ & Sociotopônimo \\
\hline 46 & córrego & Cova (L11, M11, M12) & Geomorfotopônimo \\
\hline 47 & córrego da & Cruz $(13,15)$ & Hierotopônimo \\
\hline 48 & córrego da & Cruz $(L 6, M 6)$ & Hierotopônimo \\
\hline 49 & córrego & Currais (J5) & Ergotopônimo \\
\hline 50 & córrego das & Éguas (E8, E9) & Zootopônimo \\
\hline 51 & córrego & Encascadinho (D10) & Fitotopônimo \\
\hline 52 & córrego & Encascado (D9, E9) & Fitotopônimo \\
\hline 53 & córrego & Escondido (I12) & Sociotopônimo \\
\hline 54 & córrego & Enxada (17) & Ergotopônimo \\
\hline 55 & córrego & Esteves (N6 a N8) & Antropotopônimo \\
\hline 56 & córrego da & Estiva (G7, F8) & Sociotopônimo \\
\hline 57 & córrego & Floresta (M7) & Fitotopônimo \\
\hline 58 & córrego & Fumaça $(07, N 8)$ & Igneotopônimo \\
\hline 59 & córrego & Fundo (O3) & Dimensiotopônimo \\
\hline 60 & córrego & Furnas (L5, L6) & Geomorfotopônimo \\
\hline
\end{tabular}


(continuação)

\begin{tabular}{|c|c|c|c|}
\hline $\mathbf{N}^{\circ}$ & Acidente & Topônimo & Taxionomia \\
\hline 61 & córrego & Furninha $(G 8, G 9)$ & Geomorfotopônimo \\
\hline 62 & córrego & Galheirinho (N5, M5) & Zootopônimo \\
\hline 63 & córrego & Galheiro (G12, G13) & Zootopônimo \\
\hline 64 & córrego & Galheiro $(\mathrm{H} 6)$ & Zootopônimo \\
\hline 65 & córrego & Galheiro (N5, M4, L4) & Zootopônimo \\
\hline 66 & córrego & Garimpinho $(\mathrm{C} 9, \mathrm{C} 10)$ & Sociotopônimo \\
\hline 67 & córrego do & Gato (F8, F9) & Zootopônimo \\
\hline 68 & córrego & Goiabal (M3) & Fitotopônimo \\
\hline 69 & córrego & Gorgulho (F13) & Antropotopônimo \\
\hline 70 & córrego & Grotão dos Cavalos $(\mathrm{J} 3, \mathrm{~J} 4)$ & Geomorfotopônimo \\
\hline 71 & córrego das & Guelas $(\mathrm{J} 2, \mathrm{~J} 3)$ & Somatotopônimo \\
\hline 72 & córrego & Invernada (C13) & Geomorfotopônimo \\
\hline 73 & córrego da & Invernada (F3, G4) & Geomorfotopônimo \\
\hline 74 & córrego & Jacaré (D8) & Zootopônimo \\
\hline 75 & córrego & João Deodoro (H6, G7) & Antropotopônimo \\
\hline 76 & córrego do & João Euzébio (G9, G10, H10) & Antropotopônimo \\
\hline 77 & córrego do & João Franco (G3, G4, H4) & Antropotopônimo \\
\hline 78 & córrego & Juscelino (G14, H14) & Antropotopônimo \\
\hline 79 & córrego & Lagoa (M9, N10) & Hidrotopônimo \\
\hline 80 & córrego & Lajeadinho (B10) & Litotopônimo \\
\hline 81 & córrego & Lajeadinho (E10, F10) & Litotopônimo \\
\hline 82 & córrego & Lajeadinho (L3, L4, J4) & Litotopônimo \\
\hline 83 & córrego & Lajeado (H5 a F6) & Litotopônimo \\
\hline 84 & córrego da & Lontra (L12) & Zootopônimo \\
\hline 85 & córrego & Lontra (M9, M10) & Zootopônimo \\
\hline 86 & córrego & Mangue (A10, A11) & Fitotopônimo \\
\hline 87 & córrego & Mangue (C13) & Fitotopônimo \\
\hline 88 & córrego & Marruás (N5, M5) & Zootopônimo \\
\hline 89 & córrego do & Mato (F12, F13) & Fitotopônimo \\
\hline 90 & córrego do & Meio (D16 a D18) & Cardinotopônimo \\
\hline 91 & córrego & Mutum (D8) & Zootopônimo \\
\hline
\end{tabular}


(continuação)

\begin{tabular}{|c|c|c|c|}
\hline $\mathbf{N}^{\mathbf{0}}$ & Acidente & Topônimo & Taxionomia \\
\hline 92 & córrego & Mutum $(\mathrm{J} 7, \mathrm{~J} 8)$ & Zootopônimo \\
\hline 93 & córrego da & Novilha (N2, N3) & Zootopônimo \\
\hline 94 & córrego & Olho-d'água (M8, L8) & Hidrotopônimo \\
\hline 95 & córrego da & Onça (L10, J10) & Zootopônimo \\
\hline 96 & córrego das & Pacas $(\mathrm{H} 4, \mathrm{l} 4)$ & Zootopônimo \\
\hline 97 & córrego & Pântano (E13 a G13) & Litotopônimo \\
\hline 98 & córrego & Pedra Furada (G14, G15) & Litotopônimo \\
\hline 99 & córrego & Pequeno (L8) & Dimensiotopônimo \\
\hline 100 & córrego & Piau (N2, N3, M1) & Zootopônimo \\
\hline 101 & córrego & Picadinha (L2) & Hodotopônimo \\
\hline 102 & córrego & Pindaibão (F14 a D14) & Fitotopônimo \\
\hline 103 & córrego & Pindaibinha (E6, F6) & Fitotopônimo \\
\hline 104 & córrego & Piquenique (L1, L2) & Sociotopônimo \\
\hline 105 & córrego & Ponte de Pedra (F13, G13) & Hodotopônimo \\
\hline 106 & córrego & Ponte de Pedra (N2, N3, N4) & Hodotopônimo \\
\hline 107 & córrego da & Posse (F6, G6) & Sociotopônimo \\
\hline 108 & córrego & Potreiro (17 a J9) & Ergotopônimo \\
\hline 109 & córrego & Pulador (C18, C19) & Hidrotopônimo \\
\hline 110 & córrego & Quebra-dentinho (17, I8 a F7) & Dirrematotopônimo \\
\hline 111 & córrego & Queimadinha (C14) & Igneotopônimo \\
\hline 112 & córrego & Queimado (O8) & Igneotopônimo \\
\hline 113 & córrego & Queixada (E17) & Zootopônimo \\
\hline 114 & córrego & Rapadura (B14) & Ergotopônimo \\
\hline 115 & córrego & Retirinho $(\mathrm{H} 4)$ & Sociotopônimo \\
\hline 116 & córrego da & Roça (E17) & Sociotopônimo \\
\hline 117 & córrego do & Sal (F10, G11) & Litotopônimo \\
\hline 118 & córrego & São José (H9 a I11) & Hagiotopônimo \\
\hline 119 & córrego & São Josezinho $(H 9, \mathrm{H} 10)$ & Hagiotopônimo \\
\hline 120 & córrego & São Pedro (F11 a H13) & Hagiotopônimo \\
\hline 121 & córrego & Seco (16) & Hidrotopônimo \\
\hline 122 & córrego da & Serrinha $(\mathrm{G} 3, \mathrm{H} 3, \mathrm{H} 4)$ & Geomorfotopônimo \\
\hline
\end{tabular}


(conclusão)

\begin{tabular}{l|l|l|l}
\hline $\mathbf{N}^{\circ}$ & \multicolumn{1}{|c|}{ Acidente } & \multicolumn{1}{c}{ Topônimo } & \multicolumn{1}{c}{ Taxionomia } \\
\hline 123 & córrego & Sobra (E15 a G17) & Dimensiotopônimo \\
124 córrego & Sucuri (G10, G11) & Zootopônimo \\
125 córrego & Sucuri (M8, L9, J9) & Zootopônimo \\
126 córrego da & Taca (I3) & Ergotopônimo \\
127 córrego da & Taca (L5, M6, M7) & Ergotopônimo \\
128 córrego & Tapera (F15) & Ecotopônimo \\
129 córrego & Tatu (C17, C18) & Zootopônimo \\
130 córrego do & Tiro (C17, C18) & Ergotopônimo \\
131 córrego & Tombador (L9, L10) & Geomorfotopônimo \\
132 córrego & Três Cachoeiras (M2) & Numerotopônimo \\
133 córrego & Vauzinho (E15 a C15) & Hodotopônimo \\
134 & ribeirão & Furnas (H5 a D6) & Geomorfotopônimo \\
135 & ribeirão & Guariroba (E3 a O4) & Fitotopônimo \\
136 & ribeirão & Quebra-dentes (I7 a C8) & Dirrematotopônimo \\
137 & ribeirão & São Francisco (L6 a H14) & Hagiotopônimo \\
138 & rio & Araguaia (H15 a C20) & Zootopônimo \\
139 & rio & Diamantino (O2 a A11 a C20) & Litotopônimo \\
140 & rio & São Domingos (P4 a H15) & Hagiotopônimo \\
141 & serra do & Bálsamo (O5, O6) & Fitotopônimo \\
142 serra do & Mutum (J6, J7) & Zootopônimo \\
143 serra & Taperão (O5, O6, P6) & Ecotopônimo \\
\hline
\end{tabular}

Fonte dos dados: Mapa da Secretaria de Estado de Planejamento e Coordenação Geral do Estado de Mato Grosso (SEPLAN - MT), 1990 - escala 1:100.000. 
4.6.10.2 Relação dos acidentes humanos do município de Torixoréu, de seus topônimos e taxionomias.

\begin{tabular}{lllll}
\hline $\mathbf{N}^{\mathbf{0}}$ & \multicolumn{1}{c}{ Acidente } & \multicolumn{1}{c}{ Topônimo } & \multicolumn{1}{c}{ Taxionomia } \\
\hline 01 & cidade de & Torixoréu (E17, E18) & Geomorfotopônimo \\
02 & localidade & Diamantino (L1) & Litotopônimo \\
03 & localidade & Pouso Alto (M5) & Sociotopônimo \\
\hline
\end{tabular}

Fonte dos dados: Mapa da Secretaria de Estado de Planejamento e Coordenação Geral do Estado de Mato Grosso (SEPLAN - MT), 1990 - escala 1:100.000. 


\subsubsection{Análise toponímica da microrregião Tesouro}

Os topônimos que constam nos mapas e nas cartas topográficas dos municípios que compõem a microrregião Tesouro, registrados no corpus desta pesquisa, são estudados mais detalhadamente, na segunda parte deste capítulo. Este estudo evidencia características que distinguem ou generalizam os topônimos por município, por microrregião e, até mesmo, por taxionomia toponímica.

Elaborou-se 01 (uma) tabela e vários gráficos, como nas outras microrregiões, para subsidiar a análise toponímica. A tabela contém as taxionomias elaboradas por DICK e a inclusão de mais 01 (uma) taxionomia, contribuição desta pesquisadora, inserida na dissertação de mestrado (2005). Na microrregião Tesouro constatou-se topônimos classificados em todas taxionomias.

Os municípios foram inseridos na tabela por ordem alfabética, porém, a seqüência das taxionomias está de acordo com a quantificação numérica, por ordem decrescente. Quando não ocorre o registro de determinada taxionomia em algum município, as quadrículas que lhe são correspondentes estão preenchidas com traço.

Os 09 (nove) municípios que compõem a microrregião Tesouro estão cartografados em 19 (dezenove) cartas topográficas, na escala de 1:100.000. Para o levantamento dos topônimos utilizou-se, em caráter preliminar, 07 (sete) mapas municipais na escala de 1:100.000. Os topônimos dos municípios de Guiratinga e Poxoréu foram coletados em 13 (treze) cartas topográficas em caráter preliminar, ou seja, os topônimos foram coletados diretamente nas referidas cartas topográficas.

Dentre as microrregiões que compõem a mesorregião Sudeste Matogrossense, a microrregião Tesouro é a que está formada por maior número de municípios, e conseqüentemente, a que possui maior quantidade de topônimos.

Registram-se 1.023 (mil e vinte e três) topônimos na microrregião Tesouro. São 57 (cinqüenta e sete) topônimos no município de Araguainha, 88 (oitenta e oito) em General Carneiro, 269 (duzentos e sessenta e nove) em Guiratinga, 106 (cento e 
seis) em Pontal do Araguaia, 57 (cinqüenta e sete) em Ponte Branca, 145 (cento e quarenta e cinco) em Poxoréu, 38 (trinta e oito) em Ribeirãozinho, 117 (cento e dezessete) em Tesouro e 146 (cento e quarenta e seis) em Torixoréu.

Dentre os topônimos que dão nomes a acidentes físicos e a acidentes antrópicos na microrregião Tesouro, constatou-se que 03 (três) córregos e 01 (um) rio apresentam dupla denominação. Dupla denominação ocorre quando um acidente físico ou um acidente antrópico é registrado no mapa e/ou na carta topográfica com dois topônimos distintos intercalados pela conjunção ou. Um desses córregos consta nas relações de topônimos de dois municípios porque estabelece divisa entre eles e o rio estabelece divisa entre dois municípios de microrregiões diferentes. Não devese esquecer que os segundos topônimos estão contabilizados no total geral da microrregião Tesouro, portanto, o total de topônimos é superior ao total de acidentes.

Constam, na microrregião Tesouro, 1.023 (mil e vinte e três) topônimos que denominam 984 (novecentos e oitenta e quatro) acidentes físicos: cabeceiras, córregos, lagoa, morros, ribeirões, rios e serras. São 34 (trinta e quatro) acidentes antrópicos: colônia, distritos, localidades, vilas, terras indígenas e municípios / cidades. Deve-se observar que dentre os acidentes físicos constam 03 (três) córregos e 01 (um) rio que apresentam dupla denominação, mencionados no parágrafo anterior.

Os topônimos foram classificados por taxionomia e, com base nessas classificações, as 10 (dez) mais representativas, em valores absolutos, são: 168 (cento e sessenta e oito) zootopônimos, 141 (cento e quarenta e um) fitotopônimos, 117 (cento e dezessete) hidrotopônimos, 111 (cento e onze) litotopônimos, 79 (setenta e nove) geomorfotopônimos, 73 (setenta e três) sociotopônimos, 63 (sessenta e três) ergotopônimos, 51 (cinqüenta e um) antropotopônimos, 30 (trinta) animotopônimos e 30 (trinta) hagiotopônimos.

Para elaborar a tabela, que encontra-se a seguir, fez-se o levantamento dos sintagmas toponímicos nos mapas de 07 (sete) municípios e nas 13 (treze) cartas topográficas referentes a 02 (dois) municípios, em seguida, os topônimos foram classificados por taxionomia. Com esta tabela é possível observar a quantidade de topônimos por taxionomia, por município, por microrregião, e também, a 
representatividade de cada taxionomia em cada um dos nove municípios pesquisados.

Para desenvolver a análise toponímica, os topônimos depois de agrupados por taxionomia, foram reunidos, primeiro, por etimologia indígena e, em seguida, as taxionomias foram ordenadas nos dois grupos respectivos: taxionomias de natureza física e taxionomias de natureza antrópica. Observou-se também, o valor percentual de cada taxionomia com relação ao total de topônimos da microrregião Tesouro.

Quando ocorre o registro de topônimos em apenas 02 (dois) municípios, no caso específico da microrregião Tesouro, referentes a uma mesma taxionomia ou o montante de topônimos classificados na taxionomia for igual ou inferior a 06 (seis) não se apresenta gráfico para a taxionomia.

Na seqüência analisa-se, inicialmente, as taxionomias de natureza física, com 12 (doze) taxionomias, em um total de 681 (seiscentos e oitenta e uma) ocorrências e, em seguida, as de natureza antrópica, com 18 (dezoito) taxionomias em um total de 342 (trezentas e quarenta e duas) ocorrências. 
Tabela 4 - Topônimos da microrregião Tesouro por municípios e taxionomias.

(continua)

\begin{tabular}{|c|c|c|c|c|c|c|c|c|c|c|c|}
\hline \multirow[b]{2}{*}{$\mathrm{N}^{\mathrm{O}}$} & \multirow[b]{2}{*}{ Taxionomias } & \multicolumn{9}{|c|}{ municípios } & \multirow{2}{*}{$\begin{array}{c}\text { microrregiãc } \\
\text { Tesouro }\end{array}$} \\
\hline & & Araguainha & $\begin{array}{l}\text { General } \\
\text { Carneiro }\end{array}$ & Guiratinga & $\begin{array}{c}\text { Pontal } \\
\text { do } \\
\text { Araguaia }\end{array}$ & $\begin{array}{c}\text { Ponte } \\
\text { Branca }\end{array}$ & Poxoréu & $\begin{array}{c}\text { Ribeirão- } \\
\text { zinho }\end{array}$ & Tesouro & Torixoréu & \\
\hline & Total & 57 & 88 & 269 & 106 & 57 & 145 & 38 & 117 & 146 & 1.023 \\
\hline 01 & Zootopônimos & 8 & 10 & 35 & 25 & 8 & 27 & 9 & 15 & 31 & 168 \\
\hline 02 & Fitotopônimos & 11 & 14 & 37 & 18 & 6 & 11 & 6 & 14 & 24 & 141 \\
\hline 03 & Hidrotopônimos & 6 & 11 & 33 & 10 & 9 & 20 & 6 & 12 & 10 & 117 \\
\hline 04 & Litotopônimos & 10 & 13 & 29 & 8 & 7 & 12 & - & 13 & 19 & 111 \\
\hline 05 & Geomorfotopônimos & 2 & 9 & 26 & 8 & 4 & 6 & 4 & 10 & 10 & 79 \\
\hline 06 & Sociotopônimos & 4 & 6 & 18 & 3 & 11 & 8 & 4 & 10 & 9 & 73 \\
\hline 07 & Ergotopônimos & 3 & 7 & 25 & 5 & 2 & 4 & - & 10 & 7 & 63 \\
\hline 08 & Antropotopônimos & 5 & 4 & 20 & 4 & - & 6 & 1 & 5 & 6 & 51 \\
\hline 09 & Animotopônimos & 2 & 1 & 5 & 3 & - & 9 & 2 & 5 & 3 & 30 \\
\hline 10 & Hagiotopônimos & 1 & 1 & 3 & 5 & 2 & 8 & 2 & 3 & 5 & 30 \\
\hline 11 & Dimensiotopônimos & 1 & 5 & 4 & 2 & - & 6 & - & 1 & 4 & 23 \\
\hline 12 & Cardinotopônimos & - & 1 & 10 & 1 & 1 & 4 & - & 3 & 1 & 21 \\
\hline 13 & Hodotopônimos & 1 & 1 & 4 & 1 & 2 & 4 & 1 & 1 & 4 & 19 \\
\hline 14 & Numerotopônimos & 1 & - & 3 & - & 3 & 2 & - & 3 & 1 & 13 \\
\hline
\end{tabular}


(conclusão)

\begin{tabular}{|c|c|c|c|c|c|c|c|c|c|c|c|}
\hline \multirow[b]{2}{*}{$\mathrm{N}^{\circ}$} & \multirow[b]{2}{*}{ Taxionomias } & \multicolumn{9}{|c|}{ municípios } & \multirow{2}{*}{$\begin{array}{c}\text { microrregião } \\
\text { Tesouro }\end{array}$} \\
\hline & & Araguainha & $\begin{array}{l}\text { General } \\
\text { Carneiro }\end{array}$ & Guiratinga & \begin{tabular}{|c|}
$\begin{array}{c}\text { Pontal } \\
\text { do } \\
\text { Araguaia }\end{array}$ \\
\end{tabular} & $\begin{array}{c}\text { Ponte } \\
\text { Branca }\end{array}$ & Poxoréu & $\begin{array}{c}\text { Ribeirão- } \\
\text { zinho }\end{array}$ & Tesouro & Torixoréu & \\
\hline 15 & Hierotopônimos & - & - & - & 2 & - & 7 & 1 & 1 & 2 & 13 \\
\hline 16 & Etnotopônimos & - & - & 3 & 3 & - & 3 & - & 1 & 1 & 11 \\
\hline 17 & Somatotopônimos & 1 & 2 & 1 & 1 & - & 2 & 1 & - & 2 & 10 \\
\hline 18 & Dirrematotopônimos & - & - & 2 & 3 & - & 1 & - & - & 2 & 08 \\
\hline 19 & Astrotopônimos & - & - & 5 & - & - & - & - & 1 & - & 6 \\
\hline 20 & Cromotopônimos & 1 & - & - & - & 1 & 2 & - & 1 & - & 5 \\
\hline 21 & Igneotopônimos & - & - & - & - & - & 2 & - & - & 3 & 5 \\
\hline 22 & Cronotopônimos & - & 1 & 1 & 1 & - & - & 1 & - & - & 4 \\
\hline 23 & Ecotopônimos & - & - & - & - & 1 & - & - & 1 & 2 & 4 \\
\hline 24 & Historiotopônimos & - & - & 2 & - & - & 1 & - & 1 & - & 4 \\
\hline 25 & Morfotopônimos & - & - & 1 & 1 & - & - & - & 2 & - & 4 \\
\hline 26 & Corotopônimos & - & - & 1 & 2 & - & - & - & - & - & 3 \\
\hline 27 & Poliotopônimos & - & - & 1 & - & - & - & - & 2 & - & 3 \\
\hline 28 & Mitotopônimos & - & - & - & - & - & - & - & 2 & - & 2 \\
\hline 29 & Axiotopônimo & - & 1 & - & - & - & - & - & - & - & 1 \\
\hline 30 & Meteorotopônimo & - & 1 & - & - & - & - & - & - & - & 1 \\
\hline
\end{tabular}




\section{Taxionomias de natureza física da microrregião Tesouro}

\section{Zootopônimos}

A taxionomia zootopônimos é a que apresenta maior quantidade de topônimos na microrregião Tesouro. Nos estudos toponímicos são classificadas como zootopônimos as unidades lexicais que se referem à fauna de um modo geral, quando usadas para dar nomes a acidentes físicos e a acidentes antrópicos. São 168 (cento e sessenta e oito) zootopônimos.

São 08 (oito) zootopônimos no município de Araguainha, 10 (dez) em General Carneiro, 35 (trinta e cinco) em Guiratinga, 25 (vinte e cinco) em Pontal do Araguaia, 08 (oito) em Ponte Branca, 27 (vinte e sete) em Poxoréu, 09 (nove) em Ribeirãozinho, 15 (quinze) em Tesouro e 31 (trinta e um) em Torixoréu. É a taxionomia, nos municípios de Pontal do Araguaia, Poxoréu, Ribeirãozinho, Tesouro e Torixoréu, que mais denomina acidentes. Apresenta-se a seguir o gráfico desta taxionomia com os respectivos percentuais por município (GRÁFICO 54).

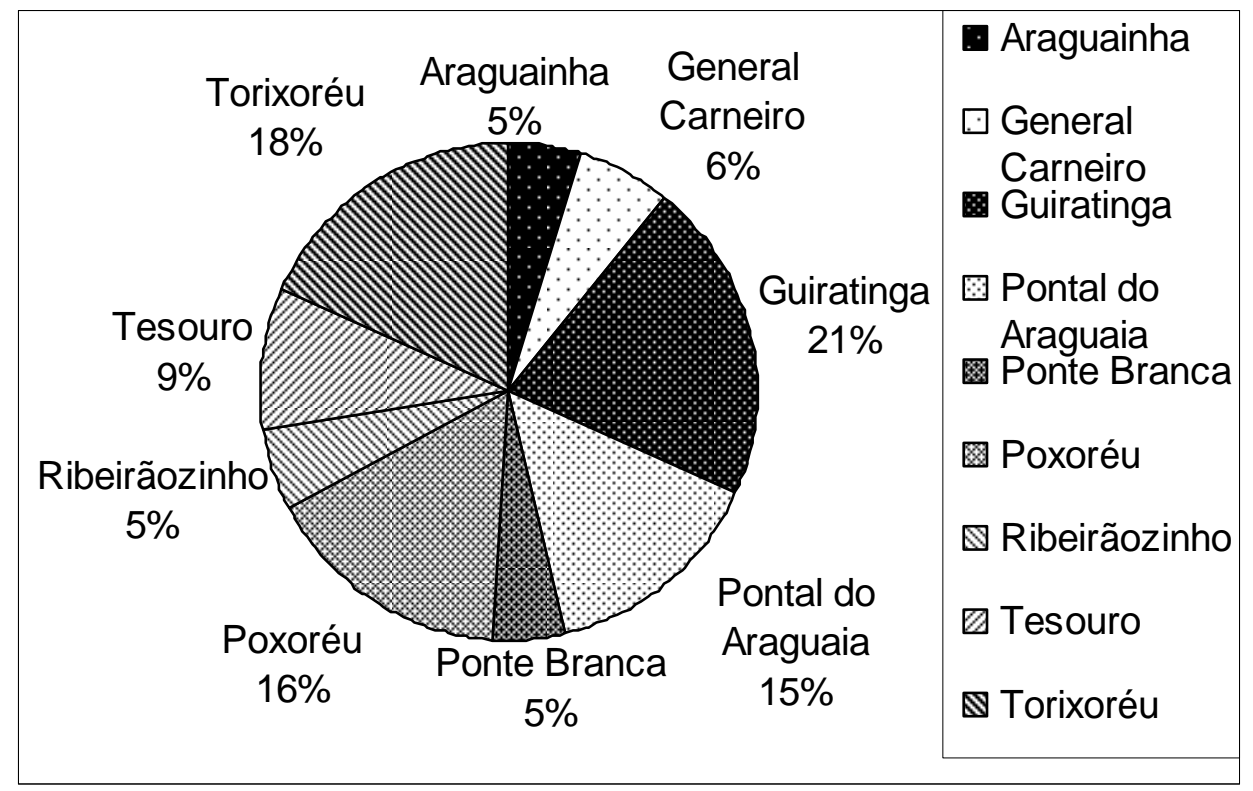

GRÁFICO 54 - Total dos zootopônimos da microrregião Tesouro. 
Do total dos zootopônimos registrados nos municípios que compõem a microrregião Tesouro somente 23 (vinte e três) se referem a animais domésticos. 0 zootopônimo Éguas denomina 01 (um) córrego no município de General Carneiro. Os zootopônimos Boi Baio, Porca e Vaca dão nomes a 04 (quatro) córregos em Guiratinga. Os zootopônimos Égua, Galinhas, Vaca e Vaca Morta dão nomes a 04 (quatro) córregos no município de Pontal do Araguaia. O zootopônimo Bois singulariza 01 (um) córrego em Ribeirãozinho. Os zootopônimos Bezerra, Boi, Cabritinha, Éguas, Gato, Marruás e Novilha nomeiam 07 (sete) córregos em Torixoréu.

Em Tesouro, o zootopônimo Tourinho nomeia 01 (um) córrego. Os zootopônimos Touro, Vaca e Vaca Morta denominam 01 (um) morro e 02 (dois) córregos no município de Poxoréu. O zootopônimo Cadela nomeia 01 (um) córrego que nasce em Guiratinga e deságua em Tesouro, por isso consta nas relações de topônimos dos dois municípios. Não houve registro de zootopônimos que se referem a animais domésticos, nos municípios de Araguainha e Ponte Branca. Os demais zootopônimos se referem a animais silvestres e evidenciam a riqueza da fauna mato-grossense.

Quanto à divisão dos zootopônimos por habitat, pode-se constatar que 25,0\% das denominações se referem a animais que vivem, a maior parte de suas vidas, no ar como, por exemplo: córrego Andorinha, córrego Beija-flor, córrego Marimbondo, ribeirão das Pombas, etc. Os zootopônimos que se referem a animais que vivem na água, como por exemplo: córrego da Lontra, córrego Jacaré, distrito Jarudore, etc, correspondem a 16,7\%. O percentual mais expressivo dos zootopônimos da microrregião Tesouro se refere a animais que vivem, a maior parte de suas vidas, em terra. São 58,3\% das denominações, como por exemplo: córrego Cadela, córrego da Ema, ribeirão da Onça, etc.

Os zootopônimos da microrregião Tesouro subdividem-se em 60 (sessenta) zootopônimos tupis, 12 (doze) zootopônimos bororos, 04 (quatro) zootopônimos africanos e 92 (noventa e dois) zootopônimos portugueses.

O município de Araguainha possui 04 (quatro) zootopônimos tupis e 04 (quatro) portugueses. O município de General Carneiro possui 03 (três) 
zootopônimos tupis, 02 (dois) bororos e 05 (cinco) portugueses. O município de Guiratinga possui 09 (nove) zootopônimos tupis, 01 (um) bororo e 25 (vinte e cinco) portugueses. O município de Pontal do Araguaia possui 10 (dez) zootopônimos tupis, 02 (dois) africanos e 13 (treze) portugueses.

O município de Ponte Branca possui 02 (dois) zootopônimos tupis e 06 (seis) portugueses. O município de Poxoréu possui 09 (nove) zootopônimos tupis, 07 (sete) bororos, 01 (um) africano e 10 (dez) portugueses. O município de Ribeirãozinho possui 07 (sete) zootopônimos tupis e 02 (dois) portugueses. O município de Tesouro possui 06 (seis) zootopônimos tupis, 01 (um) bororo e 08 (oito) portugueses. O município de Torixoréu possui 10 (dez) zootopônimos tupis, 01 (um) bororo, 01 (um) africano e 19 (dezenove) portugueses.

Considera-se, nesta pesquisa, que os zootopônimos tupis da microrregião Tesouro, quanto à estrutura, subdividem-se em simples e híbridos. São 53 (cinqüenta e três) zootopônimos de estrutura simples e 07 (sete) zootopônimos de estrutura híbrida. Eles denominam 57 (cinqüenta e sete) acidentes físicos e 03 (três) acidentes antrópicos. Os 09 (nove) municípios da microrregião Tesouro possuem zootopônimos tupis.

O zootopônimo Cutia dá nome a 01 (um) córrego no município de Araguainha. Os zootopônimos Borá e Sucuri denominam 03 (três) córregos em General Carneiro. Os zootopônimos Borá, Mutum, Piau, Pirapitanga (forma variante de piraputanga) e Sucuri toponimizam 07 (sete) córregos em Guiratinga. Os zootopônimos Ariranha, Capivara, Guaraína (forma variante de guaraúna), Jaboti, Jauru, Jia, Piau e Sucuri nomeiam 01 (uma) cabeceira, 07 (sete) córregos e 01 (um) ribeirão em Pontal do Araguaia. O zootopônimo Irara dá nome a 01 (um) córrego em Ponte Branca.

Segundo Sampaio, as unidades lexicais guaraína e jauru possuem as seguintes características: "GUARAUNA, V. Barauna. É também guará-una, a garça escura; uma Ardea, vulgo Caráo ou Caraú." e "JAURÚ, corr. yau-r-ú, os jaús comem, ou onde há jaús. Matto Grosso." (1970, p. 210; 236).

O zootopônimo Catete, Cotia (forma variante), Jaboti, Lambari, Sucuri e Urubu denominam 01 (uma) cabeceira e 06 (seis) córregos no município de 
Poxoréu. A cabeceira da Cotia estabelece divisa entre os municípios de Poxoréu e Dom Aquino, por isso consta nas relações de topônimos dos dois municípios. Os zootopônimos Borá e Quati nominam 02 (dois) córregos e 01 (uma) serra em Ribeirãozinho. O zootopônimo Jaguatirica dá nome a 01 (um) córrego e é o primeiro topônimo de 01 (um) outro córrego, ambos em Ribeirãozinho. Os zootopônimos Borá, Caçununga, Jacu e Sucuri particularizam 04 (quatro) córregos, 01 (um) distrito e 01 (um) rio em Tesouro. Os zootopônimos Jacaré, Mutum, Piau, Sucuri e Tatu nomeiam 07 (sete) córregos e 01 (uma) serra em Torixoréu.

O zootopônimo tupi Araguaia nomeia 01 (um) rio que consta nas relações de topônimos dos municípios Araguainha, Pontal do Araguaia, Ponte Branca, Ribeirãozinho e Torixoréu e estabelece divisa desses municípios com o estado de Goiás. O zootopônimo Guiratinga toponimiza 01 (um) município mato-grossense.

Segundo Sampaio, as unidades lexicais tupis araguaia e guiratinga possuem as seguintes características: "ARAGUAYA, s. c. ará-guaya, os papagaios mansos." e "GUIRATINGA, c. guirá-tinga, o pássaro branco, a garça." (1970, p. 174; 213)

O zootopônimo tupi Araguainha, formado pela unidade lexical tupi araguaia + sufixo -inha, indicador de diminutivo da língua portuguesa, denomina 01 (um) município mato-grossense e 01 (um) rio no município de Araguainha que estabelece divisa entre os municípios de Araguainha e Alto Araguaia, por isso consta nas relações de topônimos dos dois municípios. O zootopônimo Pirapitanguinha, formado pela unidade lexical tupi pirapitanga + sufixo -(u)inha, já mencionado nomina 01 (um) córrego em Guiratinga. O zootopônimo Sucurizinho, formado pela unidade lexical tupi sucuri + sufixo -(z)inho, nomeia 01 (um) córrego em Poxoréu. Os zootopônimos Araras, Iraras e Pacas apresentam o acréscimo de -s, indicador de plural na língua portuguesa às unidades lexicais tupis arara, irara e paca e dão nomes a, respectivamente, 01 (uma) serra em Poxoréu, a 01 (um) córrego em Ribeirãozinho e a 01 (um) córrego em Torixoréu.

Considera-se também, nesta pesquisa, que os zootopônimos bororos possuem estrutura simples. Os zootopônimos Jarudore e Piobogue denominam, respectivamente, 01 (um) distrito, 01 (um) morro, 01 (uma) terra indígena e 01 (um) córrego no município de Poxoréu. O zootopônimo Rocoeial denomina 01 (um) 
córrego que estabelece divisa entre os municípios de Tesouro e General Carneiro, por isso consta nas relações de topônimos dos dois municípios. É o primeiro topônimo desse córrego que possui dupla denominação. O zootopônimo Coqueial é o segundo topônimo de 01 (um) rio e esse rio estabelece divisa entre os municípios de Poxoréu e Rondonópolis, por isso consta nas relações de topônimos dos dois municípios. Deve-se ressaltar que, os vocábulos coqueial e rocoeial são formas variantes.

As unidades lexicais jarudore, piobogue coqueial / rocoeial estão registradas na Enciclopédia Bororo.

\begin{abstract}
Jarudóri - * jarudo, bagre; rí, morro [morro do bagre]. Grande rocha na margem esq. do Pogúbo, rio Vermelho a montante de Rondonópolis. Jarudore I É uma localidade muito apreciada pelos bororo pela abundância de pesca e caça e pela proximidade de extensas matas. Albisetti; Venturelli (1962, p. 686).
\end{abstract}

Ipíe Baga - * ipíe, ariranha; bága, córrego [cór. da ariranha]. Desingação: 1. de um cór. afl. da dir. do Arároe E-iao ${ }_{1}$, cór Arareau: cór Piebaga 2. de um cór. afl. da dir. do c. $\mathrm{m}$. do Pogúbo, $r$. Vermelho: cór Ipieboga. Albisetti; Venturelli (1962, p. 643).

Okóge E-iáo - * okóge, dourados; e, (d)êles; iáo, localidade [cór. dos dourados]. Designação: 1. de um cór. afl. do c. m. do Pogúbo, r. Vermelho: rib. Areia ou Floriano ou Coqueiau; 2. de um cór. afl. da esq. do Biagaréu, cór. Biagaréu: cór. Kogueau. Albisetti; Venturelli (1962, p. 831).

O zootopônimo Meruri dá nome a 01 (uma) terra indígena no município de General Carneiro. O zootopônimo Poruba denomina 01 (um) córrego em Poxoréu. O zootopônimo Aquidorobó nomeia 01 (um) córrego em Poxoréu.

As unidades lexicais meruri e poruba estão registradas na Enciclopédia Bororo: "Meruri - * méru 1 , raia; rí1, morro [morro da raia]." e "Porubí - * póru, jaú; bí 1 , morte [r. do jaú morto]. R. afl. da esq. do curso médio do Pó Ceréu: r. Porube Aidjau.)." Albisetti; Venturelli (1962, p. 797; 886). A unidade lexical aquidorobo está registrada na Enciclopédia Bororo: "Kudóro - vart. Kudóra pl. Kudorae * ? Designação: 1. da araraúna. (Psittace hyacinthina). $\mathbf{B o}_{3}$ - son. de pó e ders. Água. Pó - Água, curso d'água, rio." Albisetti; Venturelli (1962, p. 749; 278) 
O zootopônimo bororo Caicai dá nome a 01 (um) córrego no município de Guiratinga e sua forma variante o zootopônimo Cai-cai nomeia 01 (um) córrego em Torixoréu.

A unidade lexical Caicai está registrada na Enciclopédia Bororo: "Kaikái - * ? F. onom. [ave que cantando faz kaikái]. Vard de coruja." Albisetti; Venturelli (1962, p. 704).

Considera-se, nesta pesquisa, que os zootopônimos africanos possuem estrutura simples. O zootopônimo Marimbondo nomeia 02 (dois) córregos no município de Pontal do Araguaia. O zootopônimo Calango dá nome a 01 (um) córrego em Poxoréu. O zootopônimo Caxixe denomina 01 (um) córrego em Torixoréu.

Considera-se, nesta pesquisa, que os zootopônimos portugueses da microrregião Tesouro, quanto à estrutura, subdividem-se em simples e compostos. São 87 (oitenta e sete) zootopônimos de estrutura simples e 05 (cinco) zootopônimos de estrutura composta. Eles denominam 92 (noventa e dois) acidentes físicos. Os 09 (nove) municípios da microrregião Tesouro possuem zootopônimos portugueses.

Os zootopônimos compostos Boi Baio e Vaca Morta, formados por substantivo + adjetivo, dão nomes a 01 (um) córrego no município de Guiratinga, a 01 (um) córrego em Pontal do Araguaia e a 01 (um) córrego em Poxoréu. Os zootopônimos compostos Caga-fogo e Beija-flor denominam, respectivamente, 01 (um) córrego em Pontal do Araguaia e 01 (um) córrego em General Carneiro.

Os zootopônimos portugueses de estrutura simples subdividem-se em não derivados e derivados. No município de Araguainha, o zootopônimo Veado nomeia 01 (um) córrego e o zootopônimo Marreco dá nome a 01 (um) córrego que estabelece divisa de Araguainha com Ponte Branca, por isso consta nas relações de topônimos dos dois municípios. Em General Carneiro, o zootopônimo Cervo particulariza 01 (um) córrego. Em Guiratinga, os zootopônimos Abelha, Andorinha, Anta, Cascavel, Cobra, Formiga, Peixe, Porca e Vaca nomeiam 09 (nove) córregos e 01 (um) ribeirão. O zootopônimo Cadela dá nome a 01 (um) córrego que nasce no 
município de Guiratinga e deságua em Tesouro, o zootopônimo Onça nomina 01 (um) ribeirão que estabelece divisa entre Guiratinga e Alto Garças, por isso ambos constam nas relações de topônimos dos referidos municípios.

Os zootopônimos Cervo, Égua, Onça, Vaca e Veado dão nomes a 06 (seis) córregos no município de Pontal do Araguaia. Em Ponte Branca, os zootopônimos Cascavel, Cervo e Marreco denominam 03 (três) córregos e 01 (uma) serra. Em Poxoréu, os zootopônimos Anta, Cervo, Ema, Macaco, Onça, Peixe, Touro e Vaca singularizam 05 (cinco) córregos, 01 (uma) lagoa, 01 (um) morro e 01 (um) rio. Em Ribeirãozinho, o zootopônimo Peixe nomina 01 (um) córrego. Em Torixoréu, os zootopônimos Arraia, Bezerra, Boi, Gato, Lontra, Novilha e Onça denominam 08 (oito) córregos

O zootopônimo Marruás dá nome a 01 (um) córrego no município de Torixoréu e é considerado, neste estudo, topônimo de estrutura simples e sem desinência -s de plural, porque a unidade lexical marruás é forma variante de marruá, nos dicionários de língua geral Houaiss e Aurélio.

Dentre os zootopônimos simples e sem derivação constam ainda os que apresentam desinência -s de plural. Os zootopônimos Éguas e Macacos nomeiam 01 (um) córrego e 01 (um) ribeirão no município de General Carneiro. Os zootopônimos Antas, Cobras e Galinhas denominam 03 (três) córregos em Pontal do Araguaia. O zootopônimo Pombas particulariza 01 (um) ribeirão em Poxoréu. Esse ribeirão estabelece divisa entre os municípios de Poxoréu e Dom Aquino, por isso consta nas relações de topônimos dos dois municípios. O zootopônimo Bois dá nome 01 (um) córrego em Ribeirãozinho. O zootopônimo Éguas nomina 01 (um) córrego em Torixoréu. O zootopônimo Garças dá nome a 01 (um) rio que consta nas relações de topônimos dos municípios General Carneiro, Guiratinga, Pontal do Araguaia e Tesouro, porque estabelece divisa nesses municípios.

Alguns zootopônimos de estrutura simples apresentam derivação. Os zootopônimos Antinha e Tourinho, formados pelas unidades lexicais anta e touro + sufixo -inho/a, indicador de diminutivo, nomeiam 01 (um) córrego em Torixoréu, 03 (três) córregos em Tesouro e 01 (um) córrego que divide Ponte Branca e Torixoréu, por isso consta nas relações de topônimos dos dois municípios. O zootopônimo 
Cobrinhas, formado pela unidade lexical cobra + sufixo -inha, já referido, apresenta desinência de plural -s e singulariza 01 (um) córrego em Guiratinga. O zootopônimo Mosquito, formado pela unidade lexical mosca + sufixo -(qu)ito, indicador de diminutivo, dá nome a 01 (um) córrego e a 01 (um) ribeirão em Guiratinga.

Os zootopônimos Campeira, Galheiro e Mateiro, formados pelas unidades lexicais campo, galho e mato + sufixo -eiro/a, indicador de quantidade ou origem, nomeiam 03 (três) córregos em Guiratinga, 01 (um) córrego em Pontal do Araguaia, 01 (um) córrego em Tesouro e 04 (quatro) córregos em Torixoréu. O zootopônimo Queixada, formado pela unidade lexical queixo + sufixo -ada, indicador de grandeza ou extensão, é o primeiro topônimo de 01 (um) córrego em Guiratinga, e também, denomina outros 02 (dois) córregos em Guiratinga, 01 (um) córrego em Tesouro 01 (um) córrego em Torixoréu e 01 (um) córrego em Araguainha que estabelece divisa entre Araguainha e Alto Garças, por isso consta nas relações de topônimos dos dois municípios.

Os zootopônimos Galheirinho e Mateirinho apresentam dupla sufixação, formados pelas unidades lexicais galho e mato + sufixo -eiro + sufixo -inho, já mencionados, denominam, respectivamente, 01 (um) córrego em Torixoréu e 01 (um) córrego em Guiratinga. O zootopônimo Cabritinha, formado pela unidade lexical cabra + sufixos indicadores de diminutivo -ita e -inha, dá nome a 01 (um) córrego em Torixoréu. O zootopônimo Avoadeira e sua forma variante regional Avuadeira, formados pela unidade lexical avoar + sufixo -ado, já mencionado + sufixo -eira, indicador de ação, nomeiam 01 (um) córrego em Araguainha, 01 (um) córrego que nasce em Guiratinga e deságua em Tesouro, por isso consta nas relações de topônimos dos dois municípios.

Os zootopônimos da microrregião Tesouro possuem bons índices de produtividade toponímica.

O zootopônimo Borá nomeia 01 (um) córrego em General Carneiro, 01 (um) córrego em Guiratinga, 01 (um) córrego em Ribeirãozinho e outro córrego em Tesouro. O zootopônimo Caçununga dá nome a 01 (um) distrito e a 01 (um) rio, ambos em Tesouro. O zootopônimo Araguainha nomeia 01 (um) rio que estabelece 
divisa entre os municípios de Araguainha e Alto Araguaia e 01 (um) município matogrossense.

O zootopônimo Capivara denomina 01 (um) córrego e 01 (um) ribeirão no município de Pontal do Araguaia. O zootopônimo Jaboti nomeia 01 (um) córrego em Pontal do Araguaia e outro em Poxoréu. O zootopônimo Jaguatirica denomina 02 (dois) córregos em Ribeirãozinho. O zootopônimo Mutum denomina 01 (um) córrego no município de Guiratinga, 02 (dois) córregos e 01 (uma) serra em Torixoréu. O zootopônimo Quati denomina 01 (um) córrego e 01 (uma) serra em Ribeirãozinho.

O zootopônimo Piau toponimiza 02 (dois) córregos no município de Guiratinga, 01 (um) córrego em Pontal do Araguaia e outro em Torixoréu. Pode-se ainda considerar produtivo o zootopônimo Pirapitanga que singulariza 01 (um) córrego e o zootopônimo Pirapitanguinha que nomeia outro córrego, ambos em Guiratinga. O zootopônimo Irara nomeia 01 (um) córrego em Ponte Branca e o zootopônimo Iraras denomina 01 (um) córrego em Ribeirãozinho.

O zootopônimo Cutia singulariza 01 (um) córrego no município de Araguainha e o zootopônimo Cotia (forma variante) denomina 01 (uma) cabeceira em Poxoréu. O zootopônimo Sucuri denomina 02 (dois) córregos em Poxoréu, 02 (dois) córregos em Guiratinga, 02 (dois) córregos em Torixoréu, 02 (dois) córregos em Tesouro, 02 (dois) córregos em General Carneiro e 01 (um) córrego em Pontal do Araguaia. O zootopônimo Sucurizinho particulariza 01 (um) córrego em Poxoréu.

O zootopônimo Caicai dá nome a 01 (um) córrego no município de Guiratinga e o zootopônimo Cai-cai nomeia 01 (um) córrego em Torixoréu. O zootopônimo Jarudore particulariza 01 (um) distrito, 01 (um) morro e 01 (uma) terra indígena em Poxoréu. O zootopônimo Rocoeial dá nome a 01 (um) córrego que estabelece divisa entre os municípios de General Carneiro e Tesouro, o zootopônimo Coqueial é o segundo topônimo de 01 (um) rio que estabelece divisa entre os municípios de Poxoréu e Rondonópolis e, nesta pesquisa, são considerados forma variante.

O zootopônimo Marimbondo denomina 02 (dois) córregos em Pontal do Araguaia. 
O zootopônimo Anta apresenta, neste estudo, uma singularidade. Está precedido pela contração da preposição da. A preposição apresenta-se sob duas formas: d' e D'. Desse modo os zootopônimos d'Anta e D'Anta mostram-se produtivos e pode-se ainda acrescentar o zootopônimo D'Antas porque denominam, respectivamente, 01 (um) córrego no município de Guiratinga, 01 (um) córrego em Poxoréu e 01 (um) córrego em Pontal do Araguaia.

O zootopônimo Boi nomeia 01 (um) córrego no município de Torixoréu e o zootopônimo Bois designa 01 (um) córrego em Ribeirãozinho, pode ainda acrescentar o zootopônimo Boi Baio que denomina 01 (um) córrego em Guiratinga. O zootopônimo Antinha denomina 01 (um) córrego em Ponte Branca que estabelece divisa com Torixoréu, 01 (um) córrego em Torixoréu e 02 (dois) córregos em Tesouro. O zootopônimo Avoadeira e sua forma variante Avuadeira dão nomes a 01 (um) córrego em Araguainha e a 01 (um) córrego que nasce em Guiratinga e deságua em Tesouro.

O zootopônimo Campeira dá nome a 01 (um) córrego em Pontal do Araguaia e a outro em Torixoréu. O zootopônimo Cascavel denomina 01 (um) ribeirão em Guiratinga e 01 (um) córrego em Ponte Branca. O zootopônimo Cervo particulariza 01 (uma) lagoa em Poxoréu, 01 (um) córrego em Ponte Branca, 01 (um) córrego em Pontal do Araguaia e 01 (um) córrego em General Carneiro. O zootopônimo Lontra nomeia 02 (dois) córregos no município de Torixoréu.

O zootopônimo Cobra dá nome a 01 (um) córrego no município de Guiratinga, o zootopônimo Cobras nomeia 01 (um) córrego em Pontal do Araguaia e, pode-se ainda considerar, o zootopônimo Cobrinhas que nomina 01 (um) córrego em Guiratinga. O zootopônimo Égua denomina 01 (um) córrego em Pontal do Araguaia. O zootopônimo Éguas dá nome a 01 (um) córrego em General Carneiro e a outro em Torixoréu. O zootopônimo Galheiro particulariza 03 (três) córregos no município de Torixoréu, 02 (dois) córregos em Guiratinga, 01 (um) córrego em Tesouro e pode-se ainda considerar o zootopônimo Galheirinho que dá nome a 01 (um) córrego em Torixoréu.

O zootopônimo Marreco nomeia 01 (um) córrego que estabelece divisa entre Araguainha e Ponte Branca e dá nome a outro córrego e a 01 (uma) serra em Ponte 
Branca. O zootopônimo Mosquito particulariza 01 (um) córrego e 01 (um) ribeirão em Guiratinga. Pode-se ainda considerar o zootopônimo Macaco que dá nome a 01 (um) córrego em Poxoréu e o zootopônimo Macacos que denomina 01 (um) ribeirão em General Carneiro. O zootopônimo Mateiro que dá nome a 01 (um) córrego e o zootopônimo Mateirinho que toponimiza 01 (um) córrego, ambos em Guiratinga.

O zootopônimo Onça nomeia 01 (um) córrego no município de Poxoréu, 01 (um) córrego em Torixoréu, 02 (dois) córregos em Pontal do Araguaia e 01 (um) ribeirão em Guiratinga que estabelece divisa entre Guiratinga e Alto Garças. O zootopônimo Queixada dá nome a 03 (três) córregos em Guiratinga, a 01 (um) córrego em Tesouro, a 01 (um) córrego em Torixoréu e a 01 (um) córrego em Araguainha que estabelece divisa entre Araguainha e Alto Garças.

O zootopônimo Vaca nomeia 01 (um) córrego no município de Poxoréu, 02 (dois) córregos em Guiratinga, 01 (um) córrego em Pontal do Araguaia. O zootopônimo Vaca Morta dá nome a 01 (um) córrego em Poxoréu e a outro em Pontal do Araguaia. O zootopônimo Veado toponimiza 01 (um) córrego em Araguainha e 01 (um) córrego em Pontal do Araguaia. O zootopônimo Peixe denomina 01 (um) córrego em Guiratinga, 01 (um) rio em Poxoréu e 01 (um) córrego em Ribeirãozinho. O zootopônimo Touro nomeia 01 (um) morro em Poxoréu e o zootopônimo Tourinho denomina 01 (um) córrego em Tesouro.

Os zootopônimos Araguaia e Garças constam nas relações de topônimos de vários municípios, mas não são considerados produtivos. O rio Araguaia estabelece divisa dos municípios Araguainha, Pontal do Araguaia, Ponte Branca, Ribeirãozinho e Torixoréu com o estado de Goiás. O rio das Garças estabelece divisa nos municípios de General Carneiro, Guiratinga, Pontal do Araguaia e Tesouro. O zootopônimo Cadela denomina 01 (um) córrego que nasce no município de Guiratinga e deságua em Tesouro.

Os zootopônimos correspondem a $16,4 \%$ do total de topônimos da microrregião Tesouro. 
As unidades lexicais que se referem a espécies da flora, quando utilizadas para dar nomes a acidentes físicos e a acidentes antrópicos, são classificadas, nos estudos toponímicos, como fitotopônimos. Classificam-se, nesta taxionomia, 141 (cento e quarenta e um) topônimos.

São 11 (onze) fitotopônimos no município de Araguainha, 14 (quatorze) em General Carneiro, 37 (trinta e sete) em Guiratinga, 18 (dezoito) em Pontal do Araguaia, 06 (seis) em Ponte Branca, 11 (onze) em Poxoréu, 06 (seis) em Ribeirãozinho, 14 (quatorze) em Tesouro e 24 (vinte e quatro) em Torixoréu. É a taxionomia que mais registra topônimos nos municípios de Araguainha, General Carneiro e Guiratinga. Apresenta-se a seguir o gráfico desta taxionomia com os respectivos percentuais por município (GRÁFICO 55).

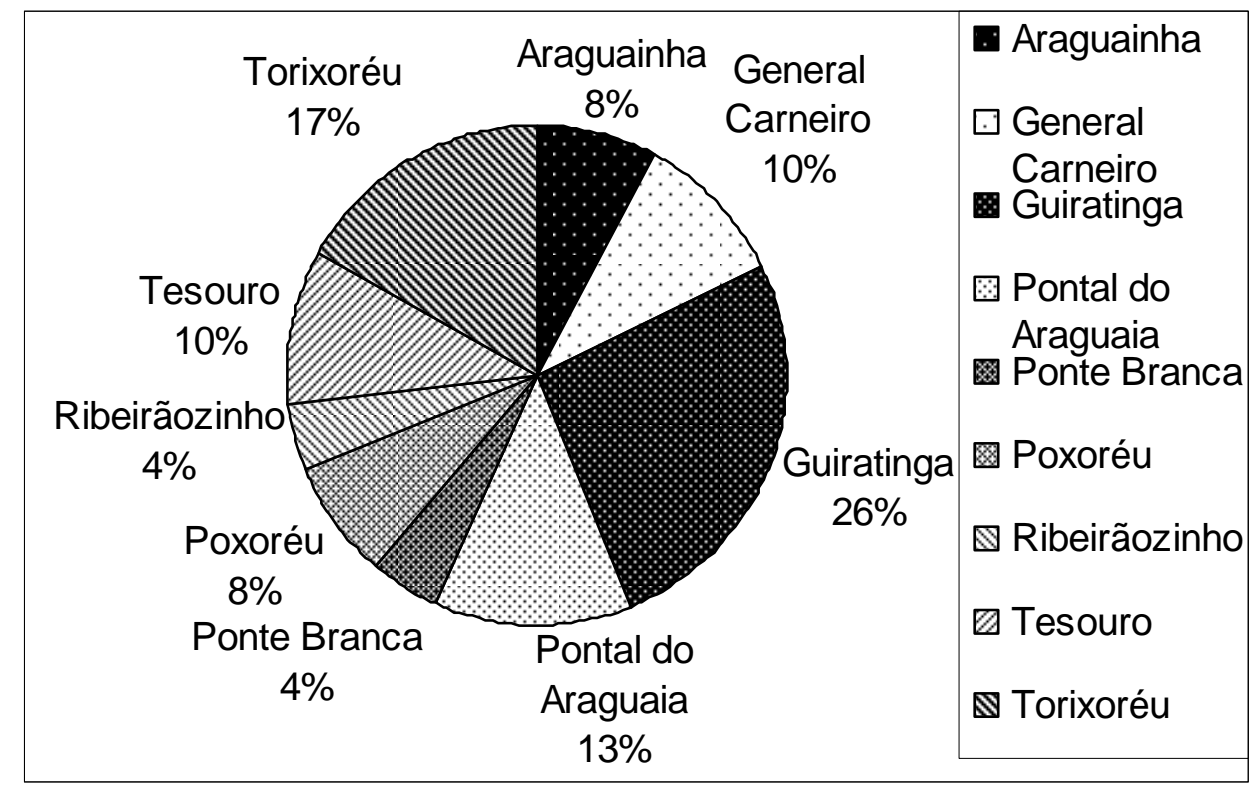

GRÁFICO 55 - Total dos fitotopônimos da microrregião Tesouro.

Ao observar as relações dos fitotopônimos da microrregião Tesouro pode-se constatar a influência das palmáceas na denominação de acidentes físicos. Os fitotopônimos, de acordo com a formação vegetal, podem ser classificados em três grandes grupos. Os fitotopônimos que se referem a exemplares de uma mesma espécie ou coletivos, são os menos representativos e correspondem a 8,5\%: Buritizal, Cabaças, Cafezal, Cocal, Goiabal. Os fitotopônimos que se referem a mais de um exemplar por espécie, como por exemplo, Capão Verde, Campo Alto, Cerradão, Mata Redonda, Moitinha, Pindaibão correspondem a 29,1\%. Ocorrem ainda os fitotopônimos que se referem a apenas um exemplar por espécie, como por 
exemplo: Arnica, Bacuri, Baunilha, Buriti, Guariroba, Jatobá e representam $62,4 \%$ do total dos fitotopônimos.

Constam, na microrregião Tesouro, 76 (setenta e seis) fitotopônimos tupis, 06 (seis) bororos e 59 (cinqüenta e nove) portugueses.

O município de Araguainha possui 05 (cinco) fitotopônimos tupis e 06 (seis) portugueses. General Carneiro possui 07 (sete) fitotopônimos tupis, 03 (três) bororos e 04 (quatro) portugueses. Guiratinga possui 28 (vinte e oito) fitotopônimos tupis e 09 (nove) portugueses. Pontal do Araguaia possui 09 (nove) fitotopônimos tupis e 09 (nove) portugueses. Ponte Branca possui 01 (um) fitotopônimo tupi e 05 (cinco) portugueses. Poxoréu possui 07 (sete) fitotopônimos tupis e 04 (quatro) portugueses. Ribeirãozinho possui 02 (dois) fitotopônimos tupis e 04 (quatro) portugueses. Tesouro possui 07 (sete) fitotopônimos tupis, 03 (três) bororos e 04 (quatro) portugueses. Torixoréu possui 10 (dez) fitotopônimos tupis e 14 (quatorze) portugueses.

São 141 (cento e quarenta e um) fitotopônimos registrados na microrregião Tesouro, deste total verifica-se que 53,9\% equivalente a 76 (setenta e seis) ocorrências em número absoluto, são de etimologia tupi, 4,3\% equivalente a 06 (seis) ocorrências são de etimologia bororo e 41,8\% equivalente a 59 (cinqüenta e nove) ocorrências são portugueses.

Considera-se, nesta pesquisa, que os fitotopônimos tupis da microrregião Tesouro, quanto à estrutura, subdividem-se em simples e híbridos. São 42 (quarenta e dois) fitotopônimos de estrutura simples e 34 (trinta e quatro) fitotopônimos de estrutura híbrida. Eles denominam 74 (setenta e quatro) acidentes físicos e 02 (dois) acidentes antrópicos. Os 09 (nove) municípios da microrregião Tesouro possuem fitotopônimos tupis.

Os fitotopônimos tupis de estrutura simples, na microrregião Tesouro, apresentam a seguinte distribuição. No município de Araguainha, os fitotopônimos Buriti e Capoeira dão nomes a 01 (uma) localidade e a 02 (dois) córregos. Em General Carneiro, os fitotopônimos Buritirana, Jatobá, Landi e Samambaia denominam 03 (três) córregos e 01 (um) ribeirão. Em Guiratinga, os fitotopônimos 
Buriti, Cambaúva, Guariroba, Jatobá, Jenipapo, Membeca, Mumbeca (forma variante), Pindaíba, Samambaia, Taboca e Tarumã nomeiam 01 (uma) localidade, 01 (um) ribeirão e 12 (doze) córregos.

No município de Pontal do Araguaia, os fitotopônimos Buritirana, Cajá, Cambaúva e Capoeira particularizam 04 (quatro) córregos. Em Ponte Branca, não há registro de fitotopônimo tupi de estrutura simples. Em Poxoréu, os fitotopônimos Babaçu, Buritirana, Coité, Jatobá e Mangaba singularizam 02 (duas) cabeceiras, 03 (três) córregos e 01 (um) rio. Em Ribeirãozinho, o fitotopônimo Bacuri é o segundo topônimo de 01 (um) córrego. Em Tesouro, os fitotopônimos Buriti, Buritirana, Cambaúva, Jatobá e Pitangi denominam 05 (cinco) córregos e 01 (um) ribeirão. Em Torixoréu, os fitotopônimos Buritirana, Cambaúva e Guariroba nomeiam 03 (três) córregos e 01 (um) ribeirão.

Segundo Sampaio, a unidade lexical tupi pitangi possui as seguintes características: "PITANGUY, s. c. pitang-y, o rio das pitangas. Minas Gerais." (1970, p.268).

Os fitotopônimos tupis híbridos Buritizal, Goiabal e Pindaibal, formados pelas unidades lexicais tupis buriti, goiaba e pindaíba + sufixo -(z)al indicador de coletivo da língua portuguesa, dão nomes a 01 (um) córrego no município de Araguainha, 01 (um) córrego em General Carneiro, 03 (três) córregos em Guiratinga, 01 (um) córrego em Pontal do Araguaia, 01 (um) córrego em Ponte Branca, 01 (uma) cabeceira em Poxoréu, 01 (um) córrego em Ribeirãozinho e 01 (um) córrego em Torixoréu.

Os fitotopônimos Buritizinho, Jatobazinho, Pindaibinha e Tarumãzinho, formados pelas unidades lexicais tupis buriti, jatobá, pindaíba e tarumã + sufixo (z)inho/a indicador de diminutivo da língua portuguesa, nomeiam 01 (um) córrego no município de Araguainha, 01 (um) córrego em General Carneiro, 05 (cinco) córregos em Guiratinga, 01 (um) córrego em Pontal do Araguaia e 02 (dois) córregos em Torixoréu.

O fitotopônimo Mangabeira, formado pela unidade lexical tupi mangaba + sufixo -eira indicador de coletivo ou o que produz da língua portuguesa, denomina 
01 (um) córrego no município de Guiratinga e 01 (um) córrego em Pontal do Araguaia. O fitotopônimo Pindaibão, formado pela unidade lexical tupi pindaíba + sufixo -ão indicador de aumentativo da língua portuguesa, singulariza 01 (um) córrego em General Carneiro, 04 (quatro) córregos no município de Guiratinga, 01 (um) córrego em Pontal do Araguaia, 01 (um) córrego em Tesouro e 01 (um) córrego em Torixoréu.

Os fitotopônimos tupis híbridos Buriti Alegre, Capão Redondo, Capão Verde e Capim Branco, formados por unidade lexical tupi + unidade lexical portuguesa, dão nomes a 01 (um) córrego no município Pontal do Araguaia, a 01 (um) córrego em Guiratinga e a 02 (dois) córregos em Torixoréu.

Considera-se, nesta pesquisa, que os fitotopônimos bororos possuem estrutura simples. Os fitotopônimos Butuie e Jeriguiga dão nomes a 02 (dois) córregos no município de General Carneiro. O fitotopônimo Ariraiau é o segundo topônimo de 01 (um) córrego que estabelece divisa entre General Carneiro e Tesouro, por isso consta nas relações de topônimos de ambos. O fitotopônimo Batovi denomina 01 (um) distrito e 01 (um) rio no município de Tesouro.

As unidades lexicais ariraiau, batovi e jeriguiga estão registradas na Enciclopédia Bororo: "Ari I J’áo Páru - * ari i, figueira; ji, sua; iáo, localidade; páru, foz [foz do cór da figueira]. Cór. afl. da esq. do c. m. do Jakoréuge E-iáo, r. das Garças e sua foz: cór Ariraiau." Albisetti; Venturelli (1962, p. 99), "Báto i - * báto, mangaba; í, árvore [árvore da mangaba]. Mangabeira. (Hancornia speciosa)." e "Jerigiga - * ji, sua; erigiga, cerne [cor. do cerne]. Cor. afl. da dir. do Kujibo Pó Rururéu, rib. Barreiro, perto da colônia indígena do Merúri Boróro." Albisetti; Venturelli (1962, p.266; 688)".

A unidade lexical butuie está registrada na Enciclopédia Bororo:

Butuie - * ? pl. butúie-dóge. Designação: 1. de uma vard. de taquarinha (Chuschea ramosissima) usada na confecção de certas flechas ou da ponta das mesmas. 2. de um tipo de túgo, flecha; 3. de um cór. afl. da direita do c. s. do Kujibo Pó Rururéu, rib. Barreiro. 4. de 1 cór. afl. da dir. do c. i. do Jakobéuge-E-iáo, rio das Garças: cór. Botuiê. Albisetti; Venturelli (1962, p. 532). 
Considera-se, nesta pesquisa, que os fitotopônimos portugueses da microrregião Tesouro, quanto à estrutura, subdividem-se em simples e compostos. São 55 (cinqüenta e cinco) fitotopônimos de estrutura simples e 04 (quatro) fitotopônimos de estrutura composta. Eles denominam 59 (cinqüenta e nove) acidentes físicos. Os 09 (nove) municípios da microrregião Tesouro possuem fitotopônimos portugueses.

Os fitotopônimos compostos Campo Alegre, Campo Alto e Mata Redonda, formados por substantivo comum + adjetivo, nomeiam 02 (dois) córregos no município de Ponte Branca e 01 (um) córrego em Ribeirãozinho. O fitotopônimo composto Mata da Onça, formado por substantivo comum + conectivo + substantivo comum, dá nome a 01 (um) córrego em Tesouro.

Os fitotopônimos Aroeirinha, Cafezinho, Matinha e Moitinha, formados pelas unidades lexicais aroeira, café, mata e moita + sufixo -(z)inho/a, indicador de diminutivo, nomeiam 01 (um) córrego no município de Araguainha, 01 (um) córrego em General Carneiro, 03 (três) córregos em Guiratinga, 01 (um) córrego em Poxoréu e 01 (um) córrego em Torixoréu. Os fitotopônimos Cafezal e Cocal, formados pelas unidades lexicais café e coco + sufixo -(z)al, indicador de coletivo, denominam 01 (um) córrego em Guiratinga e 01 (um) córrego em Ribeirãozinho. O fitotopônimo Cardão, formado pela unidade lexical cardo + sufixo -ão, indicador de aumentativo, dá nome a 01 (um) córrego no município de Torixoréu.

Os fitotopônimos Figueira, Laranjeira, Limeira, Limoeiro, Palmeira e Tronqueira, formados pelas unidades lexicais figo, laranja, lima, limão, palma e tronco + sufixo -(gu / qu)eiro/a, formador de coletivo ou o que produz, dão nomes a 03 (três) córregos no município de Pontal do Araguaia, a 02 (dois) córregos em Poxoréu e a 01 (um) córrego que estabelece divisa entre os municípios de Pontal do Araguaia e Guiratinga, por isso consta nas relações de topônimos dos dois municípios. O fitotopônimo Encascado, formado pelo prefixo en-, indicador de movimento para dentro + unidade lexical casca + sufixo -ado, quantidade, porção ou grandeza ou extensão, nomeia 01 (um) córrego em Torixoréu.

Alguns fitotopônimos apresentam dupla sufixação. O fitotopônimo Cerradão, formado pela unidade lexical cerrar + sufixo -ado + sufixo -ão, já mencionados, 
particulariza 01 (um) córrego em Torixoréu. O fitotopônimo Encascadinho, formado pelo prefixo en-, já mencionado + unidade lexical cascar + sufixos -ado e -inho, já mencionados, nomeia 01 (um) córrego em Torixoréu.

Os fitotopônimos simples e sem derivação Arnica, Baunilha e Café denominam 02 (duas) serras, 02 (dois) córregos e 01 (um) ribeirão no município de Araguainha. O ribeirão Café e a serra do Café estabelecem divisa entre os municípios de Araguainha e Alto Garças, por isso constam nas relações de topônimos dos dois municípios. Os fitotopônimos Café, Cedro e Limão dão nomes a 01 (uma) cabeceira e a 02 (dois) córregos em General Carneiro. Os fitotopônimos Arnica e Melancia toponimizam 01 (um) morro e 02 (dois) córregos em Guiratinga. 0 fitotopônimo Limão nomina 01 (um) córrego que estabelece divisa entre os municípios de Pontal do Araguaia e Guiratinga, por isso consta nas relações de topônimos dos dois municípios.

Os fitotopônimos Baunilha, Mata e Mato nomeiam 03 (três) córregos no município de Pontal do Araguaia. Os fitotopônimos Mato e Raiz nominam 02 (dois) córregos em Ponte Branca. O fitotopônimo Mangue dá nome a 01 (um) córrego que estabelece divisa entre Ponte Branca e Ribeirãozinho, por isso consta nas relações de topônimos dos dois municípios. O fitotopônimo Mata particulariza 01 (um) córrego em Poxoréu. O fitotopônimo Mato singulariza 01 (um) córrego em Ribeirãozinho. Os fitotopônimos Aroeira, Mangue e Manjerona denominam 03 (três) córregos em Tesouro. Os fitotopônimos Aroeira, Bálsamo, Floresta, Mangue e Mato toponimizam 07 (sete) córregos e 01 (uma) serra em Torixoréu.

Os fitotopônimos Cabaças e Palhas apresentam desinência de plural -s, o primeiro singulariza 01 (um) córrego em Torixoréu e o segundo dá nome a 01 (um) córrego em Pontal do Araguaia.

Pode-se observar que a taxionomia fitotopônimos apresenta, na microrregião Tesouro, bom índice de produtividade toponímica.

O fitotopônimo Buriti dá nome a 01 (uma) localidade e a 01 (um) córrego no município de Araguainha, a 01 (um) córrego em Tesouro, a 01 (um) córrego e a 01 (uma) localidade em Guiratinga. Pode-se acrescentar ainda o fitotopônimo Buriti 
Alegre que singulariza 01 (um) córrego em Pontal do Araguaia. O fitotopônimo Buritirana nomeia 01 (um) córrego em General Carneiro, 01 (um) córrego em Pontal do Araguaia, 01 (uma) cabeceira em Poxoréu, 02 (dois) córregos em Tesouro e 01 (um) córrego em Torixoréu. O fitotopônimo Buritizinho toponimiza 01 (um) córrego em Araguainha, 01 (um) córrego em Pontal do Araguaia, 02 (dois) córregos em Guiratinga e 01 (um) córrego em Torixoréu. O fitotopônimo Buritizal nomeia 01 (um) córrego em General Carneiro, 02 (dois) córregos em Guiratinga, 01 (um) córrego em Ponte Branca, 01 (uma) cabeceira em Poxoréu e 01 (um) córrego em Ribeirãozinho.

O fitotopônimo Cambaúva denomina 01 (um) córrego no município de Guiratinga, 01 (um) córrego em Pontal do Araguaia, 01 (um) ribeirão em Tesouro e 02 (dois) córregos em Torixoréu. O fitotopônimo Capoeira particulariza 01 (um) córrego em Araguainha e outro em Pontal do Araguaia. O fitotopônimo Coité dá nome a 01 (uma) cabeceira e a 01 (um) rio em Poxoréu. O fitotopônimo Guariroba nomeia 01 (um) córrego em Guiratinga e 01 (um) ribeirão em Torixoréu. O fitotopônimo Jatobá singulariza 01 (um) córrego em General Carneiro, 02 (dois) córregos em Guiratinga, 01 (um) córrego em Poxoréu e 01 (um) córrego em Tesouro. Pode-se ainda considerar o fitotopônimo tupi híbrido Jatobazinho que nomeia 01 (um) córrego em Guiratinga.

O fitotopônimo Mangabeira denomina 01 (um) córrego no município de Guiratinga e outro em Pontal do Araguaia. O fitotopônimo Membeca singulariza 01 (um) córrego e sua forma variante Mumbeca também denomina 01 (um) córrego, ambos em Guiratinga. O fitotopônimo Samambaia nomeia 01 (um) córrego em Guiratinga e 01 (um) ribeirão em General Carneiro. O fitotopônimo Taboca particulariza 01 (um) córrego e 01 (um) ribeirão em Guiratinga. O fitotopônimo Tarumã dá nome a 01 (um) córrego e o fitotopônimo Tarumãzinho também nomeia 01 (um) córrego em Guiratinga.

O fitotopônimo Pindaibal nomeia 01 (um) córrego no município de Araguainha, 01 (um) córrego em Pontal do Araguaia e outro em Guiratinga. O fitotopônimo Pindaibão toponimiza 01 (um) córrego em General Carneiro, 04 (quatro) córregos em Guiratinga, 01 (um) córrego em Pontal do Araguaia, 01 (um) córrego em Tesouro e outro em Torixoréu. O fitotopônimo Pindaibinha denomina 01 (um) 
córrego em General Carneiro, 01 (um) córrego em Guiratinga e outro em Torixoréu. O fitotopônimo Pindaíba dá nome a 01 (um) córrego em Guiratinga.

O fitotopônimo Batovi denomina 01 (um) distrito e 01 (um) rio no município de Tesouro. O fitotopônimo Arnica nomeia 01 (um) córrego e 01 (uma) serra no município de Araguainha, 01 (um) córrego e 01 (um) morro em Guiratinga. O fitotopônimo Aroeira particulariza 01 (um) córrego em Tesouro e outro em Torixoréu. O fitotopônimo Aroeirinha dá nome a 01 (um) córrego em Torixoréu. O fitotopônimo Bálsamo denomina 01 (uma) serra e 02 (dois) córregos em Torixoréu. O fitotopônimo Baunilha toponimiza 01 (um) córrego em Araguainha e outro em Pontal do Araguaia.

O fitotopônimo Mangue singulariza 01 (um) córrego no município de Tesouro, 02 (dois) córregos em Torixoréu e 01 (um) córrego que estabelece divisa entre os municípios de Ponte Branca e Ribeirãozinho. O fitotopônimo Café nomeia 01 (um) córrego em General Carneiro, 01 (uma) serra e 01 (um) ribeirão em Araguainha. 0 ribeirão Café e a serra do Café estabelecem divisas entre os municípios de Araguainha e Alto Garças. O fitotopônimo Cafezinho dá nome a 01 (um) córrego em Araguainha e o fitotopônimo Cafezal denomina 01 (um) córrego em Guiratinga.

O fitotopônimo Mato denomina 01 (um) córrego no município de Pontal do Araguaia, 01 (um) córrego em Ponte Branca, 01 (um) córrego em Ribeirãozinho e outro em Torixoréu. O fitotopônimo Mata dá nome a 01 (um) córrego em Pontal do Araguaia e a outro em Poxoréu. O fitotopônimo Matinha nomeia 01 (um) córrego em General Carneiro, 02 (dois) córregos em Guiratinga e 01 (um) córrego em Poxoréu. O fitotopônimo Limão nomeia 01 (uma) cabeceira no município de General Carneiro e 01 (um) córrego que estabelece divisa entre Guiratinga e Pontal do Araguaia. Pode-se ainda considerar o fitotopônimo Limoeiro que toponimiza 01 (um) córrego em Poxoréu. O fitotopônimo Encascado que nomina 01 (um) córrego e o fitotopônimo Encascadinho que singulariza 01 (um) córrego, ambos em Torixoréu.

Se considerar apenas a primeira unidade lexical dos topônimos, pode-se acrescentar o fitotopônimo Mata da Onça que nomeia 01 (um) córrego no município de Tesouro e o fitotopônimo Mata Redonda que toponimiza 01 (um) córrego em Ponte Branca. O fitotopônimo Capão Redondo que denomina 01 (um) córrego em Torixoréu e o fitotopônimo Capão Verde que dá nome a 01 (um) córrego em 
Guiratinga. O fitotopônimo Campo Alegre que nomeia 01 (um) córrego em Ribeirãozinho e o fitotopônimo Campo Alto que denomina 01 (um) córrego em Ponte Branca.

O fitotopônimo bororo Ariraiau é o segundo topônimo de 01 (um) córrego, mas não é considerado produtivo porque estabelece divisa entre os municípios de General Carneiro e Tesouro. O fitotopônimo português Laranjeira particulariza 01 (um) córrego que estabelece divisa entre os municípios de Guiratinga e Pontal do Araguaia.

Os fitotopônimos correspondem a 13,8\% do total de topônimos da microrregião Tesouro.

\section{Hidrotopônimos}

Os hidrotopônimos perfazem o total de 117 (cento e dezessete) ocorrências na microrregião Tesouro. Nos estudos toponímicos são classificados como hidrotopônimos as unidades lexicais que se referem a acidentes hídricos em geral, quando usadas para dar nomes a acidentes físicos e a acidentes antrópicos.

São 06 (seis) hidrotopônimos no município de Araguainha, 11 (onze) em General Carneiro, 33 (trinta e três) em Guiratinga, 10 (dez) em Pontal do Araguaia, 09 (nove) em Ponte Branca, 20 (vinte) em Poxoréu, 06 (seis) em Ribeirãozinho, 12 (doze) em Tesouro e 10 (dez) em Torixoréu. Apresenta-se a seguir o gráfico desta taxionomia com os respectivos percentuais por município (GRÁFICO 56). 


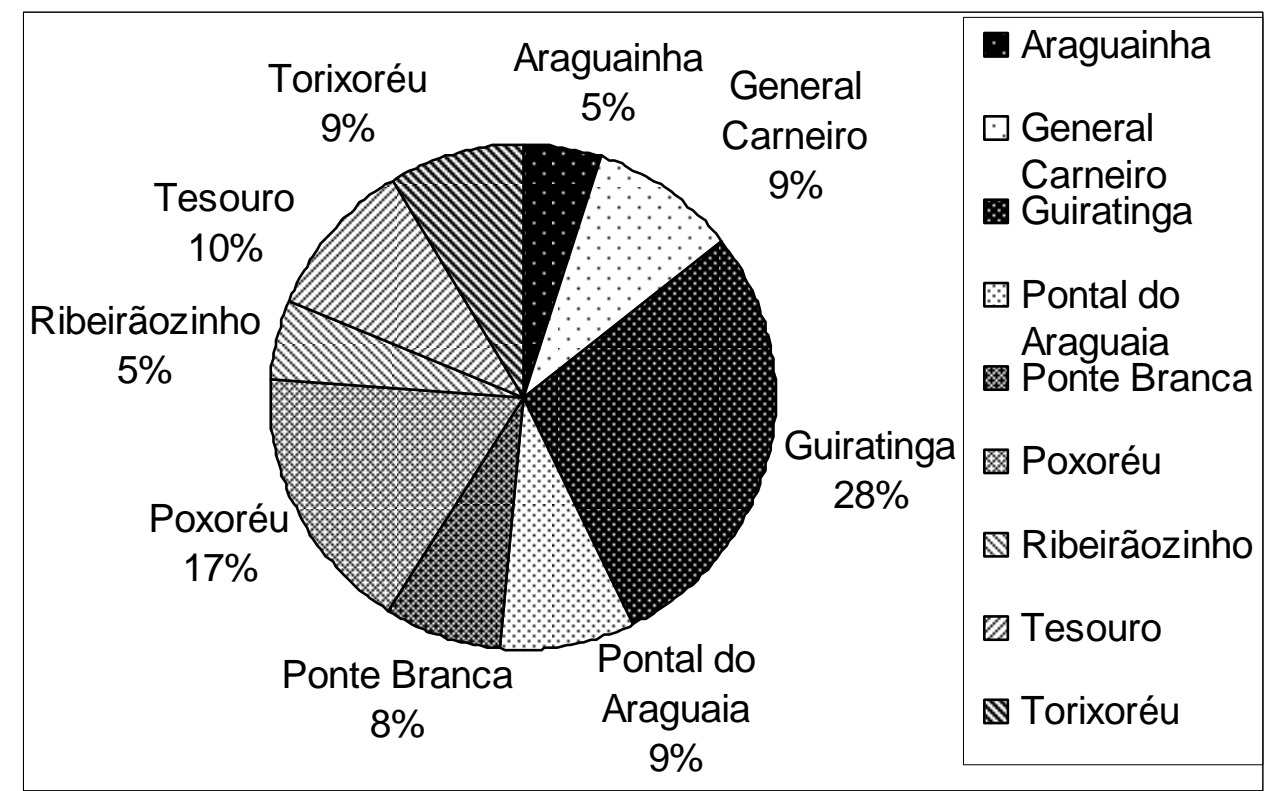

GRÁFICO 56 - Total dos hidrotopônimos da microrregião Tesouro.

Registram-se, na microrregião Tesouro, 02 (dois) hidrotopônimos tupis, 03 (três) bororos, 02 (dois) africanos e 110 (cento e dez) portugueses.

Considera-se, nesta pesquisa, que os hidrotopônimos tupis possuem estrutura simples. O hidrotopônimo Iguaçu dá nome a 01 (um) córrego em Poxoréu. O hidrotopônimo Parnaíba denomina 01 (um) ribeirão no município de Poxoréu que estabelece divisa entre os municípios de Poxoréu e Dom Aquino, por isso consta nas relações de topônimos dos dois municípios.

Segundo Sampaio, as unidades lexicais tupis iguaçu e parnaíba possuem as seguintes características: "IGUÁ, corr. y-guá, o seio d'água, o mesmo que igoá.", "AÇÚ, adj. grande, considerável.", "PARNAHIBA, v. Paranahyba.", "PARANAHYBA, corr.paranã-ayba, o grande caudal ruim, ou impraticavel. Goyaz, Matto Grosso. Alt. Parnahyba." (1970, p. 168; 218; 259 e 260).

Considera-se, nesta pesquisa, que os hidrotopônimos bororos, quanto à estrutura, subdividem-se em simples e híbrido. O hidrotopônimo Poxoréu possui estrutura simples, denomina 01 (um) município mato-grossense e sua forma variante Poxoréo dá nome a 01 (um) rio. O hidrotopônimo bororo de estrutura híbrida Poxoreozinho, formado pela unidade lexical borora poxoréu + sufixo -(z)inho indicador de diminutivo da língua portuguesa, denomina 01 (um) rio em Poxoréu. 
A unidade lexical poxoréu está registrada na Enciclopédia Bororo:

Pó Ceréu - * pó, água; ceréu, o escuro [r. de águas escuras]. Designação: 1 . do curso superior do Pogúbo, $r$. Vermelho até a foz do Porubí, r. Porube Aidjau. Nas proximidades de Jurudóri Boróro é também denominado r. São João. Com seu c. s. atravessa a cidade de Poxoreu; 2. de um r. afl. do c. i. do Pogúbo, r. Vermelho: r. Dr. Correia ou r. Ponte de Pedra ou r. Poxoreu. Albisetti; Venturelli (1962, p. 879)

Considera-se, nesta pesquisa, que os hidrotopônimos africanos, quanto à estrutura, subdividem-se em simples e híbrido. O hidrotopônimo Cacimba possui estrutura simples e dá nome a 01 (um) córrego no município de Guiratinga. O hidrotopônimo africano híbrido Cacimbinha, formado pela unidade lexical africana cacimba + sufixo -inha indicador de diminutivo da língua portuguesa, toponimiza 01 (um) córrego em General Carneiro.

Considera-se, nesta pesquisa, que os hidrotopônimos portugueses da microrregião Tesouro, quanto à estrutura, subdividem-se em simples e compostos. São 62 (sessenta e dois) hidrotopônimos de estrutura simples e 48 (quarenta e oito) hidrotopônimos de estrutura composta. Eles denominam 107 (cento e sete) acidentes físicos e 03 (três) acidentes antrópicos. Os 09 (nove) municípios da microrregião Tesouro possuem hidrotopônimos portugueses.

Os hidrotopônimos de estrutura simples subdividem-se em simples não derivados e simples com derivação. Os hidrotopônimos Açude e Seco dão nomes a 02 (dois) córregos no município de Araguainha. Os hidrotopônimos Açude e Lagoa nominam 02 (duas) cabeceiras e 01 (um) córrego em General Carneiro. O hidrotopônimo Açude nomeia 06 (seis) córregos em Guiratinga, 01 (uma) cabeceira e 01 (um) córrego em Pontal do Araguaia. Um dos córregos toponimizado Açude estabelece divisa entre Guiratinga e Alto Garças, por isso consta nas relações dos dois municípios

Os hidrotopônimos Açude e Lagoa nomeiam 02 (dois) córregos no município de Ponte Branca. O hidrotopônimo Açude dá nome a 01 (um) córrego em Ribeirãozinho e a 01 (uma) cabeceira em Tesouro. O hidrotopônimo Seco nomeia 01 (um) córrego que estabelece divisa entre os municípios de Ponte Branca e 
Ribeirãozinho, por isso consta nas relações de topônimos dos dois municípios. Os hidrotopônimos Lagoa e Seco denominam 02 (dois) córregos em Torixoréu.

Ocorrem hidrotopônimos simples e que apresentam derivação. Os hidrotopônimos Cabeceira e Cachoeira, formados pelas unidades lexicais cabeça e cacho + sufixo -eira, indicador de quantidade, denominam 01 (um) córrego no município de Poxoréu e 02 (dois) córregos em Torixoréu.

Os hidrotopônimos Caldeirão, Corgão, Poção e Ribeirão, formados pelas unidades lexicais caldeira, corgo (forma sincopada de córrego, muito usada em todo o estado de Mato Grosso), poço e ribeiro + sufixo -ão, indicador de aumentativo, nomeiam acidentes físicos. O hidrotopônimo Poção particulariza 01 (um) córrego em Pontal do Araguaia e 01 (um) córrego que estabelece divisa entre Araguainha e Ponte Branca, por isso consta nas relações de topônimos dos dois municípios. O hidrotopônimo Caldeirão nomina 01 (um) córrego em Pontal do Araguaia, 01 (um) córrego em Poxoréu e 03 (três) córregos em Guiratinga, sendo que um desses córregos estabelece divisa entre Guiratinga e Alto Garças, por isso consta nas relações de topônimos dos dois municípios. O hidrotopônimo Corgão dá nome a 01 (um) córrego em Guiratinga e a 01 (um) córrego em Pontal do Araguaia. O hidrotopônimo Ribeirão denomina 01 (um) córrego em Guiratinga e 01 (um) córrego em Poxoréu, que estabelece divisa entre Poxoréu e Dom Aquino, por isso consta nas relações de topônimos dos dois municípios.

Os hidrotopônimos Corguinho e Lagoinha, formados pelas unidades lexicais corgo e lagoa + sufixo -(u)inho/a, indicador de diminutivo, toponimizam 01 (um) córrego no município de Guiratinga e 01 (um) córrego em General Carneiro. O hidrotopônimo Escoadouro, formado pela unidade lexical escoar + sufixo -douro, indicador do local onde se dá a ação, nomeia 01 (uma) cabeceira em Poxoréu.

O hidrotopônimo Sangradouro, formado pela unidade lexical sangrar + sufixo douro, já mencionado, nomeia 01 (uma) terra indígena localizada em áreas dos municípios General Carneiro e Poxoréu, por isso consta nas relações de topônimos dos dois municípios. O hidrotopônimo Esparramado, formado pela unidade lexical esparramar + sufixo -ado, indicador de continuidade ou extensão, denomina 02 (dois) córregos em Guiratinga. O hidrotopônimo Fervedor, formado pela unidade 
lexical ferver + sufixo -dor, indicador do agente de ação, nomeia 01 (um) córrego em Pontal do Araguaia. O hidrotopônimo Pulador, formado pela unidade lexical pular + sufixo -dor, já mencionado, nomina 01 (um) córrego em Guiratinga, 01 (um) córrego em Poxoréu, 01 (um) córrego em Ribeirãozinho, 01 (um) córrego em Tesouro e 01 (um) córrego em Torixoréu.

Os hidrotopônimos Cabeceirinha, Cachoeirinha, Ribeirãozinho e Sangradourozinho apresentam dupla sufixação. Os hidrotopônimos Cabeceirinha e Cachoeirinha, formados pelas unidades lexicais cabeça e cacho + sufixo -eiro + sufixo -inha, já mencionados, nomeiam 02 (dois) córregos em General Carneiro, 01 (um) córrego em Guiratinga, 01 (um) córrego em Pontal do Araguaia, 01 (um) córrego em Ponte Branca, 01 (um) córrego em Poxoréu e 03 (três) córregos em Tesouro.

O hidrotopônimo Ribeirãozinho, formado pela unidade lexical ribeiro + sufixo ão, + sufixo -(z)inho, já mencionados, singulariza 01 (um) município mato-grossense e 01 (um) córrego no município de Ribeirãozinho. O hidrotopônimo Sangradourozinho, formado pela unidade lexical sangrar + sufixo douro + sufixo (z)inho, já mencionados, dá nome a 01 (um) ribeirão em Poxoréu. O ribeirão Sangradourozinho estabelece divisa entre os municípios de Poxoréu e Primavera do Leste, por isso consta nas relações de topônimos dos dois municípios. O hidrotopônimo Cachoeirão, formado pela unidade lexical cacho + sufixo -eira + sufixo -ão, já mencionados, dá nome a 01 (um) córrego no município de Pontal do Araguaia.

O hidrotopônimo português de estrutura composta Água Limpa, formado por substantivo comum + adjetivo, dá nome a 01 (um) córrego no município de General Carneiro. Os hidrotopônimos Água Boa, Água Bonita, Água Fria e Água Limpa denominam 04 (quatro) córregos em Guiratinga. O hidrotopônimo Água Bonita nomeia 01 (um) córrego em Poxoréu. O hidrotopônimo Poço Velho particulariza 01 (uma) serra em Ribeirãozinho.

Os hidrotopônimos Água Bonita e Água Limpa denominam 04 (quatro) córregos no município de Tesouro. Os hidrotopônimos Água Bela e Água Bonita dão 
nomes a 02 (dois) córregos em Torixoréu. O hidrotopônimo Águas Belas apresenta desinência de plural -s e dá nome a 01 (um) córrego em Torixoréu.

São 03 (três) hidrotopônimos compostos que apresentam variações de grafia nos mapas e nas cartas topográficas: Água-emendada, Água Suja e Olho-d'água. Optou-se por respeitar as grafias registradas que constam nas relações de topônimos, mas mantêm-se, nesta parte, as formas dicionarizadas. O hidrotopônimo Água-emendada (ocorre também a grafia Água Emendada), nomeia 01 (um) córrego no município de Araguainha, 01 (um) córrego em General Carneiro, 01 (um) córrego em Poxoréu, 01 (um) córrego em Tesouro e 01 (um) córrego em Torixoréu. O hidrotopônimo Água Suja (ocorre também a grafia Água-suja), formado por substantivo comum + adjetivo, dá nome a 01 (um) córrego no município de Araguainha, a 01 (um) ribeirão em Guiratinga e a 01 (um) córrego em Tesouro. 0 hidrotopônimo Olho-d'água (ocorrem também as grafias Olho d'Água e Olho dÁgua), nomeia 01 (uma) cabeceira no município de Poxoréu, 01 (um) córrego em Guiratinga e 01 (um) córrego em Torixoréu.

Os hidrotopônimos Cabeceira Alta, Cabeceira Comprida e Cabeceira Verde, formados pela unidade lexical cabeça + sufixo -eira, indicador de quantidade + adjetivo, dão nomes a 01 (um) córrego em Araguainha, a 01 (um) córrego em Pontal do Araguaia, a 03 (três) córregos em Guiratinga e a 01 (um) córrego em Ponte Branca. Os hidrotopônimos Cabeceira da Cruz, Cabeceira da Merenda, Cabeceira da Serra, Cabeceira do Açude, Cabeceira do Peixe e Cabeceira do Sangue, formados pela unidade lexical cabeceira + conectivo + substantivo comum, denominam 01 (um) córrego em Pontal do Araguaia, 03 (três) córregos em Guiratinga, 03 (três) córregos em Ponte Branca, 01 (um) córrego em Poxoréu e 01 (um) córrego em Tesouro.

O hidrotopônimo Cabeceira do Areia, formado pela unidade lexical cabeceira + conectivo + substantivo comum, apresenta a elipse do substantivo comum rio porque o conectivo que antecede o substantivo feminino areia está no masculino: do e nomeia 01 (um) córrego no município de Poxoréu. Com isso, é possível inferir que o topônimo seria Cabeceira do Rio Areia, porque na carta topográfica esse córrego inicia a formação do rio Areia. O rio Areia consta nas relações de topônimos dos municípios de Guiratinga e Poxoréu. 
O hidrotopônimo Cabeceira do Martim, formado pela unidade lexical cabeceira + conectivo + substantivo próprio, dá nome a 01 (um) córrego. O hidrotopônimo Cabeceira do Olho-d'água, formado pela unidade lexical cabeceira + conectivo + substantivo composto, singulariza 01 (um) córrego. O hidrotopônimo Cabeceira do Varjão, formado pela unidade lexical cabeceira + conectivo + unidade lexical varja + sufixo -ão, já mencionado, nomeia 01 (um) córrego. O hidrotopônimo Cachoeira Vermelha, formado pela unidade lexical cachoeira + adjetivo, dá nome a 01 (um) córrego que estabelece divisa entre Guiratinga e Alto Garças, por isso consta nas relações de topônimos dos dois municípios. Todos localizam-se no município de Guiratinga.

O hidrotopônimo Córrego Bandeira, formado por substantivo comum + substantivo comum, nomeia 01 (uma) cabeceira no município de Poxoréu. 0 hidrotopônimo Sangradouro Grande, formado pela unidade lexical sangradouro, já mencionada + adjetivo, dá nome a 01 (um) ribeirão que consta nas relações de topônimos de General Carneiro e Poxoréu, porque estabelece divisa entre os dois municípios.

$\mathrm{Na}$ microrregião Tesouro ocorre produtividade toponímica na taxionomia hidrotopônimos. O hidrotopônimo Açude nomeia 01 (um) córrego no município de Araguainha, 01 (uma) cabeceira e 01 (um) córrego em General Carneiro, 01 (uma) cabeceira e 01 (um) córrego em Pontal do Araguaia, 01 (um) córrego em Ponte Branca, 01 (um) córrego em Ribeirãozinho, 01 (uma) cabeceira em Tesouro e 06 (seis) córregos em Guiratinga, sendo que um deles estabelece divisa entre os municípios de Guiratinga e Alto Garças.

O hidrotopônimo Lagoa denomina 01 (uma) cabeceira no município de General Carneiro, 01 (um) córrego em Ponte Branca e 01 (um) córrego em Torixoréu, pode-se ainda considerar o hidrotopônimo Lagoinha que singulariza 01 (um) córrego no município de General Carneiro. O hidrotopônimo Seco toponimiza 01 (um) córrego no município de Araguainha, 01 (um) córrego em Torixoréu e 01 (um) córrego que estabelece divisa entre os municípios de Ponte Branca e Ribeirãozinho. 
O hidrotopônimo Água Bonita denomina 01 (um) córrego no município de Guiratinga, 01 (um) córrego em Poxoréu, 03 (três) córregos em Tesouro e 01 (um) córrego em Torixoréu. O hidrotopônimo Água-emendada singulariza 01 (um) córrego em Araguainha, 01 (um) córrego em General Carneiro, 01 (um) córrego em Poxoréu, 01 (um) córrego em Tesouro e 01 (um) córrego em Torixoréu. O hidrotopônimo Água Bela denomina 01 (um) córrego e o hidrotopônimo Águas Belas particulariza 01 (um) córrego, ambos em Torixoréu.

O hidrotopônimo Água Suja denomina 01 (um) córrego no município de Araguainha, 01 (um) ribeirão em Guiratinga e 01 (um) córrego em Tesouro. O hidrotopônimo Água Limpa dá nome a 01 (um) córrego em General Carneiro, a 01 (um) córrego em Guiratinga e a 01 (um) córrego em Tesouro. Pode-se ainda acrescentar, se considerar a primeira unidade lexical do topônimo, o hidrotopônimo Água Boa que nomina 01 (um) córrego e o hidrotopônimo Água Fria que nomeia 01 (um) córrego, ambos em Guiratinga

O hidrotopônimo Cabeceira Alta nomeia 01 (um) córrego em Ponte Branca e 02 (dois) córregos em Guiratinga. O hidrotopônimo Cabeceira Comprida singulariza 01 (um) córrego em Araguainha e outro em Guiratinga.

O hidrotopônimo Cabeceira da Cruz nomeia 02 (dois) córregos no município de Ponte Branca. O hidrotopônimo Cabeceira do Açude denomina 01 (um) córrego em Guiratinga, 01 (um) córrego em Ponte Branca e 01 (um) córrego em Tesouro. 0 hidrotopônimo Olho-d'água dá nome a 01 (um) córrego em Guiratinga, a 01 (uma) cabeceira em Poxoréu e a 01 (um) córrego em Torixoréu.

O hidrotopônimo Cachoeira denomina 01 (um) córrego em Poxoréu e 01 (um) córrego em Torixoréu. O hidrotopônimo Cachoeirão dá nome a 01 (um) córrego em Pontal do Araguaia. O hidrotopônimo Cachoeirinha nomeia 02 (dois) córregos em General Carneiro, 01 (um) córrego em Guiratinga, 01 (um) córrego em Pontal do Araguaia, 01 (um) córrego em Poxoréu e 03 (três) córregos em Tesouro. O hidrotopônimo Cachoeira Vermelha nomeia 01 (um) córrego em Guiratinga que estabelece divisa entre os municípios de Guiratinga e Alto Garças. 
O hidrotopônimo Caldeirão denomina 01 (um) córrego no município de Pontal do Araguaia, 01 (um) córrego em Poxoréu e 03 (três) córregos em Guiratinga, sendo que um desses estabelece divisa entre Guiratinga e Alto Garças. O hidrotopônimo Corgão nomeia 01 (um) córrego em Guiratinga, outro em Pontal do Araguaia e, o seu antônimo, o hidrotopônimo Corguinho particulariza 01 (um) córrego em Guiratinga. O hidrotopônimo Esparramado dá nome a 02 (dois) córregos em Guiratinga.

O hidrotopônimo Poção nomeia 01 (um) córrego que estabelece divisa entre os municípios de Araguainha e Ponte Branca e 01 (um) córrego em Pontal do Araguaia. O hidrotopônimo Pulador denomina 01 (um) córrego em cada um dos seguintes municípios: Guiratinga, Poxoréu, Ribeirãozinho, Tesouro e Torixoréu. O hidrotopônimo Ribeirão dá nome a 01 (um) córrego em Guiratinga e a 01 (um) córrego que estabelece divisa entre Poxoréu e Dom Aquino. O hidrotopônimo Ribeirãozinho toponimiza 01 (um) município mato-grossense e dá nome a 01 (um) córrego em Ribeirãozinho.

O hidrotopônimo Sangradouro Grande dá nome a 01 (um) ribeirão que estabelece divisa entre os municípios de General Carneiro e Poxoréu e consta nas relações de topônimos dos dois municípios, portanto, não é considerado produtivo. O hidrotopônimo Sangradouro nomeia 01 (uma) terra indígena que localiza-se em áreas de dois municípios: General Carneiro e Poxoréu. O hidrotopônimo Sangradourozinho denomina 01 (um) ribeirão em Poxoréu.

O hidrotopônimo bororo Poxoréu particulariza 01 (um) município matogrossense. O hidrotopônimo Poxoréo, sua forma variante, nomeia 01 (um) rio e o hidrotopônimo Poxoreozinho também dá nome a 01 (um) rio, ambos no município de Poxoréu. O hidrotopônimo Cacimba denomina 01 (um) córrego em Guiratinga e o hidrotopônimo Cacimbinha dá nome a 01 (um) córrego em General Carneiro.

O hidrotopônimo Cabeceira singulariza 01 (um) córrego em Torixoréu e o hidrotopônimo Cabeceirinha nomeia 01 (um) córrego em Ponte Branca. Se considerar apenas a primeira unidade lexical dos hidrotopônimos compostos podese acrescentar como produtivo os hidrotopônimos Cabeceira do Sangue e Cabeceira Verde que denominam 02 (dois) córregos em Pontal do Araguaia. Os 
hidrotopônimos Cabeceira da Serra, Cabeceira do Martim, Cabeceira do Olhod'água, Cabeceira do Peixe, Cabeceira do Varjão que nomeiam 05 (cinco) córregos em Guiratinga. Os hidrotopônimos Cabeceira da Merenda e Cabeceira do Areia que dão nomes a 02 (dois) córregos em Poxoréu.

$\mathrm{Na}$ microrregião Tesouro ocorre, na taxionomia hidrotopônimos, a toponimização do acidente físico. As unidades lexicais que em um sintagma toponímico exercem a função de termo genérico, isto é, designam o acidente físico propriamente dito e antecedem o termo específico, nesta taxionomia tornam-se nomes de acidentes físicos ou antrópicos. Os hidrotopônimos simples e não derivados Açude e Lagoa dão nomes a 03 (três) cabeceiras e 14 (quatorze) córregos. Os hidrotopônimos simples com derivação Cabeceira, Cabeceirinha, Cachoeira, Cachoeirão, Cachoeirinha, Corgão, Corguinho, Lagoinha, Ribeirão e Ribeirãozinho denominam 01 (um) município e 20 (vinte) córregos.

Os hidrotopônimos compostos Cabeceira Alta, Cabeceira Comprida, Cabeceira Verde, Cabeceira da Cruz, Cabeceira da Merenda, Cabeceira da Serra, Cabeceira do Açude, Cabeceira do Areia, Cabeceira do Martim, Cabeceira do Olhod'água, Cabeceira do Peixe, Cabeceira do Sangue, Cabeceira do Varjão, Cachoeira Vermelha e Córrego Bandeira nomeiam 01 (uma) cabeceira e 20 (vinte) córregos.

Os hidrotopônimos correspondem a $11,4 \%$ do total de topônimos da microrregião Tesouro.

\section{Litotopônimos}

São classificados como litotopônimos as unidades lexicais que se referem aos minerais em geral e à constituição do solo, quando usadas para dar nomes a acidentes físicos e a acidentes antrópicos. Registram-se 111 (cento e onze) litotopônimos nos mapas e cartas topográficas dos municípios que compõem a microrregião Tesouro. 
São 10 (dez) litotopônimos no município de Araguainha, 13 (treze) em General Carneiro, 29 (vinte e nove) em Guiratinga, 08 (oito) em Pontal do Araguaia, 07 (sete) em Ponte Branca, 12 (doze) em Poxoréu, 13 (treze) em Tesouro, 19 (dezenove) em Torixoréu. Não há registro de litotopônimo no município de Ribeirãozinho. Apresenta-se a seguir o gráfico desta taxionomia com os respectivos percentuais por município (GRÁFICO 57).

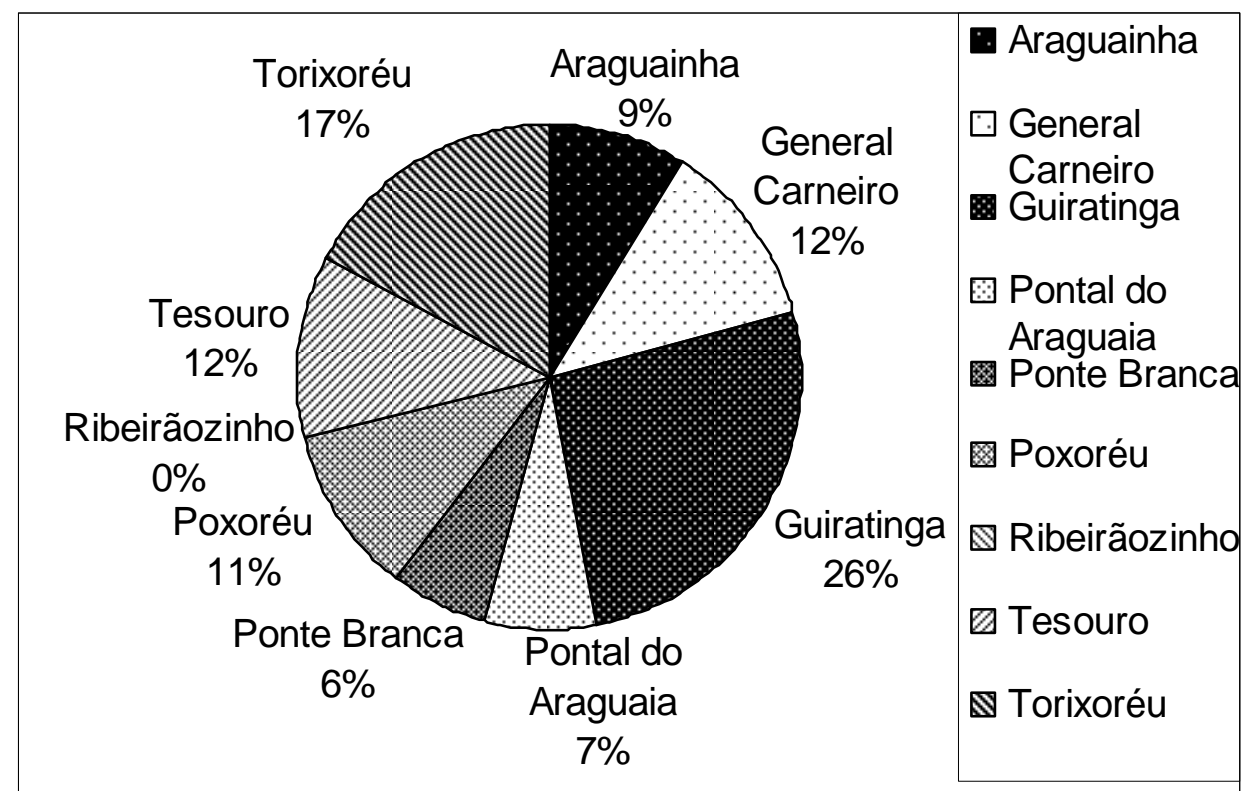

GRÁFICO 57 - Total dos litotopônimos da microrregião Tesouro.

$\mathrm{Na}$ microrregião Tesouro constam 02 (dois) litotopônimos tupis, 02 (dois) bororos e 107 (cento e sete) portugueses.

Considera-se, nesta pesquisa, que os litotopônimos tupis possuem estrutura simples. O litotopônimo Cupim denomina 01 (um) córrego no município de Guiratinga e o litotopônimo Tejuco nomeia 01 (um) córrego em Poxoréu.

Considera-se, nesta pesquisa, que os litotopônimos bororos possuem estrutura simples. O litotopônimo Toricujago dá nome a 01 (um) córrego e o litotopônimo Barigajau singulariza 01 (um) ribeirão, ambos localizam-se no município de General Carneiro.

As unidades lexicais toricujago e barigajau estão registradas na Enciclopédia Bororo: "Tóri Kujágu - * tóri, pedra; kujágu, vermelho [cór. do leito vermelho]. Cór. afl. da esq. do Jakoréuge E-iáo, r. das Garças; cór. Lageado." e "Bariga J'ao - * 
Bariga, pedra sílex; ji (d)ela; iáo, localidade [localidade da pedra sílex]. Cór. afl. da esq. do c. m. do Jakoréuge E-iáo: cór. Barigajau." Albisetti, Venturelli (1962, p. 926; 253).

Considera-se, nesta pesquisa, que os litotopônimos portugueses da microrregião Tesouro, quanto à estrutura, subdividem-se em simples e compostos. São 101 (cento e um) litotopônimos de estrutura simples e 06 (seis) litotopônimos de estrutura composta. Eles denominam 104 (cento e quatro) acidentes físicos e 03 (três) acidentes antrópicos.

Os litotopônimos compostos Barro Branco e Barro Duro, formados por substantivo comum + adjetivo, denominam, respectivamente, 01 (um) córrego no município de Guiratinga e 01 (um) córrego em Tesouro. Os hidrotopônimos Monchão Dourado e Pedra Furada, formados por substantivo comum + unidades lexicais dourar e furar + sufixo -ado, indicador de um tanto ou do efeito da ação, denominam 01 (uma) localidade em Tesouro e 01 (um) córrego em Torixoréu

O litotopônimo Pedras Altas, formado por substantivo comum + adjetivo, ambos com desinência de plural -s, dá nome a 01 (uma) serra no município de Ponte Branca. O litotopônimo Pedra de Fogo, formado por substantivo comum + preposição + substantivo comum, singulariza 01 (um) córrego em Poxoréu.

Os litotopônimos de estrutura simples subdividem-se em simples com derivação e simples sem derivação. Os litotopônimos derivados Areado, Areiado (forma variante), Atolado e Lajeado, formados pelas unidades lexicais areia, atolar e laje + sufixo -ado, indicador de quantidade, porção, denominam 01 (um) córrego no município de Araguainha, 02 (dois) córregos em Guiratinga, 01 (um) córrego em Pontal do Araguaia, 01 (um) córrego em Poxoréu, 01 (um) rio em Tesouro e 02 (dois) córregos em Torixoréu. E ainda, 01 (um) córrego que estabelece divisa entre os municípios de Guiratinga e Tesouro, por isso consta nas relações de topônimos dos dois municípios. O litotopônimo Aterrado, formado pela unidade lexical aterrar + sufixo -ado, já descrito, dá nome a 01 (um) córrego em Poxoréu.

Alguns litotopônimos apresentam dupla sufixação. O litotopônimo Atoladeira, formado pela unidade lexical atolar + sufixo -ado, já mencionado + sufixo -eira, 
indicador de quantidade, toponimiza 01 (uma) cabeceira no município de General Carneiro, 01 (um) córrego e 01 (uma) localidade em Pontal do Araguaia. O litotopônimo Barreirinho, formado pela unidade lexical barro + sufixo -eiro, já descrito + sufixo -inho, formador de diminutivo, nomeia 03 (três) córregos em Araguainha, 02 (dois) córregos em General Carneiro, 02 (dois) córregos em Guiratinga, 01 (um) ribeirão em Pontal do Araguaia, 01 (um) córrego em Ponte Branca, 01 (um) córrego em Poxoréu e 03 (três) córregos em Torixoréu. O litotopônimo Barreirão, formado pela unidade lexical barro + sufixos -eiro já descrito + -ão, formador de aumentativo, dá nome a 01 (um) córrego em Araguainha, 01 (um) córrego em Guiratinga, 01 (um) córrego em Pontal do Araguaia, 02 (dois) córregos em Poxoréu, 01 (um) córrego em Tesouro e 01 (um) córrego em Torixoréu.

O litotopônimo Pantanalzinho, formado pela unidade lexical pântano + sufixo -al, indicador de grande quantidade + -(z)inho, já descrito, dá nome a 01 (um) córrego no município de Guiratinga que estabelece divisa entre os municípios de Guiratinga e Alto Garças, por isso consta nas relações de topônimos dos dois municípios. O litotopônimo Lajeadinho, formado pela unidade lexical laje + sufixo ado e sufixo -inho, já descritos, nomeia 01 (um) córrego em Araguainha, 05 (cinco) córregos em Guiratinga, 02 (dois) córregos em Tesouro e 03 (três) córregos em Torixoréu.

O litotopônimo Malhador, formado pela unidade lexical malhar + sufixo -dor, indicador de agente de ação, dá nome a 01 (um) córrego em Tesouro. O litotopônimo Barreiro, formado pela unidade lexical barro + sufixo -eiro, já descrito, nomeia 02 (dois) córregos no município de Araguainha, 01 (uma) cabeceira e 01 (um) rio em General Carneiro que estabelece divisa entre General Carneiro e Barra do Garças, 06 (seis) córregos em Guiratinga, sendo que 01 (um) desses córregos estabelece divisa entre Guiratinga e Alto Garças, 01 (um) córrego em Ponte Branca, 02 (dois) córregos em Tesouro e 03 (três) córregos em Torixoréu. O litotopônimo Pedreira, formado pela unidade lexical pedra + sufixo -eira, já mencionado, singulariza 01 (um) córrego em Guiratinga. O litotopônimo Pedregulho, formado pela unidade lexical pedra + sufixo -(eg)ulho, indicador de coleção, dá nome a 01 (um) córrego em Guiratinga. 
Os litotopônimos Areinha, Lajinha e Pratinha, formados pelas unidades lexicais areia, laje e prata + sufixo -inha, indicador de diminutivo, dão nomes a 01 (um) córrego no município de Pontal do Araguaia, a 01 (um) córrego que estabelece divisa entre Guiratinga e Poxoréu, por isso consta nas relações de topônimos dos dois municípios e a 01 (um) ribeirão em Tesouro. Os litotopônimos Areão e Brejão, formados pelas unidades lexicais areia e brejo + sufixo -ão, indicador de aumentativo, denominam 01 (um) córrego em Guiratinga, 01 (uma) serra e 01 (um) córrego em Ponte Branca.

Os litotopônimos Cristalino e Diamantino, formados pelas unidades lexicais cristal e diamante + sufixo -ino, indicador de referência, relação, nomeiam, respectivamente, 01 (um) córrego em General Carneiro, 01 (uma) localidade em Torixoréu e 01 (um) rio que consta nas relações de topônimos dos municípios Araguainha, Guiratinga, Pontal do Araguaia, Ponte Branca e Torixoréu.

No município de General Carneiro, os litotopônimos Lama, Pântano e Pedra dão nomes a 04 (quatro) córregos. Em Guiratinga, o litotopônimo Cristal nomina 01 (um) córrego, o litotopônimo Areia nomeia 01 (um) rio que consta nas relações de topônimos de Guiratinga, Poxoréu, Rondonópolis e São José do Povo. Nas relações de topônimos de Poxoréu e Rondonópolis esse rio possui dupla denominação. $\mathrm{O}$ litotopônimo Prata singulariza 01 (um) rio que estabelece divisa entre os municípios de Guiratinga e Pedra Preta, por isso consta nas relações de topônimos dos dois municípios. Em Pontal do Araguaia, o litotopônimo Areia toponimiza 01 (um) córrego. Em Poxoréu, os litotopônimos Areia e Ouro nomeiam 02 (dois) córregos e 01 (um) morro que estabelece divisa entre Poxoréu e Juscimeira, por isso consta nas relações de topônimos dos dois municípios. Em Tesouro, os litotopônimos Areia e Laje dão nomes a 02 (dois) córregos. Em Torixoréu, os litotopônimos Areia, Pântano e Sal denominam 04 (quatro) córregos.

Os litotopônimos Areias e Pedras apresentam desinência de plural $-\mathrm{s}$ e nomeiam 01 (um) ribeirão em Araguainha, 01 (um) córrego em General Carneiro, 01 (um) córrego em Guiratinga e 01 (um) córrego em Ponte Branca.

Os litotopônimos da microrregião Tesouro apresentam produtividade toponímica. O litotopônimo Areia nomeia 01 (um) córrego no município de Pontal do 
Araguaia, 01 (um) córrego em Tesouro, 02 (dois) córregos em Torixoréu, 01 (um) córrego em Poxoréu, 01 (um) morro que estabelece divisa entre o município de Poxoréu e Juscimeira, e ainda, 01 (um) rio que estabelece divisa do município de Poxoréu com os municípios de Guiratinga, Rondonópolis e São José do Povo.

O litotopônimo Pântano denomina 01 (um) córrego no município de General Carneiro e outro em Torixoréu. O litotopônimo Pedra nomeia 02 (dois) córregos em General Carneiro. O litotopônimo Pedras dá nome a 01 (um) ribeirão em Araguainha, a 01 (um) córrego em Guiratinga e a 01 (um) córrego em Ponte Branca. Pode-se ainda acrescentar o litotopônimo composto Pedra de Fogo que toponimiza 01 (um) córrego em Poxoréu. O litotopônimo Pedra Furada que particulariza 01 (um) córrego em Torixoréu e o litotopônimo Pedras Altas que nomina 01 (uma) serra em Ponte Branca.

O litotopônimo Areias dá nome a 01 (um) córrego em General Carneiro. Os litotopônimos Areado e Areiado (forma variante) denominam 01 (um) rio em Tesouro, 01 (um) córrego em Guiratinga e outro em Torixoréu. Pode-se ainda acrescentar o litotopônimo Areão que singulariza 01 (um) córrego em Guiratinga. O litotopônimo Areinha dá nome a 01 (um) córrego que estabelece divisa entre os municípios de Guiratinga e Poxoréu.

O litotopônimo Laje nomeia 01 (um) córrego no município de Tesouro e o litotopônimo Lajinha singulariza 01 (um) córrego em Pontal do Araguaia. O litotopônimo Lajeado denomina 01 (um) córrego em Araguainha, 01 (um) córrego em Guiratinga, 01 (um) córrego em Pontal do Araguaia, 01 (um) córrego em Torixoréu, e também, particulariza 01 (um) córrego que estabelece divisa entre os municípios de Guiratinga e Tesouro. O litotopônimo Lajeadinho dá nome a 01 (um) córrego em Araguainha, a 05 (cinco) córregos em Guiratinga, a 02 (dois) córregos em Tesouro e a 03 (três) córregos em Torixoréu.

O litotopônimo Barreiro nomeia 02 (dois) córregos no município de Araguainha, 01 (uma) cabeceira e 01 (um) rio em General Carneiro, 06 (seis) córregos em Guiratinga, 01 (um) córrego em Ponte Branca, 02 (dois) córregos em Tesouro e 03 (três) córregos em Torixoréu. O litotopônimo Barreirão denomina 01 (um) córrego em Araguainha, 01 (um) córrego em Guiratinga, 01 (um) córrego em 
Pontal do Araguaia, 02 (dois) córregos em Poxoréu, 01 (um) córrego em Tesouro e 01 (um) córrego em Torixoréu. O litotopônimo Barreirinho dá nome a 03 (três) córregos em Araguainha, a 02 (dois) córregos em General Carneiro, a 02 (dois) córregos em Guiratinga, a 01 (um) ribeirão em Pontal do Araguaia, a 01 (um) córrego em Ponte Branca, a 01 (um) córrego em Poxoréu e a 03 (três) córregos em Torixoréu.

O litotopônimo Brejão denomina 01 (uma) serra e 01 (um) córrego no município de Ponte Branca. O litotopônimo Diamantino particulariza 01 (uma) localidade no município de Torixoréu e 01 (um) rio que estabelece divisa nos municípios de Araguainha, Guiratinga, Pontal do Araguaia, Ponte Branca e Torixoréu.

O litotopônimo Prata dá nome a 01 (um) rio que estabelece divisa do município de Guiratinga com Pedra Preta, por isso consta nas relações de topônimos dos dois municípios. O litotopônimo Pratinha singulariza 01 (um) ribeirão em Tesouro. O litotopônimo Atoladeira denomina 01 (uma) cabeceira em General Carneiro, 01 (um) córrego e 01 (uma) localidade em Pontal do Araguaia. O litotopônimo Cristal toponimiza 01 (um) córrego em Guiratinga e o litotopônimo Cristalino dá nome a 01 (um) córrego em General Carneiro.

Os litotopônimos correspondem a $10,9 \%$ do total de topônimos da microrregião Tesouro.

\section{Geomorfotopônimos}

As unidades lexicais que se referem às formações geológicas em geral, quando usadas para denominar acidentes físicos e a acidentes antrópicos, recebem nos estudos toponímicos a denominação de geomorfotopônimos. Registram-se, na microrregião Tesouro, 79 (setenta e nove) geomorfotopônimos. 
São 02 (dois) geomorfotopônimos no município de Araguainha, 09 (nove) em General Carneiro, 26 (vinte e seis) em Guiratinga, 08 (oito) em Pontal do Araguaia, 04 (quatro) em Ponte Branca, 06 (seis) em Poxoréu, 04 (quatro) em Ribeirãozinho, 10 (dez) em Tesouro e 10 (dez) em Torixoréu. Apresenta-se a seguir o gráfico desta taxionomia com os respectivos percentuais por município (GRÁFICO 58).

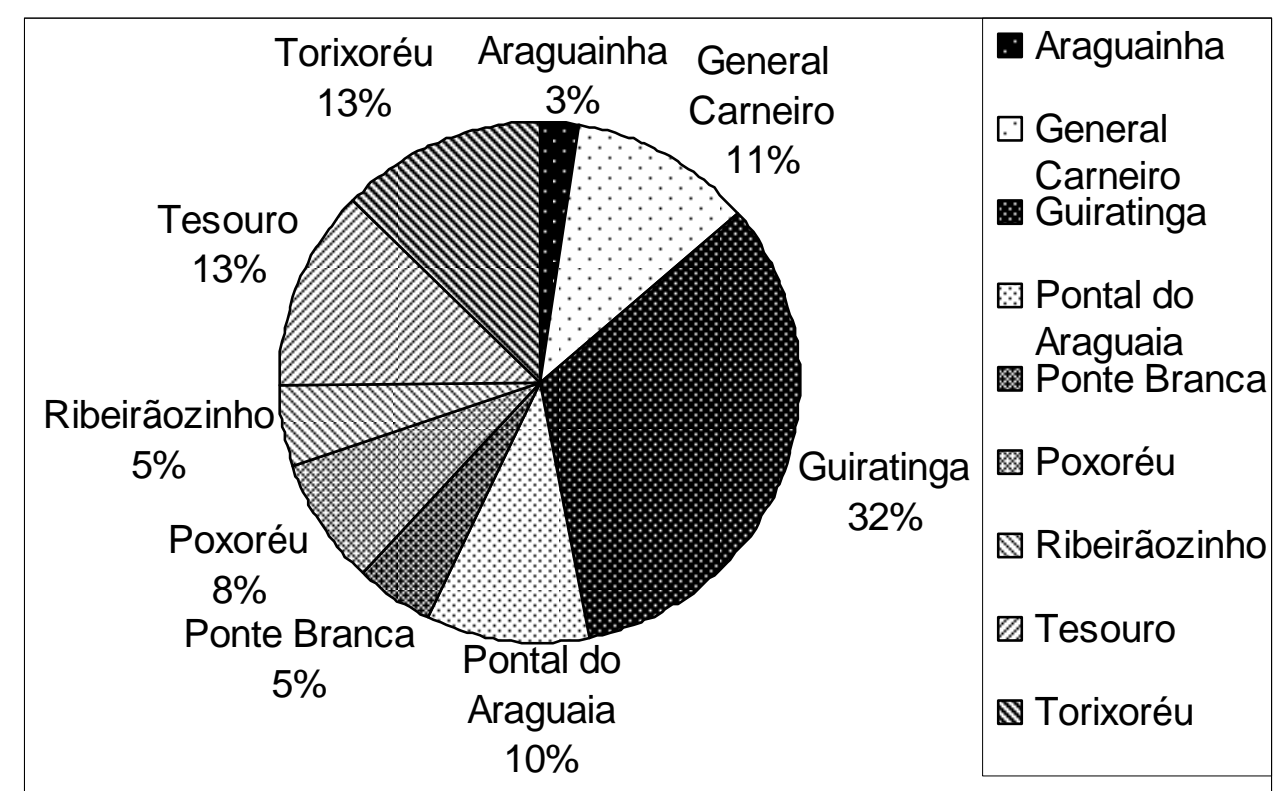

GRÁFICO 58 - Total dos geomorfotopônimos da microrregião Tesouro.

Registram-se, na microrregião Tesouro, 01 (um) geomorfotopônimo tupi, 02 (dois) bororos e 76 (setenta e seis) portugueses.

O geomorfotopônimo tupi Pontal do Araguaia possui estrutura híbrida, formado pela unidade lexical portuguesa ponta + sufixo -al, indicador de grande quantidade + conectivo + unidade lexical tupi araguaia, denomina 01 (um) município mato-grossense.

Considera-se, nesta pesquisa, que os geomorfotopônimos bororos possuem estrutura simples. O geomorfotopônimo Toriparu dá nome a 01 (uma) localidade no município de Guiratinga e o geomorfotopônimo Torixoréu nomeia 01 (um) município mato-grossense.

As unidades lexicais toriparu e torixoréu estão registradas na Enciclopédia Bororo: "Tóri Páru - * tóri, serra; páru, sopé [localidade ao pé de uma serra]. Localidade ao sopé de uma serra distante $\sim 6 \mathrm{~km}$ da cidade de Guiratinga." e "Tóri Coréu - *tóri, rocha; coréu, o escuro [morro escuro]. Pequena elevação nas 
proximidades da atual cidade de Torixoréu, na margem esquerda do Oroaríbo Kuriréu, r. Araguaia." e "Ceréu - vart. de coréu e ders. *cé, prêto; réu, suf. poss. O prêto, o escuro. ex. Pó Ceréu, Água Escura i.e. rio Escuro: rio Poxoreu." Albisetti; Venturelli (1962, p. 536; 925; 926)

Considera-se, nesta pesquisa, que os geomorfotopônimos portugueses da microrregião Tesouro, quanto à estrutura, subdividem-se em simples e compostos. São 59 (cinqüenta e nove) geomorfotopônimos de estrutura simples e 17 (dezessete) geomorfotopônimos de estrutura composta. Eles denominam 73 (setenta e três) acidentes físicos e 03 (três) acidentes antrópicos. Os 09 (nove) municípios da microrregião Tesouro possuem geomorfotopônimos portugueses.

Os geomorfotopônimos compostos Grota Funda, Monte Negro, Morro Chato, Morro Grande e Vale Rico, formados por substantivo comum + adjetivo, denominam 02 (dois) córregos em Pontal do Araguaia, 02 (dois) córregos e 01 (um) distrito no município de Guiratinga. O geomorfotopônimo Morro Alto dá nome a 01 (um) córrego em Ponte Branca e a 01 (um) córrego que estabelece divisa entre os municípios de Guiratinga e Tesouro, por isso consta nas relações de topônimos dos dois municípios.

Os geomorfotopônimos Baixa do Campo, Morro da Mesa, Morro do Chapéu e Toca da Onça, formados por substantivo comum + conectivo + substantivo comum, nomeiam 01 (um) córrego no município de Guiratinga, 01 (um) córrego em Poxoréu e 02 (dois) córregos em Tesouro. O geomorfotopônimo Paredão Grande, formado pela unidade lexical parede + sufixo -ão, formador de aumentativo + adjetivo, dá nome a 01 (um) morro, a 01 (um) ribeirão e a 01 (uma) vila em General Carneiro.

O geomorfotopônimo Grotão de Cima, formado pela unidade lexical grota + sufixo -ão, já mencionado + preposição + substantivo comum, nomeia 01 (um) córrego no município de Guiratinga. O geomorfotopônimo Grotão dos Cavalos, formado pela unidade lexical grotão, já mencionada + conectivo com desinência de plural $-s+$ substantivo comum com desinência de plural -s, particulariza 01 (um) córrego em Torixoréu. 
Os geomorfotopônimos de estrutura simples subdividem-se em derivados e não derivados. Os geomorfotopônimos Baixada e Invernada, formados pelas unidades lexicais baixar e invernar + sufixo -ada, indicador de tempo ou de grandeza, extensão, dão nomes a 01 (uma) cabeceira no município de General Carneiro, a 01 (um) córrego em Guiratinga, a 01 (um) córrego em Pontal do Araguaia, a 02 (dois) córregos em Ribeirãozinho e a 02 (dois) córregos em Torixoréu.

O geomorfotopônimo Alcantilado, formado pela unidade lexical alcantilar + sufixo -ado, indicador de grandeza ou extensão, dá nome a 01 (um) distrito em Guiratinga e a 01 (um) córrego em Poxoréu que estabelece divisa entre os municípios de Poxoréu e Dom Aquino, por isso consta nas relações de topônimos dos dois municípios. O geomorfotopônimo Esbarrancado, formado pela unidade lexical esbarrancar + sufixo -ado, já mencionado, nomeia 01 (um) córrego em Guiratinga e 01 (um) córrego em Ponte Branca,

Os geomorfotopônimos Buracão, Grotão e Varjão, formados pelas unidades lexicais buraco, grota e varja + sufixo -ão, indicador de aumentativo, nomeiam 01 (um) córrego no município de General Carneiro, 07 (sete) córregos em Guiratinga, 01 (um) córrego e 01 (uma) cabeceira em Pontal do Araguaia, 02 (dois) córregos em Poxoréu, 02 (dois) córregos em Ribeirãozinho e 04 (quatro) córregos em Tesouro. Os geomorfotopônimos Furninha, Grotinha e Serrinha, formados pelas unidades lexicais furna, grota e serra + sufixo -inha, indicador de diminutivo, dão nomes a 01 (um) córrego em General Carneiro, a 02 (dois) córregos em Guiratinga, a 01 (um) córrego em Poxoréu, a 01 (um) córrego em Tesouro e a 02 (dois) córregos em Torixoréu.

Alguns geomorfotopônimos apresentam dupla sufixação. O geomorfotopônimo Boqueirão, formado pela unidade lexical boca + sufixo -(qu)eira, indicador de aumento + sufixo -ão, já mencionado, nomeia 01 (um) córrego no município de Araguainha. O geomorfotopônimo Paredãozinho, formado pela unidade lexical parede + sufixo -ão e sufixo -inho, já mencionados, denomina 01 (um) córrego no município de General Carneiro. 
O geomorfotopônimo Chupador, formado pela unidade lexical chupar + sufixo -dor, indicador de qualidade ou estado, denomina 01 (um) córrego em Pontal do Araguaia. O geomorfotopônimo Tombador, formado pela unidade lexical tombar + sufixo -dor, já mencionado, nomina 02 (dois) córregos no município de Guiratinga, 01 (um) córrego em Poxoréu e 01 (um) córrego em Torixoréu. Vale ressaltar que um dos córregos denominado Tombador estabelece divisa entre os municípios de Guiratinga e Alto Garças, por isso consta nas relações de topônimos dos dois municípios.

Os geomorfotopônimos Coval e Pontal, formados pelas unidades lexicais cova e ponta + sufixo -al, indicador de grande quantidade, denominam 01 (um) córrego no município de General Carneiro e 01 (um) morro em Ponte Branca. O geomorfotopônimo Espinhaço, formado pela unidade lexical espinha + sufixo -aço, indicador de aumento, singulariza 01 (um) morro em Guiratinga.

O geomorfotopônimo Boqueirãozinho apresenta tripla sufixação, formado pela unidade lexical boca + sufixo -(qu)eira + sufixo -ão + sufixo -(z)inho, já mencionados, dá nome a 01 (um) córrego em General Carneiro que estabelece divisa entre General Carneiro e Barra do Garças.

Os geomorfotopônimos simples e sem derivação Cova, Estreito, Furna e Serra nomeiam 01 (um) córrego no município de Araguainha, 02 (dois) córregos em Guiratinga, 01 (um) córrego em Pontal do Araguaia, 01 (um) córrego em Ponte Branca, 02 (dois) córregos em Tesouro e 01 (um) córrego em Torixoréu. O geomorfotopônimo Furnas apresenta desinência de plural -s, dá nome a 02 (dois) córregos em Guiratinga, a 01 (um) ribeirão e a 01 (um) córrego em Torixoréu. Vale observar que o topônimo Estreito foi classificado nesta taxionomia e não na taxionomia dimensiotopônimo, porque nos mapas e nas cartas topográficas ele está precedido pelo conectivo do.

Na microrregião Tesouro ocorre, nesta taxionomia, a toponimização do acidente físico. As unidades lexicais estreito, serra, serrinha, monte, morro e vale, em geral, exercem em um sintagma toponímico a função de termo genérico, ou seja, o termo que antecede o topônimo. Nesta taxionomia, porém, elas são usadas para dar nomes a outros acidentes físico. Os geomorfotopônimos simples Serra, Estreito 
e Serrinha dão nomes a 06 (seis) córregos. Os geomorfotopônimos compostos Monte Negro, Morro Alto, Morro Chato, Morro da Mesa, Morro do Chapéu, Morro Grande e Vale Rico nomeiam 07 (sete) córregos e 01 (um) distrito.

Pode-se observar bom índice de produtividade toponímica, nesta taxionomia, na microrregião Tesouro. O geomorfotopônimo Alcantilado dá nome a 01 (um) córrego no município de Poxoréu e a 01 (um) distrito em Guiratinga. O geomorfotopônimo Furna nomeia 01 (um) córrego em Guiratinga, 01 (um) córrego em Pontal do Araguaia e outro em Tesouro. O geomorfotopônimo Furnas denomina 02 (dois) córregos em Guiratinga, 01 (um) córrego e 01 (um) ribeirão em Torixoréu. O geomorfotopônimo Furninha denomina 01 (um) córrego em General Carneiro, 01 (um) córrego em Poxoréu e outro em Torixoréu. O geomorfotopônimo Estreito dá nome a 01 (um) córrego no município de Guiratinga e a outro em Tesouro.

O geomorfotopônimo Serra toponimiza 01 (um) córrego no município de Araguainha e outro em Ponte Branca. O geomorfotopônimo Serrinha dá nome a 01 (um) córrego em Tesouro e a outro em Torixoréu. O geomorfotopônimo Buracão denomina 02 (dois) córregos em Guiratinga, 01 (um) córrego em Poxoréu e outro em Tesouro. O geomorfotopônimo Esbarrancado dá nome a 01 (um) córrego em Guiratinga e a outro em Ponte Branca.

O geomorfotopônimo Grotão nomeia 01 (um) córrego no município de General Carneiro, 04 (quatro) córregos em Guiratinga, 01 (um) córrego em Poxoréu, 01 (um) córrego em Ribeirãozinho, 02 (dois) córregos em Tesouro, 01 (um) córrego e 01 (uma) cabeceira em Pontal do Araguaia. O geomorfotopônimo Grotinha dá nome a 02 (dois) córregos em Guiratinga. Os geomorfotopônimos Grotão de Cima nomina 01 (um) córrego em Guiratinga e o geomorfotopônimo Grotão dos Cavalos particulariza 01 (um) córrego em Torixoréu.

O geomorfotopônimo Invernada denomina 01 (um) córrego no município de General Carneiro, 01 (um) córrego em Guiratinga, 01 (um) córrego em Pontal do Araguaia, 01 (um) córrego em Ribeirãozinho e 02 (dois) em Torixoréu. O geomorfotopônimo Tombador dá nome a 02 (dois) córregos em Guiratinga, a 01 (um) córrego em Poxoréu e a outro em Torixoréu. O geomorfotopônimo Varjão 
nomeia 01 (um) córrego em Guiratinga, 01 (um) córrego em Ribeirãozinho e outro em Tesouro.

O geomorfotopônimo Paredão Grande denomina 01 (um) morro, 01 (um) ribeirão e 01 (uma) vila em General Carneiro. O geomorfotopônimo Morro Alto dá nome a 01 (um) córrego no município de Ponte Branca e a 01 (um) córrego que estabelece divisa entre os municípios de Guiratinga e Tesouro, por isso consta nas relações de topônimos dos dois municípios. Pode-se acrescentar ainda, se considerar a primeira unidade lexical dos geomorfotopônimos compostos, os geomorfotopônimos Morro Chato e Morro Grande que denominam 02 (dois) córregos em Guiratinga. Os geomorfotopônimos Morro da Mesa e Morro do Chapéu denominam 02 (dois) córregos em Tesouro.

Pode-se ainda considerar o geomorfotopônimo Cova que singulariza 01 (um) córrego no município de Torixoréu e o geomorfotopônimo Coval que dá nome a 01 (um) córrego em General Carneiro. O geomorfotopônimo Boqueirão denomina 01 (um) córrego em Araguainha e o geomorfotopônimo Boqueirãozinho dá nome a 01 (um) córrego em General Carneiro. O geomorfotopônimo Pontal singulariza 01 (um) morro em Ponte Branca e o geomorfotopônimo Pontal do Araguaia nomeia 01 (um) município mato-grossense.

Os geomorfotopônimos correspondem a 7,7\% do total de topônimos da microrregião Tesouro.

\section{Dimensiotopônimos}

Registram-se 23 (vinte e três) dimensiotopônimos na microrregião Tesouro. As unidades lexicais que se referem as características dimensionais, tais como, extensão, altura, largura, grossura, etc., quando utilizadas para dar nomes a acidentes físicos e a acidentes antrópicos, recebem nos estudos toponímicos a denominação de dimensiotopônimos. 
São 01 (um) dimensiotopônimo no município de Araguainha, 05 (cinco) em General Carneiro, 04 (quatro) em Guiratinga, 02 (dois) em Pontal do Araguaia, 06 (seis) em Poxoréu, 01 (um) em Tesouro e 04 (quatro) em Torixoréu. Não há registro de dimensiotopônimos nos municípios de Ponte Branca e Ribeirãozinho. Apresentase a seguir o gráfico desta taxionomia com os respectivos percentuais por município (GRÁFICO 59).

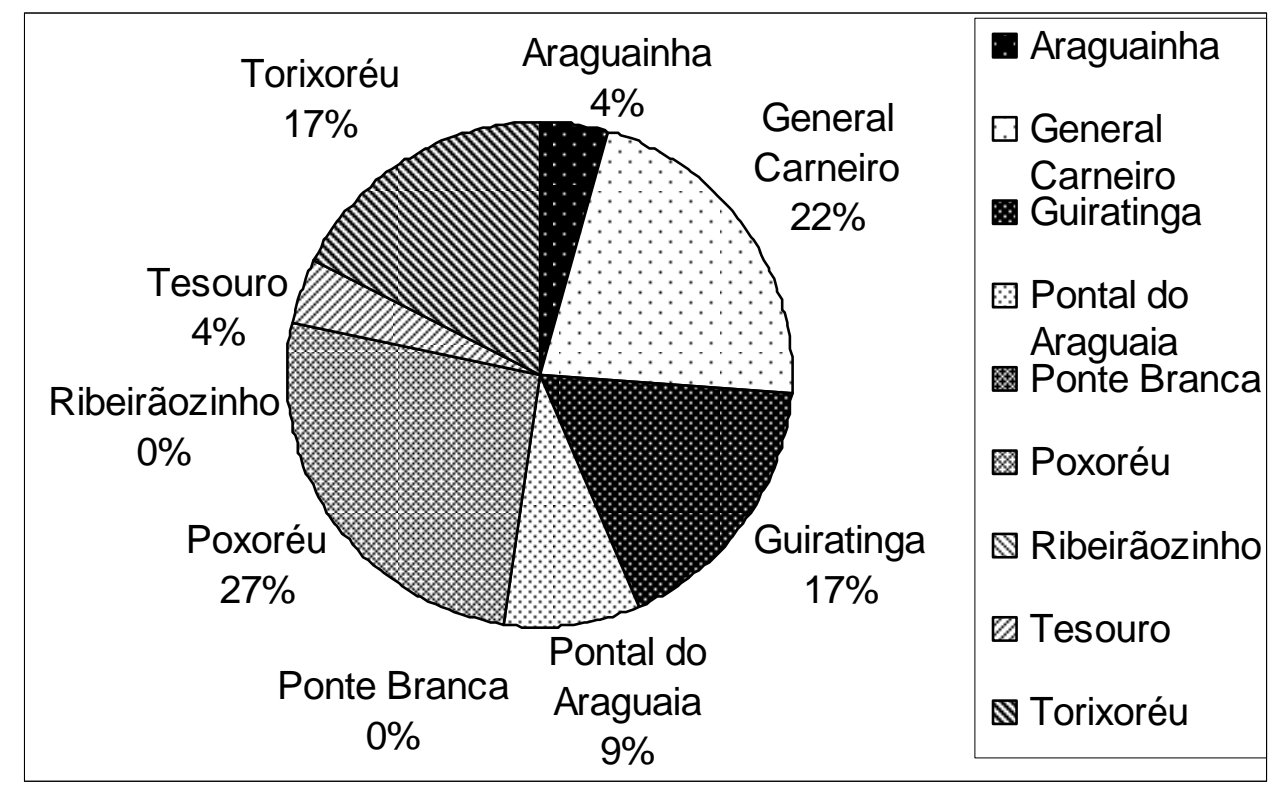

GRÁFICO 59 - Total dos dimensiotopônimos da microrregião Tesouro.

Registram-se, na microrregião Tesouro, 01 (um) dimensiotopônimo bororo e 22 (vinte e dois) portugueses.

Considera-se, nesta pesquisa, que o dimensiotopônimo bororo Bagaréu possui estrutura simples. Ele dá nome a 01 (um) córrego no município de Poxoréu que estabelece divisa entre os municípios de Poxoréu e Rondonópolis, por isso consta nas relações de topônimos dos dois municípios.

A unidade lexical bagaréu está registrada na Enciclopédia Bororo: "Biagaréu * biága, pequenos; réu, suf. poss. O pequeno, o reduzido. - * c.a. [pequeno curso d'água]. Cór. afl. da dir. do c. m. do Pogúbo, rio Vermelho: c. Biagaréu." Albisetti; Venturelli (1962, p. 271)

Considera-se, nesta pesquisa, que os dimensiotopônimos portugueses da microrregião Tesouro possuem estrutura simples. Eles denominam 22 (vinte e dois) acidentes físicos. 
O dimensiotopônimo Fundo dá nome a 01 (um) córrego no município de Araguainha, a 02 (dois) córregos em Pontal do Araguaia e a 01 (um) córrego em Tesouro. Os dimensiotopônimos Comprida e Fundo nomeiam 02 (duas) cabeceiras e 03 (três) córregos em General Carneiro. Os dimensiotopônimos Além, Comprida e Fundo nominam 01 (uma) cabeceira e 03 (três) córregos em Guiratinga. Os dimensiotopônimos Comprida, Fundo e Grande denominam 01 (uma) serra, 01 (uma) cabeceira e 03 (três) córregos em Poxoréu. A serra Grande estabelece divisa entre os municípios de Poxoréu e Primavera do Leste, por isso consta nas relações de topônimos dos dois municípios. Os dimensiotopônimos Comprida, Fundo, Pequeno e Sobra toponimizam 04 (quatro) córregos em Torixoréu.

Alguns dimensiotopônimos apresentam produtividade toponímica. $\mathrm{O}$ dimensiotopônimo Comprida nomeia 02 (duas) cabeceiras em General Carneiro, 01 (uma) cabeceira em Poxoréu, 01 (um) córrego em Torixoréu, 01 (uma) cabeceira e 01 (um) córrego em Guiratinga.

O dimensiotopônimo Fundo toponímiza 01 (um) córrego em Araguainha, 03 (três) córregos em General Carneiro, 01 (um) córrego em Guiratinga, 02 (dois) córregos em Pontal do Araguaia, 01 (um) córrego em Poxoréu, 01 (um) córrego em Tesouro e 01 (um) córrego em Torixoréu. O dimensiotopônimo Grande dá nome a 02 (dois) córregos em Poxoréu e a 01 (uma) serra que estabelece divisa entre os municípios de Poxoréu e Primavera do Leste.

Os dimensiotopônimos correspondem a 2,2\% do total de topônimos da microrregião Tesouro.

\section{Cardinotopônimos}

As unidades lexicais que se referem às posições geográficas em geral, quando usadas para dar nomes a acidentes físicos e a acidentes antrópicos, são classificadas como cardinotopônimos nos estudos toponímicos. Registram-se, na microrregião Tesouro, 21 (vinte e um) cardinotopônimos. 
São 01 (um) cardinotopônimo no município de General Carneiro, 10 (dez) em Guiratinga, 01 (um) em Pontal do Araguaia, 01 (um) em Ponte Branca, 04 (quatro) em Poxoréu, 03 (três) em Tesouro e 01 (um) em Torixoréu. Não há registro de cardinotopônimos nos municípios de Araguainha e Ribeirãozinho. Apresenta-se a seguir o gráfico desta taxionomia com os respectivos percentuais por município (GRÁFICO 60).

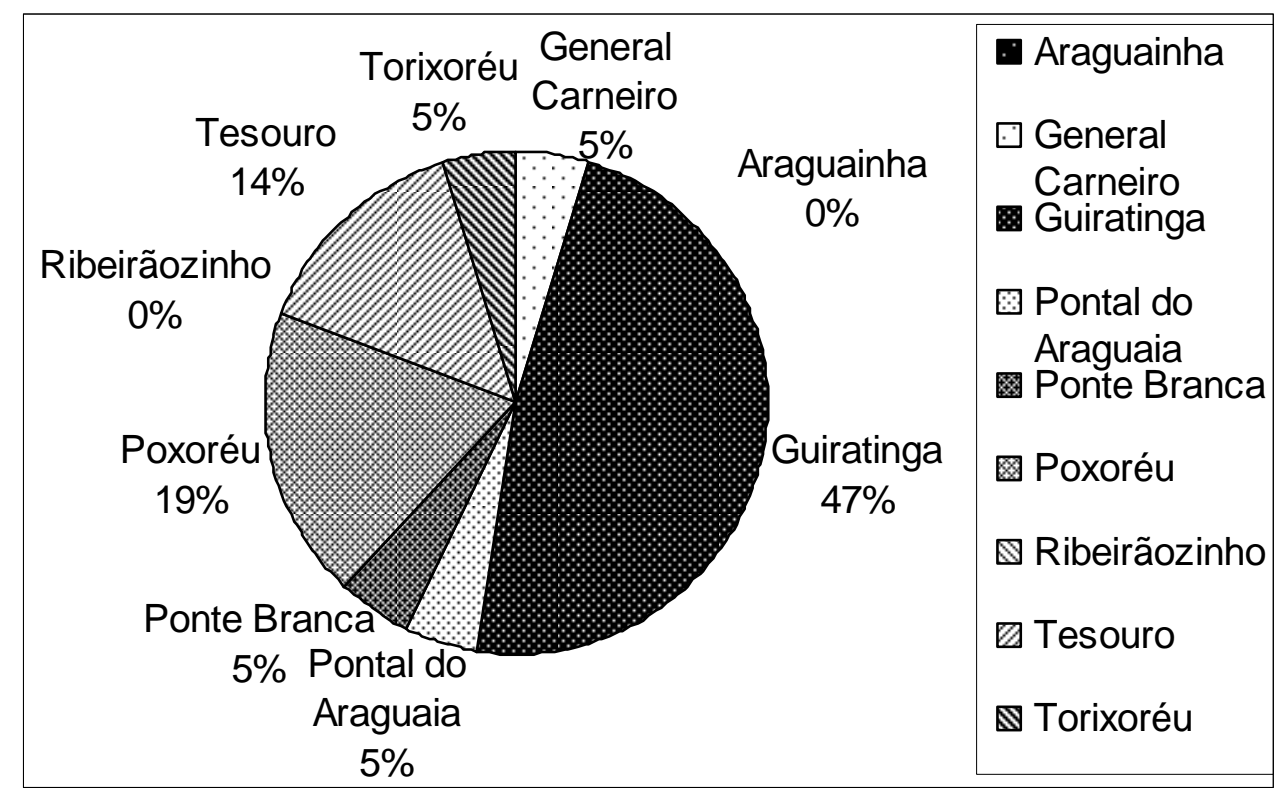

GRÁFICO 60 - Total dos cardinotopônimos da microrregião Tesouro.

São 01 (um) cardinotopônimo tupi e 20 (vinte) portugueses.

O cardinotopônimo tupi Alto Coité possui estrutura híbrida, formado pela unidade lexical portuguesa alto + unidade lexical tupi coité, dá nome a 01 (um) distrito no município de Poxoréu.

Considera-se, nesta pesquisa, que os cardinotopônimos portugueses da microrregião Tesouro possuem estrutura simples. Eles denominam 20 (vinte) acidentes físicos.

Os cardinotopônimos simples e sem derivação Alto, Divisa e Meio denominam 01 (um) córrego em General Carneiro, 01 (uma) serra, 02 (dois) morros e 05 (cinco) córregos em Guiratinga, 01 (um) morro em Ponte Branca, 03 (três) córregos em Poxoréu, 01 (um) córrego em Tesouro, 01 (um) córrego em Torixoréu e 01 (um) ribeirão que consta nas relações de topônimos dos seguintes municípos: Guiratinga, 
Pontal do Araguaia e Tesouro, porque estabelece divisa do município de Guiratinga com Pontal do Araguaia e Tesouro.

O cardinotopônimo Divisinha, formado pela unidade lexical divisa + sufixo inha, indicador de diminutivo, dá nome a 01 (um) córrego no município de Tesouro e é o segundo topônimo de 01 (um) córrego em Guiratinga.

Os cardinotopônimos apresentam produtividade toponímica na microrregião Tesouro. O cardinotopônimo Divisinha toponimiza 01 (um) córrego no município de Tesouro e outro em Guiratinga. O cardinotopônimo Alto dá nome a 01 (um) morro em Guiratinga e a outro em Ponte Branca. O cardinotopônimo Divisa nomeia 01 (um) córrego em Poxoréu, 01 (um) morro, 02 (dois) córregos, 01 (uma) serra em Guiratinga e 01 (um) ribeirão que estabelece divisa do município de Guiratinga com os municípios de Pontal do Araguaia e Tesouro. O cardinotopônimo Meio denomina 01 (um) córrego em General Carneiro, 03 (três) córregos em Guiratinga, 02 (dois) córregos em Poxoréu, 01 (um) córrego em Tesouro e outro em Torixoréu.

Os cardinotopônimos correspondem a 2,0\% do total de topônimos da microrregião Tesouro.

\section{Astrotopônimos}

Registram-se 06 (seis) astrotopônimos na microrregião Tesouro. As unidades lexicais que se referem aos corpos celestes em geral, quando usadas para nomear acidentes físicos e acidentes antrópicos, recebem nos estudos toponímicos a denominação de astrotopônimos.

São 05 (cinco) astrotopônimos no município de Guiratinga e 01 (um) em Tesouro. Não há registro de astrotopônimos nos municípios de Araguainha, General Carneiro, Pontal do Araguaia, Ponte Branca, Poxoréu, Ribeirãozinho e Torixoréu. Devido à pequena quantidade de astrotopônimos e ao fato de só 02 (dois) municípios registrarem topônimos, não se apresenta gráfico para esta taxionomia. 
Os astrotopônimos da microrregião Tesouro são portugueses e, quanto à estrutura, subdividem-se em simples e composto.

O astrotopônimo composto Estrela do Leste, formado por substantivo comum + conectivo + substantivo comum, dá nome a 01 (uma) localidade no município de Guiratinga.

Os astrotopônimos de estrutura simples e não derivados Estrela e Saturno denominam 01 (uma) serra, 02 (dois) córregos e 01 (um) ribeirão que nasce no município de Guiratinga e deságua no município de Tesouro, por isso consta nas relações de topônimos dos dois municípios. A serra da Estrela encontra-se em áreas dos municípios de Guiratinga e Alto Garças, por isso consta nas relações de topônimos dos dois municípios.

O astrotopônimo Estrela apresenta produtividade toponímica na microrregião Tesouro porque nomeia 01 (uma) serra, 01 (um) córrego e 01 (um) ribeirão.

Os astrotopônimos correspondem a 0,6\% do total de topônimos da microrregião Tesouro.

\section{Cromotopônimos}

As unidades lexicais que se referem à escala cromática em geral, quando usadas para denominar acidentes físicos e acidentes antrópicos, são classificadas, nos estudos toponímicos, como cromotopônimos. São 05 (cinco) cromotopônimos na microrregião Tesouro.

São 01 (um) cromotopônimo no município de Araguainha, 01 (um) em Ponte Branca, 02 (dois) em Poxoréu e 01 (um) em Tesouro. Não há registro de cromotopônimos nos municípios de General Carneiro, Guiratinga, Pontal do Araguaia, Ribeirãozinho e Torixoréu. Devido à pequena quantidade de topônimos, não se apresenta gráfico para esta taxionomia. 
Os cromotopônimos da microrregião Tesouro são portugueses e possuem estrutura simples.

O cromotopônimo simples e não derivado Vermelho nomeia 01 (um) rio no município de Poxoréu, esse rio deságua no município de Rondonópolis, por isso consta nas relações de topônimos dos dois municípios. O cromotopônimo simples e com derivação Ferrugem, formado pela unidade lexical ferro + sufixo -ugem, indicador de quantidade, abundância, dá nome a 01 (um) córrego em Tesouro.

O cromotopônimo Dourado, formado pela unidade lexical dourar + sufixo ado, indicador de um tanto, nomeia 01 (um) ribeirão no município de Poxoréu. O cromotopônimo Retinta, formado pelo prefixo re-, indicador de intensidade + unidade lexical tinta, denomina 01 (um) córrego que consta nas relações de topônimos de dois municípios porque estabelece divisa entre Araguainha e Ponte Branca.

Os cromotopônimos correspondem a $0,5 \%$ do total de topônimos da microrregião Tesouro.

\section{Igneotopônimos}

Nos estudos toponímicos as unidades lexicais que se referem ao fogo, abrangendo todos os produtos resultantes de sua ação direta, quando usadas para dar nomes a acidentes físicos e a acidentes antrópicos, são denominadas igneotopônimos. Registram-se 05 (cinco) igneotopônimos na microrregião Tesouro.

São 02 (dois) igneotopônimos no município de Poxoréu e 03 (três) em Torixoréu. Não há registro de igneotopônimos nos municípios de Araguainha, General Carneiro, Guiratinga, Pontal do Araguaia, Ponte Branca, Ribeirãozinho e Tesouro. Devido à pequena quantidade de igneotopônimos, não se apresenta gráfico para esta taxionomia.

Os igneotopônimos da microrregião Tesouro são portugueses e possuem estrutura simples. 
O igneotopônimo simples e não derivado Faísca dá nome a 01 (um) córrego no município de Poxoréu

O igneotopônimo Fumaça, formado pela unidade lexical fumo + sufixo -aça, indicador de aumento, denomina 01 (um) córrego em Poxoréu e 01 (um) córrego em Torixoréu. O igneotopônimo Queimado, formado pela unidade lexical queimar + sufixo -ado, indicador do efeito da ação, nomeia 01 (um) córrego em Torixoréu. 0 igneotopônimo Queimadinha apresenta dupla sufixação, formado pela unidade lexical queimar + sufixo -ado, já referido + sufixo -inha, indicador de diminutivo, toponimiza 01 (um) córrego em Torixoréu.

Apesar da pequena quantidade de igneotopônimos constata-se que ocorre produtividade toponímica, nesta taxionomia, na microrregião Tesouro. 0 igneotopônimo Fumaça dá nome a 01 (um) córrego em Poxoréu e a 01 (um) córrego em Torixoréu. Pode-se ainda considerar o igneotopônimo Queimado que toponimiza 01 (um) córrego e o igneotopônimo Queimadinha que denomina 01 (um) córrego, ambos em Torixoréu.

Os igneotopônimos correspondem a $0,5 \%$ do total de topônimos da microrregião Tesouro.

\section{Morfotopônimos}

Registram-se 04 (quatro) morfotopônimos na microrregião Tesouro. As unidades lexicais que se referem às formas geométricas, quando utilizadas para nomear acidentes físicos e acidentes antrópicos, são classificadas, nos estudos toponímicos, na taxionomia morfotopônimos.

São 01 (um) morfotopônimo no município de Guiratinga, 01 (um) Pontal do Araguaia e 02 (dois) em Tesouro. Não há registro de morfotopônimos nos municípios de Araguainha, General Carneiro, Ponte Branca, Poxoréu, Ribeirãozinho e Torixoréu. Devido à pequena quantidade de morfotopônimos, não se apresenta gráfico para esta taxionomia. 
Os morfotopônimos da microrregião Tesouro são portugueses e possuem estrutura simples.

O morfotopônimo Chato dá nome a 01 (um) morro no município de Guiratinga. O morfotopônimo Figura nomeia 01 (um) córrego em Pontal do Araguaia. O morfotopônimo Redondo denomina 01 (um) morro e o morfotopônimo Volta toponimiza 01 (um) córrego, ambos em Tesouro.

Os morfotopônimos correspondem a $0,4 \%$ do total de topônimos da microrregião Tesouro.

\section{Meteorotopônimo}

São classificados como meteorotopônimos, nos estudos toponímicos, as unidades lexicais que se referem aos fenômenos atmosféricos, quando utilizadas para denominar acidentes físicos e acidentes antrópicos. Registra-se 01 (um) meteorotopônimo na microrregião Tesouro

O meteorotopônimo da microrregião Tesouro localiza-se no município de General Carneiro. Devido ao registro de 01 (um) meteorotopônimo, não se apresenta gráfico para esta taxionomia.

O meteorotopônimo Corisco é português, possui estrutura simples e dá nome a 01 (um) córrego no município de General Carneiro.

O meteorotopônimo corresponde a $0,1 \%$ do total de topônimos da microrregião Tesouro. 


\section{Taxionomias de natureza antrópica da microrregião Tesouro}

\section{Sociotopônimos}

As unidades lexicais que se referem às atividades sociais ou laborais, quando utilizadas para dar nomes a acidentes físicos e a acidentes antrópicos, são denominadas sociotopônimos nos estudos toponímicos. Registram-se 73 (setenta e três) sociotopônimos. É a taxionomia, de natureza antrópica, que mais apresenta topônimos na microrregião Tesouro.

São 04 (quatro) sociotopônimos no município de Araguainha, 06 (seis) em General Carneiro, 18 (dezoito) em Guiratinga, 03 (três) em Pontal do Araguaia, 11 (onze) em Ponte Branca, 08 (oito) em Poxoréu, 04 (quatro) em Ribeirãozinho, 10 (dez) em Tesouro e 09 (nove) em Torixoréu. É a taxionomia que mais registra topônimos no município de Ponte Branca. Apresenta-se a seguir o gráfico desta taxionomia com os respectivos percentuais por município (GRÁFICO 61).

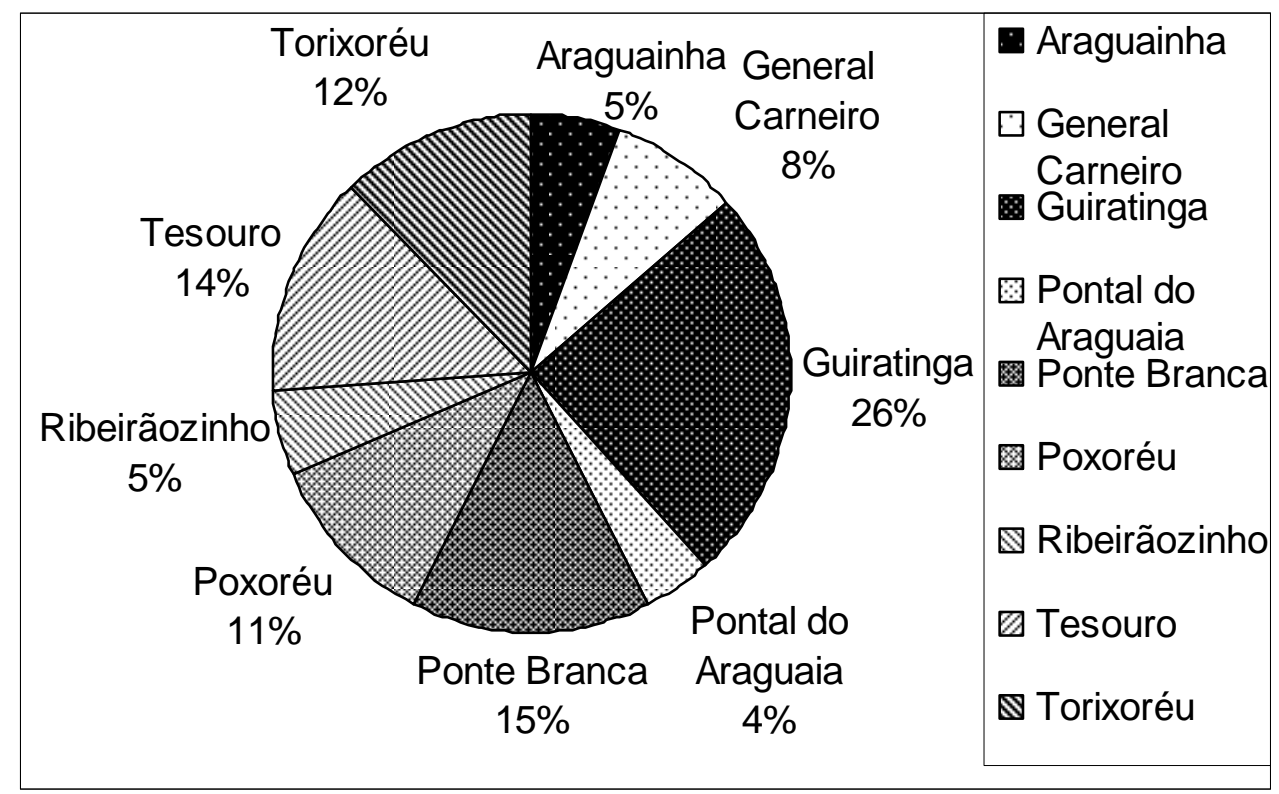

GRÁFICO 61 - Total dos sociotopônimos da microrregião Tesouro.

Os sociotopônimos da microrregião Tesouro são portugueses. 
Considera-se, nesta pesquisa, que os sociotopônimos portugueses da microrregião Tesouro, quanto à estrutura, subdividem-se em simples e compostos. São 66 (sessenta e seis) sociotopônimos de estrutura simples e 07 (sete) sociotopônimos de estrutura composta. Eles denominam 70 (setenta) acidentes físicos e 03 (três) acidentes antrópicos. Os 09 (nove) municípios da microrregião Tesouro possuem sociotopônimos portugueses.

Os sociotopônimos Bisca, Função e Retiro dão nomes a 01 (um) ribeirão e a 02 (dois) córregos no município de Araguainha. Os sociotopônimos Expedição, Olaria, Presente e Retiro nomeiam 04 (quatro) córregos em General Carneiro. Em Guiratinga, os sociotopônimos Galante, Ioiô, Olaria, Retiro e Roça denominam 09 (nove) córregos. Em Ponte Branca os sociotopônimos Casal, Fortuna, Olaria e Pouso toponimizam 01 (uma) localidade, 05 (cinco) córregos e 01 (uma) serra. Os sociotopônimos Galante, Olaria, Pouso, Roça e Trabalho denominam 05 (cinco) córregos em Poxoréu. O sociotopônimo Esparramo nomina 01 (um) córrego que estabelece divisa entre os municípios de Poxoréu e Dom Aquino, por isso consta nas relações de topônimos dos dois municípios.

Os sociotopônimos Galante, Olaria e Rainha dão nomes a 04 (quatro) córregos no município de Ribeirãozinho. Os sociotopônimos Celebra, Pouso e Tesouro nomeiam 01 (um) município mato-grossense e 03 (três) córregos em Tesouro. Os sociotopônimos Conquista, Estiva, Piquenique, Posse e Roça denominam 05 (cinco) córregos em Torixoréu. O sociotopônimo Mortes apresenta desinência de plural $-\mathrm{s}$ e dá nome a 01 (um) rio que consta nas relações de topônimos dos municípios de General Carneiro e Poxoréu, porque estabelece divisa desses dois municípios com o município de Novo São Joaquim.

Os sociotopônimos Canoeiro e Garimpeiro, formados pelas unidades lexicais canoa e garimpo + sufixo -eiro, indicador de ofício, profissão, denominam 01 (um) córrego em Pontal do Araguaia e 01 (um) córrego em Tesouro. Os sociotopônimos Boiadeiro e Salgadeira apresentam dupla sufixação, formados pelas unidades lexicais boi e salgar + sufixo -ada, indicador de quantidade, porção + sufixo -eiro/a, já mencionado, dão nomes a 01 (um) córrego em Guiratinga e a 01 (um) córrego em Tesouro. O sociotopônimo Matuta, o dicionário Houaiss considera que esta unidade lexical é formada pela unidade lexical mato + sufixo -uta, mas não foi possível 
encontrar este sufixo nas gramáticas pesquisadas. O Dicionário Etimológico da Língua Portuguesa de José Pedro Machado registra que o sufixo -uto é o correspondente erudito de -udo e traduz as idéias de quantidade, posse ou propriedade. O sociotopônimo Matuta denomina 01 (um) córrego em Tesouro.

O sociotopônimo Rusguento, formado pela unidade lexical rusga + sufixo (u)ento, indicador de tendência, estado, nomeia 01 (um) córrego no município de Guiratinga. O sociotopônimo Revoltoso, formado pela unidade lexical revoltar + sufixo -oso, indicador de abundância, cheio de, dá nome a 01 (um) córrego em Tesouro. O sociotopônimo Confusão, formado pela unidade lexical confuso + sufixo -ão, indicador de aumentativo, singulariza 01 (um) ribeirão em Tesouro. O sociotopônimo Mortandade, formado pela unidade lexical morta + sufixo -(n)dade, indicador de qualidade ou estado, nomeia 01 (um) córrego em General Carneiro e 01 (um) córrego em Guiratinga. Vale observar que o dicionário Houaiss registra que nesta unidade lexical ocorreu a nasalização da vogal a.

O sociotopônimo Escondido, formado pela unidade lexical esconder + sufixo ido, indicador do resultado da ação, dá nome a 01 (uma) cabeceira no município de Pontal do Araguaia, a 01 (um) córrego de Ponte Branca e a 01 (um) córrego em Torixoréu. Os sociotopônimos Fazendinha, Galantinho, Garimpinho, Pousinho e Retirinho, formados pelas unidades lexicais fazenda, galante, garimpo, pouso e retiro + sufixo -inho, indicador de diminutivo, nomeiam 01 (um) córrego em Araguainha, 02 (dois) córregos em Guiratinga, 01 (um) córrego em Pontal do Araguaia, 02 (dois) córregos em Ponte Branca, 01 (um) córrego em Tesouro e 02 (dois) córregos em Torixoréu.

O sociotopônimo composto Engenho de Serra, formado por substantivo comum + preposição + substantivo comum, dá nome a 01 (um) córrego no município de Guiratinga. O sociotopônimo Fazenda Divisa, formado por substantivo comum + substantivo comum, nomeia 01 (um) córrego em Guiratinga. Os sociotopônimos Fazenda Velha, Pouso Alegre, Pouso Alto e Retiro Velho, formados por substantivo comum + adjetivo, denominam 02 (dois) córregos em Guiratinga, 01 (um) córrego em Ponte Branca, 01 (um) córrego em Poxoréu e 01 (uma) localidade em Torixoréu. 
Ocorre produtividade, nesta taxionomia, na microrregião Tesouro. O sociotopônimo Casal dá nome a 01 (um) córrego e a 01 (uma) serra no município de Ponte Branca. O sociotopônimo Galante nomeia 01 (um) córrego em Guiratinga, 01 (um) córrego em Poxoréu e outro em Ribeirãozinho. O sociotopônimo Galantinho toponimiza a 01 (um) córrego em Guiratinga. O sociotopônimo Olaria denomina 01 (um) córrego em General Carneiro, 01 (um) córrego em Guiratinga, 02 (dois) córregos em Ponte Branca, 01 (um) córrego em Poxoréu e outro em Ribeirãozinho.

O sociotopônimo Pouso nomeia 01 (um) córrego em Poxoréu, 01 (um) córrego em Tesouro, 01 (um) córrego e 01 (uma) localidade em Ponte Branca. 0 sociotopônimo Pousinho dá nome a 01 (um) córrego em Ponte Branca. Pode-se acrescentar o sociotopônimo Pouso Alegre que nomina 01 (um) córrego em Guiratinga e o sociotopônimo Pouso Alto que singulariza 01 (uma) localidade em Torixoréu. O sociotopônimo Fazenda Velha nomeia 01 (um) córrego em Guiratinga e outro em Ponte Branca. Pode-se acrescentar ainda o sociotopônimo Fazenda Divisa que dá nome a 01 (um) córrego em Guiratinga.

O sociotopônimo Rainha denomina 02 (dois) córregos em Ribeirãozinho. sociotopônimo Retiro nomeia 01 (um) córrego em Araguainha, 01 (um) córrego em General Carneiro e 04 (quatro) córregos em Guiratinga. O sociotopônimo Retiro Velho dá nome a 01 (um) córrego em Poxoréu. O sociotopônimo Retirinho denomina 01 (um) córrego em Araguainha, 01 (um) córrego em Guiratinga, 01 (um) córrego em Pontal do Araguaia, 01 (um) córrego em Ponte Branca e outro em Torixoréu.

O sociotopônimo Roça dá nome a 02 (dois) córregos em Guiratinga, a 01 (um) córrego em Poxoréu e a outro em Torixoréu. O sociotopônimo Tesouro nomeia 01 (um) município mato-grossense e 01 (um) córrego em Tesouro. O sociotopônimo Escondido denomina 01 (uma) cabeceira em Pontal do Araguaia, 01 (um) córrego em Ponte Branca e outro em Torixoréu. O sociotopônimo Mortandade toponimiza 01 (um) córrego em General Carneiro e 01 (um) córrego em Guiratinga.

O sociotopônimo Mortes dá nome a 01 (um) rio, não é considerado produtivo apesar de constar nas relações de topônimos de General Carneiro e Poxoréu, porque estabelece divisa desses dois municípios com município de Novo São Joaquim. 
Os sociotopônimos correspondem a $7,1 \%$ do total de topônimos da microrregião Tesouro.

\section{Ergotopônimos}

Registram-se, na microrregião Tesouro, 63 (sessenta e três) ergotopônimos. As unidades lexicais que se referem aos elementos de cultura material, quando utilizadas para denominar acidentes físicos e acidentes antrópicos, recebem nos estudos toponímicos a denominação de ergotopônimos.

São 03 (três) ergotopônimos no município de Araguainha, 07 (sete) em General Carneiro, 25 (vinte e cinco) em Guiratinga, 05 (cinco) em Pontal do Araguaia, 02 (dois) em Ponte Branca, 04 (quatro) em Poxoréu, 10 (dez) em Tesouro e 07 (sete) em Torixoréu. Não há registro de ergotopônimo no município de Ribeirãozinho. Apresenta-se a seguir o gráfico desta taxionomia com os respectivos percentuais por município (GRÁFICO 62).

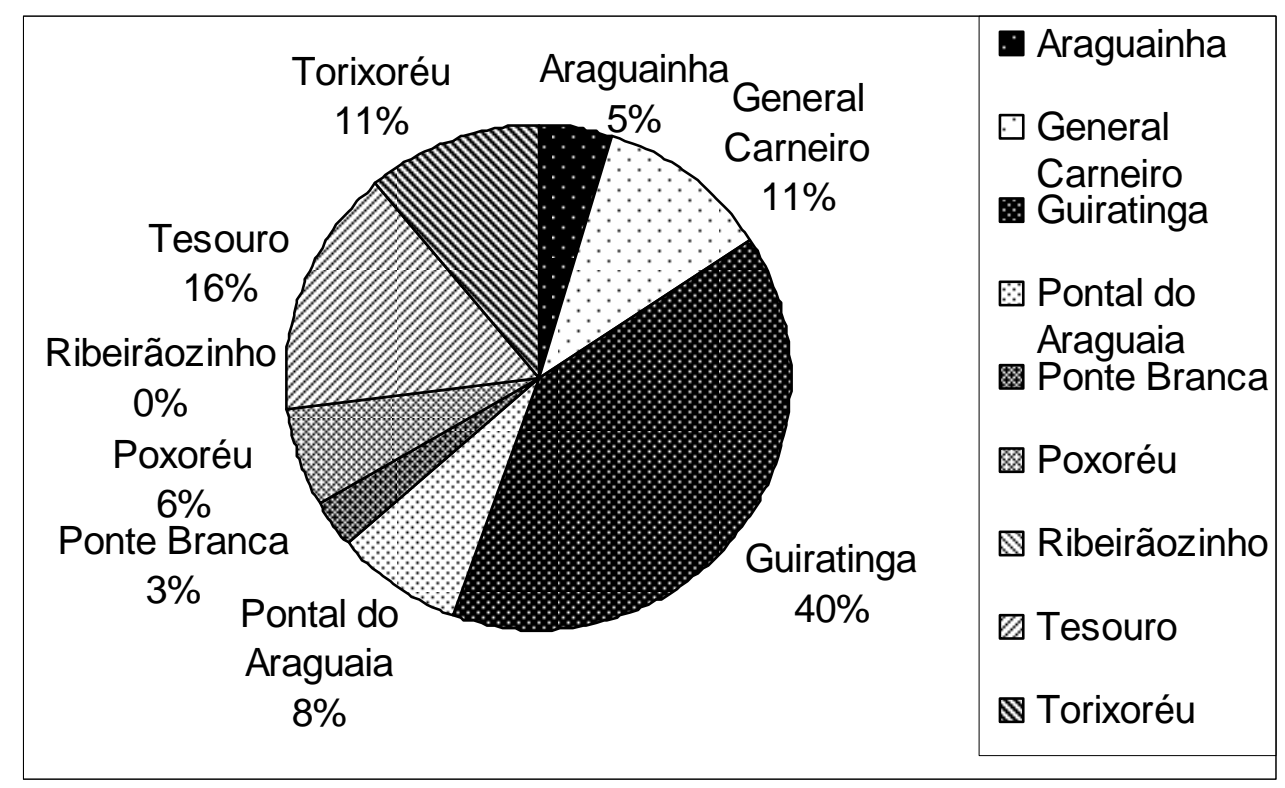

GRÁFICO 62 - Total dos ergotopônimos da microrregião Tesouro.

São 02 (dois) ergotopônimos tupis, 02 (dois) bororos, 02 (dois) africanos e 57 (cinqüenta e sete) portugueses. 
Considera-se, nesta pesquisa, que os ergotopônimos tupis Jacuba e Jirau possuem estrutura simples. O ergotopônimo Jacuba dá nome a 01 (um) córrego no município de General Carneiro e o ergotopônimo Jirau toponimiza 01 (um) córrego em Tesouro.

Considera-se, nesta pesquisa, que os ergotopônimos bororos possuem estrutura simples. O ergotopônimo bororo Tarigameridoba singulariza 01 (um) córrego no município de General Carneiro. O ergotopônimo Jurucuba nomina 01 (um) córrego em Guiratinga.

A unidade lexical tarigameridoba está registrada na Enciclopédia Bororo com as seguintes características: "Toríga - * tóri, pedra; gá, lasca [lasca de pedra]. Designação: 1. de uma lasca de pedra sílex usada como faca; 4. da faca (neol.)." e "Meridódo - vart. Meridódu, ${ }^{\star}$ meri $_{3}$, gume; dódo, suf. afiado." Albisetti; Venturelli (1962, p. 925; 792)

A unidade lexical jurucuba está registrada na Enciclopédia Bororo: "Jorúbo Kúru - *ji, (d)ele; orúbo, remédio; kúru, líqüido [cór. do remédio líqüido]. Cór. afl. da dir. do Pogúbo Borororéu Pó Ruguréu, cór. Areia: cór Jorubocura." Albisetti; Venturelli (1962, p. 691)

O ergotopônimo africano Monjolo é considerado de estrutura simples nesta pesquisa e nomeia 01 (um) córrego no município de Guiratinga e 01 (um) córrego em Tesouro.

Considera-se, nesta pesquisa, que os ergotopônimos portugueses da microrregião Tesouro, quanto à estrutura, subdividem-se em simples e compostos. São 55 (cinqüenta e cinco) ergotopônimos de estrutura simples e 02 (dois) ergotopônimos de estrutura composta. Eles denominam 57 (cinqüenta e sete) acidentes físicos.

Os ergotopônimos simples Balão, Fuzil e Matula dão nomes a 03 (três) córregos no município de Araguainha. Em General Carneiro, os ergotopônimos Botina, Eixo e Forma nomeiam 03 (três) córregos. O córrego da Forma estabelece divisa entre os municípios de General Carneiro e Barra do Garças. Os ergotopônimos Arame, Bateia, Canivete, Forma, Mesa, Panela e Pelego nomeiam 
09 (nove) córregos, 02 (dois) morros e 01 (um) ribeirão em Guiratinga. No município de Pontal do Araguaia, os ergotopônimos Farinha, Lata e Mesa particularizam 02 (dois) córregos e 01 (um) morro.

Os ergotopônimos Arame e Lixa dão nomes a 02 (dois) córregos no município de Ponte Branca. Em Poxoréu, os ergotopônimos Clarineta, Forma e Janela denominam 02 (dois) córregos e 01 (um) morro. Os ergotopônimos Bomba, Chapéu, Garapa, Pião, Rolete e Zinco denominam 06 (seis) córregos e 01 (um) morro em Tesouro. Em Torixoréu, os ergotopônimos Enxada, Taca e Tiro nomeiam 04 (quatro) córregos.

O ergotopônimo Malas apresenta desinência de plural -s e dá nome a 01 (um) ribeirão no município de Poxoréu. O ergotopônimo Currais apresenta desinência de plural -is e particulariza 01 (um) córrego em Torixoréu.

Os ergotopônimos derivados Barracão, Caixão e Portão, formados pelas unidades lexicais barraca, caixa e porta + sufixo -ão, indicador de aumentativo, nomeiam 01 (um) córrego em Pontal do Araguaia, 04 (quatro) córregos e 01 (um) morro no município de Guiratinga.

Os ergotopônimos Ponteiro, Porteira, Potreiro e Tinteiro, formados pelas unidades lexicais ponta, porta, potro e tinta + sufixo -eiro, indicador de instrumento, de aumento ou de lugar continente, nomeia 01 (um) córrego no município de General Carneiro, 04 (quatro) córregos em Guiratinga, 01 (um) córrego em Tesouro e 01 (um) córrego em Torixoréu. O ergotopônimo Torrinha, formado pela unidade lexical torre + sufixo -inha, indicador de diminutivo, toponimiza 01 (uma) cabeceira em General Carneiro.

O ergotopônimo Rapadura apresenta dupla sufixação, formado pela unidade lexical rapar + sufixo -ado, indicador de qualidade ou estado + sufixo -ura, indicador do resultado da ação, singulariza 01 (um) córrego no município de Torixoréu. O ergotopônimo Ponteirinho também apresenta dupla sufixação, formado pela unidade lexical ponta + sufixo -eiro + sufixo -inho, já referidos, dá nome a 01 (um) córrego em Guiratinga. 
O ergotopônimo composto Barracão Queimado, formado pela unidade lexical barracão, já referida + unidade lexical queimar + sufixo -ado, indicador do efeito da ação, dá nome a 01 (um) córrego no município de Guiratinga. O ergotopônimo Curral Velho, formado por substantivo comum + adjetivo, nomeia 01 (um) córrego em Pontal do Araguaia.

Ocorre produtividade toponímica, nesta taxionomia, na microrregião Tesouro. O ergotopônimo africano Monjolo nomeia 01 (um) córrego em Guiratinga e outro em Tesouro. O ergotopônimo Arame dá nome a 03 (três) córregos em Guiratinga e a 01 (um) em Ponte Branca. O ergotopônimo Forma nomina 01 (um) córrego em General Carneiro, 01 (um) córrego em Poxoréu, 01 (um) córrego e 01 (um) ribeirão em Guiratinga.

O ergotopônimo Mesa nomeia 01 (um) morro no município de Pontal do Araguaia, 02 (dois) morros e 01 (um) córrego em Guiratinga. Os ergotopônimos Pião dá nome a 02 (dois) córregos em Tesouro e o ergotopônimo Taca denomina 02 (dois) córregos em Torixoréu. O ergotopônimo Barracão toponimiza 01 (um) morro, 01 (um) córrego e o ergotopônimo Barracão Queimado dá nome a 01 (um) córrego em Guiratinga.

O ergotopônimo Caixão denomina 02 (dois) córregos no município de Guiratinga e 01 (um) córrego em Pontal do Araguaia. O ergotopônimo Porteira dá nome a 02 (dois) córregos em Guiratinga e a 01 (um) córrego em Tesouro. $\mathrm{O}$ ergotopônimo Potreiro nomeia 01 (um) córrego em Guiratinga e outro em Torixoréu. Pode-se ainda considerar os ergotopônimos Ponteirinho e Ponteiro que nomeiam 02 (dois) córregos em Guiratinga.

Os ergotopônimos correspondem a 6,2\% do total de topônimos da microrregião Tesouro.

\section{Antropotopônimos}


Os nomes próprios individuais, quando utilizados para nomeiar acidentes físicos e acidentes antrópicos, recebem nos estudos toponímicos a denominação de antropotopônimos. Registram-se 51 (cinqüenta e um) antropotopônimos na microrregião Tesouro.

São 05 (cinco) antropotopônimos no município de Araguainha, 04 (quatro) em General Carneiro, 20 (vinte) em Guiratinga, 04 (quatro) em Pontal do Araguaia, 06 (seis) em Poxoréu, 01 (um) em Ribeirãozinho, 05 (cinco) em Tesouro e 06 (seis) em Torixoréu. O município de Ponte Branca não registra antropotopônimo. Apresenta-se a seguir o gráfico desta taxionomia com os respectivos percentuais por município (GRÁFICO 63).

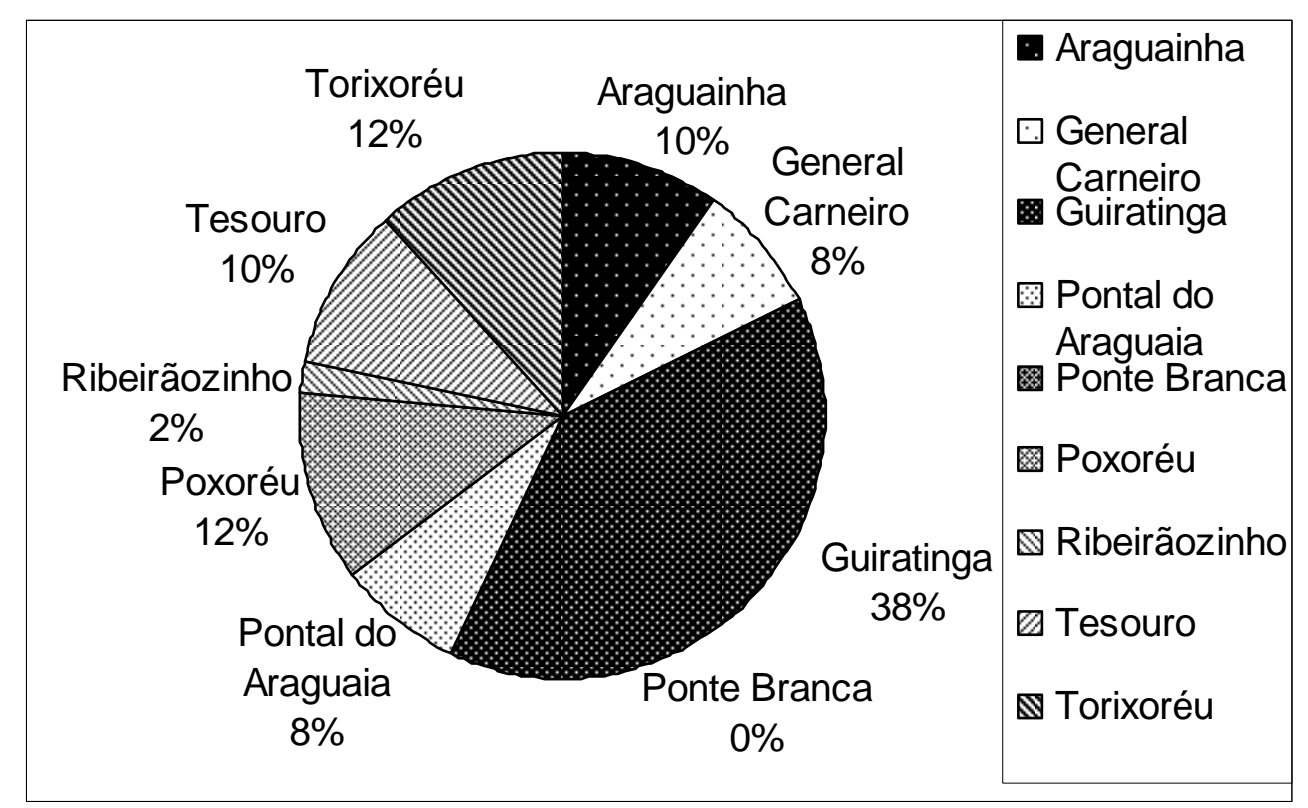

GRÁFICO 63 - Total dos antropotopônimos da microrregião Tesouro.

São 01 (um) antropotopônimo tupi e 50 (cinqüenta) portugueses.

Considera-se, nesta pesquisa, que o animotopônimo tupi Araci possui estrutura simples e dá nome a 01 (um) córrego no município de Pontal do Araguaia.

Considera-se, nesta pesquisa, que os antropotopônimos portugueses da microrregião Tesouro, quanto à estrutura, subdividem-se em simples e compostos. São 40 (quarenta) antropotopônimos de estrutura simples e 10 (dez) antropotopônimos de estrutura composta. Eles denominam 48 (quarenta e oito) acidentes físicos e 02 (dois) acidentes antrópicos. 
Os antropotopônimos de estrutura simples Correia e Garcês dão nomes a 01 (um) ribeirão e a 01 (uma) localidade Araguainha. O ribeirão Correia estabele divisa entre Araguainha e Alto Araguaia, por isso consta nas relações de topônimos dos dois municípios. Os antropotopônimos Couto e Magalhães denominam 02 (dois) córregos em General Carneiro. Em Guiratinga, os antropotopônimos Abreu, Agostinho, Armelindo, Baldiano, Bonfim, Floriano, Honorino, Jorge, Leandro, Moreiral, Ojasto, Ourino, Pio, Roque, Saturnino e Vilela nomeiam 15 (quinze) córregos e 01 (um) ribeirão. O córrego Moreiral estabelece divisa entre Guiratinga e São José do Povo, por isso consta nas relações de topônimos dos dois municípios. Os antropotopônimos Domingos, Jácomo, Pinga e Troale denominam 02 (dois) córregos e 02 (dois) morros em Poxoréu. Em Tesouro os antropotopônimos Dantas, Laura e Onofre particularizam 03 (três) córregos. Os antropotopônimos Esteves, Gorgulho e Juscelino dão nomes a 03 (três) córregos em Torixoréu.

Os hipocorísticos Joca, Juca, Kidi e Tonhá nomeiam 01 (um) córrego no município de Araguainha, 01 (uma) cabeceira em Pontal do Araguaia, 01 (um) córrego e 01 (uma) serra em Guiratinga.

Os antropotopônimos derivados Luizão e Pedrão, formados pelos substantivos próprios Luiz e Pedro + sufixo -ão, indicador de aumentativo, dão nomes a 01 (um) córrego em General Carneiro e a 01 (um) córrego em Pontal do Araguaia. Os antropotopônimos Ritinha, Teixeirinha, Pedrinho e Luizinho, formados pelos substantivos próprios Rita, Teixeira, Pedro e Luiz + sufixo -inho/a, indicador de diminutivo, nomeiam 01 (um) córrego em General Carneiro, 01 (um) córrego em Guiratinga, 01 (um) córrego em Pontal do Araguaia e 01 (um) córrego em Ribeirãozinho.

Os antropotopônimos compostos apresentam as seguintes formações:

a) nome próprio + nome de família: João Deodoro, João Franco, João Gomes e João Leite;

b) nome próprio + nome próprio: João Batista, João Euzébio e Paulo Afonso;

c) nome de família + nome de família: Correia Dantas; 
d) hipocorístico + nome de família: Chico França;

e) nome próprio + conectivo + substantivo comum: Aparecida do Leste.

Os antropotopônimos compostos Correa Dantas e João Gomes denominam 02 (dois) córregos no município de Araguainha.

O antropotopônimo Chico França singulariza 01 (um) ribeirão no município de Guiratinga.

Os antropotopônimos Aparecida do Leste e João Leite nomeiam 01 (um) distrito e 01 (um) córrego no município de Poxoréu.

Os antropotopônimos João Batista e Paulo Afonso toponimizam 02 (dois) córregos no município de Tesouro.

Os antropotopônimos João Deodoro, João Euzébio e João Franco dão nome a 03 (três) córregos no município de Torixoréu.

Ocorre produtividade toponímica, nesta taxionomia, na microrregião Tesouro, se considerar o antropotopônimo Luizão que dá nome a 01 (um) córrego no município de General Carneiro e o antropotopônimo Luizinho que nomeia 01 (um) córrego em Ribeirãozinho. Em Pontal do Araguaia, os antropotopônimos Pedrão e Pedrinho denominam 02 (dois) córregos. E se considerar o primeiro nome dos antropotopônimos compostos, pode-se relacionar os antropotopônimos João Batista, João Deodoro, João Euzébio, João Franco, João Gomes e João Leite que dão nomes a 01 (um) córrego em Araguainha, a 01 (um) córrego em Poxoréu, a 01 (um) córrego em Tesouro e a 03 (três) córregos em Torixoréu.

Os antropotopônimos correspondem a 5,0\% do total de topônimos da microrregião Tesouro.

\section{Animotopônimos}


Registram-se 30 (trinta) animotopônimos na microrregião Tesouro. As unidades lexicais que se referem à cultura espiritual, abrangendo a todos os produtos do psiquismo humano, quando utilizadas para denominar acidentes físicos e acidentes antrópicos, são denominadas animotopônimos nos estudos toponímicos.

São 02 (dois) animotopônimos no município de Araguainha, 01 (um) em General Carneiro, 05 (cinco) em Guiratinga, 03 (três) em Pontal do Araguaia, 09 (nove) em Poxoréu, 02 (dois) em Ribeirãozinho, 05 (cinco) em Tesouro e 03 (três) em Torixoréu. Não há registro de animotopônimos no município de Ponte Branca. Apresenta-se a seguir o gráfico desta taxionomia com os respectivos percentuais por município (GRÁFICO 64).

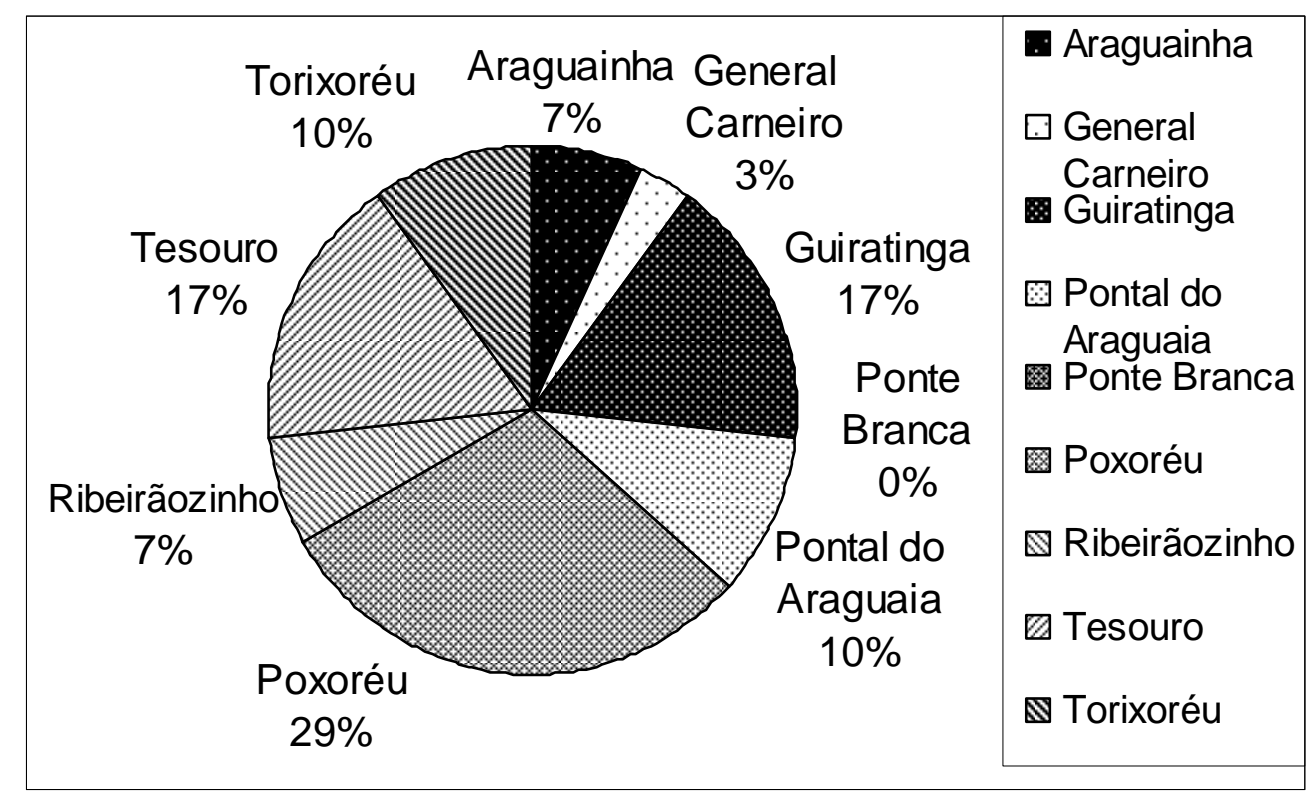

GRÁFICO 64 - Total dos animotopônimos da microrregião Tesouro.

Os animotopônimos da microrregião Tesouro são portugueses.

Considera-se, nesta pesquisa, que os animotopônimos portugueses da microrregião Tesouro, quanto à estrutura, subdividem-se em simples e compostos. São 20 (vinte) animotopônimos de estrutura simples e 10 (dez) animotopônimos de estrutura composta. Eles denominam 30 (trinta) acidentes físicos.

Os animotopônimos compostos Bela Vista, Boa Fé e Boa Vista, formados por adjetivo + substantivo comum, nomeiam 02 (dois) córregos no município de Araguainha, 02 (dois) córregos em Tesouro e 01 (um) córrego em Torixoréu. O 
animotopônimo Boa Aguada, formado por adjetivo + unidade lexical água + sufixo ada, indicador de grandeza, extensão, dá nome a 01 (um) córrego em Torixoréu.

O animotopônimo Boa Esperança, formado por adjetivo + unidade lexical esperar + sufixo -ança, indicador de qualidade ou estado, nomina 01 (um) córrego em Guiratinga, 01 (uma) cabeceira em Pontal do Araguaia, 01 (um) córrego em Tesouro e 01 (um) córrego em Torixoréu.

O animotopônimo simples e não derivado Engano dá nome a 01 (um) córrego em General Carneiro. O animotopônimo Bonito denomina 02 (dois) córregos em Guiratinga, sendo que um desses córregos estabelece divisa entre os municípios de Guiratinga e São José do Povo, por isso consta nas relações de topônimos dos dois municípios. Os animotopônimos Feio e Sossego nominam 02 (dois) córregos em Pontal do Araguaia. Os animotopônimos Engano, Inveja, Perigo e Rico nomeiam 04 (quatro) córregos em Poxoréu. Os animotopônimos Confusa e Confuso particularizam 02 (dois) córregos em Ribeirãozinho. O animotopônimo Engano toponimiza 01 (um) córrego em Tesouro.

O animotopônimo Saudade nomina 01 (uma) serra que consta nas relações de topônimos de Guiratinga, Poxoréu e Tesouro. Essa serra estabelece divisa entre os municípios de Poxoréu e Tesouro. O animotopônimo Vitória dá nome a 01 (um) córrego que estabelece divisa entre os municípios de Guiratinga e Poxoréu. Ambos constam nas relações de topônimos dos referidos municípios.

O animotopônimo Encantado, formado pela unidade lexical encantar + sufixo -ado, indicador do efeito da ação, dá nome a 01 (um) córrego no município de Poxoréu. O animotopônimo Perdidos, formado pela unidade lexical perder + sufixo ido, indicador do resultado da ação, apresenta desinência de plural -s e denomina 01 (uma) cabeceira e 01 (um) ribeirão em Poxoréu. Ambos estabelecem divisas entre os municípios de Poxoréu e Primavera do Leste, por isso constam nas relações de topônimos dos dois municípios.

Ocorre produtividade toponímica, nesta taxionomia, na microrregião Tesouro. O animotopônimo composto Boa Esperança denomina 01 (um) córrego no município de Guiratinga, 01 (uma) cabeceira em Pontal do Araguaia, 01 (um) córrego em 
Tesouro e outro em Torixoréu. O animotopônimo Boa Vista nomeia 01 (um) córrego em Araguainha, 01 (um) córrego em Tesouro e outro em Torixoréu. Se considerar a primeira unidade lexical do animotopônimo pode-se ainda acrescentar 0 animotopônimo Boa Aguada que denomina 01 (um) córrego em Torixoréu e o animotopônimo Boa Fé que dá nome a 01 (um) córrego em Tesouro.

O animotopônimo Bonito toponimiza 02 (dois) córregos no município de Guiratinga. O animotopônimo Perdidos nomeia 01 (uma) cabeceira e 01 (um) ribeirão em Poxoréu. O animotopônimo Engano nomina 01 (um) córrego no município de General Carneiro, 01 (um) córrego em Poxoréu e 01 (um) córrego em Tesouro. Pode-se ainda considerar os animotopônimos Confusa e Confuso que denominam 02 (dois) córregos em Ribeirãozinho.

O animotopônimo Saudade nomeia 01 (uma) serra que consta nas relações de topônimos de Guiratinga, Poxoréu e Tesouro. O animotopônimo Vitória dá nome a 01 (um) córrego que divide Guiratinga e Poxoréu, por isso não são considerados produtivos.

Os animotopônimos correspondem a 2,9\% do total de topônimos da microrregião Tesouro.

\section{Hagiotopônimos}

As unidades lexicais que se referem aos santos e santas da religião católicoromana, quando utilizadas para denominar acidentes físicos e acidentes antrópicos, recebem a denominação de hagiotopônimos nos estudos toponímicos. Registram-se 30 (trinta) hagiotopônimos na microrregião Tesouro.

São 01 (um) hagiotopônimo no município de Araguainha, 01 (um) em General Carneiro, 03 (três) em Guiratinga, 05 (cinco) em Pontal do Araguaia, 02 (dois) em Ponte Branca, 08 (oito) em Poxoréu, 02 (dois) em Ribeirãozinho, 03 (três) em 
Tesouro e 05 (cinco) em Torixoréu. Apresenta-se a seguir o gráfico desta taxionomia com os respectivos percentuais por município (GRÁFICO 65).

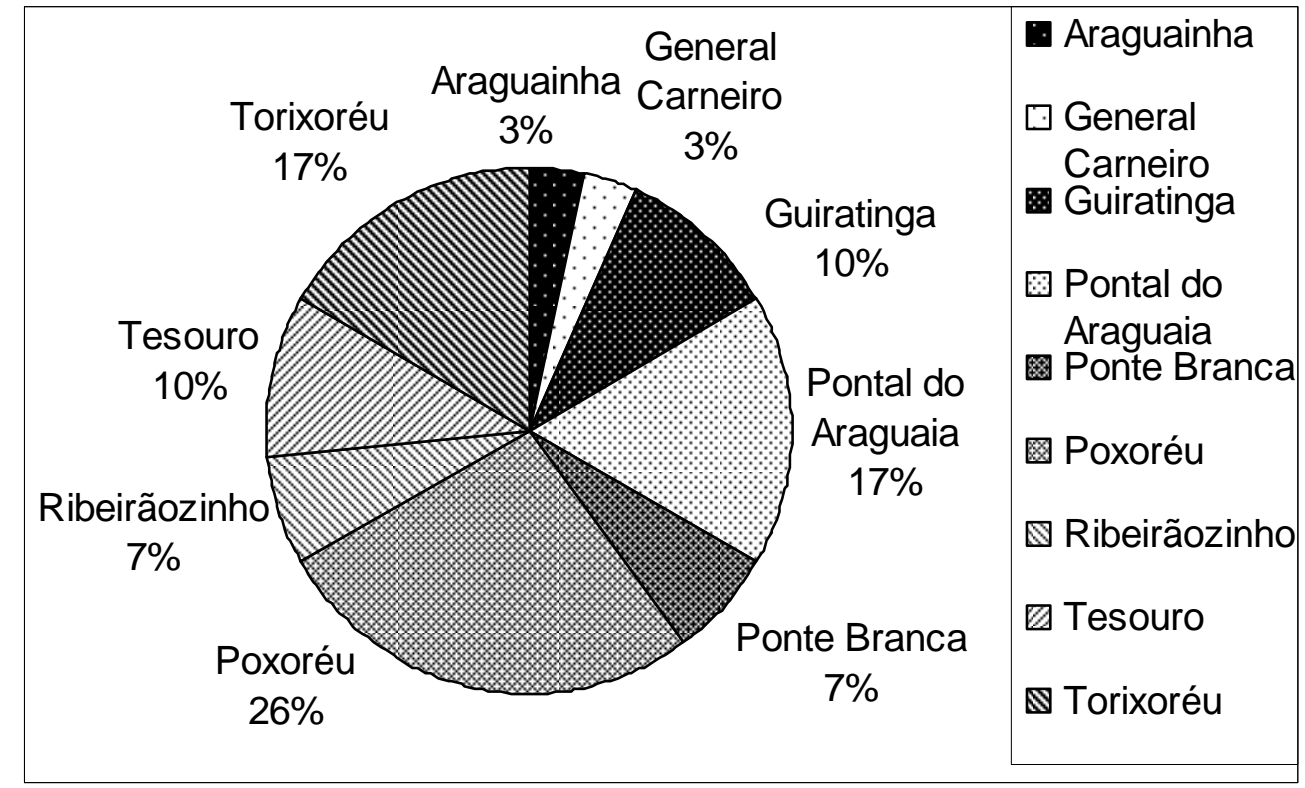

GRÁFICO 65 - Total dos hagiotopônimos da microrregião Tesouro.

Os hagiotopônimos da microrregião Tesouro são portugueses.

Os hagiotopônimos portugueses da microrregião Tesouro possuem estrutura composta. Eles denominam 29 (vinte e nove) acidentes físicos e 01 (um) acidente antrópico. Os 09 (nove) municípios da microrregião Tesouro possuem hagiotopônimos portugueses.

Os hagiotopônimos femininos Santa Arlinda e Santa Maria, formados por adjetivo + substantivo próprio, dão nomes a 01 (um) córrego em Pontal do Araguaia e a 02 (dois) córregos em Tesouro.

Os hagiotopônimos masculinos Santo Antônio e São Miguel, formados por adjetivo + substantivo próprio, nomeiam 01 (um) córrego no município de Pontal do Araguaia, 01 (uma) serra e 02 (dois) córregos em Guiratinga. Os hagiotopônimos São Carlos, São Lucas, São Paulo e São Pedro denominam 06 (seis) córregos em Poxoréu. O córrego São Paulo estabelece divisa entre os municípios de Poxoréu e São Pedro da Cipa, por isso consta nas relações de topônimos dos dois municípios. Os hagiotopônimos São Francisco e São Pedro nominam 01 (um) ribeirão e 01 (um) córrego em Torixoréu. 
O hagiotopônimo São Domingos nomeia 01 (um) rio que estabelece divisa do município de Torixoréu com os municípios de Ponte Branca e Ribeirãozinho. O hagiotopônimo São João denomina 01 (um) córrego e 01 (um) rio em Poxoréu, e também, 01 (um) ribeirão que nasce em Araguainha e estabelece divisa entre os municípios de Ponte Branca e Ribeirãozinho. O hagiotopônimo São José dá nome a 01 (uma) colônia em General Carneiro, a 01 (um) ribeirão e a 01 (um) córrego em Pontal do Araguaia, a 01 (um) córrego em Torixoréu e a 01 (um) ribeirão que estabelece divisa entre o município de Pontal do Araguaia e Tesouro, por isso consta nas relações de topônimos dos dois municípios.

O hagiotopônimo São Josezinho, formado por adjetivo + substantivo próprio José + sufixo -(z)inho, indicador de diminutivo, dá nome a 01 (um) córrego no município de Torixoréu.

Ocorre produtividade toponímica, nesta taxionomia, na microrregião Tesouro. O hagiotopônimo Santa Maria dá nome a 02 (dois) córregos no município de Tesouro. O hagiotopônimo Santo Antônio toponimiza 01 (um) córrego em Pontal do Araguaia, 01 (uma) serra e 01 (um) córrego em Guiratinga. O hagiotopônimo São Paulo singulariza 02 (dois) córregos em Poxoréu. O hagiotopônimo São Pedro nomeia 02 (dois) córregos em Poxoréu e 01 (um) córrego em Torixoréu.

O hagiotopônimo São José denomina 01 (uma) colônia no município de General Carneiro, 01 (um) córrego e 01 (um) ribeirão em Pontal do Araguaia, 01 (um) córrego em Torixoréu e 01 (um) ribeirão que estabelece divisa entre os municípios de Pontal do Araguaia e Tesouro. Pode-se ainda acrescentar o hagiotopônimo São Josezinho que toponimiza 01 (um) córrego em Torixoréu. 0 hagiotopônimo São João nomeia 01 (um) rio e 01 (um) córrego no município de Poxoréu e também 01 (um) ribeirão que nasce em Araguainha e estabelece divisa entre os municípios de Ponte Branca e Ribeirãozinho.

O hagiotopônimo São Domingos dá nome a 01 (um) rio que consta nas relações de topônimos dos municípios Ponte Branca, Ribeirãozinho e Torixoréu, porque estabelece divisa entre eles, por isso não é considerado produtivo. 
Os hagiotopônimos correspondem a 2,9\% do total de topônimos da microrregião Tesouro.

\section{Hodotopônimos}

As unidades lexicais que se referem às vias de comunicação urbana ou rural, quando utilizadas para denominar acidentes físicos e acidentes antrópicos, recebem a denominação de hodotopônimos nos estudos toponímicos. Registram-se 19 (dezenove) hodotopônimos na microrregião Tesouro.

São 01 (um) hodotopônimo no município de Araguainha, 01 (um) em General Carneiro, 04 (quatro) em Guiratinga, 01 (um) em Pontal do Araguaia, 02 (dois) em Ponte Branca, 04 (quatro) em Poxoréu, 01 (um) em Ribeirãozinho, 01 (um) em Tesouro e 04 (quatro) em Torixoréu. Apresenta-se a seguir o gráfico desta taxionomia com os respectivos percentuais por município (GRÁFICO 66).

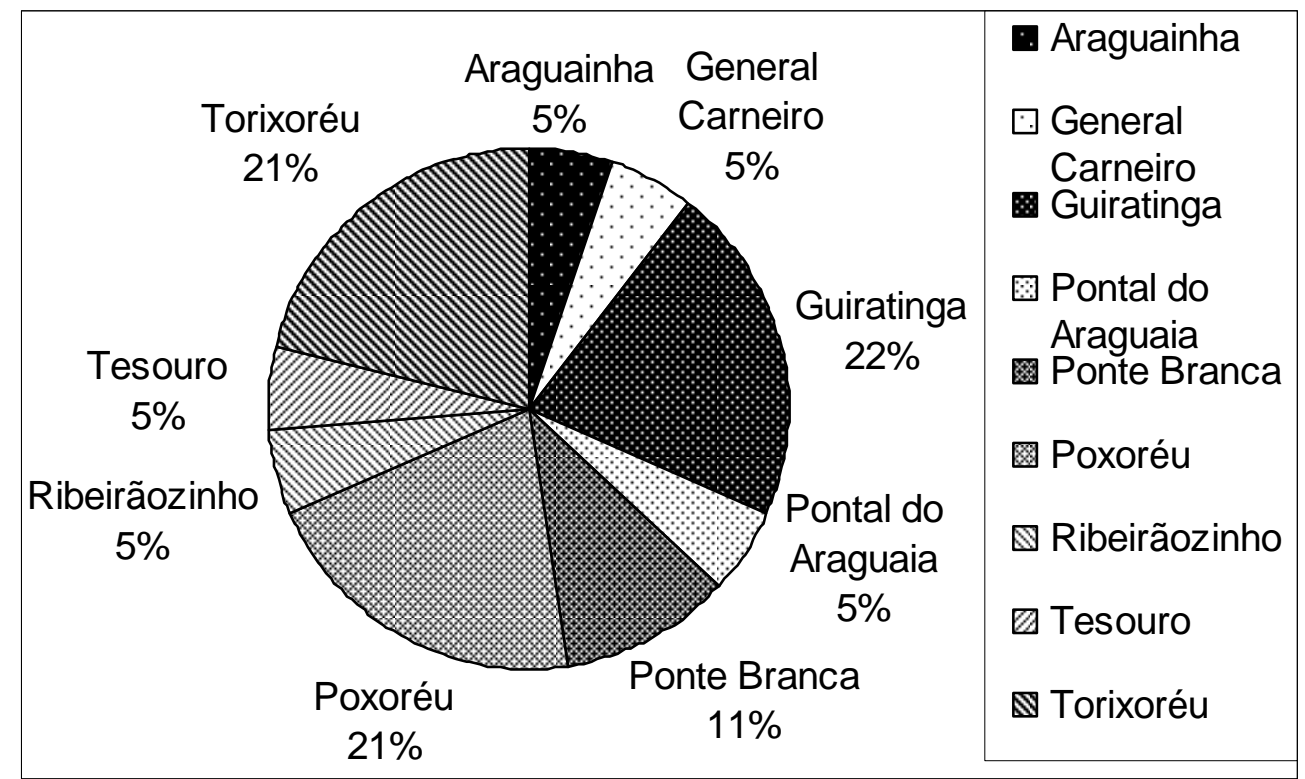

GRÁFICO 66 - Total dos hodotopônimos da microrregião Tesouro.

Os hodotopônimos da microrregião Tesouro são portugueses.

Considera-se, nesta pesquisa, que os hodotopônimos portugueses da microrregião Tesouro, quanto à estrutura, subdividem-se em simples e compostos. São 07 (sete) hodotopônimos de estrutura simples e 12 (doze) hodotopônimos de 
estrutura composta. Eles denominam 18 (dezoito) acidentes físicos e 01 (um) acidente antrópico. Os 09 (nove) municípios da microrregião Tesouro possuem hodotopônimos portugueses.

Os hodotopônimos compostos Ponte Alta e Ponte Branca, formados por substantivo comum + adjetivo, dão nomes, respectivamente, a 01 (um) córrego no município de Guiratinga e a 01 (um) município mato-grossense. O hodotopônimo Ponte de Pedra, formado por substantivo comum + preposição + substantivo comum, denomina 01 (um) córrego no município de Araguainha, 01 (um) ribeirão em Guiratinga, 01 (um) córrego em Pontal do Araguaia, 02 (dois) córregos em Torixoréu e 02 (dois) córregos em Poxoréu, sendo que um deles estabelece divisa entre Poxoréu e Dom Aquino, por isso consta nas relações de topônimos dos dois municípios. O hodotopônimo Ponte de Terra, formado por substantivo comum + preposição + substantivo comum, nomeia 01 (um) córrego no município de Guiratinga, 01 (um) córrego em Ponte Branca e 01 (um) córrego em Tesouro.

O hodotopônimo simples e não derivado Vão dá nome a 01 (um) córrego no município de Guiratinga. Os hodotopônimos Atalho e Desvio nomeiam 02 (dois) córregos em Poxoréu.

Os hodotopônimos Pontinha e Vauzinho, formados pelas unidades lexicais ponte e vau + sufixo -(z)inho/a, indicador de diminutivo, toponimizam 01 (um) córrego em General Carneiro, 01 (um) córrego em Ribeirãozinho e 01 (um) córrego em Torixoréu. O hodotopônimo Picadinha apresenta dupla sufixação, formado pela unidade lexical picar + sufixo -ada, indicador do efeito da ação + sufixo -inha, já mencionado, denomina 01 (um) córrego em Torixoréu.

Ocorre produtividade toponímica, nesta taxionomia, na microrregião Tesouro. O hodotopônimo Pontinha dá nome a 01 (um) córrego em General Carneiro e a outro em Ribeirãozinho. O hodotopônimo Ponte de Pedra nomeia 01 (um) córrego em Araguainha, 01 (um) ribeirão em Guiratinga, 01 (um) córrego em Pontal do Araguaia, 02 (dois) córregos em Poxoréu e 02 (dois) córregos em Torixoréu.

O hodotopônimo Ponte de Terra denomina 01 (um) córrego em Guiratinga, 01 (um) córrego em Ponte Branca e outro em Tesouro. Pode-se ainda acrescentar, se 
considerar a primeira unidade lexical dos hodotopônimos compostos, os hodotopônimos Ponte Alta que nomeia 01 (um) córrego em Guiratinga e o hodotopônimo Ponte Branca que dá nome a 01 (um) município mato-grossense.

Os hodotopônimos correspondem a 1,8\% do total de topônimos da microrregião Tesouro.

\section{Numerotopônimos}

As unidades lexicais que se referem aos adjetivos numerais, quando utilizados para nomear acidentes físicos e acidentes antrópicos, recebem a denominação de numerotopônimos nos estudos toponímicos. Registram-se 13 (treze) numerotopônimos na microrregião Tesouro.

São 01 (um) numerotopônimo no município de Araguainha, 03 (três) em Guiratinga, 03 (três) em Ponte Branca, 02 (dois) em Poxoréu, 03 (três) em Tesouro e 01 (um) em Torixoréu. Não há registro de numerotopônimos em General Carneiro, Pontal do Araguaia e Ribeirãozinho. Apresenta-se a seguir o gráfico desta taxionomia com os respectivos percentuais por município (GRÁFICO 67).

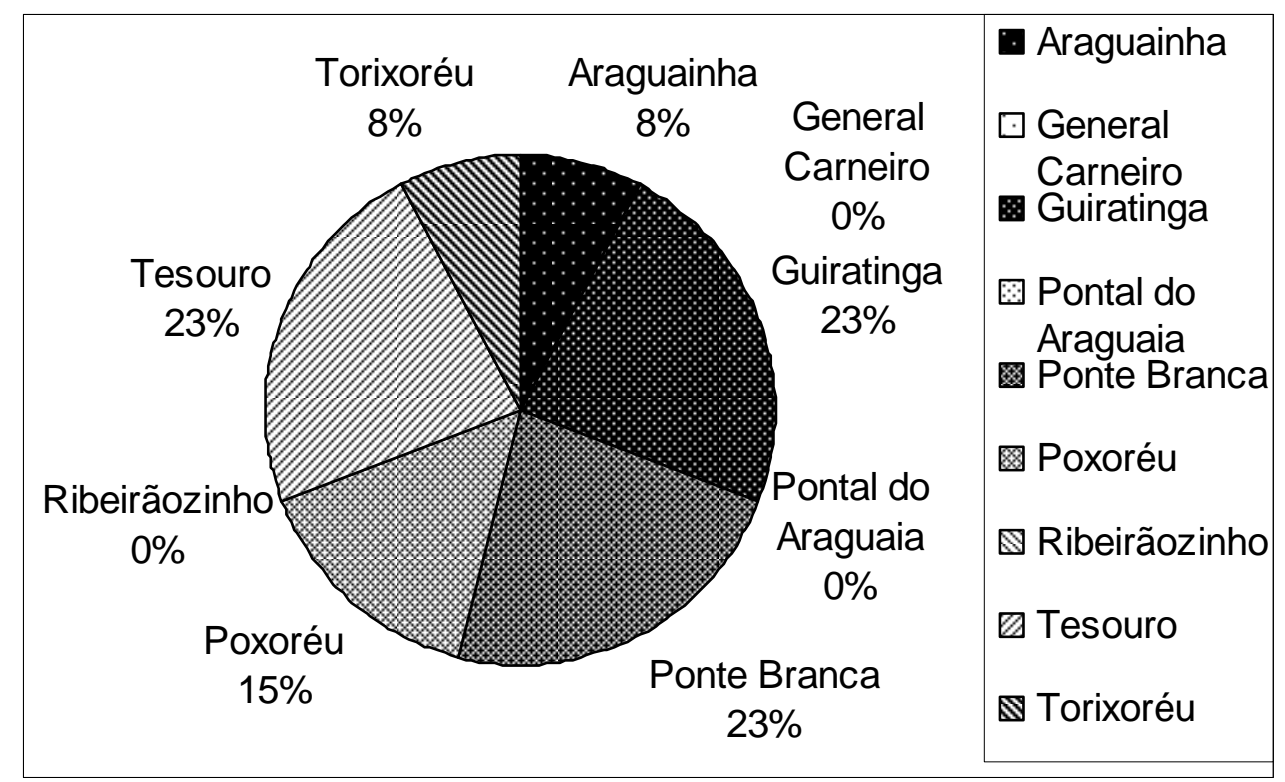

GRÁFICO 67 - Total dos numerotopônimos da microrregião Tesouro. 
Os numerotopônimos da microrregião Tesouro são portugueses.

Considera-se, nesta pesquisa, que os numerotopônimos portugueses da microrregião Tesouro, quanto à estrutura, subdividem-se em simples e compostos. São 01 (um) numerotopônimo de estrutura simples e 12 (doze) numerotopônimos de estrutura composta. Eles denominam 13 (treze) acidentes físicos.

O numerotopônimo de estrutura simples Sete particulariza 01 (um) córrego no município de Poxoréu e consta nas relações de topônimos dos municípios de Poxoréu e São Pedro da Cipa, porque estabelece divisa entre os dois municípios.

Os numerotopônimos compostos, formados por numeral + substantivo comum, apresentam desinência de plural. Os numerotopônimos Dois Córregos, Dois Galhos e Dois Irmãos denominam 03 (três) córregos no município de Guiratinga. O numerotopônimo Quatro Passagens particulariza 01 (um) córrego e 01 (uma) serra em Ponte Branca. O numerotopônimo Duas Barras dá nome a 01 (um) córrego em Poxoréu. Os numerotopônimos Três Barras e Três Irmãos nomeiam 02 (dois) córregos e 01 (um) morro em Tesouro. O numerotopônimo Três Cachoeiras nomina 01 (um) córrego em Torixoréu. O numerotopônimo Sete Voltas nomeia 01 (um) córrego que consta nas relações de topônimos dos municípios de Araguainha e Ponte Branca porque estabelece divisa entre eles.

Observa-se produtividade toponímica, nesta taxionomia, na microrregião Tesouro. O numerotopônimo Quatro Passagens dá nome a 01 (um) córrego e a 01 (uma) serra no município de Ponte Branca. O numerotopônimo Três Irmãos nomeia 01 (um) morro e 01 (um) córrego em Tesouro. Se considerar a primeira unidade lexical do numerotopônimo composto, pode-se acrescentar os numerotopônimos Dois Córregos, Dois Galhos e Dois Irmãos que dão nomes a 03 (três) córregos em Guiratinga. Os numerotopônimos Três Barras e Três Cachoeiras toponimizam, respectivamente, 01 (um) córrego no município de Tesouro e 01 (um) córrego em Torixoréu. O numerotopônimo Sete nomina 01 (um) córrego em Poxoréu e o numerotopônimo Sete Voltas denomina 01 (um) córrego que divide Araguainha e Ponte Branca. 
Os numerotopônimos correspondem a 1,3\% do total de topônimos da microrregião Tesouro.

\section{Hierotopônimos}

As unidades lexicais que se referem aos nomes sagrados de diferentes crenças: cristãs, maometanas, hebraicas, etc., às associações religiosas e aos locais de culto, quando utilizadas para nomear acidentes físicos e acidentes antrópicos, recebem nos estudos toponímicos a denominação de hierotopônimos. Registram-se 13 (treze) hierotopônimos na microrregião Tesouro.

São 02 (dois) hierotopônimos no município de Pontal do Araguaia, 07 (sete) em Poxoréu, 01 (um) em Ribeirãozinho, 01 (um) em Tesouro e 02 (dois) em Torixoréu. Não há registro de hierotopônimos nos municípios de Araguainha, General Carneiro, Guiratinga e Ponte Branca. Apresenta-se a seguir o gráfico desta taxionomia com os respectivos percentuais por município (GRÁFICO 68).

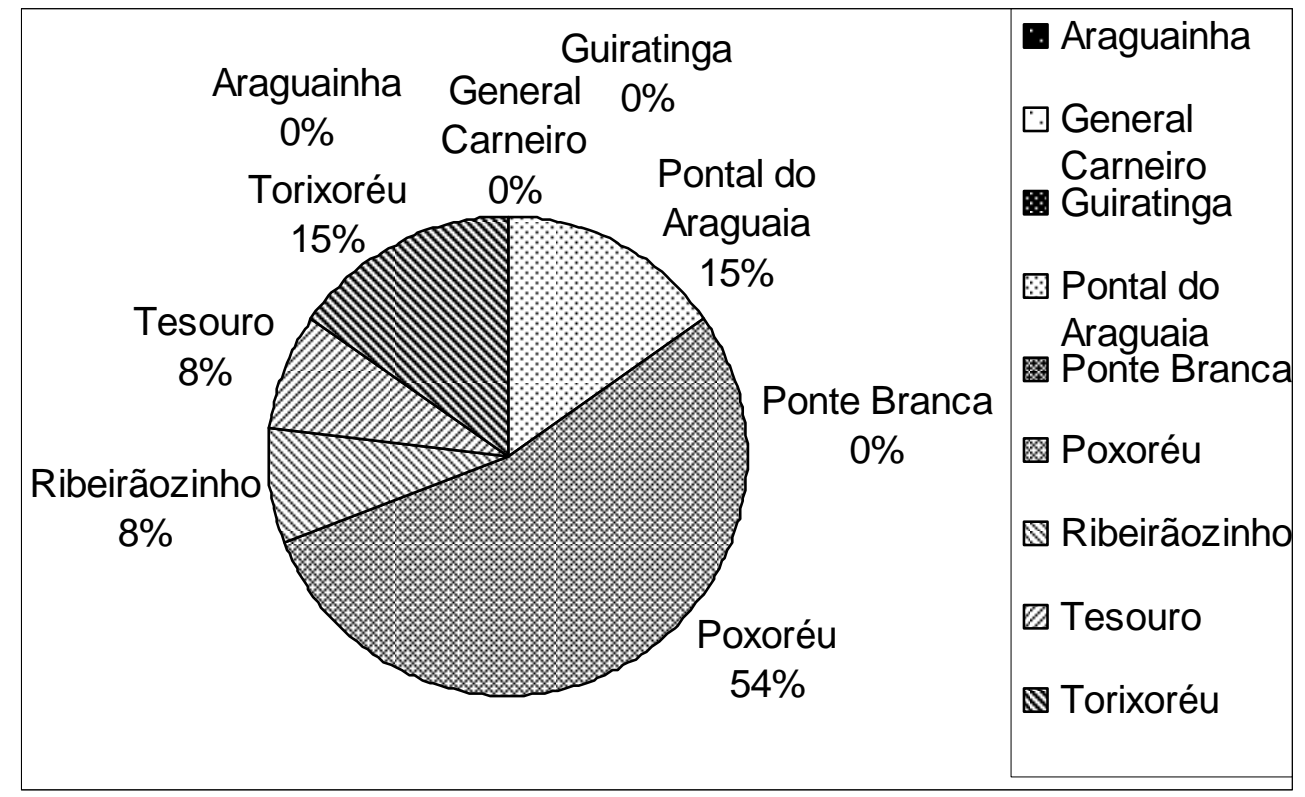

GRÁFICO 68 - Total dos hierotopônimos da microrregião Tesouro.

São 01 (um) hierotopônimo tupi e 12 (doze) portugueses na microrregião Tesouro. 
Considera-se, nesta pesquisa, que o hierotopônimo tupi da microrregião Tesouro possui estrutura híbrida. O hierotopônimo Jaraguazinho, formado pela unidade lexical tupi jaraguá + sufixo -(z)inho, indicador de diminutivo da língua portuguesa, dá nome 01 (um) córrego no município de Pontal do Araguaia.

Segundo Sampaio, a unidade lexical jaraguá possui as seguintes características: "JARAGUÁ, corr. yara-guá, a baixa do senhor, o valle do dono. Pode ser corrupção de yara-quã que significa - o dedo de Deus, a ponta do senhor." (1970, p. 236).

Considera-se, nesta pesquisa, que os hierotopônimos portugueses da microrregião Tesouro, quanto à estrutura, subdividem-se em simples e compostos. São 09 (nove) hierotopônimos de estrutura simples e 03 (três) hierotopônimos de estrutura composta. Eles denominam 11 (onze) acidentes físicos e 01 (um) acidente antrópico.

O hierotopônimo composto Paraíso do Leste, formado por substantivo comum + conectivo + substantivo comum, nomeia 01 (um) distrito no município de Poxoréu. O hierotopônimo Bom Jesus, formado por adjetivo + substantivo próprio, denomina 01 (um) córrego em Poxoréu e 01 (um) córrego em Tesouro.

Os hierotopônimos simples subdividem-se em simples sem derivação e simples com derivação. O hierotopônimo Almas apresenta desinência de plural -s e toponimiza 01 (um) ribeirão no município de Poxoréu. Os hierotopônimos Cruz, Natal e Paraíso nomeiam 01 (um) morro em Pontal do Araguaia, 02 (dois) córregos em Torixoréu, 01 (um) morro, 01 (um) córrego e 01 (um) rio em Poxoréu.

Os hierotopônimos Alminhas e Igrejinha, formados pelas unidades lexicais alma e igreja + sufixo -inha, já mencionado, dão nomes, respectivamente, a 01 (um) ribeirão no município de Poxoréu e a 01 (um) córrego em Ribeirãozinho. O hierotopônimo Alminhas apresenta desinência de plural -s.

Ocorre produtividade toponímica, nesta taxionomia, na microrregião Tesouro. O hierotopônimo Bom Jesus nomeia 01 (um) córrego em Poxoréu e outro em Tesouro. O hierotopônimo Cruz denomina 01 (um) morro em Pontal do Araguaia e 02 (dois) córregos em Torixoréu. O hierotopônimo Paraíso dá nome a 01 (um) 
córrego e a 01 (um) rio em Poxoréu. O hierotopônimo Paraíso do Leste singulariza 01 (um) distrito em Poxoréu. O hierotopônimo Almas denomina 01 (um) ribeirão e o hierotopônimo Alminhas também nomeia 01 (um) ribeirão, ambos em Poxoréu.

Os hierotopônimos correspondem a 1,3\% do total de topônimos da microrregião Tesouro.

\section{Etnotopônimos}

As unidades lexicais que se referem aos elementos étnicos, isolados ou não (povos, tribos, castas), quando utilizadas para nomear acidentes físicos e acidentes antrópicos, recebem a denominação de etnotopônimos nos estudos toponímicos. Registram-se 11 (onze) etnotopônimos na microrregião Tesouro.

São 03 (três) etnotopônimos no município de Guiratinga, 03 (três) em Pontal do Araguaia, 03 (três) em Poxoréu, 01 (um) em Tesouro e 01 (um) em Torixoréu. Não há registro de etnotopônimos nos municípios de Araguainha, General Carneiro, Ponte Branca e Ribeirãozinho. Apresenta-se a seguir o gráfico desta taxionomia com os respectivos percentuais por município (GRÁFICO 69).

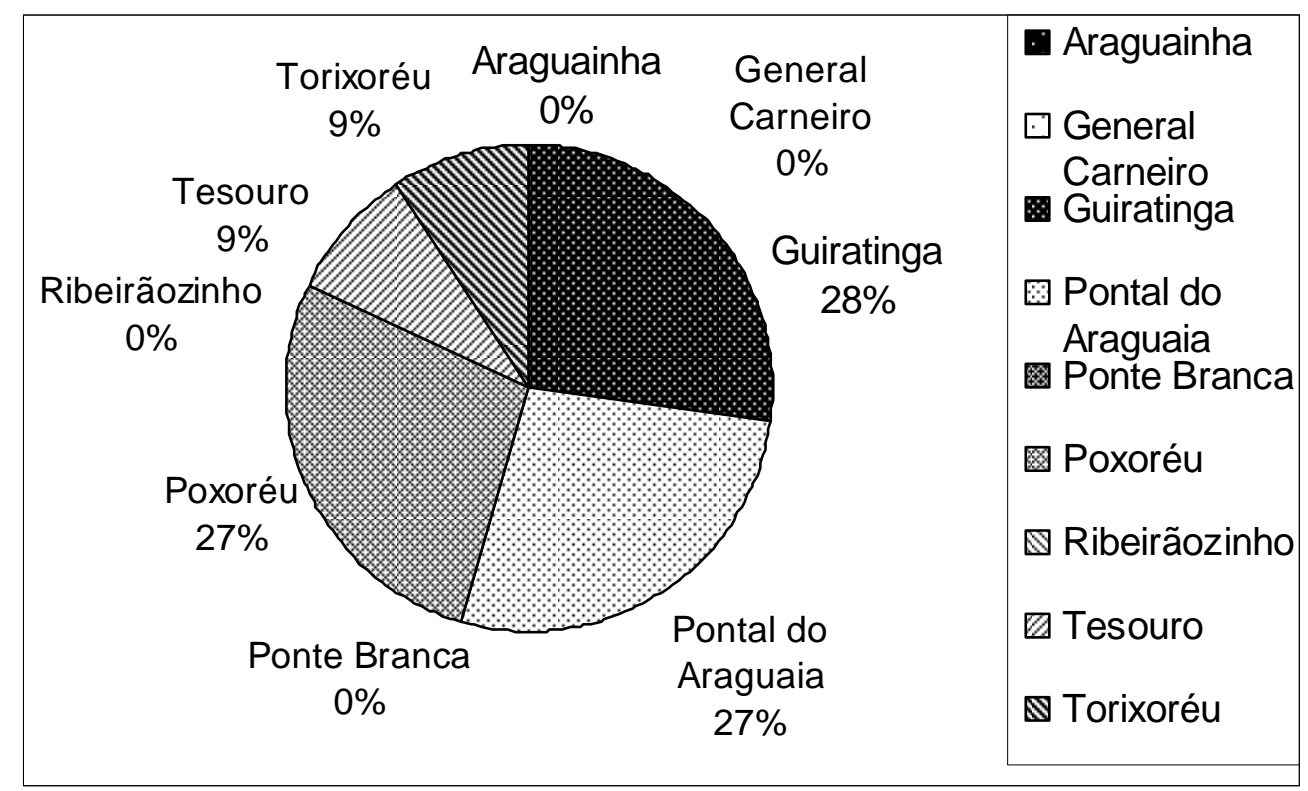

GRÁFICO 69 - Total dos etnotopônimos da microrregião Tesouro.

São 01 (um) etnotopônimo bororo, 01 (um) africano e 09 (nove) portugueses. 
Considera-se, nesta pesquisa, que o etnotopônimo bororo possui estrutura híbrida. O etnotopônimo Cuiabano, formado pela unidade lexical borora cuiabá + sufixo -ano, indicador de naturalidade, origem da língua portuguesa, nomeia 01 (um) córrego no município de Tesouro.

A unidade lexical cuiabá está registrada na Enciclopédia Bororo:

Ikuiapá - * ikúia, flecha-arpão; pá, lugar [lugar da flecha-arpão]. Designação: 1 . de uma localidade onde se pesca com a flechaarpão; 2. de uma localidade onde antigamente os bororo costumavam pescar com flecha-arpão correspondente à foz do Ikuiébo, cór. da Prainha, afl. da esq. do r. Cuiabá, na cidade homônima. Julgamos que o nome da capital de Mato Grosso, Cuiabá, justamente edificada nas duas margens do cór. da Prainha, não seja outra coisa que a corrupção e sonorização de Ikuiapá. Albisetti; Venturell (1962, p. 610)

Considera-se, nesta pesquisa, que o etnotopônimo africano Moleque possui estrutura simples. Ele nomeia 01 (um) córrego no município de Guiratinga.

Considera-se, nesta pesquisa, que os etnotopônimos portugueses da microrregião Tesouro possuem estrutura simples. Eles denominam 09 (nove) acidentes físicos.

O etnotopônimo simples e não derivado Bororo toponimiza 01 (um) córrego no município de Poxoréu.

Os etnotopônimos simples Bugres, Índios, Negros e Pretos apresentam desinência de plural -s e denominam 01 (um) córrego em Guiratinga, 02 (dois) córregos em Poxoréu, 01 (um) córrego e 02 (duas) serras em Pontal do Araguaia.

O etnotopônimo Baianos, formado pela unidade lexical Bahia + sufixo -ano, já mencionado + desinência $-\mathrm{s}$ de plural, nomeia 01 (um) córrego em Torixoréu. O etnotopônimo Moreninha, formado pela unidade lexical moreno + sufixo -inha, indicador de diminutivo, dá nome a 01 (um) córrego em Guiratinga

Constata-se produtividade toponímica, nesta taxionomia, na microrregião Tesouro. O etnotopônimo Índios nomeia 01 (um) córrego e 01 (uma) serra no 
município de Pontal do Araguaia. O etnotopônimo Pretos dá nome a 01 (um) córrego em Guiratinga e a 01 (uma) serra em Pontal do Araguaia.

Os etnotopônimos correspondem a 1,1\% do total de topônimos da microrregião Tesouro.

\section{Somatotopônimos}

As unidades lexicais que se referem à partes do corpo humano ou do animal, quando utilizadas para nomear acidentes físicos e acidentes antrópicos, recebem nos estudos toponímicos a denominação de somatotopônimos. Registram-se 10 (dez) somatotopônimos na microrregião Tesouro.

São 01 (um) somatotopônimo no município de Araguainha, 02 (dois) em General Carneiro, 01 (um) em Guiratinga, 01 (um) em Pontal do Araguaia, 02 (dois) em Poxoréu, 01 (um) em Ribeirãozinho e 02 (dois) em Torixoréu. Não há registro de somatotopônimos em Ponte Branca e Tesouro. Apresenta-se a seguir o gráfico desta taxionomia com os respectivos percentuais por município (GRÁFICO 70).

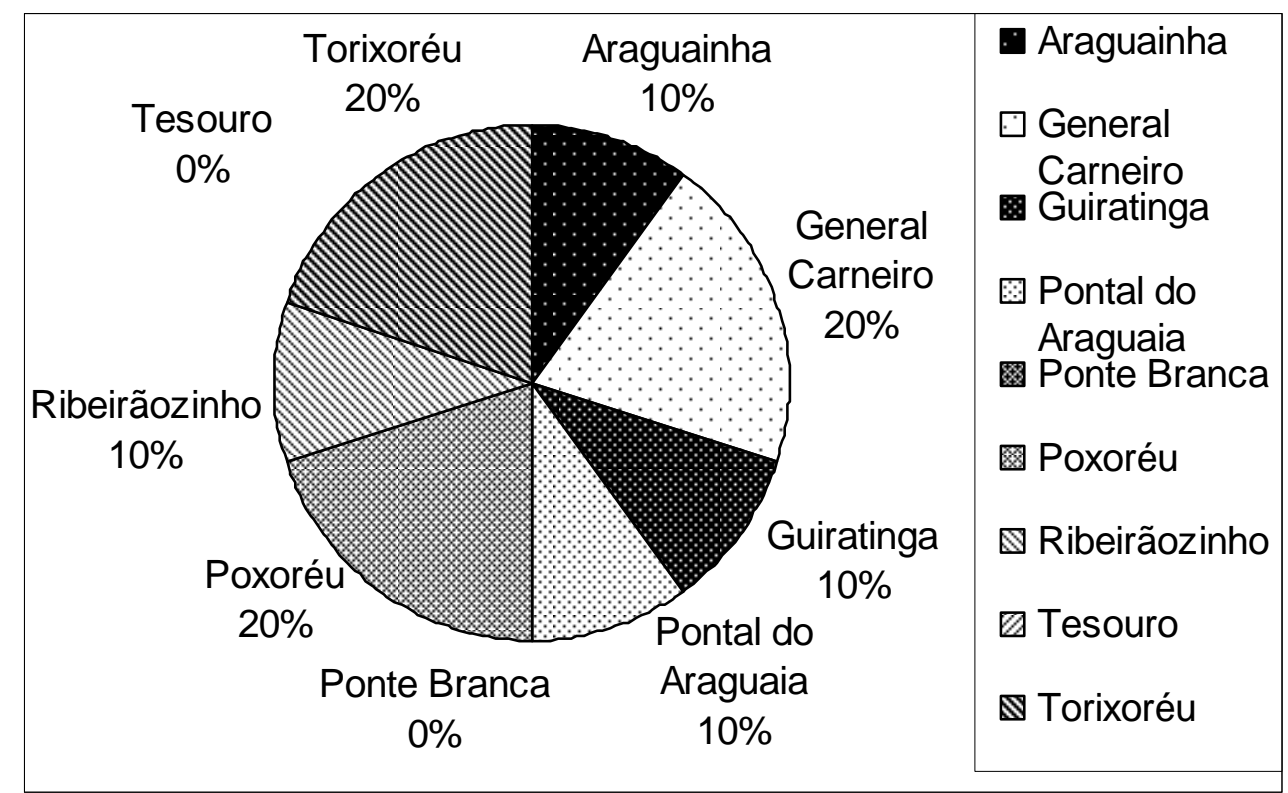

GRÁFICO 70 - Total dos somatotopônimos da microrregião Tesouro. 
São 02 (dois) somatotopônimos bororos e 08 (oito) portugueses.

Considera-se, nesta pesquisa, que os somatotopônimos bororos possuem estrutura simples. O somatotopônimo Auracoré nomeia 01 (um) córrego no município de Poxoréu. O somatotopônimo Canagora dá nome a 01 (um) córrego em General Carneiro.

As unidades lexicais auracoré e canagora estão registradas na Enciclopédia Bororo: "Aora O-Kóri - * aóra, cabeça; $\mathbf{O}_{1}$ (d)elas; kóri, dor [cór. da dor de cabeça]. Cór. afl. da dir. do c. m. do Porubí, rib. Porube Aidjau: cór. Auracoré." e "Kána Braço e antebraço, asa, barbatana peitoral, perna anterior dos quadrúpedes." e "Góri - * ? Cheiro de queimado, de assado, de chamuscado, queima, assadura, chamusca." Albisetti; Venturelli (1962, p. 74; 589; 705)

Considera-se, nesta pesquisa, que os somatotopônimos portugueses da microrregião Tesouro, quanto à estrutura, subdividem-se em simples e composto. São 07 (sete) somatotopônimos de estrutura simples e 01 (um) somatotopônimo de estrutura composta. Eles denominam 08 (oito) acidentes físicos.

O somatotopônimo composto Couro de Porco, formado por substantivo comum + preposição + substantivo comum, dá nome a 01 (um) córrego no município de General Carneiro.

Os somatotopônimos simples e não derivados Barriga e Coxo denominam, respectivamente, 01 (um) córrego no município de Ribeirãozinho e 01 (um) córrego em Araguainha. O somatotopônimo simples Guelas apresenta desinência de plural s e dá nome a 01 (um) córrego em Torixoréu.

O somatotopônimo Cabeçudo, formado pela unidade lexical cabeça + sufixo udo, indicador de abundância, denomina 01 (um) córrego no município de Torixoréu. O somatotopônimo Gemedor, formado pela unidade lexical gemer + sufixo -dor, indicador de agente da ação, nomeia 01 (um) córrego em Guiratinga. 0 somatotopônimo Gordura, formado pela unidade lexical gordo + sufixo -ura, indicador de qualidade ou estado, toponimiza 01 (uma) cabeceira em Poxoréu e 01 (um) córrego em Pontal do Araguaia. 
Ocorre somente 01 (um) caso de produtividade toponímica, nesta taxionomia, na microrregião Tesouro. O somatotopônimo Gordura dá nome a 01 (uma) cabeceira em Poxoréu e a 01 (um) córrego em Pontal do Araguaia.

Os somatotopônimos correspondem a 1,0\% do total de topônimos da microrregião Tesouro.

\section{Dirrematotopônimos}

Registram-se 08 (oito) dirrematotopônimos na microrregião Tesouro. São classificados como dirrematotopônimos, nos estudos toponímicos, as unidades lexicais constituídas por frases ou enunciados lingüísticos, quando utilizadas para denominar acidentes físicos e acidentes antrópicos.

São 02 (dois) dirrematotopônimos no município de Guiratinga, 03 (três) em Pontal do Araguaia, 01 (um) em Poxoréu e 02 (dois) em Torixoréu. Não há registro de dirrematotopônimos nos municípios de Araguainha, General Carneiro, Ponte Branca, Ribeirãozinho e Tesouro. Apresenta-se a seguir o gráfico desta taxionomia com os respectivos percentuais por município (GRÁFICO 71).

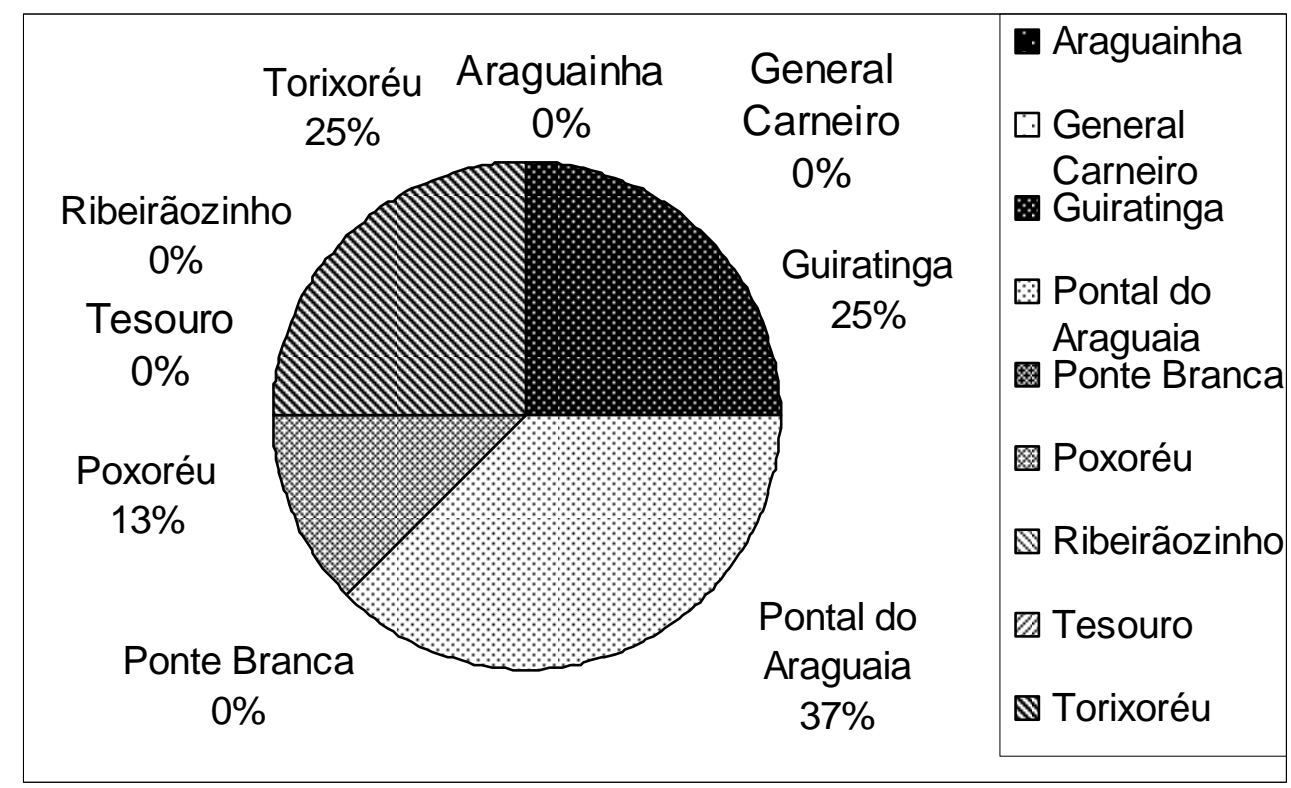

GRÁFICO 71 - Total dos dirrematotopônimos da microrregião Tesouro. 
Os dirrematotopônimos da microrregião Tesouro são portugueses, possuem estrutura composta e apresentam as seguintes subdivisões:

a) dirrematotopônimos formados por substantivo comum + preposição + substantivo comum: Arroz sem Sal e Boca para Cima;

b) dirrematotopônimo formado por verbo conjugado no presente do indicativo + verbo conjugado no presente do indicativo: Rela-Rela;

c) dirrematotopônimos formados por verbo conjugado no presente do indicativo + substantivo comum: Rola Burro e Mata-cachorro;

d) dirrematotopônimo formado por verbo conjugado no presente do indicativo + substantivo comum com desinência de plural -s: Quebra-dentes;

e) dirrematotopônimo formado por verbo conjugado no presente do indicativo + unidade lexical dente + sufixo -inho, indicador de diminutivo: Quebra-dentinho.

O dirrematotopônimo Arroz sem Sal dá nome a 01 (um) córrego no município de Poxoréu. O dirrematotopônimo Boca para Cima denomina 02 (dois) córregos em Pontal do Araguaia. O dirrematotopônimo Rela-Rela dá nome a 01 (um) córrego em Pontal do Araguaia.

Os dirrematotopônimos Mata-cachorro e Rola Burro nomeiam 02 (dois) córregos no município de Guiratinga. O dirrematotopônimo Quebra-dentes dá nome a 01 (um) ribeirão e o dirrematotopônimo Quebra-dentinho nomeia 01 (um) córrego, ambos em Torixoréu.

Constata-se produtividade toponímica, na microrregião Tesouro, nesta taxionomia. O dirrematotopônimo Boca para Cima dá nome a 02 (dois) córregos no município de Pontal do Araguaia. Pode-se ainda considerar o dirrematotopônimo Quebra-dentes que particulariza 01 (um) ribeirão e o dirrematotopônimo Quebradentinho que nomeia 01 (um) córrego, ambos em Torixoréu.

Os dirrematotopônimos correspondem a 0,8\% do total de topônimos da microrregião Tesouro. 


\section{Cronotopônimos}

A microrregião Tesouro possui 04 (quatro) cronotopônimos. Classificam-se como cronotopônimos, nos estudos toponímicos, as unidades lexicais que se referem ao tempo, quando utilizadas para dar nomes a acidentes físicos e a acidentes antrópicos.

São 01 (um) cronotopônimo no município de General Carneiro, 01 (um) em Guiratinga, 01 (um) em Pontal do Araguaia e 01 (um) Ribeirãozinho. Não há registro de cronotopônimos nos municípios de Araguainha, Ponte Branca, Poxoréu, Tesouro e Torixoréu. Devido à pequena quantidade de cronotopônimos, não se apresenta gráfico para esta taxionomia.

Os cronotopônimos da microrregião Tesouro são portugueses e subdividemse, quanto à estrutura, em simples e composto.

O cronotopônimo composto Nova Olinda, formado por adjetivo + substantivo próprio, dá nome a 01 (um) córrego no município de General Carneiro. Os cronotopônimos simples e sem derivação Moderno, Nova e Novo nomeiam, respectivamente, 01 (um) córrego em Ribeirãozinho, 01 (uma) vila em Guiratinga e 01 (um) córrego em Pontal do Araguaia.

Ocorre produtividade toponímica, na microrregião Tesouro, se considerar os cronotopônimos Nova que dá nome a 01 (uma) vila no município de Guiratinga, o cronotopônimo Novo que toponimiza 01 (um) córrego em Pontal do Araguaia e o cronotopônimo Nova Olinda que denomina 01 (um) córrego em General Carneiro.

Os cronotopônimos correspondem a 0,4\% do total de topônimos da microrregião Tesouro.

\section{Ecotopônimos}


$\mathrm{Na}$ microrregião Tesouro classificam-se 04 (quatro) ecotopônimos. As unidades lexicais que se referem às habitações de um modo em geral, quando utilizadas para dar a acidentes físicos e a acidentes antrópicos, recebem nos estudos toponímicos a denominação de ecotopônimos.

São 01 (um) ecotopônimo no município de Ponte Branca, 01 (um) em Tesouro e 02 (dois) em Torixoréu. Não há registro de ecotopônimos nos municípios de Araguainha, General Carneiro, Guiratinga, Pontal do Araguaia, Poxoréu e Ribeirãozinho. Devido à pequena quantidade de ecotopônimos não se apresenta gráfico para esta taxionomia.

Os ecotopônimos da microrregião Tesouro são tupis e, quanto à estrutura, subdividem-se em simples e híbrido.

O ecotopônimo Tapera dá nome a 01 (um) córrego no município de Tesouro e 01 (um) córrego em Torixoréu. O ecotopônimo de estrutura híbrida Taperão, formado pela unidade lexical tupi tapera + sufixo -ão, indicador de aumentativo da língua portuguesa, nomeia 01 (uma) serra em Torixoréu e 01 (um) córrego em Ponte Branca.

Ocorre produtividade toponímica, nesta taxionomia, na microrregião Tesouro. O ecotopônimo Tapera dá nome a 01 (um) córrego no município de Tesouro e a 01 (um) córrego em Torixoréu. O ecotopônimo Taperão singulariza 01 (uma) serra em Torixoréu e 01 (um) córrego em Ponte Branca.

Os ecotopônimos correspondem a $0,4 \%$ do total de topônimos da microrregião Tesouro.

\section{Historiotopônimos}

As unidades lexicais que se referem aos movimentos de cunho históricosocial e aos seus membros, assim como as datas correspondentes, quando utilizadas para nomear acidentes físicos e acidentes antrópicos, recebem nos 
estudos toponímicos a denominação de historiotopônimos. Registram-se 04 (quatro) historiotopônimos na microrregião Tesouro.

São 02 (dois) historiotopônimos no município de Guiratinga, 01 (um) em Poxoréu e 01 (um) em Tesouro. Não há registro de historiotopônimos nos municípios de Araguainha, General Carneiro, Pontal do Araguaia, Ponte Branca, Ribeirãozinho e Torixoréu. Devido à pequena quantidade de historiotopônimos não se apresenta gráfico para esta taxionomia.

Os historiotopônimos da microrregião Tesouro são portugueses e possuem estrutura simples.

O historiotopônimo simples e não derivado Bandeira nomeia 01 (um) córrego no município de Poxoréu, 01 (um) rio e 01 (um) córrego em Guiratinga. O historiotopônimo Bandeirinha, formado pela unidade lexical bandeira + sufixo -inha, indicador de diminutivo, dá nome a 01 (um) córrego em Tesouro.

Pode-se constatar produtividade toponímica, nesta taxionomia, na microrregião Tesouro. O historiotopônimo Bandeira nomeia 01 (um) córrego em Poxoréu, 01 (um) córrego e 01 (um) rio no município de Guiratinga. O historiotopônimo Bandeirinha singulariza 01 (um) córrego em Tesouro.

Os historiotopônimos correspondem a $0,4 \%$ do total de topônimos da microrregião Tesouro.

\section{Corotopônimos}

As unidades lexicais que se referem a nomes de continentes, países, regiões, estados, cidades, quando utilizadas para nomear acidentes físicos e acidentes antrópicos, recebem a denominação de corotopônimos nos estudos toponímicos. Registram-se 03 (três) corotopônimos na microrregião Tesouro. 
São 01 (um) corotopônimo no município de Guiratinga e 02 (dois) em Pontal do Araguaia. Não há registro de corotopônimos nos municípios de Araguainha, General Carneiro, Ponte Branca, Poxoréu, Ribeirãozinho, Tesouro e Torixoréu. Devido à pequena quantidade de corotopônimos não se apresenta gráfico para esta taxionomia.

Os corotopônimos da microrregião Tesouro são portugueses e, quanto à estrutura, subdividem-se em simples e composto.

O corotopônimo composto Pão de Açúcar, formado por substantivo comum + preposição + substantivo comum, dá nome a 01 (um) morro no município de Guiratinga.

Os corotopônimos simples Babilônia e Fortaleza denominam 02 (dois) córregos no município de Pontal do Araguaia.

Os corotopônimos correspondem a 0,3\% do total de topônimos da microrregião Tesouro.

\section{Poliotopônimos}

As unidades lexicais que se referem aos aglomerados humanos: vila, aldeia, cidade, povoação, arraial, quando utilizadas para dar nomes a acidentes físicos e a acidentes antrópicos, recebem nos estudos toponímicos a denominação de poliotopônimos. Registram-se 03 (três) poliotopônimos na microrregião Tesouro.

São 01 (um) poliotopônimo no município de Guiratinga e 02 (dois) em Tesouro. Não há registro de poliotopônimos nos municípios de Araguainha, General Carneiro, Pontal do Araguaia, Ponte Branca, Poxoréu, Ribeirãozinho e Torixoréu. Devido à pequena quantidade de poliotopônimos não se apresenta gráfico para esta taxionomia. 
O poliotopônimo Aldeia é português, possui estrutura simples e dá nome a 01 (um) córrego no município de Tesouro e a 01 (um) ribeirão que estabelece divisa entre os municípios de Guiratinga e Tesouro e por isso consta nas relações de topônimos dos dois municípios.

Constata-se produtividade toponímica, nesta taxionomia, na microrregião Tesouro porque o poliotopônimo Aldeia nomeia 01 (um) córrego em Tesouro e 01 (um) ribeirão que consta nas relações de topônimos dos dois municípios.

Os poliotopônimos correspondem a 0,3\% do total de topônimos da microrregião Tesouro.

\section{Mitotopônimos}

As unidades lexicais que se referem às entidades mitológicas, quando utilizadas para nomear acidentes físicos e acidentes antrópicos, recebem nos estudos toponímicos a denominação de mitotopônimos. Registram-se 02 (dois) mitotopônimos na microrregião Tesouro.

O município de Tesouro possui 02 (dois) mitotopônimos. Não há registro de mitotopônimos nos municípios de Araguainha, General Carneiro, Guiratinga, Pontal do Araguaia, Ponte Branca, Poxoréu, Ribeirãozinho e Torixoréu. Devido à pequena quantidade de mitotopônimos, não se apresenta gráfico para esta taxionomia.

O mitotopônimo é português e possui estrutura simples. O mitotopônimo Inferninho, formado pela unidade lexical inferno + sufixo -inho, indicador de diminutivo, dá nome a 02 (dois) córregos no município de Tesouro.

Apesar da pequena quantidade de mitotopônimos constata-se produtividade toponímica, nesta taxionomia, na microrregião Tesouro, porque o mitotopônimo Inferninho nomeia 02 (dois) córregos. 
Os mitotopônimos correspondem a $0,2 \%$ do total de topônimos da microrregião Tesouro.

\section{Axiotopônimo}

As unidades lexicais que se referem aos títulos e dignidade de que se fazem acompanhar os nomes próprios individuais, quando utilizadas para dar nomes a acidentes físicos e a acidentes antópicos, recebem nos estudos toponímicos a denominação de axiotopônimos. Registra-se 01 (um) axiotopônimo na microrregião Tesouro.

O município de General Carneiro possui 01 (um) axiotopônimo. Não há registro de axiotopônimos nos municípios de Araguainha, Guiratinga, Pontal do Araguaia, Ponte Branca, Poxoréu, Ribeirãozinho, Tesouro e Torixoréu. Devido à unicidade de axiotopônimo não se apresenta gráfico para esta taxionomia.

O axiotopônimo é português e possui estrutura composta. O axiotopônimo General Carneiro, formado por substantivo comum + apelido de família, denomina 01 (um) município mato-grossense.

O axiotopônimo corresponde a 0,1\% do total de topônimos da microrregião Tesouro. 


\section{Considerações Parciais}

Estas considerações parciais objetivam apresentar alguns aspectos dos topônimos tesourenses, em uma visão de conjunto, agrupados por microrregião.

Do total de 1.023 (mil e vinte e três) topônimos registrados na microrregião Tesouro, 681 (seiscentos e oitenta e um) são de natureza física e 342 (trezentos e quarenta e dois) são de natureza antrópica.

No cômputo final do levantamento dos topônimos, na microrregião Tesouro, pôde-se constatar, dentre os topônimos de natureza física, que eles estão classificados em 12 (doze) taxionomias e apresentam os seguintes somatórios por município: 39 (trinta e nove) topônimos no município de Araguainha, 64 (sessenta e quatro) em General Carneiro, 180 (cento e oitenta) em Guiratinga, 73 (setenta e três) em Pontal do Araguaia, 36 (trinta e seis) em Ponte Branca, 90 (noventa) em Poxoréu, 25 (vinte e cinco) em Ribeirãozinho, 72 (setenta e dois) em Tesouro e 102 (cento e dois) em Torixoréu. Apresenta-se a seguir o gráfico dos topônimos de natureza física com os respectivos percentuais por municípios. (GRÁFICO 72).

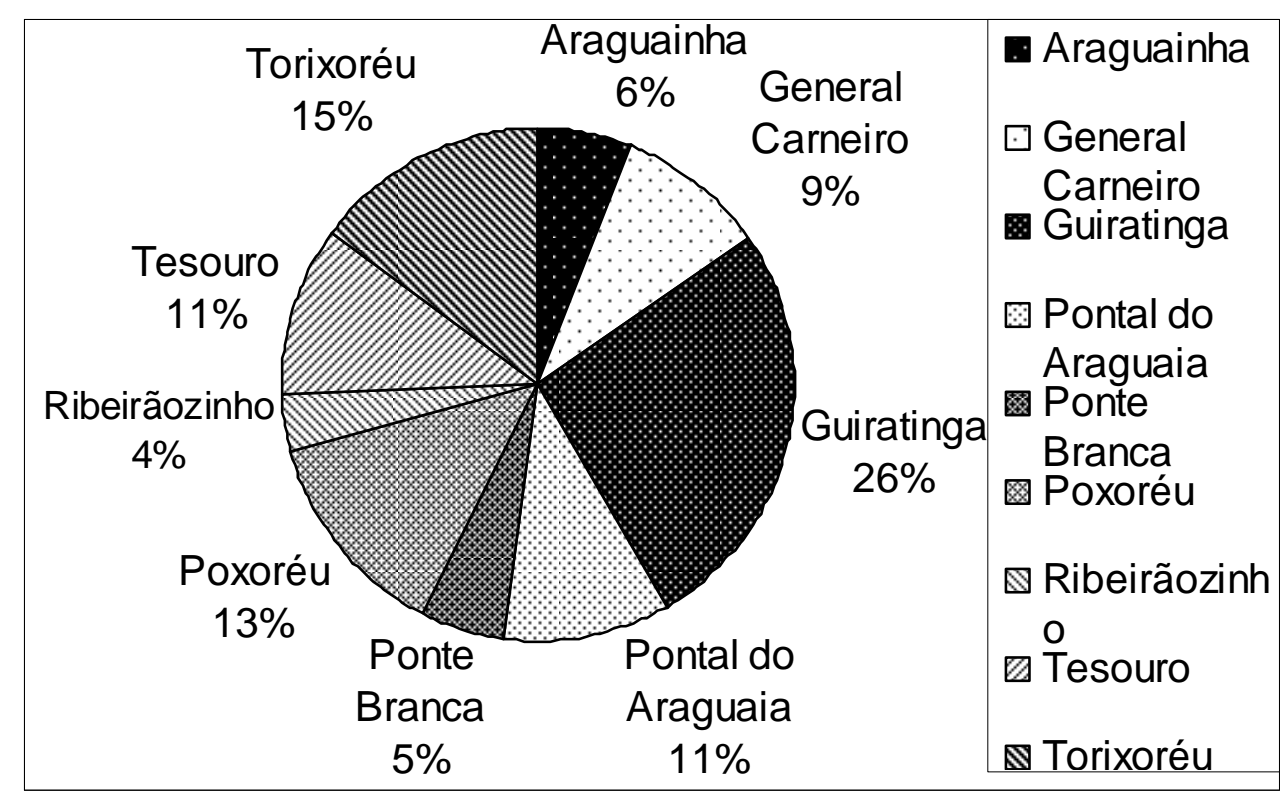

GRÁFICO 72 - Total dos topônimos de natureza física da microrregião Tesouro.

Computam-se 342 (trezentos e quarenta e dois) topônimos, de natureza antrópica, classificados em 18 (dezoito) taxionomias, nos mapas e cartas 
topográficas dos municípios que compõem a microrregião Tesouro. Eles apresentam as seguintes distribuições por município: 18 (dezoito) no município de Araguainha, 24 (vinte e quatro) em General Carneiro, 89 (oitenta e nove) em Guiratinga, 33 (trinta e três) em Pontal do Araguaia, 21 (vinte e um) em Ponte Branca, 55 (cinqüenta e cinco) em Poxoréu, 13 (treze) em Ribeirãozinho, 45 (quarenta e cinco) em Tesouro e 44 (quarenta e quatro) em Torixoréu. Apresenta-se a seguir o gráfico dos topônimos de natureza antrópica com os respectivos percentuais por municípios. (GRÁFICO 73).

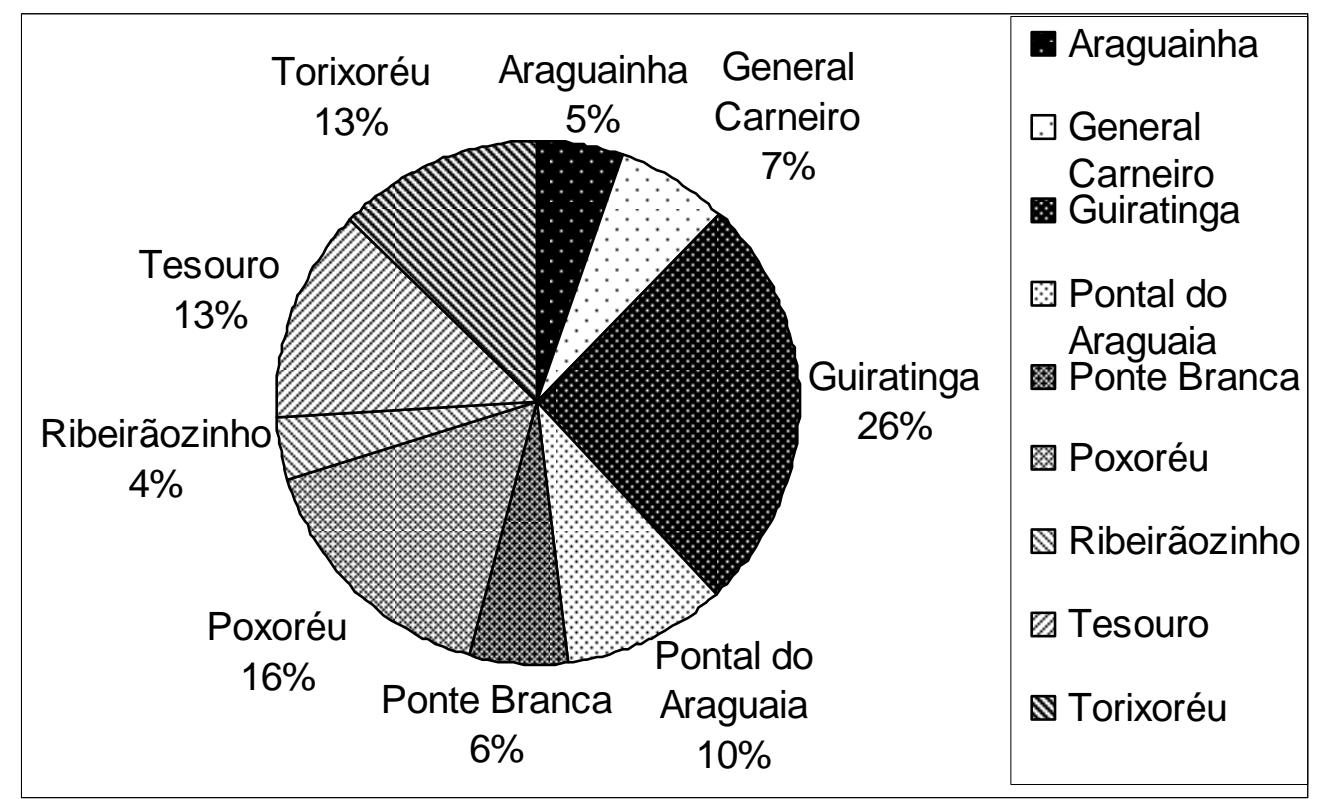

GRÁFICO 73 - Total dos topônimos de natureza antrópica da microrregião Tesouro.

É bastante expressiva a representatividade dos topônimos de natureza física no total de topônimos da microrregião Tesouro. Os topônimos de natureza física correspondem a $66,6 \%$ e os topônimos de natureza antrópica representam 33,4\%.

Os topônimos da microrregião Tesouro foram agrupados por grupos lingüísiticos. Registram-se 150 (cento e cinquenta) topônimos tupis, 31 (trinta e um) bororos, 09 (nove) africanos e 833 (oitocentos e trinta e três) portugueses. Apresenta-se a seguir o gráfico dos topônimos por grupos lingüísticos com os respectivos percentuais por municípios. (GRÁFICO 74). 


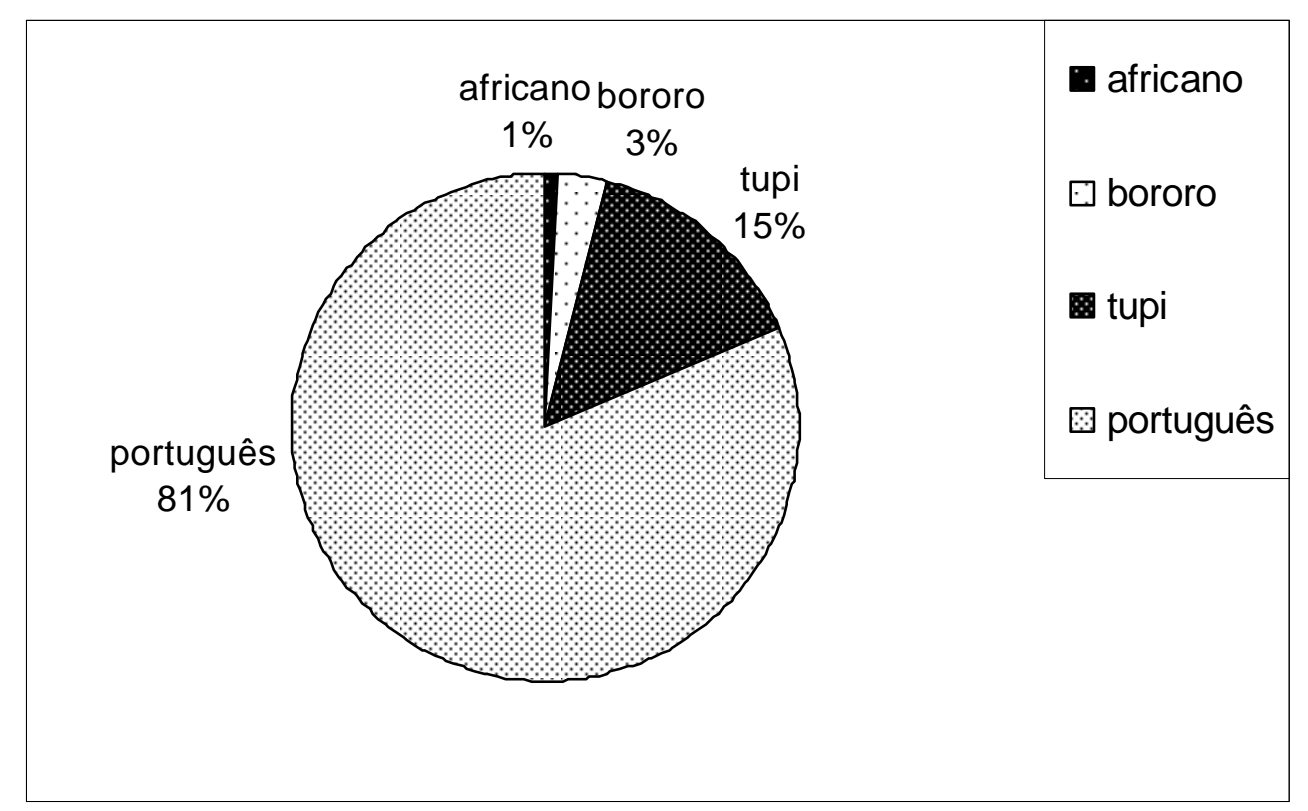

GRÁFICO 74 - Total dos topônimos por grupos lingüísticos da microrregião Tesouro.

$\mathrm{Na}$ classificação dos topônimos por grupos lingüísticos observa-se que o montante de 150 (cento e cinquenta) topônimos tupis representa 14,7\% do total dos topônimos da microrregião Tesouro. São 142 (cento e quarenta e dois) topônimos tupis classificados nas taxionomias de natureza física: cardinotopônimos, fitotopônimos, geomorfotopônimos, hidrotopônimos, litotopônimos e zootopônimos. Os topônimos tupis de natureza antrópica perfazem 08 (oito) ocorrências e estão classificados nas taxionomias: antropotopônimos, ecotopônimos, ergotopônimos e hierotopônimos.

Os topônimos bororos correspondem a 3,0\% do total dos topônimos da microrregião Tesouro. São 26 (vinte e seis) topônimos bororos classificados em 06 (seis) taxionomias de natureza física: dimensiotopônimos, fitotopônimos, geomorfotopônimos, hidrotopônimos, litotopônimos e zootopônimos. São 05 (cinco) topônimos bororos classificados em 03 (três) taxionomias de natureza antrópica: etnotopônimos, ergotopônimos e somatotopônimos.

Os topônimos africanos correspondem a 0,9\% do total dos topônimos da microrregião Tesouro. São 06 (seis) topônimos classificados nas taxionomias hidrotopônimos e zootopônimos, de natureza física e 03 (três) topônimos classificados nas taxionomias ergotopônimos e etnotopônimos, de natureza antrópica. 
Na microrregião Tesouro, a representatividade de cada município no total dos topônimos tesourenses, apresenta-se assim: 57 (cinqüenta e sete) topônimos no município de Araguainha, 88 (oitenta e oito) em General Carneiro, 269 (duzentos e sessenta e nove) em Guiratinga, 106 (cento e seis) em Pontal do Araguaia, 57 (cinqüenta e sete) em Ponte Branca, 145 (cento e quarenta e cinco) em Poxoréu, 38 (trinta e oito) em Ribeirãozinho, 117 (cento e dezessete) em Tesouro e 146 (cento e quarenta e seis) em Torixoréu, registrados nos mapas e nas cartas topográficas dos municípios. Apresenta-se a seguir o gráfico do total geral dos topônimos da microrregião Tesouro. (GRÁFICO 75).

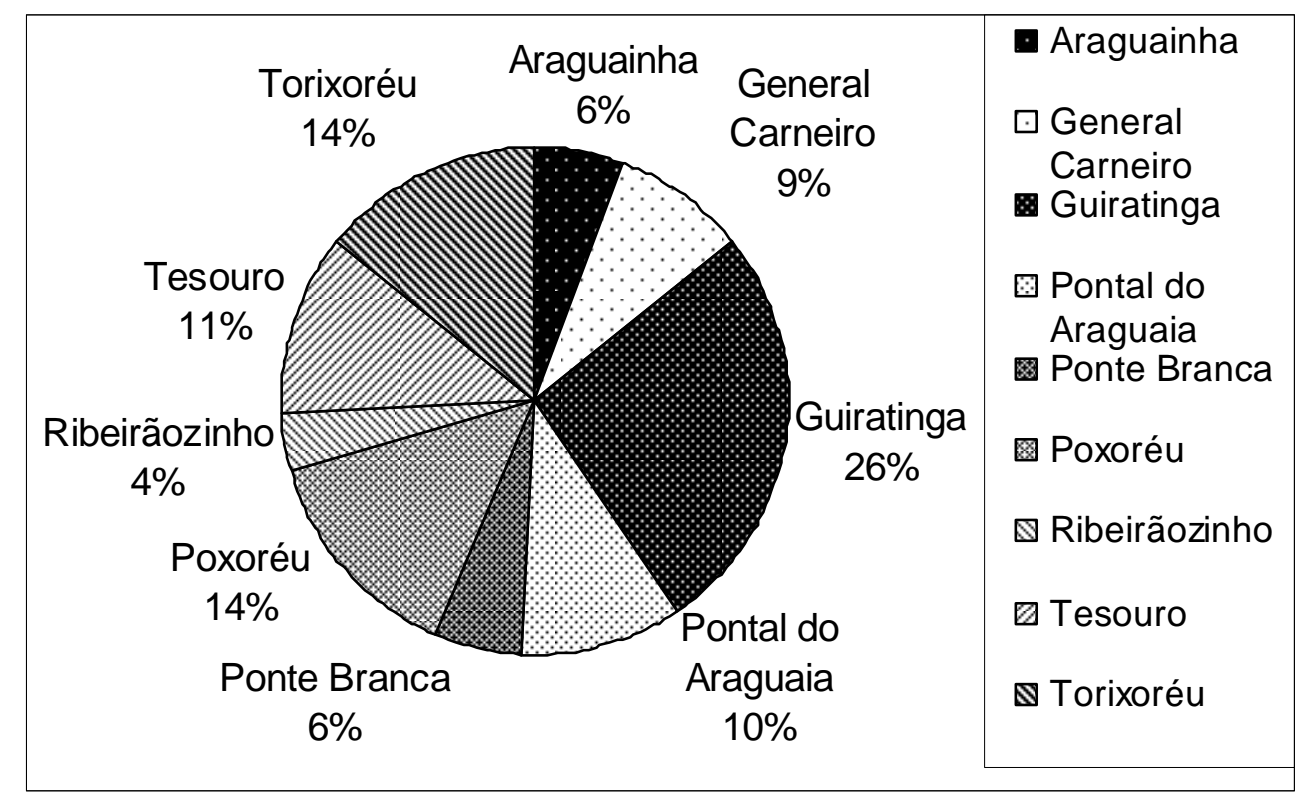

GRÁFICO 75 - Total geral dos topônimos da microrregião Tesouro.

Ocorre registro de topônimos em todas as taxionomias na microrregião Tesouro.

As taxionomias zootopônimos fitotopônimos, hidrotopônimos e litotopônimos são as que mais possuem topônimos e correspondem a 52,5\% do total de topônimos da microrregião Tesouro.

A microrregião Tesouro é a que apresenta maior quantidade de topônimos. O volume dos topônimos tesourenses representa 43,6\% do total de topônimos da mesorregião Sudeste Mato-grossense. 


\section{CONSIDERAÇÕES FINAIS}

Pretende-se, com a presente pesquisa, apresentar a conclusão da segunda etapa do Atlas Toponímico do Estado de Mato Grosso, e também, evidenciar novos campos de pesquisas etnolingüísticas e lexicológicas.

Pode-se asseverar que a delimitação prévia do corpus desta pesquisa foi de primordial importância para um bom desenvolvimento do trabalho. Esse fator possibilitou seqüenciar as etapas de coleta, de armazenamento e de agrupamentos dos topônimos em taxionomias e, em uma etapa subseqüente, realizar a pesquisa lexicográfica. O somatório dos topônimos que estão registrados nos mapas e nas cartas topográficas dos 22 (vinte e dois) municípios que compõem as microrregiões Alto Araguaia, Primavera do Leste, Rondonópolis e Tesouro é expressivo e, por isso, requer criterioso levantamento dos sintagmas toponímicos para que não haja necessidade de retornos consecutivos à base de dados, fator que promove desgastes e atrasos na pesquisa.

Os termos genéricos dos sintagmas toponímicos da mesorregião Sudeste Mato-grossense não são tão variados quanto os da mesorregião Centro-Sul Matogrossense, mas equiparam-se, em termos de quantidade. Pode-se registrar também que a riqueza toponímica, em ambas mesorregiões, são equivalentes.

A quantidade preponderante de cursos d'água evidencia a abundância de recursos hídricos, riqueza natural e inestimável do estado de Mato Grosso e ratificam a importância da mesorregião Sudeste Mato-grossense como grande divisor de águas da região Centro-Oeste do Brasil. Nessa área do estado de Mato Grosso, como já mencionado, cabeceiras, córregos, lagoas, riachos, ribeirões, rios e vazantes distribuem-se em três importantes bacias hidrográficas brasileiras: Amazônica, Araguaia-Tocantina e Pratina.

A experiência adquirida no decorrer da elaboração da dissertação de mestrado, quando foi desenvolvida a pesquisa toponímica da mesorregião CentroSul Mato-grossense, primeira fase do Atlas Toponímico do Estado de Mato Grosso, desempenhou importante contribuição para o desenvolvimento do presente estudo. 


\section{REFERÊNCIAS BIBLIOGRÁFICAS}

ALBISETTI, Cesar. VENTURELLI, Angelo Jayme. Enciclopédia Bororo. Vol I. 1. ed. São Paulo. Escolas Profissionais Salesianas, 1962.

ALMEIDA, N. M. Gramática Metódica da Língua Portuguesa. 40. ed. São Paulo: Saraiva, 1995.

ANDRADE, Maria Margarida. Introdução à Metodologia do Trabalho Científico. 6. ed. São Paulo: Atlas, 2003.

. Como Preparar Trabalhos para Cursos de Pós-Graduação. 5. ed. São Paulo: Atlas, 2002.

BACKHEUSER, Everardo. Toponímia. Suas regras, sua evolução. In: Revista geográfica. Rio de Janeiro: Instituto Pan-Americano de Geografia e História. v. IX, X. $n^{\circ} 25,1940$ a 1950, p. 163-195.

BARBOSA, Pe. A. Lemos. Pequeno dicionário tupi-português. Rio de Janeiro: São José, 1955.

BARBOSA, Maria Aparecida. Língua e discurso: contribuição aos estudos semântico-sintáxicos. 4. ed. São Paulo: Plêiade, 1996.

. Lexicologia, lexicografia, terminologia, terminografia, identidade científica, objeto, métodos, campos de atuação. In: Simpósio Latino-Americano de Terminologia, 2., Brasília: Anais do I Encontro Brasileiro de Terminologia TécnicoCientífica. 1990.

- Reflexões sobre o projeto lexicográfico: análise e descrição da forma de conteúdo da unidade lexical. In: XVIII Anais do GEL. São Paulo: GEL, 1989.

- Da microestrutura dos vocabulários técnico-científicos. In: Encontro Nacional da ANPOLL, 4. Recife : 1989. 
A estruturação do léxico e a organização do conhecimento. v. 22, $n^{0} 4$. Porto Alegre : Letras de Hoje. PUC-RS. 1987, p. 81-96.

BIDERMANN, Maria Teresa Camargo. A formação do léxico português. Anais do XI encontro nacional da ANPOLL. Letras e Lingüística. João Pessoa: UFPB-ANPOLL, 1996, p. 320-321.

BRANDÃO, S. A Geografia Lingüística no Brasil. São Paulo: Ática, 1992.

CASAL, Pe. Manuel Aires de. Corografia Brasílica ou Relação Histórico-Geográfica do Reino do Brasil. São Paulo: Cultura, 1943, Tomo I.

CORRÊA FILHO, V. História de Mato Grosso. Instituto Nacional do Livro - MEC. Rio de Janeiro. 1969.

COSERIU, Eugenio. Teoria da Linguagem e Lingüística Geral: cinco estudos. Rio de Janeiro: Presença; São Paulo: EDUSP, 1979.

. Lições de Lingüística Geral. Rio de Janeiro: Ao Livro Técnico S/A, 1980.

COUTINHO, I. L. Gramática Histórica. 7. ed. Rio de Janeiro: Ao Livro Técnico, 1976.

CUNHA, Antônio Geraldo. Dicionário Histórico das Palavras Portuguesas de Origem Tupi. São Paulo: Melhoramentos; Brasília: Editora UNB, 1999.

CUNHA, Celso; LINDLEY, Cintra. Nova gramática do português contemporâneo. 2. ed. Rio de Janeiro: Nova Fronteira, 1985.

D'ALINCOURT, Luiz. Memória sobre a Viagem do Porto de Santos à Cidade de Cuiabá. São Paulo 1953.

DAUZAT, Albert. Les noms de personnes. Origine et Évolution. Paris: Delagrave, 1925.

. Les noms de lieux. Origine et Évolution. Paris: Delagrave, 1926.

DICK, Maria Vicentina de Paula do Amaral. Rede de Conhecimento e Campo Lexical: Hidrônimos e Hidrotopônimos na Onomástica Brasileira. In: As ciências do 
léxico: Lexicologia, Lexicografia, Terminologia. Campo Grande: UFMS. 2004. p. 121130.

- Método e Questões Terminológicas na Onomástica. Estudo de Caso: o Atlas Toponímico do Estado de São Paulo. Investigações, Lingüística e Teoria Lliterária. In: Revista do Programa de Pós-graduação em Letras e Lingüística da UFPE, v. 9, p. 1999. 119-148.

. Nomes como marcadores ideológicos(Os). In: Acta Semiótica et Lingvistica. São Paulo: Plêiade / SBPL, v. 7. 1998. p. 97-122.

- Sistema onomástico: bases lexicais e terminológicas, posição e freqüência(O). In: As ciências do léxico: Lexicologia, Lexicografia, Terminologia. Campo Grande: UFMS. 1998. p. 77-88.

. Significação Hiponímica e Hiperonímica nas Práticas Onomásticas $(A)$. In: Anais do I Encontro Nacional do GT de Lexicologia, Lexicografia e Terminologia da ANPOLL, Recife: 1998.

. Construção do léxico onomástico $(A)$ : escritura e oralidade. In: Anais do $48^{a}$ Sessão Anual do SBPC. São Paulo: 1997. p. 158-159.

. Projeção léxico-cultural na Onomástica(A). Um estudo de caso. In: Revista do IEB, n. ${ }^{\circ}$ 40. São Paulo: 1996 b

Atlas Toponímico do Brasil. Estudo de Caso: o Projeto ATESP. In: Acta Semiótica et Lingvistica. v. 6, São Paulo : SBPL e Plêiade, 1996. p. 27-44.

. Toponímia e dicionário especializado. In: Estudos Lingüísticos. XXIV Anais de Seminário do GEL. FFLCH/USP-SP. São Paulo: 1995.

. Toponímia e línguas indígenas do Brasil. In: Estudos Avançados, vol. 8 n 22. São Paulo: USP. 1994.

. Morfologia do signo toponímico(A). Anais da XLII Reunião da Sociedade Brasileira para o Progresso da Ciência. São Paulo: 1992. 
Aspectos descritivos do Atlas Toponímico do Estado de S. Paulo. XLIV Reunião Anual da Sociedade Brasileira para o Progresso da Ciência. São Paulo: 1992.

- Tratamento lexicográfico do Atlas Toponímico do Estado de São Paulo. In: VII Encontro Nacional da ANPOLL. Porto Alegre: 1992.

- Toponímia e Antroponímia no Brasil - Coletânea de estudos. 3.ed. São Paulo: FFLCH/USP, 1992.

. Documentação em Toponímia(A). In: XXXIV Seminário do GEL. Franca : 1991.

. Vocábulos toponímicos básicos no "vocabulário na língua brasílica" e sua relação geográfica. In: Revista do Instituto de Estudos Brasileiros. no 31 . São Paulo : 1990. p. 95-111.

. Toponímia e cultura. In: Instituto Estudos Brasileiros. São Paulo. 1987, p. 93-101.

. Toponímia brasileira: os estudos que faltam. In: D. O. Leitura. São Paulo: 1986, p. 12-13.

. Características do signo toponímico. In: Língua e Literatura. São Paulo: 1980, p.287-293.

. Motivação toponímica. Princípios teóricos e modelos taxionômicos(A). São Paulo, 1980. 351 f. Tese (Doutorado em Lingüística) - Faculdade de Filosofia, Letras e Ciências Humanas, Universidade de São Paulo.

DUBOIS, Jean et al. Dicionário de Lingüística. São Paulo: Cultrix, 1973.

DRUMOND, Carlos. Contribuição do Bororo à Toponímia Brasílica. São Paulo: USP/IEB, 1965.

ELIA, Sílvio. A língua portuguesa no mundo. São Paulo: Ática, 1989.

DELTA LAROUSSE. Enciclopédia Delta Universal. Rio de Janeiro: 1985. 
FERREIRA, Aurélio Buarque de Holanda. Novo Dicionário da Língua Portuguesa. Rio de Janeiro: Nova Fronteira, 1975.

FERREIRA, João Carlos Vicente. Mato Grosso e seus Municípios. Cuiabá: Buriti, 2001.

FERREIRA, João de Freitas. A pedagogia do léxico: uma tentativa de aplicação da lexemática ao ensino do português. Porto: Claret, 1985.

GREGÓRIO, Irmão José. Contribuição Indígena ao Brasil. Volumes I e II, Belo Horizonte: União Brasileira de Educação e Ensino. Belo Horizonte. [196]

GUÉRIOS, Rosário Farâni Mansur. Dicionário Etimológico - Nomes \& Sobrenomes, Tudo o que você gostaria de saber e não Ihe contaram. São Paulo: Ave Maria, 1994.

HOUAISS, Antônio. VILLAR, Mauro de Salles. Dicionário Houaiss da Língua Portuguesa, Rio de Janeiro: Objetiva, 2001.

IBGE (Instituto Brasileiro de Geografia e Estatística). Base Territorial - Censo 2000. Rio de Janeiro: IBGE, 2000.

- Divisão do Brasil em Mesorregiões e Microrregiões Geográficas. Rio de Janeiro: IBGE, 1990.

. Enciclopédia dos Municípios Brasileiros. v. XXXV. Rio de Janeiro: 1958.

LEROY, Maurice. As Grandes Correntes da Lingüística Moderna. São Paulo: Cultrix, 1971.

LIMA FIGUEIRÊDO, Major. Índios do Brasil. São Paulo: Editora Nacional, 1939.

LOPES, Edward. Fundamentos da Lingüística Contemporânea. 5. ed. São Paulo: Cultrix, 1981.

LYONS, John. Semântica. v. I. Lisboa: Presença; São Paulo: Martins Fontes, 1980.

MACHADO, José Pedro. Dicionário Etimológico da Língua Portuguesa. v. V. 2. ed. Lisboa: Livros Horizonte, 1967. 
MAGALHÃES, Erasmo D’Almeida et al. Dicionário de Geografia do Brasil. São Paulo: Melhoramentos, 1973.

MENDONÇA, Rubens de. Dicionário Biográfico Mato-grossense. Mato Grosso: Instituto Histórico de Mato Grosso e Academia mato-grossense de Letras; Lisboa: Sociedade de Geografia de Lisboa, 1971.

MIGUEL, J. Curso de Língua Portuguesa. São Paulo: HARBRA, 1989.

OCHOA, Gonçalo. Pequeno Dicionário Bororo-Português: a serviço da escola bororo. Campo Grande: UCDB, 1997.

PÓVOAS, Nilo. Galeria dos Varões Ilustres de Mato Grosso. v. 1. Fundação Cultural de Mato-Grosso, 1977.

. História Geral de Mato Grosso: dos primórdios à queda do império. v. 1. Fundação Cultural de Mato-Grosso, 1995.

RONDON, Cândido Mariano da Silva. Carta do Estado de Mato Grosso e Regiões Circunvizinhas. Escala 1:1.000.000. Ministério da Guerra - Estado Maior do Exército, 1952.

ROSTAING, Charles. Les noms de lieux. Paris: Presses Universitaires de France, 1969.

SACCONI, L. A. Nossa Gramática - Teoria 15. ed São Paulo: Atual, 1992

SAMPAIO, Mário Arnaud. Palavras indígenas no linguajar brasileiro. Porto Alegre: Sagra D. C. Luzzato, 1995.

SAMPAIO, Theodoro. O Tupi na geografia nacional. 4.ed. São Paulo: EDUSP, 1970.

SAUSSURE, Ferdinand de. Curso de Lingüística Geral. 2. ed. São Paulo: Cultrix, 1970.

SEPLAN - MT (Secretaria de Estado de Planejamento e Coordenação Geral). Anuário Estatístico de Mato Grosso. Cuiabá: 2009. 
SGARBOSSA, Mário. GIOVANNINI, Luigi. Um santo para cada dia. 4. ed. São Paulo: Paulus, 1996.

SOUZA, Álvaro José de. Geografia Lingüística: Dominação e Liberdade. 2 ed. São Paulo: Contexto, 1991, Tomo II.

TAUNAY, Affonso de Escrangnolle. História das Bandeiras Paulista. 2. ed. São Paulo: Melhoramentos, [199] Tomo II.

TAUNAY, Alfredo Escrangnolle. Relatos Monçoeiros. São Paulo: Itatiaia; EDUSP, 1981.

ULLMANN, Stephen. Semântica: uma introdução à ciência do significado. Lisboa: Fundação Calouste Gubenkian. 1977. 


\section{MAPAS MUNICIPAIS}

ALTO ARAGUAIA: mapa físico, político e rodoviário. Cuiabá: Fundação de Pesquisas Cândido Rondon (FCR), 1990. 1 mapa p\&b. Escala 1:100.000.

ALTO GARÇAS: mapa físico, político e rodoviário. Cuiabá: Fundação de Pesquisas Cândido Rondon (FCR), 1989. 1 mapa p\&b. Escala 1:100.000.

ALTO TAQUARI: mapa físico, político e rodoviário. Cuiabá : Fundação de Pesquisas Cândido Rondon (FCR), 1990. 1 mapa p\&b. Escala 1:100.000.

ARAGUAINHA: mapa físico, político e rodoviário. Cuiabá : Fundação de Pesquisas Cândido Rondon (FCR), 1984. 1 mapa p\&b. Escala 1:100.000.

CAMPO VERDE: mapa físico, político e rodoviário. Cuiabá : Fundação de Pesquisas Cândido Rondon (FCR), 1990. 1 mapa p\&b. Escala 1:100.000.

DOM AQUINO: mapa físico, político e rodoviário. Cuiabá : Fundação de Pesquisas Cândido Rondon (FCR), 1986. 1 mapa p\&b. Escala 1:100.000.

GENERAL CARNEIRO: mapa físico, político e rodoviário. Cuiabá : Fundação de Pesquisas Cândido Rondon (FCR), 1984. 1 mapa p\&b. Escala 1:100.000.

GUIRATINGA: mapa físico, político e rodoviário. Fundação de Pesquisas Cândido Rondon (FCR), 1983. 1 mapa p\&b. Escala 1:250.000.

ITIQUIRA: mapa físico, político e rodoviário. Fundação de Pesquisas Cândido Rondon (FCR), 1988. 1 mapa p\&b. Escala 1:250.000.

JACIARA: mapa físico, político e rodoviário. Cuiabá: Secretaria de Estado de Planejamento e Coordenação Geral do Estado de Mato Grosso (SEPLAN - MT), 1990. 1 mapa p\&b. Escala 1:100.000.

JUSCIMEIRA: mapa físico, político e rodoviário. Fundação de Pesquisas Cândido Rondon (FCR), 1983. 1 mapa p\&b. Escala 1:250.000.

PEDRA PRETA: mapa físico, político e rodoviário. Fundação de Pesquisas Cândido Rondon (FCR), 1983. 1 mapa p\&b. Escala 1:250.000.

PONTAL DO ARAGUAIA: mapa físico, político e rodoviário. Cuiabá : Fundação de Pesquisas Cândido Rondon (FCR), 1984. 1 mapa p\&b. Escala 1:100.000.

PONTE BRANCA: mapa físico, político e rodoviário. Cuiabá : Fundação de Pesquisas Cândido Rondon (FCR), 1984. 1 mapa p\&b. Escala 1:100.000.

POXORÉU: mapa físico, político e rodoviário. Fundação de Pesquisas Cândido Rondon (FCR), 1981. 1 mapa p\&b. Escala 1:250.000. 
PRIMAVERA DO LESTE: mapa físico, político e rodoviário. Cuiabá : Fundação de Pesquisas Cândido Rondon (FCR), 1991. 1 mapa p\&b. Escala 1:100.000.

RIBEIRÃOZINHO: mapa físico, político e rodoviário. Cuiabá : Fundação de Pesquisas Cândido Rondon (FCR), 1984. 1 mapa p\&b. Escala 1:100.000.

RONDONÓPOLIS: mapa físico, político e rodoviário. Cuiabá : Fundação de Pesquisas Cândido Rondon (FCR), 1985. 1 mapa p\&b. Escala 1:100.000.

SÃO PEDRO DA CIPA: mapa físico, político e rodoviário. Cuiabá : Fundação de Pesquisas Cândido Rondon (FCR), 1991. 1 mapa p\&b. Escala 1:100.000.

SÃO PEDRO DA CIPA: mapa físico, político e rodoviário. Fundação de Pesquisas Cândido Rondon (FCR), 1991. 1 mapa p\&b. Escala 1:250.000.

TESOURO: mapa físico, político e rodoviário. Cuiabá: Secretaria de Estado de Planejamento e Coordenação Geral do Estado de Mato Grosso (SEPLAN - MT), 1990. 1 mapa p\&b. Escala 1:100.000.

TORIXORÉU: mapa físico, político e rodoviário. Cuiabá: Secretaria de Estado de Planejamento e Coordenação Geral do Estado de Mato Grosso (SEPLAN - MT), 1990. 1 mapa p\&b. Escala 1:100.000. 


\section{CARTAS TOPOGRÁFICAS}

ANHUMAS folha SE.21-X-B-V. Brasília: Ministério do Exército, Diretoria de Serviço Geográfico, (DSG). 1976. 1 carta, color. Escala 1:100.000.

ALTO ARAGUAIA folha SE.22-V-C-II. Rio de Janeiro: Instituto Brasileiro de Geografia e Estatística (IBGE), Superintendência de Cartografia, Departamento de Cartografia, 1976. 1 carta, color. Escala 1:100.000.

ALTO GARÇAS folha SE.22-V-A-IV. Rio de Janeiro: Instituto Brasileiro de Geografia e Estatística (IBGE), Superintendência de Cartografia, Departamento de Cartografia, 1976. 1 carta, color. Escala 1:100.000.

ARAGUAINHA folha SE.22-V-A-VI. Rio de Janeiro: Instituto Brasileiro de Geografia e Estatística (IBGE), Superintendência de Cartografia, Departamento de Cartografia, 1976. 1 carta, color. Escala 1:100.000.

BARRA DO GARÇAS folha SD.22-Y-D-IV. Rio de Janeiro: Instituto Brasileiro de Geografia e Estatística (IBGE), Superintendência de Cartografia, Departamento de Cartografia, 1976. 1 carta, color. Escala 1:100.000.

BATOVI folha SD.22-Y-C-IV. Brasília: Ministério do Exército, Diretoria de Serviço Geográfico (DSG). 1976. 1 carta, color. Escala 1:100.000.

BAÚS folha SE-22-Y-A-II. Rio de Janeiro: Instituto Brasileiro de Geografia e Estatística (IBGE), Superintendência de Cartografia, Departamento de Cartografia, 1976. 1 carta, color. Escala 1:100.000.

BOM JARDIM DE GOIÁS folha SE.22-V-B-II. Rio de Janeiro: Instituto Brasileiro de Geografia e Estatística (IBGE), Superintendência de Cartografia, Departamento de Cartografia, 1976. 1 carta, color. Escala 1:100.000.

BRASILÂNDIA - folha SD.21-Z-B-V. Brasília: Ministério do Exército, Diretoria de Serviço Geográfico (DSG). 1976. 1 carta, color. Escala 1:100.000.

BURITI folha SE.22-V-A-II. Rio de Janeiro: Instituto Brasileiro de Geografia e Estatística (IBGE), Superintendência de Cartografia, Departamento de Cartografia, 1976. 1 carta, color. Escala 1:100.000.

CACIMBA folha SD.21-Z-B-VI. Brasília: Ministério do Exército, Diretoria de Serviço Geográfico (DSG). 1976. 1 carta, color. Escala 1:100.000.

COLÔNIA MERURI folha SD.22-Y-C-V. Brasília: Ministério do Exército, Diretoria de Serviço Geográfico (DSG). 1976. 1 carta, color. Escala 1:100.000.

CÓRREGO CACHOEIRA folha SE.21-X-D-II. Brasília: Ministério do Exército, Diretoria de Serviço Geográfico (DSG). 1976. 1 carta, color. Escala 1:100.000. 
CÓRREGO BENJAMIM folha SE.21-X-D-VI. Brasília : Ministério do Exército, Diretoria de Serviço Geográfico (DSG). 1976. 1 carta, color. Escala 1:100.000.

DOM AQUINO folha SD.21-Z-D-V. Brasília: Ministério do Exército, Diretoria de Serviço Geográfico (DSG). 1976. 1 carta, color. Escala 1:100.000.

FAZENDA PRATA folha SE.21-X-B-I. Brasília : Ministério do Exército, Diretoria de Serviço Geográfico (DSG). 1976. 1 carta, color. Escala 1:100.000.

FAZENDA LUCIANA folha SD.21-Z-D-III. Brasília: Ministério do Exército, Diretoria de Serviço Geográfico (DSG). 1976. 1 carta, color. Escala 1:100.000.

FAZENDA TAIAMÃ folha SE.21-X-B-IV. Brasília: Ministério do Exército, Diretoria de Serviço Geográfico (DSG). 1976. 1 carta, color. Escala 1:100.000.

FAZENDA TRÊS MARIAS folha SE.21-X-D-I. Brasília: Ministério do Exército, Diretoria de Serviço Geográfico (DSG). 1976. 1 carta, color. Escala 1:100.000.

GALHEIRO folha SD.21-Z-D-II. Brasília: Ministério do Exército, Diretoria de Serviço Geográfico (DSG). 1976. 1 carta, color. Escala 1:100.000.

GENERAL CARNEIRO folha SD.22-Y-C-VI. Brasília: Ministério do Exército, Diretoria de Serviço Geográfico (DSG). 1976. 1 carta, color. Escala 1:100.000.

GUIRATINGA folha SE.22-V-A-I. Rio de Janeiro: Instituto Brasileiro de Geografia e Estatística (IBGE), Superintendência de Cartografia, Departamento de Cartografia, 1976. 1 carta, color. Escala 1:100.000.

ITIQUIRA folha SE.21-X-D-III. Brasília : Ministério do Exército, Diretoria de Serviço Geográfico (DSG). 1976. 1 carta, color. Escala 1:100.000.

JARUDORE folha SE.21-X-B-III. Brasília: Ministério do Exército, Diretoria de Serviço Geográfico (DSG). 1976. 1 carta, color. Escala 1:100.000.

LAGOA DO CERVO folha SD.22-Y-C-I. Brasília: Ministério do Exército, Diretoria de Serviço Geográfico (DSG). 1976. 1 carta, color. Escala 1:100.000.

MORRO FORMOSO folha SE.21-X-D-IV. Brasília: Ministério do Exército, Diretoria de Serviço Geográfico (DSG). 1976. 1 carta, color. Escala 1:100.000.

PEDRA PRETA folha SE.21-X-B-VI. Brasília: Ministério do Exército, Diretoria de Serviço Geográfico (DSG). 1976. 1 carta, color. Escala 1:100.000.

PONTE BRANCA folha SE.22-V-A-VI. Rio de Janeiro: Instituto Brasileiro de Geografia e Estatística (IBGE), Superintendência de Cartografia, Departamento de Cartografia, 1976. 1 carta, color. Escala 1:100.000.

PORTO COQUEIRO folha SE.21.X-C-III . Brasília: Ministério do Exército, Diretoria de Serviço Geográfico (DSG). 1976. 1 carta, color. Escala 1:100.000. 
POXORÉO folha SD.21-Z-D-VI . Brasília: Ministério do Exército, Diretoria de Serviço Geográfico (DSG). 1976. 1 carta, color. Escala 1:100.000.

RIO CASCA folha SD.21-Z-D-I. Brasília: Ministério do Exército, Diretoria de Serviço Geográfico (DSG). 1976. 1 carta, color. Escala 1:100.000.

RIO ITIQUIRA folha SE.22-V-C-I. Rio de Janeiro: Brasileiro de Geografia e Estatística (IBGE), Superintendência de Cartografia, Departamento de Cartografia, 1976. 1 carta, color. Escala 1:100.000.

RONDONÓPOLIS folha SE.21-X-B-II. Brasília: Ministério do Exército, Diretoria de Serviço Geográfico (DSG). 1976. 1 carta, color. Escala 1:100.000.

SÃO MARCOS folha SD.22.Y-C-III. Brasília: Ministério do Exército, Diretoria de Serviço Geográfico (DSG). 1976. 1 carta, color. Escala 1:100.000.

SÃO VICENTE folha SD.21-Z-D-IV. Brasília: Ministério do Exército, Diretoria de Serviço Geográfico (DSG). 1976. 1 carta, color. Escala 1:100.000.

SERRA DO TAQUARI folha SE-22-Y-A-I. Rio de Janeiro: Instituto Brasileiro de Geografia e Estatística (IBGE), Superintendência de Cartografia, Departamento de Cartografia, 1976. 1 carta, color. Escala 1:100.000.

TAQUARI folha SE-22-V-C-V. Rio de Janeiro: Instituto Brasileiro de Geografia e Estatística (IBGE), Superintendência de Cartografia, Departamento de Cartografia, 1976. 1 carta, color. Escala 1:100.000.

TORI-COEJO folha SD.22-Y-C-II. Brasília: Ministério do Exército, Diretoria de Serviço Geográfico (DSG). 1976. 1 carta, color. Escala 1:100.000.

TORIXORÉU folha SE.22-V-A-III Rio de Janeiro: Instituto Brasileiro de Geografia e Estatística (IBGE), Superintendência de Cartografia, Departamento de Cartografia, 1976. 1 carta, color. Escala 1:100.000.

VILA DE BURITI folha SE-22-V-C-IV. Rio de Janeiro: Instituto Brasileiro de Geografia e Estatística (IBGE), Superintendência de Cartografia, Departamento de Cartografia, 1976. 1 carta, color. Escala 1:100.000.

VOLTA GRANDE folha SD.22-Y-A-IV. Brasília: Ministério do Exército, Diretoria de Serviço Geográfico (DSG). 1976. 1 carta, color. Escala 1:100.000. 


\section{APÊNDICES}


APÊNDICE A - FICHAS LEXICOGRÁFICO-TOPONÍMICAS 
Ficha lexicográfico-toponímica de acidente físico

\begin{tabular}{|l|l|l|l|l|}
\hline$N^{\circ}$ & Unidade da Federação: & Mesorregião: & Microrregião: & Município: \\
\hline
\end{tabular}

\begin{tabular}{|l|l|l|l|}
\hline Acidente físico: & Topônimo: & Variante gráfica: & Taxionomia: \\
\hline Estrutura do topônimo: & Estrutura gramatical: \\
\hline
\end{tabular}

\begin{tabular}{|l|l|}
\hline Etimologia indígena ou africana: & Fonte: \\
\hline
\end{tabular}

\begin{tabular}{|l|l|}
\hline Entrada lexical: & Fonte: \\
\hline Informações enciclopédicas: & Fonte: \\
\hline
\end{tabular}

Contexto

Observações gerais:

Órgão expedidor: Data do mapa: Escala do mapa:

Pesquisadora:

Revisora:

Local e data da coleta: 
Ficha lexicográfico-toponímica de acidente humano

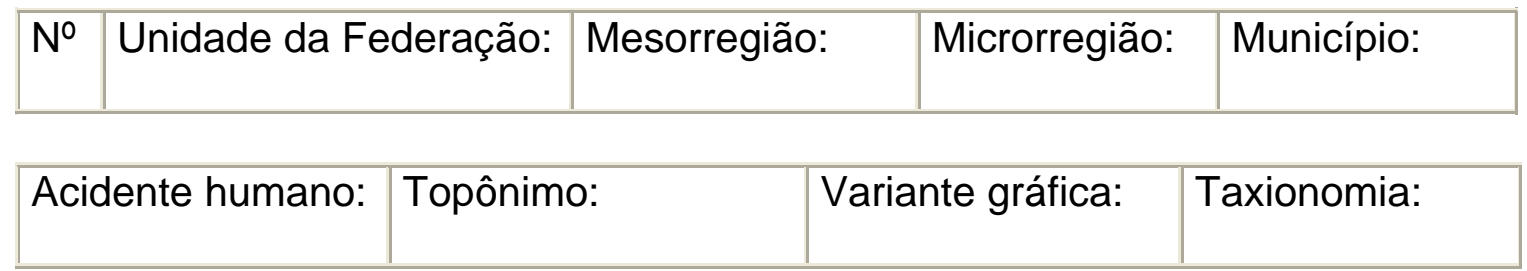

Estrutura do topônimo: Estrutura morfológica:

Etimologia indígena ou africana:

Fonte:

\begin{tabular}{|l|l|}
\hline Entrada lexical: & Fonte: \\
\hline & \\
\hline Informações enciclopédicas: & Fonte: \\
\hline
\end{tabular}

Contexto:

Observações gerais:

Órgão expedidor:

Data do mapa: Escala do mapa:

Pesquisadora:

Revisora:

Local e data da coleta: 
Ficha lexicográfico-toponímica de município

\begin{tabular}{|l|l|l|l|l|}
\hline$N^{0}$ & Unidade da Federação: & Mesorregião: & Microrregião: & Município: \\
\hline
\end{tabular}

\begin{tabular}{|l|l|l|l|}
\hline Acidente humano: & Topônimo: & Variante gráfica: & Taxionomia: \\
\hline
\end{tabular}

\begin{tabular}{|l|l|}
\hline Estrutura do topônimo: & Estrutura morfológica: \\
\hline
\end{tabular}

\begin{tabular}{|l|l|}
\hline Etimologia indígena ou africana: & Fonte: \\
\hline
\end{tabular}

\begin{tabular}{|l|l|}
\hline Entrada lexical: & Fonte: \\
\hline Informações enciclopédicas: & Fonte: \\
\hline
\end{tabular}

\section{Contexto}

Limites:

Observações gerais:

\begin{tabular}{|l|l|l|}
\hline Órgão expedidor: & Data do mapa: & Escala do mapa
\end{tabular}

\begin{tabular}{|l|l|}
\hline Pesquisadora: & Revisora: \\
\hline
\end{tabular}

Local e data da coleta: 
Ficha lexicográfico-toponímica de acidente físico

\begin{tabular}{|l|l|l|l|l|}
\hline $\begin{array}{l}N^{0} \\
1\end{array}$ & $\begin{array}{l}\text { Unidade da Federação: } \\
\text { Mato Grosso - MT }\end{array}$ & $\begin{array}{l}\text { Mesorregião: } \\
\text { Sudeste Mato- } \\
\text { grossense }\end{array}$ & $\begin{array}{l}\text { Microrregião: } \\
\text { Alto Araguaia }\end{array}$ & $\begin{array}{l}\text { Município: } \\
\text { Alto Taquari }\end{array}$ \\
\hline
\end{tabular}

\begin{tabular}{|l|l|l|l|}
\hline $\begin{array}{l}\text { Acidente físico: } \\
\text { córrego do }\end{array}$ & $\begin{array}{l}\text { Topônimo: } \\
\text { Capão (E7, E8) }\end{array}$ & $\begin{array}{l}\text { Variante Gráfica: } \\
\varnothing\end{array}$ & $\begin{array}{l}\text { Taxionomia: } \\
\text { fitotopônimo }\end{array}$ \\
\hline
\end{tabular}

\begin{tabular}{|l|l|}
\hline $\begin{array}{l}\text { Estrutura do topônimo: } \\
\text { simples }\end{array}$ & $\begin{array}{l}\text { Estrutura gramatical: } \\
\text { substantivo comum }\end{array}$ \\
\hline
\end{tabular}

\begin{tabular}{|l|l|}
\hline Etimologia tupi: & Fonte: \\
capão s.m. (1624 cf. ABN) FITOG 1 formação arbórea de pequena & Houaiss \\
extensão, volume e composição variados, e de aspecto diverso da & \\
vegetação que a circunda; caapuã, capuão, capuão de mato, ilha de & \\
mato 2 m.q. bosque ('formação') & \\
\hline
\end{tabular}

\begin{tabular}{|l|l|}
\hline Entrada lexical: & Fonte: \\
$\varnothing$ & $\varnothing$ \\
\hline & \\
\hline Informações enciclopédicas: & Fonte: \\
$\varnothing$ & $\varnothing$ \\
\hline
\end{tabular}

\begin{tabular}{l|l|}
\hline Contexto \\
$\varnothing$ \\
\hline
\end{tabular}

\begin{tabular}{l|}
\hline Observações gerais: \\
Deságua no rio Araguaia. \\
\hline
\end{tabular}

\begin{tabular}{|l|l|l|}
\hline Órgão Expedidor: & Data do mapa: & Escala do mapa: \\
Fundação de Pesquisas Cândido Rondon (FCR) & 1988 & $1: 100.000$ \\
\hline
\end{tabular}

\begin{tabular}{|l|l|}
\hline Pesquisadora: & Revisora: \\
Maria Aparecida de Carvalho & DICK \\
\hline
\end{tabular}

Local e data da coleta:

Cuiabá, janeiro / 2007 
Ficha lexicográfico-toponímica de acidente físico

\begin{tabular}{|l|l|l|l|l|}
\hline $\begin{array}{l}\mathrm{N}^{\mathrm{O}} \\
2\end{array}$ & $\begin{array}{l}\text { Unidade da Federação: } \\
\text { Mato Grosso - MT }\end{array}$ & $\begin{array}{l}\text { Mesorregião: } \\
\text { Sudeste Mato- } \\
\text { grossense }\end{array}$ & $\begin{array}{l}\text { Microrregião: } \\
\text { Primavera do } \\
\text { Leste }\end{array}$ & $\begin{array}{l}\text { Município: } \\
\text { Campo Verde }\end{array}$ \\
\hline
\end{tabular}

\begin{tabular}{|l|l|l|l|}
\hline $\begin{array}{l}\text { Acidente físico: } \\
\text { cabeceira do }\end{array}$ & Topônimo: & Variante gráfica: & $\begin{array}{l}\text { Taxionomia: } \\
\text { litotopônimo Branco (18 a I10) }\end{array}$ \\
\hline
\end{tabular}

\begin{tabular}{|l|l|}
\hline $\begin{array}{l}\text { Estrutura do topônimo: } \\
\text { híbrida }\end{array}$ & $\begin{array}{l}\text { Estrutura gramatical: } \\
\text { substantivo comum + adjetivo }\end{array}$ \\
\hline
\end{tabular}

\begin{tabular}{|l|l|}
\hline Etimologia tupi: & Fonte: \\
cupim s.m. (1734 cf. RAPM) 2 ent m.q. cupinzeiro & Houaiss \\
cupinzeiro s.m. B 1 ent aglomerado de terra e outros resíduos, & \\
edificado pelos cupins, constituindo o seu ninho & \\
\hline
\end{tabular}

\begin{tabular}{l|l|}
\hline Entrada lexical: & Fonte: \\
branco adj. (1251 cf. PMH) 1 que apresenta a cor da neve recém- & Houaiss \\
caída 2 diz-se dessa cor & \\
\hline
\end{tabular}

\begin{tabular}{|l|l|}
\hline Informações enciclopédicas: & Fonte: \\
$\varnothing$ & $\varnothing$ \\
\hline
\end{tabular}

\section{Contexto}

$\varnothing$

\section{Observações gerais: \\ Deságua no córrego Cupim Branco.}

\begin{tabular}{|l|l|l|}
\hline Órgão Expedidor: & Data do mapa: & Escala do mapa: \\
Fundação de Pesquisas Cândido Rondon (FCR) & 1990 & $1: 100.000$ \\
\hline
\end{tabular}

\begin{tabular}{|l|l|}
\hline Pesquisadora: & Revisora: \\
Maria Aparecida de Carvalho & DICK \\
\hline
\end{tabular}

\begin{tabular}{l} 
Local e data da coleta: \\
Cuiabá, outubro / 2008 \\
\hline
\end{tabular}


Ficha lexicográfico-toponímica de acidente físico

\begin{tabular}{|c|c|c|c|c|}
\hline $\begin{array}{l}\mathrm{N}^{\mathrm{O}} \\
3\end{array}$ & $\begin{array}{l}\text { Unidade da Federação: } \\
\text { Mato Grosso - MT }\end{array}$ & $\begin{array}{l}\text { Mesorregião: } \\
\text { Sudeste Mato- } \\
\text { grossense }\end{array}$ & $\begin{array}{l}\text { Microrregião: } \\
\text { Primavera do } \\
\text { Leste }\end{array}$ & $\begin{array}{l}\text { Município: } \\
\text { Primavera do } \\
\text { Leste }\end{array}$ \\
\hline
\end{tabular}

\begin{tabular}{|c|c|c|c|c|c|}
\hline $\begin{array}{l}\text { Acidente físico: } \\
\text { córrego }\end{array}$ & $\begin{array}{l}\text { Topônimo: } \\
\text { Cacimba } \\
\text { D16) }\end{array}$ & Velha & (E15, & $\begin{array}{l}\text { Variante gráfica: } \\
\varnothing\end{array}$ & $\begin{array}{l}\text { Taxionomia: } \\
\text { hidrotopônimo }\end{array}$ \\
\hline
\end{tabular}

\begin{tabular}{|l|l|}
\hline $\begin{array}{l}\text { Estrutura do topônimo: } \\
\text { híbrida }\end{array}$ & $\begin{array}{l}\text { Estrutura gramatical: } \\
\text { substantivo comum + adjetivo }\end{array}$ \\
\hline
\end{tabular}

\begin{tabular}{l|l|}
\hline Etimologia africana: & Fonte: \\
1'cacimba s.f. (1575 MMA III 131) 1 cova aberta em terreno úmido & Houaiss \\
ou pantanoso, para recolher a água presente no solo que nela se & \\
acumula por ressumação 2 buraco que se cava até atingir um lençol \\
de água subterrâneo; poço, cisterna 3 B N.E. escavaçâo, \\
semelhante a um poço, em local baixo e úmido ou em leito seco de \\
rio, onde a água do solo se acumula
\end{tabular}

\begin{tabular}{|l|l|}
\hline Entrada lexical: & Fonte: \\
velho adj. (1162 cf. JM3) 1 que não é jovem, novo; que tem muito & Houaiss \\
tempo de vida ou de existência 2 que data de época remota; antigo & \\
\hline
\end{tabular}

\begin{tabular}{|l|l|}
\hline Informações enciclopédicas: & Fonte: \\
$\varnothing$ & $\varnothing$ \\
\hline
\end{tabular}

\begin{tabular}{l|l|} 
Contexto \\
$\varnothing$ \\
\hline
\end{tabular}

Observações gerais:
Deságua no córrego Xavante.

\begin{tabular}{|l|l|l|}
\hline Órgão Expedidor: & Data do mapa: & $\begin{array}{l}\text { Escala do mapa: } \\
\text { Fundação de Pesquisas Cândido Rondon (FCR) }\end{array}$ \\
\hline
\end{tabular}

\begin{tabular}{|l|l|}
\hline Pesquisadora: & Revisora: \\
Maria Aparecida de Carvalho & DICK \\
\hline
\end{tabular}

Local e data da coleta:

Cuiabá, outubro / 2008 
Ficha lexicográfico-toponímica de acidente humano

\begin{tabular}{|l|l|l|l|l|}
\hline $\begin{array}{l}N^{0} \\
4\end{array}$ & $\begin{array}{l}\text { Unidade da Federação: } \\
\text { Mato Grosso - MT }\end{array}$ & $\begin{array}{l}\text { Mesorregião: } \\
\text { Sudeste Mato- } \\
\text { grossense }\end{array}$ & $\begin{array}{l}\text { Microrregião: } \\
\text { Rondonópolis }\end{array}$ & $\begin{array}{l}\text { Município: } \\
\text { Rondonópolis }\end{array}$ \\
\hline
\end{tabular}

\begin{tabular}{|l|l|l|l|}
\hline $\begin{array}{l}\text { Acidente humano: } \\
\text { vila }\end{array}$ & Topônimo: & Variante gráfica: & Taxionomia: \\
& Naboreiro $(G 15, G 16)$ & $\varnothing$ & zootopônimo \\
\hline
\end{tabular}

\begin{tabular}{|l|l|}
\hline $\begin{array}{l}\text { Estrutura do topônimo: } \\
\text { simples }\end{array}$ & $\begin{array}{l}\text { Estrutura gramatical: } \\
\text { substantivo comum }\end{array}$ \\
\hline
\end{tabular}

$\begin{aligned} & \text { Etimologia bororo } \\ & \text { Naburéri }-* \text { nabúre, ararapiranga; rí, morro [morro da Enciclopédia }\end{aligned}$
ararapiranga]: Morro a $\sim 45 \mathrm{Km}$ ao sul da atual cidade de Poxoreu: Bororo
morro Naburere.

\begin{tabular}{|l|l|}
\hline Entrada lexical: & Fonte: \\
$\varnothing$ & $\varnothing$ \\
\hline & \\
\hline Informações enciclopédicas: & Fonte: \\
$\varnothing$ & $\varnothing$ \\
\hline
\end{tabular}

\section{Contexto:}

$\varnothing$

Observações gerais:

Localiza-se à margem direita do córrego Bagaréu.

\begin{tabular}{|l|l|l|}
\hline Órgão expedidor: & Data do mapa: & Escala do mapa: \\
Fundação de Pesquisas Cândido Rondon (FCR) & 1984 & $1: 100.000$ \\
\hline
\end{tabular}

\begin{tabular}{|l|l|}
\hline Pesquisadora: & Revisora: \\
Maria Aparecida de Carvalho & DICK \\
\hline
\end{tabular}

Local e data da coleta:

Cuiabá, dezembro / 2008. 
Ficha lexicográfico-toponímica de município

\begin{tabular}{|l|l|l|l|l|}
\hline $\begin{array}{l}N^{0} \\
5\end{array}$ & $\begin{array}{l}\text { Unidade da Federação: } \\
\text { Mato Grosso - MT }\end{array}$ & $\begin{array}{l}\text { Mesorregião: } \\
\text { Sudeste Mato- } \\
\text { grossense }\end{array}$ & $\begin{array}{l}\text { Microrregião: } \\
\text { Rondonópolis }\end{array}$ & $\begin{array}{l}\text { Município: } \\
\text { Itiquira }\end{array}$ \\
\hline
\end{tabular}

\begin{tabular}{l|l|l|l|}
\hline $\begin{array}{l}\text { Acidente humano: } \\
\text { município / cidade }\end{array}$ & $\begin{array}{l}\text { Topônimo: } \\
\text { Itiquira (338 - M19) }\end{array}$ & $\varnothing$ & $\begin{array}{l}\text { Variante gráfica: } \\
\text { hidrotopônimo: }\end{array}$ \\
\hline
\end{tabular}

\begin{tabular}{|l|l|}
\hline $\begin{array}{l}\text { Estrutura do topônimo: } \\
\text { simples }\end{array}$ & $\begin{array}{l}\text { Estrutura morfológica: } \\
\text { substantivo comum }\end{array}$ \\
\hline
\end{tabular}

\begin{tabular}{|c|c|}
\hline $\begin{array}{l}\text { Etimologia tupi: } \\
\text { ITIQUIRA, corr. y-tykyra, a água vertente, o minadouro. }\end{array}$ & $\begin{array}{l}\text { Fonte: } \\
\text { Th. Sampaio }\end{array}$ \\
\hline $\begin{array}{l}\text { Entrada lexical: } \\
\varnothing\end{array}$ & $\begin{array}{l}\text { Fonte: } \\
\varnothing\end{array}$ \\
\hline $\begin{array}{l}\text { Informações enciclopédicas: } \\
\varnothing\end{array}$ & $\begin{array}{l}\text { Fonte: } \\
\varnothing\end{array}$ \\
\hline
\end{tabular}

\section{Contexto \\ $\varnothing$}
Limites:
Alto Garças, Barão de Melgaço, Pedra Preta, Rondonópolis, Santo Antônio de Leverger e Mato Grosso do Sul

Observações gerais:

A cidade de Itiquira localiza-se às margens do rio Itiquira.

\begin{tabular}{l|l|l|}
\hline Órgão Expedidor: & Data da carta: & $\begin{array}{l}\text { Escala da carta: } \\
1: 100.000\end{array}$ \\
Instituto Brasileiro de Geografia e Estatística & 1976 & \\
(IBGE) e Diretoria de Serviço Geográfico (DSG) & & \\
do Ministério do Exército. & & \\
\hline
\end{tabular}

Pesquisadora:
Maria Aparecida de Carvalho

Revisora:

DICK

Local e data da coleta:

Cuiabá, dezembro / 2008. 
Ficha lexicográfico-toponímica de município

\begin{tabular}{|l|l|l|l|l|}
\hline $\begin{array}{l}N^{0} \\
6\end{array}$ & $\begin{array}{l}\text { Unidade da Federação: } \\
\text { Mato Grosso - MT }\end{array}$ & $\begin{array}{l}\text { Mesorregião: } \\
\text { Sudeste Mato- } \\
\text { grossense }\end{array}$ & $\begin{array}{l}\text { Microrregião: } \\
\text { Tesouro }\end{array}$ & $\begin{array}{l}\text { Município: } \\
\text { Poxoréu }\end{array}$ \\
\hline $\begin{array}{l}\text { Acidente humano: } \\
\text { município / cidade }\end{array}$ & $\begin{array}{l}\text { Topônimo: } \\
\text { Poxoréu } \\
\text { T7, U8) }\end{array}$ & $\begin{array}{l}\text { Variante gráfica: } \\
\varnothing\end{array}$ & $\begin{array}{l}\text { Taxionomia: } \\
\text { hidrotopônimo }\end{array}$ \\
\hline
\end{tabular}

\begin{tabular}{|l|l|}
\hline $\begin{array}{l}\text { Estrutura do topônimo: } \\
\text { simples }\end{array}$ & $\begin{array}{l}\text { Estrutura morfológica: } \\
\text { substantivo comum }\end{array}$ \\
\hline
\end{tabular}

\begin{tabular}{l|l|}
\hline Etimologia bororo: & Fonte: \\
Pó Ceréu - *pó, água; ceréu, o escuro [r. de águas escuras]. & Enciclopédia \\
Designação: 1. do curso superior do Pogúbo, r. Vermelho até a foz Bororo \\
do Porubí, r. Porube Aidjau. Nas proximidades de Jurodóri Boróro é \\
também denominado r. São João. Com seu c. s. atravessa a cidade \\
de Poxoreu; 2. de um r. afl. do c. i. do Pogúbo, r. Vermelho: r. Dr. \\
Correia ou r. Ponte de Pedra ou r. Poxoreu.
\end{tabular}

\begin{tabular}{|c|c|}
\hline $\begin{array}{l}\text { Entrada lexical: } \\
\varnothing\end{array}$ & $\begin{array}{l}\text { Fonte: } \\
\varnothing\end{array}$ \\
\hline $\begin{array}{l}\text { Informações enciclopédicas: } \\
\varnothing\end{array}$ & $\begin{array}{l}\text { Fonte: } \\
\varnothing\end{array}$ \\
\hline
\end{tabular}

\begin{tabular}{ll|} 
Contexto \\
$\varnothing$
\end{tabular}

\footnotetext{
Limites:

Dom Aquino, General Carneiro, Guiratinga, Juscimeira, Novo São Joaquim, Primavera do Leste, Rondonópolis, Santo Antônio do Leste, São José do Povo, São Pedro da Cipa e Tesouro
}

Observações gerais:

A cidade de Poxoréu localiza-se às margens do rio Poxoréo.

\begin{tabular}{|c|c|c|}
\hline $\begin{array}{l}\text { Órgão Expedidor: } \\
\text { Instituto Brasileiro de Geografia e Estatística } \\
\text { (IBGE) e Diretoria de Serviço Geográfico (DSG) } \\
\text { do Ministério do Exército. }\end{array}$ & $\begin{array}{l}\text { Data da carta: } \\
1976\end{array}$ & $\begin{array}{l}\text { Escala da carta } \\
\text { 1:100.000 }\end{array}$ \\
\hline
\end{tabular}

\begin{tabular}{|l|l}
\hline Pesquisadora: & Revisora: \\
Maria Aparecida de Carvalho & DICK \\
\hline
\end{tabular}

Local e data da coleta:

Cuiabá, novembro / 2008. 
APÊNDICE B - COMPOSIÇÃO DA MESORREGIÃO SUDESTE MATOGROSSENSE 
Composição da Mesorregião Sudeste Mato-grossense

\begin{tabular}{l|c|c|l}
\hline \multicolumn{4}{c}{ Mesorregião Sudeste Mato-grossense } \\
\hline $\begin{array}{c}\text { microrregião Alto } \\
\text { Araguaia }\end{array}$ & $\begin{array}{c}\text { microrregião } \\
\text { Primavera do } \\
\text { Leste }\end{array}$ & $\begin{array}{c}\text { microrregião } \\
\text { Rondonópolis }\end{array}$ & $\begin{array}{c}\text { microrregião } \\
\text { Tesouro }\end{array}$ \\
\hline Alto Araguaia & Campo Verde & Dom Aquino & Araguainha \\
Alto Garças & Primavera do Leste & Itiquira & General Carneiro \\
Alto Taquari & Jaciara & Guiratinga \\
& & Juscimeira & Pontal do Araguaia \\
& & Pedra Preta & Ponte Branca \\
& & Rondonópolis & Poxoréu \\
& São José do Povo & Ribeirãozinho \\
& São Pedro da Cipa & Tesouro \\
& & & Torixoréu \\
\hline
\end{tabular}


APÊNDICE C - TOPÔNIMOS DA MESORREGIÃO SUDESTE MATO-GROSSENSE, POR GRUPOS LINGÜÍSTICOS, MICRORREGIÕES E MUNICÍPIOS 
Tabela 5 - Topônimos da mesorregião Sudeste Mato-grossense, por grupos lingüísticos, microrregiões e municípios.

\begin{tabular}{|c|c|c|c|c|c|c|c|}
\hline \multirow{3}{*}{$\mathrm{N}^{0}$} & \multicolumn{7}{|c|}{ mesorregião Sudeste Mato-grossense } \\
\hline & \multirow{2}{*}{$\begin{array}{l}\text { mesorregião, microrregiões e } \\
\text { municípios }\end{array}$} & \multicolumn{6}{|c|}{ grupos lingüísticos } \\
\hline & & $\begin{array}{l}\text { topônimos } \\
\text { tupis }\end{array}$ & $\begin{array}{l}\text { topônimos } \\
\text { bororos }\end{array}$ & $\begin{array}{l}\text { topônimos } \\
\text { africanos }\end{array}$ & $\begin{array}{c}\text { topônimos } \\
\text { portugueses }\end{array}$ & $\begin{array}{l}\text { topônimo } \\
\text { s/c }\end{array}$ & Total geral \\
\hline 1 & $\begin{array}{l}\text { mesorregião Sudeste Mato- } \\
\text { grossense }\end{array}$ & 361 & 69 & 25 & 1.892 & 1 & 2.348 \\
\hline 1.1 & microrregião Alto Araguaia & 94 & 1 & 8 & 468 & - & 571 \\
\hline 1.1 .1 & Alto Araguaia & 47 & 1 & 6 & 273 & - & 327 \\
\hline 1.1 .2 & Alto Garças & 38 & - & 2 & 168 & - & 208 \\
\hline 1.1 .3 & Alto Taquari & 9 & - & - & 27 & - & 36 \\
\hline 1.2 & microrregião Primavera do Leste & 30 & 1 & 4 & 100 & 1 & 136 \\
\hline 1.2 .1 & Campo Verde & 22 & - & 2 & 72 & - & 96 \\
\hline 1.2 .2 & Primavera do Leste & 8 & 1 & 2 & 28 & 1 & 40 \\
\hline 1.3 & microrregião Rondonópolis & 87 & 36 & 4 & 491 & - & 618 \\
\hline 1.3.1 & Dom Aquino & 8 & - & 1 & 69 & - & 78 \\
\hline 1.3 .2 & Itiquira & 21 & - & - & 133 & - & 154 \\
\hline 1.3 .3 & Jaciara & 7 & - & - & 31 & - & 38 \\
\hline 1.3 .4 & Juscimeira & 8 & 4 & 2 & 52 & - & 66 \\
\hline 1.3 .5 & Pedra Preta & 15 & 6 & - & 78 & - & 99 \\
\hline 1.3 .6 & Rondonópolis & 22 & 23 & 1 & 89 & - & 135 \\
\hline
\end{tabular}


(conclusão)

\begin{tabular}{|c|c|c|c|c|c|c|c|}
\hline \multirow{3}{*}{$\mathrm{N}^{\mathrm{O}}$} & \multicolumn{7}{|c|}{ mesorregião Sudeste Mato-grossense } \\
\hline & \multirow[b]{2}{*}{$\begin{array}{l}\text { mesorregião, microrregiões e } \\
\text { municípios }\end{array}$} & \multicolumn{6}{|c|}{ grupos lingüísticos } \\
\hline & & $\begin{array}{l}\text { topônimos } \\
\text { tupis }\end{array}$ & $\begin{array}{l}\text { topônimos } \\
\text { bororos }\end{array}$ & $\begin{array}{l}\text { topônimos } \\
\text { africanos }\end{array}$ & $\begin{array}{c}\text { topônimos } \\
\text { portugueses }\end{array}$ & $\begin{array}{l}\text { topônimo } \\
\text { s/c }\end{array}$ & Total geral \\
\hline 1.3 .7 & São José do Povo & 3 & 3 & - & 14 & - & 20 \\
\hline 1.3 .8 & São Pedro da Cipa & 3 & - & - & 25 & - & 28 \\
\hline 1.4 & microrregião Tesouro & 150 & 31 & 9 & 833 & - & 1.023 \\
\hline 1.4 .1 & Araguainha & 9 & - & - & 48 & - & 57 \\
\hline 1.4 .2 & General Carneiro & 11 & 9 & 1 & 67 & - & 88 \\
\hline 1.4 .3 & Guiratinga & 38 & 3 & 3 & 225 & - & 269 \\
\hline 1.4 .4 & Pontal do Araguaia & 22 & - & 2 & 82 & - & 106 \\
\hline 1.4 .5 & Ponte Branca & 4 & - & - & 53 & - & 57 \\
\hline 1.4 .6 & Poxoréu & 20 & 12 & 1 & 112 & - & 145 \\
\hline 1.4 .7 & Ribeirãozinho & 9 & - & - & 29 & - & 38 \\
\hline 1.4 .8 & Tesouro & 15 & 5 & 1 & 96 & - & 117 \\
\hline 1.4 .9 & Torixoréu & 22 & 2 & 1 & 121 & - & 146 \\
\hline
\end{tabular}


ANEXOS 


\section{ANEXO A - MAPA DE MATO GROSSO POR MICRORREGIÕES}

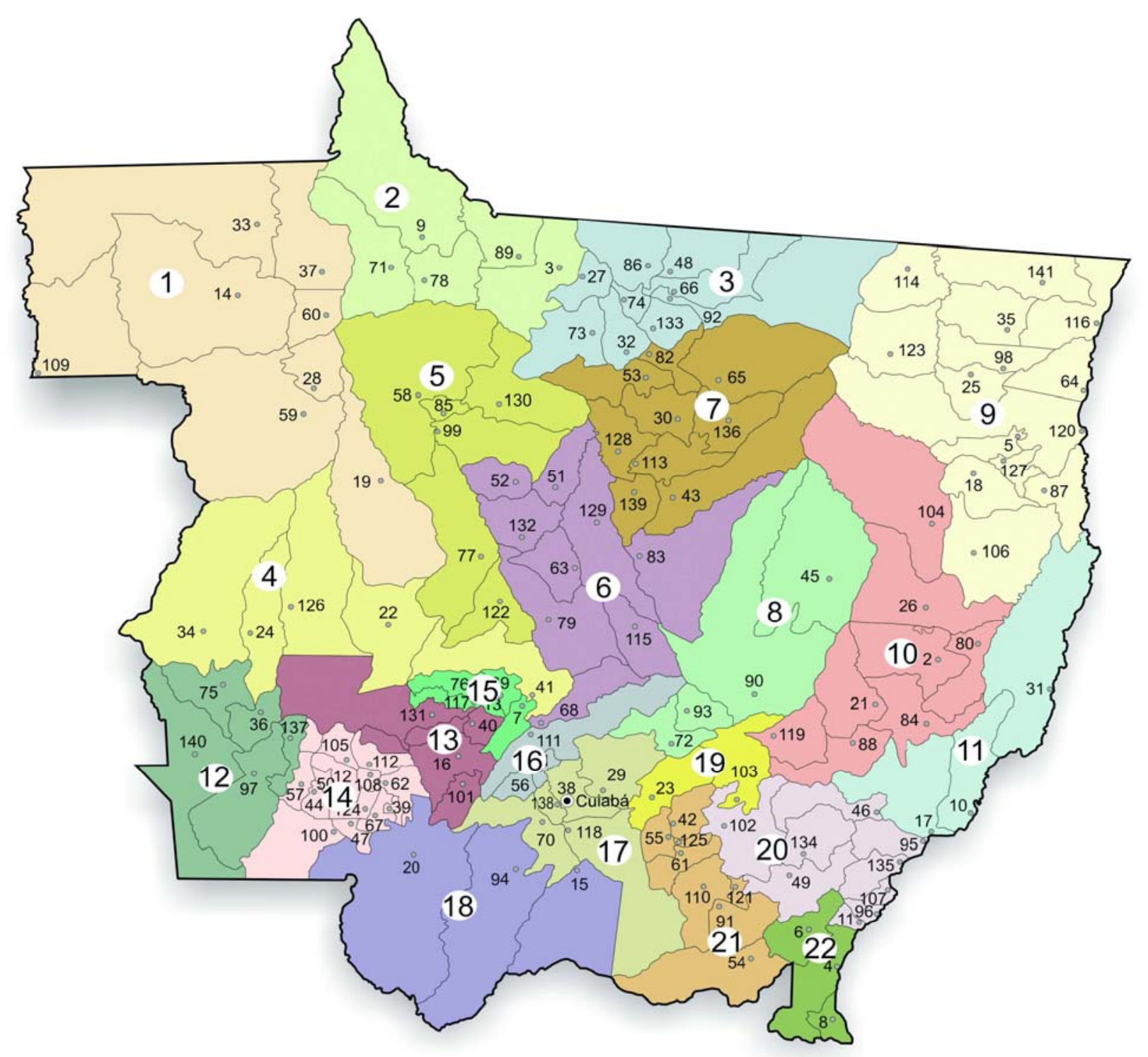

Fonte: Seplan 2007

Aripuanã

Alta Floresta

Colíder

Parecis

Arinos

Alto Teles Pires

Sinop

Paranatinga

Norte Araguaia

Canarana

Médio Araguaia
Alto Guaporé

Tangará da Serra Jauru

Alto Paraguai

Rosário Oeste

Cuiabá

Alto Pantanal

Primavera do Leste

Tesouro

Rondonópolis

Alto Araguaia 


\section{ANEXO B - FICHA LEXICOGRÁFICO-TOPONÍMICA DO PROJETO ATESP}

Projeto ATESP - Atlas Toponímico do Estado de São Paulo

Coordenadora: Profa ${ }^{a}$. Dra ${ }^{\mathrm{a}}$. Maria Vicentina de Paula do Amaral Dick (DLCV-DL/USP)

Subárea: Toponímia Geral e do Brasil

Localização-Município:

Topônimo:

A.G.:

Taxionomia:

Etimologia:

Entrada Lexical:

Estrutura Morfológica:

Histórico:

Informações Enciclopédicas:

Contexto:

Fonte:

Pesquisador: Revisor:

Data de Coleta: 